\title{
Due Diligence procedures
}

Citation for published version (APA):

Brink, M. (2008). Due Diligence procedures. [Doctoral Thesis, Maastricht University]. https://doi.org/10.26481/dis.20081106mb

Document status and date:

Published: 01/01/2008

DOI:

10.26481/dis.20081106mb

Document Version:

Publisher's PDF, also known as Version of record

\section{Please check the document version of this publication:}

- A submitted manuscript is the version of the article upon submission and before peer-review. There can be important differences between the submitted version and the official published version of record.

People interested in the research are advised to contact the author for the final version of the publication, or visit the DOI to the publisher's website.

- The final author version and the galley proof are versions of the publication after peer review.

- The final published version features the final layout of the paper including the volume, issue and page numbers.

Link to publication

\footnotetext{
General rights rights.

- You may freely distribute the URL identifying the publication in the public portal. please follow below link for the End User Agreement:

www.umlib.nl/taverne-license

Take down policy

If you believe that this document breaches copyright please contact us at:

repository@maastrichtuniversity.nl

providing details and we will investigate your claim.
}

Copyright and moral rights for the publications made accessible in the public portal are retained by the authors and/or other copyright owners and it is a condition of accessing publications that users recognise and abide by the legal requirements associated with these

- Users may download and print one copy of any publication from the public portal for the purpose of private study or research.

- You may not further distribute the material or use it for any profit-making activity or commercial gain

If the publication is distributed under the terms of Article $25 \mathrm{fa}$ of the Dutch Copyright Act, indicated by the "Taverne" license above, 


\section{Due diligence}

\section{Een beschouwing over het due diligence onderzoek volgens het Nederlands recht}

\section{Proefschrift}

ter verkrijging van de graad van doctor

aan de universiteit Maastricht,

op gezag van de Rector Magnificus, Prof. Mr. G.P.M.F. Mols,

volgens het besluit van het College van Decanen,

in het openbaar te verdedigen op

donderdag 6 november 2008 om 16:00 uur

door

\section{Martin Brink}

geboren te Amersfoort op 5 oktober 1948

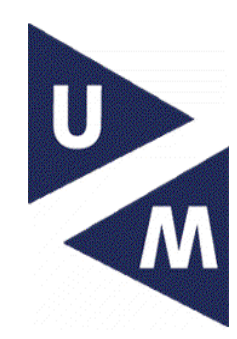


Promotor:

Beoordelingscommissie:

Prof. mr. G.R. de Groot (voorzitter)

Prof. mr. M.J.G.C. Raaijmakers

Prof. mr. B.T.M. Steins Bisschop 
(c) mr. M. Brink - 2008

Voor:

John, Jacqueline, Cees, Anke, Rinke, Pim, Marlies, Hans, Arno, Arjan, Alice, Annelies, Marcel, Pieter, Frank en Johan. 
"It is uncertain whether the Dodgers' hopes of a winning season may have come to an end with the injury of pitcher Brad Penny. Why? Because the Marlins may have failed to disclose Penny's weakness during the mid-season trade? Did the Marlins hide the facts during negotiations? As the team's physician Jobe said, he has not asked to give Penny a physical examination before the Dodgers finalised the trade. Jobe said he did consult with the Marlins' medical staff and was assured Penny had no health problems at the time of the trade. Failure to do adequate discovery before finalising a deal? The Dodgers are facing the possibility of trying to get to October without Penny".

Uit: “The Lessons of Rojas: Let's Play Ball”, door E. Moreno in Newsletter Mediate.com, augustus 2004 


\section{INHOUDSOPGAVE}

Voorwoord

pagina 10

Lijst met gebruikte afkortingen

pagina 11

1. Inleiding

1.1 Introductie en plan van aanpak

pagina 13

1.2 Begripsomschrijving

1.3 Duitsland, Engeland en Frankrijk

pagina 13

pagina 14

pagina 16

$1.4 \quad$ Kapitaalmarkttransacties en onderhandse transacties

pagina 18

1.5 LOI

1.6 Bronnen van (eigen) informatie

pagina 19

$1.7 \quad$ Voorwerp van due diligence

pagina 20

1.8 Technologisch onderzoek

pagina 21

1.9 Juridisch onderzoek

1.10 Financieel onderzoek

pagina 22

pagina 23

1.11

Onderscheid met perdiodiek accountantsonderzoek of waarde-onderzoek

1.12 Fiscaal onderzoek

1.13 Commercieel onderzoek

1.14 Intellectuele eigendomsrechten

pagina 24

1.15 Milieu-aspecten

1.16 Pensioenaspecten

1.17 Mededingingsrechtelijke aspecten

1.18 Cultuuronderzoek

1.19 Onderscheid met legal audit of legal risk management project

pagina 25

pagina 28

pagina 28

pagina 29

pagina 30

pagina 31

pagina 32

pagina 34

pagina 34

1.20 Legal scan

1.21 Business audit

1.22 NCGC

1.23 Rating

1.24 Enquête

pagina 35

pagina 35

pagina 36

pagina 36

pagina 36

2. Soorten van due diligence onderzoek

$2.1 \quad$ Inleiding

2.2 Pre due diligence, pre-acquisition investigation of vendor due diligence

pagina 38

pagina 38

2.3 Investigative of confirmatory onderzoek

$2.4 \quad$ Single purpose or multi purpose

2.5 Diepgang \& omvang (quick scan, review, beperkt of volledig rapport)

- Quick scan

- Review

- Beperkt rapport

- Volledig rapport

- Documentatie

2.6 Operationele due diligence

2.7 Cultural due diligence

2.8 Post-acquisition review of completion audit

2.9 Off-premises due diligence

2.10 Onderzoek alleen of ook advies

2.11 Customer due diligence for banks

2.12 Virtuele due diligence

2.13 Noodzakelijke beperking

pagina 39

pagina 41

pagina 41

pagina 42

pagina 42

pagina 42

pagina 42

pagina 42

pagina 42

pagina 43

pagina 43

pagina 44

pagina 44

pagina 45

pagina 45

pagina 47

pagina 47

3. Causa efficiens, aanleiding voor het instellen van een due diligence onderzoek

pagina 49 3.1 Aanleiding voor een due diligence onderzoek

pagina 49 
3.2 Reglement Procedure Beursnotering (IPO)

3.3 Obligatoire regelingen. LOI / andere documentatie emissie, financieringstransactie, koop en verkoop

3.4 Due diligence en ondernemingsstrategie

4. Plaatsbepaling van een due diligence onderzoek in het Nederlands recht

pagina 54

4.1 Inleiding

- Causa remota, privaatrechtelijke redenen voor het instellen van een

pagina 54 due diligence onderzoek

4.2 Mededelingsplicht en onderzoeksplicht?

- Wederzijdse zorgplicht

- Eigen verantwoordelijkheid bij mededelingen

- Niet 'schuldig' verzwijgen

- Verkeersopvattingen

- Eigen verantwoordelijkheid bij onderzoek

- Opgewekt vertrouwen

- Mededelingsplicht versus onderzoeksplicht?

- Nogmaals, de verkeersopvattingen

- Vuistregels?

4.3 Enkele eerste gevolgtrekkingen

- Algemeen

- De omstandigheden van het geval

- Enige vorm van onderzoek vereist

- Spanningsveld tussen onderzoeks- en mededelingsplicht

- Deskundigheid betrokkenen van belang

- Wederkerig belang

pagina 56

pagina 59

pagina 59

pagina 60

pagina 60

pagina 61

pagina 63

pagina 67

pagina 69

pagina 70

pagina 72

pagina 75

pagina 75

pagina 77

pagina 77

pagina 79

pagina 80

pagina 81

5. De leerstukken welke ten grondslag liggen aan een onderzoeksplicht en een mededelingsplicht

pagina 83

5.1 Inleiding

5.2 Onderzoeksplicht

5.3 Mededelingsplicht

5.4 Zorgplicht

5.5 Dwaling

5.6 Conformiteitseis en wanprestatie

- Algemeen

- Klachtplicht koper

- Onderzoeksplicht en mededelingsplicht

- Dwaling óf wanprestatie?

5.7 Onrechtmatige daad

5.8 Bedrog en misbruik van omstandigheden

5.9 Bestuurdersaansprakelijkheid

- Artikel 2:9

- Elementaire beginselen van behoorlijk ondernemerschap

- Belangenverstrengeling

pagina 83

pagina 85

pagina 88

pagina 90

pagina 92

pagina 95

pagina 95

pagina 98

pagina 103

pagina 105

pagina 106

pagina 106

pagina 107

pagina 107

pagina 107

pagina 113

6. Recente ontwikkelingen in de rechtspraak

pagina 115

6.1 Inleiding

6.2 Casuïstiek

- Verschoonbare onachtzaamheid

pagina 115

pagina 115

- Opnieuw, de verkeersopvattingen

- Toerekenbare veronderstelling

- Onevenwichtige verdeling van deskundigheid

- Stelplicht en bewijslast

- Verdiscontering / risicoverdeling

- Toerekening

- Bijkomende vereisten

pagina 115

pagina 116

pagina 116

pagina 122

pagina 124

pagina 126

pagina 131

pagina 132 
6.3 Nadere gevolgtrekkingen

pagina 135

- De NCGC en due diligence

pagina 137

7. Juridische aspecten welke samenhangen met het fenomeen due diligence

7.1 Due diligence en garanties

- Garanties - algemeen

- Disclosure letter

- Gelden garanties onverminderd een uitgevoerd onderzoek?

- Naar beste wetenschap?

- Nogmaals garanties en het due diligence onderzoek

- Eigen wetenschap?

7.2 Meldplicht tijdens en na due diligence?

- Algemeen

- Meldplicht tijdens due diligence?

- Material adverse change

- Meldplicht na due diligence?

7.3 Opschortende of ontbindende voorwaarde

7.4 Potestatieve voorwaarde

- Subject to board approval

7.5 Bestuurdersaansprakelijkheid

7.6 Kosten van het due diligence onderzoek

pagina 139

pagina 139

pagina 139

pagina 139

pagina 140

pagina 143

pagina 147

pagina 148

pagina 149

pagina 149

pagina 150

pagina 154

pagina 155

pagina 155

pagina 156

pagina 156

pagina 161

pagina 162

8. Due diligence in de kapitaalmarkt

8.1 Due diligence en de beursvennootschap

- Openbaar bod

- Openbaar bod en voorwetenschap

- Non-disclosure and adbstention agreement

- Eigen voorwetenschap en voorwetenschap over zichzelf

- Kosten emissie due diligence aftrekbaar

8.2 Aansprakelijkheid in de primaire markt

- Prospectusaansprakelijkheid: de effectenuitgevende instelling

- Prospectusaansprakelijkheid: de lead manager van de emissiebegeleidende banken

- Prospectusaansprakelijkheid: (verbintenisrechtelijke) acties jegens de uitgevende instelling en de lead manager

- Prospectusaansprakelijkheid: de accountant

- Prospectusaaansprakelijkheid: bestuurders en commissarissen

- Prospectusaansprakelijkheid: administratiefrechtelijke aansprakelijkheid

- Enkele uitspraken

8.3 Aansprakelijkheid in de secundaire markt

- Aansprakelijkheid van beleggingsondernemingen bij overtreding van de vergunningplicht

- Aansprakelijkheid van beleggingsondernemingen bij overtreding van de gedragsregels

- Artikel 3:40 BW en artikel 1:23 Wft

pagina 164

pagina 164

pagina 164

pagina 165

pagina 169

pagina 171

pagina 171

pagina 172

pagina 173

pagina 174

pagina 175

pagina 177

pagina 177

pagina 178

pagina 178

pagina 183

pagina 184

pagina 185

pagina 186

9. Vragen rond de uitvoering van een due diligence onderzoek

pagina 187

9.1 Uitvoering onderzoek en waarborgen

- Algemeen

- De opdrachtformulering

- Het eindrapport van het onderzoek

- Aan wie wordt de opdracht verleend?

- Inzage vooraf?

9.2 Kwaliteitswaarborgen

9.3 Uitvoering onderzoek

pagina 187

pagina 187

pagina 187

pagina 187

pagina 188

pagina 188

pagina 188

pagina 193 
9.4 Hoor en wederhoor

pagina 196

9.5 Questionnaire

pagina 198

9.6 Forensische accountants

pagina 198

9.7 Settlement deed

9.8 Verklaring van de wijze van prijsbepaling

pagina 198

pagina 199

10. Aspecten van geheimhouding

pagina 200

10.1 Algemeen

pagina 200

10.2 Concurrentiepositie

10.3 Verbod overneming van personeel

10.4 Sanctionering

10.5 Positie adviseurs en derden

10.6 Geheimhoudingsplicht adviseurs

- Bankiers

- Fusiebemiddelaars

- Accountants

- Belastingadviseurs

- Advocaten

- Notarissen

- Bedrijfsjuristen

- Andere adviseurs

- Doelwitvennootschap zelf en curator

10.7 Dataroom en locatie

10.8 Wet bescherming persoonsgegevens

10.9 Document management

pagina 202

pagina 202

pagina 202

pagina 203

pagina 204

pagina 204

pagina 205

pagina 206

pagina 206

pagina 207

pagina 207

pagina 207

pagina 207

pagina 207

pagina 209

pagina 210

pagina 211

11. Verplichting tot het openbaren van de resultaten van een due diligence onderzoek?

11.1 Algemeen

11.2 Exhibitieplicht in fiscalibus

- Algemeen

- Verschoningsrecht bij belastingadviseurs

- WID en MOT

- De Fortis-uitspraak

- Inlichtingen

- Voor wie is het rapport bestemd?

- Hoge Raad 23 september 2005

- Verschoningsrecht bij bedrijfsfiscalisten

- Verschoningsrecht bij accountants

11.3 Exhibitieplicht in civilibus

- Algemeen

- Jurisprudentie artikel 843a Rv

- Voorwaarden blijkens jurisprudentie

- Verschoningsgerechtigden in civilibus

- Notarissen en advocaten

- Bedrijfsjuristen in dienstbetrekking

11.4 Gevolgtrekkingen

11.5 Recht op toegang tot informatie na overdracht daarvan

pagina 212

pagina 212

pagina 213

pagina 213

pagina 213

pagina 214

pagina 215

pagina 215

pagina 216

pagina 217

pagina 219

pagina 220

pagina 221

pagina 221

pagina 222

pagina 226

pagina 228

pagina 229

pagina 232

pagina 233

pagina 233

11.6 Artikel 843a Rv dwingend recht?

11.7 Wet Melding Ongebruikelijke Transacties

11.8 Due diligence en mediation

pagina 234

pagina 235

pagina 237

12. Due diligence en de ondernemingsraad

pagina 238

12.1 Artikel 25 WOR

pagina 238

12.2 Artikel 26 WOR

pagina 238 
13. Beroepsaansprakelijkheid en exoneratie

pagina 240

13.1 Aspecten van aansprakelijkheid

pagina 240

- Aansprakelijkheid onderzoeker, mogelijkheden tot beperking

pagina 240

- Afbakenen onderzoek

- De opdrachtformulering

pagina 242

- Het eindrapport van het onderzoek

pagina 243

- Verspreiding van het rapport

- De mogelijkheid om de aansprakelijkheid zelf te beperken

pagina 243

pagina 243

pagina 244

- 'Onderaanneming'

- Moeilijke bewijsopdracht

13.2 Aansprakelijkheid belastingadviseur / accountant

pagina 245

pagina 245

- Wtaa en Accountantskamer

pagina 246

- Accountants

- Bewustzijnscriterium

pagina 246

pagina 246

pagina 253

- Causaal verband

13.3 Toerekening van de kennis van de onderzoeker aan de opdrachtgever pagina 254

pagina 255

13.4 Reliance Letter

13.5 Spontane adviesplicht adviseur?

13.6 Eigen aanspraken adviseur

14. Slotopmerkingen

pagina 262

Samenvatting

pagina 271

Summary

pagina 278

Lijst van geraadpleegde literatuur en jurisprudentie

pagina 285 


\section{Voorwoord}

Hoewel het begrip due diligence in de rechtspraktijk veelvuldig wordt gebruikt, is het een abstract thema, dat vele gedaanten kent. $\mathrm{Er}$ is in ons land over het onderwerp wel het nodige gepubliceerd, maar steeds fragmentarisch. Het leek daarom de moeite waard een terreinverkenning te doen.

Hopelijk kunnen de resultaten van mijn werk bijdragen aan een overzichtelijk beeld van het onderwerp due diligence. Ik heb mij daarbij vooral beperkt tot de verschillende aspecten welke naar Nederlands recht betrokken zijn bij het onderwerp. Het doel van dit boek is om het fenomeen due diligence een eigen gezicht te geven in de juridische landkaart van ons land. Door de breedte van het onderwerp moesten er concessies worden gedaan aan (verdere) verdieping, waar aspecten van de materie daartoe soms wel uitnodigden. Door beperking als een noodzakelijk kwaad te aanvaarden, is het hopelijk gelukt tenminste een basis te scheppen, waar vervolgstudies op gebaseerd kunnen worden.

Hierna wordt het begrip due diligence in de verschillende voorkomende verschijningsvormen besproken. Daarbij wordt verwezen naar artikelen in het Burgerlijk Wetboek, tenzij anders is aangegeven.

Ik heb veel van de gangbare Angelsaksische terminologie gebruikt, die nu eenmaal in de praktijk een eigen plaats heeft verworven. Het vertalen van al die begrippen - hoewel dus vaak wel mogelijk - zou voor gebruikers van dit boek in de due diligence praktijk een aantal vreemde eenden in de bijt hebben opgeleverd, die wellicht afbreuk aan de bruikbaarheid zouden hebben gedaan.

Ik dank mijn echtgenote Anita en mijn dochters Anne en Suzanne voor hun begrip en aanmoediging in de periode dat ik dit boek schreef.

Daarnaast ben ik vooreerst verschuldigd aan mijn partners bij Van Benthem \& Keulen in Utrecht, die mij kostbare tijd gegund hebben om dit boek te schrijven. Ik draag dit boek aan hen op en aan Johan Koggink, de directeur van mijn kantoor, welke laatste het project van dit boek zo van harte heeft ondersteund. Andere kantoorgenoten aan wie ik dank verschuldigd ben, zijn in het bijzonder ook Saskia Wilmes, Sylvia Braun en Gülhan van Gool, "de dames van de bibliotheek". Danielle Schutten en Linda Zwijnenberg ben ik veel dank verschuldigd voor het nalezen van het manuscript en hun vele nuttige bijdragen. Ik bedank ook Annemieke van der Linden en Machtelt van Term. Daarnaast waren meerdere kantoorgenoten steeds bereid om met mij mee te denken, zoals mijn sectiegenoten Pim Schermer, Frank Richel en Sander Marges. Zonder mijn secretaresse Muriëlle Derks tenslotte, zoveel is zeker, zou dit boek er nooit zijn gekomen. Ik bedank hen allen.

Professor C.A. Schwarz heeft niet afgelaten mij tot het schrijven van een boek aan te zetten. Zijn stimulerende ondersteuning is steeds belangrijk voor mij geweest. Ook professor M.J.G.C. Raaijmakers heeft veel bijgedragen aan mijn geloof dat het schrijven van een boek op het snijvlak van wetenschap en praktijk de moeite waard kon zijn. Hun vertrouwen was een belangrijke stimulans.

De tekst voor dit boek is op 1 mei 2008 afgesloten. Nadien verschenen literatuur of rechtspraak is niet meer verwerkt, met uitzondering van een enkel gegeven dat middels een bijzondere noot $\left(^{*}\right)$ nog kon worden toegevoegd.

Martin Brink

Bosch en Duin, 1 juli 2008 


\section{Lijst met gebruikte afkortingen}

\begin{tabular}{|c|c|}
\hline AFM & Autoriteit Financiële Markten \\
\hline$A-G$ & Advocaat generaal \\
\hline AktG & Aktiengesetz \\
\hline AMvB & Algemene Maatregel van Bestuur \\
\hline A.w. / a.w. & Aangehaald werk \\
\hline AWR & Algemene Wet in zake Rijksbelastingen \\
\hline $\mathrm{Bb}$ & Bedrijfsjuridische Berichten \\
\hline CBB & College van Beroep voor het Bedrijfsleven \\
\hline Contracteren & Tijdschrift voor de contractspraktijk \\
\hline CoVo & EG Concentratie Verordening (Verordening 139/2004) \\
\hline De NV & De Naamlooze Vennootschap \\
\hline EK & Eerste Kamer \\
\hline HvJ EG & Europese Hof van Justitie \\
\hline FD & Het Financieele Dagblad \\
\hline $\mathrm{F} \& \mathrm{O}$ & Fusie \& Overname \\
\hline GBAA & $\begin{array}{l}\text { Gedrags- en Beroepsregels Accountant Administratie-consulen- } \\
\text { ten }\end{array}$ \\
\hline GBR & Gedrags- en Beroepsregels Registeraccountants 1994 \\
\hline Groningse Serie & $\begin{array}{l}\text { Serie publicaties vanwege het Instituut voor Ondernemingsrecht } \\
\text { Rijksuniversiteit Groningen, uitgegeven door Kluwer }\end{array}$ \\
\hline HR & Hoge Raad \\
\hline JOR & Jurisprudentie Ondernemingsrecht \\
\hline Koper & $\begin{array}{l}\text { Zowel als koopster, maar ook investeerder en aandeelhouder, al } \\
\text { naar gelang het geval }\end{array}$ \\
\hline LOI & Letter of Intent \\
\hline Mw. & Mededingingswet \\
\hline NIVRA & Koninklijk Nederlands Instituut van Registeraccountants \\
\hline Nijmeegse Serie & $\begin{array}{l}\text { Serie publicaties vanwege het Van der Heijden Instituut, uitgege- } \\
\text { ven door Kluwer }\end{array}$ \\
\hline NJ & Nederlandse Jurisprudentie \\
\hline NJB & Nederlands Juristenblad \\
\hline NMa & Nederlandse Mededingings Autoriteit \\
\hline NV COS & Nadere Voorschriften Controle- en Overige Standaarden \\
\hline p. & Pagina \\
\hline PP & Practisch Procederen \\
\hline O\&F & Onderneming \& Financiering \\
\hline OR & Ondernemingsraad \\
\hline OK & Ondernemingskamer van het gerechtshof te Amsterdam \\
\hline $\mathrm{PbEG}$ & Publicatieblad van de Europese Gemeenschap \\
\hline Prg. & Praktijkgids \\
\hline $\mathrm{Rb}$. & Rechtbank \\
\hline $\mathrm{Sr}$ & Wetboek van Strafrecht \\
\hline t.a.p. & Ter aangehaalde plekke \\
\hline $\mathrm{T} \& \mathrm{C}$ & Tekst \& Commentaar Burgerlijk Wetboek, Kluwer \\
\hline TK & Tweede Kamer \\
\hline TOP & Tijdschrift voor de Ondernemingsrechtpraktijk \\
\hline VGC & Verordening Gedrags Code \\
\hline V\&O & Vennootschap \& Onderneming \\
\hline VrA & Vermogensrechtelijke annotaties \\
\hline Wfd & Wet financiële dienstverlening \\
\hline Wft & Wet financieel toezicht \\
\hline
\end{tabular}


Vr. Wft

Wtaa

Wta

Wte

Wmz

WvS

WPNR
Vrijstellingsregeling $\mathrm{Wft}$

Wet tuchtrechtspraak accountants

Wet toezicht accountantsorganisaties

Wet toezicht effectenverkeer

Wet melding zeggingschap

Wetboek van Strafrecht

Weekblad voor Privaatrecht, Notariaat en Registratie 


\section{Inleiding}

\section{$1.1 \quad$ Introductie en plan van aanpak}

Dit boek bevat de neerslag van een poging om de plaats van het fenomeen due diligence - vooral bij onderhandse transacties - in ons recht te bepalen. Het onderwerp due diligence staat met diverse leerstukken van ons recht in verbinding. Dwaling, bedrog, conformiteit (wanprestatie), algemeen verbintenissenrecht (garanties, voorwaarden) en onrechtmatige daad om de belangrijkste te noemen. Dit boek bevat geen studie van al deze leerstukken en heeft ook niet die pretentie. Voor zover er op een of meer van de hier voor bedoelde leerstukken wordt ingegaan, is dat uitsluitend ter ondersteuning van de poging om zicht te bieden op de aard en omvang van het verschijnsel due diligence. Ik erken daarom meteen in de eerste paragraaf van dit boek mijn beperkingen te beseffen, waar het een (verdergaande) mate van diepgang betreft daar waar een of meer van de bedoelde leerstukken aan de orde komen. Veel schrijvers hebben die leerstukken bekwaam onderzocht en uitgediept, zij het niet altijd vanuit het paradigma van een due diligence onderzoek. Mij is het er om te doen geweest het fenomeen due diligence een gezicht te geven. Tot dusverre is dit te onzent niet veel meer dan een abstract begrip, waaraan iedereen wel enige, maar zeker niet steeds dezelfde betekenis toekent. Een boek dat zich vooral op een verdieping van dat thema richt - daarbij de juridische context opzoekend -en dat de verschillende aspecten van het fenomeen due diligence juridisch kwalificeert, leek het daarom te verdienen om te worden geschreven.

De wijze van aanpak is aldus, dat er in dit Hoofdstuk 1 eerst een begripsomschrijving zal worden gegeven en zal worden ingegaan op de eigen plaats van het due diligence onderzoek te midden van andere vormen van onderzoek.

In hoofdstuk 2 worden de verschillende verschijningsvormen van een due diligence onderzoek geïnventariseerd en besproken.

Hoofdstuk 3 staat stil bij de verschillende aanleidingen die er kunnen zijn om een due diligence onderzoek te ondernemen.

In een poging het fenomeen due diligence te plaatsen in het Nederlands recht wordt in hoofdstuk 4 na een korte inleiding een geselecteerd aantal uitspraken van de Hoge Raad en andere rechters besproken, waarin overwegingen voorkomen, die vertaald naar het onderwerp van een due diligence onderzoek relevantie toekomen. Daarbij moest - gelet op de hoeveelheid casuïstische jurisprudentie die voorhanden is - noodzakelijk worden volstaan met een keuze. De keuze is gemaakt op grond van de overwegingen van vooral de Hoge Raad, die laten zien welke rode draad te trekken is vanaf het arrest Baris/Riezenkamp naar nu.

In hoofdstuk 5 zal dan nog kort ingegaan worden op de betekenis van de leerstukken van dwaling, bedrog, conformiteit en onrechtmatige daad, ter positionering in ons recht van de zin en onzin van het uitvoeren van een due diligence onderzoek. Daarna zal in hoofdstuk 6 meer jurisprudentie worden besproken. Daarbij zal worden geprobeerd nog meer het verband op te zoeken tussen het onderwerp due diligence, de ontwikkelingen in de rechtspraak en - waar aangewezen - de literatuur. Dat hoofdstuk zal worden afgesloten met enkele nadere gevolgtrekkingen en een enkele opmerking over due diligence en de Nederlandse Corporate Governance Code.

Daarna zullen in hoofdstuk 7 nog verschillende juridische aspecten worden aangesproken, die verband houden met het due diligence onderzoek. Te denken valt aan de relatie tot garanties en de vraag of er een verplichting kan worden aangenomen om tijdens het uitvoeren van een due diligence onderzoek ontdekte gebreken te melden aan de wederpartij. Een enkel woord zal worden besteed aan de betekenis van voorwaarden, in het bijzonder de potestatieve voorwaarde.

In hoofdstuk 8 wordt stil gestaan bij de bijzondere positie van een beursvennootschap in relatie tot het onderwerp van een due diligence onderzoek.

In hoofdstuk 9 wordt ingegaan op aspecten van de uitvoering van een onderzoek en waarborgen voor kwaliteit. Aspecten van geheimhouding en een exhibitieplicht komen in hoofdstuk 10 en 11 aan de orde. $\mathrm{Na}$ te hebben stil gestaan bij de rol van de ondernemingsraad in relatie tot due diligence in hoofdstuk 12, wordt in hoofdstuk 13 nader ingegaan op aspecten van beroepsaansprakelijkheid, exoneratie en rechtskeuze. Hoofdstuk 14 noemt nog een aantal slotopmerkingen. 
Waar er sprake kan zijn van due diligence bij zowel kapitaalmarkttransacties als onderhandse transacties, kan er sprake zijn van partijen die in onderscheidene gevallen verschillend te benoemen zijn: koper en verkoper, investeerder, kredietverschaffer en zo verder. Tenzij het bedoeld is aan de benaming waar het om gaat een bijzondere betekenis toe te kennen, dient in het navolgende onder het begrip koper en/of verkoper tevens een andere betiteling te worden begrepen, wanneer hetgeen hierna wordt opgemerkt ook in andere situaties dan koop en verkoop van toepassing kan zijn. Dit laatste zal vaak het geval zijn.

\section{$1.2 \quad$ Begripsomschrijving}

De term 'due diligence', zoals die heden te dage in de transactiepraktijk wordt gekend, is de uitdrukking van een activiteit ter vermijding van aansprakelijkheid, welke is voortgekomen uit de Amerikaanse financiële praktijk ${ }^{1}$. Hoewel daarin met zoveel woorden niet genoemd, heeft het begrip in de Verenigde Staten van Amerika aanvankelijk vooral betekenis gekregen door de regeling van Artikel 11 jo. 12 van de Securities Act van 1933. Voor zover relevant, luidt Section 11 van de Securities Act 1933, welke bepaling het best kan worden vergeleken met te onzent de regelgeving op grond van de Prospectusrichtlijn:

"In case any part of the registration statement, when such part became effective, contained an untrue statement of a material fact or omitted to state a material fact required to be stated therein or necessary to make the statements therein not misleading, any person acquiring such security (unless it is proved that at the time of such acquisition he knew of such untruth or omission) may, either at law or in equity, in any court of competent jurisdiction sue:

(1) every person who signed the registration statement;

(2) every person who was a director of (or person performing similar functions) or partner in the issuer at the time of the filing of the part of the registration statement with respect to which his liability is asserted;

(3) every person who, with his consent, is named in the registration statement as being or about to become a director, person performing similar functions, or partner;

(4) every accountant, engineer, or appraiser, or any person whose profession gives authority to a statement made by him, who has with his consent been named as having prepared or certified any part of the registration statement, or as having prepared or certified any report or valuation which is used in connection with the registration statement, with respect to the statement in such registration, statement, report, or valuation, which purports to have been prepared or certified by him;

(5) every underwriter with respect to such security...."

Section 11(b)(3)(A) zegt verder:

"(...) no person, other than the issuer, shall be liable as provided therein who shall sustain the burden of proof that (...) he had, after reasonable investigation, reasonable ground to believe and did believe, at the time such part of the registration statement became effective, that the statements therein were true and that there was no omission to state a material fact required to be stated therein or necessary to make the statements therein not misleading."

Section 11(c) zegt dat bij het vorenstaande de maatstaf heeft te gelden van een 'prudent man in the management of his own property'.

G.T.M.J. Raaijmakers noemt in Garanties bij overnames (p. 19) een uitspraak van een Engelse rechter uit 1881, waarin het begrip al voorkomt (Redgrave v. Hurd 20Ch.D.1, p. 13): "If a man is enduced to enter into a contract by false representation it is not a sufficient answer for him to say: If you had used due diligence you would have found out that the statement was untrue."

2 Prospectusrichtlijn (2003/71/EG), als op 31 december 2003 gepubliceerd in PbEG L 345/64, 31.12.2003, en per die datum in werking getreden. De Prospectusrichtlijn is op 1 juli 2005 in ons land geïmplementeerd. Bij de Prospectusrichtlijn hoort de Verordening Nr. 809/2004 die rechtstreeks doorwerkt in onze nationale wetgeving. 
Ook artikel 12(2) van de Securities Act 1933 en een aantal andere bepalingen in de Amerikaanse effectenverkeersrecht regelingen ${ }^{3}$ kennen een disculpatiegrond indien er aangetoond kan worden, dat er een zorgvuldig onderzoek heeft plaatsgevonden naar de correctheid van de inhoud van het ter gelegenheid van een transactie in effecten opgesteld document. Volgens Lawrence ${ }^{4}$ heeft veruit het merendeel van de gevallen waarin er in de Verenigde Staten sprake is van potentiële aansprakelijkheid voor onvoldoende zorgvuldig onderzoek, dit betrekking op de denkbare aansprakelijkheid op grond van de Securities Act 1933 bij de openbare uitgifte van effecten:

"In a corporate finance setting, the due diligence investigation is designed to, among other things, provide a basis for "due diligence" or "reasonable investigation" defense to parties (other than the issuer) who may have liability under Section 11 of the Securities Act of 1933. In addition effective due diligence investigations can be helpful in limiting exposure under Sections 12(2) and 17(a) of that Act and under Section 10(b) and Rule 10b-5 of the Securities Exchange Act of 1934.

In a merger/acquisition setting, the due diligence investigation focuses on the target company and its corporate records and other documents, and is generally designed to test the accuracy of representations and warranties contained in the related purchase agreement and items disclosed in the disclosure schedule attached to it. ${ }^{5} \mathrm{In}$ both corporate finance and merger/acquisition settings the process will also provide the basis and backup for any legal opinion the firm may be required to issue in connection with the transaction."

en

"Nowhere in the 1933 Act, the Securities Exchange Act, or any rule thereunder do the words "due diligence" appear. The phrase is more a "term of art" extrapolated from the language of Section 11, where if the underwriters reasonably believed after a reasonable investigation that no violation existed, and that the underwriter could not have known a violation existed after exercising reasonable care, liability is precluded under Section 12(2)."

In de Verenigde Staten van Amerika vooral geboren dus uit een defensieve insteek - men kon aansprakelijkheid afhouden als duidelijk kon worden gemaakt dat er voldoende zorgvuldig onderzoek was verricht en bijvoorbeeld niet alleen was afgegaan op verklaringen van bestuurders ${ }^{6}$ - kreeg een due diligence onderzoek gaandeweg ook betekenis als instrument om (andere) risico's te inventariseren, adresseren en helpen te voorkomen. De "benodigde zorgvuldigheid", die begrepen werd onder het begrip "due diligence" kwam ook al tot uitdrukking in de regels die waren neergelegd in een door de National Association of Securities Dealers in 1973 opgesteld concept voor een gedragscode, ${ }^{7}$ zij het niet onder die benaming. Niettemin heeft het begrip "due diligence" uiteindelijk eigen merkbekendheid gekregen en is de toepassing buiten het effectenverkeersrecht ook in de fusie en overname praktijk algemeen geworden.

In materieel opzicht is er zowel in de Verenigde Staten van Amerika als bij ons en overal sprake van een inspanning om zich te vergewissen van de deugdelijkheid van verklaringen of de betrouwbaarheid van personen of instellingen, waarmee in zakelijk opzicht contact wordt onderhouden vanaf het moment waarop de eerste argeloze koper het slachtoffer werd van een listige verkoper. Tenzij het een ezel betrof, die zich twee maal aan dezelfde steen stootte - maar in ieder geval niet al diegenen die van het gebeurde getuige waren geweest - gebeurde dat bij voorkeur niet (nog eens). Die aangeleerde voorzichtigheid, drijt nog steeds de behoefte om tijdig een onderzoek te doen naar de betrouwbaarheid van zaken en personen, en in "de Wereld van Peter Stuyvesant", waarin het om grote bedra-

\footnotetext{
Zoals artikel 17(a) van de Securities Act 1933 en Section 10(b) and Rule 10b-5 van de Securities Exchange Act 1934. Gary M. Lawrence, Due Diligence in Business Transactions (ISBN 9781588520661), para 2.02.

Lawrence heeft het hier - zoals in hoofdstuk 2 zal blijken - alleen over de zogenaamde confirmatory due diligence.

Het feit dat Drexel Burnham Lambert Inc. had volstaan met zich te verlaten op verklaringen van het management (zogenaamde management certificates) leidde tot aansprakelijkheid in Escott v. BarChris Construction Corp. (283 F. Supp. 643 S.D.N.Y. 1968), in welk geval de rechter oordeelde: 'the underwriters must make some reasonable attempt to verify data submitted to them by management". Raaijmakers verwijst (a.w., p. 18) nog naar Rule 176 bij de Securities Act, waarin omstandigheden zijn genoemd die in ieder geval moeten worden meegenomen bij de beoordeling of een persoon in kwestie, zoals de lead manager, voldoende zorgvuldig te werk is gegaan ("Circumstances Affecting the Determination of What Constitutes Reasonable Investigation and Reasonable Grounds for Belief Under Section 11 of the Securities Act").

7 Underwriter inquiry and investigation standards in connection with issuances of securities. Het bleef bij een concept.
} 
gen en grote belangen gaat heeft die voorzichtigheid de vorm gekregen van een due diligence onderzoek.

Het begrip due diligence laat zich niet goed naar het Nederlands vertalen. $\mathrm{Er}$ is geen Nederlands equivalent voor deze term, of het zou "gepaste voorzichtigheid" danwel "verschuldigde oplettendheid" moeten zijn. Er is uiteraard verschil tussen een voorzichtigheid die onder omstandigheden gepast is enerzijds en voorzichtigheid die berust op een verplichting (verschuldigdheid) anderzijds. Op de vraag in hoeverre er sprake is van een verschuldigdheid in dit opzicht, wordt elders in dit boek ingegaan.

Met due diligence wordt (ook) in ons land het onderzoek bedoeld dat wel plaatsvindt als er sprake is van een wijziging in de zeggenschap in een rechtspersoon of in de eigendom van een onderneming of er een (andere) financiële transactie van betekenis aan de orde is. ${ }^{8}$ Een due diligence onderzoek vindt met name plaats bij voorgenomen beursintroducties, fusies, overnames, joint ventures, bij het nemen van een financiële of juridische deelneming of bij het aangaan van leningsarrangementen. Nu het bij transacties als hier voor bedoeld voor diegenen die de investeringen doen of de beslissingen moeten nemen, 'van buitenaf' niet te zien is of er in de doelwitvennootschap problemen te verwachten zijn of onwelgevallige verplichtingen zijn aangegaan, dan wel voor de doelwitvennootschap aansprakelijkheden aan de orde (kunnen) zijn, wordt een onderzoek uitgevoerd om zoveel mogelijk duidelijkheid te verkrijgen over het voorwerp van koop en/of over de partij waarmee een transactie wordt aangegaan. Een due diligence onderzoek kan ook nuttig zijn om (vooraf of achteraf) vast te stellen of een (te betalen of betaalde) prijs niet te hoog of te laag is (geweest). Partijen beogen soms ook een zekere waarborg te verkrijgen in de oneigenlijke zin van een "verzekering", wanneer derden een onderzoek hebben ingesteld. Mocht er iets over het hoofd zijn gezien, dan is er denkbaar verhaal voor schade bij meer partijen dan alleen de eigen wederpartij. Bovendien is het resultaat van een due diligence onderzoek vaak van belang bij het formuleren van overname- of andere transactiedocumenten. De uitkomst van het due diligence onderzoek kan mede bepalend zijn voor de vraag welke garanties en/of vrijwaringen er verlangd (zullen) worden.

Due diligence komt daarnaast ook voor in de zin van een deugdelijkheidsonderzoek, bijvoorbeeld bij het verlenen van financieringen door banken (de zogenaamde customer due diligence, waarover later meer).

Bij een regulier due diligence onderzoek, binnen het kader van een commerciële transactie tussen ondernemingen, zal een due diligence onderzoek veelal verschillende onderzoeksterreinen betreffen. Elk van die terreinen wordt onderzocht door een specialist op het desbetreffende gebied. Men onderscheidt hoofdzakelijk de volgende gebieden:

- $\quad$ financiële en accountancy aspecten

- $\quad$ fiscale aspecten

- $\quad$ juridische aspecten

- milieu aspecten

- $\quad$ technologie aspecten, en laatstelijk ook:

- $\quad$ synergie en integratievoordelen (cultuuraspecten).

Het begrip "due diligence" wordt overigens te pas en te onpas gebruikt. Ook voor zaken die eigenlijk weinig van doen hebben met de traditionele betekenis van het begrip, die hiervoor is aangegeven. Als voorbeeld noem ik een questionnaire die onder de naam "nieuw 'due diligence' instrument voor commissarissen" werd gepubliceerd door PricewaterhouseCoopers. De questionnaire blijkt een zelftest in de vorm van een vragenlijst die commissarissen zou moeten helpen bij het nemen van de beslissing over het wel of niet accepteren van een commissariaat. ${ }^{9}$

Due diligence in de gebruikelijke zin van het woord is, als gezegd, niet noodzakelijk een uitsluitend juridische aangelegenheid. ${ }^{10}$ Specialisten op de hiervoor genoemde terreinen worden wel ingeschakeld om op het gebied van de eigen expertise, het onderzoek te verrichten.

\subsection{Duitsland, Engeland en Frankrijk}

\footnotetext{
8 N.W. Vlaar en A. Ezinga in Het due diligence-onderzoek en de rol van de accountant (MAB, december 1997, p. 636) noemen het due diligence onderzoek 'een integrale bedrijfsdoorlichting'.

9 Zie www.fd.nl.

10 Zie ook A.N. Lodder en I. Seitz, Het due diligence onderzoek, de koper wil financieel, fiscaal, juridisch en milieutechnisch alles weten, F\&O april 1996, nr. 4, p. 13 e.v.
} 
In Duitsland geldt dat het bestuur van een vennootschap (AG) verplicht is een due diligence onderzoek uit te (doen) voeren in het geval van een overname ${ }^{11}$ :

"Als Ergebnis ist festzuhalten, dass die Mitglieder des Vorstands seiner AG sowohl im Vorfeld eines Unternehmenskaufs als auch nach Erwerb des Unternehmens zur Durchführung einer Due-Diligence-Prüfung verpflichtet sind. Diese Pflicht zur Due Diligence ist eine spezielle Ausformung der allgemeinen Pflicht des Vorstands zur sachgerechten Vorbereitung seiner Entscheidungen, zu der er nach § 93 Abs. 1 Satz 1 AktG verpflichtet ist."

In Duitsland kent men wel het beginsel 'Forvertragliche Aufklärungspflichten'. Het onvermeld laten van gegevens, waarvan de verkoper weet dat die essentieel zijn voor de koper, kwalificeert wel als 'Eigentlichtige Täuschung'. ${ }^{12}$

In Engeland geldt het beginsel van caveat emptor ("buyer beware") ${ }^{13}$. Dit beginsel brengt in het algemeen mee dat het de verantwoordelijkheid van een koper is om zeker te stellen dat het voorwerp van koop of van een transactie (door een investeerder) voldoende begrepen wordt voordat een verplichting wordt aangegaan. Binnen dat kader is het due diligence proces in Engeland een belangrijke stap om meer te weten te komen van het voorwerp van koop of het voorwerp van een transactie. De bedoeling is vooraf door middel van prijsreducties of garanties en vrijwaringen zich te verzekeren tegen teleurstellingen achteraf. In Engeland wordt aangenomen dat de eigen verantwoordelijkheid het leidende beginsel is. Zo kan een derde in het algemeen ook niet afgaan op de cijfers van de accountant van de doelwitvennootschap. ${ }^{14}$

In Engeland geldt het principe van non-disclosure. De wetenschap van belangrijke informatie die van invloed kan zijn op het wel of niet aangaan van een transactie, behoeft op zichzelf niet bij de wederpartij een verplichting tot spreken mee te brengen. De wederpartij heeft eerst een spreekplicht wanneer de koper om bijzondere informatie vraagt: "It is therefore up to the purchaser to do what he can, by investigation (the due diligence exercise) and contractual provision, to ensure that the target company owns those assets which it is thought to process and that it has no liabilities apart from those of which the purchaser is aware"15. De koper van een onderneming in Engeland kan geen beroep doen op dwaling zoals bij ons, wanneer hij niet over alle informatie met betrekking tot het voorwerp van een transactie heeft beschikt, zodat deze zich zal proberen in te dekken door het bedingen van zoveel mogelijk garanties. Bij schending van die garanties kan worden geageerd wegens wanprestatie.

Due diligence is in Frankrijk niet wettelijk geregeld. Evenmin als een verplichting om informatie te verschaffen, voorafgaand aan de overdracht van een onderneming. De due diligence procedure wordt in Frankrijk beschouwd als het geheel van maatregelen van onderzoek en controle van informatie dat de onderzoekers in staat (moet) stellen een oordeel te vormen over de activa, de activiteiten, de financiële situatie en de toekomstmogelijkheden van de onderneming waarin men wil deelnemen.

$\mathrm{Er}$ is wel een aanbeveling van de Commission des Opérations de Bourse ("COB") van 6 november $2003^{16}$ met bepalingen volgens welke de belangen van aandeelhouders moeten worden beschermd tegen misbruik van voorwetenschap middels procedureafspraken bij het gebruik maken van een dataroom. Die regels hebben betrekking op het beschermen van vertrouwelijke informatie. Zij houden geen

11 R. Werner, Haftungsrisiken bei Unternehmensakquisitionen: die Plicht des Vorstands zur Due Diligence, Zeitschrift für Wirtschaftsrecht, 9 juni 2000/S. 989, p. 996.

12 Zie gerechtshof te 's-Gravenhage 26 juni 2002, Prg. 2003, 6056, p. 483 e.v., een uitspraak van de Nederlandse rechter, gebaseerd op paragraaf $2.49 \mathrm{bdb}$. Bij het aangaan van de koopovereenkomst was de verkoper op de hoogte van de armzalige liquiditeitspositie van de doelwitvennootschap. De laatstgenoemde betaalde haar personeel alleen nog netto salaris en was gestopt met het betalen van loonbelasting en het afdragen van sociale premies. Wel de schuldeisers maar niet de aspirant-kopers werden daaromtrent ingelicht.

13 Zie over de Engelse rechtsfiguur, welke met dwaling bij ons te vergelijken is (negligent misrepresentation) M. van Oosten, De onderzoeksplicht bij de koop van aandelen, V\&O februari 2004, nr. 2, p. 22 e.v.

${ }^{14}$ Zie Caparo Industries v. Dickman [1990] 2 WLR 358 en ADT Ltd. v. BDO Binder Hamlin [1996] BCC 808. Zie ook www.practicallaw.com/6-107-3752:: Due diligence and post-completion integration: acquisitions.

15 Door M. van Oosten genoemd (a.w.) en ontleend aan Ronald D. Fox, Due diligence, disclosures and warranties in the corporate acquisitions practice, London (Graham \& Trotman) 1988, p. 137.

16 Zie D. Schmidt, Commentaire de la recommendation no. 2003-01 de la COB relative aux procédures dites de 'data room', JCP E 2004, no. 560. 
verplichting in tot verschaffing van informatie door een verkoper. Voor zover er voor een verkoper een verplichting bestaat om informatie te verschaffen, is in Frankrijk die verplichting gebaseerd op algemene regels van redelijkheid en billijkheid. Indirecte grondslag daarvoor is dan artikel 1134 derde alinea van de Franse Code Civil. Zowel de rechtsverhouding ten tijde van het tot stand komen van een overeenkomst als bij de tenuitvoerlegging daarvan, wordt volgens de recente rechtspraak meer en meer beheerst door de redelijkheid en billijkheid op grond van de genoemde wetsbepaling. ${ }^{17}$ Op contractspartijen rust een verplichting te vermijden dat de zwakte van de ander wordt uitgebuit. Waar er verschil in positie bestaat tussen een koper en verkoper vanwege een voorsprong in informatie, zal in het geval van problemen tussen beiden, de Franse rechter geneigd zijn aan te nemen dat de verkoper - die degene met de informatievoorsprong zal zijn - (meer) informatie had behoren te verschaffen. Niet veel anders dan te onzent, geldt in Frankrijk, dat een verkoper niet mag zwijgen wanneer het informatie betreft, waarvan hij weet dat de koper niet zou hebben willen contracteren, wanneer die met de informatie bekend zou zijn geweest. Wanneer een koper evenwel over voldoende informatie beschikt om gewaarschuwd te zijn, zal die zelf nader onderzoek moeten verlangen alvorens te contracteren. Indien er informatie beschikbaar wordt gemaakt, zal een koper die moeten raadplegen. Ook in Frankrijk dient een koper van een onderneming zich er van bewust te zijn, dat het drijven van een onderneming risico's meebrengt. De koper dient zich daartegen naar vermogen te beschermen bij het aangaan van een transactie. In Frankrijk geldt, dat het enkele raadplegen van de jaarcijfers daarvoor onvoldoende is. Evenals in andere landen spelen ook in Frankrijk garanties een belangrijke rol in overname overeenkomsten.

\subsection{Kapitaalmarkttransacties en onderhandse transacties}

Ik zal hierna - tenzij anders aangegeven - geen bijzonder onderscheid (meer) maken tussen due diligence bij kapitaalmarkttransacties enerzijds en bij onderhandse bedrijfsovernames of corporate finance transacties anderzijds. Dit boek gaat over due diligence ter gelegenheid van transacties tussen in het algemeen professionele partijen. Wel wordt hierna ook aandacht besteed aan de discrepantie welke er kan bestaan tussen professionele en niet of minder professionele partijen, en de invloed welke die discrepantie in de rechtspraak doet gelden. Ik doel daarbij op 'gewone' commerciële transacties zoals de koop van een onderneming of van aandelen in onderhandse transacties. Voor financiële of kapitaalmarkttransacties waarbij niet aan beide zijden professionele partijen zijn betrokken, gelden soms de regels ter bescherming van marktpartijen, zoals te onzent de regelgeving op grond van de Prospectusrichtlijn of soortgelijke regelingen, die eenzijdig verplichtingen opleggen aan de professionele partij die bij een transactie betrokken is. Met de invoering van de Markets in Financial Instruments Directive (MiFID) per 1 november 2007 is er sprake van een uitbreiding van de zorgplicht van financiële instellingen ten opzichte van niet professionele en bepaalde professionele partijen waardoor de zorg voor voldoende duidelijkheid over de inhoud van financiële producten nog meer bij de uitgevende instellingen en hun adviseurs wordt gelegd. ${ }^{18}$ Ook is het beginsel "ken uw cliënt" verder uitgewerkt. ${ }^{19}$

Dit betekent niet dat een niet-professionele partij zich in het geheel niets behoeft af te vragen bij het aangaan van transacties met een professionele partij. De jurisprudentie, waarbij - in gevallen waarin bijvoorbeeld op grond van het onvoldoende in acht nemen van een zorgplicht door een bank een vordering tot vergoeding van schade werd ingesteld - de rechter tot het oordeel komt, dat er aan de zijde van de niet-professionele partij sprake is van medeschuld, is talrijk.

\footnotetext{
17 Zie Traité Joly, Sociétés Commerciales, Tome 2, p. 25 e.v.

18 Zie C.H.D.W. van den Borne-Verheijen, De zorgplicht, de Wft en MiFID, Bb 2007, 47, p. 183 e.v. In het belang van een goede beleggersbescherming dient de relatie tussen de belegger en de persoon die onder het Nationaal regime diensten verleent, duidelijk vast te worden gelegd in een cliëntenovereenkomst. Bedoeld is op die wijze de verantwoordelijkheid voor de betrokken persoon die onder het Nationaal regime diensten verleent, beter kenbaar te maken richting de cliënt en wordt tevens de aansprakelijkheid in verband met die verantwoordelijkheid vastgelegd. Artikel 4:90 Wft is van overeenkomstige toepassing verklaard. Het Nationaal regime is de Nederlandse uitwerking van de NiFID teneinde de lasten welke de implementatie van de richtlijn zou meebrengen voor bepaalde categorieën van tussenpersonen wat te verlichten. Hierbij moet gedacht worden aan het ontvangen en doorgeven van orders met betrekking tot rechten van deelneming door tussenpersonen in het kader van effectenhypotheken, pensioenproducten, bankspaarproducten en vermogensopbouwprodukten met een beleggingscomponent en het adviseren over transacties in dergelijke financiële instrumenten.

19 Zie bijvoorbeeld Rb. Arnhem 24 januari 2007, LJN AZ9570, in welk geval werd aangenomen, dat een basale onderzoeksplicht kon volstaan om de beleggingsdoelstelling van de cliënt enkelvoudig en genoegzaam duidelijk vast te stellen en Rb. Amsterdam 24 januari 2007, JOR 2007, 94, in welk geval een grondig en actief onderzoek van de bank werd verlangd naar het beleggersprofiel van de cliënt.
} 
Raaijmakers ${ }^{20}$ wijst er terecht op, dat due diligence bij kapitaalmarkttransacties in een heel andere context gebruikt wordt dan bij onderhandse bedrijfsovernames. Het doel kan in belangrijke opzichten verschillen. Hij stelt: er zijn belangrijke verschillen, waar het bijvoorbeeld bij een emissie van aandelen op de kapitaalmarkt gaat over de mate van zorgvuldigheid die een bank als lead manager moet betrachten jegens het beleggend publiek met betrekking tot informatieverschaffing over de uitgevende instelling, gaat het bij onderhandse overname over het onderzoek dat de koper verricht primair ten behoeve van zichzelf. Bij kapitaalmarkttransacties wordt het due diligence onderzoek verricht door derden, zoals banken, andere financieel adviseurs en directeuren van de uitgevende instelling, en zij verrichten dat onderzoek op eigen verantwoordelijkheid ten behoeve van de kopers, te weten de beleggers. Een belangrijke doelstelling is daarbij tevens de behoefte om de eigen aansprakelijkheidsrisico's voor zich zelf te beperken. Bij een onderhandse overname is het de koper zelf die onderzoek verricht of zijn het door de koper in de arm genomen deskundigen.

De wijze waarop het onderzoek wordt uitgevoerd komt echter in belangrijke mate overeen. In beide gevallen gaat het er om een zo goed mogelijk beeld te krijgen van een organisatie en bijvoorbeeld de betrouwbaarheid of deskundigheid van de daarbij betrokkenen. Deze laatst genoemde omstandigheid doet Raaijmakers niet zonder reden vermoeden dat het gebruik van de term due diligence om een onderzoek als hier voor bedoeld aan te duiden, ook in de praktijk van onderhandse overnames (en ik voeg daar aan toe, andere financiële transacties, zoals onderhandse private equity of corporate finance transacties) gaandeweg is overgenomen.

De zorgvuldigheidsplicht van opdrachtnemers als lead managers en onderzoekers bijvoorbeeld, heeft denkbaar een andere inhoud dan de zorgvuldigheidsplicht in interne verhoudingen (zoals die van bestuurders en commissarissen) ten opzichte van de eigen aandeelhouders. Er is daarbij vrijwel steeds sprake van een ander(soortig) deskundigheidsniveau. In ieder geval kunnen de grondslagen verschillen op grond waarvan aansprakelijkheidsvragen beantwoord dienen te worden. ${ }^{21}$ Ook is er als gevolg van de hier voor bedoelde verschillen verschil mogelijk ten aanzien van het antwoord op de vraag wie er wie aansprakelijk kan stellen of houden. Hier en daar komen de verschillen die hier bedoeld worden hierna aan de orde, maar dit boek gaat niet in de eerste plaats over de gevolgen van het (nalaten van) het verrichten van een due diligence onderzoek. Ik maak daarom, als gezegd, tenzij ik hierna anders aangeef, in het navolgende (ook) wat dit betreft geen onderscheid tussen due diligence bij kapitaalmarkttransacties enerzijds en onderhandse transacties anderzijds. Het gaat mij om het fenomeen due diligence als zodanig. In hoofdstuk 15 zal niettemin kort worden stilgestaan bij vragen van beroepsaansprakelijkheid. Duidelijk is het dat er bij kapitaalmarkttransacties niet altijd sprake zal zijn van een rechtstreeks verbintenisrechtelijke band tussen alle betrokken spelers. Ik durf de stelling echter aan, dat zowel in het geval van de zorgvuldige uitvoering van een verbintenis uit overeenkomst als in het geval van een verbintenis uit de wet, de zorgvuldigheidsnorm steeds zal verlangen dat een onderzoek nauwgezet zal worden uitgevoerd. Wel - zoals wij hierna nog zullen zien - kan de oorzaak van een verbintenis meebrengen dat er zowel procestechnisch als waar dit bijvoorbeeld het aantonen van schade betreft, van de nodige verschillen sprake kan zijn.

\section{$1.5 \quad$ LOI}

De eerste afspraken met betrekking tot een due diligence onderzoek zullen in veel gevallen worden neergelegd in een LOI. ${ }^{22}$ Een LOI markeert in veel gevallen een belangrijke mijlpaal bij de voorbereiding van een transactie. Ik spreek liever over een voorovereenkomst, dan over een letter of intent, omdat het fenomeen van een overeenkomst - hoe tentatief ook bedoeld - welke naar de aard daarvan niet verbindend is, in ons recht niet gekend wordt. Het doet er niet toe hoe voorlopig bedoelde afspraken zijn betiteld Heads of Agreement; Memorandum of Understanding; Points of Reference, Principles of Cooperation, Term Sheet, Merger Protocol of wat dies meer zij. ${ }^{23}$ Te onzent geldt dat pacta servanda sunt. Het hangt dus van de inhoud van de afspraken af, hoe vrijblijvend de in een LOI neergelegde afspraken zijn, niet van de benaming van dat stuk. Ook ten aanzien van de uitleg van de inhoud van een LOI gelden de normale regels van het verbintenissenrecht en de op grond daarvan gevormde jurispru-

\footnotetext{
20 A.w., p.19

21 De toets van artikel 6:162 is bijvoorbeeld een ander dan die op grond van artikel 2:9.

${ }^{22}$ Zie onder meer H.J. de Kluiver, Overnamecontracten, Letters of Intent en garanties, Dossier 47, juli 2001, p. 34 e.v.

${ }^{23}$ Zie W.S.M. Schut, Letters of Intent, Studiepockets privaatrecht, 186 en B. Wessels, Overname-onderhandelingen in Bedrijfsovername (Tjeenk Willink), p. 6, en de door deze auteurs genoemde literatuur.

Zie ook H.J. de Kluiver, Overnamecontracten, Letters of Intent en Garanties, O\&F november 2003, 58, p. 36.e.v.
} 
dentie (Haviltex doctrine, aanvullende en derogerende werking van de redelijkheid en billijkheid, toerekenbare schijn, afbreken van onderhandelingen, enzovoort). ${ }^{24}$ Het vorenstaande kwam helder tot uitdrukking in een uitspraak van de president van de rechtbank te Haarlem van 1 december $1987^{25}$ :

"(...) dat (...) de gebruikte benaming niet van doorslaggevende betekenis is. Of in casu contractuele gebondenheid is ontstaan, dient te worden beoordeeld zowel naar de inhoud van de Letter of Intent als naar de feiten en omstandigheden die zich in verband met het tot stand komen ervan of het vervolg erop hebben voorgedaan. Al deze factoren zijn van belang om te beoordelen of, gerekend naar de maatstaf van de over en weer kenbare bedoelingen van partijen, over de hoofdzaken van de beoogde overeenkomst overeenstemming is ontstaan en of eventueel nog aanwezige leemten in de overeenkomst, gelet op de wel reeds bereikte overeenstemming, dienen te worden aangevuld op voet van de aard van de sluiten overeenkomst, de wet, gewoonte of eisen van de redelijkheid en billijkheid, waarmede alsdan het totale pakket van rechtsgevolgen van de overeenkomst gegeven is."

Wessels ${ }^{26}$ bespreekt de denkbare inhoud van een LOI uitgebreid in zijn bijdrage aan de bundel Bedrijfsovername.

Hij is bij ons de importeur van de door hem in buitenlandse literatuur gevonden term "TINILEA", die hier echter nooit echt ingang heeft gevonden. Die term staat voor een clausule in een LOI, die moet uitdrukken dat partijen de gemaakte afspraken als vrijblijvend willen beschouwen ("This Is Not Intended to be a Legally Enforceable Agreement'). Juist omdat een dergelijke vrijblijvendheid in ons rechtssysteem niet aan alleen een dergelijke opmerking kan worden ontleend, zijn er andere clausules nodig om de vrijheid van weglopen zeker te stellen. Te onzent moet men zich bedienen van het systeem van voorwaarden om ruimte te bedingen zonder tot schadevergoeding gehouden te worden, zich nog te kunnen terugtrekken. ${ }^{27}$ In verband met een due diligence onderzoek vraagt de wijze waarop een voorwaarde wordt geformuleerd bijzondere aandacht in verband met de regeling van artikel 6:23 (waarop hierna onder 7.4 nader wordt ingegaan).

Wessels wijst er verder op dat twee belangrijke hoofdstukken in een LOI het onderwerp van de geheimhouding en dat van de exclusiviteit zullen zijn. De aard en omvang van een due diligence onderzoek, de te maken vervolgafspraken omtrent de uitvoering, het tijdpad, en al dat soort zaken zullen in de LOI echter geen minder belangrijke plaats mogen innemen.

De LOI is bij voorkeur de plaats - met name in het geval van het hierna te noemen investigative onderzoek - waar geregeld zou moeten worden, hoe men wil omgaan met een (on)bevredigende uitkomst van het due diligence onderzoek. Het enkele feit dat er sprake is van een confirmatory investigation (zie hierna onder 2.2) zal al snel aanleiding geven tot de gedachte dat er sprake is van meer dan alleen een $\mathrm{LOI}^{28}$

\section{$1.6 \quad$ Bronnen van (eigen) informatie}

Een dezer dagen de meest voor de hand liggende bron van informatie als men iets over een doelwitvennootschap te weten wil komen, is het internet. Niet alleen de eigen website van de doelwitvennootschap, maar ook de informatie welke via andere internetsites kan worden gevonden, kan vaak al een eerste beeld opleveren van hoe de doelwitvennootschap zich zelf ziet en hoe anderen die zien.

Verder zijn er de nodige andere openbare bronnen, zoals de registers welke door de Kamer van Koophandel en het Kadaster worden bijgehouden, en de archieven van kranten, tijdschriften en van bijvoorbeeld de zogenaamde credit rating agencies. Brancherapporten van banken leveren vaak belangrijke informatie op, hoewel die niet noodzakelijk informatie over individuele ondernemingen noemen. Ook deurwaarderskantoren kunnen een waardevolle bron van informatie zijn.

24 Zie laatstelijk omtrent Haviltex HR 20 februari 2004, RvdW 2004, 34 (DSM/Fox), HR 19 januari 2007, NJ 2007, 575 (Meyer/Pontmeyer), HR 29 juni 2007, NJ 2007576 (Derksen/Homburg) en HR 19 oktober 2007, NJ 2007, 565 (Vodafone). Zie ook R. Bierenbroodspot, Uitleg van overeenkomsten: maatwerk op basis van Haviltex, O\&F 2008, nr. 1, p. 62 e.v.

25 KG 1988, 49

26 A.w.

27 Een recent voorbeeld van een uitspraak waarin op grond van de TINILEA-clausule en bijkomende formulering een partij werd geacht niet de verplichting te hebben om een definitieve koopovereenkomst aan te gaan, is te vinden in Rechtbank Amsterdam 4 juli 2007, RCR 2008, 21.

28 Zie bij wijze van voorbeeld rechtbank Arnhem 19 maart 2008, LJN BC8052, r.o. 4.1. 
De meest aangewezen bron van informatie wordt (verder) vanzelfsprekend gevonden bij het bestuur en de commissarissen van de doelwitvennootschap zelf. Een indringend gesprek met het bestuur van de doelwitvennootschap wordt volgens Beckman ${ }^{29}$ door onze zuiderburen wel 'biechtstoel due diligence' genoemd. Duidelijk zal zijn dat toegang tot deze laatst bedoelde bron van informatie eerst zal worden verkregen, nadat het befaamde eerste kopje koffie zal zijn gedronken. Het zetten van de eerste stap in een fusie of overname proces, levert een belangrijk moment op. De meest essentiële informatie, die dient te worden ingewonnen, is of er aan de zijde van de doelwitvennootschap überhaupt belangstelling is om over een samengaan na te denken. Het verdere verloop van het proces van informatie voorziening wordt sterk bepaald door de opstelling van (het bestuur en de commissarissen van) de doelwitvennootschap. Om een eerste contact in te leiden, wordt daarom het verzoek om "samen eens een kopje koffie te drinken" in het bedrijfsleven als een codewoord (te) verstaan voor een vrijblijvend oriënterend gesprek over de visie welke beide gesprekspartners hebben op hun markt en vooral de toekomst van de eigen onderneming in die markt. Een dergelijk gesprek biedt dan ook de gelegenheid om de wederzijdse posities af te tasten, zonder dat er direct met de deur in huis gevallen behoeft te worden.

Te doen gebruikelijk is dat informatie, welke verder gaat dan beleefdheden tussen concurrenten of hetgeen er via de openbare website bekend is gemaakt, door de doelwitvennootschap zelf eerst wordt verschaft nadat er een geheimhoudingsovereenkomst is ondertekend. In de praktijk zullen soms zelfs uitgebreide gesprekken met bestuur en commissarissen en een goed gevulde kamer vol met documentatie, niet volstaan. Ook gesprekken met managers en andere werknemers in een of meer lagen van de organisatie onder het bestuur bijvoorbeeld, kunnen voor een koper gewenst zijn om over een voldoende mate van geruststelling te komen beschikken om met een bedrijfsfusie of overname door te gaan.

In het geval er sprake kan zijn van koersgevoelige informatie, zal het bestuur van de doelwitvennootschap aandringen op een afspraak omtrent het afzien van het nemen van posities in stukken in of met betrekking tot het kapitaal van de doelwitvennootschap (een zogenaamde stand still). Over deze aspecten wordt meer gezegd in hoofdstuk 8 en 10 hierna. Ook met het verschaffen van 'gewone' informatie, die bijvoorbeeld in commercieel opzicht van waarde is, zal - wanneer men verstandig is - terughoudend worden omgegaan.

Het geven van een opening van zaken vormt immers een risico in geval de beoogde transactie geen doorgang vindt. Ter voorkoming hiervan wordt in de praktijk - naast het maken van afspraken omtrent geheimhouding - wel een oplossing gezocht in onder meer:

- het beperken van het aantal personen dat op de hoogte worden gebracht van concurrentiegevoelige informatie (alleen zij die 'need to know' hebben);

- $\quad$ het afschermen van de informatie voor personen/ afdelingen die belang zouden kunnen hebben bij dergelijke informatie (sales/marketing). Het is niet ongebruikelijk om bijvoorbeeld een notaris of accountant toegang te verlenen tot bepaalde informatie op grond van de afspraak dat die bijvoorbeeld gegevens met betrekking tot leveranciers of afnemers niet in diens rapportage zal vermelden, maar slechts de gevonden cijfermatige informatie;

- $\quad$ het beperken van de informatie zelf (is het bijv. redelijkerwijs noodzakelijk deze informatie beschikbaar te stellen; kunnen er in plaats van harde cijfers ook schattingen worden gegeven, enz.). ${ }^{30}$

\section{$1.7 \quad$ Voorwerp van due diligence}

Voorafgaand aan een due diligence proces heeft er als het goed is in het geval van een overname of fusie eerst een selectieproces plaatsgevonden om de doelwitvennootschap als een geschikte kandidaat te identificeren. Voor de selectie wordt dan een zoekprofiel opgesteld, waarin zaken zullen worden aangesproken als:

- $\quad$ wat is de betekenis van een doelwitvennootschap voor de eigen onderneming?

- $\quad$ wat is de waarde van een doelwitvennootschap?

29 H. Beckman, Due diligence en overname in Ondernemingsrecht 1999-16, p. 435.

30 Zie over informatieverschaffing door de verkoper - en de doelwitvennootschap - Ch.E. Honée, Mededelings-, informatie- en onderzoeksplicht bij een aandelenfusie - De positie van de over te nemen vennootschap, in Onderneming en 5 jaar nieuw burgerlijk recht, Serie Onderneming en Recht, deel 7, p. $46-52$. 
- $\quad$ welke premie zal er moeten worden betaald?

- $\quad$ is het management goed en zal het willen blijven?

- $\quad$ is de bijdrage van een doelwitvennootschap op het terrein van de technologie combineerbaar met de eigen technologie?

wat is (verder) de bijdrage aan de business case?

hoe haalbaar is een integratie?

wat zijn de risico's?

Vergelijkbare overwegingen gelden bij het identificeren van investeringsmogelijkheden in het algemeen en het verrichten van financiële transacties (denk aan het verlenen van krediet of van een verzekeringsdekking).

Vlaar en Ezinga ${ }^{31}$ noemen de volgende zaken als voorwerp van een due diligence onderzoek:

- $\quad$ Historische risico's. Dit zijn risico's die in het verleden zijn ontstaan. Hierbij kan worden gedacht aan belastingclaims, onvolwaardige debiteuren en milieuproblematiek. Het financiële gedeelte van het onderzoek geldt voornamelijk de balans en resultatenrekening.

- $\quad$ Toekomstige risico's. Daarbij wordt een onderscheid gemaakt tussen interne-, externe- en synergie risico's.

Interne risico's hebben te maken met de interne organisatie zoals het productieapparaat en het management en synergierisico's houden verband met de samenwerking tussen ondernemingen. Bijvoorbeeld botsende administratieve systemen, verschillende opvattingen van het management en cultuurverschillen.

Waar het toekomstige risico's betreft, geldt dat de koper na een transactie ook te maken kan krijgen met producten waar deze geen kennis van heeft of geen ervaring mee heeft opgedaan. Er kunnen nieuwe distributiekanalen worden toegevoegd, die moeilijk te beheersen zijn totdat er meer ervaring mee is opgedaan. Nieuwe technologie die wordt toegevoegd, maakt de koper afhankelijk van de kennis die in de doelwitvennootschap, maar niet noodzakelijk ook al in de eigen organisatie voorhanden is. Zo zijn meer risico's te bedenken, bijvoorbeeld ook het betreden van nieuwe (geografische) markten, die eerder voor aanvaarding in aanmerking komen, wanneer daarin door een gedegen due diligence onderzoek een zeker inzicht is verworven.

Een belangrijk voorwerp van een due diligence onderzoek zal de vraag zijn, hoe een transactie die wordt overwogen, zal worden gestructureerd. Of er van een aandelentransactie of een activa-transactie sprake zal zijn, is één van de belangrijke vragen die mede aan de hand van een due diligence onderzoek beantwoording kunnen krijgen. Met name indien de onderneming van de rechtspersoon welke wordt onderzocht, een aantal risico's meebrengt die de koper niet wenst over te nemen, kan een activa-passiva transactie aangewezen zijn.

Gebaseerd op onderzoek in 1993 concludeert Slagter ${ }^{32}$ dat het bij een due diligence onderzoek in hoofdzaak om drie te onderzoeken aspecten gaat, in volgorde van indertijd uit het onderzoek gebleken mate van door de praktijk beleefde belangrijkheid: de financiële-, fiscale- en commerciële aspecten van een onderneming. Pas daarna zou ook een juridisch due diligence onderzoek als relevant worden gezien. Slagter voegt in 1995 zelf aan de in 1993 gevonden onderzoeksresultaten toe, dat naar zijn overtuiging in Engeland en de Verenigde Staten op de juridische aspecten een sterkere nadruk ligt, dan in Nederland. Inmiddels is ook in ons land wat dat betreft de situatie veranderd en zijn de juridische aspecten van een due diligence onderzoek gelijkwaardig belangrijk geworden. De samenleving is sedert 1993 in verdergaande mate gecompliceerder geworden en het is mijn inschatting dat een nader onderzoek deze dagen zou uitwijzen, dat de juridische aspecten van een due diligence onderzoek een niet veel minder belangrijke plaats zouden innemen, dan de overige aspecten daarvan. Ik aarzel dan ook niet met een korte profielschets van het juridisch due diligence onderzoek aan te vangen.

${ }^{31}$ N.W. Vlaar en A. Ezinga, Het due diligence-onderzoek en de rol van de accountant, MAB december 1997, p. 636.

32 Zie W.J. Slagter, Risicobeheersing door een due diligence onderzoek, Preadvies van de Nederlandse vereniging van Ondernemingsrechtadviseurs 1995, p. 15. Het onderzoek waar hij naar verwijst is uitgevoerd door Ernst\&Young in samenwerking met Parisbas Corporate Finance en faculteit Bedrijfskunde van de Erasmus Universiteit en gepubliceerd in november 1993 door P.D.J. Zuyderhoudt en R.A.I. Frederikslust. 
Eén van de allereerste dingen waarnaar de belangstelling zal uitgaan bij de koper, is het automatiseringssysteem dat door de doelwitvennootschap wordt gebruikt. Het kan belangrijke investeringen vergen om het eigen systeem te laten communiceren met het systeem van de doelwitvennootschap en voor integratie en andere doeleinden zijn dit belangrijke voorwerpen van onderzoek. In due diligence vragenlijsten komt inmiddels ook wel de vraag voor of de onderneming over een chatbox beschikt en of daar de afgelopen periode negatieve opmerkingen in zijn ontvangen. Het voorwerp van de technologie mag niet worden onderschat. Dat voorwerp bepaalt in niet onbelangrijke mate mede welke kwaliteit er van de administratie mag worden verwacht.

\section{Zie ook hierna onder 1.14.}

Welke juridische aspecten worden bij een due diligence onderzoek zoal onderzocht? Het betreft de navolgende. Op een aantal hiervan zal in volgende paragrafen nog nader worden ingegaan, maar voor een eerste verkenning kunnen de volgende juridische aandachtsgebieden worden onderscheiden:

- $\quad$ Belangrijke overeenkomsten. Hierbij moet gedacht worden aan joint venture-overeenkomsten, distributie-, agentuur-, licentie- en franchiseovereenkomsten, koop- en verkoopovereenkomsten, intentieverklaringen, overeenkomsten die de ondernemingen langere tijd binden, en dergelijke;

- $\quad$ Financiële informatie. Hierbij kan gedacht worden aan geldleningen, bankgaranties, pand- en hypotheekrechten, borgstellingen, kredietovereenkomsten, lease-overeenkomsten, schuldbewijzen, kruisverbanden, 403-verklaringen, deponeringsgegevens, jaarrekeningen, en dergelijke;

- $\quad$ Fiscale aspecten. Zie hierna onder 1.11.

- $\quad$ Intellectuele en industriële eigendomsrechten. Te denken valt aan bijzondere knowhow, geregistreerde modellen en merkrechten, auteursrechten, octrooien, toegangscodes, informatie- en communicatietechnologie en dergelijke;

- $\quad$ Juridische procedures. Van belang zijn alle vonnissen waarbij de onderneming partij was, adviezen, vaststellingsovereenkomsten, dagvaardingen, gebeurtenissen welke tot aansprakelijkheden of procedures kunnen leiden, en dergelijke;

- $\quad$ Juridische structuur en interne organisatie. Hierbij kan gedacht worden aan de akte van oprichting, de huidige statuten, notulen van directie/ commissarissen/ aandeelhoudersvergaderingen, eventuele gedragscodes, het aandeelhouders/certificaathoudersregister, een directiereglement, een reglement van de raad van commissarissen, toezeggingen of verbintenissen tot emissie of bezwaring van aandelen, nog niet uitgevoerde besluiten die de identiteit van de vennootschap veranderen of een belangrijk onderdeel van de onderneming van de vennootschap betreffen, evenals aan uittreksels uit het Handelsregister en volmachten aan procuratiehouders, en dergelijke;

- Mededinging. Van belang zijn afspraken met concurrenten, prijsafspraken, correspondentie met de Nederlandse of Europese mededingingsautoriteiten. Is er bijvoorbeeld overheidssteun ontvangen (en is er ter zake een goedkeuring van de zijde van de Europese Commissie?) en dergelijke;

- $\quad$ Onroerende zaken. Te denken valt aan huurovereenkomsten, eigendomsakten, hypotheekakten, kwalitatieve rechten, milieuaspecten, en dergelijke. ${ }^{33}$ Aandacht verdient het voorwerp van de Wet kenbaarheid publiekrechtelijke beperkingen, welke sedert 1 juli 2007 van toepassing is. Op grond van deze wet worden bepaalde publiekrechtelijke beperkingen waaraan on-

\footnotetext{
33 Zie N.S.J. Koeman, Aspecten van milieurecht in het kader van bedrijfsovername, De NV 1995/73, p. 192 e.v. Het onderzoek naar een aantal milieu-aspecten (zie hierna onder 1.15) valt meer als een zelfstandig onderdeel van een due diligence onderzoek te kwalificeren dan als onderdeel van het juridisch onderzoek.
} 
roerende zaken onderworpen kunnen zijn kenbaar gemaakt doordat zij in een openbaar register moeten worden ingeschreven. ${ }^{34}$

- Personeel. Hierbij valt te denken aan arbeidsovereenkomsten (denk vooral ook aan concurrentiebedingen), CAO's, verzekeringen ten behoeve van het personeel, pensioenregelingen en/of andere pensioentoezeggingen, aandelen/optieregelingen, OR-reglement, medezeggenschapsregels, toezeggingen en opgewekte verwachtingen ten opzichte van de werknemers op het punt van arbeidsvoorwaarden en/of op het gebied van medezeggenschap, en dergelijke;

- $\quad$ Toepasselijke regelgeving en vergunningen. Hierbij gaat het om licenties, vergunning ontheffingen, certificaten (ISO bijvoorbeeld), en dergelijke.

Verzekeringen. Hierbij zijn van belang inhoud en looptijd van verzekeringspolissen en de bijbehorende algemene en bijzondere voorwaarden, de dekkingsomvang, de kring van verzekerden, tijdige premiebetaling, en dergelijke.

Bovenstaande lijst is niet uitputtend. Het betreft als gezegd een algemene verkenning. Van geval tot geval zal bekeken moeten worden welke aspecten meer en welke minder aandacht behoeven. Het gaat er om dat (de waarde van) het voorwerp van koop en de daar mee samenhangende onzekerheden en risico's goed kunnen worden ingeschat. Bijzondere aandacht verdienen daarbij bijvoorbeeld zogenaamde "change of control-clausules". Waneer een overdracht van een onderneming of een verandering van zeggenschap in een vennootschap een wederpartij bij een overeenkomst het recht geeft die overeenkomst te beëindigen, kan dat vanzelfsprekend grote invloed uitoefenen op de commerciële waarde van de onderneming. Dergelijk clausules geven die wederpartij(en) de gelegenheid om zich aan meerjarige verbintenissen te onttrekken of om nieuwe voorwaarden te bedingen in ruil voor een bereidheid om van een dergelijke clausule geen gebruik te maken of om in te stemmen met het aangaan van een nieuwe verbintenis. De waarde van een onderneming kan daardoor als gezegd sterk worden uitgehold. ${ }^{35}$ Hoewel in de praktijk standaardmethoden van onderzoek en geüniformeerde vragenlijsten worden gebruikt, blijft het - waar maar enigszins mogelijk - wenselijk om niet alleen ter plaatse de situatie in ogenschouw te hebben genomen, maar ook het onderzoek in te richten naar de omstandigheden en behoeften van elk geval. Aan 'bijzondere eenden in de bijt' moet ook worden gedacht, zoals emissierechten en melkquota, wanneer die vermogensrechten aan de orde kunnen zijn. Zo zijn meer voorbeelden te noemen van niet alledaags en bij alle ondernemingen voorkomende voorwerpen van onderzoek, die toch niet over het hoofd mogen worden gezien.

Hierna zal een enkel deelaspect wat nader worden besproken, nu die deelaspecten in de recente jaren een belangrijker plaats zijn gaan innemen in een due diligence onderzoek. De hiervoor genoemde onderwerpen blijven allemaal van belang, maar er kan een zekere accentverschuiving worden waargenomen nu bijvoorbeeld onder invloed van o.a. het internet en de nieuwe media intellectuele eigendom een steeds belangrijker onderdeel is geworden van de waarde van veel ondernemingen.

\section{$1.10 \quad$ Financieel onderzoek}

Zie ook hierna onder 1.11.

Blijkens het hier voor genoemde, in 1993 uitgevoerd onderzoek zou in veel gevallen het financiële onderzoek het zwaartepunt bij een due diligence onderzoek vormen. ${ }^{36}$

Bos en Owen ${ }^{37}$ hebben een inventarisatie gemaakt van de onderzoeksgebieden waartussen bij een financieel due diligence onderzoek ten behoeve van de opdrachtgever naar verbanden zal worden gezocht.

In plaats van het controleren van de verstrekte gegevens worden bij een due diligence onderzoek door een accountant gegevens verzameld, vastgelegd en geïnterpreteerd en wordt er gezocht naar verban-

${ }^{34}$ Zie hierover C.G. Breedveld-de Voogd, De Wet kenbaarheid publiekrechtelijke beperkingen en de aansprakelijkheid van de verkoper, V\&O 2008, nr. 3, p. 54 e.v.

35 Zie voor een sprekend voorbeeld waarin een change of control tot het afbreken van vergevorderde onderhandelingen leidde HR 26 oktober 2007, RCR 2008,2 (Roompot / De Efteling).

${ }^{36}$ Zie W.J. Slagter, Het due diligence onderzoek en de aansprakelijkheid van de accountant, Dossier nummer 24, 1996, p. 56.

37 F. Bos en J.P.F. Owen, Due diligence. De onmisbare schakel in het acquisitieproces, Tijdschrift voor Corporate Finance, 1999 , nr. 3, p. 77 
den tussen de verstrekte financiële, bedrijfseconomische, fiscale, juridische en commerciële informatie. Bij een financieel due diligence onderzoek worden bovendien verbanden gelegd tussen de stuurinformatie uit het management informatiesysteem en de meest recente- door de externe accountant van de onderneming - gecertificeerde financiële informatie. Van deze laatste informatie zal de accountant van de onderneming het bestaan, de eigendom en de waardering normaliter hebben gecontroleerd.

Als belangrijkste (mogelijke) gebieden van een financieel due diligence onderzoek worden genoemd:

- $\quad$ het beoordelen van de verschillende posten van de verlies \& winstrekening;

- $\quad$ het onderzoek naar subjectieve elementen in de gehanteerde 'accounting principles';

- $\quad$ het beoordelen van de verschillende balansposten;

- $\quad$ het beoordelen van de kwaliteit van het management informatiesysteem en de aansluiting van de management informatie op de jaarrekening;

- $\quad$ het identificeren van verborgen claims en/of stille en geheime reserves;

- $\quad$ het beoordelen van de cashflow;

- $\quad$ het beoordelen van intercompany-transacties, -geldstromen en/of winsten;

- $\quad$ de analyse met betrekking tot de kwaliteit van de winst, op basis van het verleden van de winstbron;

- $\quad$ het beoordelen van de doorgaande opbrengsten- en kostenniveaus in relatie tot de activiteiten van de doelwitvennootschap;

- $\quad$ het beoordelen van het stelsel van interne controlemaatregelen;

- de gevoeligheidsanalyse met betrekking tot wijzigingen in uitkomsten van variabelen van belangrijke veronderstellingen en de bijbehorende invloed op de verwachte toekomstige cashflows.

De hier voor genoemde inventarisatie dateert uit 1999. Inmiddels kan aan de lijst ongetwijfeld ook worden toegevoegd het beoordelen van de corporate governance vereisten, zoals voortvloeiend uit bijvoorbeeld de NCGC.

Richtlijn 2006/46/EG verplicht beursvennootschappen om jaarlijks een corporate governance verklaring openbaar te maken. Ook moeten middelgrote en grote ondernemingen informatie bekend maken over transacties met gerelateerde partijen en 'off balance arrangements'. Tenslotte bevat de Richtlijn bepalingen met betrekking tot de collectieve verantwoordelijkheid van bestuur en commissarissen voor de financiële verslaggeving en aansprakelijkheid voor onjuistheden daaromtrent. De Richtlijn moet op 5 september 2008 zijn uitgevoerd. Op het moment van schrijven van dit boek was een wetsontwerp in het vooruitzicht gesteld tot aanpassing van Titel 9 van Boek $2 .{ }^{38}$

Volgens NV COS nummer 5500N (Transactiegerelateerde adviesdiensten) van het NIVRA is het adviesproces (zoals het uitvoeren van een due diligence opdracht dient te worden gekwalificeerd) een analytisch proces, dat bestaat uit (een combinatie van) activiteiten o.a. met betrekking tot:

- $\quad$ het bepalen van de doelstelling van de opdracht;

- $\quad$ het verzamelen, analyseren en interpreteren van de voor de transactie relevante informatie;

- $\quad$ het definiëren van risico's en mogelijkheden;

- $\quad$ het evalueren van alternatieven;

- $\quad$ het ontwikkelen van aanbevelingen inclusief een advies over te nemen stappen;

- $\quad$ het communiceren van de uitkomsten en soms implementatie en follow up (Inl. onder 7).

\subsection{Onderscheid met periodiek accountantsonderzoek of waarde-onderzoek}

Een due diligence onderzoek dient te worden onderscheiden van een periodiek accountantsonderzoek. De verschillen zijn groot. Niet alleen wordt een accountantsonderzoek door de onderzochte vennootschap zelf opgedragen, maar ook het oogmerk en de aan de uitkomsten van een dergelijk onderzoek te verbinden consequenties zijn verschillend. Zo is het oogmerk bij een periodiek accountantsonderzoek veelal het voldoen aan de wettelijke verplichting om een jaarrekening op te stellen en te publiceren en daarbij een verkeerde voorstelling van zaken te vermijden. Een dergelijk onderzoek is

\footnotetext{
38 Zie TK 2007-2008, 29 752, nr. 5, p. 8-9.
} 
veelal minder diepgaand, maar breder dan een gebruikelijk due diligence onderzoek. Het vormt de grondslag voor de accountantscontrole. Is er sprake van tekortkomingen in het accountantsonderzoek, dan kan dit tot winstverschuiving aanleiding geven. ${ }^{39}$ In het geval van een due diligence onderzoek kunnen tekortkomingen in de volledigheid daarvan leiden tot een miskoop. Een due diligence onderzoek dient veelal op een kortere termijn plaats te vinden dan een accountantsonderzoek. Bij het laatste onderzoek volstaat het wanneer er een getrouw, duidelijk en stelselmatig beeld wordt opgeleverd van de financiële situatie van de onderneming. In het geval van een due diligence onderzoek gaat het veelal om het elimineren van subjectieve schattingen en oordelen. Een accountantsonderzoek richt zich op het verleden, terwijl een due diligence onderzoek veelal zal strekken tot bepaling van de waarde in het kader van toekomstverwachtingen. ${ }^{40}$

Een waarde-onderzoek is weer geen accountantsonderzoek. Voor zover een due diligence onderzoek betekenis moet hebben voor een waardebepaling, dient dit onderzoek niet te worden verricht door een accountant, maar door een deskundige op het terrein van corporate finance. Hiermee wil ik overigens niet gezegd hebben, dat een accountant niet in staat zou zijn om een waarde van een onderneming te bepalen. De desbetreffende activiteit behoort echter niet tot de normale werkzaamheden van een accountant.

Vanzelfsprekend kan een accountant ook een due diligence onderzoek uitvoeren. Slagter ${ }^{41}$ meent dat een accountant die een due diligence onderzoek uitvoert daarbij specifieke controlewerkzaamheden zou moeten uitvoeren, "met name om te voorkomen dat later lijken uit de kast rollen". Hij is bovendien van oordeel dat op een accountant die een due diligence onderzoek verricht een zwaardere aansprakelijkheid rust, dan op een accountant die periodiek de jaarrekening controleert, "hetgeen met name te verklaren is uit het feit dat fouten bij een due diligence onderzoek in het algemeen veel ernstiger gevolgen hebben dan bij een periodiek onderzoek naar de jaarrekening, omdat in het laatste geval fouten vaak in een volgend boekjaar kunnen worden gecorrigeerd."

Ik zou niet weten waarop het standpunt dat een accountant die een due diligence onderzoek uitvoert, tevens accountantscontrole zou moeten toepassen, gebaseerd moet worden. Een accountant is niet altijd gehouden zijn werkzaamheden als controlewerkzaamheden te verrichten. Dat een controle gewenst kan zijn, is een ander ding, maar dit moet dan met de accountant wel vooraf uitdrukkelijk zijn overeengekomen. Een advocaat bijvoorbeeld zal ook niet zijn bevindingen in de vorm van een legal opinion rapporteren, terwijl ook fouten van een advocaat (of van andere adviseurs) grote gevolgen kunnen hebben.

De hier voor genoemde opvatting van Slagter wordt ook door accountants zelf niet gedeeld. ${ }^{42}$ Doelstelling van de koper is een bevestiging te krijgen van zijn beeldvorming over de doelwitvennootschap en haar onderneming en over de voorwaarden waaronder een transactie tot stand kan komen. Het is niet de bedoeling de accountantscontrole die eerder is uitgevoerd, nog eens over te doen. In een overnameproces ontbreekt vaak de tijd om een controle te verrichten. Het balansmoment is vaak al verstreken, zodat het bestaan van bepaalde posten (bijvoorbeeld voorraden) niet meer vastgesteld kan worden. De onderzoeker is niet in staat om de openingsbalans te controleren, waardoor hij per definitie het boekhoudkundig resultaat over het jaar niet kan controleren. Tenslotte krijgt de onderzoeker niet altijd de voor een controle benodigde, ongelimiteerde toegang tot gegevens van de onderneming waar het om gaat.

Volgens NV COS nummer 5500N (Transactiegerelateerde adviesdiensten) van het NIVRA (onder 8.) is het primaire doel van een opdracht tot het verlenen van transactiegerelateerde adviesdiensten het ondersteunen van de geautoriseerde gebruiker bij aspecten van het besluitvormingsproces in zake een voorgenomen transactie. Met de opdrachtgever kunnen ook andere transactieondersteunende diensten worden overeengekomen. Voorbeelden die worden genoemd, zijn assistentie bij het opstellen en analyseren van waarderingsmodellen of prognoses, bedrijfswaarderingen, het ondersteunen bij het ontwikkelen van een businessplan, assistentie bij openbare biedingen, strategische en commerciële analyses, om maar enkelen te noemen. Een transactiegerelateerde adviesopdracht omvat volgens de

39 Zie artikel 2:362 lid 6 indien nadat de jaarrekening is vastgesteld, blijkt van ernstige tekortkomingen in het geven van een inzicht omtrent de financiële toestand op de balansdatum.

40 Zie over de hier genoemde en andere denkbare verschillen tussen een due diligence onderzoek en een periodiek accountantsonderzoek verder W.J. Slagter, Het due diligence onderzoek, TVVS 1994, nr. 94/9, p. 225 e.v.

41 Zie vorige noot.

42 N.W. Vlaar en A. Ezinga, Het due diligence-onderzoek en de rol van de accountant, MAB december 1997, p. 639, die menen, dat bij een due diligence onderzoek de analyse van de informatie belangrijker is dan de verificatie. Zie uitgebreider over de hier aangesproken polemiek W.J. Slagter, Het due diligence-onderzoek en de aansprakelijkheid van de accountant, Dossier 1996, nr. 24, p. 56 e.v. F. Bos en J. Owen in Fusies en Overnames 2007, Elsevier. 
gedragsregels voor accountants niet een oordeel over de vraag of een voorgenomen transactie voldoet aan de door de geautoriseerde gebruikers gestelde criteria, of de beslissing om al dan niet een transactie voort te zetten. Men wil de verantwoordelijkheid voor deze afwegingen nadrukkelijk bij de opdrachtgever laten.

Slagter meent dat een due diligence onderzoek een diepgaander onderzoek op een beperkter terrein betreft dan een periodiek accountantsonderzoek. Een fout bij een due diligence onderzoek kan grotere gevolgen hebben dan bij een periodiek accountantsonderzoek, nu in een volgend jaar fouten in een accountantsonderzoek weer geredresseerd kunnen worden. Er heeft dan alleen winst of verlies verschuiving plaatsgevonden. Zo ziet hij nog wat minder relevante verschillen (zoals dat een accountantsonderzoek alleen naar het verleden kijkt), die naar mijn oordeel alle zijn terug te voeren naar het feit dat een periodiek accountantsonderzoek nu eenmaal geen due diligence onderzoek is. Een accountant die een due diligence onderzoek uitvoert, treedt niet op als controlerend accountant. In de laatst bedoelde hoedanigheid werkt de accountant in een onpartijdige rol met een verantwoordelijkheid ten opzichte van het maatschappelijk verkeer. In de eerst bedoelde hoedanigheid is hij een opdrachtnemer die zich bijzonderlijk zal richten op de belangen van zijn opdrachtgever als koper, partij bij een fusie of een joint venture.

Bos en Owen $^{43}$ hebben er op gewezen dat verschillen als hier laatst bedoeld dienen te worden gerelativeerd. Een accountant zal bij gelegenheid van het periodiek accountantsonderzoek zich niet helemaal kunnen onttrekken aan het paradigma dat wordt ingegeven door het feit dat de vennootschap zijn opdrachtgever is en vooral kijken of wat in de jaarrekening verwerkt is nog wel 'door de beugel' kan. De verschillen mogen echter niet worden genegeerd. De verschillende invalshoeken mogen (ook) bij een due diligence onderzoek niet worden veronachtzaamd.

Wanneer de uitkomst van een due diligence onderzoek aanleiding geeft tot correcties op de (ver)koopprijs, betekent dit niet ipso facto dat de controlerende accountant diens werk niet goed heeft gedaan. De accountantscontrole gaat niet verder dan met een redelijke mate van zekerheid vaststellen dat de jaarrekening geen onjuistheden van materieel belang bevat. ${ }^{44}$ De controle is bovendien niet opgezet en uitgevoerd in het kader van de transactie die aanleiding geeft tot het uitvoeren van een due diligence onderzoek. Zo noemen Bos en Owen als voorbeeld, dat ter gelegenheid van een due diligence onderzoek de opdrachtgever de waarderingsmethodiek van posten ter discussie kan (wil) stellen die in het kader van de transactie voor hem onaanvaardbaar zijn, maar die binnen de uitgangspunten (waaronder tolerantiegrenzen) die bij de jaarrekening controle gehanteerd worden wel aanvaardbaar kunnen zijn. Een koper of partner bij een fusie of joint venture kan bijzondere belangstelling hebben voor onderwerpen, die niet of niet zo uitgebreid tijdens de accountantscontrole aan de orde zijn geweest en daarom in het dossier van de accountant geen weerslag hebben gevonden. Een due diligence onderzoek kan (mede) op juist die onderwerpen gericht worden.

Als andere voorbeelden van bevindingen die door een due diligence onderzoek kunnen worden vastgesteld, noemen zij:

- $\quad$ toegepaste grondslagen van waardering en resultaatbepaling die in het algemeen, of in vergelijking tot de grondslagen die de koper hanteert, minder conservatief zijn;

- $\quad$ (stelsel)wijzigingen in grondslagen van waardering en/of resultaatbepaling, waardoor het resultaat optisch is verbeterd;

het uitstellen van vervangingsinvesteringen;

- $\quad$ het tijdelijk achterwege laten van bepaalde uitgaven, zoals opleidingskosten voor personeel en reclame uitgaven, waardoor het resultaat op korte termijn toeneemt;

\footnotetext{
43 Zie F. Bos en J.P.F. Owen, Due diligence. De onmisbare schakel in het acquisitieproces, Tijdschrift voor Corporate Finance, 1999, nr. 3, p.77.

44 C.M. Harmsen, Materieel belang: de waarde van de accountantsverklaring en de werking van de verordening op de fraudemelding, TVVS 1996, 11, p.304-307. Zie ook r.o. 3.59 in OK 28 december 2007, JOR 2008, 38 (Spyker), waarin wordt geconstateerd dat er op een aantal punten terecht bezwaren zijn geuit tegen de inhoud van de jaarrekening van Spyker, maar dat de OK die - mede in het licht van toegezegde aanpassingen - niet van zodanig ernstige aard acht dat het geven van specifieke aanwijzingen voor toekomstige jaarrekeningen zou zijn geboden. Zie over deze uitspraak ook H.K.O. Reimers, AFM vs. Spyker, Bb 27 februari 2008, nr. 5, p. 43 e.v. De AFM heeft blijkens een persbericht van 10 maart 2008 tegen de uitspraak van de OK inmiddels cassatie ingesteld. Op het moment van afsluiten van de tekst voor dit boek, was er door de Hoge Raad nog geen uitspraak gedaan.
} 
- $\quad$ incidentele baten en lasten die onderdeel uitmaken van het resultaat, maar niet bijdragen aan de kwaliteit van de winst (die in de toekomst gegenereerd kan worden).

Overigens kan de opdracht tot uitvoering van een transactiegerelateerde adviesdienst samen lopen met werkzaamheden met een assurance-karakter als bedoeld in het Stramien voor Assurance-opdrachten van de NIVRA. In de opdrachtbevestiging en in de schriftelijke rapportage dient de accountant werkzaamheden met een assurance-karakter dan wel duidelijk te scheiden van de adviesdiensten. Dit dient te geschieden door in de opdrachtbrief ten minste gebruik te maken van afzonderlijke paragrafen en in de rapportage door het gebruik van afzonderlijke secties.

Een opdracht tot het verlenen van transactiegerelateerde adviesdiensten kan elementen bevatten die voldoen aan de definitie van assurance-opdrachten, maar hoeft daarmee volgens NV COS nummer $5500 \mathrm{~N}$ (Transactiegerelateerde adviesdiensten, onder 4 en 5) van het NIVRA nog niet te voldoen aan de vereisten van de Standaarden zo lang voor de oordelen, standpunten of uitspraken waaraan een gebruiker zekerheid zou kunnen ontlenen, elk van de onderstaande punten geldt:

- $\quad$ de oordelen, standpunten of uitspraken zijn slechts van ondergeschikte betekenis binnen de gehele opdracht;

- $\quad$ het gebruik van elk schriftelijk rapport dat wordt verstrekt, is uitdrukkelijk beperkt tot personen die hiervoor geautoriseerd zijn op grond van een overeenkomst tussen de opdrachtgever en de beroepsbeoefenaar (geautoriseerde gebruikers). De geautoriseerde gebruikers worden geïdentificeerd in het rapport of worden geïdentificeerd in een specifieke overeenkomst; op grond van een schriftelijke afspraak met de geautoriseerde gebruikers is de opdracht niet bedoeld als een assurance-opdracht; en

- de opdracht wordt in het rapport van de beroepsbeoefenaar niet aangemerkt als een assurance-opdracht.

Wanneer een opdrachtgever waarvoor door een accountantskantoor wordt gewerkt in verband met de wettelijke controle van de financiële overzichten aan dat kantoor tevens een opdracht wil verstrekken tot het verlenen van transactiegerelateerde adviesdiensten, dan zal de opdracht niet mogen worden aanvaard dan na overleg met de voor de wettelijke controle verantwoordelijke accountant van dat kantoor.

\section{$1.12 \quad$ Fiscaal onderzoek}

Bij het due diligence onderzoek naar fiscale aspecten, zal de aandacht vooral naar de navolgende onderwerpen uitgaan:

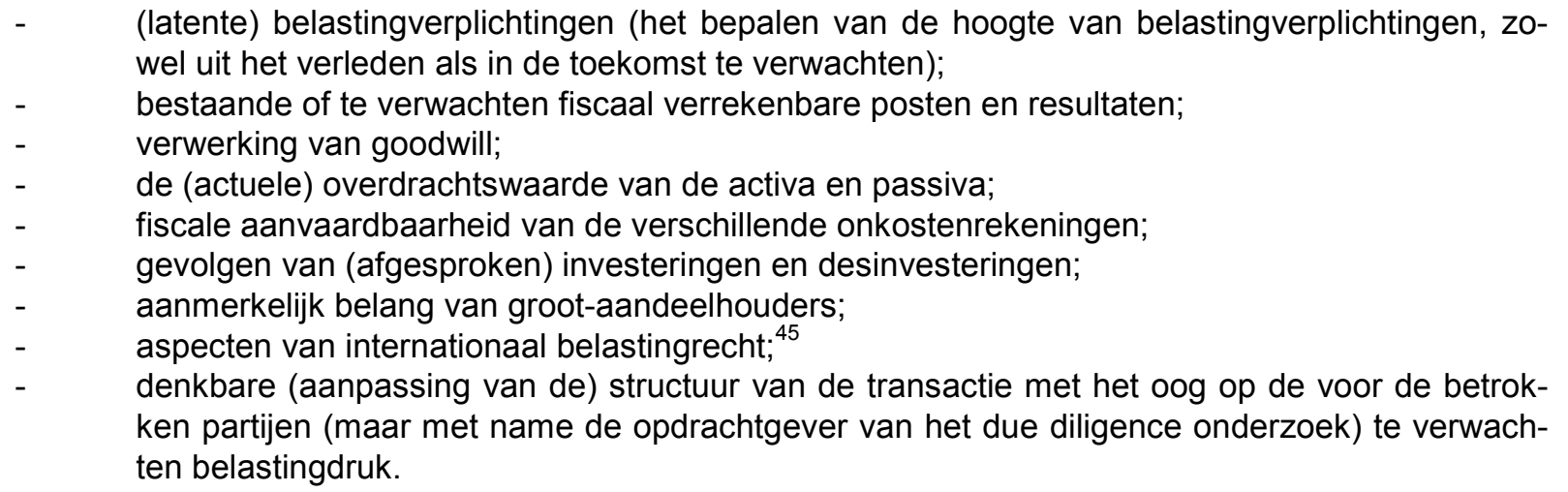

Het zijn niet zelden - maar overigens niet alleen - de resultaten van een fiscaal onderzoek, die mede de keuze zullen doen bepalen voor de structuur van een transactie. Te denken valt aan het gebruik willen maken van compensabele verliezen (keuze voor een aandelentransactie, wanneer de onderneming van de vennootschap op going concern wordt voortgezet en eerder of na de transactie niet be-

45 Zie bijvoorbeeld EHvJ 17 januari 2008 (zaak C-105/07) over renteaftrek door een dochtermaatschappij als vergoeding voor lening die is verstrekt door in een andere lidstaat gevestigde moeder. 
langrijk werd of wordt ingekrompen) of het willen behouden van verleende vrijstellingen voor overdrachtsbelasting (keuze voor een aandelentransactie al dan niet in de vorm van een emissie, bijvoorbeeld in de vorm van een emissie, omdat de vrijstellingen anders verloren kunnen gaan), het willen vermijden van onzekerheden, bijvoorbeeld wanneer er sprake is van een dispuut met de fiscus over de vaststelling van posten ten behoeve van een aanslag of naheffing (keuze voor een activa-passiva transactie).

\subsection{Commercieel onderzoek}

Tijdens een due diligence onderzoek wordt vanzelfsprekend ook een foto gemaakt van de commerciële kracht van de doelwitvennootschap. Veelal zal omtrent de commerciële positie van de doelwitvennootschap al wel een indruk bestaan. Meestal vormde die aanleiding voor de gesprekken die uiteindelijk aanleiding gaven tot het uitvoeren van het due diligence onderzoek. Waar het niet allemaal goud behoeft te zijn dat schittert en de kansen om synergie voordelen een belangrijke drijfveer vormen voor transacties die aanleiding vormen voor een due diligence onderzoek, wordt het belangrijk gevonden om de eigen indrukken en al eerder verkregen informatie, te verifiëren.

Dit deel van een due diligence onderzoek wordt over het algemeen door de koper zelf gedaan. Op basis van de uit de overige bestanddelen van een due diligence onderzoek verkregen informatie - zoals omzetcijfers, klantenbestanden, debiteurenpositie, de rol van sleutelfiguren en dergelijke - wordt een inschatting gemaakt van de uit een eventuele combinatie van activiteiten te behalen voordelen.

De mededingingsrechtelijke aspecten zullen weer door adviseurs worden gewogen.

Het commercieel due diligence onderzoek zal zich richten op zaken als:

- $\quad$ welke gezamenlijke marktpositie kan er resulteren;

- $\quad$ een sterkte zwakte analyse van de onderneming van de doelwitvennootschap ("SWOT-analyse);

- $\quad$ analyse van het producten/dienstenpakket en het bestand van leveranciers en afnemers;

- $\quad$ de kansen en bedreigingen van de producten en/of diensten van de doelwitvennootschap in haar huidige markt en in de toekomst;

- $\quad$ de te behalen operationele synergievoordelen;

- $\quad$ de kwaliteit van het management en de opbouw van het personeelsbestand.

In steekwoorden is de portee van een commercieel due diligence onderzoek ook wel weergegeven als "waarom, wat, wanneer, waar en hoe?". Daarmee is bedoeld om aan te geven dat de reden voor een commercieel due diligence onderzoek (het "waarom") neer komt op het vermijden of verminderen van risico, het kunnen bepalen van een juiste waardering, het ondersteunen van de onderhandelingspositie en een beeld kunnen vormen van de mogelijkheden om de beide organisaties te integreren. Het "wat" richt zich op de toekomstige rentabiliteit, te behalen in de te onderzoeken markt, dankzij de concurrentiepositie en met het beschikbare management. Gekeken wordt dan naar potenties en risico's. De geldende winstgevendheid maar ook de te verwachten stand van de markt (komt er een recessie aan?) zijn er nieuwe technologieën te verwachten, is er een consolidatie aan de gang in de markt en zijn er nieuwe toetreders te verwachten? Hoe is het management opgebouwd? Is er kans op verloop? Het "wanneer" heeft betrekking op de fasering van de transactie, de beslismomenten en de manier waarop met het proces zal worden omgegaan. Het "waar" heeft te maken met de plaats van onderhandelingen en de plaatsen waar een transactie op het toneel kan komen. Te denken valt aan kapitaalmarkttransacties, waar media een belangrijke rol kunnen spelen. Ook kan het "waar" duiden op de vraag of een transactie door eigen mensen (inhouse) zal worden behandeld of dat er elders hulp zal worden gezocht.

Het "hoe" heeft te maken met de wijze waarop de transactie zal worden uitgevoerd en uiteindelijk de transactie zal worden geconsumeerd. Het commerciële due diligence onderzoek richt zich op het verzamelen van zoveel mogelijk informatie ter beantwoording van de hiervoor bedoelde vragen.

\section{$1.14 \quad$ Intellectuele eigendomsrechten}


Zoals gezegd is de wereld veranderd. Intellectuele eigendomsrechten nemen een steeds belangrijker plaats in binnen het vermogen van vennootschappen. ${ }^{46}$ Het onderzoek naar intellectuele eigendomsrechten vormt onderdeel van het juridisch due diligence onderzoek. Bij dat onderzoek moet rekening worden gehouden met verschillende soorten intellectuele eigendomsrechten. Bij sommige rechten, zoals het octrooi, is een registratie vereist voordat het recht gevestigd wordt. Anders ligt dit bij het auteursrecht, voor het ontstaan van dit recht is geen registratie of enige andere handeling vereist. Het auteursrecht wordt automatisch gevestigd. Bij andere rechten is dit weer anders, bijvoorbeeld het merkenrecht. De geregistreerde rechten zijn gemakkelijk na te gaan. De rechten waarbij geen registratie is vereist, zijn moeilijker verifieerbaar.

Er zijn drie soorten geregistreerde rechten (het octrooirecht, het modelrecht en het kwekersrecht). Verder zijn er rechten waarbij de registratie een optie is, maar geen vereiste. Registratie heeft tot gevolg dat het recht de hoogste mate van bescherming verkrijgt, maar ook buiten de registratie kan bescherming worden verkregen (merkenrecht en handelsnaamrecht). Het handelsnaamrecht is verbonden met het bedrijf en kan alleen samen met de onderneming worden overgedragen (artikel 2 Handelsnaamwet). Die overdracht is echter geen automatisme en zal wel expliciet geregeld moeten worden.

Bijzondere aandacht verdient de moeilijk op papier verifieerbare vraag of er sprake kan zijn van een dreiging van vervallenverklaring van een merkrecht wegens non-usus ${ }^{47}$.

Rechten die niet behoeven te worden geregistreerd zijn als gezegd moeilijker verifieerbaar (auteursrecht en naburige rechten). Ten aanzien van belangrijk auteursrechtelijk materiaal (denk bijvoorbeeld aan software) zal eerst moeten worden nagegaan wie de maker/rechthebbende is. Ook zal er steeds moeten worden bezien hoe overdracht van één of meer rechten kan plaatsvinden en of er ter zake daarvan belemmeringen te verwachten zijn. ${ }^{48}$ Zogenaamde escrowbepalingen zijn in dit opzicht ook relevant. Het komt vaak voor dat met de leverancier van software overeengekomen wordt dat de broncode (de software in voor mensen begrijpelijke programmeertaal) van de software bij een notaris of een speciaal escrowbureau wordt opgeslagen indien de intellectuele eigendomsrechten op de software bij de leverancier berusten. In een escrowbepaling wordt dan een aantal afgiftegronden opgenomen. Indien de leverancier van de software bijvoorbeeld in de toekomst failliet gaat, of de ondersteuning van de software staakt, dan is het essentieel voor de gebruiker om over de broncode te kunnen beschikken teneinde zelf het onderhoud aan de software mogelijk te maken. Dit is zonder broncode niet goed mogelijk. Bepalingen met betrekking tot een escrow dienen onderwerp van een due diligence onderzoek te zijn.

Het is tot nu toe niet zeker hoe het recht op een domeinnaam juridisch gekwalificeerd moet worden. Het feit dat domeinnamen een aanzienlijke vermogenswaarde kunnen vertegenwoordigen, maakt de vraag naar de juridische kwalificatie ook in economisch opzicht relevant ${ }^{49}$. Een domeinnaam kan worden gezien als het intellectuele eigendomsrecht van degene die deze bedacht heeft. Het gaat om een bepaalde naam als aanduiding van een adres (reeks van 10 cijfers met een bepaalde logische structuur, vergelijkbaar met een telefoonnummer) van een aan het internet verbonden computer. Een zogenaamd "IP-adres". De koppeling van een domeinnaam aan een IP-adres wordt verzorgd door de ICANN (the Internet Corporation for Assigned Names and Numbers), die deze taak heeft gedelegeerd aan nationale internetorganisaties. In Nederland is dat voor de domeinnamen die op .nl eindigen, de SIDN (Stichting Internet Domeinregistratie Nederland). ${ }^{50}$

Tielemans inventariseert in V\&O van november $2006^{51}$ een aantal overeenkomsten welke door hem als "ICT-overeenkomsten" worden geduid. Hij noemt softwareovereenkomsten, hardwareovereenkom-

\footnotetext{
46 R. Graham en Chr. Barrett, IT Due diligence corporate transactions, European Counsel, mei 1998, p. 21 e.v. en Thelen, Reid, Priest LLP, Intellectual property due diligence: a must when assets are transferred, door: Technolgy, Intellectual Property and Trade Regulation Practice Group, 5 augustus 2002. Vindplaats: http://www.constructionweblinks.com. Zie ook N. Mulder en D. Stols, Rechten tegen het licht houden, F\&O, mei 2005, p. 10 e.v.

Zie ook Th. Adam-van Straaten, Due diligence - een practische handleiding, BMM-Bulletin 2002, nr. 97, p. 142 e.v.

47 Zie recent bijvoorbeeld HR 11 januari 2008, RvdW 2008, 97.

48 Ch. Gielen, IE-rechten, acquisities en joint ventures, De NV 74, 9 september 1996, p. 227 e.v.

49 F.P. van Koppen, De vermogensrechtelijke status van het recht op de domeinnaam, Maandblad voor Vermogensrecht, juni 2006, nr. 6, p. 111 e.v.

50 Voor de vraag of een domeinnaam een vermogensrecht betreft, zie Rechtbank 's-Hertogenbosch 27 december 2005, Domjur 2006, 250.

51 W.J. Tielemans, Het juridische ICT due diligence onderzoek voorafgaand aan een overname, V\&O 2006, nr. 11, p. 210 e.v.
} 
sten, dienstenovereenkomsten, service- en onderhoudsovereenkomsten, outsourcing overeenkomsten en telecommunicatiegerelateerde overeenkomsten.

\section{$1.15 \quad$ Milieu-aspecten}

Ter gelegenheid van een overname moet vroegtijdig de nodige aandacht uitgaan naar milieuaspecten. De vraag moet altijd gesteld worden of er aan het soort van activiteit van de over te nemen onderneming risico's verbonden kunnen zijn (geweest) waar het de vervuiling van grond, water of lucht betreft. Het onderzoek van de bodem en eventuele opstallen kan worden gezien als een zelfstandig (onderdeel van een) due diligence onderzoek. Het hierna te noemen onderzoek naar vergunningen kan tot het juridisch onderzoek worden gerekend. Afhankelijk van de vraag of het voorzien is dat er grond en/of opstallen zullen worden overgenomen, moet worden nagegaan of er aan het (voormalig) gebruik van de desbetreffende grond en met betrekking tot de opstallen (denk bij dit laatste vooral aan het gebruik van asbest en/of andere milieu-onvriendelijke stoffen) risico's verbonden kunnen zijn. Geenszins ongebruikelijk is het om - zodra de plannen om tot een overname over te gaan, zich concretiseren van de verkoper medewerking te verlangen aan een indicatief bodemonderzoek. De uitkomst van dat onderzoek vormt veelal de basis voor verdere afspraken, zoals het opnemen van (opschortende of ontbindende) voorwaarden in de overnameovereenkomst en/of het bedingen van garanties en/of vrijwaringen.

Gemeenlijk wordt eerst gekeken naar het huidige proces van bedrijfsvoering, de daarbij gebruikte stoffen en de manier waarop die worden verwerkt. Gekeken moet ook worden naar omgevingsfactoren, zoals de aanpalende percelen en de activiteiten die daarop worden verricht. Relevant kan ook zijn welke activiteiten voorheen op aanpalende percelen zijn verricht. De richting van grondwaterstromen is belangrijk in verband met vervuiling welke van andere percelen onder het perceel van de doelwitvennootschap terecht kan (zijn) (ge)komen en welke eigenaren van belendende percelen zouden kunnen stellen dat vervuiling in hun perceel door activiteiten op het terrein welk door de doelwitvennootschap is gebruikt, kan zijn veroorzaakt.

Niet alleen verdient het historisch gebruik van het perceel en de opstallen die op het moment van een beoogde overname bij de onderneming van de doelwitvennootschap in gebruik zijn de aandacht, maar - mede gelet op de toepassing van de Wet bodemsanering - ook het gebruik van elders gelegen percelen welke voorheen bij de doelwitvennootschap in gebruik zijn geweest.

Aandacht verdient verder het vergunningenstelsel. Bekeken moet worden of bij activa en passiva transacties de voorhanden vergunningen overdraagbaar zijn en in zowel dat geval als in het geval van aandelentransacties of de vergunningen die er zijn, nog wel voldoende zijn, gelet op ontwikkelingen welke zich in de bedrijfsvoering kunnen hebben voorgedaan sedert de datum van de verlening van de vergunning.

\subsection{Pensioenaspecten}

Het onderzoek naar aspecten van pensioenrecht en pensioenverzekering zal gebruikelijk onderdeel uitmaken van het juridisch onderzoek, maar kan even goed een plaats krijgen binnen het kader van het financieel onderzoek. ${ }^{52}$ Voor de hand liggend is dat zowel de juridische als de verzekeringstechnische (financiële) aspecten van pensioenen worden onderzocht. Daarbij gaat het niet alleen om een inschatting van denkbare risico's, maar ook om mogelijkheden om in de toekomst de gehanteerde pensioensystemen te harmoniseren en/of financierbaar te houden. Er moet worden gelet op de eerder genoemde zogenaamde change of control bepalingen, maar dan nu in de pensioenovereenkomst en er moet worden geverifieerd of er geen verplichting bestaat tot deelneming in een bedrijfspensioenfonds (na een eventuele fusie of overname).

Is er sprake van een aandelentransactie, dan zijn er verschillende mogelijkheden. Het ondernemingspensioenfonds zal ook worden overgenomen of blijft achter bij de andere partij. Kan er wel of niet in het ondernemingspensioenfonds een vertegenwoordiger in het bestuur worden benoemd door de nieuwe werkgever? Kunnen de statuten van het ondernemingspensioenfonds worden gewijzigd zonder veel problemen? Hoe zit het met waardeoverdracht voor werknemers die bij de verkoper achterblijven en de verrekening van voorschotten?

\footnotetext{
${ }^{52}$ Zie W. van Heest, Pensioenaanspraken bij fusies en overnames, TOP 2008, 3, p. 99 e.v.
} 
In het geval van een activa/passiva-transactie is er de verplichting tot continuering van de bestaande pensioenverzekering (artikel 7:664), tenzij de nieuwe werkgever aan de overgenomen werknemer dezelfde pensioentoezegging doet als aan zijn eigen werknemers of de werknemer gaat deelnemen in een bedrijfstakpensioenfonds, dat al voor de werknemers van de nieuwe werkgever of combinatie van toepassing is. Bij het onderzoek moet aandacht worden gegeven aan bepalingen van CAO's. Indien de geldende pensioentoezeggingen (dienen te) worden gehandhaafd, moet de pensioenverzekering van de verkoper worden overgenomen (indeplaatstreding) en zullen er actuariële consequenties moeten worden doorgerekend. Waar er sprake is van een waardeoverdracht naar een nieuwe pensioenverzekeraar of een nieuw ondernemingspensioenfonds, zullen voldoende middelen beschikbaar moeten zijn om de geldende pensioentoezeggingen gestand te doen. In dit geval zal er op de koper een onderzoeksplicht rusten. ${ }^{53}$

De koper zal bedacht dienen te zijn op de volgende potentiële risico's:

- $\quad$ Rendement en winstdeling, met name bij zogenaamde verzekerde regelingen;

- $\quad$ De duur van geldende overeenkomsten, zowel bij rechtstreekse verzekering als in het geval van herverzekering (het risico van change of control clausules kwam al aan de orde);

- $\quad$ Het risico van boetes en/of dwangsommen van de zijde van de toezichthouder;

- $\quad$ Aspecten van de Wet gelijke behandeling;

- $\quad$ Een goede röntgenfoto van de wijze van financiering (mede met het oog op uitstel financiering);

In gang gezette veranderingen van stelsels of afspraken, zowel bij de (vorige) werkgever als in de branche (CAO's of andere afspraken);

- De fiscale aspecten welke kunnen samenhangen met de uitvoering of oversluiting van fiscale regelingen, dienen nadrukkelijk de aandacht te krijgen.

De pensioenproblematiek is in het algemeen zeer ingewikkeld. ${ }^{54}$ Het is in de praktijk niet ongebruikelijk om voor het onderzoeken daarvan specialisten in te huren, die dan deel gaan uitmaken van het due diligence team. Juist in situaties, waarin er van veranderingen sprake is, overgang van werkgever of pensioenverzekeraar, komen niet zelden problemen aan het licht, die eerder in de routine van alle dag nog niet waren opgevallen of ongemerkt aan de aandacht ontschoten waren.

\subsection{Mededingingsrechtelijke aspecten}

In het algemeen wordt in het overnametraject pas aan de invloed van het mededingingsrecht gedacht op het moment dat eventueel sprake moet zijn van een melding bij de Nederlandse Mededingingsautoriteit (NMa) of bij de Europese Commissie (Commissie). Mededingingsrechtelijke aspecten kunnen evenwel eerder op verschillende terreinen doorwerken. Hierbij dient te worden gedacht aan de volgende onderwerpen:

- Bestaande overeenkomsten. In het kader van het due diligence onderzoek kan het zinvol zijn om overeenkomsten waarbij de doelwitvennootschap partij is te bekijken om na te gaan of daarin geen bedingen voorkomen die mogelijk niet rechtsgeldig (nietig) zijn wegens strijdigheid met het mededingingsrecht. De koper loopt in dat geval immers het risico dat dergelijke overeenkomsten in hun geheel niet afdwingbaar zijn. Mededingingsrechtelijke risico's kunnen met name tot uitdrukking komen in de nietigheid van overeenkomsten of clausules uit overeenkomsten tussen de doelwitvennootschap en haar wederpartijen. Deze nietigheid kan tot het verwezenlijken van verschillende ri-

53 Zie HR 4 januari 1991, NJ 1991, 254 (Avery / VRG). Deze zaak ging over een verwijt dat de koper niet voldaan had aan haar onderzoeksplicht naar hetgeen de 'tot nu toe gevolgde consistente (actuariële) methode' inhield. Er was geen misverstand over het feit dat alle informatie met betrekking tot de pensioenregeling ter beschikking was, toen partijen afspraken maakten over een garantie dat de premiereserves van het pensioenfonds ter dekking van de aldaar ondergebrachte pensioenafspraken zou worden overgeheveld naar het nog op te richten pensioenfonds van de koper. Toen er over de te gebruiken rekenrente problemen ontstonden, oordeelde het hof - daarin gesteund door de Hoge Raad - dat de vraag op wie een onderzoeksplicht rustte, steeds door de omstandigheden van het geval dient te worden beantwoord, maar in het onderhavige geval niet onjuist was beantwoord door te stellen dat op de koper een verplichting rustte om dieper door te vragen.

54 Zie over de gevolgen van de met ingang van 1 januari 2005 voor beursgenoteerde ondernemingen binnen de Europese Unie toepasselijke IFRS (IAS 19 waar het de verwerking van pensioentoezeggingen in de jaarrekening betreft en in Nederland Richtlijn 271), A. Peters en C. Snoeks, De transparantie van pensioenverplichtingen, Fusie \& Overname 2005 , p. 22 e.v. 
sico's leiden. Allereerst doordat de wederpartij zich beroept op de nietigheid en zich niet aan de desbetreffende verbintenissen gebonden acht. Te denken valt aan afspraken om niet te concurreren. Een ander risico bestaat daar in dat derden, afnemers/leveranciers, een klacht indienen bij de NMa of naar de burgerlijke rechter stappen, bijvoorbeeld ingeval van een vermeende gebiedsafbakening, dan wel dat de NMa of de Europese Commissie ambtshalve een onderzoek initiëren. Bedingen die aan afdwingbaarheid in de weg kunnen staan zijn o.a. marktverdelingbepalingen (tussen concurrenten), prijsafspraken (tussen concurrenten), verticale prijsbindingen (tussen producent en distributeur) en non-concurrentiebedingen.

- Machtspositie. Indien de te onderzoeken onderneming een groot marktaandeel heeft zodat sprake is van een economische machtspositie, dient onderzocht te worden of de bepalingen in de verschillende overeenkomsten niet in strijd zijn met art. 24 Mw. of artikel 82 EG-Verdrag.

- Concentratiecontrole. Een transactie moet worden gemeld bij de NMa indien de transactie (1) kwalificeert als een concentratie ${ }^{55}$ en (2) bepaalde omzetdrempels ${ }^{56}$ worden overschreden. Een concentratie komt in mededingingsrechtelijke zin onder andere tot stand door een fusie van twee of meer voorheen onafhankelijke ondernemingen en door het direct of indirect verkrijgen van zeggenschap door een of meer ondernemingen over een andere onderneming of delen daarvan. ${ }^{57}$ Partijen kunnen een wat wel genoemd wordt antitrust due diligence uitvoeren indien zij bijvoorbeeld problemen verwachten bij de goedkeuring van de concentratie door de mededingingsautoriteit(en). Daarbij wordt onderzoek gedaan naar de invloed van een concentratie op de relevante markt. In dat kader wordt de 'relevante' geografische- en productmarkt afgebakend, worden de marktaandelen van partijen in de nieuwe situatie op die markt berekend en worden mogelijke 'remedies' onderzocht. Door deze informatie reeds op voorhand beschikbaar te hebben kan in sommige gevallen de procedure voor de mededingingsautoriteiten sterk worden ingekort. Dit kan in het kader van een vendor due diligence een overweging zijn om met behulp van adviseurs die kunnen helpen inventariseren welke informatie in welke vorm beschikbaar moet worden gemaakt, die informatie bijeen te brengen en voorhanden te maken. Het is mogelijk dat de NMa zal besluiten dat het uitgebreidere, zogenaamde 'tweede fase' onderzoek niet nodig is. ${ }^{58}$ Een antitrust due diligence kan vanzelfsprekend ook al worden verricht vóór tekenen van de overnameovereenkomst, zodat het voor partijen zelf een rol kan spelen bij de onderhandelingen omtrent de beoogde transactie.

Partijen dienen zich er rekenschap van te geven dat zij tot het moment waarop de mededingingsautoriteiten hun fiat geven, géén uitvoering mogen geven aan hun transactie. Het vooraf opstellen van integratieplannen (pre-closing integration planning) is vanzelfsprekend wel mogelijk, maar de uitvoering hiervan zal nog niet mogen plaatsvinden. Doen zij dit toch, dan riskeren zij boetes ${ }^{59}$ en/of het opleggen van de verplichting de oude situatie te herstellen door middel van het ontbinden van de overeenkomst en/of het treffen van andere maatregelen.

- Uitwisseling van gegevens. Er dient tijdens het toestaan en/of uitvoeren van een due diligence onderzoek voor gewaakt te worden dat er geen concurrentiegevoelige gegevens worden uitgewisseld. Dit speelt vanzelfsprekend in het bijzonder wanneer de betrokken partijen onderling concurrenten zijn. Een dergelijke pre-closing coördination vormt ook een risico voor de doelwitvennootschap als de transactie uiteindelijk niet doorgaat. De bescherming welke afspraken tot geheimhouding moeten bieden is vaak moeilijk afdwingbaar, doordat het bewijs dat dergelijke afspraken geschonden zijn, in de regel moeilijk te leveren is.

55 Indien partijen niet zeker zijn of een transactie kwalificeert als concentratie in de zin van de Mw., bestaat de mogelijkheid om een informele zienswijze te vragen aan de NMa (termijn in beginsel 2 weken). Een dergelijke zienswijze biedt weliswaar geen rechtszekerheid, maar is wel van praktisch belang omdat het duidt wat het formele standpunt van de NMa zal zijn.

56 Artikel $29 \mathrm{Mw}$. stelt dat de gezamenlijke wereldwijde omzet van de betrokken ondernemingen $€ 113,5$ miljoen dient te zijn en tenminste twee van de betrokken ondernemingen ieder in Nederland een omzet van $€ 30$ miljoen behalen. De omzet van de verkopende onderneming dient buiten beschouwing te worden gelaten. Artikel 1 CoVo geeft de omzetdrempels voor een melding bij de Europese Commissie.

57 Ingevolge artikel $26 \mathrm{Mw}$. wordt onder zeggenschap verstaan de mogelijkheid om op grond van feitelijke of juridische omstandigheden een beslissende invloed uit te oefenen op activiteiten van een onderneming.

$58 \mathrm{Bij}$ de NMa duurt de eerste fase in principe maximaal 4 weken, de tweede fase maximaal 13 weken (zie artikel 37 resp. artikel 44 Mededingingswet). Bij de Europese Commissie duurt het maximaal 25 resp. maximaal 90 werkdagen (artikel 10 CoVo).

$5910 \%$ van de jaaromzet op grond van de CoVo; $€ 450.000$ of $10 \%$ van de jaaromzet op grond van de Mw. 
Zo werden door Essent mededingingsrechtelijke argumenten aangevoerd om ter gelegenheid van een voorgenomen fusie met Nuon de commerciële mensen van Nuon geen toegang te geven tot haar bedrijfsinformatie. Hoewel Essent stelde, dat er bereidheid zou zijn geweest om over veel zaken informatie te verschaffen (zoals waardering van centrales en pensioen- en fiscale posities), was er geen bereidheid om over financiële en commerciële posities volledige openheid van zaken te geven, zo lang de Mededingingsautoriteit NMa geen toestemming had gegeven voor de fusie. Essent wilde daarom de commerciële mensen van Nuon nog niet over de vloer hebben, zo lang de NMa-horde nog niet genomen was. "Je blijft concurrenten van elkaar. Zo lang de deal niet rond is, moet je onafhankelijk van elkaar kunnen blijven opereren". ${ }^{60}$ Nuon had niet ingestemd met een eerder voorstel van Essent om het boekenonderzoek bij een handelsdivisie (waar de grootste sensitiviteit gold) door de accountant van Nuon te laten doen. Zie ook hier voor onder 1.5.

- Procedures en boetes. Het is van belang om te onderzoeken of de mededingingsautoriteiten ${ }^{61}$ onderzoeken hebben lopen tegen de bij de concentratie betrokken onderneming(en). Indien onderzoeken gaande zijn, zal een inschatting moeten worden gemaakt van denkbare boetes van de zijde van de mededingingsautoriteiten en daarmee gepaard gaande eventuele claims van derden.

- Staatssteun. Gedurende een due diligence onderzoek kan geconstateerd worden dat er gelden vanwege de overheid zijn verkregen die mogelijk kwalificeren als 'staatssteun'. Er is sprake van staatssteun indien de steun maatregelen van een overheid betreft of iets met staatsmiddelen is bekostigd, waardoor een niet marktconform voordeel aan onderneming(en) is verschaft, de verleende steun selectief is, de mededinging vervalst of dreigt te vervalsen en een ongunstige invloed heeft op de tussenstaatse handel. Een steunmaatregel ziet op voordelen die met staatsmiddelen zijn bekostigd, ongeacht of deze direct, dan wel indirect, middels van overheidswege ingestelde of aangewezen publieke-, semi-publieke- of private beheersorganen worden verleend. De maatregelen van staten en de staatsmiddelen omvatten niet alleen positieve prestaties, zoals subsidies, leningen of deelnemingen in het kapitaal van ondernemingen, maar ook maatregelen die, in verschillende vormen, de lasten verlichten die normaliter op het budget van een onderneming drukken en daardoor - zonder nog subsidies te zijn in de strikte zin van het woord - van gelijke aard zijn en identieke gevolgen hebben. Staatssteun is pas rechtmatig wanneer de Commissie de steunmaatregel heeft goedgekeurd. ${ }^{62}$ In overige gevallen is de steun onrechtmatig en kan de Commissie de genoten steun terugvorderen. ${ }^{63}$ Onrechtmatig verkregen staatssteun dient te worden teruggevorderd van de onderneming die de steun feitelijk heeft genoten ${ }^{64}$, dan wel van de entiteit die deze verplichting heeft overgenomen. ${ }^{65} \mathrm{De}$ Commissie zal (via tussenkomst van de lidstaat) de koper van de onderneming aanspreken voor de terugbetaling van de onrechtmatige steun. Bij het uitvoeren van een due diligence onderzoek en het opstellen van de overname documentatie (denk vooral ook aan de omvang van de garanties) dient men bedacht te zijn op de rechtmatigheid van deze van overheidswege verkregen gelden.

- Europese aanbestedingsregels. Een (deel) van een onderneming die onderworpen is aan een due diligence onderzoek kan overeenkomst(en) hebben gesloten met een aanbestedende dienst. In dat geval is het verstandig te inventariseren of dit contract Europees is aanbesteed en zo niet, of dat contract Europees aanbesteed had moeten worden. In beginsel is het niet de verantwoordelijkheid van de onderneming om de aanbestedende dienst er op te wijzen dat een contract Europees aanbesteed had moeten worden. Niettemin bestaat het risico dat in een dergelijk geval het contract (tussentijds) beëindigd wordt. Eveneens kan de over te nemen onderneming hebben deelgenomen aan een Europese aanbestedingsprocedure. De vraag die hierbij speelt is of deze aanbestedingsprocedure volgens de Europese aanbestedingsrichtlijnen is verlopen. Wanneer dit niet het geval is kan ook in dat geval het contact (tussentijds) worden beëindigd. Tenslotte kan het zich voor doen dat de over

\footnotetext{
${ }^{60}$ Zie FD 10 september 2007, p. 11.

${ }^{61}$ Naast de Europese Commissie en de NMa kunnen ook gespecialiseerde toezichthouders als Opta, NZa en AFM of buitenlandse toezichthouders onderzoek verrichten.

62 Artikel 88 EG Verdrag en artikel 2 lid 1 van verordening 659/1999 van de Raad van 22 maart 1999 tot vaststelling van andere bepalingen voor de toepassing van artikel 93 [nu 88] van het EG Verdrag, PbEG 1999, L 83/1.

${ }^{63}$ HvJEG 21-11-1991, zaak C-354/90, Saumon, Jur. 1991, p. I-5505, r.o. 12.

64 Koenig, "Determining the addressee of a decision ordering the recovery of state aid after the sale of substantial assets of the undertaking in receipt of aid", [2001] ECLR issue 6, Sweet \& Maxwell, p.238.

65 1999/720/EC, Besluit van de Commissie van 8 juli 1999, "GSW" besluit, [1999] PB L292/27; 2000/567/EC, Besluit van de Commissie van 11 april 2000, "SMI" besluit [2000] PB L238/50; 2000/796/EC Besluit van de Commissie van 21 juni 2000 "CDA" besluit, [2000] PB L318/62.
} 
te nemen onderneming mee heeft gedongen naar een opdracht van een aanbestedende dienst waarbij zogenaamde 'voorvergaderingen' gehouden zijn. Dergelijke kartels zijn in strijd met artikel 6 Mededingingswet en worden gesanctioneerd met (persoonlijke) boetes.

\subsection{Cultuuronderzoek}

Het besef is in de laatste jaren toegenomen dat de haalbaarheid van een integratieproces van verschillende ondernemingen in belangrijke mate beïnvloed wordt door de verenigbaarheid van culturen. Een onderzoek naar de bestaande culturen - voorafgaande aan of tijdens een overnameprocedure of fusieproces - kan teleurstellingen achteraf helpen voorkomen. Zie ook hierna onder 2.7.

\subsection{Onderscheid met legal audit of legal risk management-project}

Een due diligence onderzoek is niet hetzelfde als een legal audit of een legal risk management project. Ook al zullen de onderscheidingen tussen de verschillende figuren niet altijd even duidelijk zijn en worden de begrippen in het spraakgebruik regelmatig door elkaar gehaald.

Een legal audit is vergelijkbaar met een 'boekenonderzoek' naar de in een onderneming voorhanden juridische documentatie. Wanneer een onderzoek zich bezig houdt met de vraag welke juridische documentatie er eigenlijk zou moeten zijn, welke juridische risico's er voor de onderzochte onderneming kunnen worden geïdentificeerd, en hoe het risk management (de risicobeheersing) ten aanzien van die risico's verdeeld en georganiseerd is, is er sprake van een legal risk management project.

Wessels ${ }^{66}$ benoemt risico-management als " $(\ldots)$ het continue proces van planning, organisatie, besturing en beheersing van activiteiten en middelen van een organisatie op zodanige wijze dat de mogelijkheid van schade of verlies wordt teruggebracht tot het laagst mogelijke peil tegen de laagst mogelijke kosten."

De opzet van een legal risk management project is gebruikelijk dat er niet alleen wordt gekomen tot het inventariseren van de juridische en andere risico's waarmee een onderneming kan worden geconfronteerd, maar ook dat de verantwoordelijkheid voor het vermijden en beperken van die risico's wordt toebedeeld aan benoemde personen, die bij voorkeur deel uitmaken van leidinggevende segmenten in de organisatie. Hoewel ook een juridische afdeling niet zelden bemoeienis zal hebben bij de uitvoering van een risk management project, is het toch meer een multi disciplinair project, aangestuurd onder de uiteindelijke verantwoordelijkheid van de hoogste leiding. Er wordt - om in ondernemingstermen te spreken - 'lijnverantwoordelijkheid' gelegd bij mensen die het tot hun normale kerntaken (moeten) rekenen om de gesignaleerde risico's te 'managen'. Daarmee wordt bereikt dat voor een langere periode het oog gericht blijft op het beheersen van risico's welke werden geïdentificeerd en er wordt gestreefd naar het verbeteren van processen om risico's tegen te gaan. Een due diligence onderzoek betreft (meer) een moment opname en de houdbaarheidsdatum van resultaten daarvan is dan ook eerder verstreken. Een ander verschil is, dat een legal risk management project kan worden uitgevoerd in de eigen onderneming, terwijl een due diligence onderzoek zich zal afspelen met betrekking tot de onderneming van vooralsnog een ander.

\section{$1.20 \quad$ Legal scan}

"Legal Scann" is de merknaam voor een juridisch onderzoek van een door KPMG in Spanje ontwikkeld product, dat bedoeld is om alle juridische risico's in kaart te brengen die relevant kunnen zijn voor het afgeven van een goedkeurende verklaring door een accountant. De redenering is ook in dit geval dat de onderneming te maken heeft met tal van juridische risico's. Accountants plegen te proberen zicht op die risico's te krijgen door het vragen van een zogenaamde lawyer's letter aan juridische adviseurs van een rechtspersoon. Door de uit dien hoofde ontvangen informatie te inventariseren en te evalueren, wordt gehoopt de juridische risico's in kaart gebracht te krijgen. Vanzelfsprekend betreft dit uitsluitend

${ }^{66}$ B. Wessels, Risicobeheer bij advisering, Preadvies van de Nederlandse vereniging van Ondernemingsrechtadviseurs 1995, p. 46. 
die juridische aangelegenheden, waarvoor extern juridische assistentie is ingeroepen. Door middel van zogenaamde management certificates zal de accountant proberen zich verder te informeren. ${ }^{67}$

De Legal Scann bestaat uit een computer questionnaire en is bedoeld als een instrument om risicovolle situaties te signaleren binnen het kader van de uitvoering van controle werkzaamheden door de accountant. Het gaat om software die de controlewerkzaamheden van de accountant op de voet volgt. De bedoeling is dat er aldus extra steun wordt gegeven aan de geruststelling van de accountant dat diens verklaring achteraf op goede gronden is gebaseerd. Het systeem is niet bedoeld om risico's te kwantificeren, maar wel om die te identificeren. Het product vertoont gelijkenis met een legal audit, maar heeft ook elementen van een legal risk management-project. Het is echter bedoeld om in de pas te lopen met de controle werkzaamheden van de accountant en is als zodanig beoogd een hulpmiddel te zijn voor de accountant, met een stille ambitie van de ontwerpers om tevens een rol te vervullen in een due diligence proces. Het kan dan vooral dienst doen om nadere toelichting te verkrijgen bij de jaarcijfers van de doelwitvennootschap.

\subsection{Business audit}

De laatste loot aan de onderzoekstamboom is de zogenaamde business audit. Dit betreft een eveneens door KPMG gelanceerd product dat in de brochure als volgt wordt omschreven: een vernieuwde aanpak waarmee de accountants aan de hand van de jaarrekeninggegevens de onderneming op 7 additionele aandachtsgebieden analyseren. Doelstelling is een praktische analyse uit te voeren, die gevolgd wordt door adviezen die dienstig moeten zijn aan de verhoging van het rendement, de beheersing van risico's of de optimalisering van processen. De zeven desbetreffende aandachtsgebieden zijn fiscaliteit, financiering, human resource accounting, kwaliteit van de financiële functie, procesoptimalisatie, rendementsverbetering en risicobeheersing. Het zal de laatste variant van een bedrijfsonderzoek wel niet zijn.

\section{$1.22 \quad$ NCGC}

Wanneer er bij een transactie sprake is van een beursgenoteerde doelwitvennootschap, zal in het due diligence onderzoek aandacht moeten worden besteed aan de vraag of de bepalingen van de Nederlandse Corporate Governance Code worden nagevolgd danwel of er in de jaarverslaggeving voldoende uitleg is gegeven aan de redenen voor afwijking daarvan. Aandacht zal nodig zijn voor onder meer de navolgende elementen:

- Interne risicobeheersings- en controlesystemen (beschrijving van het risicoprofiel en van het interne risico en controlesysteem);

- De bezoldiging van bestuurders (de rol van de remuneratiecommissie en de structuur van het beloningsssysteem);

Het profiel van de raad van commissarissen;

- Het bestaan van een klokkenluidersreglement, voorwetenschapreglement, selectie- en benoemingscommissiereglement, remuneratiecommissiereglement, auditcommissiereglement, reglement voor de raad van commissarissen en bestuursreglement;

- (Potentiële) tegenstrijdige belangen.

Verder is het goed dat er wordt nagegaan of voldaan is aan de bepalingen van de Wmz.

De schending van statutaire bepalingen of zorgvuldigheidsnormen door een vennootschap kan toewijzing van een enquêteverzoek - in het licht van de omstandigheden van een geval - rechtvaardigen. Hoewel de Ondernemingskamer tot het gelasten van zo'n onderzoek geenszins gehouden is, dient daar toch rekening mee te worden gehouden. ${ }^{68}$

${ }_{67}$ Management certificates zijn van bestuurders en andere leidinggevenden gevraagde verklaringen dat alle relevante informatie aan de accountant is verschaft.

68 Zie A-G Timmerman in diens conclusie onder HR 15 december 2006, zaaknummer R06/040HR, LJN AZ3172, die ter illustratie een tweetal arresten noemde: HR 1 september 2006 (zaaknummer R05/081HR - Emba, artikel 81 RO), waarin sprake was van de schending van een zorgvuldigheidsnorm door de vennootschap, en HR 23 juni 2006, zaaknummer R05/092HR (OK 120, Call Active, artikel $81 \mathrm{RO}$ ), waarin sprake was van schending van wettelijke en statutaire voorschriften door de vennootschap. 
Ook in de Verenigde Staten is het thema van Corporate Governance nadrukkelijk opgemerkt als een onderwerp dat op de agenda van een due diligence onderzoek thuishoort:

"Assessing the quality of governance practices requires going beyond an assessment of the internal control systems (a Sarbanes Oxly requirement). Shareholders not on the board should expect a Corporate Governance report as part and parcel of M\&A information, addressing questions such as whether the target company support effective governance policies, communication, company ethics and antifraud policies, and whether it can prove it. (...). M\&A also provide the momentum to revisit long established governance practices and to open a dialogue with employees and various stakeholders on Corporate Governance issues, farness processes and ethical values. ${ }^{, 69}$

\section{$1.23 \quad$ Rating}

Rating is een classificatie van zaken in verschillende categorieën aan de hand van vooraf gestelde en op alle vergeleken objecten algemeen toegepaste criteria. Rating is geen due diligence onderzoek, maar het resultaat van een met een due diligence onderzoek te vergelijken onderzoek naar een aantal kengetallen en omvat veelal tevens een onderzoek naar en waardering van bestaande systemen en mogelijkheden.

\subsection{Enquête}

Het begrip 'enquête' wordt in het algemeen op twee manieren gebruikt. Enerzijds om een getuigenverhoor aan te duiden. Zie artikel 163-185 Rv. Anderzijds om het onderzoek aan te duiden dat de OK kan doen instellen naar het beleid en de gang van zaken van een rechtspersoon (artikel 2:345). Het onderzoek dat door de door de OK benoemde onderzoeker kan worden ingesteld, moet worden onderscheiden van een due diligence onderzoek zoals in dit boek bedoeld. Overigens zouden onderzoekers, die een due diligence onderzoek als in dit boek bedoeld uitvoeren, ter oriëntatie kennis kunnen nemen van de Richtlijnen voor de onderzoeker in enquêteprocedures. ${ }^{70}$ Die richtlijnen bevatten aanbevelingen met betrekking tot de inrichting van het onderzoek, de aanleg van het dossier, de communicatie met de bij het onderzoek betrokken personen, over tussentijdse rapportage en over de verslaglegging.

\footnotetext{
69 L. Capron en K. Schnatterly, How M\&A's cal lead to governance failure, FT Master in Corporate Governance, p. 6.

70 J.M. Blanco Fernandez, M. Holtzer en G. van Solinge, Nijmeegse Serie, deel 78.
} 


\section{Soorten van due diligence onderzoek}

\section{$2.1 \quad$ Inleiding}

$\mathrm{Na}$ in het vorige hoofdstuk te hebben stil gestaan bij een eerste begripsomschrijving en een eerste plaatsbepaling van het begrip due diligence temidden van andere soorten van onderzoek, wordt in dit hoofdstuk ingegaan op de verschillende varianten van een due diligence onderzoek die zich laten onderscheiden. Zoals zal blijken is een due diligence onderzoek vrijwel altijd maatwerk. ${ }^{71}$ Een due diligence onderzoek wordt uitgevoerd met een bijzonder doel voor ogen binnen het kader van een specifieke transactie. Daardoor worden niet alleen het moment waarop het onderzoek plaatsvindt, maar ook de plaats, de vorm, de diepgang en andere elementen die deel uitmaken van een due diligence onderzoek bepaald. Keuzen ter zake van al die onderdelen van een due diligence onderzoek worden ingegeven door de wensen van de opdrachtgever van de onderzoeker(s), maar niet in de laatste plaats mede beïnvloed door de attitude van degene(n), die toegang tot de te onderzoeken informatie of een ander voorwerp van onderzoek moet(en) toestaan. De laatst genoemde(n) bepalen immers wanneer zij en op welke plaats welke informatie op welke wijze beschikbaar willen maken, voor hoe lang en onder welke voorwaarden. Wanneer later in dit boek wordt stil gestaan bij de juridische aspecten welke samenhangen met de gevolgtrekkingen welke kunnen worden verbonden aan de vraag of er wel of niet (een voldoende mate) van due diligence heeft plaatsgevonden bij het aangaan van een transactie, dan zou de laatst genoemde omstandigheid door degene die een oordeel velt, niet buiten beschouwing mogen worden gelaten. Daarmee bedoel ik, dat het aan te bevelen is om in een overeenkomst of andere documentatie ter gelegenheid van een transactie uitdrukkelijk aan te geven welke ruimte er geboden is om een onderzoek uit te voeren. Men dient er immers rekening mee te houden - normaliter zal dit het geval zijn - dat na het voltooien van een transactie de kwaliteit van het uitgevoerde onderzoek mee in de weegschaal kan worden gelegd bij de beoordeling van de vraag of er aanspraak gemaakt kan worden op een verwijt ter zake van het voorwerp van koop of op gebreken in een andere transactie. De houding van de wederpartij wordt dan mede betrokken bij een beoordeling achteraf van de mate van zorgvuldigheid welke men voorafgaand aan een transactie in acht heeft kunnen nemen. De waarde van de aldus voor de eventualiteit van een geschil achteraf vast te leggen situatieschets mag aan de andere kant ook weer niet worden overschat. Het is immers steeds een door iedere betrokkene zelf te maken afweging of de medewerking, of het ontbreken van medewerking van de wederpartij, (niet) van zodanige aard is, dat van de transactie had moeten worden afgezien. Duidelijkheid over de positie waarin men zich bevond voorafgaande aan het aangaan van een transactie, waartoe ook een uitdrukking van de noodzaak of motieven voor het aangaan daarvan gerekend kan worden, is iets 'waarvan het beter is om er mee dan om verlegen te zijn'. De omstandigheden van het geval zullen uiteindelijk steeds bepalend zijn. Het zijn ook die omstandigheden die mede bepalen welk van de hierna te noemen varianten van een due diligence onderzoek in welke situatie het meest geïndiceerd is om te worden toegepast, dan wel - vanwege de opstelling van de andere betrokken partij(en) - het best kan worden uitgevoerd.

Mollan en Solt hebben geprobeerd het onderscheid te benoemen tussen aspecten welke tijdens een due diligence onderzoek in het geval van fusies en overnames enerzijds en in het geval van participaties (en ook joint ventures) anderszijds de aandacht zouden verdienen. ${ }^{72}$ Volgens deze auteurs zou het bij een onderzoek dat vooraf gaat aan fusies en overnames vooral gaan om het onderzoeken van oude verantwoordelijkheden (valkuilen) en hoofdzakelijk juridische en financiële kwesties betreffen, zoals bestaande overeenkomsten, verzekeringskwesties, fouten in financiële verslaglegging en dergelijke. Waar dit het nemen van een participatie zou betreffen zou het accent veel meer (moeten) liggen op de toekomst en de mogelijkheden van toekomstige samenwerking, het strategische doel. Zij stellen daarbij voor ook vooral regelingen te treffen met het oog op veranderingen die partijen kunnen moeten doormaken en zelfs al meteen een regeling af te spreken om van echt te scheiden voor het geval het achteraf allemaal toch zou blijken tegen te vallen. Ik vind het aangebrachte onderscheid gezocht en een miskenning inhouden van het feit dat een zorgvuldige voorbereiding van elke soort van transactie

\footnotetext{
${ }_{71}^{71}$ Zie H.H. Kersten, Het due diligence onderzoek, vrijwilige en onvrijwillige beperkingen, Dossier 47, juli 2001, p. 27 e.v.

72 D. Mollan en Q. Solt, Wie neemt u mee naar het bedriffsbal? Het Financieele Dagblad, 13 februari 2006, p. 4 e.v.
} 
aandacht nodig maakt voor zowel de historie van het voorwerp van de transactie als de toekomst verwachtingen terzake daarvan. Zoals ik hier voor al opmerkte, is een due diligence onderzoek een op de voorhanden situatie toegesneden instrument, dat moet passen als een maatpak. Niettemin zijn er elementen, die gemeenschappelijk zouden moeten zijn bij elk onderzoek en die betreffen naast aandacht voor verleden en toekomst vooral de zorgvuldigheid waarmee het onderzoek wordt uitgevoerd en begrip voor de situatie waarin het onderzoek kan en moet worden verricht. Hierna zal worden aangegeven welke soorten onderzoek zich in de praktijk zoal laten onderscheiden. De hier genoemde gemeenschappelijke componenten moeten bij al de verschillende soorten van onderzoek steeds in het oog worden gehouden.

Hierna is als gezegd een poging gedaan om de verschillende soorten due diligence onderzoeken die zich laten onderscheiden te benoemen en daarbij aan te geven hoe de inhoud daarvan zal zijn. De gebruikte terminologie is niet altijd eenduidig. Bij gebreke van een werk als het onderhavige is er geen bepalend referentiekader. Ook in de buitenlandse literatuur vindt men verschillende varianten van een due diligence onderzoek aangeduid onder verschillende benamingen. Hierna is zoveel mogelijk aangesloten bij de te onzent in de overname en financiële praktijk gebruikte terminologie.

\subsection{Pre due diligence, pre-acquisition investigation of vendor due diligence}

Bij een pre due diligence investigation is er nog geen officieel contact geweest tussen de geïnteresseerde en de doelwitvennootschap. De opdrachtgever van een pre due diligence investigation heeft al wel een transactie in gedachten, maar deze is nog niet actueel voorwerp van onderhandeling. Om na te gaan in hoeverre een transactie kans van slagen zal hebben, wil men een inventarisatie van de stand van de dingen hebben. Met behulp van soms allerlei openbare informatiebronnen zoals jaarverslagen, statuten, enz. wordt bekeken of de doelwitvennootschap in het gewenste profiel past en in hoeverre een transactie haalbaar of gewenst lijkt te zijn. Zie ook hiervoor onder 1.5 voor de daarbij wel gebruikte bronnen van informatie. Het begrip pre due diligence investigation onderscheidt zich van het hierna genoemde begrip vendor due diligence in die zin dat in het laatst bedoelde begrip duidelijk tot uitdrukking komt dat dit een inspanning is die wordt gedaan door de verkoper. Wanneer er over een pre due diligence investigation wordt gesproken, gaat dit dus in het gewone geval om een eigen oriëntatie van een koper of investeerder.

Wanneer er al wel contact bestaat tussen de geïnteresseerde en de doelwitvennootschap, maar toegang tot informatie is nog niet mogelijk of toegestaan, is er wel sprake van een (verzoek) om een limited preliminary due diligence. Het gaat dan om een soort quick scan (of review, zie hierna onder 2.5) veelal vooreerst alleen te baseren op een Information Memorandum (vergelijk het hierna genoemde bidbook, maar dan uitgebreider), of beperkte informatie die anderszins verkregen wordt.

In het geval van pre-acquisition investigation wordt aan de eigen adviseurs gevraagd een due diligence onderzoek uit te voeren. Nu het begrip acquisition zowel vanuit de positie van een koper als vanuit de positie van een verkoper kan worden verstaan, wordt een onderzoek als hier bedoeld daarom ook wel en over het algemeen vaker vendor due diligence genoemd. Wanneer de pre acquisition investigation gebreken in de organisatie of de beschikbare financiële, juridische of andere documentatie aan het licht brengt, is de doelwitvennootschap in staat die gebreken te verhelpen, alvorens er op enig moment van een due diligence onderzoek door een derde sprake zal zijn. Het helpt voorkomen dat er voor de verkoper verrassingen optreden bij diens poging om de optimale prijs te realiseren. In het overnameproces zal een voltooide vendor due diligence zorgen dat er minder tijddruk op het management komt te rusten. Er kan kostbare tijd worden gewonnen verderop in het proces, denk bijvoorbeeld aan het vragen van een opinie van de mededingingsautoriteiten (zie hiervoor onder 1.14). Verder kan het helpen bij het opstellen van een realistische planning, het beheersbaar maken van de informatieverstrekking en het zo goed mogelijk presentabel maken van de te verschaffen informatie. Ook kan een uitgevoerde vendor due diligence aanleiding zijn voorafgaand aan een transactie de eigen organisatie anders in te richten, bijvoorbeeld door het zelfstandig afstoten van een of meer onderdelen. Het is bedoeld voor het maximaliseren van de waarde. De koper zal uit zijn op erosie van de waarde. Door het constateren van gebreken, die veelal als verrassingen zullen worden gepresenteerd of het nadruk leggen op verplichtingen en risico's zal de koper de historische prestaties van de onderneming in diens voordeel proberen te 'normaliseren'. De bedoeling is om in de onderhandelingen een sterkere positie 
te krijgen. Een vendor due diligence kan een belangrijke bijdrage leveren aan (meer) succesvolle onderhandelingen, bezien van uit het standpunt van de verkoper.

De voordelen van een vendor due diligence zijn - anders geformuleerd - in een 10-tal punten benoemd door Van Veen, Modderman, Van Suchtelen en De Bruijn ${ }^{73}$ :

(1) grotere competitie tussen bieders aangezien het rapport aan meerdere partijen kan worden verstrekt zonder dat exclusiviteit wordt gegeven aan een koper;

(2) verstrekt inzicht aan de verkoper zodat men precies weet wat er wordt verkocht. Dat resulteert in een betere controle over het proces, zowel juridisch als commercieel;

(3) voorkomt het verlies van het momentum in het proces omdat de kopers geen uitgebreide due diligence hoeven te doen nadat de bieding is geaccepteerd;

(4) voorkomt discussie over de prijs aangezien potentiële kopers in een vroegtijdig stadium worden voorzien van een volledig beeld van de onderneming;

(5) geeft de verkoper een sterke onderhandelingspositie aangezien bij het verstrekken van het volledige beeld zowel de positieve als negatieve kanten zijn getoond aan de kopers en deze hierin in de bieding rekening hebben kunnen houden;

(6) geeft mogelijkheden om in een vroegtijdig stadium de meest ideale dealstructuur op te zetten voor zowel de koper als de verkoper, waarbij fiscaliteit een belangrijke rol speelt;

(7) geeft de verkoper inzicht in het soort vragen die mogelijk de kopers hebben tijdens het proces. Het geeft tevens de mogelijkheid om zich op de gevolgen hiervan voor te bereiden;

(8) beperkt de ontregeling van de organisatie aangezien er maar eenmaal een due diligenceteam langskomt in plaats van alle mogelijke partijen met hun adviseurs;

(9) beperkt de afrondingsprocedure omdat een belangrijk deel van de bevindingen en observaties al kunnen worden meegenomen in de eerste versies van de verkoopovereenkomsten; en

(10) kan mogelijk leiden tot de identificatie van verborgen waarden die ook niet bekend waren bij de verkopende partij en waarbij nu nog de mogelijkheid bestaat deze te laten meewegen in biedingen.

In de praktijk zal niet alle informatie welke uit een vendor due diligence wordt verkregen direct in het Information Memorandum terechtkomen. Er kan selectief met die informatie worden omgegaan, zeker in de eerste en tweede ronde van overnamebesprekingen, met name wanneer er ook andere marktpartijen mee inschrijven (bijvoorbeeld bij een zogenaamde controlled auction of veilingverkoop) ${ }^{74}$ Verder zal ook de verkoper zich willen beschermen tegen vorderingen achteraf, zodat over het algemeen een Information Memorandum niet anders zal worden verspreid dan onder de mededeling dat naar de beste wetenschap van de verkoper alle relevante informatie in dat Information Memorandum is verstrekt. ${ }^{75}$ Bestuurders en commissarissen zullen willen proberen zich al in een Information Memorandum te vrijwaren tegen individuele aansprakelijkheden, voor zover er op enig tijdstip naderhand mocht blijken dat toch niet alle informatie uitputtend in het Information Memorandum aan de orde is gekomen.

De vendor due diligence wordt dus op verzoek van de doelwitvennootschap zelf uitgevoerd. Een dergelijk onderzoek is niet ongebruikelijk bij een voornemen om een vennootschap ter beurze te doen noteren, danwel voorwerp van een veiling of een verkoop te maken. In het geval van een voorgenomen veiling of het doen van voorstellen met betrekking tot een transactie aan derden, zal de uitslag van een vendor due diligence belangrijk zijn voor de samenstelling van het zogenaamde bid book (de informatiebundel), aan de hand waarvan verschillende partijen een bod kunnen bepalen en uitbrengen. De koper zal ongetwijfeld zelf ook nog een onderzoek willen houden, maar kan in een voorkomend geval volstaan met klein(er) onderzoek, gericht op de beantwoording van zijn specifieke vragen. Dit laatste zal alleen aan de orde zijn wanneer het mogelijk is garanties te verkrijgen omtrent de inhoud van het vendor due diligence rapport, dat soms in de informatiebundel zal zijn opgenomen.

Ook bij onderhandse transacties echter, kan een vendor due diligence zoals uit het voorafgaande blijkt, goede diensten bewijzen.

\footnotetext{
${ }^{73}$ L. van Veen, F. Modderman, C. Suchtelen en J. de Bruijn, Vendor due diligence, vroegtijdig de meest ideale dealstructuur, Fusie \& Overname januari 2005, p. 30 e.v.

74 Zie hierover o.m. M. Loefs, De bank als belangrijke speler in een overnameproces, V\&O 2008, nr. 4, p. 70 e.v.

${ }^{75}$ Zie over de toevoeging "naar beste wetenschap" nader onder 7.1 hierna.
} 
Vanuit het gezichtspunt van de koper zal soms meer en soms minder waarde aan een rapport naar aanleiding van een vendor due diligence worden besteed. Belangrijk is daarbij ook wat de aard van de onderneming van de doelwitvennootschap is. Het resultaat van een vendor due diligence levert in de meeste gevallen in ieder geval een goede basis op voor een onderzoek door een koper, nu die op de resultaten daarvan kan voortbouwen en zelf een gerichter onderzoek kan instellen. Onder omstandigheden kan dan een rapport van een vendor due diligence tezamen met garanties gemaakt worden, zodat op korte(re) termijn tot een transactie kan worden gekomen.

\subsection{Investigative of confirmatory onderzoek}

Het onderzoekende due diligence onderzoek (investigative due diligence) vindt plaats voordat er sprake is van een overname- of andere definitieve overeenkomst. Dit onderzoek kan, als eerder gezegd, voortvloeien uit bijvoorbeeld afspraken gemaakt in een LOI. De koper wil, alvorens hij beslist de doelwitvennootschap al dan niet over te nemen of een transactie te doen, eerst meer informatie over de vennootschap en mogelijke problemen van de vennootschap verkrijgen. Op basis van de uitkomst van het due diligence onderzoek zal de koper beslissen de overname al dan niet door te zetten. Een onderzoek zal als investigative worden aangeduid, wanneer er nog het nodige dient te worden onderzocht aan de hand van gegevens die alsnog ter beschikking gesteld dienen te worden.

Het bevestigende due diligence onderzoek (confirmatory due diligence onderzoek) heeft een andere insteek. In dit geval is er vaak al wel een definitieve overeenkomst tot stand gekomen. Het rapport van het due diligence onderzoek fungeert nu in het kader van een ontbindende voorwaarde (artikel 6:22). Bevalt het resultaat van het onderzoek als blijkend uit de inhoud van het rapport van de due diligence de opdrachtgever van het onderzoek niet, dan wordt de overeenkomst ontbonden of zal die niet worden uitgevoerd. Zie ook hierna onder 7.3.

Overigens kan een due diligence onderzoek ook confirmatory genoemd worden, wanneer er nog geen definitieve overeenkomst tot stand gekomen is, maar er al wel de nodige informatie is verstrekt (bijvoorbeeld in de vorm van een bid book, Information Memorandum, information package of anderszins). Het onderzoek strekt er dan toe bevestigd te krijgen dat de verschafte informatie volledig is en in overeenstemming met de werkelijkheid. De meest gebruikelijke betekenis van het begrip confirmatory due diligence is niettemin die van een onderzoek dat plaatsvindt, wanneer er al van een partijen verbindende overeenkomst sprake is, waarvan de binding afhankelijk is gemaakt van de uitkomst van een nog uit te voeren onderzoek.

Tenslotte kan er sprake zijn van een inmiddels tot stand gekomen overeenkomst, maar nog geen definitieve vaststelling van het voorwerp van de transactie (bijvoorbeeld koop). In dat geval is een confirmatory due diligence bedoeld om tot een definitieve bepaling van de omvang van de transactie te komen. Daarbij wordt veelal een mechanisme van verrekening van prijzen gehanteerd, waarbij het de bedoeling is dat op basis van nacalculatie er een aanpassing van de prijs volgt naar gelang de uit het onderzoek gebleken omvang van (bijvoorbeeld op going concern basis overgedragen) activa en passiva. $^{76}$

Het vorenstaande bevestigt dat voorzichtigheid is geboden met het lichtvaardig gebruik van begrippen als bijvoorbeeld pre acquisition due diligence en confirmatory due diligence, nu die afhankelijk van de context en de situatie waarin die begrippen worden gebruikt niet steeds hetzelfde zullen betekenen. Minder ervaren spelers in het veld, doen er dan ook goed aan zich af te vragen en zeker te stellen hoe in een voorhanden situatie een gebruikt begrip is te plaatsen om misverstanden of erger achteraf te voorkomen.

\section{$2.4 \quad$ Single purpose or multi purpose}

Een due diligence onderzoek kan ingezet worden voor meerdere doeleinden. In de meest voorkomende gevallen zal de due diligence door een koper worden gebruikt in zijn afweging (de onderneming van) een doelwitvennootschap al dan niet over te nemen. De resultaten kunnen echter ook dienst doen als parameter voor het verwoorden en ten uitvoer leggen van vrijwarings- en garantiebepalingen, of

\footnotetext{
$\overline{76}$ Zie voor een voorbeeld de uitspraak van de Rechtbank Haarlem van 9 januari 2008, LJN BC 3247 (Laurus / Vomar).
} 
ook als richtsnoer voor toekomstige maatregelen die genomen moeten worden nadat de vennootschap is overgenomen. Zo zijn meer doelstellingen te bedenken. Zie in dit verband ook hierna onder 2.10 over het belang om de verschillende doelstellingen wel duidelijk vooraf te onderscheiden en tot uitdrukking te brengen.

\subsection{Diepgang \& omvang (quick scan, review, beperkt of volledig rapport)}

De diepte en de omvang van het due diligence onderzoek worden bepaald door de opdrachtgever en niet zelden mede diens wederpartij en het bestuur van de doelwitvennootschap. Afhankelijk van hetgeen de opdrachtgever en het bestuur van de doelwitvennootschap overeenkomen, kan besloten worden de onderzoekers een quick scan, een review, een beperkt of een volledig rapport te laten uitvoeren c.q. opmaken. Het is uiteindelijk de opdrachtgever die de omvang van de opdracht bepaalt, maar daarbij zal zoals wij hier voor al vast stelden niet zonder medewerking van de wederpartij bij een overeenkomst en doelwitvennootschap uitvoering aan het onderzoek kunnen worden gegeven.

\section{Quick scan}

Bij de quick scan maken de onderzoekers alleen een overzicht van de belangrijkste onderdelen. Dit zeer beperkte overzicht kan het resultaat zijn van de zeer geringe ruimte (in tijd) die de onderzoekers hebben om de doelwitvennootschap te onderzoeken of van het preliminaire stadium waarin besprekingen zich bevinden.

Een quick scan wordt ook wel toegepast als voorbereiding op een uitgebreid(er) due diligence onderzoek. Deze quick scan - die dan voornamelijk zal bestaan uit interviews met de leiding en de diverse adviseurs van de doelwitvennootschap - is dan bedoeld om een eerste indruk te krijgen van doelwitvennootschap en haar onderneming en om te bepalen of een aanpassing van de reikwijdte en diepgang van het due diligence onderzoek aangewezen is. ${ }^{77}$ De quick scan onderscheidt zich van een pre due diligence investigation doordat een quick scan met medewerking van de doelwitvennootschap wordt uitgevoerd.

\section{Review}

Bij de review wordt iets dieper dan bij de quick scan ingegaan op mogelijke problemen bij de doelwitvennootschap. In geen geval kan de review als een volwaardig due diligence onderzoek aangemerkt worden. Het zal vaak meer een beschrijvend verslag van bevindingen zijn van die informatie die (wel) is verschaft, indrukken bevatten van de onderzoeker(s) en vaststellen welke informatie er nog ontbrak. De aard van het resultaat van een review is dat dit (veel) oppervlakkiger is dan het resultaat van een volwaardig due diligence onderzoek. Het verslag zal zich dan ook kenmerken door (nog meer) voorbehouden en uitsluitingen van aansprakelijkheid van de zijde van de onderzoeker(s), dan al te doen gebruikelijk in het geval van een rapport naar aanleiding van een volledig due diligence onderzoek.

\section{Beperkt rapport}

In het geval van een beperkt rapport is er wel een min of meer volledig due diligence onderzoek uitgevoerd, maar wordt van de bevindingen uitsluitend of in hoofdzaak verslag gedaan door middel van mededeling van de conclusies en (eventueel, waar gevraagd) aanbevelingen.

\section{Volledig rapport}

In een volledig rapport worden niet alleen de conclusies maar ook de onderliggende werkzaamheden, redeneringen en (soms) documentatie opgenomen als weergave van de bevindingen van het onderzoek. Zoals hierna nog aan de orde zal komen (zie in hoofdstuk 13) is het van belang dat bij het bespreken van een opdracht tot het uitvoeren van een due diligence onderzoek er duidelijke afspraken worden nagestreefd over niet alleen de omvang van een onderzoek, maar ook over de wijze waarop dit zal worden uitgevoerd en de manier waarop - en in welke vorm - er verslag zal worden gedaan.

77 N.W. Vlaar en A. Ezinga, Het due diligence-onderzoek en de rol van de accountant, MAB december 1997, p. 637. 


\section{Documentatie}

Meer nog dan bij een regulier due diligence onderzoek zal in het geval van een niet-volledig onderzoek de relatie met de bijkomende documentatie belangrijk zijn. Zo kan er eerder met een dataroom review worden ingestemd wanneer er door het bestuur van de doelwitvennootschap een letter of representation wordt afgegeven dat er geen voor de bedrijfsvoering of kenbaarheid van de financiële situatie van de doelwitvennootschap relevante gegevens in de dataroom ontbreken (maar bijvoorbeeld alleen de concurrentiegevoelige informatie). Er is sprake van een harmonicawerking. Hoe meer comfort er persoonlijk wordt gegeven zijdens het management, hoe meer er kan worden vertrouwd op een beperkt onderzoek. Eenzelfde relatie bestaat er vanzelfsprekend tussen de kwaliteit van het due diligence onderzoek en de omvang van de te verlangen garanties en vrijwaringen in de uiteindelijke documentatie met betrekking tot een overname, fusie of andersoortige (financiële) transactie. ${ }^{78}$

\subsection{Operationele due diligence}

Bij een operationele due diligence worden (relevante delen van) de betrokken ondernemingen in kaart gebracht, die voor het functioneren van de onderneming van betekenis zijn. Bijvoorbeeld wordt onderzocht hoe zij waarde scheppen voor hun afnemers en hoe hun waardeketen er uit ziet. Het is de bedoeling om aan de voorkant van een fusie of overname te onderkennen of er na de transactie in de praktijk van alledag integratievoordelen zullen kunnen worden behaald. Verticale integraties bijvoorbeeld, die op zich in heel wat branches een logische en aantrekkelijke optie lijken te zijn, blijken in de praktijk nog al eens moeizaam te realiseren te zijn. Processen blijken bijvoorbeeld niet goed op elkaar aan te sluiten en bijbehorende managementsystemen evenmin. Dit kan zich evengoed bij horizontale integratiepogingen voordoen. Problemen kunnen het gevolg zijn van afwijkende processen en organisatievormen of doordat er moeilijk te combineren ICT-oplossingen zijn gekozen. Een operationele due diligence kan dit soort moeilijkheden van te voren helpen identificeren, evenals potentiële belemmeringen in de bij beide ondernemingen toegepaste managementstijl, beloningsstructuur en andere bestaande regelingen of structuren. Een dergelijke due diligence zal worden uitgevoerd door verschillende soorten specialisten. Dat zijn niet de accountants en juristen, die gebruikelijk een regulier due diligence onderzoek uitvoeren, maar deskundigen op het terrein van operationele ondernemingsprocessen. Daarom zal een operationele due diligence vaak weliswaar gelijktijdig met het 'andere' due diligence onderzoek worden uitgevoerd - en binnen het kader van eenzelfde samenstel van afspraken over het uitvoeren van een due diligence onderzoek - maar als proces een eigen verloop hebben. De resultaten van een operationele due diligence worden dan ook veelal in een afzonderlijke rapportage neergelegd.

\subsection{Cultural due diligence}

Een bijzonder soort due diligence onderzoek is de cultural due diligence. Dit is gericht op het in kaart brengen van de cultuurverschillen (een cultuur-assessment) tussen de overnemende partij en de doelwitvennootschap. Het betreft een onderzoek, dat gericht is op het herkennen van cultuurverschillen en het inventariseren van de mogelijkheden tot het succesvol integreren van (schijnbaar) tegengestelde waarden. Het is een vaak onderschatte voorwaarde om een fusie of overname succesvol te maken. De cultural due diligence wordt ook wel aangeduid als "social due diligence". Het is de bedoeling dat het due diligence onderzoek naar de hier bedoelde aspecten inzichten oplevert over de kwaliteit van de organisatie en de waarde daarvan. Aandacht gaat uit naar risico's en synergie-effecten ten aanzien van de organisatiestructuur, het top management, het personeelsbeleid en de cultuur. Waar het de organisatiestructuur betreft, wordt gekeken naar de kerncompetenties waar de doelwitvennootschap over dient te beschikken om een unieke en complementaire toegevoegde waarde op te leveren. Ook wordt gekeken naar de (beslis)structuur in de doelwitvennootschap. Uitgezocht wordt over welke competenties het topmanagement beschikt en in hoeverre dit aanvullend is met de eigen bezetting. Daarnaast wordt gekeken over welke competenties het personeel beschikt en dient te beschikken en aan welke culturele aspecten belang kan worden gehecht.

78 Zie Rechtbank Rotterdam 24 oktober 2007, LJN BB7874. In deze zaak hechtte de Rechtbank Rotterdam waarde aan het feit dat er naar aanleiding van vragen die waren opgekomen tijdens een due diligence onderzoek, de verkoper gemakkelijk instemde met balansgaranties, nu "er geen problemen te verwachten zouden zijn". 
Hoewel het over het algemeen als "softe" componenten wordt geduid, betreft het belangrijke vragen zoals de wijze waarop de organisatie van de doelwitvennootschap hiërarchisch is opgebouwd; hoe de arbeidsproductiviteit van het personeel is; welk percentage arbeidsverzuim er is als gevolg van arbeidsongeschiktheid en in welke mate er in het personeel is geïnvesteerd (er wordt bijvoorbeeld gekeken naar het percentage van de omzet dat wordt besteed aan opleiding en vaardigheidstraining). Ook verloopcijfers worden onder de loep genomen. Het cultuuronderzoek houdt zich bezig met de wijze van besluitvorming (hoe vaak wordt er vergaderd, hoe effectief vergadert men), wat is de stijl van leiding geven, de mate van betrokkenheid en de manier van communiceren. ${ }^{79}$

Een nieuw element waarnaar gekeken kan worden in een cultuuronderzoek is de vraag hoe "disputewise" de doelwitvennootschap is. Met "dispute-wise" wordt gedoeld op de wijze waarop de doelwitvennootschap omgaat met het beheersen van conflicten. De vraag is daarbij in hoeverre een kostenefficiënte en ook anderszins effectieve wijze van het oplossen van geschillen onderdeel uitmaakt van de cultuur van de onderneming van de doelwitvennootschap. Het besef dringt steeds meer door dat alternatieve geschillenbeslechting veel kosten kan doen besparen en relaties met stakeholders behouden kan doen blijven. Onderzoek heeft uitgewezen dat het daarbij belangrijk is in hoeverre de juridische afdeling een geïntegreerd onderdeel van de organisatie uitmaakt en de doelstellingen van de onderneming in bredere zin begrijpt en nastreeft. ${ }^{80}$

\subsection{Post-acquisition review of completion audit}

Een post-acquisition review is een onderzoek om na te gaan of een bepaalde fusie of overname nu wel of niet tot het gewenste resultaat heeft geleid. Een dergelijk onderzoek kwalificeert niet meer als een due diligence onderzoek, maar vertoont daar verder wel veel trekken van, met name van een operationele due diligence. Het wordt alleen enige tijd na het voltooien van de transactie uitgevoerd om na te gaan of de kosten en de opbrengsten zich hebben voorgedaan en ontwikkelen als voorafgaand aan het verrichten van de transactie voorzien.

Een post acquisition review wordt ook wel completion audit genoemd. De laatst genoemde term heeft meer in het bijzonder een accountants technische connotatie. Omdat bij het due diligence onderzoek vaak gebruik wordt gemaakt van tussentijdse financiële gegevens waarop (gedeeltelijk) geen accountantscontrole is toegepast, wordt na het sluiten van de koopovereenkomst alsnog een uitgebreide accountantscontrole toegepast. De reikwijdte van dit laatst bedoelde onderzoek gaat doorgaans verder dan het vaststellen of de overnamebalans een getrouw beeld geeft van de grootte en samenstelling van het vermogen op de balansdatum. Ook de tussen partijen overeengekomen afspraken en/of te leveren prestaties worden op een juiste naleving en afloop getoetst. ${ }^{81}$

\section{$2.9 \quad$ Off-premises due diligence}

Omdat niet zelden - zeker in de voorfase - besprekingen over een fusie of overname in het grootste geheim plaatsvinden, zal het duidelijk zijn, dat het inrichten van een dataroom en het ontvangen van een due diligence team in de eigen kantoren gelijk staat aan een mededeling op het prikbord in de kantine. In dit kader is een virtuele due diligence soms een uitkomst (zie hierna onder 2.12).

Hoewel het niet altijd makkelijk zal zijn om de soms aanzienlijke hoeveelheid informatie ongemerkt naar elders over te brengen, is een off-site of off-premises dataroom anders een antwoord. Er zal in veel gevallen sowieso niet aan kunnen worden ontkomen om toch een beperkt aantal mensen in de eigen organisatie in kennis te stellen van hetgeen er speelt. Die kunnen worden ingeschakeld om elders een dataroom in te richten. Naarmate een organisatie groter is, zijn de kansen groter dan in een overzichtelijker organisatie om min of meer ongemerkt een grote hoeveelheid informatie bijeen te brengen ten kantore van de advocaat, notaris of accountant. Als het een kleine organisatie betreft, is de omvang van hetgeen in een dataroom terecht moet komen vaak gering en kan er gemakkelijk(er) on site een dataroom worden ingericht. De koper moet dan niet een groot due diligence team sturen,

${ }^{79}$ Zie ook R. Bering, Eerst de cultuur veranderen, daarna komen de cijfers, als gepubliceerd in Leren excelleren, 12 jaar General Electric tegen de achtergrond van het INK-model, door F. Stevens, R. Bering en K. Stevens (ISBN $901407347 \mathrm{X}$ ).

80 Zie American Arbitration Association, Dispute-wise Business Management-Improving Economic and Non-Economic Outcomes in Managing Business Conflicts, New York 2006.

81 Zie F. Bos en J.P.F. Owen, Due diligence. De onmisbare schakel in het acquisitieproces, Tijdschrift voor Coprporate Finance, 1999, nr. 3, p. 76. 
maar dat zal dan vaak ook niet nodig zijn. Het kantoor van een investment banker lijkt een minder goede locatie voor het uitvoeren van een off premises due diligence, nu die al snel met fusies en overnames in verband zal worden gebracht. In het geval van de andere adviseurs kan in de eigen organisatie met enige oprechtheid worden volgehouden dat er behoefte is om eens een röntgenfoto van de eigen organisatie te laten maken. Met wat minder oprechtheid kan dat dan geplaatst worden in de context van (ook) de wens om een legal audit te laten uitvoeren of nu eens serieus werk te maken van een risk management project, zonder in de eigen organisatie teveel afleiding te veroorzaken. Een transparant proces is in alle gevallen te verkiezen, maar zal onder omstandigheden niet - en met name niet in een aanvangsfase van een transactieproces - eenvoudig uitvoerbaar zijn. Het afbraakrisico is groot wanneer er onrust in een organisatie of bij sleutelfunctionarissen wordt veroorzaakt terwijl er nog geenszins zekerheid bestaat omtrent het wel of niet doorgaan van een transactie.

\subsection{Onderzoek alleen of ook advies}

Het is van belang voor ogen te houden dat - zonder andere instructies - een due diligence onderzoek betrekking heeft op de vaststelling van feitelijke waarnemingen. Vanzelfsprekend kunnen ook opmerkingen worden gemaakt over voorstellen tot verbetering of verandering, maar dat moet dan wel vooraf duidelijk zijn afgesproken met de opdrachtgever. Het is van belang om het onderscheid tussen vaststellingen (bevindingen) van de onderzoeker(s) en meningen goed voor ogen te houden, ook voor de bruikbaarheid van het rapport, in de context van de verwachtingen, die de opdrachtgever heeft ter zake van de uitkomst en/of het gebruik van de rapportage.

Het onvoldoende duidelijk in het oog houden van de in het vorige hoofdstuk bedoelde onderscheidingen tussen de verschillende soorten van onderzoek of tussen een onderzoeks- en een adviesopdracht, wil in de praktijk nog wel eens aanleiding geven tot verwikkelingen. Voorbeeld: in het due diligence rapport worden kritische opmerkingen gemaakt bij bestaande systemen, die in de ogen van de onderzoeker onvoldoende inspelen op denkbare risico's, terwijl die systemen op zichzelf adequaat functioneren binnen de doelwitvennootschap. $\mathrm{Er}$ is dan onvoldoende uitdrukking gegeven aan het verschil tussen werkelijkheid en wenselijkheid. ${ }^{82}$ Volgens NV COS nummer $5500 \mathrm{~N}$ (Transactiegerelateerde adviesdiensten) van het NIVRA wordt er niet zo'n duidelijk onderscheid gemaakt tussen het vaststellen van de actualiteit en het evalueren van alternatieven of het ontwikkelen van aanbevelingen, inclusief een advies over de te nemen stappen, zodat er zowel bij de opdrachtgever als bij degene die een rapport opmaakt, wel duidelijk voor ogen moet staan waarvan sprake is. Er is niets op tegen dat er (meer) naar wenselijkheid dan naar werkelijkheid wordt gekeken, maar waar dit onderscheid niet duidelijk tot uitdrukking komt, kunnen vervelende misverstanden ontstaan.

Er is evenmin iets op tegen wanneer er in een due diligence onderzoek tevens wordt gekeken naar de toekomst en trends. De aandacht voor de werkelijke value drivers en soortgelijke, andere thema's kan zo groot zijn als de opdrachtgever wil, maar dient wel te worden onderscheiden van de te maken foto van de bestaande situatie. Wanneer rapportages zich richting de opdrachtgever meer kenmerken door interpretaties dan door feitelijkheden, kan een probleem ontstaan.

Een due diligence onderzoek zal zich in beginsel richten op potentiële dealbrekers, de noodzaak om garanties en vrijwaringen te vragen en aanleidingen voor prijscorrecties. In de meeste gevallen zullen tekortkomingen die na de overname eenvoudig corrigeerbaar zijn, niet als dealbreker worden genoteerd, maar in aanmerking worden gebracht voor verdiscontering als correctie op de prijs.

\subsection{Customer due diligence for banks}

Wij kennen in ons land een basale onderzoeksplicht voor dienstverleners, te weten de customer due diligence, die - zakelijk weergegeven - er op neer komt dat een dienstverlener dient te weten wie zijn cliënt is. De desbetreffende onderzoeksplicht vloeit voort uit de Wet identificatie bij dienstverlening ("WID"). ${ }^{83}$ Daarnaast bestaat voor banken een uitgebreidere onderzoeksplicht.

82 Chr. Davis, New Dimensions in Due Diligence, ICCLR 1997, 7, p. 243 e.v.

${ }^{83}$ Artikel 2 e.v. Wet identificatie bij dienstverlening van 16 december 1993, Staatsblad 1993, 704. 
In oktober 2001 is door het Basel Committee on Banking Supervision, onderdeel van de Bank for International Settlements, een rapport opgesteld met de titel "Customer due diligence for banks". Het rapport is opgesteld door een Working Group on Crossborder banking. ${ }^{84}$ In de introductie van het rapport wordt gewezen op het belang van de zogenaamde customer due diligence:

\begin{abstract}
"Supervisors around the world are increasingly recognising the importance of ensuring that their banks have adequate controls and procedures in place so that they know the customers with whom they are dealing. Adequate due diligence on new and existing customers is a key part of these controls. Without this due diligence, banks can become subject to reputational, operational, legal and concentration risks, which can result in significant financial cost."
\end{abstract}

Van banken wordt verwacht dat zij een zogenaamde "know-your-customer-policy" hebben. ${ }^{85}$

Bij circulaire van De Nederlandsche Bank van 7 juni 2002 is het hiervoor bedoelde rapport onder banken in Nederland verspreid en bij circulaire van 8 mei 2003 is een gezamenlijke toelichting van De Nederlandsche Bank en de Nederlandse Vereniging van Banken op het rapport onder banken verspreid. In de toelichting wordt het reputatierisico gedefinieerd als: "Het risico dat door nadelige publiciteit kan ontstaan (kortweg: "zou ik samen met deze cliënt in de krant willen staan?")".

In de toelichting wordt opgemerkt dat de relatie met een cliënt moet worden beëindigd, indien die relatie een onacceptabel risico vormt.

In 2003 hebben de voorschriften uit het rapport Customer Due Diligence for Banks een juridische grondslag gekregen in de regeling CDD Kredietinstellingen en Verzekeraars, ${ }^{86}$ welke regeling ondermeer is gebaseerd op - kort aangeduid - het Besluit Integere Bedrijfsvoering Kredietinstellingen en Verzekeraars. ${ }^{87}$ Artikel 3 lid 1 sub c van dat Besluit verwoordt het beginsel dat een financiële onderneming een adequaat beleid moet voeren dat ertoe strekt dat niet wegens haar cliënten het vertrouwen in de financiële onderneming of in de financiële markten in het algemeen, wordt geschaad. Artikel 3 lid 2 van het Besluit legt de verplichting op financiële instellingen om ervoor zorg te dragen dat er een beleid wordt geïmplementeerd in organisatorische en administratieve procedures en maatregelen, dat voorkomt dat de instelling betrokken raakt bij strafbare feiten of handelingen die anderszins in het maatschappelijk verkeer schadelijk kunnen zijn voor het vertrouwen in de financiële onderneming of in de financiële markt in het algemeen. De toepassing van deze zogenaamde "CDD-Regelgeving" kan leiden tot een weigering om een relatie aan te gaan of kan aanleiding zijn tot beëindiging van een relatie. ${ }^{88}$

Voor transacties waarbij niet aan beide zijden professionele partijen zijn betrokken, gelden de regels ter bescherming van marktpartijen, zoals te onzent de regelgeving op grond van de Prospectusrichtlijn of soortgelijke regelingen, die eenzijdig verplichtingen opleggen aan de professionele partij die bij een transactie betrokken is. De zorgplicht van financiële instellingen ten opzichte van niet-professionele en ook bepaalde professionele partijen voor voldoende duidelijkheid over de inhoud van financiële producten wordt nog meer bij de uitgevende instellingen en hun adviseurs gelegd. Sinds 1 januari 2007 is in de Wft het "ken uw cliënt" beginsel verankerd. ${ }^{89}$ Dit beginsel heeft met de invoering van de Markets in Financial Instruments Directive (MiFID) per 1 november 2007 nog een ruimere toepassing gekre-

84 Onder voorzitterschap van Ch. Freeland en C. Powell.

85 Zie p. 2 van het rapport van de Basel Committee on Banking Supervision.

86 Zie Stcrt. 23 december 2003, nr. 248, p. 59

87 Staatsblad 2003, 396. De Wet Actualisering en Harmonisatie Financiële Toezichtwetten (Staatsblad 2003, 55) introduceert integriteit als een expliciete toezichtsdoelstelling in de financiële toezichtswetgeving. De artikelen 5, eerste lid, onder c, en 12, eerste lid, onder c, van de Wtb, de artikelen 7, vierde lid, onder c en 11, eerste lid, onder c, van de Wte 1995, de artikelen 22a en 30ca van de Wtk 1992, artikel 31 van de Wtn en de artikelen 70a en 98a van de Wtv 1993 strekken ertoe dat beleggingsinstellingen, effecteninstellingen, kredietinstellingen en (natura-uitvaart)verzekeraars worden onderworpen aan regels die betrekking hebben op het voeren van een integere bedrijfsvoering. Deze regels worden vastgesteld bij of krachtens Algemene Maatregel van Bestuur. Het Besluit Integere Bedrijfsvoering Kredietinstellingen en Verzekeraars strekte ertoe aan deze bepalingen uitvoering te geven. Daarnaast strekte het Besluit tot aanpassing aan de Wet Actualisering en Harmonisatie Financiële Toezichtwetten (Staatsblad 2003, 55) van het Besluit Financiële Bijsluiter, het Btb, het Bte 1995, het Besluit Vrijgestelde Onderlinge Waarborgmaatschappijen 1994, het Overdrachtsbesluit Wtb, het Overdrachtsbesluit Wte 1995 en het Besluit Politieregisters.

88 Zie bij wijze van voorbeeld Voorzieningenrechter Rb. Alkmaar, 23 juni 2005, LJN AT8139.

89 Zie artikel 4:23 en 4:24 Wft., Staatsblad 2006, 475 en 664. Zie eerder over het moeten kennen door banken van de uiteindelijk belanghebbende bij transacties M. Jurgens, Financiële toezichtwetgeving op de agenda, gepubliceerd in Bank- en Effectenbedrijf september 2003, p. 4-5. 
gen. ${ }^{90}$ Het is ook van toepassing geworden op de advisering over financiële producten aan professionele beleggers. In de jurisprudentie krijgt het beginsel "ken uw cliënt" inhoudelijk verder vorm. ${ }^{91}$

In het geval van transacties met professionele partijen zal de bank ook willen weten waar deze aan toe is en bijvoorbeeld in het geval van de begeleiding van de verkoop van een onderneming er op staan kennis te mogen nemen van uitgebrachte due diligence rapporten. ${ }^{92}$ Naarmate een overnameproces langer duurt, zal een bank er op staan om updates van de gemaakte rapporten te verlangen.

\subsection{Virtuele due diligence}

Virtuele due diligence onderscheidt zich van een gewone due diligence doordat deze hoofdzakelijk plaatsvindt in een zogenaamde digitale dataroom. ${ }^{93}$ Een dataroom is de plaats waar de in het kader van een due diligence onderzoek te raadplegen documentatie zich bevindt. Het samenbrengen van documenten - middels technieken als scanning en microfiches - in digitale vorm heeft de inrichting van virtuele datarooms mogelijk gemaakt. De voordelen daarvan zijn voldoende om een toenemend gebruik van de virtuele dataroom te doen ontstaan. De inrichting van een digitale dataroom is even tijdrovend (zo niet meer tijdrovend, nu het uploaden van veel documenten meer tijd kan nemen dan het bijeen brengen of kopiëren daarvan) dan het opzetten van een fysieke dataroom, maar eenmaal 'in de lucht' is de tijdwinst aanzienlijk. Er behoeft niet meer te worden gereisd, catering is niet meer nodig en het bewaken van de dataroom kan vaak via instructies in de software worden geregeld. ${ }^{94}$ Gegevens kunnen ook beschikbaar gemaakt op een laptop, zodat de informatie ook beschikbaar is op reis en kan worden geraadpleegd tijdens vergaderingen. Aanpassingen en aanvullingen zijn gemakkelijk door te voeren.

Het gebruik van de virtuele due diligence neemt ook toe omdat het technisch mogelijk is om documenten slechts op het scherm van de onderzoeker te laten verschijnen, zonder dat die documenten door hem of haar kunnen worden geprint of kunnen worden opgeslagen. In de praktijk zullen die technieken wel te omzeilen zijn. Zo blijft het in ieder geval mogelijk om foto's van een beeldscherm te nemen.

Een voordeel van virtuele due diligence voor de verkoper is, dat deze eenvoudig zal kunnen aantonen welke documenten de koper heeft kunnen bekijken en dus welke documenten als "disclosed" moeten worden beschouwd. Ook is een voordeel dat meerdere partijen tegelijk due diligence onderzoek kunnen doen (bijvoorbeeld in het kader van een controlled auction). Evenals bij een traditionele dataroom zal er ook ter gelegenheid van het bezoek aan een virtuele dataroom een due diligence protocol worden opgesteld, waarin afspraken zijn neergelegd over de toegang tot en het gebruik maken van de te raadplegen informatie. Een dergelijke procedureafspraak zal normaliter vergezeld gaan van een geheimhoudingsovereenkomst.

Waar een virtuele due diligence in een beperkte tijd dient te kunnen worden uitgevoerd, is het raadzaam om er voor te zorgen dat een deskundige op het gebied van computertechnologie en programmering standby is gedurende de duur van het onderzoek, zodat technische problemen de uitvoering of voortzetting van een due diligence onderzoek dan niet kunnen beletten of verstoren.

\subsection{Noodzakelijke beperking}

Er wordt ter afsluiting van dit onderdeel nogmaals gewezen op het feit dat bij een due diligence onderzoek de onderzoekers uiteindelijk - bij elke verschijningsvorm van een due diligence onderzoek - af-

\footnotetext{
90 Wijziging van de Wft, Staatsblad 2007, 406 en 408. Zie ook C.H.D.W. van den Borne-Verheijen, De zorgplicht, de Wft en MiFID, Bb 2007, 47, p. 183 e.v.

91 Zie bijvoorbeeld Rb. Arnhem 24 januari 2007, LJN AZ9570, waarbij werd aangenomen, dat een basale onderzoeksplicht kon volstaan omdat de beleggingsdoelstelling van de cliënt enkelvoudig en genoegzaam duidelijk was en Rb. Amsterdam 24 januari 2007, JOR 2007, 94, in welk geval een grondig en actief onderzoek van de bank werd verlangd naar het beleggingsprofiel van de cliënt.

92 Zie hierover o.m. M. Loefs, De bank als belangrijke speler in een overnameproces, V\&O 2008, nr. 4, p. 70 e.v. en hierna on der 13.4 (over een reliance letter).

93 Zie P. Gelderman en F. Modderman, Dataroom als middel nog vaak onderschat (electronische dataroom maakt snel furore) in Fusie \& Overname juni 2004, p. 7 e.v.

94 Zie K. Hoyng, Due diligence 24/7, F\&O 4, mei 2006, p. 28-29.
} 
hankelijk zullen zijn van hetgeen zij van de doelwitonderneming aangeleverd krijgen. In veel gevallen is het voor de onderzoeker niet mogelijk vast te stellen of en in hoeverre het aangeleverde materiaal compleet is. De onderzoekers kunnen derhalve slechts een oordeel geven over hetgeen zij gezien hebben en over hetgeen er op hun bijzonderlijk verzoek nog nader is aangeleverd. De $\mathrm{Ru}^{95}$ heeft er terecht op gewezen, dat de hier bedoelde afhankelijkheid van de onderzoekers van de medewerking van de doelwitvennootschap steeds een niet onbelangrijke beperking oplevert. Een door de wederpartij af te geven garantie dat de verstrekte informatie juist en volledig is, doet daar, zo benadrukt hij, niet aan af: "Noch een accountant, noch een advocaat is een fraude-rechercheur." Een en ander - in samenhang met het feit dat wel verstrekte informatie slechts zelden eenduidig kan worden geïnterpreteerd brengt mee dat de betekenis van de inhoud van een due diligence rapport gerelativeerd moet worden. Zowel de opdrachtgever als de opdrachtnemer dienen hiervan doordrongen te zijn. Het rapport kan niet meer betekenen dan een ondersteuning van de opdrachtgever bij de besluitvorming.

De Ru waarschuwt - naar mijn mening met reden - voor de valkuil die zich ook met betrekking tot een accountantsverklaring wel voordoet, namelijk dat er sprake is van een expectation gap. Er wordt al licht meer verwacht dan gerechtvaardigd is: "Een due diligence rapport verschaft geen (absolute) zekerheid, het is geen garantie."

\footnotetext{
95 C.F de Ru, Due diligence onderzoek en beroepsaansprakelijkheid, V\&O, december 1995, afl. 12, p. 126 e.v.
} 


\section{Causa efficiens, aanleiding voor het instellen van een due diligence onderzoek}

\subsection{Aanleiding voor een due diligence onderzoek}

Er zijn meerdere redenen om een due diligence onderzoek uit te laten voeren. Redenen kunnen bijvoorbeeld zijn het voornemen om een beursnotering of een kapitaalmarkttransactie te doen plaatsvinden, maar ook kan een obligatoire regeling aanleiding zijn, zoals afspraken in een LOI of andere documentatie (zoals in een emissieprospectus, afspraken betreffende een financieringstransactie, of een koopovereenkomst bijvoorbeeld). Afhankelijk van hoe ruim men het begrip due diligence wenst te zien, kan onder bestaande regelingen, die aanleiding geven tot een due diligence, ook de instructie worden gezien die voor verleners van financiële diensten gelden ingevolge Hoofdstuk $4.2 \mathrm{Wft}$. Volgens de in dat hoofdstuk vervatte regels moet van iedere belegger een beleggingsprofiel worden vastgesteld (artikel 4:23 Wft.). Zo zijn er meer voorbeelden denkbaar.

Een vorm van vendor due diligence is het prospectus dat soms verplicht en soms op vrijwillige basis door een uitgevende instelling of een investeringsvehikel wordt uitgegeven. De inhoud gaat in op de structuur van de organisatie, de vermogensrechtelijke verhoudingen, de strategie, de risico's en andere zaken welke voor investeerders van betekenis kunnen zijn om kennis van te nemen alvorens de beslissing tot participatie wordt genomen. Wanneer het onderzoek door een de emissie begeleidende bank wordt uitgevoerd betreft het geen vendor due diligence in de eigenlijke zin van het woord, maar een gewoon due diligence onderzoek dat door de bank op grond van eigen verantwoordelijkheid wordt uitgevoerd.

Het is mijn opvatting, welke in hoofdstuk 4 hierna aan de orde zal komen, dat in ons recht als uitgangspunt heeft te gelden, dat professionele partijen zowel bij een kapitaalmarkttransactie als bij een onderhandse transactie - alvorens een transactie aan te gaan - gehouden zijn ten minste enige vorm van onderzoek te doen. Voor niet-professionele partijen geldt dit in mindere mate. Die zullen zich meer moeten en mogen verlaten op de mededelingen waarover die ingevolge een prospectus, financiële bijsluiter of andere uitingen zijdens de aanbieder van een financieel product kunnen komen te beschikken. Van hen zal wel (mogen) worden verwacht, dat zij van die informatie aandachtig kennis nemen. Deze en andere gevolgtrekkingen vormen het voorwerp van de volgende hoofdstukken. Hieronder zal nu eerst aandacht worden gegeven aan een inmiddels niet langer toepasselijke regeling. De relevantie daarvan is dat de inhoud aanleiding vormde voor de introductie in ons land van de noodzaak om een due diligence onderzoek uit te voeren door banken die een beursintroductie begeleidden. Hoewel de desbetreffende regeling dus inmiddels niet langer van toepassing is - maar het aan de eigen verantwoordelijkheid van banken wordt overgelaten om zich in materiële zin te blijven gedragen als voorheen door de hier na te bespreken regeling werd verlangd - lijkt het gerechtvaardigd om aan de inhoud van het Reglement Procedure Beursnotering in dit boek toch ruimte toe te meten.

\subsection{Reglement Procedure Beursnotering (IPO)}

In verband met toelating van een fonds of van nog niet toegelaten stukken van een fonds tot de officiële markt van de Euronext-Effectenbeurs waren tot 1 juli 2005 in een Reglement Procedure Beursnotering ("RPB") eisen en regels vastgelegd, waaraan diende te worden voldaan bij een initial public offering of een kapitaalmarkttransactie, verband houdende met genoteerde of te noteren effecten (bijvoorbeeld een herplaatsing, een obligatielening of een introductie door verhandeling). Hoewel zoals gezegd het desbetreffende reglement per 1 juli 2005 is afgeschaft, wordt de inhoud daarvan toch - zij het kort - besproken, nu daarin definities voorkwamen en andere regelingen, die niet alleen helpen zicht te krijgen op het fenomeen due diligence, maar dus ook nog een nagalm hebben. Banken die een transactie als hiervoor bedoeld begeleiden, zullen denkbaar het voorheen geldende RPB nog steeds als benchmark gebruiken bij het tot stand brengen van transacties als hiervoor bedoeld. De reden voor Euronext om het RPB af te schaffen, was dat het in het vervolg tot de eigen (civielrechtelijke) verantwoordelijkheid van de begeleidende bank wordt gerekend om te zorgen dat er 
geen onjuiste gegevens worden vermeld in een prospectus en anderszins geen misleidende informatie wordt verstrekt. ${ }^{96}$

Volgens het RPB moest op het moment dat in verband met een kapitaalmarkttransactie een prospectus of een pricing supplement in Nederland verkrijgbaar werd gesteld, de sponsor (de begeleidende bank) een due diligence onderzoek uit (laten) voeren (artikel 11.1 RPB). Een due diligence onderzoek werd omschreven als een door een sponsor met betrekking tot een door deze begeleide kapitaalmarkttransactie te verrichten onderzoek ten aanzien van de status van een onderneming en de juistheid en de volledigheid van de in het prospectus gedane mededelingen in het licht van de vereisten voor beursnotering (artikel 1.6 RPB).

Een due diligence dossier in het kader van het RPB was een dossier dat door de begeleidende bank moest worden aangehouden met betrekking tot het uitgevoerde due diligence onderzoek (artikel 1.7 RPB).

Doel van het onderzoek was om met de verkregen informatie de wezenlijke mededelingen in het prospectus te verifiëren (artikel 11.2 \& 11.4 RPB). Verificatie was het gedeelte van een due diligence onderzoek dat een controle behelsde op de juistheid en volledigheid van wezenlijke mededelingen, waar redelijkerwijs mogelijk door het verrichten of doen verrichten van onderzoek of het plegen van overleg. Het laat zich aan de hand van de discussies die zijn ontstaan naar aanleiding van de inhoud van het prospectus, dat ter gelegenheid van de beursgang van World on Line werd uitgebracht, uitleggen dat er interpretatieverschillen kunnen bestaan over de vraag wat onder 'wezenlijke mededelingen' moet worden verstaan. ${ }^{97}$

Bij het RPB waren bijlagen gevoegd, die als leidraad dienden voor het uitvoeren van het due diligence onderzoek (Bijlage A tot en met C). Bijlage A inventariseerde de bescheiden welke per type transactie aan Euronext Amsterdam overgelegd moesten worden. Bijlage B had betrekking op de belangrijke onderzoekspunten betreffende de producten en de markt van de desbetreffende onderneming, financiële en andere relevante informatie. Bijlage $C$ betrof de antecedenten van bestuurders en commissarissen. In het due diligence onderzoek dienden volgens artikel 11.2 RPB zodanige onderwerpen aan de orde te komen als redelijkerwijs nodig was om tot een verificatie te komen, waarbij de Bijlage B en $\mathrm{C}$ als leidraad dienden voor het bepalen van de in het onderzoek te betrekken onderwerpen en documentatie. Tot de factoren die van invloed konden zijn op de keuze van de bij het onderzoek te betrekken onderwerpen, behoorden: de aard van de aangeboden effecten en de modaliteiten van de kapitaalmarkttransactie en de aard van de uitgevende instelling.

De sponsor was als gezegd verplicht een due diligence dossier bij te houden. Dit dossier diende als bewijs dat er daadwerkelijk een due diligence had plaatsgevonden. In dit dossier moesten alle onderzoekspunten uit de bijlagen B \& C genoemd worden. Waren er één of meerdere onderzoekspunten waarnaar geen onderzoek was verricht, dan moet aangegeven worden wat hiertoe de reden was. Daarnaast diende het dossier alle gegevens en documenten te bevatten welke van invloed waren geweest op het oordeel dat de sponsor zich omtrent de status van de te introduceren onderneming en de juistheid van de in de prospectus gedane mededelingen had gevormd (artikel 12.1 RPB). Het was gebruikelijk dat in een verificatievergadering op basis van het concept-prospectus nog eens goed met de vennootschap welke notering wenste, werd doorgesproken of de inhoud van het prospectus in overeenstemming zou zijn met de voorschriften van de beurs.

Bij due diligence onderzoeken van een begeleidende bank, vroeg deze normaliter in een zogenaamde blood letter van de uitgevende instelling de mededeling, dat er geen onderwerpen verzwegen zijn die voor de sponsor relevant zijn. Een dergelijke blood letter-soms in de vorm van een besprekingsverslag - wordt nog steeds gevraagd.

Ingevolge het RPB werd bij het uitvoeren van het due diligence onderzoek de sponsor gecontroleerd door de afdeling compliance van Euronext Amsterdam. Deze controle beperkte zich tot een formele toetsing ten aanzien van de vraag of de sponsor had gehandeld overeenkomstig hetgeen in artikel 11

\footnotetext{
96 Vergelijk ook het hiervoor onder 2.11 besproken customer due diligence. Zie ook V.P.G. de Serière, Regelgeving van de Amsterdamse Effectenbeurs in zake beursintroducties, Jubileumbundel van de Vereniging voor Effectenrecht, p. 127 e.v. en A.F.J.A. Leijten, Reglement procedure beursnotering en due diligence, V\&O april 1997, afl. 4, p. 40 e.v.

97 Voor een beschrijving van het probleem in de kwestie van WorldOnline, zie hoofdstuk 8 onder "Enkele uitspraken".
} 
RPB werd bepaald (artikel 12.3 RPB). Sedert 1 juli 2005 is dat toezicht vervallen en is het dus aan de eigen verantwoordelijkheid van de sponsor overgelaten om ervoor zorg te dragen dat er in een prospectus of anderszins geen verkeerde of onvolledige voorstelling van zaken wordt gegeven.

In dit hoofdstuk gaat het over aanleidingen voor het (doen) uitvoeren van een due diligence onderzoek. In hoofdstuk 8 zal nader worden stilgestaan bij aspecten die te maken hebben met de uitvoering van een due diligence onderzoek waarbij een beursgenoteerde of aan de beurs te noteren vennootschap is betrokken.

\subsection{Obligatoire regelingen. LOI / andere documentatie emissie, financieringstransactie, koop en verkoop}

Zowel bij kapitaalmarkttransacties als bij andere transacties, is de aanleiding tot het houden van een due diligence onderzoek vaak gelegen in een voornemen om een contractuele verplichting te aanvaarden. Het uitvoeren van een due diligence zal zoals wij zagen vrijwel steeds voortvloeien uit een voorafgaande afspraak. Bij koop en verkoop van ondernemingen of andere transacties, wordt over een due diligence onderzoek vaak een afspraak gemaakt in één van de allereerste contacten (in een letter of intent of term sheet). Zoals hierna nog aan de orde zal komen, kan er voor een koper of andere partij die overweegt toe te treden tot een obligatoire rechtsverhouding aanleiding zijn om zich te verdiepen in de kwaliteit van de wederpartij of het voorwerp van de transactie. Die aanleiding kan ontstaan door onbekendheid met de materie of de betrokken partij(en), maar ook omdat er aanwijzingen zijn dat er een discrepantie bestaat tussen de aanprijzingen en de waar te nemen realiteit of het door andere omstandigheden verwijtbaar kan worden, wanneer de 'gepaste voorzichtigheid' niet in acht wordt genomen.

\subsection{Due diligence en ondernemingsstrategie}

Davis is in een bijdrage aan International Company and Commercial Law Review in 1997 ingegaan op de verschillende overwegingen, welke kunnen worden geïdentificeerd om medewerking te verlenen aan het uitvoeren van een due diligence onderzoek. ${ }^{98}$ Zowel de koper als de verkoper kunnen onder omstandigheden baat hebben bij een dergelijk onderzoek. Davis vergelijkt een due diligence proces met een leger oefening. De koper is daarbij het aanvallende leger. Hij is er op uit zoveel mogelijk terrein te veroveren (informatie winst) alvorens aan de (uiteindelijke) onderhandelingen te beginnen en zo gunstig mogelijke voorwaarden te (kunnen) bedingen. Bij de eerste onderhandelingen - bijvoorbeeld ter gelegenheid van het tot stand brengen van een LOI - probeert elk van de legers de beste positie te verkrijgen voor het geval de gevechtshandelingen beginnen. Nu in de meeste gevallen de verkoper de (meeste) informatie betreffende de doelwitvennootschap en haar onderneming bezit, beschikt die wat dat betreft over een voordelige uitgangspositie.

Een defensieve verkoper zal op de voorhand proberen te bedingen dat een onderzoek er (alleen) op gericht kan zijn om na te gaan of er geen verborgen gebreken zijn en of de verschafte informatie klopt. Hij zal willen stipuleren, dat de prijs niet meer zal kunnen worden beïnvloed door de uitkomst van het onderzoek. Dit is overigens een positie die in de praktijk heel moeilijk houdbaar blijkt. Als erkenning van die realiteit worden wel marges afgesproken, waarbinnen nog bepaalde aanpassingen bespreekbaar gemaakt kunnen worden, wanneer er nog konijnen uit de hoed zouden komen. Nu kunnen kopers vaak goed goochelen en vinden niet zelden een kunstje om toch een konijn te voorschijn te toveren. Een afspraak die voor duidelijkheid kan zorgen, is bij welke grens een aanpassing van de koopprijs niet meer aan de orde kan zijn en de transactie zal zijn afgeblazen als de koper die grens wil overschrijden.

Het is in ieder geval altijd raadzaam dat beide partijen proberen hun eigen doelstellingen en grenzen vooraf zo objectief mogelijk te formuleren. De doelstelling van de één zal daarbij vanzelfsprekend niet overeen stemmen met die van de ander. De verkoper zal vrijwel steeds een zo hoog mogelijke opbrengst nastreven, maar kan daarnaast veel andere doelen kennen (continuïteit van de onderneming, een eigen plaats in het bestuur van de combinatie, het belang van de werkgelegenheid en zo verder). De verkoper zal een zo voordelig mogelijke transactie willen doen, maar kan daarnaast ook andere belangen hebben (synergie voordelen van de combinatie, strategische marktpositie, en zo verder).

\footnotetext{
98 Chr. Davis, New Dimensions in Due Diligence, ICCLR 1997, nr. 7, p. 243 e.v.
} 
Belangrijk in het hier voor bedoelde eerste stadium van de schermutselingen is het vestigen van een cultuur in de onderhandelingen. Een oud adagium is, dat het maken van een overeenkomst belangrijker is dan de overeenkomst zelf. Tijdens het tot stand brengen van afspraken, leert men elkaar goed kennen. Dit geldt ook met betrekking tot de gesprekken over het tot stand komen van een LOI. Wanneer het eerste kopje koffie partijen goed heeft gesmaakt en zolang het over de positieve aspecten gaat welke beide partijen - soms vanuit een volstrekt verschillend en per saldo niet te verenigen paradigma - op het oog hebben, is een eerste moment van de waarheid in cultureel opzicht, het moment waarop de intenties op schrift geformuleerd gaan worden. Afgezien van bijzondere afspraken en bijzondere omstandigheden, zal een redelijke balans in de positie tussen partijen moeten worden gevonden. Ondervindt een van beide partijen daarbij weerstanden die niet passen in de sfeer van de eerste gesprekken - en dat doet zich aan beide zijden gemakkelijk een keer voor - dan is het de vraag hoe een en ander zich oplost. Onderhandelen is een kwestie van cultuur. Wordt er creatief gezocht naar gezamenlijke oplossingen of dreigt het gesprek voortdurend in een impasse te geraken of zelfs stuk te lopen? Voor een defensieve verkoper, is dit een belangrijke fase. In de gesprekken over de inhoud van de LOI zullen de belangrijkste grenspalen al worden geslagen. Bij dit alles geldt, dat de verkoper zal moeten voldoen aan diens mededelingsplicht - zoals die hierna nog aan de orde zal komen - en koper aan zijn - eveneens nog te bespreken - onderzoeksplicht. De spanning tussen de belangen van beiden zal in het algemeen onvermijdelijk blijven.

Naast de bevestiging van positieve elementen zal een potentiële koper inzicht willen hebben in de risico's die aan een acquisitie kleven. Deze informatie omtrent risico's kan leiden tot het heronderhandelen van de prijs en/of het prijsafrekenmechanisme; het eisen van garanties en vrijwaringen; het voorstellen van een andere transactiestructuur en tot inzichten in hoe de doelwitvennootschap na een eventuele transactie kan worden gereorganiseerd.

Een wat wel als 'offensieve strategie' van de koper wordt aangeduid, kan dan ook meebrengen dat deze het due diligence onderzoek ook (en soms vooral) wil gebruiken om redenen te vinden die aanleiding kunnen zijn om een verlaging van de prijs te bedingen, even zo goed als het dus een bijkomende overweging kan zijn om een zoektocht te organiseren naar argumenten om zoveel mogelijk garanties en vrijwaringen binnen te halen. Een confirmatory due diligence is bij uitstek een middel om eerst binding te bewerkstelligen van de verkoper en vervolgens de aanval op de initieel afgesproken prijs in te zetten. Het is een gekende strategie van kopers - in het bijzonder ten opzichte van minder professionele verkopers, zoals directeuren/groot aandeelhouders in familiebedrijven - om een verkoopproces zo ver te laten vorderen, dat de emotionele drempel om te verkopen aan de zijde van de verkoper is komen te verkeren in een fase, waarin de opbrengst van de verkoop bij wijze van spreken al een bestemming heeft gekregen en de band met het bedrijf emotioneel eindelijk is losgelaten. Het loont vaak om in dat stadium argumenten op te werpen, die de hele transactie op losse schroeven zetten. Een confirmatory due diligence onderzoek is daar voor als gezegd een bij uitstek geschikt middel. De gedachte dat de hele transactie niet door zal gaan, vergt soms zoveel nieuwe mentale omschakeling - waarbij de trein in zijn achteruit moet worden gezet richting een met veel moeite verlaten station - dat er tegen alle oorspronkelijke voornemens en verwachtingen in niet zelden alsnog belangrijke prijsconcessies worden gedaan. Omgekeerd proberen uitgeslapen verkopers op een vergelijkbare wijze gebruik te maken van de psychologische processen die in het spel kunnen komen. Door een transactie met een professionele koper (lees: vertegenwoordigers van een grote organisatie, die in het inkoopproces intern in een aantal stadia een aantal hiërarchisch hoger geordende instanties hebben moeten overtuigen van de zin van de transactie) eerst ver te laten vorderen, brengen zij hun gesprekspartners in een situatie waarin het niet doorgaan van een transactie hen in hun eigen organisatie als een mislukking kan worden aangerekend, waaraan (naar dan achteraf blijkt) ten onrechte tijd en geld besteed is. De druk om de transactie niet te laten mislukken, komt dan in zeker opzicht bij (de vertegenwoordigers van) de koper terecht.

Een wat minder offensieve insteek van een koper zal meebrengen dat er niet zo zeer op zoek gegaan wordt naar redenen om de prijs te beïnvloeden, maar dat het onderzoek er in hoofdzaak op gericht wordt om na te gaan of het eerder verkregen beeld - en de eerder verschafte informatie - overeenstemt met de werkelijkheid en volledig is. Men spreekt over een (meer) 'defensieve strategie' van de koper wanneer die een onderzoek slechts op een aantal sleutelkwesties (deal breakers) richt of marginaal doet en zich verder verlaat op garanties (al dan niet aangevuld met een of meer vrijwaringen). Overigens zijn garanties en vrijwaringen - waarbij bovendien vaak een bovengrens zal worden gesteld 
aan eventuele betalingsverplichtingen van de verkoper - geen panacee voor alle risico's die gemoeid kunnen zijn met een transactie.

Voorbeelden van deal breakers als hier voor bedoeld zijn: er blijkt van een (te) grote afhankelijkheid van één of van slechts enkele leveranciers of belangrijke afnemers zonder dat daarmee langlopende overeenkomsten zijn of kunnen worden afgesloten of er is een grote afhankelijkheid van slechts een enkele sleutelfiguur, die mogelijk de onderneming zal verlaten na de transactie (bijvoorbeeld de directeur-groot aandeelhouder of iemand die aan zijn persoon het netwerk van belangrijke leveranciers of afnemers gebonden weet). Andere voorbeelden zijn aanzienlijke potentiële fiscale risico's of te verwachten wijziging in wet- of regelgeving, waardoor de resultaten van de onderneming sterk beïnvloed zullen worden, maar ook een (te) grote discrepantie tussen de onderhanden werk positie en de administratie of twijfel omtrent de betrouwbaarheid van de afgegeven winstprognoses. Het enkele gegeven van andere uitkomsten van het due diligence onderzoek dan in overeenstemming met de door de wederpartij gewekte verwachtingen kan vanzelfsprekend ook al aanleiding opleveren (verder) van een transactie af te zien. ${ }^{99}$

Een offensieve - of zo men wil, pro actieve - strategie van een verkoper kan zijn om tijdig een vendor due diligence uit te (doen) voeren (hiervoor ook wel pre-acquisition investigation genoemd). Het kan zoals gezegd nooit kwaad om de eigen onderneming nog eens goed onder de loep te laten nemen door deskundigen. Het heeft echter meer voordelen om over een goed due diligence rapport met betrekking tot de eigen onderneming te beschikken, wanneer er eenmaal gesprekken over overname, fusie, beursgang, joint venture of een andere financiële transactie aan de orde komen. Gebreken die uit het rapport blijken, kunnen wellicht tijdig gerepareerd worden. Een disclosure letter zal minder uitvoerig kunnen worden, wanneer er problemen vooraf opgeruimd konden worden. In ieder geval kan met meer gevoel van zekerheid worden bepaald wat wel en niet in dat document vermeld dient te worden. Er kan beter gefundeerd worden besloten waar het gaat om de omvang van de garanties die men zal willen afgeven. Een due diligence onderzoek van de koper (of welke andere partij dan ook) kan beperkter zijn, nu kan worden uitgegaan van het al beschikbare rapport. Eventuele prijsaanpassingen kunnen vooraf plaatsvinden of nochtans kan een weigering om de vraagprijs (verder) aan te passen beter worden onderbouwd. De doorloop tijd van de totstandkoming van een transactie kan worden bekort, doordat er meer inzicht in eventuele risico's zal zijn verkregen en de andere partij daarmee minder onzekerheid zal ervaren.

Waar partijen het over de zin van een transactie eens zijn, en ook over veel van de afspraken of in ieder geval principes welke zij willen laten gelden bij de uitvoering, dan is het denkbaar dat beide bij de transactie betrokken partijen dezelfde adviseur(s) inschakelen om een due diligence onderzoek uit te voeren. Dit komt in de praktijk voor waar er over en weer een informatie behoefte bestaat. Bijvoorbeeld bij het tot stand brengen van een joint venture, en bespaart dan vanzelfsprekend tijd en kosten. De ingeschakelde adviseur(s) zal/zullen goede afspraken willen over de inhoud van de opdracht, wijze van rapporteren, betaling, exoneratie en dergelijke, maar wanneer beide partijen bij de transactie dit aandurven, is het op zich zelf een praktische werkwijze. De hier voor genoemde verschillende strategische posities van elk van de partijen - bijvoorbeeld op het punt van de vaststelling van een ruilverhouding zal op de achtergrond desondanks blijven meespelen.

Zie ook hierna onder 9.1, waarin de vraag wordt aangesproken hoe raadzaam het is of kan zijn om voorafgaand aan een transactie een verkregen due diligence rapport aan de wederpartij ter inzage te verschaffen.

\footnotetext{
${ }^{99}$ Zie voor een sprekend voorbeeld: Rechtbank Middelburg 14 april 2004, LJN AO9310.
} 


\section{Plaatsbepaling van een due diligence onderzoek in het Nederlands recht}

\subsection{Inleiding}

Het fenomeen due diligence is in ons land geïntroduceerd door wat tegenwoordig the free flow of capital of ook wel globalisering genoemd wordt. Ondernemingen vestigen zich daar waar lonen of andere kosten het laagst zijn en proberen aanwezig te zijn op zoveel mogelijk markten (de concurrent doet dat immers ook). Grote geldbedragen bewegen zich over de wereld op zoek naar plaatsen waar het meeste rendement kan worden gemaakt, veelal onder aansturing van grote internationale financiële instellingen. Die importeren bij ons hun eigen cultuur en die is in financiële kringen veelal de Angelsaksische. ${ }^{100}$ Dit verklaart ook het grote aantal Angelsaksische termen in dit boek. De grotere vaderlandse advocatenkantoren hebben inmiddels een eigen vestiging in de Verenigde Staten van Amerika of Engeland of werken samen met Angelsaksische kantoren in allianties of andersoortige netwerken. In internationale transacties en netwerken is Engels de voertaal.

Door die omstandigheden worden in internationale transacties bij het aangaan daarvan en in de documentatie waarin die worden bestendigd, eisen gesteld die tegemoet komen aan de gebruiken en verwachtingen van de betrokken investeerders en hun adviseurs. Deze als gezegd zijn niet zelden van Angelsaksische herkomst of werken volgens de in de financiële markten geaccepteerde normen. In een wereld waarin het zeker voor openbare vennootschappen vaak een kwestie is van eten of gegeten worden, zijn overnames een van de belangrijkste instrumenten geworden om het leven te houden en de continuïteit althans voor enige tijd veilig te stellen. Of het doen van een overname zonder een behoorlijk due diligence onderzoek uit te voeren, verantwoord is in termen van wat de Ondernemingskamer 'elementaire eisen van verantwoord ondernemerschap' noemt, is een vraag die hierna nog zal worden aangesproken. Duidelijk zal ook nu al wel zijn, dat naarmate - om een andere uitdrukking van de ondernemingskamer te gebruiken - 'moderne opvattingen van corporate governance' meer transparantie verlangen en het afleggen van verantwoording door bestuur en commissarissen, het kunnen motiveren van bepaalde investeringsbeslissingen vereist zal zijn om décharge te kunnen verwachten. ${ }^{101}$ Het instellen of achterwege laten van een due diligence onderzoek, zal dan een beslissing zijn die bij een beoordeling achteraf niet zonder relevantie is.

Het onderwerp due diligence is op de golven van de hier voor genoemde ontwikkelingen te onzent als herkenbaar fenomeen benoemd in het kader van de opkomst van internationale fusies en overnames en andere internationale transacties.

$\mathrm{Nu}$ het fenomeen due diligence in ons recht geen eigen plaats had, moest die plaats worden gevonden door middel van kwalificatie van de verschillende elementen welke daarin te onderscheiden waren. Dat leidde tot toepassing van de leerstukken van de mededelingsplicht en de onderzoeksplicht, zoals die zich in ons recht hebben ontwikkeld.

De vraag die zich laat stellen, is wat er aan het verschijnsel 'due diligence' onderscheidend is ten opzichte van een algemene mededelings- of onderzoeksplicht bij bijvoorbeeld gewone consumententransacties? Op het eerste gezicht lijkt er niet veel aanleiding om een groot verschil aanwezig te achten.

In het boek Due diligence, disclosures and warranties in the corporate acquisitions practice ${ }^{102}$ komt de volgende constatering voor, die kan helpen te verklaren waarom het onderwerp due diligence uit de financiële- en de fusie en overname praktijk, toch een eigen plaats toekomt:

\footnotetext{
100 Tot de verbeelding sprekende zaken leveren voorbeelden op, zoals het gevecht rond Gucci (geëindigd in HR 27 september 2000, JOR 2000, 217, m.nt. M. Brink) en Rodamco North America (geëindigd in HR 18 april 2003, JOR 2003, 110 m.nt. Blanco Fernández). In die zaken was duidelijk herkenbaar dat het ontwerp van de acties gemaakt was op de tekentafel van Amerikaanse adviseurs.

101 Zie bijvoorbeeld ook II.1 in de Nederlandse Corporate Governance Code.

102 Due diligence, disclosures and warranties in the Corporate Acquisitions Practice, onder redactie van David Baker en Robert Jillson (second edition, 1992) Graham\&Trotman and IBA, p. xiii.
} 


\begin{abstract}
"One of the reasons for this development no doubt lies in the far-reaching exposures and liabilities inherent in the operation of almost any business today (taxation, product liability, environmental matters, employees' rights, to mention only the most pertinent ones). Furthermore, and specifically in the Civil Law countries, it has been realised that the statutory provisions relating to the purchase of goods which normally form the basis for the purchase of the shares of a corporation are in many respects inadequate with respect to the complexity of the acquisition of the underlying business."
\end{abstract}

Het vorenstaande brengt op zich zelf niet mee dat er sprake is van een rechtsfiguur sui generis. Ik ben echter van mening dat het leerstuk betreffende due diligence wel een eigen plaats in ons rechtsbestel verdient en als zodanig, wellicht mede als gevolg van de ontwikkelingen die in dit boek zijn beschreven, toch als een leerstuk sui generis een meer identificeerbare plaats zal verwerven. Dat dit niet meebrengt dat een koper aan het nalaten van een (in de omstandigheden passend) onderzoek rechten kan ontlenen, is duidelijk, maar - omgekeerd - kan een koper wel rechten ontlenen of althans rechten bewaard doen blijven, wanneer deze een passend onderzoek uitvoert. Op dit moment is er op het vlak van due diligence al sprake van de toepassing van de leerstukken van de mededelings- en onderzoeksplicht in bijzondere situaties. Die situaties brengen hun eigen dynamiek mee en zullen onder omstandigheden er toe (kunnen) leiden dat op een aan die situaties gerelateerde wijze antwoorden zullen (moeten) volgen op vragen naar aanleiding van een mededelings- of onderzoeksplicht. $\mathrm{Nu}$ is dat op zich zelf ook weer niet bijzonder, omdat, zoals wij nog zullen zien, ook bij de toepassing van de leerstukken van de mededelings- en onderzoeksplicht steeds de bijzondere omstandigheden van het geval bepalend zijn. Wat wel zo is, is dat er een bijzondere categorie van gevallen onderscheiden kan worden - financiële transacties en overnames of fusies - waarin aan een mededelings- en onderzoeksplicht een eigen inhoud te geven is. Het gaat in ieder geval gemeenlijk zoals het hier boven genoemde citaat ook zegt, over grote bedragen en gecompliceerde transacties, waarbij niet zelden een samenstel van rechtsbetrekkingen en meerdere rechtsgebieden betrokken zijn. Bovendien betreft het transacties die zich niet gemakkelijk weer ongedaan laten maken. De toepassing van artikel 6:230 zal niet altijd een antwoord zijn als er sprake is van problemen. Het in het eerste hoofdstuk genoemde onderscheid dat kan worden gezien tussen due diligence ten behoeve van kapitaalmarkttransacties enerzijds en onderhandse transacties anderzijds kan - zo laat zich denken - ook een rol spelen bij de wijze waarop een antwoord wordt verkregen op vragen bij de toepassing van de algemene leerstukken. Ik denk bijvoorbeeld aan het hierna te noemen begrip dat met 'verkeersopvattingen' kan worden samen gevat. Onder omstandigheden wordt aangenomen dat er geen mededelingsplicht bestaat, wanneer er naar verkeersopvattingen op het desbetreffende moment sprake is van gegevens van algemene bekendheid. ${ }^{103}$ Ook moet volgens artikel 3:12 dat zowel bij kapitaalmarkt- als bij onderhandse transacties van toepassing is, bij de vaststelling van hetgeen redelijkheid en billijkheid eisen, rekening worden gehouden met algemeen erkende rechtsbeginselen en met de in Nederland levende rechtsovertuigingen. Hiertoe worden ook - weliswaar niet algemeen maar in een bepaalde kring van personen, waartoe de bij een transactie betrokkenen behoren - de levende rechtsovertuigingen mee gewogen. ${ }^{104}$

Per sector kunnen zo verschillende normen gelden, waar het de invulling betreft van hetgeen te gelden heeft op het vlak van de mededelings- en onderzoeksplicht. Hetgeen naar verkeersopvattingen in een bepaalde branche te gelden heeft, kan bepalend zijn voor de omvang van een onderzoeks- en mededelingsplicht.

Zo is er rechtspraak gevormd waar het bijvoorbeeld de autobranche betreft ${ }^{105}$, de paardenhandel ${ }^{106}$, de onroerend goed branche ${ }^{107}$ of ter zake van kredietverlening en borgtocht. ${ }^{108}$ Aan de vraag of er ook in

${ }^{103}$ Zie over het onderscheid tussen gewoonte en verkeersopvattingen, Asser-Hartkamp 4-II, nr. 293. Volgens Hartkamp is de verkeersopvatting op zichzelf geen bron van verbintenissen, maar moet daarmee rekening worden gehouden bij de vaststelling van hetgeen de billijkheid vordert.

104 T\&C, aant. 2 onder 3:12. Als voorbeeld wordt HR 12 januari 1996, NJ 1996, 683 genoemd, welke zaak in de verzekeringswereld speelde.

105 Zie bijvoorbeeld HR 15 november 1985, NJ 1986, 213; HR 25 juni 1993, NJ 1994, 291;HR 15 april 1994 , NJ 1995, 614 en het nog te noemen arrest Van der Geest/Nederlof., maar ook HR 4 april 1986, NJ 1986, 810 en HR 7 oktober 2005, RvdW 2005, 112. In dit laatst genoemde arrest maakte de Hoge Raad uit dat - uitzonderingen daar gelaten - de verkrijger van een tweedehands auto, wil hij ten tijde van de verkrijging te goeder trouw zijn, ten minste de autopapieren (het kentekenbewijs en de kopie deel III van het kentekenbewijs) moet hebben onderzocht met het oog op de beschikkingsbevoegdheid van zijn voorman.

De rechtbank Arnhem gaat nog een stap verder. Zie de uitspraak van 22 juni 2005, LJN AU1567, en stelt dat bij verificatie van een kenteken er tevens moet worden gevraagd om een legitimatie. Onder omstandigheden wil de (lagere) rechtspraak echter ook nog wel tot andere conclusies komen. Zo werd in de uitspraak van de rechtbank Zutphen van 1 augustus 2007 , 
het geval van een aandelentransactie van verkeersopvattingen kan worden gesproken, besteedt A-G Langemeijer zoals wij hierna zullen zien aandacht in diens conclusie onder het hierna te bespreken arrest Vletter-Stijnman. ${ }^{109}$

\section{Causa remota; privaatrechtelijke redenen voor het instellen van een due diligence onderzoek}

In het volgende hoofdstuk zullen de leerstukken die ten gronde liggen aan de leerstukken van een mededelings- en onderzoeksplicht - met de beperking welke past bij het onderwerp van dit boek, dat over due diligence gaat en per saldo niet over de leerstukken van dwaling, conformiteit, bedrog, onrechtmatige daad of wanbeleid - worden bezien. Nu wil ik eerst nader bezien waarom welke regels gelden voor bij een transactie betrokken partijen met betrekking tot mededelings- en onderzoeksplichten. Een rechtstreeks antwoord zal in de wet tevergeefs worden gezocht. ${ }^{110}$ Het antwoord dient daarom te worden gevonden in de rechtspraak en de literatuur. Mededelings- en onderzoeksplicht zijn bovenal voorwerp van rechtersrecht, dat vooral tot stand is gekomen tegen de achtergrond van het leerstuk van dwaling bij koop (onder het huidig BW artikel 6:228) dan wel het leerstuk over het conformiteitsvereiste (artikel 7:17 e.v.). In geen van de hierna te bespreken uitspraken komt met zoveel woorden een due diligence onderzoek voor.

Door talrijke auteurs is inmiddels al veel gezegd over de leerstukken van een mededelings- en onderzoeksplicht. $^{111}$

Ik vond het verhelderend om een aantal van de uitspraken van de Hoge Raad waarin de contouren van hetgeen wij nu kennen als mededelings- en onderzoeksplicht gestalte heeft gekregen - en waarop de hier voor bedoelde auteurs hun bevindingen hebben gebaseerd - nog eens op een rijtje te zetten. Hoewel er ook voor 1958 enkele belangrijke uitspraken op bijvoorbeeld het vlak van het leerstuk van dwaling zijn gedaan ${ }^{112}$, begin ik bij mijn selectie van uitspraken in 1958. Hoewel een aantal van de namen van de hierna te noemen arresten door de tijd tot huishoudnamen zijn geworden, leek het de moeite waard vanuit de optiek van een due diligence onderzoek die overwegingen van ons hoogste rechtscollege uit de desbetreffende uitspraken te lichten, die het geraamte opgeleverd hebben voor het voorwerp van dit boek. Ik eindig deze tour d'horizon aan het einde van het jaar 2000.

In het volgende hoofdstuk zal dan ingegaan worden op de betekenis van de leerstukken van dwaling, bedrog, conformiteit en onrechtmatige daad, ter positionering in ons recht van de zin en onzin van het uitvoeren van een due diligence onderzoek. Daarbij en daarna wordt nog de rechtspraak van na het jaar 2000 besproken, waarin (onderwerpen met betrekking tot of naar aanleiding van) een due diligence onderzoek meer in het bijzonder aan de orde kwamen. Vòòr het jaar 2000 ontstond van het onderwerp due diligence in de rechtspraak middels niet meer dan enkele grove pennestreken een portret. Weliswaar tekenden zich daarbij enkele contouren af, die aan de uiteindelijke vormgeving belangrijk richting gaven, maar meer dan een enigszins nader ingekleurd beeld is er inmiddels nog niet. Er is nog ruimte voor detaillering. Zoals in de aanhef van dit boek werd gezegd, leverde de literatuur tot dusverre van het verschijnsel due diligence evenmin een overzichtsfoto op. Het betreft een relatief oud leerstuk (dwaling, verborgen gebreken, wanprestatie), maar een relatief jong verschijnsel. De eerste uitspraak van de Hoge Raad die bij een koop van aandelen min of meer rechtstreeks terug te voeren viel tot (onvoldoende) due diligence onderzoek dateert pas uit 1991. Overigens verdient het hierbij aantekening,

NJF 2007, 567 het een koper weer niet aangerekend, dat deze niet naar een kopie van deel III behorende bij het kentekenbewijs had gevraagd en geen onderzoek naar de beschikkingsbevoegdheid van diens verkoper had uitgevoerd.

106 Zie - na 2000 - Rechtbank Arnhem 24 mei 2004, LJN AP 4372 en gerechtshof Amsterdam 15 juli 2004 , Prg. 2005 (1), nr. 2 m.nt. P. Abas.

107 Zie bijvoorbeeld HR 18 april 1986, NJ 1986, 747. Zie ook Y. Borrius, Mededelings- en onderzoeksplicht bij (ver)koop van verontreinigde grond, Contracteren 2001/4, p. 86 e.v.

108 Zie bijvoorbeeld HR 1 juni 1990, NJ 1991, 759; HR 3 juni 1994, NJ 1997, 287 en HR 19 mei 1995, NJ 1997, 648.

109 HR 16 juni 2000, NJ 2001, 559.

110 Zie Asser-Hijma 5-I, nr. 233 en de aldaar genoemde literatuur.

111 Zie o.m. Dunné en eerder: J.M. van Dunné, De heroriëntatie bij dwaling (WPNR 1968, nrs. 4978, 4979, 4980, 4981); E. Cohen Henriquez, Spreken is zilver, zwijgen is fout (NJB 1976, p. 625 e.v.);

Jac. Hijma, Nietigheid en vernietigbaarheid van rechtshandelingen (Kluwer 1988);

J.B.M. Vranken, Mededelings-, informatie- en onderzoeksplichten in het verbintenissenrecht (Tjeenk Willink, 1988); A.G. Castermans, De mededelingsplicht in de onderhandelingsfase (Kluwer, 1992); Asser-Hijma 5-I 319, 230-232, 242, 249, 253254, 337, 338, e.v. en 546-547; C. Bollen, Onjuiste mededelingen en de samenloop tussen dwaling en wanprestatie: de ene mededeling is de andere niet!, NBTR 2004/9, p. 414 e.v., en vele anderen.

112 Zoals HR 14 november 1924, NJ 1925, 97 (Koperdraad), waaruit volgde dat een verkoper geen mededelingen hoeft te doen van zaken die als van algemene bekendheid mogen worden verondersteld en HR 29 maart 1935, NJ 1935 , 1470 (Nieuwendijkcafé), waaruit volgde dat onder omstandigheden een gezond wantrouwen op zijn plaats is. 
dat het hierna als eerste te bespreken arrest eveneens de koop van een onderneming betrof (fabriek van rijwielhulpmotoren). Niettemin is dat arrest niet in verband gebracht met een due diligence onderzoek. Op zich zelf bevestigt dit, dat het fenomeen due diligence eerst later een eigen naam heeft verworven. Het zou na 1991 nog vier jaar duren voordat er opnieuw een uitspraak van de Hoge Raad volgde, die betrekking had op de vraag of er bij de koop van een onderneming (ditmaal betrof het een activa-passiva transactie) voldoende due diligence was betracht.

Uitzondering op hetgeen ik hier voor zeg, wordt wellicht gevormd door een arrest dat door de Hoge Raad in 1993 werd gewezen (Varkensmesterij). ${ }^{113}$ De desbetreffende zaak handelde over schuldvernieuwing, maar strikt genomen ook over due diligence. Cattier verkocht aan Waanders een boerderijtje met vier varkensschuren, een kippenhok, een opslagloods annex garage, ondergrond, erf en tuin. Cattier hield ter plekke een varkensmesterij, waarop de bepalingen van toepassing waren van de Interimwet beperking varkens en pluimveehouderijen ("Interimwet"). Om een lang verhaal kort te maken kwam het er op neer, dat in het concentratiegebied waar de boerderij lag geen uitbreiding van het bedrijf was toegestaan en het aantal varkens dat mocht worden gehouden aan een maximum gebonden kon zijn. Waanders was in grote lijnen bekend met die op zich zelf ingewikkelde regeling. Cattier had Waanders niet geïnformeerd omtrent de opgaven van het door hem te houden aantal varkens als aan de overheid gedaan. Na het ondertekenen van de koopovereenkomst maar voor de levering heeft Waanders (nader) onderzoek gedaan bij de bevoegde instanties naar de vraag welk aantal varkens op basis van de Interimwet op het door hem gekochte perceel gehouden mocht worden. Dat bleken er niet meer dan 200 te zijn. Waanders meende om die reden niet gehouden te zijn de koopovereenkomst te consumeren. Hij stelde bij de koop te zijn uitgegaan van een aantal van 400 . De koopovereenkomst noemde geen aantallen varkens. Voor Cattier niettemin aanleiding om de koopprijs merkbaar te verminderen. De boerderij werd vervolgens geleverd. Later bleek dat na ondertekening van de koopovereenkomst, maar voorafgaand aan de nieuwe prijsafspraak, Cattier van de overheid te horen had gekregen dat er ook geen 200 varkens op het perceel gehouden zouden mogen worden. Hem werd verweten te hebben verzuimd aan een onder die omstandigheden passende mededelingsplicht te hebben voldaan. De rechtbank zag niets in de vordering die Waanders vervolgens had ingesteld. Omdat de koopovereenkomst niet sprak over aantallen varkens, zo meende de rechtbank, bestond er geen wilsovereenstemming over de introductie van een bepaald aantal varkens. Waanders ging in hoger beroep op de niet onbegrijpelijke grond, dat de rechtbank een onjuiste maatstaf had aangelegd bij de beoordeling van de wat vroeger 'objectieve novatie' heette. Waanders had zijn vordering in prima gebaseerd op het leerstuk van de onrechtmatige daad. Er was volgens hem sprake van een nalaten in strijd met de zorgvuldigheid welke in het maatschappelijk verkeer jegens Cattier had behoren te worden betracht. Subsidiair stelde hij te hebben gedwaald ten aanzien van het aantal varkens dat hij zou mogen houden. De rechtbank meende dat er van schade geen sprake was. Het gerechtshof oordeelde dat de goede trouw Cattier - bekend met de veronderstelling van Waanders dat die tenminste 200 varkens zou mogen houden - gebood Waanders in kennis te stellen van de onjuistheid van zijn veronderstelling. Aanleiding voor Waanders om in te stemmen met de schuldvernieuwing zo meende het hof was nu juist de onduidelijkheid in de koopovereenkomst omtrent het aantal te houden varkens. Ook het hof meende dat de rechtbank het wezenlijke van de schuldvernieuwing had miskend en veroordeelde Cattier tot het betalen van schadevergoeding. Cattier tekende cassatie aan. Een voor het onderwerp van dit boek interessant middel dat werd aangevoerd was dat een "door het hof aangenomen mededelingsplicht buiten het verband met een beroep op dwaling of bedrog en een daaruit voortvloeiende vernietiging van de overeenkomst die uit hoofde van een zodanig wilsgebrek tot stand is gekomen geen deel uitmaakt van het Nederlands recht." Zo'n mededelingsplicht zou volgens Cattier evenmin bestaan in een geval waarin tussen contracterende partijen verschil van mening bestaat omtrent de vraag welke eigenschappen een verkochte zaak ingevolge de koopovereenkomst zou dienen te bezitten en zij vervolgens in een nadere overeenkomst ter voorkoming van een procedure en daarmee verband houdende langdurige periode van onzekerheid in een nadere overeenkomst de oorspronkelijk bedongen koopsom op een lager bedrag vaststellen. Een ander middel betoogde dat er van een gehoudenheid om schade te vergoeden alleen sprake kon zijn ingeval een overeenkomst die tot stand kwam na of door schending van een verplichting tot het doen van mededelingen, uit hoofde van dwaling of bedrog zou worden vernietigd. In de onderhavige zaak was de uitspraak gebaseerd op de niet nakoming van een verbintenis uit de wet (artikel 6:1 speelde in de onderhavige zaak nog niet). Op die grond

113 HR 2 april 1993, NJ 1994, 94 m.nt. CJHB. 
zou slechts, aldus betoogde Cattier in cassatie, tot veroordeling om schade te vergoeden kunnen worden gekomen, wanneer de niet nakoming van een mededelingsplicht in strijd was geweest met hetgeen in het maatschappelijk verkeer betaamde. Daarbij zouden dan alle omstandigheden van het geval moeten worden meegewogen, dus ook het feit dat Cattier zich bij de oorspronkelijke overeenkomst niet had willen verbinden tot het leveren van een varkensmesterij met en bepaald aantal varkens. Hij zou de nadere overeenkomst alleen zijn aangegaan omdat Waanders weigerde de oorspronkelijk gesloten overeenkomst uit te voeren, als gezegd uitsluitend ter voorkoming van een slepende procedure (die hij vervolgens dus toch over zich had afgeroepen en wel met een duur van vijf jaar).

De Hoge Raad rekent kort af met de gedachte dat het niet nakomen van een mededelingsplicht alleen maar grond kan opleveren tot vernietiging van de overeenkomst op grond van dwaling of bedrog:

\begin{abstract}
"Dit betoog kan niet als juist worden aanvaard. Niet-nakoming van een zodanige, op de eisen van redelijkheid en billijkheid (goede trouw) berustende mededelingsplicht kan ook een verplichting tot schadevergoeding in het leven roepen."
\end{abstract}

Naar het oordeel van de Hoge Raad had Cattier in de gegeven omstandigheden Waanders in kennis moeten stellen van de onjuistheid van zijn veronderstelling bij de onderhandelingen over een nadere overeenkomst. Het betoog dat schadevergoeding wegens het niet nakomen van een mededelingsplicht als door het hof aangenomen alleen maar voor toewijzing in aanmerking zou komen, wanneer die niet nakoming in strijd is met hetgeen in het maatschappelijk verkeer betaamt, werd niet aanvaard. Een schadevergoedingsplicht kon volgens de Hoge Raad even goed intreden wanneer het niet nakomen van een mededelingsplicht strijdig is met de goede trouw. In zijn noot onder het hier besproken arrest stelt Brunner een oud discussiepunt aan de orde, en wel of verplichtingen uit de redelijkheid en billijkheid moesten worden onderscheiden van verplichtingen uit het ongeschreven recht waarvan schending een onrechtmatige daad oplevert. Hartkamp wijst er naar mijn mening terecht op dat het in het geval van het geschil tussen Cattier en Waanders bij de novatie ging om een rechtsverhouding die gebaseerd was op een al eerder tot stand gekomen koopovereenkomst. ${ }^{114}$ Overigens onderschrijft hij - in tegenstelling tot bijvoorbeeld Oostwouder - de dogmatische keuze voor de redelijkheid en billijkheid als grond voor een denkbare verbintenis tot vergoeding van schade in de onderhandelingsfase, zonder de onrechtmatige daad als bron voor precontractuele aansprakelijkheid in de ban te doen ${ }^{115}$ : "Indien ...er sprake is van onbehoorlijk gedrag (onbetamelijk uitspelen van gegadigden, misleiding, misbruik van vertrouwelijke informatie, etc.) is er geen reden die rechtsgrond te vermijden." Hij noemt de aanknoping bij de redelijkheid en billijkheid aantrekkelijk omdat aldus niet slechts het onderscheid wordt uitgewist met het geval waarin de overeenkomst tot stand komt, maar ook met situaties waarin er reeds in de onderhandelingsfase uit anderen hoofde (al) sprake is van verbintenissen tussen partijen. Mij dunkt dat het steeds verstandig zal zijn om voor twee ankers te gaan liggen, primair de redelijkheid en billijkheid, gebaseerd op de visie van de Hoge Raad die uit het hier voor laatst besproken arrest blijkt en subsidiair een onrechtmatige daad. Zo werkt het samenstel van dogmatische mogelijkheden in de praktijk het best. ${ }^{116}$ Het gaat in dit boek evenwel over due diligence. Vragen omtrent een recht op schadevergoeding naar aanleiding van dingen die in de precontractuele fase mis zijn gelopen, moeten dan beantwoord worden in het kader van het algemene leerstuk van de afgebroken onderhandelingen. ${ }^{117} \mathrm{lk}$ verwijs verder ook naar hoofdstuk 7.2 hierna (Meldplicht tijdens en na due diligence).

Aangenomen werd dat Waanders de kennis, waarvan hij wist dat die voor Cattier relevant was en waarover hij beschikte voordat de nadere overeenkomst tot stand kwam, met Cattier had moeten delen. Toch is het de vraag of de hier voor bedoelde zaak anno 2007 of 2008 op dezelfde wijze zou zijn afgelopen. Ik durf te denken van niet. De wijze van kijken naar de eigen verantwoordelijkheid van een koper van een onderneming - en daar ging het in het geval van de varkensmesterij toch ook om ook al had Waanders het geprobeerd te doen voorkomen dat hij alleen een onroerend goed aan Cattier had verkocht - heeft (zoals wij hierna nog zullen zien) een ontwikkeling doorgemaakt, die een duidelijke(r) invulling geeft aan de eigen verantwoordelijkheid van een koper. In het geval van Cattier laat zich achteraf de vraag stellen of diens due diligence onderzoek wel voldoende grondig is geweest en of hij

\footnotetext{
114 Asser-Hartkamp 4-II, nr. 165a.

115 A.w., nr. 166 en W.J. Oostwouder, Management Buy-out, Groningse serie, deel 27, p. 50.

116 Vergelijk de vordering welke werd ingesteld in de zaak die eindigde in het door Brunner geannoteerde arrest Beliën / Provincie Brabant, HR 24 maart 1995, NJ 1997, 569 m.nt. CJHB. Eerst nakoming en subsidiair onrechtmatige daad.

117 Zie bijvoorbeeld HR 12 augustus 2005, NJ 2005, 467 m.nt. CBB/JPO.
} 
niet meer had moeten doen met het op het moment van het tot stand komen van de nadere overeenkomst hem bekende gegeven, dat de door Waanders aangeleverde informatie niet uitblonk door betrouwbaarheid. Zie hoofdstuk 6.2 onder Verdiscontering/risicoverdeling. Laat ik echter niet te ver op de dingen vooruit lopen. Ik zou eerst kijken naar een aantal van de uitspraken van de Hoge Raad waarin de contouren van hetgeen wij nu kennen als mededelings- en onderzoeksplicht gestalte heeft gekregen.

Inmiddels kan er overigens over een mededelingsplicht en een onderzoekplicht in veel varianten worden gesproken. Daarbij is ook het onderscheid tussen mededelingsplicht en informatieplicht lang niet altijd even helder. Ik noem - zij het goeddeels van na het jaar 2000 - een aantal voorbeelden. Zo valt te denken aan de verplichting om in door de wet aangewezen omstandigheden een ondernemingsraad van informatie te voorzien (bijvoorbeeld artikel 25 lid 3 en artikel 31 lid 2 WOR) of werkgevers aan werknemers (artikel 7:655) of aan werknemers in het geval van de overgang van een onderneming (artikel 7:665a). ${ }^{118}$ Accountants hebben soms een mededelingsplicht (vergelijk artikel 2:384 lid 3). Een ander voorbeeld is de informatieplicht welke sedert 30 juni 2004 van toepassing is bij het aangaan van een overeenkomst langs elektronische weg (artikel 6:227b). De notaris kent onder omstandigheden een uit zijn zorgplicht voor beide in de akte vermelde partijen voortvloeiende onderzoeksplicht. ${ }^{119}$ Ook de waarschuwingsplicht van de aannemer kan aldus genoemd worden (artikel 7:754). ${ }^{120}$ Wanneer openbare mededelingen worden gedaan, moeten die kloppen, zie bijvoorbeeld artikel 6:194. ${ }^{121}$ Overigens is de regel van artikel 6:194 van belang ook met het oog op kapitaalmarkttransacties, waarover meer hierna in hoofdstuk 8. Zo zijn meer voorbeelden te noemen, maar dergelijke andere mededelings- en ook onderzoeksplichten vallen buiten het bestek van dit boek.

\subsection{Mededelingsplicht en onderzoeksplicht?}

\section{Wederzijdse zorgplicht}

1958 is het jaar waarin de Hoge Raad een arrest wees, dat de aftrap vormde voor een reeks van uitspraken over de mededelings- en onderzoeksplicht en dat bekendheid zou krijgen onder de naam Baris/Riezenkamp. In dit fameus te noemen arrest van 15 november $1958^{122}$ ging het om het navolgende: Riezenkamp wilde van Baris een fabriek kopen waarin rijwielhulpmotoren werden gefabriceerd. Riezenkamp is bereid voor deze fabriek een prijs van NLG 110.000,-- te betalen.

Dit bod was gebaseerd op mededelingen van Baris dat de kostprijs per motor niet hoger kwam dan NLG 135,--. Later bleek dat de kostprijs hoger lag dan Riezenkamp zich die had voorgesteld. Riezenkamp weigerde de koopprijs te betalen en stelde te hebben gedwaald omtrent de kostprijs.

\section{De Hoge Raad oordeelde:}

"dat immers partijen, door in onderhandeling te treden over het sluiten van een overeenkomst, tot elkaar komen te staan in een bijzondere, door de goede trouw beheerste, rechtsverhouding, medebrengende, dat zij hun gedrag mede moeten laten bepalen door de gerechtvaardigde belangen van de wederpartij; dat dit onder meer medebrengt, dat voor degene die overweegt een overeenkomst aan te gaan, tegenover de wederpartij een gehoudenheid bestaat om binnen redelijke grenzen maatregelen te nemen om te voorkomen dat hij onder den invloed van onjuiste veronderstellingen zijn toestemming geeft, de omvang van welke gehoudenheid mede hierdoor wordt bepaald, dat men in den regel mag afgaan op de juistheid van door de wederpartij gedane mededeling".

Aan het arrest - dat naar de regels van het oude Burgerlijk Wetboek werd gewezen - kunnen de volgende beginselen worden ontleend, die nog steeds actueel zijn:

\footnotetext{
${ }^{118}$ Zie ook HR 26 oktober 2007, JAR 2007, 285, waarin werd vastgesteld dat de werkgever versluierde informatie had gegeven aan een juridisch niet geschoolde medewerker omtrent de rechtspositie bij overgang van (een deel van) de onderneming. Daarmee werd de betrokkene op onvolledige en onjuiste gronden tot een keuze bewogen, aldus de Hoge Raad.

119 Zie HR 14 december 2007, NJ 2008, 8.

120 Zie recentelijk rechtbank Arnhem 9 januari 2008, LJN BC2568.

${ }^{121}$ Zie bijvoorbeeld HR 11 juni 2004, LJN AP1639.

122 NJ 1958, 67
} 
1. door in onderhandeling te treden komen partijen tot elkaar te staan in een rechtsverhouding welke wordt beheerst door de redelijkheid en billijkheid; ${ }^{123}$

2. binnen redelijke grenzen dient elke partij te voorkomen dat hijzelf in dwaling contracteert;

3. elke partij mag in de regel afgaan op wat de wederpartij zegt;

4. spant een der partijen zich onvoldoende in om te voorkomen dat hij of zij zelf in dwaling handelt, dan kunnen de redelijkheid en billijkheid aan een beroep op dwaling door de desbetreffende partij in de weg staan;

5. een partij moet voorkomen dat zijn wederpartij in dwaling komt te verkeren, anders kan de eerst genoemde zich niet verweren tegen een beroep op dwaling van diens wederpartij.

\section{Eigen verantwoordelijkheid bij mededelingen}

Een goede tweede in het rijtje van de uitspraken van ons hoogste rechter, waarmee de onderwerpen mededelingsplicht en onderzoeksplicht vorm hebben gekregen, is een arrest van 21 januari 1966, dat bekendheid verkreeg onder de naam Booy/Wisman. ${ }^{124} \mathrm{Nu}$ ging het om problemen die ontstonden naar aanleiding van een koopovereenkomst met betrekking tot een mobiele kraan.

Booy deelde aan Wisman mede dat er reeds meerdere afnemers waren met dezelfde kraan en dat ook voor deze kraan wel een kentekenbewijs zou worden verstrekt. De kraan bleek echter te zwaar en het kentekenbewijs werd niet verstrekt. Hierop spreekt Wisman Booy aan op grond van dwaling subsidiair op grond van wanprestatie.

De Hoge Raad kwam tot het volgende oordeel:

"dat voor degene die overweegt een overeenkomst aan te gaan, tegenover de wederpartij een gehoudenheid bestaat om binnen redelijke grenzen maatregelen te nemen om te voorkomen dat hij onder de invloed van onjuiste veronderstellingen zijn toestemming geeft (......); dat in het algemeen die gehoudenheid tegenover de wederpartij niet zo ver gaat, dat hij niet zou mogen afgaan op de juistheid van door deze wederpartij gedane mededelingen, en integendeel veelal de regels van de goede trouw er zich tegen zullen verzetten, dat de wederpartij ter afwering van een beroep op dwaling aanvoert dat ten onrechte op de juistheid van haar mededelingen is vertrouwd".

\section{Niet 'schuldig' verzwijgen}

Op 30 november 1973 wijst de Hoge Raad het arrest Van der Beek/Van Dartel. ${ }^{125}$

Van der Beek koopt een bovenwoning van Van Dartel. Reeds voor de verkoop van de woning is door de gemeente per brief aan Van Dartel medegedeeld dat maatregelen in overweging zouden worden genomen tot vordering van het gebruik van de woning indien Van Dartel niet meewerkte aan het tot stand komen van een doelmatige bewoning ervan. Ondanks dat Van Dartel wist van deze naderende vordering heeft hij dit aan Van der Beek verzwegen. Enige tijd na de koop gaat de gemeente daadwerkelijk over tot de vordering. Van der Beek stelde bij het sluiten van de overeenkomst in dwaling te hebben verkeerd en dat hij niet zou hebben ingestemd met de overeenkomst indien hij op de hoogte was geweest van de juiste stand van zaken. De Hoge Raad overwoog:

"dat wanneer een partij voor de totstandkoming van een overeenkomst aan de wederpartij bepaalde inlichtingen had behoren te geven ten einde te voorkomen dat de wederpartij zich omtrent het betreffende punt een onjuiste voorstelling zou maken, de goede trouw er zich in het algemeen tegen zal verzetten dat eerstbedoelde partij ter afwering van een beroep op dwaling aanvoert dat de wederpartij het ontstaan van de dwaling mede aan zichzelf heeft te wijten".

\footnotetext{
${ }_{123}^{123}$ De hier gevonden regel zou later terug komen in het arrest Plas/Valburg. NJ 1983, 723.

${ }^{124}$ NJ 1966, 183

${ }^{125}$ NJ 1974, 97
} 
De hiervoor genoemde overweging maakt duidelijk dat degene die verzuimde aan de mededelingsplicht te voldoen, zich tegen een beroep op dwaling niet kan verweren door diens wederpartij te verwijten dat die niet (in voldoende mate) aan diens onderzoeksplicht heeft voldaan.

Een thema in zaken als die waar het in het hier voor genoemde arrest om ging, is niet zelden de vraag of het achterwege laten van inlichtingen, geschied is met het oogmerk om te misleiden. Naar het oordeel van de Hoge Raad had het hof meer aandacht moeten besteden aan de beantwoording van de vraag of er sprake was van het opzettelijk achterhouden van de brief van de gemeente, waarin de verkoper was geïnformeerd door het College van B\&W van Den Haag dat deze overwoog om tot vordering van het gebruik van de woning waar het om ging, over te gaan.

Het verband met een uitspraak van de Hoge Raad van 10 april $1998^{126}$ rechtvaardigt dat er in de tijd een stap wordt overgeslagen en er al op deze plaats melding wordt gemaakt van de na te noemen overweging van dat rechtscollege. Het ging om de aankoop van een woonhuis dat scheuren vertoonde, die zichtbaar waren. De koper had de scheuren gezien en naar de oorzaak daarvan geen onderzoek laten doen. Na de aankoop bleek dat er structurele problemen waren met de fundamenten, die niet dan tegen hoge kosten verholpen zouden kunnen worden. De koper stelde een vordering in op grond van bedrog, dwaling, wanprestatie dan wel onrechtmatige daad. Het hof was van oordeel dat er voldoende aanleiding was geweest voor de koper om nader onderzoek in te stellen: zichtbare scheuren in de muren; een taxatierapport, dat niet over de scheuren repte en afdekking van andere muren door panels waardoor de achterliggende muur aan het oog was onttrokken. De koper had op eigen gezag geoordeeld dat de scheurvorming niet meer dan krimpscheuren betrof. Onder die omstandigheden meende het gerechtshof dat de koper er zich achteraf niet op kon beroepen dat de verkoper tot meer gehouden was geweest dan deze op de scheurvorming in het huis te wijzen, hetgeen deze had gedaan (r.o. 1). De Hoge Raad overwoog:

"Het is immers (...) onjuist om, zoals het Hof heeft gedaan, ervan uit te gaan dat het oordeel dat de koper is tekortgeschoten in de gegeven omstandigheden op hem rustende plicht om te onderzoeken hoe ernstig de scheurvorming in het huis was, of deze een structureel karakter droeg en zo ja wat daarvan de oorzaak was, zonder meer de slotsom wettigt dat op de verkopers ter zake geen mededelingsplicht rustte. Het Hof had zich, integendeel, de vraag moeten stellen of de verkopers, die - naar de koper aan zijn vorderingen ten grondslag heeft gelegd en het Hof in het midden heeft gelaten, zodat daarvan in cassatie veronderstellenderwijs moet worden uitgegaan - wisten dat de scheurvorming in het huis van structurele aard is en wordt veroorzaakt doordien de fundering van het huis te wensen overlaat, alsmede dat de oplossing van het probleem zeer kostbaar is waardoor de waarde van het huis ernstig wordt aangetast, toen zij constateerden dat de koper zo onvoorzichtig was om, hoewel hij scheurvorming en zettingen had gezien en hoewel hem (in de visie van het Hof) ook was 'meegedeeld dat er scheurvorming in het huis aanwezig was', geen vragen omtrent scheurvorming te stellen en daarnaar geen onderzoek te doen, naar de in het verkeer geldende opvattingen gehouden waren hem van voormelde, hun bekende feiten mededeling te doen. Het antwoord zal afhangen van hetgeen omtrent voormelde, veronderstellenderwijs aangenomen feiten en de andere omstandigheden van het geval zal komen vast te staan en derhalve eerst na een nader onderzoek te dier zake kunnen worden gegeven."

De vraag wanneer een verkoper mag zwijgen, was mede de inzet van de procedure welke tot de hier voor laatst genoemde uitspraak heeft geleid. Het komt er op neer, dat een verkoper gebreken onvermeld mag laten waarvan hij weet dat de koper die kent. Het wordt ingewikkelder wanneer het om gebreken gaat die de koper na een normaal onderzoek kan kennen, nu er op zich zelf geen wettelijk voorschrift is dat een koper voorschrijft dat deze een onderzoek moet instellen. Wanneer de koper ook na een normaal onderzoek gebreken niet kan ontdekken, dan wordt zonder twijfel aangenomen dat een verkoper een mededelingsplicht heeft. In zijn noot onder het arrest van 10 april 1998 constateert Kleijn, dat er sprake kan zijn van een "schuldig" verzwijgen. Het zal steeds door de omstandigheden van het bijzondere geval worden bepaald in welke richting de oplossing gevonden moet worden op het kruispunt waar de redelijkheid het nemen van een eigen verantwoordelijkheid voor een onderzoek (of in ieder geval doorvragen) aan de zijde van de koper de zorgplicht van de verkoper ontmoet, welke

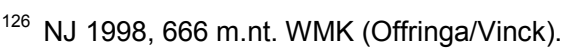


laatste moet voorkomen dat de koper op grond van een verkeerde voorstelling van zaken tot een transactie overgaat. In de procedure die eindigde in de uitspraak van 10 april 1998 was een veelzeggende omstandigheid dat het zwembad dat zich bij het huis in kwestie bevond op de dag van bezichtiging door de koper vol water stond, terwijl later bleek dat dit zwembad al lang lekte.

\section{Verkeersopvattingen}

Wat dient te worden verstaan onder "de in het verkeer geldende opvattingen", zal niet altijd duidelijk zijn. Wel besliste de Hoge Raad in een arrest van 22 november $1996^{127}$ dat het betekenis toekomt of de gebreken waarvan geen mededeling werd gedaan bij de in dat geval verkoper zelf bekend verondersteld hadden moeten of kunnen worden:

"Het onderdeel strekt ten betoge dat het Hof een onjuiste maatstaf heeft aangelegd door te miskennen dat naar in het maatschappelijk verkeer geldende opvattingen de verkoper van een onroerende zaak, teneinde zich op een exoneratiebeding als het onderhavige te kunnen beroepen, in ieder geval aan de koper dient mede te delen dat zich in het gekochte een olietank bevindt, zulks los van de vraag of de verkoper al dan niet bekend is of had behoren te zijn met een mogelijke verontreiniging van bodem en water tengevolge van de aanwezigheid van die olietank.

In het midden kan blijven of dit betoog wel in de feitelijke instanties is gevoerd. Het faalt omdat niet kan worden aangenomen dat ten tijde van het sluiten van de onderhavige koopovereenkomst de maatschappelijke opvattingen meebrachten dat de verkoper van een perceel grond waarop zich een ingegraven huisbrandolietank bevond, ongevraagd, en ongeacht of hij al dan niet bekend was of had behoren te zijn met een mogelijke verontreiniging van bodem en water tengevolge van de aanwezigheid van die tank, van de aanwezigheid van die tank mededeling behoorde te doen met als gevolg dat het uitblijven van een zodanige mededeling naar maatstaven van redelijkheid en billijkheid onaanvaardbaar zou worden om een beding als het onderhavige in te roepen".

In het arrest van 10 april 1998 overweegt de Hoge Raad (onder 3.5):

"Bij het beantwoorden van de vraag of een partij ter zake van bepaalde relevante gegevens naar de in het verkeer geldende opvattingen een mededelingsplicht heeft, dan wel of hij die gegevens voor zich mag houden omdat hij erop mag vertrouwen dat zijn wederpartij, die gehouden is om binnen redelijke grenzen maatregelen te nemen om te voorkomen dat hij onder invloed van onjuiste veronderstellingen zijn toestemming geeft, ter nakoming van deze verplichting een onderzoek zal instellen en daardoor met meerbedoelde gegevens bekend zal worden, moet niet alleen worden gelet op alle bijzonderheden van het gegeven geval - die dan ook zo volledig en zo nauwkeurig mogelijk behoren te worden vastgesteld -, maar ook en vooral daarop dat voormelde regel juist ertoe strekt ook aan een onvoorzichtige koper bescherming te bieden tegen de nadelige gevolgen van dwaling veroorzaakt door het verzwijgen van relevante gegevens."

Ook de beslissing in het hierna te noemen arrest bevestigt dat een eigen verantwoordelijkheid van een koper om een onderzoek in te stellen niet altijd wordt aangenomen. De omstandigheden van elk geval zullen als gezegd steeds bepalend zijn. Het is in zoverre inderdaad niet correct om van een onderzoeksplicht te spreken. De wet te onzent legt geen algemene onderzoeksverplichting op. Tegen het spraakgebruik moet men zich echter niet willen verzetten. Dogmatisch meer correcte termen als 'onderzoeksverantwoordelijkheid' hebben in de praktijk van fusies en overnames of in een andere verbintenisrechtelijke context nu eenmaal niet postgevat. Zie niettemin hierna onder Mededelingsplichtversus onderzoeksplicht?

In een arrest van 21 december 1990 ging het om de koop van een tweedehands auto.

Van der Geest had van Nederlof een tweedehands auto gekocht. Op de dag dat de koopovereenkomst was gesloten, heeft Van Geest een keuring aangevraagd bij de ANWB. De conclusie van de ANWB

\footnotetext{
${ }^{127}$ NJ 1997, 527 (Bloemendaalse olietank).
} 
was, kort gezegd, dat de auto gezien de schade in matige staat verkeerde en dat deze schade matig tot slecht was hersteld. Later komt het uit dat Nederlof ten tijde van verkoop wist dat de betreffende auto betrokken was geweest bij een ernstig ongeval en dat de verzekeraar van de toenmalige eigenaar de auto als total loss beschouwde. De vraag welke de Hoge Raad in deze moest beantwoorden was in hoeverre de koper van een tweedehands auto een onderzoeksplicht heeft. ${ }^{128}$

In het arrest dat de geschiedenis in is gegaan als Van der Geest/Nederlof ${ }^{129}$ overwoog de Hoge Raad:

"Of van de koper van een tweedehands auto moet worden gevergd dat hij de auto door een deskundige laat onderzoeken alvorens tot aankoop over te gaan, hangt af van de omstandigheden van het geval. Anders dan het Hof klaarblijkelijk heeft aangenomen, brengt het enkele feit dat de koper ondeskundig is niet mee dat hij, op straffe van verlies van het recht zich op dwaling te beroepen verplicht is een dergelijk onderzoek te doen verrichten".

De omstandigheden van het geval kunnen zaken betreffen als de leeftijd van de auto en de vraag of er garantie wordt verleend. Een en ander bepaalt mede wat de koper mocht verwachten met betrekking tot een normaal van de auto te maken gebruik. ${ }^{130}$

\section{Eigen verantwoordelijkheid bij onderzoek}

In 1995, op 22 december van dat jaar, wijst de Hoge Raad dan een arrest dat voor de praktijk van het due diligence onderzoek een belangrijke les oplevert, Hoog Catharijne (ABP/FGH). ${ }^{131}$ De inhoud heeft betrekking op de vraag waar onder omstandigheden een grens getrokken kan worden met betrekking tot de mededelingsplicht van een verkoper. In zoverre betrof het een volgende bouwsteen in het gebouw van het leerstuk van de mededelingsplicht. Wat de casus interessant maakt en daarom zo relevant voor de ontwikkeling van de due diligence praktijk, was dat de Hoge Raad een vraag voorgelegd kreeg waarbij de thematiek ditmaal rechtstreeks te maken had met een echt due diligence onderzoek. Waar ging het om?

Het complex Hoog Catharijne te Utrecht werd bij wijze van activa-passiva transactie door de Maatschappij tot Exploitatie van Onroerende Goederen Hoog Catharijne B.V. (HC) verkocht aan onder meer het ABP. Breevast N.V. en FGH Bank N.V. hadden samen de nakoming van de verplichtingen van $\mathrm{HC}$ gegarandeerd. Deze verplichtingen bestonden voornamelijk uit garantieverplichtingen, vastgelegd in de koopovereenkomst. De garanties hielden onder meer in dat de definitieve balans een getrouw beeld van de samenstelling en grootte van het vermogen van $\mathrm{HC}$ zou geven en dat er geen andere schulden of verplichtingen zouden zijn dan blijkend uit de definitieve balans. Ook werd verklaard dat $\mathrm{HC}$ alle informatie had verstrekt die van belang was voor de koper ter zake van de beoordeling van de waarde van de overgedragen onderneming. $\mathrm{HC}$ droeg activa bestaande uit erfpacht- en opstalrechten en passiva over aan het ABP. Deel van de passiva bestond in een tweetal geldleningen welke door de Gemeente Utrecht aan de verkoper waren verstrekt. De annuïteiten van die geldleningen zouden als onderdeel van een verschuldigde canon worden terugbetaald aan de Gemeente Utrecht. In de procedure welke tussen partijen volgde, was er tussen partijen geen misverstand over dat de canonverplichtingen niet in een balans van $\mathrm{HC}$ tot uitdrukking zouden worden gebracht. Het $\mathrm{ABP}$ stelde daardoor de achterliggende geldleningen niet (tijdig) te hebben opgemerkt en werd later geconfronteerd met de verplichtingen ingevolge de geldleningen. Tijdens het due diligence onderzoek was onder

\footnotetext{
128 Zie ook HR 4 april 1986, NJ 1986, 810.

129 NJ 1991, 251.

130 Zie ook hier voor onder 4.1 en verder HR 15 november 1985, NJ 1986, 213, in welk geval de Hoge Raad een oordeel van een lagere rechter sanctioneerde dat inhield "dat van een koper van een vijf jaar oude auto van het onderhavige merk en type in het algemeen mag worden verwacht, dat indien de verkoper, zoals hier, geen garantie ter zake geeft, hij zich ervan vergewist dat de auto niet zodanige gebreken heeft dat deze bijvoorbeeld een gevaar op de weg oplevert; dat de koper daartoe verschillende wegen openstaan; dat hij met name bij voldoende eigen deskundigheid de auto zelf kan inspecteren en dat hij, bij gebreke daarvan, dit door een meer deskundige derde, bijvoorbeeld de ANWB, kan laten doen alvorens tot aankoop over te gaan".

131 NJ 1996, 300. In de tekst verder ook wel het "Hoog Catharijne-arrest" genoemd. Zie over dit arrest o.m. Ch. E. Honée, Mededelings-informatie- en onderzoeksplicht bij een aandelenfusie - De positie van de over te nemen vennootschap, (p. 39 e.v.) en J.M. van Dunné, Onderzoeks- en spreekplichten bij bedrijfsovername, Hoe "due" is "due diligence" sinds Hoog Catharijne? (p. 399 e.v.), beiden in Onderneming en 5 jaar nieuw burgerlijk recht, Serie Onderneming en Recht, deel 7. Ook: G.T.M.J. Raaijmakers, Garanties bij overnames, p. 116-118.
} 
meer een boek met informatie ter beschikking gesteld door $\mathrm{HC}$ waarin alleen indirect verwezen werd naar de twee geldleningen (in een stuk van de Gemeente), maar de hoofdsom van die leningen was niet als schuld geactiveerd nu de annuïteiten als canonverplichtingen werden aangemerkt. Er bevonden zich in de informatiebundel geen stukken betreffende de geldleningen en evenmin stukken waaruit het bestaan rechtstreeks bleek. Het ABP sprak $\mathrm{HC}$ aan tot betaling van rente en aflossing van de geldleningen. ABP stelde omtrent de geldleningen niet voldoende te zijn geïnformeerd en beriep zich op de door HC afgegeven garantie dat alle relevante informatie zou zijn verstrekt.

De rechtbank te Maastricht oordeelde dat het op de weg van HC B.V. (FGH Bank N.V. en Breevast N.V.) had gelegen om de beide geldleningen van de gemeente Utrecht onder de aandacht van het ABP te brengen. De rechtbank overwoog daartoe dat de informatieplicht van de verkoper in beginsel zwaarder woog dan de onderzoeksplicht van de koper. Dit zou slechts anders zijn wanneer de koper reden had te twijfelen aan de juistheid en volledigheid van de door de koper aangebrachte informatie. In het onderhavige geval had het ABP geen redenen gehad om aan de (volledigheid van) verstrekte informatie te twijfelen, zodat er geen aanleiding bestond voor een verzwaarde onderzoeksplicht. HC B.V., FGH Bank N.V. en Breevast N.V. waren naar het oordeel van de rechtbank op basis van de door hen afgegeven garanties aansprakelijk voor betaling aan de gemeente Utrecht van aflossing en rente, verschuldigd uit hoofde van de desbetreffende geldleningen.

\section{De Hoge Raad oordeelde:}

"De reikwijdte van de verplichting van de verkoper om aan de koper alle informatie te verschaffen, wordt mede bepaald door hetgeen de verkoper in de gegeven omstandigheden aan onderzoeksinspanningen aan de zijde van de koper mag verwachten. Vanaf het moment dat de koper de beschikking had over een bijzonderlijk samengesteld informatiepakket - waarmee aan de aanvankelijke informatiebehoefte van de koper was voldaan - hield in de onderhavige zaak de spontane mededelingsplicht voor de verkoper op. Aan de hand van de inhoud van dat informatiepakket had de koper behoren aan te geven op welke punten deze nader geïnformeerd wenste te worden. Door niet te communiceren omtrent welke punten zij behoefte had aan nadere informatie, is de omstandigheid dat de koper geen kennis droeg van bepaalde informatie, voor rekening en risico van de koper en is die omstandigheid niet het gevolg van het niet nakomen van haar informatieplicht door de verkoper.

Een garantie dat alle informatie en volledige gegevens zijn verstrekt, moet worden uitgelegd met inachtneming van de omstandigheden van het geval. Deze omstandigheden kunnen zijn: het bestaan van een deskundig due diligence-team en een due diligence rapport, de omstandigheid dat de verkoper niet weet dat de koper bepaalde verplichtingen niet kent en verkoper niet weet welk gewicht de koper aan deze verplichtingen toekent".

Aan de overwegingen van het gerechtshof te 's-Hertogenbosch en van de Hoge Raad - waar die de overwegingen van het hof sanctioneerde of ten grondslag legde aan de eigen overwegingen - kan worden ontleend, dat de omvang van de informatieplicht en van de onderzoeksplicht mede kan afhangen van de navolgende omstandigheden:

- $\quad$ De deskundigheid (en dus ook het verschil in deskundigheid) van de over en weer betrokkenen;

- $\quad$ Hetgeen bekend is gegeven en aan de hand daarvan aanleiding kon geven tot doorvragen;

- $\quad$ Bekendheid bij een partij of aan deze toe te rekenen bekendheid, dat bepaalde informatie door de wederpartij als relevant zal (kunnen) worden aangemerkt voor het verrichten van de transactie;

- $\quad$ De relatieve betekenis van informatie in relatie tot de omvang van de met een transactie gemoeide belangen;

- $\quad$ Mate van diepgang van een ingesteld onderzoek (soort onderzoek);

- $\quad$ Tijdstip van informatievoorziening of verzoek om informatie (fasering procedure);

- $\quad$ "Rechtsverwerking", risico-aanvaarding door na te laten voorwaarden te bedingen of garanties te vragen. 
Het arrest maakte bovendien duidelijk dat begrippen als "alle relevante informatie" en "instaan voor" niet zo eenduidig zijn als deze lijken. De Hoge Raad merkt op dat het begrip "instaan voor" niet een door "vast juridisch spraakgebruik" bepaalde betekenis toekomt, in die zin dat degene die instaat, daarmee in beginsel aansprakelijkheid aanvaardt voor (de schadelijke gevolgen van) het uitblijven van gebeurtenissen, handelingen of feiten, voor het intreden of uitblijven waarvan hij instaat.

Het begrip "instaan voor" dient steeds te worden uitgelegd naar hetgeen partijen bij een transactie in de gegeven omstandigheden over en weer redelijkerwijs onder dat begrip mochten verstaan, gelet op de wijze waarop het is gehanteerd, de omstandigheden waarin en mede ingekleurd door hetgeen zij over en weer van elkaar mochten verwachten. ${ }^{132}$

Advocaat-generaal Hartkamp onderscheidt al zo vijf verschillende invullingen voor het begrip in zijn conclusie onder het arrest:

- $\quad$ een voorwaardelijke prestatieplicht: wanneer een derde iets doet of niet doet of een bepaalde gebeurtenis wel of niet plaatsvindt (een soort borgtocht onder voorwaarde, geen performance guarantee tot betaling on first simple demand);

- $\quad$ een eigen verbintenis van een schuldenaar tot een doen of niet-doen: een uitdrukkelijke of stilzwijgende toezegging om in te staan voor bepaalde feiten of gebeurtenissen, waarvan het voorvallen of uitblijven aan nakoming in de weg staat;

- $\quad$ een resultaatsverbintenis;

- $\quad$ een soort garantie, als te vinden in een garantiebewijs: naast het verzekeren van een bepaald resultaat, bevat deze soort van instaan ook vaak een exoneratie;

- $\quad$ een vaststellingsfeit voor een bepaald rechtsgevolg of feitelijke toestand, gecombineerd met een bevestiging van de wettelijke schadevergoedingsplicht in geval van tekortschieten.

Evenals bij andere contractuele bedingen, dient de betekenis van een beding "om in te staan voor" door uitleg te worden vastgesteld (Haviltex). ${ }^{133}$

Tjong Tjin Tai ${ }^{134}$ heeft - afgezien van volgens hem minder belangrijke interpretaties - de betekenis die doorgaans aan het begrip 'garantie' kan worden gegeven, als volgt juridisch geduid:

a. een onvoorwaardelijke toezegging dat een resultaat bereikt (is nagekomen) zal worden;

b. het louter toezeggen van dat resultaat, of

c. een toezegging dat schadevergoeding zal worden betaald als het resultaat niet wordt bereikt.

Welke informatie relevant is, zal afhangen van de hoedanigheid van partijen en de bijzondere omstandigheden van elk geval. Voor het beantwoorden van de vraag welke informatie "relevant" is, is eveneens de hoedanigheid van partijen van belang en zullen daarbij mede de bijzondere omstandigheden bepalend zijn.

Overigens is er op de uitspraak van de Hoge Raad in de Hoog Catharijne zaak van gezaghebbende kant kritiek gekomen. ${ }^{135}$ Hammerstein schrijft in 1997 nog dat jurisprudentie en literatuur over garanties betrekkelijk schaars is. ${ }^{136}$ De reden zou volgens hem kunnen zijn dat zich over garanties weinig problemen voor zouden doen. Wel zegt hij de indruk te hebben dat het belang van het thema van garantie van meer betekenis aan het worden is als gevolg van het feit dat de onzekerheid over de (rechts)gevolgen dwingt tot het aanscherpen van de voorwaarden van een overeenkomst. Zoals wij hierna nog zullen zien, klopte zijn waarneming wel. Garanties geven in toenemende mate aanleiding tot jurisprudentie. Toch was er op het moment dat Hammerstein vaststelde dat er in de praktijk niet veel problemen rond garanties speelden, al sprake van meer rechtspraak over garanties dan hij aan de

\footnotetext{
132 In HR 25 januari 1991, NJ 1992, 97 had de Hoge Raad het begrippen "garantie" en "instaan" al eens zo uitgelegd, dat die niet betrekking hadden op een eindresultaat, maar dienden te worden uitgelegd als een verbondenheid om schade te vergoeden welke zou worden geleden, wanneer door toedoen van de betrokkene het beoogde eindresultaat niet zou zijn gerealiseerd.

${ }^{133}$ Zie voor een ampele bespreking van het Hoog Catharijne-arrest J.M. van Dunné, Onderzoeks- en spreekplichten bij bedrijfsovername; hoe "due" is "due diligence" sinds Hoog Catharijne? in Onderneming en 5 jaar nieuw burgerlijk recht, Serie Onderneming en Recht, deel 7, p. 399 e.v. en A. Hammerstein, Garanties zijn geen garanties, in dezelfde bundel, p. 389 e.v.

134 T.F.E. Tjong Tjin Tai, Garantie, nakoming en schadevergoeding, WPNR 04/6577, p. 363 e.v.

135 O.m. W.J. Slagter, Due diligence en garanties, TVVS 1996 / 11, p. 327; G.T.M.J. Raaijmakers, Garanties bij overnames: het arrest ABP-FGH, WPNR 1996 / 6219, p. 267-268; A. Hammerstein, Garanties zijn geen garanties, in Onderneming en 5 jaar nieuw burgerlijk recht, Serie Onderneming en Recht, deel 7, p. 389 e.v.; M. Wolters, De due-diligenceparadox, Contracteren, 1999/1, p. 3 e.v. en M.M. Tuytel, (Balans)garanties, V\&O 2001, p. 174-179.

${ }^{136}$ A.w.
} 
hand van raadpleging van de gewone bronnen kon weten. Als arbiter heb ik ook in de door Hammerstein bedoelde periode regelmatig deel mogen uitmaken van een scheidsgerecht dat zaken te behandelen kreeg over garanties in overeenkomsten betreffende overnames, fusies of joint ventures. De uitspraken die in die zaken gegeven werden, werden in de meeste gevallen niet gepubliceerd. Het is eerder regel dan uitzondering dat professionele partijen in hun overnamen overeenkomsten voor arbitrage kiezen in een geschillenregeling, juist omdat zij publiciteit willen vermijden.

De kritiek van Hammerstein op het arrest in de zaak rond Hoog Catharijne komt er op neer, dat onvoldoende tot uitdrukking is gekomen dat het feit dat een koper een deskundige inschakelt om een onderzoek te doen, de verkoper niet mag ontslaan van diens informatieplicht. De koper die een deskundige inschakelt mag niet beter af zijn, dan een koper die in het geheel geen onderzoek laat uitvoeren. Een zorgvuldige koper zou anders in een nadeliger positie kunnen komen te verkeren dan een koper die geen onderzoek doet. Met Raaijmakers ${ }^{137}$ meent hij dat het gerechtshof de strekking van de garantiebepalingen in de overeenkomst tussen de partijen in dit geval had miskend. Die bepalingen beoogden de partij die de garantie verstrekte er toe te bewegen volledige inlichtingen te geven. De verkoper kon er niet zeker van zijn dat de koper met de leningen waar het allemaal om draaide bekend was en zou zich er van hebben moeten vergewissen dat dit wel het geval was.

Niettemin verklaarde de Hoge Raad ook zelf in HR 4 februari $2000^{138}$ met zoveel woorden dat in overnameovereenkomsten het begrip garantie geen vaste betekenis toekomt. In de lijn van de Haviltex-doctrine stelt de Hoge Raad in de desbetreffende uitspraak dat de vraag welke aard en strekking garantiebepalingen hebben, moet worden beantwoord door de uitleg ervan, "waarbij het aankomt op de zin die partijen bij de overeenkomst in de gegeven omstandigheden over en weer redelijkerwijs daaraan mochten toekennen en op hetgeen zij redelijkerwijs te dien aanzien van elkaar mochten verwachten".

Helemaal verrassend was de uitkomst van het geschil in de zaak rond Hoog Catharijne niet, wanneer wij kijken naar het arrest dat werd gewezen in een geschil tussen het Amerikaanse Avery International Corporation ("Avery") enerzijds en de VRG Groep N.V. en de Stichting "Pensioenfonds VRG" (tezamen "VRG") anderzijds op 4 januari 1991. ${ }^{139}$ De casus vertoont sterke overeenkomst met het geschil in de kwestie rond Hoog Catharijne. Waar ging het in dit geval om?

Avery kocht van VRG alle aandelen in het kapitaal van Avery etiketten B.V. Daarbij garandeerde VRG aan Avery dat de premiereserves die in het pensioensfonds van VRG waren gevormd ter dekking van de pensioenaanspraken van werknemers van Avery etiketten B.V. zouden worden overgeheveld naar een nog op te richten pensioenfonds van Avery. In een gesprek over de overdracht van de pensioenrechten werd afgesproken dat de omvang van de overdracht zou worden bepaald door de omvang van de premiereserve per een bepaalde datum, 'zoals vastgesteld volgens de tot dan toe gevolgde (consistente) actuariële methode. Later ontstaat er tussen partijen verschil van opvatting over de toepassing van de rekenrente. VRG gaat er vanuit dat een "hinkende rekenrente" moet worden gerekend, die tot dan toe ook is toegepast. Avery stelt daar niet op te hebben gerekend, nu de methode van "hinkende rekenrente" zo ongebruikelijk was, dat zij er niet op bedacht behoefde te zijn, dat die van toepassing zou zijn. Avery had wel vernomen van de toepassing van "hinkende rekenrente", maar was er vanuit gegaan dat die slechts betrekking had op in het verleden gehanteerde sterftetafels, welke verouderd waren. Vergelijkbaar met het geschil met Hoog Catharijne deed de vraag zich derhalve voor of Avery - die overigens alle informatie ter beschikking kon krijgen, waar zij om zou hebben gevraagd had moeten doorvragen. Het aangevoerde cassatiemiddel (nadat Avery nul op het rekest heeft gekregen bij de rechtbank en het gerechtshof) maakt de overeenkomst met de Hoog Catharijne thematiek duidelijk:

"In r.o. 4.13 gaat het Hof, overwegende dat Avery in het gesprek op 22 augustus 1986 kennelijk niet heeft geïnformeerd naar wat de "tot nu toe gevolgde (consistente) actuariële methode inhield, uit van de rechtsopvatting dat Avery te dien aanzien een onderzoeksplicht had, althans dat het op de weg van Avery lag daar naar te informeren.

\footnotetext{
${ }^{137}$ G.T.M.J. Raaijmakers, Garanties bij overnames: het arrest ABP-FGH, WPNR 6219, p. 267-268.

${ }^{138}$ NJ 2000, 562 m.nt. JBMV, zie r.0. 3.3

${ }^{139}$ HR 4 januari 1991, NJ 1991, 254. Zie hierover en ook over het Hoog Catharijne-arrest R.P.J.L. Tjittes, Naar een bijzonder contractenrecht voor ondernemers in Onderneming en 5 jaar nieuw burgerlijk recht in Serie Onderneming en Recht, deel 7 , p. 384-385.
} 
- Die rechtsopvatting is onjuist, althans is in r.o. 4.13 onbegrijpelijk zulks op grond van het navolgende.

- In de eerste plaats had Avery - in haar visie dat de bedoelde passage slechts betrekking had op het aanhouden van de verouderde sterftetafels - geen aanleiding om te informeren of die passage misschien iets ander zou kunnen betekenen.

- In de tweede plaats lag het eerder op de weg van VRG om uit eigen beweging Avery te informeren dat de "tot nu toe gevolgde consistente methode" betekende dat de zogenoemde "hinkende rekenrente" $8 \% / 4 \%$, nu die immers, naar Avery heeft gesteld (r.o. 4.9 sub b.) en het hof blijkbaar daarom veronderstellenderwijs aanneemt - ongebruikelijk was (is). Het hanteren van een "hinkende rekenrente" was slechts een tijdelijk verschijnsel en iets abnormaals waarop Avery niet bedacht hoefde te zijn. Avery heeft dat blijkens r.o. 4.9 sub b. gesteld en het hof heeft die stelling niet ontzenuwd. De (wellicht) door het hof aangenomen professionele deskundigheid van Avery's vertegenwoordigers doet er niet aan af dat eerder een informatieplicht op VRG rustte dan een onderzoeksplicht op Avery".

De Hoge Raad beslist als volgt:

"Onderdeel 1 heeft tot uitgangspunt dat in 's hofs r.o. 4.13 besloten ligt dat Avery naar 's hofs oordeel een "onderzoeksplicht" had ten aanzien van hetgeen de "tot nu toe gevolgde consistente (actuariële) methode" inhield. Dit uitgangspunt is in zoverre juist dat het hof bij zijn verwerping van het hiervoor vermelde betoog van Avery - naast andere omstandigheden - mede van belang heeft geacht de omstandigheid dat Avery bij het gesprek van 22 augustus 1986 niet heeft "geïnformeerd" naar hetgeen die methode inhield en derhalve het achterwege laten van onderzoek door Avery relevant heeft geacht voor zijn beslissing omtrent de interpretatie van de afspraak. Het onderdeel betoogt nu dat 's hofs oordeel dat op Avery in voege als voormeld een "onderzoeksplicht" rustte, blijk geeft van een onjuiste rechtsopvatting. Dit betoog faalt. Of op een partij in een situatie als zich hier voordoet - een gesprek dat tot doel heeft een contractuele bepaling nader uit te werken in voege als hiervoor omschreven een plicht tot onderzoek rust, bij voorbeeld aldus dat de wederpartij omtrent bepaalde punten om opheldering wordt gevraagd, hangt af van de omstandigheid van het geval. Door onder de hier door het hof vastgestelde omstandigheden in voege als voormeld zulk een onderzoeksplicht aan te nemen, heeft het hof niet blijk gegeven van een onjuiste rechtsopvatting".

Nu de omstandigheden van feitelijke aard werden geacht, gaat de Hoge Raad daar verder niet op in. Niettemin wordt een obiter dictum toegevoegd.

"Omtrent het onderdeel valt nog het volgende op te merken. Het stelt "in de eerste plaats" dat Avery - in haar visie dat de bedoelde passage slechts betrekking had op het aanhouden van verouderde sterftetafels - geen aanleiding had te informeren of die passage misschien iets anders zou kunnen betekenen. Het hof heeft evenwel kennelijk geoordeeld dat het in dit gesprek in het kader van een professionele bedrijfsuitoefening wel op de weg lag van de op financieel gebied deskundige topfunctionarissen van Avery om opheldering te vragen, ook al had Avery evenbedoelde - door het hof in rechtsoverweging 4.9 onder a. vermelde - visie. "In de tweede plaats" doet het onderdeel een beroep op een ongebruikelijkheid van voormelde "hinkende rekenrente". Het hof heeft Avery's beroep op de ongebruikelijkheid - waarvan het hof de juistheid in het midden heeft gelaten - niet beslissend geacht mede omdat VRG reeds sedert 1981 door de Verzekeringskamer was toegestaan om deze rente te hanteren; in de gedachtegang van het hof was dus de methode, hoewel wellicht ongebruikelijk, in ieder geval aanvaard door het orgaan dat hier krachtens de wet met toezicht is belast".

Ook in dit geval werd - evenals in het geval van Hoog Catharijne - de deskundigheid van de vertegenwoordigers van de partij die zich beriep op het verkrijgen van onvoldoende inzicht - meegewogen als een factor die verantwoordelijkheid voor het gebeurde legde bij de principaal van die vertegen- 
woordigers. Avery was vertegenwoordigd door haar vicepresident European Treasury Operations en haar European Counsel, van wie volgens het hof financiële deskundigheid kon worden verwacht.

\section{Opgewekt vertrouwen}

In de zaak die eindigde met een arrest van 16 juni 2000, Vletter-Stijnman ${ }^{140}$ was de verwachting welke de ene partij mocht ontlenen aan mededelingen van de ander een element van betekenis.

De Hoge Raad bevestigde bij dezelfde gelegenheid ook de eerder op 10 april 1998 gedane uitspraak, dat het enkele feit dat een partij haar onderzoeksplicht naar bepaalde relevante gegevens verzaakt, niet uitsluit dat de andere partij ter zake van diezelfde gegevens een mededelingsplicht heeft. ${ }^{141}$ Waar ging het in dit geval om?

Vletter sloot voor zich zelf en voor zijn vrouw (Stijnman) een lijfrente/stamrechtovereenkomst. In deze overeenkomst stond dat M.A. Vletter B.V. jaarlijks het ingebrachte ad $f 123.463,-$, met $9 \%$ rente moest verhogen. Na 1 januari 1989 was er geen rente meer bijgeschreven. In 1985 werd een deel van de aandelen in het kapitaal van M.A. Vletter B.V. verkocht aan L.E. Beheermaatschappij BV ("L.E. Beheer"), een persoonlijke vennootschap van Van Egmond. Van Egmond was een persoonlijke relatie van Vletter. De beiden werkten al jaren samen en Van Egmond was de opvolgend directeur van M.A. Vletter B.V. Zij vertrouwden elkaar blindelings. In 1991 werd door L.E. Beheer het resterende gedeelte van de aandelen gekocht. Vletter had eerder tegenover Van Egmond verklaard dat er geen rente meer bijgeschreven behoefde te worden en dat de vennootschap na betaling van een bepaald bedrag aan Vletter "overal van af" zou zijn. Na het overlijden van Vletter vordert Stijnman betaling van de rente over een periode van 1 januari 1989 tot 27 december 1990. L.E. Beheer vordert vervolgens in een procedure een verklaring voor recht dat de koopovereenkomst waarbij de aandelen in M.A. Vletter B.V. werden verkocht (a) wegens wanprestatie gedeeltelijk ontbonden zal zijn en (b) wegens dwaling vernietigd zal zijn. Zij stelde de overeenkomst te zijn aangegaan onder invloed van de door Vletter voorafgaand aan het aangaan van de transactie gewekte onjuiste voorstelling van zaken. Op de door Vletter gedane mededelingen zou zij hebben mogen afgaan. De Hoge Raad oordeelde dat het hof deze stellingen van L.E. Beheer niet onbesproken had mogen laten. (Het hof had L.E. Beheer verweten dat deze - kennis dragende van het bestaan van de stamrecht overeenkomst, en niet ondenkbaar na de uitspraak in de kwestie rond Hoog Catharijne - niet had doorgevraagd en niet had onderzocht of de echtgenote van Vletter aan die overeenkomst mede rechten kon ontlenen.) De Hoge Raad overwoog verder:
"Wanneer een partij voor de totstandkoming van een overeenkomst aan de wederpartij bepaalde inlichtingen had behoren te geven om te voorkomen dat de wederpartij zich omtrent betreffende punten een onjuiste voorstelling zou maken, zal in het algemeen de goede trouw zich ertegen verzetten dat de eerstgenoemde partij ter afwering van een beroep op dwaling aanvoert dat de wederpartij het ontstaan van de dwaling aan zichzelf heeft te wijten. Het enkele feit dat een partij een onderzoeksplicht naar bepaalde rele- vante gegevens verzaakt, sluit niet uit dat de andere partij ter zake van diezelfde gege- vens een mededelingsplicht heeft. Bij de mededelingsplicht van de verkoper kunnen van belang zijn de in het verkeer geldende opvattingen alsmede de bijzonderheden van het geval" ${ }^{142}$

In dit arrest grijpt de Hoge Raad terug op de arresten Baris/Riezenkamp en Booy/Wisman. Uitgangspunt blijft dat beide partijen zowel bij zich zelf als bij de wederpartij dienen te voorkomen dat gehandeld wordt onder een onjuiste voorstelling van zaken. Ook komt de regel terug die in Van der Beek/Van Dartel (zie hiervoor) werd geformuleerd, namelijk dat de redelijkheid en billijkheid zich er in het algemeen tegen zal verzetten, dat een partij die zelf haar mededelingsplicht niet is nagekomen, zich ter afwering van een beroep op dwaling erop zou kunnen beroepen dat de ander het ontstaan van de dwaling aan zich zelf te wijten heeft.

\footnotetext{
${ }^{140}$ NJ 2001, 559 m.nt. JH

141 NJ 1998, 666

${ }^{142}$ Een bijzondere omstandigheid kan bijvoorbeeld zijn, dat - zoals in het geval van Vletter en Van Egmond - partijen al lang samenwerkten.
} 
Zelfs wanneer inlichtingen volkomen te goeder trouw zijn gegeven, staat dat aan een beroep op dwaling niet in de weg. ${ }^{143}$

Als aanvulling op de hier voor genoemde beginselen zijn aan het arrest van de Hoge Raad in de procedure van L.E. Beheer tegen Vletter-Stijnman nog de navolgende regels te ontlenen:

- $\quad$ De grens tussen mededelingsplicht en onderzoeksplicht wordt bepaald door de in het verkeer geldende opvattingen alsmede door de bijzonderheden van het geval. De rechter dient bij zijn beoordeling te motiveren welke in het verkeer geldende opvattingen en welke bijzondere omstandigheden de invulling van de omvang van de onderzoeksplicht of informatieplicht in een desbetreffend geval hebben bepaald. In het hier voor genoemde arrest van 10 april 1998, had de Hoge Raad al duidelijk gemaakt dat er aan de feitenrechter hoge eisen worden gesteld op het punt van de motivering, waar het er om gaat aan te geven welke in het verkeer geldende opvattingen in het geding zijn;

- $\quad$ Ook herkenbaar uit het arrest van 10 april 1998 is de opvatting van de Hoge Raad, dat er, ook al is er aan de zijde van de wederpartij bekendheid met gegevens, onder omstandigheden dan desondanks nog steeds een mededelingsplicht kan bestaan;

- $\quad$ Het is van belang of er informatie is verschaft, waardoor bij de wederpartij een gerechtvaardigd vertrouwen is opgewekt omtrent de juistheid van die informatie;

- $\quad$ De mate van vertrouwen welke kan zijn opgewekt en de mate van zorgvuldigheid welke van de wederpartij kan worden verlangd, wordt mede bepaald door de relatie tussen partijen. Hoe meer afstand, hoe groter de voorzichtigheid dient te zijn.

\section{Mededelingsplicht versus onderzoeksplicht?}

In zijn noot onder het arrest Vletter-Stijnman stelt Hijma de door enkele auteurs ${ }^{144}$ opgeworpen vraag nog weer aan de orde of de gehoudenheid van de ene partij in principe zal ophouden waar die van de andere partij begint, zodat mededelingsplicht en onderzoeksplicht elkaars component vormen. Hij stelt vast dat de Hoge Raad deze visie niet in alle opzichten volgt. De Hoge Raad acht de over en weer bestaande verplichtingen niet noodzakelijk complementair. De 'gestapeld-voorzichtige wijze' waarop de Hoge Raad zijn standpunt verwoordt ("het enkele feit" plus "niet uitsluit"), doet echter vermoeden, aldus Hijma, dat in de optiek van de Hoge Raad de wederzijdse plichten wel degelijk complementair kunnen zijn en wellicht niet zelden zullen zijn. Hij vervolgt: "Een indicatie in die richting levert ook rov. 3.5 van Offringa/Vinck ${ }^{145}$, waarin de Raad de te beantwoorden vraag als volgt formuleert: “(...) of een partij ter zake van bepaalde relevante gegevens naar in het verkeer geldende opvattingen een mededelingsplicht heeft, dan wel of hij die gegevens voor zich mag houden omdat hij er op mag vertrouwen dat zijn wederpartij, die gehouden is om binnen redelijke grenzen maatregelen te nemen om te voorkomen dat hij onder invloed van onjuiste veronderstellingen zijn toestemming geeft, ter nakoming van deze verplichting een onderzoek zal instellen en daardoor met meerbedoelde gegevens bekend zal worden(...)"(enz). In deze passage gaat de Hoge raad er onmiskenbaar van uit dat de (omvang van de) mededelingsplicht van de een met de (omvang van de) onderzoeksplicht van de ander in verbinding staat. Gezien het feit dat bij de afweging aan beide kanten veelal grotendeels dezelfde feiten en omstandigheden een rol spelen, lijkt het bestaan van zulk een verbondenheid inderdaad meer regel dan uitzondering".

Mijn mening is dat het er niet zo veel toe doet of de door Hijma bedoelde verbondenheid bestaat of niet. Volgens mij is er geen noodzaak om een relatie als door Hijma bedoeld, een belangrijke betekenis toe te kennen. Het zijn steeds - zoveel is hier voor wel duidelijk geworden - de bijzondere omstandigheden van het geval, die beslissend zijn voor een antwoord op de vraag op wie er welke verantwoordelijkheden drukken. Niet valt in te zien waarom wederkerige inspanningen complementair zouden (moeten) zijn en niet zouden kunnen overlappen. Allerhande omstandigheden spelen een rol. De bekwaamheid of deskundigheid van partijen, de verhouding waarin zij zich ten opzichte van elkaar bevinden, maar ook de mededelingen welke er over en weer zijn gedaan, de gewekte verwachtingen, de plaatselijke omstandigheden en zo verder. In zoverre kan volgens mij worden volstaan met de gevolgtrekking, waartoe per saldo ook Hijma komt, namelijk dat de Hoge Raad zich niet achter de al te een-

\footnotetext{
143 T\&C, aant. 3 onder artikel 2:228 lid 1 met verwijzing naar de parlementaire geschiedenis.

144 Hij noemt: Van Dam in Bloembergen c.s., Rechtshandeling en Overeenkomst (2001), nr. 169 en een bijdrage van zijn eigen hand in Ars Aequi 1991, p. 664-665.

145 Dit betreft het door mij genoemde arrest van 10 april 1998, NJ 1998, 666
} 
voudige redenering heeft willen scharen, dat er geen mededelingsplicht zou bestaan, omdat er onder omstandigheden voor de dwalende partij aanleiding was om een (nader) onderzoek in te stellen.

Er rusten - wat ten onzent ook als Obliegenheiten is aangeduid ${ }^{146}$ - 'verplichtingen' op beide partijen die voornemens zijn om toe te treden tot een verbintenisrechtelijke betrekking ter zake van een transactie. Brunner ${ }^{147}$ merkt op dat de bij onderhandelingen uit de redelijkheid en billijkheid voortvloeiende mededelingsplicht van een andere aard is dan de onderzoeksplicht. De schending van een mededelingsplicht kan verplichten tot schadevergoeding. De mededelingsplicht is daarom volgens hem geen Obliegenheit. ${ }^{148}$ Dat is anders bij een onderzoeksplicht: "Heeft een onderhandelende partij nagelaten het nodige onderzoek te verrichten, dan schendt zij niet een verplichting jegens de wederpartij, maar gaat zij onzorgvuldig om met haar eigen belang." Nalaten van geboden onderzoek is niet onrechtmatig en maakt niet schadeplichtig. Wel komen de nadelige gevolgen voor risico van degene die (onvoldoende) onderzoek doet. In het geval van dwaling zal de betrokkene zich over het algemeen in een weinig benijdenswaardige positie bevinden. De conclusie van Brunner, dat bij het nalaten van een onderzoek op een gebrek in de prestatie geen beroep meer kan worden gedaan (waarbij hij verwijst naar artikel 6:89 en 7:23) gaat in zijn algemeenheid te ver. Men kan zich immers verlaten hebben op gerichte mededelingen van de ander of andere te rechtvaardigen gronden hebben gehad om (nog) geen onderzoek te hebben uitgevoerd of te hebben kunnen uitvoeren. Beide partijen hebben een eigen verantwoordelijkheid. Er kan zeker in het kader van een due diligence onderzoek sprake zijn van een verbondenheid van de verplichtingen van de een met die van de ander, maar de omstandigheden zullen bepalen of daarvan sprake dient te zijn bij de beoordeling van de wijze waarop ieder van de betrokken partijen invulling aan de eigen verantwoordelijkheid heeft gegeven. Een zorgvuldige opstelling van iedere betrokkene vergt dat het invullen van de eigen verantwoordelijkheid de norm moet zijn. Het vertrouwen op een verbondenheid met de verplichting van de ander om op het punt van de invulling van de eigen verantwoordelijkheid ook maar iets aan het toeval (of het vertrouwen in de wederpartij) over te laten, houdt risico's in die zich - afhankelijk van de omstandigheden van elk geval - kunnen materialiseren. Het is om met de Engelse Jip en Janneke te spreken 'better to be safe than sorry.' Voor zover een onderzoeksplicht in ons recht niet naar een bijzondere wetsbepaling kan worden teruggevoerd, geldt in ieder geval dat het nalaten of onvoldoende invullen van een onderzoeksplicht tot rechtsgevolgen kan leiden, zoals door Brunner bedoeld met zijn verwijzing naar artikel 6:89 en 7:23. Feit blijft dat op dit moment de verkoper zich niet kan beroepen op een afdwingbare verbintenis - al dan niet gegrond op de vereiste zorgvuldigheid welke in het maatschappelijk verkeer tussen ondernemers past, wanneer een koper nalaat om een (grondig) onderzoek in te stellen. Het gaat steeds om het handhaven of verloren gaan van het recht van een koper om zich na het tot stand komen van een transactie te beroepen op gebreken in de prestatie.

De vraag naar waar de onderzoeksplicht van de koper eindigt en de mededelingsplicht van de verkoper begint, dient beantwoord te worden aan de hand van de in het verkeer geldende opvattingen en de bijzondere omstandigheden van het geval. Ook afgegeven garanties dienen in het licht van deze opvattingen en omstandigheden beoordeeld te worden. Bij onmiskenbare schendingen van de onderzoeks- of de mededelingsplicht kan rekening houdende met de gerechtvaardigde belangen van de wederpartij, onder omstandigheden een beroep op dwaling worden gedaan. "Schuldig verzwijgen", zal vrijwel steeds door de rechter worden afgestraft. ${ }^{149}$ De Hoge Raad heeft duidelijk gemaakt dat de rechter geroepen is om verantwoording af te leggen van de belangen die hij heeft laten meewegen en van de eventuele rechtsbeginselen die hij op het oog heeft gehad. Bij de motivering van zijn uitspraak zal hij vaak niet kunnen volstaan met opsomming van omstandigheden die voor hem beslissend zijn geweest voor zijn oordeel omtrent wat redelijkheid en billijkheid in het gegeven geval eisen, maar zal hij

\footnotetext{
${ }^{146}$ Zie voor een nadere beschouwing over het wel of niet terechte gebruik van het begrip Obliegenheiten te onzent, W.J. Oostwouder, Management Buy-out, Groningse serie, deel 27, p. 46 e.v. en de door hem genoemde literatuur. Oostwouder meent dat de vergelijking met 'gehoudenheden' in het Nederlandse recht met 'Obliegenheiten' slechts opgaat voor zover deze gehoudenheden voldoen aan de definitie van 'Obliegenheit' zoals een precontractuele onderzoeksplicht. Hij is kennelijk van oordeel dat die laatst bedoelde 'verplichting' een algemeen aan te nemen gehoudenheid betreft, zij het niet terug te voeren op een wetsbepaling.

${ }^{147}$ In zijn noot onder HR 2 april 1993, NJ 1995, 94 (onder 4).

148 Aldus ook J.B.M. Vranken, Mededelings- informatie en onderzoeksplichten in het verbintenissenrecht, $n r$. 166. Hijma in Asser-Hijma 5-I meent op zijn beurt dat in het kader van het dwalingsleerstuk de mededelingsplicht niet te beschouwen is als een werkelijke verbintenis of verplichting, maar als een Obliegenheit, inhoudende dat degene op wie die rust bij het niet in acht nemen 'slechts' de eigen positie ondergraaft omdat die zich een dwalingsberoep zal moeten laten welgevallen.

149 Een fraai voorbeeld is te vinden in HR 14 november 1997, RvdW 1997, 228c (Het niet melden van bodemverontreiniging).
} 
ook voldoende inzicht moeten geven in zijn gedachtegang ter zake, hetgeen van belang is voor de toetsbaarheid in cassatie. ${ }^{150}$

Mede naar aanleiding van de uitspraak in de zaak Vletter-Stijnman wordt wel aangenomen, dat 'de mededelingsplicht boven de onderzoeksplicht gaat'. ${ }^{151}$ Een zelfde conclusie is wel verbonden aan de uitkomst van de zaak rond Hoog Catharijne. Naar aanleiding van hetgeen ik hier voor heb opgemerkt met betrekking tot verbondenheid van beide verplichtingen, zal duidelijk zijn dat ik meen dat er moet worden gewaakt tegen het toekennen van te veel gezag aan dit adagium. De omstandigheden van het geval zullen in voorkomende gevallen, ook hier tot uitkomsten kunnen leiden, die bevestigen dat het recht een levend iets is en er maar weinig gevallen zijn, waarin iets in beton gegoten is of het daar in te gieten valt.

\section{Nogmaals, de verkeersopvattingen}

In diens conclusie bij het arrest van de Hoge Raad in de zaak Vletter-Stijnman stelt A-G Langemeijer vast dat in de desbetreffende zaak de klacht voortbouwde op eerdere uitspraken van de Hoge Raad. Die hadden de regel opgeleverd, dat wanneer een partij voor de totstandkoming van een overeenkomst aan de wederpartij bepaalde inlichtingen had behoren te geven teneinde te voorkomen dat de wederpartij zich omtrent de betreffende punten een onjuiste voorstelling zou maken, de goede trouw zich in het algemeen ertegen zal verzetten dat eerstgenoemde partij ter afwering van een beroep op dwaling aanvoert dat de wederpartij het ontstaan van de dwaling aan zichzelf te wijten heeft. Hij stelt vast dat er in het middel als vanzelfsprekend vanuit is gegaan, dat die regel ook van toepassing was op aandelentransacties en vroeg zich af of dat wel zo vanzelfsprekend was. De voorafgaande jurisprudentie betrof geen aandelentransacties, maar andersoortige overeenkomsten:

"Stuk voor stuk overeenkomsten, voornamelijk in de consumentsfeer, waarbij menselijkerwijs nog is te overzien welke informatie voor de wederpartij van belang kan zijn en daarom niet verzwegen mag worden. Bij een overeenkomst van koop en verkoop van aandelen in een onderneming - ongeacht of het gaat om enkele aandelen, een meerderheidsbelang of alle aandelen - kunnen in beginsel álle van de onderneming deel uitmakende rechten en verplichtingen van belang zijn voor het sluiten van de overeenkomst (i.h.b. voor de koopprijs). Een onderneming is doorgaans gebonden aan huur-, verzekerings- en arbeidsovereenkomsten, milieuvergunningen, afspraken met de Belastingdienst enz. Kan van de verkoper van aandelen worden verwacht dat hij niet alleen het bestáán van die overeenkomsten, vergunningen etc. maar ook alle daarmee samenhangende rechten en verplichtingen (dus: alle contractsvoorwaarden, alle polisbepalingen, alle vergunningsvoorschriften en dergelijke) ongevraagd aan de aspirant-koper mededeelt teneinde te voorkomen dat de koper zich omtrent de desbetreffende punten een onjuiste voorstelling zal maken?"

Langemeijer vervolgt met de vraag of het voldoende was dat er op het bestaan van de stamrechtovereenkomst was gewezen. Moest er aan de koper ook nog worden meegedeeld voor wie er rechten uit de stamrechtovereenkomst voorvloeiden en welke rechten dat waren? In de zaak Vletter-Stijman heeft de Hoge Raad op die vraag geen antwoord gegeven. In die zaak volgde de conclusie dat het hof haar oordeel beter had moeten motiveren en werd de zaak terug verwezen. In het Hoog Catharijne-arrest was - zoals wij zagen - de door Langemeijer opgeworpen vraag door de Hoge Raad wel beantwoord. Mij gaat het op deze plaats echter om de bevestiging van ook mijn opvatting, dat het relevant is over wat voor een soort zaak het gaat. Dát bepaalt immers met welke verkeersopvattingen rekening gehouden kan en mag worden gehouden.

Langemeijer signaleert dat het in het door hem besproken geval om een aandelentransactie ging en dat er daarbij - en dit geldt per saldo ook voor kapitaalmarkt transacties en andere soortgelijke transacties als joint venture overeenkomsten - door partijen in de regel pro actief regelingen plegen te worden getroffen:

\footnotetext{
${ }^{150}$ Zie A.G. Castermans, De mededelingsplicht in de onderhandelingsfase, Kluwer 1992, p.47.

${ }^{151}$ Aldus ook W.L. Valk in T\&C, aant. 3 onder artikel 6:228 lid 1.
} 
"In het bedrijfsleven, vanuit de daar bestaande behoefte aan rechtszekerheid, worden bij bedrijfsovernames vaak regelingen getroffen door partijen zelf. Zo kan de koper van aandelen in een bedrijf garanties van de verkoper bedingen omtrent de eigenschappen van hetgeen verkocht wordt (bijv: bedingen dat de verkoper instaat voor bepaalde financiële gegevens of in het algemeen voor de juistheid en volledigheid van de ter inzage gegeven jaarstukken). Ook kunnen de onderhandelende partijen onderling regelen op welke wijze de verkoper aan zijn mededelingsplicht resp. de koper aan zijn onderzoeksplicht voldoet. Daartoe vindt dikwijls een due diligence-onderzoek plaats. Zo'n onderzoek houdt in dat de koper gericht informatie bij de koper opvraagt, waarop de verkoper documenten en inlichtingen verschaft, welke door of namens de koper kunnen worden bestudeerd. Uit de vakliteratuur leid ik af dat deze praktijk wordt geïnspireerd door Engels en Amerikaans recht, waarin non-disclosure als hoofdregel geldt. Deze regel, overigens niet onomstreden, houdt kort gezegd in dat een partij in een onderhandelingsfase niet verplicht is ongevraagd inlichtingen aan de wederpartij te verschaffen. Door deze regel wordt de koper in feite genoodzaakt gericht vragen te stellen aan de wederpartij of garanties te bedingen. Het Engels recht kent overigens uitzonderingen, waarin wel een spreekplicht wordt aangenomen (zoals bij de zgn. "contracts uberimae fidei")."

Tot welke gevolgtrekkingen leidt het vorenstaande op het punt van verkeersopvattingen? De A-G vervolgt met een verwijzing naar het standpunt van de Hoge Raad, dat de vraag of een partij ter zake van bepaalde relevante gegevens 'naar de in het verkeer geldende opvattingen' een mededelingsplicht heeft, moet worden beantwoord aan de hand van de bijzonderheden van het gegeven geval, en stelt dan:

\begin{abstract}
"Het is niet zo gemakkelijk, uit een regel, die zo is toegesneden op de bijzonderheden van het gegeven geval gevolgtrekkingen te maken voor aandelentransacties. De verwijzing naar 'in het verkeer geldende opvattingen' door de Hoge Raad houdt, naar ik vermoed, verband met het tweede lid van artikel 6:228 BW, waar deze term wordt gebruikt. In dat tweede lid is onder meer bepaald dat de vernietiging wegens dwaling niet kan worden gegrond op een dwaling die in verband met de aard van de overeenkomst, de in het verkeer geldende opvattingen of de omstandigheden van het geval voor rekening van de dwalende behoort te blijven. Dat spreekt welhaast voor zich, wanneer iemand bijv. aandelen Koninklijke Olie koopt. De in het verkeer geldende opvattingen omtrent de gang van zaken bij overname van aandelen (zelfs van een heel bedrif) behoeven niet dezelfde te zijn als de in het verkeer geldende opvattingen bij consumentenovereenkomsten. De verkeersopvattingen kunnen mede worden beïnvloed door in het bedriffsleven geldende gebruiken, welke op hun beurt weer door Engelse of Amerikaanse zeden kunnen zijn beïnvloed."
\end{abstract}

Langemeijer veronderstelt (onder 2.14 van zijn conclusie) dat het hof in de zaak Vletter-Stijnman toen hij oordeelde dat het op de weg van de koper had gelegen inzage te verlangen in de van de stamrechtovereenkomst opgemaakte akte dan wel bij de verkoper had moeten informeren of bij die overeenkomst mede ten behoeve van de echtgenote aanspraken waren toegekend - is uitgegaan van een geldende verkeersopvatting, "waarin het in gevallen als dit (overname van een meerderheidsbelang in een onderneming) voldoende is dat de verkoper het enkele bestaan van de desbetreffende contractuele relatie (in casu: het stamrecht) aan de aspirant-koper meldt, waarna het initiatief komt te liggen bij de aspirant-koper." Neemt de koper het initiatief niet over nadat die op het bestaan van bepaalde contractuele relaties is gewezen, dan zou de dwaling voor diens rekening dienen te blijven. Aldus was ook de uitkomst in de zaak rond Hoog Catharijne. In die zaak was de beslissing van het hof in stand gelaten, dat de reikwijdte van de mededelingsplicht van de verkoper mede wordt bepaald door hetgeen deze aan onderzoeksinspanningen aan de zijde van de koper mocht verwachten. De uitspraak van het hof in de zaak Vletter-Stijnman was in lijn met de "verkeersopvatting" welke kon worden gelezen in de uitspraak van de Hoge Raad in de Hoog Catharijne zaak. Niet vreemd dat het hof de oren daar naar heeft laten hangen. In het algemeen zal - naar mijn mening afhankelijk van de soort zaak (omvang, complexiteit en dergelijke) en de hoedanigheid van de betrokkenen (deskundigheid, ervaring, onderlinge relatie en dergelijke) - het volstaan dat een verkoper melding maakt van het bestaan van rele- 
vante omstandigheden en documenten, waarna het initiatief bij de andere partij komt te liggen. Laat die dan na nadere vragen te stellen of een nader onderzoek te verrichten, dan kwalificeert dat naar mijn mening als risicoaanvaarding. Tjittes komt tot eenzelfde conclusie op grond van het arrest in de zaak van Avery. ${ }^{152}$ Belangrijk hierbij is dat er dan wel acht wordt geslagen op de kwaliteit van de ter beschikking gestelde informatie. De indicatie dat er op een bepaald punt doorgevraagd moet worden moet wel goed waarneembaar zijn. Ik vraag mij af of dit gezegd kan worden van de situatie in het geval van Hoog Catharije. De betrokkenheid van deskundige onderzoekers (was daarbij en) is in het algemeen een relevante factor - dat kan de Hoge Raad worden toegegeven - waar het gaat om de beantwoording van de vraag of een indicatie dat er nader onderzoek vereist is voldoende waarneembaar kan worden geacht. Misschien hadden de deskundigen in het geval van Hoog Catharijne inderdaad beter moeten opletten. Duidelijker vind ik de situatie in het geval van Vletter-Stijnman, waar omtrent het bestaan van de omstreden overeenkomst geen enkele twijfel kon bestaan. De weging van de gevolgen van die overeenkomst mag dan niet achterwege blijven, ook niet in het geval er (minder of) geen deskundige is ingeschakeld. Desnoods moet dan alsnog een deskundige worden geraadpleegd.

\section{Vuistrege/s?}

Wat de mededelings- en onderzoeksplicht betreft, concludeerde Vranken ${ }^{153}$ in 1989 dat de reikwijdte van het verschijnsel mededelings-, informatie- en onderzoeksplichten in het verbintenissenrecht groot was geworden. Hij vat samen dat ter zake van het leerstuk van dwaling - en overeenkomstig dat van bedrog, nu dat er sterk tegen aanleunt - naar de stand van de toen (nog op grond van het Oud BW) gevormde rechtspraak de volgende algemene regels konden worden geformuleerd:

- $\quad$ Buiten gevallen van opzet, kwade trouw of grove onzorgvuldigheid en buiten gevallen van mededelingen gedaan door derden, mag men in het algemeen afgaan op (voldoende) concrete mededelingen van de wederpartij;

- Wanneer men bij normale oplettendheid redenen heeft tot twijfel, moet men zelf een onderzoek instellen. Wanneer dat het geval is, is moeilijk in een algemene formule uit te drukken. Het hangt af van de inhoud en de vorm van de mededelingen, de betrokken partijen, de aard van de overeenkomst, enz.;

- $\quad$ Ook het antwoord op de vraag of er een mededelingsplicht geldt, hangt af van de bijzondere omstandigheden van het geval. Een algemene formule is ook ter zake hier van niet te geven.

Als vuistregel kan worden gehanteerd, dat geen mededelingen behoeven te worden verstrekt omtrent verwachtingen, schattingen en interpretaties van feiten en omstandigheden. Evenmin zal kennis die het gevolg is van een specifieke deskundigheid, behoeven te worden geëtaleerd, althans niet zodra nog enige onzekerheid blijft bestaan. Alleen vaststaande feiten en omstandigheden of ontwikkelingen zullen in beginsel moeten worden vermeld. Uitzonderingen kunnen voortvloeien uit de aard van de overeenkomst.

De vraag wanneer een mededelingsplicht (spreekplicht) bestaat kan niet in algemene termen worden beantwoord. Wel kunnen voor de aanwezigheid van een mededelingsplicht vier basisvoorwaarden worden geformuleerd, waaraan in ieder geval voldaan zal moeten zijn:

1. de wederpartij kent de juiste stand van zaken, althans mag geacht worden die te kennen;

2. de wederpartij weet of moet weten dat het bewuste punt voor de ander van gewicht is (kenbaarheid van het causale karakter van dat punt);

3. de wederpartij moet rekening houden met de mogelijkheid dat de ander dwaalt. De vraag of inderdaad een mededelingsplicht is geschonden kan pas definitief worden beantwoord, nadat ook een laatste vereiste in de beschouwingen is betrokken;

4. de wederpartij behoort in de gegeven omstandigheden naar verkeersopvattingen de ander uit droom te helpen. ${ }^{154}$

Algemeen wordt aangenomen dat ten aanzien van bedrog soortgelijke conclusies kunnen worden getrokken. Dat dit ook geldt met betrekking tot het leerstuk van de conformiteit, is minder algemeen aanvaard. Bongard en Van Wechem zijn het niet eens dat de voor dwaling geldende rechtsregels ook in

\footnotetext{
${ }^{152}$ R.P.J.L. Tjittes, Naar een bijzonder contractenrecht voor ondernemers in Onderneming en 5 jaar nieuw burgerlijk recht, Serie Onderneming en Recht, deel 7, p. 384.

153 J.B.M. Vranken, Mededelings- informatie- en onderzoeksplichten in het verbintenissenrecht, p.10 e.v.

${ }^{154}$ Nummer 233.
} 
het kader van conformiteit bruikbaar zijn. ${ }^{155}$ Volgens hen beïnvloedt het feit dat een verkoper geen mededelingen doet niet de vraag of een afgeleverde zaak al dan niet aan de overeenkomst beantwoordt. Daarvoor zou slechts van belang zijn of de zaak de eigenschappen heeft die de koper op grond van de overeenkomst mocht verwachten. Een verplichting voor de verkoper tot het doen van mededelingen kan volgens hen uit artikel 7:17 dus niet worden afgeleid. ${ }^{156}$

Andere vuistregels, die Hijma - meer in het bijzonder gerelateerd aan een koopovereenkomst - samenvat als te ontlenen aan de stand van de rechtspraak en literatuur eind 2000 zijn:

- $\quad$ Een mededelingsplicht zal ruimer zijn naarmate de partijverhouding van een meer vertrouwelijke aard is en/of meer afhangt van persoonlijke factoren, en evenzo ruimer jegens een vaste relatie dan tegenover iemand met wie men voor het eerst handelt;

- $\quad$ Een mededelingsplicht zal ruimer zijn - en dit is met name voor ons onderwerp relevant naarmate het object van de transactie gecompliceerder is of aan gecompliceerde voorschriften of beperkingen is onderworpen;

- $\quad$ Ter zake van bij toeval verkregen informatie zal eerder een mededelingsplicht bestaan dan ten aanzien van kennis die men door min of meer kostbaar onderzoek heeft vergaard;

- Een verkoper zal eerder mededeling moeten doen van abnormale of bijzondere eigenschappen dan van normale of algemene hoedanigheden van de zaak;

- Het gegeven dat de bewuste factor in de sfeer van betrokkene zelf (bijvoorbeeld een overheidslichaam) ligt, wijst in de richting van een mededelingsplicht;

Bij onroerende zaken zal eerder een mededelingsplicht bestaan ten aanzien van materiële gebreken en privaatrechtelijke beperkingen dan ten aanzien van beperkingen van publiekrechtelijke origine;

- $\quad$ Indien de veiligheid van een ander in het geding is, zal de mededelingsplicht ruimer zijn;

- $\quad$ Een in principe aanwezige mededelingsplicht kan worden ingeperkt door het gegeven dat jegens een derde een zwijgplicht bestaat.

Wolters noemde in 1999 een aantal op de overname praktijk georiënteerde vuistregels die volgens hem konden worden ontleend aan de rechtspraak tot dan toe: ${ }^{157}$

- Een contractspartij dient rekening te houden met de gerechtvaardigde belangen van zijn wederpartij; ${ }^{158}$

- $\quad$ De koper heeft een onderzoeksplicht. Hij dient binnen redelijke grenzen maatregelen te nemen om te voorkomen dat hij contracteert onder invloed van een onjuiste voorstelling van zaken. ${ }^{159}$ Wanneer de dwalende een deskundige of een ondernemer is, rust op deze eerder en een verdergaande onderzoeksplicht dan op een leek of een particulier. Indien een ondernemer zich bij het aangaan van een overeenkomst laat bijstaan door een deskundige, zal in de regel op hem een onderzoeksplicht rusten. Met andere woorden: het inschakelen van een due diligence team leidt tot een verzwaarde onderzoeksplicht van de koper;

- Voor ondernemers geldt dat, wanneer een deskundige faalt, dit voor risico komt van de professionele dwalende die hem inschakelde. ${ }^{160}$ Deze regel gaat niet op wanneer de dwalende een particulier is;

- De verkoper heeft onder omstandigheden een mededelingsplicht. ${ }^{161}$ Of dit het geval is, hangt in belangrijke mate af van de wederzijdse professionaliteit en deskundigheid. Compétence oblige. ${ }^{162}$ Tussen deskundige ondernemers staat voorop dat ieder in beginsel zijn eigen belang nastreeft. In de regel bestaat er geen mededelingsplicht ten opzichte van een dwalende ondernemer met

\footnotetext{
155 Zie M.P. Bongard en T.H.M. van Wechem, Mededelingen van de verkoper en het leerstuk van de conformiteit, NTBR 1995/5, p. 115. Op de leerstukken van dwaling, bedrog en conformiteit, wordt in het volgende hoofdstuk nader ingegaan.

156 Zie ook Asser-Hijma, 5-I, nr. 547.

157 M. Wolters, De due-diligence paradox, Contracteren 1999/1, p. 6.

${ }^{158}$ HR 15 november 1957, NJ 1958, 67 m.nt. LEHR (Baris / Riezenkamp).

${ }^{159}$ HR 15 november 1957, NJ 1985, 67 m.nt. LEHR (Baris / Riezenkamp).

${ }^{160}$ HR 11 april 1986, NJ 1986, 570 (Kelly / Rietvelt); zie ook R.P.J.L. Tjittes, De hoedanigheid van contractspartijen, p. 56.

${ }_{161}$ HR 19 juni 1959, NJ 1960, 59 (Kantharos van Stevensweert).

162 HR 1 juni 1990, NJ 1991, 759 m.nt. CJHB (Van Lanschot/ Binck) en J.H. Nieuwenhuis, Een gevaar op de weg, AA 1986, p. 315-321.
} 
een vergelijkbare deskundigheid. Naarmate de dwalende deskundige is, wordt de mededelingsplicht voor de ander minder; ${ }^{163}$

- $\quad$ De koper mag in de regel afgaan op de juistheid van de mededelingen van de verkoper. ${ }^{164}$ Tussen deskundigen en professionele ondernemers geldt echter dat men niet klakkeloos op de mededelingen van de andere partij mag afgaan. Naarmate de dwalende partij deskundige is, weegt zijn eigen onderzoeksplicht zwaarder. ${ }^{165}$ Wanneer de verkoper een deskundige ondernemer is, terwijl de koper een ondernemer is die geen deskundigheid heeft ten aanzien van het onderwerp van de overeenkomst, mag de koper in beginsel op de mededelingen van de verkoper afgaan; ${ }^{166}$

- De mededelingsplicht van de verkoper weegt in beginsel zwaarder dan de onderzoeksplicht van de koper, ${ }^{167}$ ook van de onvoorzichtige koper. ${ }^{168}$ Voor deskundige ondernemers geldt dat men niet klakkeloos op mededelingen van een andere partij mag afgaan;

- De omvang van de mededelingsplicht van de verkoper wordt mede bepaald door hetgeen aan onderzoek van de koper mag worden verwacht. ${ }^{169}$ Tussen ondernemers geldt dat, naarmate de deskundigheid van de koper (en zijn adviseurs) groter is, zijn onderzoeksplicht de mededelingsplicht van de verkoper absorbeert. Na een periode waarin de mededelingsplicht steeds meer werd opgerekt, kan het Hoog Catharijne arrest worden gezien als een trendbreuk. ${ }^{170}$

Hierna zal ik voortbouwend en acht slaande op de hier voor genoemde vuistregels op een aantal punten proberen de lus nog wat strakker te trekken om het onderwerp van due diligence.

\subsection{Enkele eerste gevolgtrekkingen}

\section{Algemeen}

In het arrest Baris/Riezenkamp wordt de regel geformuleerd, dat - door in onderhandeling te treden over het sluiten van een overeenkomst - partijen tot elkaar komen te staan in een door de redelijkheid en billijkheid beheerste relatie. Die regel brengt volgens de Hoge Raad mee dat er tegenover de wederpartij - het maakt daarbij niet uit aan welke zijde van de transactie die zich bevindt - een gehoudenheid bestaat om binnen redelijke grenzen maatregelen te nemen om te voorkomen dat deze onder invloed van een onjuiste veronderstelling toestemming wordt gegeven. Deze laatst bedoelde regel is herhaald in het arrest Booy/Wisman. Waartoe de desbetreffende gehoudenheid kan leiden, wordt onder meer in het arrest Van der Beek/Van Dartel duidelijk. Er moet aan een mededelingsplicht worden voldaan, wanneer - naar men weet of behoort te weten - de wederpartij op grond van een onjuiste veronderstelling tot het aangaan van de transactie dreigt over te gaan. Dat het in het arrest Van der Beek/Van Dartel daarbij om het niet toelaten van een verweer ging, doet niet af aan de constatering van de Hoge Raad dat het had gepast om bepaalde inlichtingen te geven. In het arrest van 10 april 1998 (Offringa/Vinck) zien wij een voorbeeld van een situatie, waarin spreken op zijn plaats was. Wanneer moet er gesproken worden, wanneer mag men zwijgen? Daarbij speelt mee of men iets verzwijgt, dat bekend is, danwel zwijgt bij gebreke van eigen wetenschap (Bloemendaalse olietank). "Schuldig verzwijgen" is niet toegestaan. ${ }^{171}$ Geen mededelingsplicht wordt aangenomen, wanneer de gegevens waar het om gaat naar verkeersopvattingen van algemene bekendheid kunnen worden verondersteld.

Dat een partij (alleen) 'in redelijkheid' (binnen redelijke grenzen) een zorgplicht heeft om te voorkomen dat de ander onder invloed van een onjuiste veronderstelling een transactie aangaat, maakt het er allemaal niet eenvoudiger op, of misschien juist wel. Is in de overweging van de Hoge Raad in het arrest

\footnotetext{
${ }^{163}$ HR 15 mei 1981, NJ 1981, 641 m.nt. CJHB (Joba / Gerber).

${ }^{164}$ HR 15 november 1957, NJ 1958, 67 m.nt. LEHR (Baris / Riezenkamp).

${ }_{165}^{16}$ HR 13 maart 1981, NJ 1981, 442 m.nt. CJHB (Hilders / De Galan); HR 6 januari 1989, NJ 1989,281 (De Vor / Amro).

${ }^{166}$ HR 21 januari 1966, NJ 1966, 183 m.nt. GJS (Booy / Wisman).

167 HR 30 november 1973, NJ 1974, 97 m.nt. GJS (Van der Beek / Van Dartel); HR 21 november 1990, NJ 1991, 251 (Van Geest / Nederlof).

${ }^{168}$ HR 10 april 1998, RvdW 1998, 84 (Antilliaans zwembad).

169 HR 22 december 1995, NJ 1996, 300 (Hoog Catharijne); HR 10 april 1998, RvdW 1998, 84 (Antilliaans zwembad).

${ }^{170}$ Wolters verwijst hierbij naar P. Klik, De verhouding tussen spreek-en onderzoeksplicht, , NTBR 1998/8, p. 297.

${ }^{171}$ Zie E. Cohen Henriquez, Spreken is zilver, zwijgen is fout, NJB 8 mei 1976, p. 625 e.v.
} 
Baris/Riezenkamp niet een instructie gegeven aan beide partijen bij een transactie om te voorkomen dat er - nu parafraseer ik - moet worden vermeden dat er op grond van verkeerde veronderstelling wordt gecontracteerd? Valt daaronder naar redelijkheid en billijkheid niet ook een verplichting tot het doen van behoorlijk onderzoek te begrijpen. De traditionele gedachte dat een koper die nalaat om onderzoek te verrichten daarmee alleen zich zelf heeft, gaat immers alleen maar op wanneer het zwart wit situaties betreft. Wie helemaal geen onderzoek verricht, heeft achteraf weinig te klagen. Wie onvoldoende onderzoek verricht, kan ook een probleem krijgen, maar dan gelden toch voorwaarden die vervuld moeten zijn, wil die sanctie intreden (vergelijk het Hoog Catharijne-arrest). Er moeten dan aanwijzingen zijn genegeerd, hetgeen de koper aan te rekenen moet zijn (dit zal gebeuren afhankelijk van de vraag of er deskundige onderzoekers zijn en konden worden aangezocht, afhankelijk van hetgeen de verkoper aan informatie heeft verschaft en afhankelijk ook van het soort van aanwijzingen dat over het hoofd gezien werd). Wanneer er een beperkt onderzoek is geweest in combinatie met gegeven garanties is de zaak ook genuanceerder.

In de periode van 1958 tot en met het jaar 2000 heeft zich in de jurisprudentie een ontwikkeling voorgedaan, waarin niet alleen het leerstuk van dwaling (zowel zoals voor 1992 geregeld in artikel 1358 BW (oud) als daarna in artikel 6:228) tot ontwikkeling is gekomen, maar ook het leerstuk van due diligence in ons recht meer handen en voeten heeft gekregen. De betekenis van de in de hier voor besproken periode gevormde rechtspraak was niet alleen dat daarin beantwoording plaatsvond van een aantal van de vragen rond mededelings- en onderzoeksplichten, maar met name ook dat het voor de due diligence praktijk meer duidelijkheid opleverde. Er is in de desbetreffende periode jurisprudentie gevormd die rechtstreeks betrekking heeft op koop en verkoop van aandelen en ondernemingen, hetgeen toch iets anders is dan de koop en verkoop van tweede hands auto's, huizen, geiten of andere enkelvoudige goederen. Het betreft transacties die zich niet altijd gemakkelijk laten terugdraaien. Toepassing van artikel 6:230 zal niet altijd soelaas bieden. Kenmerk is dat er in het algemeen bij transacties betreffende aandelen of ondernemingen sprake zal zijn van partijen met een zeker zakelijk inzicht, of in ieder geval een aanwezig te veronderstellen zakelijke insteek. Dat betekent niet altijd dat het professionele of deskundige partijen betreft. Er zal anderzijds moeten worden opgepast voor sjablonen. Tjittes hanteert een naar mijn smaak te grof raster, wanneer hij suggereert, dat (alle) ondernemers zogenaamde "repeat-players" zijn. ${ }^{172}$ Er bestaat een scala van mogelijkheden waar het er om gaat om kopers en verkopers te typeren. Van uiterst bekwame, ervaren en deskundige partijen die als hun hoofdactiviteit het kopen en verkopen van ondernemingen hebben, al dan niet middels aandelentransacties tot kleine ondernemers die een maal in hun leven met een koop of verkooptransactie van doen krijgen. Wat al die partijen evenwel gemeenschappelijk hebben, is dat het voorwerp van koop bij de koop en verkoop van een onderneming al dan niet middels de overdracht van aandelen betrekking heeft op moeilijk op de voorhand voldoende te wegen abstracties en risico's - hetgeen zich vanzelfsprekend overigens ook bij andere voorwerpen van koop kan voordoen - waar nochtans een grote mate van voorzichtigheid bij geboden is. Dat brengt naar de aard van de transactie mee, zo is mijn opvatting, dat - tenzij er aantoonbare en betrouwbare zekerheid is, dat het allemaal in orde is - er een serieus te nemen onderzoek moet zijn gedaan naar de in het eerste hoofdstuk van dit boek genoemde gebruikelijk te onderzoeken aspecten. Oostwouder ${ }^{173}$ stelde dit eerder: "De overname van een onderneming is dermate complex dat daarbij vrijwel altijd zowel een mededelingsplicht van de verkoper bestaat als een onderzoeksplicht van de koper." Als de middelen ontbreken om daarbij deskundigen in de arm te nemen, bijvoorbeeld omdat de omvang van het met de transactie gemoeide belang dat niet rechtvaardigt, dan moet in ieder geval de koper zelf een onderzoek in stellen. Op internet en anderszins zijn vragenlijsten te vinden die kunnen worden gebruikt om te zorgen dat er daarbij geen dingen over het hoofd worden gezien. Ook hierbij geldt mutatis mutandis het adagium dat het maken van de overeenkomst belangrijker kan zijn dan het hebben er van. Wanneer niet op alle gestelde vragen een genoegzaam antwoord volgt, geldt voor een koper de parabel van de Chinese boer, die een brug over een ravijn wilde betreden waarbij een bord was geplaatst, dat die brug maar één persoon tegelijk kon dragen. Toen de boer halverwege was stortte de brug in en belandde de boer op de bodem van de ravijn waar een tweede bord hem er aan herinnerde dat een gewaarschuwd mens voor twee geldt. Tjittes heeft de vraag opgeworpen of wij niet toe moeten naar een bijzonder overeenkomstenrecht voor ondernemers. $^{174}$ Met de vraag of er al dan niet terecht risico's zijn geaccepteerd kan dan meer

\footnotetext{
172 R.P.J.L. Tjittes, Naar een bijzonder contractenrecht voor ondernemers in Onderneming en 5 jaar nieuw burgerlijk recht, Serie Onderneming en Recht, deel 7, p. 375 e.v.

${ }_{173}$ W.J. Oostwouder, Management Buy-out, Groningse serie, deel 27, p. 64.

174 A.w.
} 
bijzonderlijk rekening worden gehouden. Hij zegt: "Ondernemen is het inschatten van risico's. Doe je dat goed, dan word je rijk. Doe je dat minder goed of verkeerd, dan wordt je minder rijk of ga je failliet. Om die risico-inschatting zo goed mogelijk te kunnen maken, hebben ondernemers behoefte aan duidelijke en harde regels. Regels van contractenrecht zijn regels van risico-verdeling. Zij bepalen wie van de partijen het risico moet dragen van de verstoring van de normale gang van zaken, en daardoor van het niet uitkomen van daarop gebaseerde verwachtingen. Mede op basis van die risico-regels beslist een ondernemer om al dan niet een transactie aan te gaan, en zo ja, op welke voorwaarden (waaronder de prijs) alsmede voor welke risico's hij zich desgewenst wil verzekeren. Voor het kunnen inschatten van risico's is het wenselijk dat de rechtsregels dienaangaande duidelijk en zeker zijn." Voorlopig moeten wij het doen met de gevolgtrekkingen welke kunnen worden ontleend aan in hoofdzaak onder het gemene verbintenissenrecht gevormde wetsuitleg en jurisprudentie. Ik voeg daar aan toe, dat de uitspraak van de Hoge raad in zake Hoog Catharijne wat dat betreft wel effect heeft gesorteerd. De rechtspraktijk ontving een heldere waarschuwing, dat goed kijken en doorvragen absoluut vereist is wanneer er een due diligence onderzoek wordt uitgevoerd. Door meer aandacht van rechters en in de literatuur voor het bijzondere vraagstuk van (het wel of niet genoegzaam voldoen aan) een onderzoeksplicht - want daar komt het bij het vraagstuk van een due diligence onderzoek meer nog dan op een mededelingsplicht op aan - kan worden bijgedragen aan de vorming van in elk geval in materieel opzicht overeenkomstenrecht voor ondernemers. Wanneer een koper - en dit laat de eigen verantwoordelijkheid en de eigen verplichtingen van een verkoper onverlet - nalaat om bij een transactie als waarover dit boek handelt een naar diens vermogen optimaal onderzoek uit te doen voeren of zelf uit te voeren, dan treedt daarmee aan zijn kant van het spectrum in de rechtsverhouding een component van risicoaanvaarding binnen. Zoals ik hiervoor aangaf, ben ik het niet met Tjittes eens dat alle ondernemers over één kam geschoren kunnen worden als repeat players. Er zal nadrukkelijk moeten worden gekeken naar de hoedanigheid van partijen. Dit geldt zowel aan de zijde van de koper als aan de zijde van de verkoper. Zoals in de rechtspraak naar aanleiding van Haviltex ook tot uitdrukking komt, dient de hoedanigheid van partijen nadrukkelijk te worden meegewogen. Hoe de component van risicoaanvaarding te wegen, zal derhalve toch weer worden bepaald door alle omstandigheden van het geval. Dat die zullen (moeten) worden meegewogen, lijdt voor mij geen twijfel. Daarbij spelen ook de na te noemen factoren dan weer een rol. Het trekken van grenzen is moeilijk. Ook wanneer een koper nalaat om voldoende onderzoek te doen, levert dit de verkoper immers geen vrijbrief op om te zwijgen waar spreken geboden is. It takes two to tango voor een rechtshandeling die de tand van de door artikel 7:23 en 6:228 toebemeten tijd kan doorstaan.

\section{De omstandigheden van het geval}

Zoals ik heb betoogd, dienen de aan de jurisprudentie te ontlenen regels te worden uitgelegd naar de gebruiken en normen in de markten die zij betroffen. Dat zijn in het geval van een due diligence, zoals die het voorwerp van dit boek vormt de kapitaalmarkt, de onderhandse financiële markten en de markt van fusies, overnames en joint ventures. Ik vat die markten hierna verder samen onder het begrip financiële markten - tenzij ik een onderscheid benoem - en betrek in dat begrip dus zowel kapitaalmarkt- als onderhandse transacties, waaronder dus bijvoorbeeld ook arrangementen ter corporate finance, tot onderhandse verschaffing van private equity en het syndiceren van leningen. Daarbij blijft gelden, dat waar ik over "koper" spreek, het evengoed een andersoortige transactie dan koop en verkoop kan betreffen. Onder dat begrip moet dan tevens de partij worden begrepen die zich aan de kant van de transactie bevindt van degene die de financiële middelen ter beschikking stelt om een transactie tot stand te brengen (investeerder, aandeelhouder of anders).

Ik ontleen aan de hier voor genoemde uitspraken de overtuiging dat er vooreerst moet worden gekeken naar de omvang van de transactie. Waarom zou - even los gezien van motiveringsgebreken - de uitkomst in bijvoorbeeld het geval Vletter-Stijnman kunnen zijn dat de koper er mee zou mogen volstaan te vertrouwen op mededelingen van de verkoper (zelf niet de akte hoefde te raadplegen en naar aanleiding daarvan geen nader onderzoek hoefde te doen) en in het geval van Hoog Catharijne ABP c.s. wel naar aanleiding van verschafte documenten verdergaand onderzoek zou moeten doen?

Ook in andersoortige transacties dan consumentkoop geldt, dat de 'overzienbaarheid' van betekenis is. Wanneer het voorwerp van de transactie overzienbaar en relatief gemakkelijk te beoordelen is, is er minder verantwoordelijkheid bij de verkoper te leggen, zo zou ik menen. Omgekeerd geldt, dat naar- 
mate het voorwerp van de transactie minder makkelijk te overzien en te doorzien valt, er meer verantwoordelijkheid toekomt aan de verkoper (of aanbieder van producten, vergelijk de ontwikkelingen rond de zorgplicht bij de verkoop van financiële producten en bij transacties op de kapitaalmarkt). Er mogen dan meer inspanningen worden verlangd om een en ander toegankelijk en inzichtelijk te maken.

Een gewaarschuwde partij zal eerder worden geacht een risico te hebben aanvaard dan een partij die ondanks gedegen onderzoek vooraf geen aanwijzingen heeft kunnen vinden, dat er zaken niet in orde waren.

\section{Enige vorm van onderzoek vereist}

Zoals ik hier voor al aangaf, is een gevolgtrekking die aan de gevormde jurisprudentie - voor zover die hier voor aan de orde kwam - te ontlenen valt dat als uitgangspunt heeft te gelden, dat er in beginsel een due diligence onderzoek zal dienen te worden uitgevoerd wanneer in de financiële markten een transactie wordt overwogen. Er dient - zij het binnen redelijke grenzen - voor te worden gewaakt dat men op grond van een onjuiste veronderstelling zijn toestemming verleent. De uitzonderingen op het beginsel dat een onderzoek vereist wordt, moeten passen binnen de marge van de 'redelijke grenzen'. Daarbij is te denken aan een transactie waarmee relatief (afgemeten naar de draagkracht van de partij die een risico loopt bij een transactie) een gering bedrag gemoeid is of aan een situatie waarin de betrokken partij niet over de middelen beschikt om een onderzoek uit te (doen) voeren bijvoorbeeld. De laatst bedoelde omstandigheid zal echter niet snel als een verontschuldiging worden aanvaard. Een (zelf uitgevoerd) beperkt onderzoek zal vrijwel altijd mogelijk zijn. Wel is het denkbaar dat een partij zich financieel niet kan veroorloven om de vereiste deskundigheid te engageren, om de inhoud van een dataroom naar waarde te kunnen schatten. In beide hier voor laatst bedoelde gevallen, blijft er sprake van een risico inschatting en - in vrijwel al die gevallen, zo zou ik menen - sprake van vragen van risico-aanvaarding. Men is in het normale geval immers altijd vrij om van een transactie af te zien, ook al betekent dat verlies van kosten of het missen van kansen in de markt. Van Mohammed Ali is de fraaie spreuk: "if you want to realise your dreams, wake up." Wanneer met het oog op het realiseren van groei scenario's of door andere ambities ingegeven een transactie toch wordt doorgezet, zonder dat er voldoende due diligence heeft plaatsgevonden, betreft dat op zich zelf een afweging van kansen en risico's. Alles heeft een prijs. Het zal dan alleen niet steeds mogelijk zijn om het prijskaartje dat hangt aan de met een transactie verbonden risico's bij de verkoper neer te leggen wanneer er lijken in de kast worden aangetroffen.

Waar men in beginsel mag afgaan op gedane mededelingen zal dit voor particulieren in gevallen, waarin een prospectus voorhanden is, kunnen rechtvaardigen, dat die geen (ander) due diligence onderzoek doen, dan het kennis nemen van de beschikbare documentatie, het "zorgvuldig lezen van de financiële bijsluiter". 175

Een andere uitzondering op de verplichting om een due diligence onderzoek in te (doen) stellen, kan bestaan in een oprecht (vermeend) voldoende inzicht in het voorwerp van de transactie. Het veroorzaken van de kosten welke met een onderzoek in de regel zijn gemoeid, is dan niet nodig. De kostenafweging kan ook in andere omstandigheden aanleiding zijn om van een onderzoek af te zien en op het eigen oordeel te vertrouwen. Ik meen dat er dan wel een kenbare grond moet zijn om te rechtvaardigen dat er verlaten wordt op het eigen oordeel. Voor de hand liggende voorbeelden van situaties als laatst bedoeld zijn zogenaamde buy out transacties. Dit zijn transacties waar - al dan niet met financiële steun van de verkoper of externe financiers en al dan niet door middel van een koop van aandelen - leidinggevenden (een deel van) de onderneming kopen van hun werkgever. ${ }^{176}$

Betekent het vorenstaande nu dat er te onzent een verplichting moet worden aangenomen om een due diligence onderzoek in te stellen? Mos (noem het een verkeersopvatting) is volgens mij om wel een

\footnotetext{
175 Zie o.m. M.A. Blom, Prospectusaansprakelijkheid van de lead manager, Nijmeegse Serie, deel 53; A.F.J.A. Leijten, V\&O 1996, p. 114; H.F.C. Schoordijk, Prospectusaansprakelijkheid, een garantieverplichting?, in Onderneming en 5 jaar nieuw burgerlijk recht, Serie Recht en Onderneming, deel 7, p. 329 e.v.; G.T.J. Hoff, De lessen van het Co op-arrest, zelfde bundel, p. 347 e.v.

176 Zie W.J. Oostwouder, Management Buy-out, Groningse Serie, deel 27, p. 33, die overigens van mening is dat ook in het geval van een management buy out een due diligence onderzoek van belang blijt: "In de eerste plaats omdat financiers ook graag een onafhankelijk oordeel willen hebben over de achtergronden en perspectieven van de betrokken onderneming maar ook omdat het goed is voor het management om bepaalde gegevens door externe deskundigen te laten verifiëren. Terwijl ook gegevens essentieel kunnen zijn waarover het management niet beschikt zoals (fiscale) claims die voortkomen uit de holding of de periode voordat het management benoemd was." Niettemin is het denkbaar dat het zittende management de dingen voldoende overziet om zonder due diligence onderzoek tot een transactie over te gaan. Bovendien komen niet bij iedere management buy out externe fiananciers te pas.
} 
onderzoek in te (doen) stellen, in welke vorm dan ook, alvorens een transactie van enige importantie wordt aangegaan. Zoals ik al heb opgemerkt, dient de importantie te worden gerelateerd aan de positie van degene die middelen investeert. Afgezien van uitzonderingen als hier voor vermeld, meen ik dat er te onzent inderdaad van moet worden uitgegaan, dat enige vorm van eigen onderzoek verlangd wordt. Voor het achterwege laten van een due diligence onderzoek, moeten als gezegd gerechtvaardigde redenen aanwezig zijn, gerelateerd aan de omvang van de transactie en de positie van de betrokken investeerder(s). De betekenis van de in hoofdstuk 2 genoemde verschillende soorten van onderzoek, van heel beperkt tot uiterst uitgebreid, blijkt hier. Waar "enige vorm van onderzoek" vereist is, kan er sprake zijn van een op de aard van de transactie, de draagkracht van de betrokken partij en andere omstandigheden afgestemde voorzichtigheid, die in ieder geval de betrokkene tegemoet zal doen komen aan het vereiste dat deze een eigen verantwoordelijkheid heeft om te voorkomen dat deze op grond van een onjuiste veronderstelling instemt. De wijze van rapporteren kan zelfs mondeling zijn. ${ }^{177}$

Wat nu, als (enige vorm van) onderzoek toch achterwege gelaten wordt? Ik denk dat Hijma dan gelijk heeft, die concludeert, dat de onderzoeksplicht - evenals als de mededelingsplicht - geen afdwingbaar wettelijk voorschrift betreft. ${ }^{178} \mathrm{Om}$ die reden wordt wel van een Obliegenheit gesproken. Het gaat om een eigen verantwoordelijkheid. Het niet nemen van die verantwoordelijkheid brengt mee dat de eigen positie wordt ondergraven. Een spijtoptant kan dan niet achteraf klagen onvoldoende kennis te hebben gehad en een vordering bijvoorbeeld op grond van dwaling, kan om die reden stranden (onverschoonbare dwaling). Het gaat er niet om wat iemand had kunnen ontdekken, maar om wat hij, mede in het licht van het handelen (spreken) en nalaten (zwijgen) van zijn wederpartij had behoren te ontdekken. Wat dat betreft, heeft Tjittes ook gelijk met de constatering, dat als er iets onduidelijk is er nu eenmaal navraag gedaan moet worden. ${ }^{179}$

Evident is, dat de wederpartij van degene die bij het aangaan van een transactie (volledig) heeft afgezien van het verrichten van een onderzoek, binnen het kader van een risicoverdeling niet zal nalaten te wijzen op de risicoaanvaarding welke de ander door diens beslissing op zich genomen heeft. Dat dit onder omstandigheden een mededelingsverplichting niet opheft, leerde het arrest Vletter-Nijman.

Soms wordt men niet in de gelegenheid gesteld om een due diligence onderzoek in te stellen. Toevlucht zal dan moeten worden genomen tot het bedingen van garantie, verrekeningsmechanismen en dergelijke, of afzien van de transactie. Wanneer er geen kijk in de keuken genomen kan worden, is het alternatief dat er gedetailleerde vragen worden gesteld. Aan de omvang en kwaliteit van de alsdan te verkrijgen informatie moeten hoge eisen worden gesteld. Degene die heeft geweigerd om een due diligence onderzoek toe te staan, neemt daarmee ook een verantwoordelijkheid op zich om er voor in te staan dat de wel verschafte informatie deugdelijk is. Het kan voorkomen dat een verkoper kan worden geacht toch voldoende aan de informatieplicht te hebben voldaan, ondanks het feit dat geen due diligence onderzoek werd toegelaten. ${ }^{180}$ Nodeloos te zeggen dat in een geval waarin onvoldoende eigen waarneming mogelijk is geweest, niet alleen garanties, maar ook zekerheden voor de nakoming van die garanties proportioneel in belang toenemen. Ik herhaal, dat er in het normale geval altijd de mogelijkheid is om een transactie geen doorgang te laten vinden.

\section{Spanningsveld tussen onderzoeks- en mededelingsplicht}

Waar er in beginsel mag worden afgegaan op mededelingen van de wederpartij, kan een (verdergaand) onderzoek (ook) achterwege blijven, wanneer er een prospectus, bid book of dataroom content voorhanden is, waarvan mag worden aangenomen, dat die een volledig beeld geeft van de transactie of de doelwitvennootschap en haar onderneming. Het Hoog Catharijne-arrest heeft als gezegd geleerd, dat de overtuiging dat een volledig beeld verkregen is, niet te snel mag ontstaan. Beter sluitende garanties dan in het geval van de transactie betreffende Hoog Catharijne moeten dan voor de benodigde aanvulling zorgen.

\footnotetext{
${ }^{177}$ Ik citeer H. Beckman: "Er is geen regel die dwingt tot schriftelijke rapportage, waarom zou het ook. Vervelend is daarom dat achteraf wel eens blijkt dat rechters, arbiters, door rechters benoemde deskundigen, enz. een mondelinge rapportage maar gek vinden. Het komt zelfs voor dat dan geoordeeld wordt dat geen due diligence is ingesteld. Onzin natuurlijk!" in Due diligence en de overname (Ondernemingsrecht 1999-16, p. 435).

${ }_{178}^{178}$ Asser-Hijma 5-I, nr. 242.

179 R.P.J.L. Tjittes, Naar een bijzonder contractenrecht voor ondernemers in Onderneming en 5 jaar nieuw burgerlijk recht, Serie Onderneming en Recht, deel 7, p. 375 e.v.

180 Zie gerechtshof Amsterdam 16 april 1998, NJ 1999, 161
} 
Zo goed als het verstandig is om voorafgaand aan het aangaan van een transactie de eigen doelstelling daarbij duidelijk te formuleren, is het goed om voorafgaand aan een due diligence onderzoek voor zich zelf duidelijk te inventariseren welke (soort van) informatie men belangrijk vindt om te leren kennen en te verifiëren, en hierover met het bestuur van de doelwitvennootschap te communiceren. Een goed uitgevoerde due diligence vergt een goed uitgewerkt 'due diligence plan".

Het stellen van duidelijke vragen, geeft mede invulling aan de bepaling van de omvang van de mededelingsplicht van de wederpartij.

Een reden om af te zien van een onderzoek zou daarom kunnen zijn dat er adequate garanties worden verstrekt. Is er sprake van minder garanties dan kan ook worden volstaan met een onderzoek dat zich beperkt tot die terreinen ter zake waarvan geen garanties worden gegeven. De kwestie rond Hoog Catharijne leerde dat er wel voor moet worden gezorgd, dat er geen misverstanden kunnen bestaan over wat wel en wat niet onder - in dat geval - balansgaranties wordt begrepen. In die zaak ging het om zogenaamde off balance sheet verplichtingen. ${ }^{181}$ Bedacht dient bovendien steeds te worden dat een garantie zo goed is "als de portemonnee" van degene die de garantie afgeeft. Er kunnen omstandigheden zijn, waaronder niet kan worden volstaan met te vertrouwen op hetgeen verklaard of zelfs gegarandeerd lijkt te zijn, zoals het Hoog Catharijne arrest leerde. Hetgeen wel wordt meegedeeld dient te worden gewogen en naar aanleiding daarvan kan het nodig zijn nader onderzoek in te stellen.

De vraag die in de Hoog Catharijne zaak vervolgens rees, was of voldaan was aan de garantie van de verkoper dat hij verklaarde ervoor in te staan, dat 'alle relevante informatie' was verschaft. Het desbetreffende arrest leerde verder dat ook de uitleg van op zich zelf wel duidelijk lijkende garanties of verklaringen door de rechter nog voor verrassingen kan zorgen. "Meten is weten" en "beter mee verlegen dan om verlegen", zijn raadgevingen, die van veel volkswijsheid getuigen.

Afspraken zijn mogelijk over de reikwijdte van de onderzoeksplicht, zoals die tussen partijen zal gelden. Zo kan worden overeen gekomen, dat de onderzoeksplicht niet verder reikt dan het bestuderen van de documentatie die is verschaft naar aanleiding van een overgelegde vragenlijst. Dat een dergelijke afspraak "flankerend beleid" vergt, zal duidelijk zijn. Bedongen zal dienen te worden dat de wederpartij alle overige informatie, waarvan die weet of behoort te veronderstellen dat die voor de ander relevant is, desondanks zal hebben te verschaffen. Ook zal afgesproken moeten worden, dat door de inrichting van de afspraken over de reikwijdte van het onderzoek, er achteraf geen verwijt door de wederpartij gemaakt zal worden over de (te beperkte) omvang van het onderzoek. Evenzo goed wordt er in overname overeenkomsten gebruikelijk door de overnemer geprobeerd de afspraak opgenomen te krijgen dat het doen instellen van due diligence onderzoek uitsluitend geschiedt ten dienste van het verkrijgen van een goed beeld van de doelwitvennootschap en haar onderneming, maar niet mag meebrengen dat daardoor het recht om zich achteraf op een garantie te beroepen zou worden beperkt. Verderop in dit boek zal op de status en het (intellectuele) eigendom van een due diligence rapport nader worden ingegaan. Zie hoofdstuk 11.

\section{Deskundigheid betrokkenen van belang ${ }^{182}$}

Zoals Cohen Henriquez het uitdrukte, ${ }^{183}$ gaat het bij het vraagstuk van de mededelingsplicht meer in het algemeen 'over de verplichting van de ene partij bij een overeenkomst om zijn wederpartij van bepaalde omstandigheden op de hoogte te stellen om te voorkomen dat de wetende partij profiteert van de onwetendheid van de andere.' Naarmate een partij meer als deskundige (vakkundige) optreedt, heeft hij een grotere spreekplicht.

Castermans $^{184}$ neemt als uitgangspunt, dat de positie van onderhandelende partijen gelijk moet zijn. Zodra één der partijen wat kennis betreft meer in haar mars heeft dan de ander is er volgens hem reden om een mededelingsplicht aan te nemen. Hij meent echter dat dit slechts een uitgangspunt betreft.

\footnotetext{
${ }^{181}$ Ter vermijding van misverstanden als in het geval van Hoog Catharijne wordt in de praktijk naast of in de plaats van een algemene balansgarantie wel een garantie verlangd, dat er op een balansdatum een zeker vermogen zal zijn waarbij in de definitie van 'vermogen' rekening wordt gehouden met off balance sheet verplichtingen. De rechtbank Utrecht kreeg in 1997 te oordelen over de vraag of een balans, opgemaakt in het kader van een going concern jaarrekening wel dienst kon doen als overnamebalans (Rb. Utrecht 23 april 1997, JOR 1997, 92). Het verschil tussen de ene en de andere soort balans zijnde dat een balans die voor een overname bestemd is een meer volledig inzicht zou dienen te geven in de verplichtingen van de vennootschap. In dezelfde uitspraak werd overigens aangenomen dat de term "instaan" voor betekende het "risico aanvaarden voor".

182 Zie R.P.J.L. Tjittes, De hoedanigheid van contractspartijen, Kluwer 1994.

183 E. Cohen Henriquez, Spreken is zilver, zwijgen is fout, NJB 8 mei 1976, p. 625.

${ }^{184}$ A.w., p. 189 e.v.
} 
Volgens hem dient bij het bepalen van de grenzen van de mededelingsplicht en de gevolgen van schending naar een evenwicht te worden gezocht tussen enerzijds het gelijkheidsidee en anderzijds de bescherming van het eigenbelang en de eigen waardigheid. Mijn idee is, dat een evenwicht alleen evenwichtig zal zijn wanneer er sprake is van handicapverrekenig, waar het een verschil in deskundigheid betreft. Naarmate een partij meer als deskundige optreedt, wordt de spreekplicht van de andere partij minder, aldus ook Cohen Henriquez. ${ }^{185} \mathrm{Hijma}^{186}$ en hij zijn het er over eens, dat het daarbij gaat om hoe men zich aan de ander presenteert en niet om de vraag of men feitelijk gesproken deskundig is.

Hijma voegt aan die opvatting naar mijn mening terecht toe, dat de (on)deskundigheidsfactor van eminent gewicht is.

In kapitaalmarkttransacties komt tot uitdrukking dat - daar waar er een verschil in deskundigheid kan worden verondersteld - de beschermingsgedachte meebrengt, dat het accent terecht komt bij een mededelingsplicht, denk aan de zogenaamde prospectusplicht en de verplichting om bij ieder complex financieel product een financiële bijsluiter toe te voegen. Naarmate het verschil in deskundigheid minder groot wordt verondersteld, verandert dit. Ik noem maar de uitzonderingen van artikel 5:1a Wft. op het verbod van tegenwoordig artikel 5:2 van diezelfde wet. Artikel 5:3 Wft. denkt het beleggend publiek meer eigen mogelijkheden toe om zelf te (kunnen) onderzoeken of het verstandig is om tot een transactie over te gaan, wanneer het een doelgroep betreft, die aan de in artikel 5:3 lid $1 \mathrm{Wft}$. genoemde voorwaarden voldoet.

De uitspraak van de Hoge Raad in de kwestie rond Hoog Catharijne heeft geleerd dat waar het een onderzoeksplicht betreft, bij onderhandse transacties de eigen verantwoordelijkheid van de onderzoeker recht evenredig toeneemt met diens deskundigheid. Deskundigheid van de onderzoeker wordt toegerekend aan de risicosfeer van diens opdrachtgever. Zie ook hoofdstuk 15 hierna.

Onder professionals mag daarbij verder van het bestaan van bepaalde verkeersopvattingen worden uitgegaan. Die kunnen per professie verschillen.

\section{Wederkerig belang}

De koper zal uit defensieve overwegingen een due diligence onderzoek instellen om te vermijden dat een transactie per saldo verlies zal opleveren, dus om aan risico beheersing te doen en tegelijkertijd offensieve overwegingen doen gelden om het vertrouwen te verwerven dat de transactie de toevoeging aan de eigen marktpositie zal opleveren die wordt nagestreefd, dat integratie mogelijk zal zijn en de prijs passend is. Door het uitvoeren van een due diligence onderzoek dient de koper diens eigen belang. De verkoper heeft er niettemin eveneens belang bij dat er een due diligence onderzoek zal plaats vinden. De uitvoering van het onderzoek brengt mee dat de verkoper in het algemeen zal kunnen stellen aan diens mededelingsplicht te hebben voldaan, er van uitgaande dat toegang is verleend tot alle relevante informatie. Door het moeten beantwoorden van een questionnaire, door het inrichten van een dataroom en te moeten afwegen welke garanties en vrijwaringen wel of niet gegeven kunnen worden (en te moeten bedenken wat er in een disclosure letter zou moeten worden opgenomen), wordt de verkoper er toe aangezet aan een vorm van zelf onderzoek te doen, die kan meebrengen dat problemen achteraf worden voorkomen. Een verstandige verkoper zal daarom zorgen voor een zo goed mogelijke informatie voorziening. Voor zover de koper er al overspannen verwachtingen op nahield, moet die worden geacht (in staat te zijn gesteld om) te hebben kunnen nagaan hoe de actuele situatie was. De kansen op aantasting van de overeenkomst op grond van dwaling, wanprestatie, een gebrek in conformiteit, wegens bedrog of onrechtmatige gedraging - waarover meer in het volgende hoofdstuk - wordt daar door aanzienlijk verkleind. De andere kant van de medaille is dat in het merendeel van de gevallen het argument dat een koper niet aan diens onderzoeksplicht heeft voldaan, minder gemakkelijk inzetbaar zal worden in geval van een probleem achteraf. Zoals wij in hoofdstuk 11 zullen zien, levert de aanwezigheid van een due diligence rapport in handen van de koper - en afhankelijk van de gemaakte afspraken, ook in handen van de verkoper - de beschikbaarheid van documentatie op die een belangrijke rol kan vervullen wanneer er achteraf vragen rijzen omtrent de kennis waarover de koper ten tijde van het aangaan van de transactie beschikte. Voor de koper geldt weer, dat een behoorlijke inventarisatie van de beschikbaar gemaakte informatie in een due diligence rapport achteraf bij kan dragen aan de beantwoording van de vraag of de verkoper daadwerkelijk alle rele-

\footnotetext{
${ }^{185}$ A.w., p. 631.

${ }^{186}$ Asser-Hijma 5-I, nr. 236.
} 
vante informatie beschikbaar heeft gemaakt. Zo gelden over en weer overwegingen die maken dat het uitvoeren van een due diligence onderzoek zowel in het belang van de koper als van dat van de verkoper kan worden geacht. De reden daarvan is vooral, dat in het geval er sprake is van teleurgestelde verwachtingen of andere problemen na het tot stand komen van de transactie, ons recht een aantal acties kent die kunnen worden ingesteld om tot ongedaanmaking van de transactie te komen of tot het verhalen van schade. Op deze juridische context die steeds ook een belangrijke rol speelt bij beantwoording van de vraag of het aangewezen is om een due diligence onderzoek in te stellen, wordt in het nu volgende hoofdstuk ingegaan. 


\title{
5. De leerstukken welke ten grondslag liggen aan een onder- zoeksplicht en een mededelingsplicht
}

\section{$5.1 \quad$ Inleiding}

Ter introductie van dit hoofdstuk kan een citaat dienen van de bijdrage van Van Dunné aan "Onderneming \& 5 jaar Nieuw Burgerlijk Recht": ${ }^{187}$

\begin{abstract}
"Augen auf, Kauf ist Kauf!" lijkt een toepasselijk adagium bij het kopen van een bedrijf; al noemen wij het overname, in wezen gaat het om een gewone koop. Althans, dat adagium zal de verkoper inroepen; of een teleurgestelde koper van een bedrijf daar ook zo over denkt als hij zijn ogen uitgewreven heeft, valt echter te betwijfelen. Als hij niet uit zijn doppen gekeken heeft bij de onderhandelingen die aan de overname vooraf gingen, ligt het verwijt voor de hand dat de wederpartij hem de zaak mooier voorgespiegeld heeft dan in overeenstemming met de werkelijkheid was. Sinds de Romeinen weten wij dat de teleurgestelde koper in beginsel een aantal acties ten dienste staat: behalve die uit wanprestatie, die uit verborgen gebreken, dwaling of bedrog. Het zal van de casus afhangen welke actie het beste bij het geval past en de meeste kans van slagen heeft. Is er een toezegging of garantie gedaan, dan komt wanprestatie in beeld; is er een misleidende verklaring gedaan, dan is er de mogelijkheid van dwaling (onopzettelijke misleiding) of bedrog (opzettelijke misleiding); betreft het een gebrek met betrekking tot de kwaliteit of het gebruik van de zaak, dan kan men de verborgen gebreken-actie instellen. Aldus het klassieke tableau, in landen van Europa, waar de Fransen ooit langs zijn geweest".
\end{abstract}

Zoals hier voor werd opgemerkt zal vooral de verkoper willen vermijden dat een transactie achteraf nog weer kan worden aangetast of dat deze achteraf met een vordering tot vergoeding van schade kan worden geconfronteerd. Een due diligence onderzoek toestaan kan bijdragen aan het bereiken van die doelstelling. Voor een koper is een due diligence onderzoek een belangrijk instrument om te vermijden dat die een kat in de zak koopt. De wat ik noem juridische context van een due diligence onderzoek wordt gevormd door de leerstukken van dwaling, onder omstandigheden bedrog, conformiteit en onrechtmatige daad. Die leerstukken bieden voor kopers instrumenten om zich te verhalen op verkopers wanneer er zich gebreken in de prestatie van de verkoper zouden voordoen. Het is voor een koper van belang te weten welke stappen al vroeg in een transactieproces vereist zijn om de rechten welke ingevolge die instrumenten geldend zouden kunnen of moeten worden gemaakt niet prijs te geven. Het doen van behoorlijk onderzoek naar het voorwerp van een transactie wordt zeker tussen professionele partijen of wanneer de koper een professionele partij is, gerekend tot een inspanning die van een koper wordt verlangd wil die niet naderhand het verwijt krijgen de risico's waarover deze zich wil beklagen, bewust te hebben aanvaard.

Een due diligence onderzoek is als gezegd een belangrijk middel om te voorkomen, dat er bij het aangaan van een transactie of achteraf ongelukken gebeuren. Een due diligence onderzoek bestaat vooral daarin dat er in meer of mindere mate voldaan wordt aan de mededelings- en onderzoeksplicht, zoals die laatst bedoelde Obliegenheiten in het vorige hoofdstuk (onder 4.2) zijn benoemd.Op de vraag hoe accuraat de term Obliegenheit is waar het een mededelingsplicht betreft, is elders in dit boek ingegaan. ${ }^{188}$ Als twee partijen een transactie aan willen gaan is het, zoals wij hebben gezien, van belang dat zij beiden bij het tot stand komen van een overeenkomst een juiste voorstelling van zaken hebben. Dit is in het belang van een succesvol zakelijk verkeer. Partijen zullen er in het belang van het door hen te behalen rendement naar (moeten) streven er voor te zorgen dat er zo weinig mogelijk gereclameerd, hersteld of geprocedeerd behoeft te worden. Dit kan worden bevorderd door het instellen van een onderzoek voorafgaand aan het formaliseren van een transactie. Er zal niet alleen met aandacht

\footnotetext{
187 J.M. van Dunné, Onderzoeks- en spreekplichten bij bedrijfsovername, Onderneming en 5 jaar Nieuw Burgerlijk Recht, Serie Onderneming \& Recht, deel 7, p. 399 e.v.

${ }^{188}$ Zie het vorige hoofdstuk onder Mededelingsplicht- versus onderzoeksplicht?
} 
kennis moeten worden genomen van de mededelingen van de wederpartij, maar ook invulling moeten worden gegeven aan de eigen verantwoordelijkheid om te voorkomen dat onder een onjuiste voorstelling van zaken, beslissingen worden genomen. Wordt een due diligence onderzoek bij het aangaan van een commerciële transactie of een transactie op de financiële markten achterwege gelaten of onvoldoende gedaan, dan worden er door de koper of investeerder aanzienlijke risico's gelopen. In zeker opzicht geldt dit ook ten aanzien van de wederpartij bij die transacties, die om problemen achteraf te voorkomen er goed aan doet adequate voorlichting te geven.

Een overeenkomst die tot stand is gekomen onder invloed van dwaling en bij een juiste voorstelling van zaken niet zou zijn gesloten, is onder bepaalde omstandigheden namelijk vernietigbaar (artikel 6:228 lid 1). Zo al niet de hele transactie ongedaan zal worden gemaakt, is het denkbaar dat - op grond van artikel 6:230 - de beoogde gevolgen van een overeenkomst, niet onveranderd zullen gelden. Indien bepaalde reeds ingetreden rechtsgevolgen bezwaarlijk ongedaan gemaakt kunnen worden, kan in plaats van gehele of gedeeltelijke vernietiging de rechter (ook) schadevergoeding toewijzen op grond van artikel 3:53 lid 2. Een overeenkomst, waarbij blijkt, dat de afgeleverde zaak, mede gelet op de aard van de zaak en de mededelingen die de verkoper over de zaak heeft gedaan, niet de eigenschappen bezit die de koper op grond van de overeenkomst mocht verwachten, kan de verkoper op grond van artikel 7:17 verschillende sancties opleveren. De koper heeft aanspraak op correcte nakoming. Een vordering tot schadevergoeding of ontbinding is denkbaar op voet van artikel 6:74 respectievelijk 6:265. Op de hier genoemde grond kan ook een vordering wegens dwaling volgen en - onder omstandigheden - op grond van bedrog op voet van artikel 6:228 of 3:44. ${ }^{189}$ Op grond van artikel 6:230 kan een verplichting tot vergoeding van nadeel ontstaan of - wanneer aan de vereisten daarvoor is voldaan - ingevolge artikel 6:162 e.v. een gehoudenheid om schade te vergoeden op grond van een onrechtmatige daad. ${ }^{190}$ De mogelijkheid om een beroep op dwaling te doen staat in beginsel niet aan beroep op een andere vernietigingsgrond in de weg, noch aan op een tekortkoming in de nakoming gebaseerde actie, terwijl omgekeerd dergelijke acties een beroep op dwaling niet in de weg staan.

Gronden die een beroep op dwaling rechtvaardigen, komen volgens een ruim gedragen visie in aanmerking voor overeenkomstige toepassing bij een beroep van een koper op de hierna te bespreken non-conformiteit als bedoeld in artikel 7:17 BW ${ }^{191}$ (alhoewel er over deze laatst genoemde opvattingen niet volstrekt eenduidig gedacht wordt. Zie hierna onder 5.6).

Een reden om zorgvuldig te werk te gaan bij het aangaan van transacties is ook het vermijden van verwijten achteraf, dat er in strijd is gehandeld met de zorgvuldigheid welke past bij behoorlijk bestuur (artikel 2:9) of bij behoorlijk toezicht op het bestuur (artikel 2:259).

Wil er sprake zijn van bestuurdersaansprakelijkheid, zal er volgens de jurisprudentie sprake moeten zijn van onbehoorlijke taakvervulling, in zonderheid van een 'ernstig verwijt'. 192

In de visie van Assink, is het aannemen van persoonlijke aansprakelijkheid van bestuurders gerechtvaardigd, wanneer - gelet op alle omstandigheden van het geval - de zorgvuldigheidsplicht van de bestuurder zodanig is geschonden, dat deze:

(a) een jegens de vennootschap in acht te nemen, onder de zorgvuldigheidsplicht ressorterende, gedragsnorm heeft geschonden (i.e. ondermaats gedrag heeft vertoond);

(b) terwijl hij dit had kunnen weten én zich anders had kunnen gedragen (i.e. waarvan de bestuurder schuld treft). ${ }^{193}$

Opmaat naar de vaststelling dat er van een ernstig verwijt sprake is, kan zijn dat gedragingen van het bestuur en/of de commissarissen door de OK voorzien worden van de kwalificatie wanbeleid binnen het kader van het enquêterecht. ${ }^{194}$ Zie verder hierna onder 5.9.

\footnotetext{
${ }^{189}$ Wanneer een partij niet in staat was diens wil te bepalen, kan de overeenkomst voor vernietiging in aanmerking komen, tenzij de wederpartij zich met succes kan beroepen op het in artikel 3:35 BW neergelegde vertrouwensbeginsel. Zie voor een recent voorbeeld Rechtbank Arnhem 20 februari 2008, LJN BC5068.

190 De artikelen 7:24 en 7:25 geven regels voor schadevergoeding bij consumentenkoop.

191 Zie de opsomming van auteurs in Bijzondere overeenkomsten I (Van Rossum), artikel 17, aantekening 11, en Asser-Hijma 5I, 2001, nr. 340 en AG J. Wuijsman onder HR 25 mei 2007, LJN BA2012 (onder 3.4.).

192 Zie HR 10 januari 1997, NJ 1997, 360 (Staleman/Van de Ven) en HR 29 november 2002, JOR 2003, 2 m.nt. Bartman (Schwandt/Berhuizer Papierfabriek). Zie ook J.B. Wezeman, Aansprakelijkheid van bestuurders, Groningse Serie, deel 29.

${ }^{193}$ B.F. Assink, Rechterlijke toetsing van bestuurlijk gedrag, Groningse Serie, deel 59, p. 616.

${ }^{194}$ In HR 10 januari 1990, NJ 1990, 466 besliste de Hoge Raad dat het niet nodig is voor de kwalificatie wanbeleid van de rechtspersoon, dat aan bestuurders en/of commissarissen persoonlijk wanbeleid moet kunnen worden verweten. In HR 4 juni 1997, NJ 1997, 671 werd uitgemaakt dat bij de vaststelling bij wie de verantwoordelijkheid berust voor mogelijk blijkend wanbeleid, in de eerste plaats valt te denken aan de verantwoordelijkheid van de onderscheiden organen van de rechtspersoon. Bij een onderzoek naar het beleid en de gang van zaken van de rechtspersoon zal de beoordeling van de
} 
Al de hier voor genoemde omstandigheden maken dat een due diligence onderzoek van belang is tegen de achtergrond van de juridische complicaties die zich laten denken, wanneer er voorafgaand aan het aangaan van een transactie onvoldoende zicht is verkregen of gegeven op de informatie die nodig is om verantwoord te besluiten tot het aangaan van de transactie en het zonder problemen uitvoeren daarvan.

\subsection{Onderzoeksplicht}

De onderzoeksplicht is niet te herleiden naar een bepaald wetsartikel.

In het algemeen worden vorderingen van zogenaamde "teleurgestelde kopers" op één van twee soorten gronden ingesteld: op grond van "wanprestatie" (toerekenbare tekortkoming in de nakoming) of op grond van dwaling. Nu het onderwerp van dit boek "due diligence" betreft, zal worden volstaan met slechts een algemene beschrijving van de leerstukken van dwaling en non-conformiteit. De leerstukken van bedrog en onrechtmatige daad, zullen met nog minder woorden aan de orde komen. Niettemin is het noemen van deze leerstukken nodig, nu die steeds het decor vormen waartegen een due diligence onderzoek aan de orde kan zijn.

Met name zal bij transacties een onderzoek relevant zijn om te weten hoe de risicoverdeling in eventuele documentatie moet worden geregeld, danwel welke risicoverdeling, bij gebreke van een regeling, te verwachten valt. Als er dingen mis gaan, is immers per saldo de vraag hoe de risicoverdeling tussen partijen is op basis van alle relevante (risico)factoren. Raaijmakers ${ }^{195}$ meent dat het palet aan risicofactoren die een rol spelen bij de rechtsvinding, inmiddels feitelijk breder is dan alleen strikte mededelingsplicht en onderzoeksplichten, zij het dat er nog altijd - zijns inziens ten onrechte - een sterke neiging bestaat om alle relevante risicofactoren in het keurslijf van één van die twee 'plichten' onder te brengen. Hij meent dat het er per saldo om gaat dat wij een instrumentarium nodig hebben om uit te drukken dat gegeven bepaalde omstandigheden een risico voor de koper danwel de verkoper dient te komen. Hij spreekt dan ook liever van risicofactoren, zorgplichten en eigen verantwoordelijkheid als beslissende ijkpunten voor het vaststellen van een risicoverdeling. ${ }^{196}$ Raaijmakers duidt erop dat in wezen risicoverdeling steeds meer plaatsvindt als afweging in het spectrum tussen zorgplicht en eigen verantwoordelijkheid, waarvan mededelings- en onderzoeksplichten slechts een deel uitmaken. Ik ben het hier van harte mee eens en wil verder op in dit boek een poging doen een en ander te vertalen naar de betekenis daarvan voor een due diligence onderzoek (zie hoofdstuk 1, onder 1.3).

Overigens wordt op dit moment al aangenomen dat een mededelingsplicht en een onderzoeksplicht naast elkaar kunnen bestaan. ${ }^{197}$ Hier voor zagen wij dat de opvatting leeft dat de mededelingsplicht in het algemeen wat zwaarder zal wegen dan een onderzoeksplicht en wel in die zin, dat een verzaking van een onderzoeksplicht aan de zijde van de koper niet altijd ter afwering van een beroep op dwaling door de verkoper zal kunnen worden ingeroepen. Over dit laatstbedoelde onderwerp wordt echter genuanceerd gedacht. ${ }^{198}$ In een zaak die handelde over de verkoop van een voor de verhuur bestemd beleggingspand, had de verkoper verklaard dat er geen procedures gaande waren bij de rechter, de huurcommissie of een andere instantie. In weerwil van dat antwoord was er door huurders al een verzoek bij de huurcommissie ingediend tot aanpassing van de huur, overeenkomstig artikel 17 van de Huurprijzenwet. Na de verkoop van het beleggingspand stelde de kantonrechter een lagere huur voor de desbetreffende woning vast. Het gerechtshof was van oordeel dat de koper een beroep op dwaling mocht doen, nu deze er aan de hand van het ingediende vragenformulier op had mogen vertrouwen dat de situatie met betrekking tot procedures aangaande het pand juist was weergegeven. Niet de mo-

verantwoordelijkheid van een orgaan van de rechtspersoon niet altijd los gezien kunnen worden van de individuele verantwoordelijkheid van de personen die het orgaan uitmaken. In zijn algemeenheid kan dan ook niet gezegd worden dat een enquête zich niet kan uitstrekken tot een onderzoek naar het functioneren van de personen die de rechtspersoon doen optreden. Toen al werd uitgemaakt dat ook déchargebesluiten ten aanzien van bestuurders en commissarissen vernietigd kunnen worden op grond van artikel 2:356 sub a.

195 G.T.M.J. Raaijmakers, Garanties in het contractenrecht, Rechtsgeleerd Magazijn Themis 2005-3, p. 124 e.v.

196 Zie hierover ook G.T.M.J. Raaijmakers, Bedrijfsovernames: lijken in kasten en katten in zakken, Ars Aequi 2003, p. 892-893.

197 Aldus ook HR 10 april 1998, NJ 1998, 666. Zie G.J.P. de Vries, Mededelings- en onderzoeksplicht bij een vergoedingsaanspraak op grond van dwaling, Noot bij HR 18 januari 2002, C00/106 HR, NTBR 2002, 7, p. 341 e.v., laatstbedoelde arrest is eveneens te vinden onder LJN AD4924.

${ }^{198}$ Zie de conclusie van A-G Huydecoper onder HR 8 december 2006, LJN AY7456 
gelijkheid dat een rechter op enig tijdstip in de toekomst een lagere huurprijs zou kunnen vaststellen, leverde grond op voor een op dwaling gebaseerde vordering, maar wel het feit dat de verkoper had moeten meedelen dat die mogelijkheid (ten dele) reeds realiteit was geworden doordat één van de huurders zich tot de huurcommissie had gewend. Het gerechtshof was daarnaast van oordeel dat een koper van een beleggingspand met huurwoningen wel een onderzoeksplicht had ter zake van de wetgeving op het punt van huurprijzen, waardoor de omstandigheid dat er in de toekomst een lagere huurprijs zou kunnen worden vastgesteld, niet iets was ter zake waarvan op de verkoper een mededelingsplicht rustte. De Hoge Raad overweegt dan als volgt:

"Redelijkheid en billijkheid verzet zich niet tegen de door het Hof aangebrachte splitsing van de omstandigheden waaromtrent de koper dwaalde in die ten aanzien waarvan de dwaling voor rekening van de koper moet blijven en die ten aanzien waarvan de verkoper haar mededelingsplicht heeft geschonden en daarom het beroep van de koper op dwaling wél - zij het met minder verstrekkende gevolgen op het punt van het door de koper ondervonden nadeel - kunnen dragen".

In dit opzicht levert het arrest van de Hoge Raad van 8 december 2006 een nieuwe bevestiging op van het feit dat een mededelingsplicht en onderzoeksplicht naast elkaar kunnen bestaan.

In diens conclusie bij HR 14 mei $2004^{199}$ biedt A-G Timmerman een blik op de wijze waarop hij in het algemeen tegen de verhouding tussen een mededelings- en onderzoeksplicht aankijkt, gebaseerd op de voorhanden jurisprudentie:

"Zo volgt mijns inziens uit deze jurisprudentie dat professionaliteit van de koper, die in het algemeen mee zal brengen dat de koper geacht wordt betrekkelijk veel te weten of door onderzoek veel te weten te kunnen komen een reducerend effect heeft op de omvang van de mededelingsplicht van de verkoper. In geval van professionaliteit van de koper komt de mededelingsplicht van de verkoper echter niet zonder meer en onder alle omstandigheden te vervallen. Hetzelfde geldt, wanneer de koper een due diligence doet uitvoeren. Op zichzelf brengt het uitvoeren van een due diligence onderzoek niet mee dat de mededelingsplicht van de verkoper komt te vervallen. Er zijn omstandigheden denkbaar waarin de verkoper ondanks dat een due diligence door de koper gehouden is bepaalde mededelingen aan de koper dient te doen. Dat feiten en omstandigheden een belangrijke rol spelen, is ook weer gebleken in een recent arrest van de Hoge Raad. Daarin kwam naar voren dat de bijzondere omstandigheid van een verlaging van een aanvankelijk overeengekomen koopprijs geacht werd tot gevolg te hebben dat bepaalde risico's voor rekening van de koper kwamen. Dit leidde er in het onderhavige geval toe dat de mededelingsplichten van de verkoper beperkt werden.

Ik wil met dit alles onderstrepen dat we in Nederland m.i. niet de hoofdregel van non disclosure kennen, d.w.z. de regel dat een partij niet verplicht is ongevraagd inlichtingen aan de wederpartij te verschaffen. Deze regel geldt ook niet zonder meer in geval van een professionele koper of wanneer er een due diligence is verricht. Veel, zo niet alles hangt af van de omstandigheden van het geval."

Interessant zijn de overwegingen welke A-G Huydecoper in zijn noot onder het arrest van 8 december 2006 wijdt aan de juridische duiding van een onderzoeksplicht in relatie tot een mededelingsplicht. Ik noem allereerst hoe deze A-G een onderzoeksplicht kwalificeert:

“... ik denk namelijk dat wanneer wij spreken van een "onderzoeksplicht" die een partij die een beroep op dwaling doet zou hebben "verzaakt" het in feite gaat om een zegswijze waarmee (slechts) wordt aangegeven dat de onwetendheid (of het misverstand) waar de betrokkene een beroep op doet, voor zijn rekening moet blijven. In de doctrine is algemeen aanvaard dat de "plicht" die hier wordt ingeroepen, geen werkelijke plicht is, maar de status heeft van wat in het Duits "Obliegenheit" wordt genoemd: men kan niet

\footnotetext{
${ }^{199}$ LJN AO1214 (M\&M Beheer), onder 4.1.
} 
worden verplicht zich daarnaar te gedragen, maar men moet tegen zich laten gelden dat men op het desbetreffende punt niet beter geïnformeerd was".

De A-G vervolgt:

\begin{abstract}
"Ik meen dus (ook) dat er geen wezenlijk verschil bestaat tussen de maatstaf waarnaar moet worden beoordeeld of dwaling "(on)verschoonbaar" is, danwel of dwaling naar verkeersopvatting voor rekening van de dwalende partij moet blijven, of er sprake is van een "onderzoeksplicht" die, als daaraan niet voldaan is, aan een beroep op dwaling in de weg mag staan: in ieder van deze varianten gaat het erom dat de omstandigheden van dien aard zijn dat de dwaling waarop een beroep wordt gedaan, voor rekening van de dwalende behoort te blijven. De verschillen in gekozen aanduidingen zien niet op een verschillende beoordelingsmaatstaf, maar geven slechts een indicatie van de categorie van omstandigheden die in het beoogde geval als doorslaggevend voor de toerekening aan de dwalende wordt aangemerkt (bij de aanduidingen "(on)verschoonbaar" danwel "onderzoeksplicht" denkt men dan eerder aan een al te lichtvaardige benadering door de dwalende partij zelf (of diens "hulppersoon"), terwijl "verkeersopvattingen" eerder zullen aanknopen bij de aard van de informatie waaromtrent gedwaald is: "gebrekkige kennis van sommige informatie wordt gerekend tot de risicosfeer van de partij die met miskenning daarvan tot een overeenkomst toetreedt en (gebrekkige) kennis omtrent andere informatie juist niet)."
\end{abstract}

De hier voor blijkende benadering van de A-G lijkt aan te sluiten bij de door Raaijmakers gekozen insteek.

Of onwetendheid dan wel misverstand omtrent bepaalde gegevens is toe te rekenen tot de risicosfeer van de onwetende die daardoor nadeel meent te ondervinden danwel (mede) voor rekening van de andere partij mag worden gebracht, is weliswaar als een rechtsvraag te beschouwen maar wordt toch nagenoeg altijd in sterke, in vaak beslissende mate bepaald door omstandigheden die slechts aan de hand van feitelijke waardering en afweging kunnen worden beoordeeld.

De A-G benadrukt dat er tegelijkertijd sprake kan zijn van een onderzoeksplicht en van een mededelingsplicht. Hij wijst erop dat het bestaan van een niet in acht genomen mededelingsplicht gewoonlijk met zich meebrengt dat de partij die deze plicht verzaakte, zich er niet op kan beroepen dat aan haar eigen verzuim voorbij mag worden gegaan, gezien de (eveneens verzaakte) onderzoeksplicht van de andere partij. De A-G wil niet de regel onderschrijven dat een onderzoeksplicht geheel door een mededelingsplicht verdrongen kan worden. Wel blijft het zo dat men in het algemeen moet kunnen afgaan op hetgeen al dan niet ingevolge een mededelingsplicht is meegedeeld.

De A-G stelt vervolgens vast dat er gewaakt moet worden tegen een te algemene toepassing van de regel dat de mededelingsplicht voor de onderzoeksplicht gaat. ${ }^{200}$ Die regel is alleen al niet algemeen toepasselijk nu het ook mogelijk is dat er van elkaar te onderscheiden (groepen van) gegevens aan de orde kunnen zijn die het rechtvaardigen dat de toerekening van dwaling voor ieder van die twee (groepen van) gegevens verschillend zal dienen te worden beoordeeld. Volgens de A-G zal de vraag of daarvan sprake kan zijn en of dat een verantwoorde benadering is, afhankelijk zijn van de (feitelijke) waardering van o.a. de aard van de desbetreffende gegevens en de mate waarin zij elkaar beïnvloeden. Ook speelt de hoedanigheid van de betrokken partijen een rol. Tjittes ${ }^{201}$ gaat in op de verschillen in de verhouding welke tussen verschillende soorten van partijen kunnen bestaan.

Het gerechtshof te Amsterdam meende eerder, op 16 april $1998^{202}$ dat een koper in ieder geval een onderzoeksplicht tot zijn risicosfeer moet rekenen, waar het gebreken betreft die zichtbaar zijn of

\footnotetext{
${ }^{200}$ Zie R.P.J.L. Tjittes in De hoedanigheid van contractspartijen, Kluwer 1994, p. 57 en de door hem aldaar genoemde rechtspraak en literatuur.

201 A.w. p. 58 e.v

${ }^{202}$ NJ 1999, 453.
} 
waarvan het bestaan door uiterlijk waarneembare verschijnselen kan worden vermoed. In dezelfde uitspraak werd ook overwogen dat de schending van een mededelingsplicht door de verkoper wel kan veroorzaken dat aan de koper niet kan worden tegengeworpen dat deze op bepaalde punten geen nader onderzoek heeft verricht. In een uitspraak van de Hoge Raad van 14 november $1997^{203}$ werd het verzwijgen van een door een verkoper gekende bodemverontreiniging - ondanks een contractuele uitsluiting van aansprakelijkheid voor verborgen gebreken en het uitsluiten van het recht op ontbinding in de akte van levering - als onrechtmatig beschouwd. Die uitspraak bevestigt hoe zeer de omstandigheden van het geval steeds bepalend zijn. In het geval waarin de Hoge Raad op 14 november 1997 oordeelde, werd namelijk ook aangenomen dat de koper ervan op de hoogte had kunnen zijn dat ten aanzien van het bedrijfsterrein waar het om ging, een verhoogd risico van bodemverontreiniging bestond doordat deze op het bedrijfsterrein een bodemvervuiling moest hebben gezien en de peilbuizen van een bodemonderzoeker. Duidelijk is - zeker sedert de uitspraak van de Hoge Raad in de zaak rond Hoog Catharijne, dat, wanneer er aanwijzingen zijn dat er iets meer aan de hand kan zijn, of er omtrent aannames onzekerheid kan bestaan, een nader onderzoek door de koper geïndiceerd is, willen de gevolgen niet voor diens rekening kunnen blijven. ${ }^{204}$

Over de vraag wanneer een koper bekend kan zijn met gebreken, zegt A-G Huydecoper: ${ }^{205}$ Wanneer zijn gebreken kenbaar? Dat is een verwijzing die een vrij brede ruimte voor interpretatie laat - zo ongeveer variërend van "kenbaar = bekend" als meest beperkte uitleg, tot: "kenbaar = alles wat bij (uiterst) zorgvuldig onderzoek aan het licht zou zijn gekomen" als meest ruime. In het bestreden arrest heeft het hof, zoals ik zijn beslissing versta, gekozen voor een uitleg die tussen de geschetste uitersten een midden kiest, namelijk zo ongeveer: "kenbaar = wat bij het redelijkerwijs te vergen onderzoek aan het licht zou komen". Het dringt zich enigszins op dat een dergelijke, naar het "redelijke midden" neigende uitleg niet gauw als ongerijmd zal kunnen worden aangemerkt. Ik verwijs verder naar hetgeen elders is opgemerkt over de toerekenbare veronderstelling.

Over de verhouding tussen de onderzoeksplicht van een koper en een mededeling van de verkoper overweegt de Hoge Raad op 19 september $2003^{206}$ als volgt:

“... degene die overweegt een overeenkomst aan te gaan, is tegenover de wederpartij gehouden om binnen redelijke grenzen maatregelen te nemen om te voorkomen dat hij onder invloed van onjuiste voorstellingen zijn toestemming geeft, doch deze gehoudenheid gaat niet zover dat hij niet zou mogen afgaan op de juistheid van door deze wederpartij gedane mededelingen. De onjuistheid van dergelijke mededelingen rechtvaardigt in beginsel een beroep op dwaling, maar de aard van de overeenkomst, de in het verkeer geldende opvattingen of de omstandigheden van het geval kunnen meebrengen dat de dwaling voor rekening van de dwalende behoort te blijven (artikel 6:228 lid 2 $B W)$ ".

\subsection{Mededelingsplicht}

In de literatuur bestaan verschillende opvattingen over de oorsprong van de mededelingsplicht. Een aantal schrijvers is van mening dat een mededelingsverplichting is terug te voeren op de eisen van redelijkheid en billijkheid die de precontractuele fase beheersen. Hijma noemt daarom de mededelingsplicht ook een Obliegenheit. ${ }^{207}$ De verkoper van een varkensmesterij had voor het aangaan van een nadere overeenkomst tot vermindering van de koopprijs bij verkoop van de varkensmesterij, niet meegedeeld dat de koper krachtens de Interimwet beperking varkens- en pluimveehouderijen nog minder dieren mocht houden dan het aantal waarop de vermindering van de koopprijs was gebaseerd. Nietnakoming van een zodanige op de eisen van redelijkheid en billijkheid (goeder trouw) berustende mededelingsplicht leverde niet slechts grond op tot vernietiging van de overeenkomst op grond van dwa-

\footnotetext{
${ }^{203}$ NJ 1998, 657

${ }^{204}$ Zie voor een voorbeeld, waarin de koper werd verweten een aanname niet te hebben geverifieerd: Rechtbank Middelburg 6 februari 2008, LJN BC8397.

205 In zijn conclusie bij HR 12 oktober 2007, LJN BA7630 (onder 7), naar aanleiding van de clausule in de standaard NVMovereenkomst, dat de verkoper niet in staat voor gebreken die aan de koper kenbaar zijn op het moment van het tekenen van de overeenkomst

${ }^{206}$ HR 19 september 2003, NJ 2005, 234 m.nt. JH (r.o. 3.5.2.)

${ }^{207}$ Zie ook Asser-Hijma 5-I, nr. 233 en overigens de aldaar genoemde literatuur. Zie ook HR 2 april 1993, NJ 1995, 94, m.nt. Brunner.
} 
ling of bedrog, maar kon ook een verplichting tot schadevergoeding in het leven roepen. Aangenomen werd dat een schadevergoedingsplicht evenzeer (naast gegrondheid op basis van toerekenbare nietnakoming) gebaseerd zou kunnen worden op het niet-nakomen van een mededelingsplicht welke in strijd is te achten met de redelijkheid en billijkheid. ${ }^{208}$ Brunner in zijn noot onder een arrest van 2 april $1993^{209}$ wijst erop dat er sprake is van een rare dogmatische strijd over een antwoord op de vraag of de niet- nakoming van een verplichting uit de redelijkheid en billijkheid (goeder trouw), naast de onrechtmatige daad een zelfstandige bron van verbintenis tot schadevergoeding kan zijn. De Hoge Raad besliste inmiddels dat een schadevergoedingsplicht evenzeer kan intreden, indien het niet-nakomen van de mededelingsplicht in strijd komt met de redelijkheid en billijkheid. Brunner wijst erop dat het antwoord op die vraag in het arrest Plas/Valburg nog door de Hoge Raad in het midden was gelaten. Hij stelt dat de beslissing van de Hoge Raad op 2 manieren kan worden uitgelegd. Het kan betekenen dat verplichtingen uit de redelijkheid en billijkheid moeten worden onderscheiden van verplichtingen uit het ongeschreven recht waarvan de schending een onrechtmatige daad oplevert. Ik verwijs naar de door Brunner in zijn noot genoemde literatuur. Volgens Brunner is het praktisch niet van veel belang of de geschonden verplichting van ongeschreven recht uit de redelijkheid en billijkheid wordt onderscheiden van een gelijke verplichting uit hetgeen in het maatschappelijk verkeer betaamd. Noem het convergentie van grondslagen. Het rechtsgevolg van de schending is hetzelfde: een verplichting tot schadevergoeding, die weliswaar niet uitdrukkelijk in de wet is geregeld, maar is terug te voeren op een wettelijke regeling (artikel 6:1). Een andere interpretatie is om de bedoelde overweging van de Hoge Raad te vertalen naar een mededelingsplicht als een uit de redelijkheid en billijkheid voortvloeiende verbintenis, waarvan de niet-nakoming wanprestatie oplevert. Brunner noemt het aantrekkelijke van die laatstbedoelde opvatting dat zij het ontstaan van een verbintenis tot schadevergoeding bij schending op natuurlijke wijze verklaart en de omweg via de onrechtmatige daad overbodig maakt. Voor het overeenkomstenrecht zou deze opvatting voor de hand liggen, omdat daar de naar redelijkheid en billijkheid aanvullende verplichtingen om te geven, te doen of na te laten in het leven kunnen worden geroepen, die als verbintenis dienen te worden beschouwd en waarvan de nakoming in rechte kan worden afgedwongen. Mij dunkt dat de onrechtmatige daad-benadering toch meer voor de hand ligt, nu verbintenissen nu eenmaal een sterkere grondslag kennen wanneer die uit de wet voortvloeien (zoals in het geval van artikel 6:162 e.v.), dan wanneer die hun grondslag moeten vinden in rechtersrecht. Ik teken hierbij aan dat het rechtersrecht waar het dan om gaat de grondslag moet vinden in de aanvullende werking van de redelijkheid en billijkheid (artikel 6:2), welke rechtsbepaling door de rechter over het algemeen terughoudender zal worden toegepast dan de bepalingen welke betrekking hebben op de derogerende werking van de redelijkheid en billijkheid. Bovendien blijt de vraag of de regel van artikel 6:162 e.v. niet derogeert aan de nog algemener gestelde bepalingen van artikel 6:2 en 3:12.

A-G Huydecoper maakt in zijn conclusie onder het arrest van 23 januari $2004^{210}$ de navolgende opmerkingen over het hiervoor aangesproken onderscheid:

"Verschillende bronnen merken als grondslag aan, dat het verzaken van de mededelingsplicht in de precontractuele fase onrechtmatig is, en dat aan deze onrechtmatige handelwijze, nadat een overeenkomst tot stand is gekomen, (ook) gevolgen mogen worden verbonden die inhoudelijk dezelfde als de gevolgen van een tekortkoming in de uitvoering van een overeenkomst (waarbij dan onderscheid kan worden gemaakt tussen de sanctie van ongedaanmaking van de overeenkomst, die op een wilsgebrek kan worden gebaseerd, en overige sancties, die als (vorm van) schadevergoeding wegens het onrechtmatig handelen kunnen gelden. Een andere benadering - die de eerder besprokene overigens niet uitsluit - berust op deze gedachtegang: veronachtzaming van de mededelingsplicht in de fase vóór er een overeenkomst wordt gesloten leidt er gewoonlijk toe

\footnotetext{
${ }^{208}$ Zie ook gerechtshof Amsterdam 16 april 1998, NJ 1999, 161 (r.o. 5.3: "Nu het te dezen gaat om een overeenkomst die na onderhandelingen tot stand is gekomen, is hetgeen in de precontractuele fase is geschiedt van belang voor de rechtsverhouding zoals die tussen partijen voor het aangaan van de Agreement is ontstaan" en (r.o. 5.4.: "voor het antwoord op de vraag of SL/DE te dezen heeft voldaan aan haar mededelingsplicht, geldt als uitgangspunt dat partijen zich ten opzichte van elkaar, zowel tijdens de onderhandelingsfase als bij het aangaan van de Agreement en in de periode daarna dienden te gedragen overeenkomstig de eisen van redelijkheid en billijkheid. Dit brengt mee dat zij hun gedrag mede dienden te laten bepalen door elkaars gerechtvaardigde belangen en dat zij over en weer rekening dienden te houden met elkaars gerechtvaardigde wensen."

209 In zijn noot onder HR 2 april 1993, NJ 1995, 94. Zie hierover ook hoofdstuk 4.1

${ }^{210}$ LJN AL7051 (Pont Eecen/Stratex)
} 
dat de gegevens ten aanzien waarvan een mededelingsplicht bestond, vervolgens eigenschappen van het onderwerp van de overeenkomst zijn geworden, ten aanzien waarvan de wederpartij de verwachtingen mocht koesteren die (mede) door de niet in acht genomen mededelingsplicht zijn gevormd. Doordat de mededelingsplicht niet is nagekomen, zijn bij de andere partij bij de inmiddels gesloten overeenkomst gerechtvaardigde maar onjuiste verwachtingen ten aanzien van het onderwerp van de overeenkomst gewekt, of blijven bestaan. Als het onderwerp van de overeenkomst niet voldoet aan de gerechtvaardigde verwachtingen van een van de partijen, en aannemelijk is dat een veronachtzaamde mededelingsplicht daaraan debet is, moet er, zolang er geen andere gegevens zijn die tot een andere uitkomst leiden, worden aangenomen dat er een (toerekenbare) tekortkoming is aan de kant van de partij die haar mededelingsplicht veronachtzaamde: verwachtingen die de andere partij op grond van de betreffende overeenkomst mocht koesteren worden dan beschaamd, door een aan de "mededelingsplichtige" partij toe te rekenen oorzaak."

De AG noemt het een betrekkelijk irrelevant en zelfs willekeurig keuzevraagstuk of de grondslag het etiket onrechtmatig handelen opgeplakt krijgt, dan wel schending van de mededelingsplicht of zelfs het toerekenbaar tekort schieten doordat het onderwerp van de overeenkomst door een aan de "mededelingsplichtige" partij toerekenbare oorzaak, niet aan de gerechtvaardige verwachtingen van de wederpartij beantwoord. Alle wegen leiden volgens hem naar dezelfde (materiële) uitkomsten; en als de mededelingsplicht in een uitdrukkelijke (garantie)clausule was opgenomen, doet dat feit aan die uitkomsten maar heel weinig toe of af. Op meerdere plaatsen in dit boek blijkt dat gewaakt moet worden tegen de gedachte dat een verbintenis op grond van de redelijkheid en billijkheid als een min of meer uniforme categorie van verbintenissen kan worden geïdentificeerd. Het is naar mijn mening een te beperkte benadering om uitsluitend op basis van verantwoordelijkheid voor verwachtingen een mededelingsplicht aan te nemen, hoewel in veel gevallen een dergelijk criterium wel werkbaar zal kunnen zijn.

Een mededelingsplicht kan alleen van toepassing zijn wanneer degene op wie die mededelingsplicht zou (moeten) rusten, zelf over de relevante wetenschap beschikt. ${ }^{211}$

\subsection{Zorgplicht}

Een begrip dat in de afgelopen jaren is overgewaaid uit de dogmatiek met betrekking tot het leerstuk van de onrechtmatige daad, betreft de bijzondere zorgplicht. In de rechtspraktijk is dit begrip laatstelijk vooral tot ontwikkeling gekomen ten opzichte van financiële instellingen met het oog op de rol welke deze in het maatschappelijk verkeer vervullen. ${ }^{212}$ Van Baalen inventariseerde recentelijk de zorgplichten op het terrein van de effectenhandel. ${ }^{213}$ In de rechtspraak is de gedachte ontwikkeld dat de maatschappelijke rol van financiële instellingen een bijzondere zorgplicht met zich meebrengt. Die instellingen dienen onder omstandigheden aan de belangen van hun cliënten meer zorg te besteden dan de zorg die contractspartijen normaliter tegenover elkaar in acht dienen te nemen. Deze zorgplicht gaat soms zo ver dat de financiële instelling met name particuliere cliënten tegen zichzelf in bescherming

211 Zie gerechtshof Leeuwarden 12 april 2006 (r.o. 1.6.), kenbaar uit HR 7 december 2007, LJN BB9421, waarin ook werd opgemerkt dat een contractuele bepaling terzijde kan worden gesteld vanwege de derogerende werking van de redelijkheid en billijkheid. Voorwaarde is dan dat er sprake is van 'schuldig' verzwijgen.

212 Zie bijvoorbeeld HR 11 juli 2003, NJ 2005, 103. Een bank dient een cliënt schriftelijk voor te lichten omtrent de risico's - zeker wanneer de bank tevens als adviseur optreedt - en transacties te ontraden wanneer die strijdig zijn met het doel dat de belegger nastreeft.

In HR 14 december 2007, RAV 2008, 23 ging het over de zorgplicht van een notaris. De vraag was of op de notaris een onderzoeks- en een waarschuwingsplicht rustte in het geval van speculatieve transacties. Die beide laatstgenoemde elementen vormen dan componenten van de zorgplicht van de notaris. De Hoge Raad (r.o. 3.6.1) overwoog dat in beginsel op een notaris niet de verplichting rust om te informeren naar de beweegredenen voor een transactie, wanneer hij op grond van eerdere contacten met een partij ervan mag uitgaan dat deze de te verrichten transactie evenals voorafgaande transacties wenst aan te gaan uit speculatieve overwegingen. Daaraan werd echter toegevoegd dat omstandigheden in samenhang met hetgeen de notaris overigens bekend is omtrent de aard van de beoogde transactie en de ernst van de daarmee samenhangende risico's alsmede omtrent de hoedanigheid van de betrokken partij, mee kunnen brengen dat een notaris er niet mee kan volstaan bij de wederpartij te informeren naar de beweegredenen voor een transactie, maar ook bij de betrokken partij zelf daarnaar informeert en zo nodig wijst op de aan de transactie verbonden risico's.

${ }^{213}$ S.B. van Baalen, Zorgplichten in de effectenhandel, Serie Recht en Praktijk, deel 140. 
moet nemen. ${ }^{214}$ Goede informatieverstrekking moet zeker stellen dat een financiële instelling bij het aangaan van een transactie - met name bij particuliere cliënten - niet achteraf het verwijt kan krijgen onvoldoende aan haar informatieplicht en daarmee haar zorgplicht te hebben voldaan.

Waar dit het toezicht op de financiële markten betreft is door de invoering van Wft/Wfd dit toezicht volgens Rinkes 'gekanteld'. De markten worden niet meer branchegericht, maar productgericht benaderd bij de uitoefening van het prudentieel (DNB) en gedragstoezicht (AFM) ${ }^{215}$ Kantelend inzicht heeft geleid tot functioneel toezicht. Informatie- en zorgplichten nemen daarbij een belangrijke plaats in, evenals transparantie. Een belangrijk punt daarbij is de mogelijke onevenwichtige verdeling van deskundigheid tussen partijen. Zo dient een financiële dienstverlener aan tal van vakbekwaamheidseisen te voldoen, en moet deze instaan voor een uitvoerige catalogus aan informatie- en zorgplichten. ${ }^{216}$ Rinkes wijst erop dat de reikwijdte van de zorgvuldigheidsnorm welke hiervoor wordt bedoeld ook wordt bepaald door macro-economische overwegingen: "vooral macro-economische belangen spelen (kennelijk) een belangrijke rol bij de 'Dexia-kwestie', de perikelen rond beleggingspolissen en - in de nabije toekomst - bij problemen op de hypotheekmarkt (ook Nederland kent hypotheekvormen die gevaarlijk dicht bij de VS ‘sub-prime hypotheken' liggen).

De regelingen van de Wft en MiFiD bevatten meerdere bepalingen met betrekking tot een zorgvuldige dienstverlening. Informatie dient feitelijk juist, begrijpelijk en niet misleidend te zijn (artikel 4:19 lid 2 $\mathrm{Wft}$ ); voorafgaand aan het adviseren, het verlenen van een beleggingsdienst of de totstandkoming van een overeenkomst in zake een financieel product of instrument verstrekt een financiële dienstverlener de afnemer van die diensten informatie voor zover dit redelijkerwijze relevant is te achten voor een adequate beoordeling van het desbetreffende product of instrument (artikel 4:20 Wft). Ook tijdens de looptijd van een verbintenis moet informatie worden verstrekt over wezenlijke of redelijkerwijs relevant te achten wijzigingen. Bij advisering dient informatie te worden ingewonnen over de afnemer van de desbetreffende producten. Er dient een beleggersprofiel te worden opgesteld betreffende de financiële positie, kennis, ervaring, doelstellingen en risicobereidheid van de betrokkene, voor zover dit relevant is te achten voor het te verlenen advies. Zoals hier voor onder 2.11 opgemerkt, wordt de verplichting om een beleggersprofiel op te stellen, aangeduid als het "ken uw cliënt-beginsel". Met de desbetreffende profilering dient rekening te worden gehouden bij de uiteindelijke advisering. De vraag of een dienst geschikt is voor een cliënt verdient aandacht (artikel 4:24 Wft) en bij alles staan zorgvuldigheidsregels voorop (artikel 4:25 Wft). ${ }^{217}$

Overigens wordt het begrip "zorgplicht" te pas en te onpas gebruikt. Ik verwijs naar een uitspraak van het gerechtshof te Amsterdam van 13 september 2007, ${ }^{218}$ waarin een toerekenbare niet nakoming wordt benoemd als het niet voldoen aan een uit een aandeelhoudersovereenkomst voortvloeiende zorgplicht.

Tjong Tjin Tai heeft eerder gesignaleerd dat het niet duidelijk is wat zorgplichten precies zijn. ${ }^{219} \mathrm{Hij}$ wijst er op dat de Hoge Raad de term regelmatig gebruikt ${ }^{220}$ en dat de wetgever zich er over buigt of er niet meer met zorgplichten moet worden gewerkt. ${ }^{221} \mathrm{Hij}$ definieert een juridische zorgplicht als:

“.. een plicht tot handelen of nalaten ten behoeve van één of meer concrete belangen van een persoon of object. Zo'n plicht verplicht tot veel verschillende daden over een langere

${ }^{214}$ Zie bijvoorbeeld HR 23 december 2005, JOR 2006, 20. Zie ook S.B. van Baalen, De bijzondere zorgplicht bij financiële contracten, in Contracteren 2006/4, p. 74 e.v. Zie hof Arnhem 17 juli 2007, JOR 2007, 241 voor een voorbeeld van een geval, waarin de bank werd geacht te kort te zijn geschoten in het in acht nemen van een zorgvuldigheidsnorm en derhalve werd geacht onrechtmatig te hebben gehandeld. Wanneer het echter een eenvoudig, vrij risicoloos product betreft, dat naar aard en strekking te overzien is, is de rechter minder snel geneigd een zorgplicht van de financiële instelling aan te nemen. Zie bij wijze van voorbeeld rechtbank Arnhem, 19 september 2007, NJF 2007, 562.

215 J.G.J. Rinkes, Juridische aspecten van de informatie- en zorgplichten van financiële ondernemingen onder het regime van de Wet op het financieel toezicht, Nederlands Tijdschrift voor Handelsrecht 2007-6, p. 223 e.v.

216 Zie over zorgplichten en zorgethiek het in de vorige noot genoemde artikel van J.G.J. Rinkes en de door hem genoemde literatuur en rechtspraak.

217 J.G.J. Rinkes, a.w., p. 234

218 LJN BC0317 (UPC).

219 T.F.E. Tjong Tjin Tai, Zorgplichten en zorgethiek, (diss. UvA), Kluwer 2007 en T.F.E. Tjong Tjin Tai, Zorgplichten en zorgethiek, AA (56) 2007-9, p. 702 e.v.

$220 \mathrm{Ik}$ noem als voorbeeld HR 9 november 2001, LJN AD5302, waarin het ging om de grenzen van de zorgplicht van een Waterschap. Tjong Tjin Tai noemt als voorbeeld HR 13 oktober 2006, RvdW 2006, 941-943 (Vie d'Or).

${ }^{221}$ Rapport Ruimte voor zorgplichten, TK 2003-2004, 29279, nr. 14. 
periode. Zij valt in wezen uiteen in vele concrete zorgverplichtingen, verplichtingen tot concrete zorgdaden. In de rechtspraktijk spreekt men vaak over zorgplichten, terwijl men eigenlijk op zorgverplichtingen doelt. ${ }^{, 222}$

Waar dit het onderwerp van due diligence betreft, werken zorgverplichtingen uit in verplichtingen om onder omstandigheden onderzoek te verrichten of mededelingen te doen. Bij kapitaalmarkttransacties werken de zorgverplichtingen uit in informatieverplichtingen en andere zorgvuldigheidsnormen. Zie ook hierna in hoofdstuk 8.

\section{5}

Dwaling

De in dwaling aangegane overeenkomst komt volgens het eerste lid van artikel 6:228 in drie gevallen voor vernietiging in aanmerking:

a. indien de dwaling is te wijten aan een inlichting van de wederpartij, tenzij deze mocht aannemen dat de overeenkomst ook zonder de inlichting zou worden gesloten. ledere door de wederpartij gegeven inlichting komt als grondslag voor een beroep op dwaling in aanmerking, ongeacht of de wederpartij de onjuistheid ervan kende of moest kennen;

b. $\quad$ indien de wederpartij in verband met hetgeen zij omtrent de dwaling wist of behoorde te weten, de dwalende had behoren in te lichten; ${ }^{223}$

c. indien de wederpartij bij het sluiten van de overeenkomst van dezelfde onjuiste voorstelling als de dwalende is uitgegaan, tenzij zij ook bij een juiste voorstelling van zaken niet had behoeven te begrijpen dat de dwalende daardoor van het sluiten van de overeenkomst zou worden afgehouden.

Een beroep op dwaling is volgens lid 2 van artikel 6:228 uitgesloten indien de dwaling een uitsluitend toekomstige omstandigheid betreft ${ }^{224}$ of voor rekening hoort te blijven van de partij die vernietiging wenst, hetzij omdat partijen dat zijn overeengekomen ${ }^{225}$, hetzij omdat zulks uit de aard van de

222 AA(56) 2007-9, p. 703.

${ }^{223} \mathrm{Bij}$ deze dwalingsgrond wordt doorgaans gesproken van schending van een mededelingsplicht. Zie ook A-G L. Timmerman onder 3.4) in zijn conclusie bij HR 10 oktober 2003, LJN AI0306.

224 Een aansprekend voorbeeld betrof het geschil dat eindigde in een vonnis van de rechtbank te Breda van 22 januari 2003 (LJN AF 3737), over een vordering, gegrond op dwaling ter zake van wat onder oud recht "de persoon" betrof. De eiser had zich ingeschreven bij een relatiebemiddelingsbureau met het oog op zijn wens om een duurzame affectieve relatie aan te gaan met een vrouwelijke partner. Hij kwam door bemiddeling van het bureau in contact met de gedaagde. Na enige tijd een vriendschappelijke relatie te hebben onderhouden, verklaarde de gedaagde een duurzame relatie niet te willen maar zich te willen beperken tot een vriendschappelijke verhouding. In de tussenliggende periode had de eiser uitgaven gedaan door kosten van uitstapjes die hij met gedaagde en haar kinderen ondernam voor zijn rekening te nemen, door huishoudelijke uitgaven ten behoeve van het gezin van gedaagde voor zijn rekening te nemen en door gedaagde en haar kinderen geschenken te geven. Eiser vordert van de gedaagde een bedrag van ruim $€ 5.000,--$, nu hem later was gebleken dat gedaagde beroepsmatig tegen betaling intieme contacten onderhield met een groot aantal regelmatig wisselende mannelijke personen en dat van een bedoeling om tot een duurzame en exclusieve relatie met hem te komen, van haar kant van meet af aan geen sprake was. Hij stelde dat de overeenkomsten waarbij hij ten behoeve van gedaagde goederen voor haar had gekocht en betaald, tot stand waren gekomen onder invloed van dwaling. Indien hij had geweten dat gedaagde niet de bedoeling had om tot een exclusieve relatie te komen, zou hij de betreffende gelden en goederen niet aan haar ter beschikking hebben gesteld, hetgeen gedaagde had behoren te weten. De eiser vorderde ook nog $€ 2.000,--$ als vergoeding voor de emotionele schade die hij had geleden als gevolg van het bedrog door gedaagde. Hij stelde geestelijk te zijn ingestort en zich onder behandeling te hebben moeten stellen van een psychiater. De gedaagde stelde niet tekort te zijn geschoten in een mededelingsplicht omtrent haar werkzaamheden als gezelschapsdame. De rechtbank honoreerde het beroep op dwaling niet. De rechtbank overwoog dat niet kon worden volgehouden dat gedaagde wist of behoorde te weten dat de eiser haar de gestelde schenkingen niet had willen doen indien hij had geweten van haar (neven)werkzaamheden. Het aannemen van een dergelijke wetenschap impliceert de juistheid van de niet in ernst vol te houden stelling dat de uitoefening van het beroep van gezelschapsdame in de weg zou staan aan het kunnen opbouwen van een mogelijk in een duurzame affectieve relatie uitmondende, vriendschapsband, waarin vrijgevigheid tussen partners, van een aard en omvang als in de desbetreffende zaak aan de orde, een normale zaak is. Volgens de rechtbank geldt voor een dame met het beroep als de gedaagde geen mededelingsplicht ten aanzien van het door haar uitgeoefende beroep. De door de eiser gestelde dwaling werd uitgelegd als een teleurstelling in gekoesterde toekomstverwachtingen.

225 Uit de literatuur en de rechtspraak blijkt dat partijen mogen overeenkomen dat een beroep op dwaling zal zijn uitgesloten. Zie J. Hijma in verbintenissenrecht aant. 25 bij artikel 6:228. HR 26 oktober 2007, LJN BA 4494, HR 23 november 2007 , LJN BB3733, en C.T. van der Weij, Dwaling en bedrog bij het sluiten van overnameovereenkomsten, V\&O, p. 52. Een dergelijk beding komt vanzelfsprekend wel in aanmerking voor de algemene toets van artikel 248 lid 2. Zie ook C.E. du Perron en T.H.M. van Wechem. Het uitsluiten van het beroep op dwaling in overnameovereenkomsten: een acceptabele of 
overeenkomst, de verkeersopvattingen of de omstandigheden voortvloeit. Dat de dwalende zelf onvoldoende onderzoek heeft gedaan om een onjuiste voorstelling van zaken te voorkomen, kan aan een beroep op dwaling in de weg staan. ${ }^{226}$

Wel is het belangrijk onderscheid te maken tussen een uitsluitend toekomstige omstandigheid enerzijds en anderzijds een mededeling van de verkoper omtrent een toekomstige omstandigheid. Die mededeling op zichzelf kan waar dit het leerstuk van dwaling betreft, een ander toetsingskader opleveren dan het zich voordoen van een teleurgestelde toekomstverwachting als zodanig.

$\mathrm{Er}$ is onderzocht of de algemene regels ter zake van dwaling (veelal gevormd naar aanleiding van geschillen in de consumentensfeer) eveneens van toepassing zijn op dwaling in het kader van een aandelentransactie. ${ }^{227}$ Aan te nemen valt dat dit in beginsel het geval zal zijn. Verkeersopvattingen kunnen verschillen en de omstandigheden zullen vaak niet volledig hetzelfde zijn als bij consumententransacties.

Het gaat er met betrekking tot de onderzoeksplicht niet om wat de dwalende had kunnen ontdekken, maar om wat hij had behoren te ontdekken. Tegen deze achtergrond heeft de Hoge Raad twee algemene regels ontwikkeld:

1. in de eerste plaats mag men in de regel afgaan op de juistheid van door de wederpartij gedane mededelingen. Er zijn echter uitzonderingen denkbaar, wanneer een mededeling te onbetekenend is om een beroep op dwaling te rechtvaardigen, bijvoorbeeld in geval van aanprijzingen in algemene bewoordingen, onvoldoende gespecificeerde mededelingen, evident onjuiste mededelingen etc. In die gevallen zal de dwaling voor het risico van de dwalende horen te blijven. 2. in de tweede plaats kan de wederpartij die zelf haar mededelingsplicht schond de dwalende in het algemeen niet tegenwerpen dat hij te weinig onderzoek verrichtte.

De mededelingsplicht valt terug te voeren op de bepaling van artikel 6:228 lid 1 sub b. Uit die bepaling kan een gehoudenheid afgeleid worden om inlichtingen te verschaffen omtrent hetgeen iemand in verband met eventuele dwaling wist of behoorde te weten.

Zo leidde op grond van artikel 6:228 jo. 6:230 een vordering op grond van dwaling tot een vermindering van de koopprijs van een woning, omdat de verkoper verzuimd had de koper te informeren omtrent het gedrag van de buren. Na de totstandkoming van de koop bleek dat er sprake was van ernstige overlast doordat de buren voortdurend ruzie maakten, gepaard gaande met schreeuwen, schelden en slaan. Ook bleek er sprake van het inslaan van ruiten en brand in de schuur. "Daarnaast ondervindt de buurt, blijkens de verklaringen van buurtbewoners, overlast van grote groepen vogels die door de buren worden gelokt doordat zij meerdere malen per dag voedsel (patat en bami) buiten zetten." Dergelijke omstandigheden mag een verkoper niet onvermeld laten, ook al heeft deze - zoals in de desbetreffende zaak werd aangevoerd - zelf minder last van een en ander (gehad). ${ }^{228}$

Zoals in het vorige hoofdstuk aan de orde kwam, kan ook het gestelde in artikel 6:228 lid 1 sub a relevantie toekomen. In het arrest Vletter-Stijnman ${ }^{229}$ was degene die zich op dwaling beriep afgegaan op mededelingen van haar wederpartij, waarbij het aannemelijk was dat de overeenkomst waar het om ging zonder de desbetreffende mededeling niet (onder dezelfde voorwaarden) zou zijn gesloten. Het is daarbij - anders dan bij bedrog - geen voorwaarde dat de wederpartij de uitlatingen met een bepaald doel of in een bepaalde context heeft gedaan, maar voldoende is dat de wederpartij kan worden toegerekend dat deze een bepaalde schijn heeft gewekt. Het kan daarom ook zijn, dat bij de dwalende partij - zoals in het geval van de procedure die eindigde met het arrest in de zaak tegen Vletter-Stijnman de onjuiste veronderstelling in het leven is geroepen door opmerkingen die al (geruime tijd) voorafgaand aan het tot stand komen van de transactie werden gedaan. De grens ligt daar waar de weder-

onacceptabele kostenplaats VrA 2004, p. 4-18. Een uitspraak van de Rechtbank te Rotterdam van 12 december 2007 (RCR 2008,30 ), levert een bevestiging op van het feit dat een regeling van de gevolgen van een (eventueel) beroep op dwaling in een overeenkomst wel uitdrukkelijk en duidelijk moet zijn. In de desbetreffende zaak werd aangenomen dat er sprake was van de schending van een mededelingsplicht aan de zijde van de verkoper. Het verweer van de verkoper dat de koper in de overeenkomst verklaarde de woning waar het om ging te hebben geaccepteerd in de staat waarin deze zich ten tijde van het sluiten van de overeenkomst bevond, ging volgens de rechtbank niet op, "aangezien artikel [..] geen specifieke uitsluiting bevat van de mogelijkheid van de koper om zich op dwaling te beroepen.

226 Zie HR 10 oktober 2003 (Dutch Paint), LJN Al 0306

227 Zie M. van Oosten, De onderzoeksplicht bij de koop van aandelen, V\&O februari 2004, nr. 2 , p. 22 e.v.

${ }^{228}$ Zie gerechtshof Amsterdam 8 november 2007, NJF 2008, 88, r.o.3.4.1.

${ }^{229}$ HR 16 juni 2000, NJ 2001, 559. 
partij niet meer hoefde te beseffen dat de bewuste mededeling(en) nog op de besluitvorming van de ander van invloed waren. ${ }^{230}$

Indien is voldaan aan de vereisten van artikel 6:228 lid 1 betekent dat op zichzelf nog niet dat een beroep op dwaling zal slagen. Volgens artikel 6:228 lid 2 kunnen de aard van de overeenkomst, de verkeersopvattingen of de omstandigheden van het geval maken dat de dwaling voor rekening van de dwalende behoort te blijven (dit betreft drie afzonderlijke, gelijkwaardige factoren).

De aard van de overeenkomst, verkeersopvattingen en de omstandigheden van het geval zullen dus in belangrijke mate bepalend zijn voor een antwoord op de vraag of een van de genoemde factoren - en in het voorkomend geval welke van die factoren - kunnen veroorzaken of een dwaling voor rekening van de dwalende behoort te blijven. ${ }^{231}$

De onderzoeksplicht is, zoals eerder opgemerkt niet te herleiden naar een wetsartikel. Uitgangspunt van de onderzoeksplicht is het arrest Van der Beek/Van Dartel. ${ }^{232}$ Met betrekking tot de onderzoeksplicht overwoog de Hoge Raad:

"dat wanneer een partij voor de totstandkoming van een overeenkomst aan de wederpartij bepaalde inlichtingen had behoren te geven teneinde te voorkomen dat de wederpartij zich omtrent het betreffende punt een onjuiste voorstelling zou maken, de goede trouw er zich in het algemeen tegen zal verzetten dat eerstbedoelde partij ter afwering van een beroep op dwaling aanvoert dat de wederpartij het ontstaan van de dwaling mede aan zichzelf heeft te wijten".

De aard van de overeenkomst, verkeersopvattingen en de omstandigheden van het geval kunnen meebrengen dat degene die zich op dwaling beroept zelf een onderzoeksplicht had te vervullen. Wie overweegt om met een ander een overeenkomst aan te gaan, is tegenover diens wederpartij gehouden om binnen redelijke grenzen maatregelen te nemen om te voorkomen dat de transactie op grond van een onjuiste voorstelling van zaken wordt aangegaan. Ook ten aanzien van de onderzoeksplicht geldt dat op de vraag of en zo ja in welke mate een onderzoeksplicht zal worden aangenomen, geen algemeen antwoord mogelijk is. Ook in dit geval zullen de aard van de overeenkomst en de omstandigheden van het geval in belangrijke mate bepalend zijn voor een antwoord op de vraag of een dwaling voor rekening van de dwalende behoort te blijven.

Is aan de vereisten van artikel 6:228 voldaan, dan kan als gezegd de dwalende de overeenkomst vernietigen, maar ook kan deze verzoeken om rechterlijke aanpassing van de gevolgen van de overeenkomst (art. 6:230 lid 2).

Een voorbeeld van dit laatste geval is vermindering van de koopprijs ten behoeve van een dwalende koper. Voor vernietiging is niet vereist dat de dwalende, indien hij wel een juiste voorstelling van zaken had gehad, in het geheel geen overeenkomst zou zijn aangegaan; voldoende is dat hij niet op dezelfde voorwaarden zou hebben gecontracteerd. Een beroep op dwaling kan worden gedaan gedurende drie jaar nadat de dwaling is ontdekt (zie artikel 3:52). ${ }^{233}$ Voor koop geldt een afwijkende regeling (artikel $7: 23$ ). De verjaringstermijn is dan twee jaar na het door de koper - tijdig - gedaan protest. Zie hierna onder 6.4 .

Een recht op schadevergoeding heeft de dwalende alleen als de wederpartij onrechtmatig jegens hem heeft gehandeld, en daarnaast aan de overige vereisten van artikel 6:162 is voldaan. Naar de heersende visie zal de wederpartij die haar mededelingsplicht schond, vrijwel steeds uit onrechtmatige daad kunnen worden aangesproken. In het geval van gegeven inlichtingen zal de wederpartij die foutieve informatie verschaft daarmee vaak onrechtmatig handelen, maar dit hoeft niet altijd het geval te zijn (bijvoorbeeld niet indien de wederpartij meende dat de inlichtingen die deze gaf, juist waren). Ho-

\footnotetext{
${ }^{230}$ Aldus ook Jac. Hijma in zijn noot in NJ 2001, 559. Zie ook C. Bollen, Onjuiste mededelingen en de samenloop tussen dwaling en wanprestatie: de ene mededeling is de andere niet!, NTBR 2004/9, p. 414 e.v.

${ }^{231}$ Zie ook M. van Oosten, De onderzoeksplicht bij de koop van aandelen, V\&O februari 2004, 2, p. 22 e.v.

${ }^{232}$ HR 30-11-1973, NJ 1974, 97.

${ }^{233}$ Zie niettemin HR 15 april 1994, NJ 1995, 614, welke uitspraak duidelijk maakt dat de omstandigheden van het bijzondere geval kunnen maken dat een beroep op dwaling wordt geacht toch niet tijdig te zijn ingesteld, ook al gebeurt dit binnen de door artikel 3:52 genoemde periode van drie jaar. Zie in dit verband ook artikel 6:89. Zie laatstelijk HR 8 februari 2008, LJN $\mathrm{BC} 3880$, waarin werd bevestigd dat de verjaringstermijn eerst een aanvang neemt nadat de dwaling is ontdekt.
} 
ger is opgemerkt, dat een vordering wegens schending van de mededelingsplicht veelal op meerdere grondslagen zal zijn gebaseerd (primair en subsidiair), waaronder artikel 6:162.

Zou een wederpartij een beroep op dwaling willen afweren met de stelling dat deze voorafgaand aan het tot stand komen van de transactie aan diens mededelingsplicht ter zake heeft voldaan, dan komen er vragen van bewijsrecht in het spel. Houdt de wederpartij vol dat er geen onjuiste voorstelling van zaken is gegeven (de stelling is dat er in het geheel geen sprake is van dwaling), dan zal de bewijslast rusten op de partij die stelt te hebben gehandeld op grond van een onjuiste veronderstelling van zaken. ${ }^{234}$

Een ander geval is dat waarin de wederpartij niet tegenspreekt dat er van dwaling sprake kan zijn geweest, maar daarbij zich op het standpunt stelt, dat - in verband met hetgeen de dwaler wél wist of in ieder geval had behoren te begrijpen - een en ander voor rekening van die laatst bedoelde moest blijven. In dat geval zal de wederpartij de bewijslast hebben te dragen, dat de dwalende partij de relevante feiten wel kende of had behoren te kennen. ${ }^{235}$

Het is zoals elders in dit boek ook blijkt, niet mogelijk om in het algemeen aan te geven hoe ver de precieze omvang van de onderzoeks- en mededelingsplicht reikt. Het antwoord op de vraag aan wie in het niemandsland tussen onderzoeksinspanning en informatieverschaffing het risico voor een verkeerde voorstelling van zaken zal worden toebedeeld, zal afhangen van de specifieke omstandigheden van het geval. Het hier voor kort aangestipte leerstuk van de dwaling maakt dat een due diligence onderzoek - waar ook maar enigszins mogelijk en betaalbaar - altijd aan te raden is. De betekenis van het leerstuk van dwaling als achtergrond voor de beslissing om een due diligence onderzoek uit te voeren, is in het vorenstaande, naar ik hoop in ieder geval duidelijk geworden.

\subsection{Conformiteitseis en wanprestatie}

\section{Algemeen}

Een zeker niet minder belangrijke juridische context voor een due diligence onderzoek, vormt het leerstuk van de conformiteit.

Om te bepalen of sprake is van wanprestatie moeten de verplichtingen die voortvloeien uit de overeenkomst worden vastgesteld. Volgens artikel 7:17 moet de verkochte zaak aan de overeenkomst beantwoorden (conformiteitseis). Een zaak beantwoordt op grond van artikel 7:17 lid 2 niet aan de overeenkomst, indien zij niet de eigenschappen bezit die de koper op grond van de overeenkomst mocht verwachten. De koper mag verwachten dat de zaak de eigenschappen bezit die voor een normaal gebruik daarvan nodig zijn en waarvan hij de aanwezigheid niet hoefde te betwijfelen. ${ }^{236}$

\footnotetext{
${ }^{234}$ Zie HR 8 oktober 1999, NJ 1999, 781.

${ }^{235}$ Zie HR 1 juni 1990, NJ 1991, 759.

${ }^{236}$ Een aansprekend geschil over conformiteit is kenbaar uit Rechtbank Haarlem 22 februari 2006, LJN AV 5199, waarbij het in de kern van het geschil ging over de vraag of geleverde geiten ten tijde van de aflevering aan de koopovereenkomst beantwoordden. Met name of, gelet op de aard van de zaak en de mededelingen die de verkoper over de zaak had gedaan, de geiten de eigenschappen bezaten die op grond van de overeenkomst verwacht mochten worden en die nodig waren voor het normale gebruik dat bij de overeenkomst was voorzien. Waarbij het ging om de hoeveelheid melk die van de geiten te verkrijgen was.

Om in de agrarische sector te blijven: de voorzieningenrechter van de rechtbank Arnhem oordeelde op 24 mei 2004 (LJN AP 4372) over de vraag of 'lucht zuigen' een rijpaard ongeschikt maakte voor normaal gebruik. Lucht zuigen is een gedragsafwijking bij paarden, die bijna altijd gepaard gaat met kribbe bijten. Het paard zuigt op een abnormale wijze lucht aan, met als voorkomend gevolg vergroting van de kans op een koliek en in het algemeen een slechtere conditie van het paard. Bij het kribbe bijten zet het paard zijn tanden op bijvoorbeeld de voerbak, waardoor de (voor)tanden van het paard op een voor kribbebijters specifieke manier slijten. Partijen verschilden van mening of op het moment van koop - welke was voorafgegaan aan een veterinaire keuring - aan de tanden van het paard al te zien zou zijn geweest dat het een kribbebijter betrof. De rechtbank achtte dit onvoldoende aangetoond. Het geschil ging over toepassing van artikel 7:18 lid 2, nu binnen een periode van 6 maanden na aflevering het gebrek zich openbaarde. Het betrof een kwaal, dat elk paard binnen een periode van veel korter dan 6 maanden spontaan kon aanleren. Het paard was gekocht op een veiling en de verkoper voerde - als onvoldoende weersproken - aan, dat in de voorwaarden bij de veiling van paarden standaard bedongen wordt dat de verkoper slechts een paar dagen instaat voor een gebrek als lucht zuigen. In het geval van de koop van een woonhuis oordeelde het gerechtshof te 's-Gravenhage op 8 januari 2008 (NJF 2008, 191) dat 'normaal gebruik' betrekking heeft op wat daaronder naar gangbaar spraakgebruik wordt verstaan ten aanzien van de grond alsmede de zich daarop bevindende bebouwing. Ondanks het feit dat het gekochte huis 85 jaar oud was, behoefde volgens het hof de koper daarom niet te verwachten dat het dak in zodanige staat verkeerde dat het woonhuis niet voor normaal gebruik geschikt was.
} 
Artikel 7:17 ziet zowel op de koop van activa/passiva als op de koop van aandelen. Zie artikel 7:47. Het betreft aanvullend recht, zodat de toepasselijkheid van artikel 7:17 kan worden uitgesloten. Een nuance past ter zake van gebreken die de verkoper kende of niet kende, maar hem ernstig te verwijten zijn. A-G Huydecoper merkt ter zake in zijn conclusie bij een arrest van de Hoge Raad van 12 oktober $2007^{237}$ het navolgende op:

"Het lijkt mij aannemelijk dat de ruimte die artikel 7:17 BW biedt voor conctractuele afwijking van de uitgangspunten van het wetsartikel, ongeveer overeenkomt met de ruimte die ook overigens voor bepalingen van "exonorerende" strekking bestaat; en dat daarom de verkoper het risico van "kenbare" gebreken bij de koper mag leggen, voor zover hem geen opzet of ernstige nalatigheid ten aanzien van het kennen en verzwijgen van de desbetreffende gebreken valt te verwijten".

Artikel 7:17 vindt ook toepassing op een koop van aandelen. Zie artikel 7:47, welke bepaling zegt dat een koop ook op een vermogensrecht betrekking kan hebben. In dat geval zijn de bepalingen van de desbetreffende afdeling van toepassing voor zover dit in overeenstemming is met de aard van het recht. ${ }^{239}$ Artikel 7:17 bevat een nadere regeling van de algemeen redelijk geachte verplichting van partijen om hun verbintenissen naar behoren na te komen. De aanvullende werking heeft tot gevolg dat, indien partijen niets omtrent conformiteit bepalen, de regeling ex artikel 7:17 van toepassing is. Uit het vorenstaande volgt dat er wel afspraken denkbaar zijn, die de toepasselijkheid van de desbetreffende regeling uitsluiten. ${ }^{240}$

Het antwoord op de vraag welke eigenschappen de koper op grond van de overeenkomst mocht verwachten is afhankelijk van de omstandigheden van het geval. Soms zal op de koper een onderzoeksplicht rusten, bij niet-nakoming waarvan hem geen beroep op non-conformiteit zal toekomen. Het gaat er namelijk niet alleen om wat de koper heeft verwacht, maar ook om wat hij, alle omstandigheden van het geval in aanmerking genomen, heeft mogen verwachten. Hier zal de over en weer aanwezige deskundigheid van gewicht zijn: net als bij dwaling heeft de professionele koper in de regel een grotere onderzoeksplicht dan een consument. Overigens geldt ook hier wat bij bijna alle dingen geldt, namelijk dat het argument ook kan worden omgedraaid. Hoe deskundiger een koper is, hoe minder aanleiding deze kan zien om een uitgebreid onderzoek in te stellen. Niettemin zal het nalaten van een onderzoek en/of het over het hoofd zien van een gebrek, een deskundige koper zwaar(der) worden aangerekend.

De vraag wat de koper mag verwachten wordt mede beïnvloed door eventuele mededelingen die de verkoper omtrent de zaak heeft gedaan. Er kunnen drie gradaties van mededelingen worden onderscheiden: ${ }^{241}$

1. blote mededelingen, die onvoldoende gewicht hebben om via de conformiteitsregel tot contractsinhoud te worden;

2. serieuze mededelingen, die wel van voldoende gewicht zijn om bij onjuistheid het non-conformiteitsoordeel met de daaraan voor koper verbonden rechtsmiddelen te dragen;

\footnotetext{
${ }^{237}$ LJN BA7630 (onder 10 en in noot 9 bij zijn conclusie)

${ }^{238}$ De A-G verwijst daarbij ook naar Huijgen, Koop en verkoop van onroerende zaken, 2003, par. 22d.

239 De toepasselijkheid van artikel 7:17 op een aandelentransactie is in het verleden wel eens in twijfel getrokken (zie M.P.P. de Planque, Non-conformiteitsvereiste bij overnames, V\&O 2000, p. 190), of heel genuanceerd benaderd, zie B. Wessels, Koop: algemeen, Monografieën Nieuw BW B65a, nummer 83, maar inmiddels is de toepasselijkheid niet langer aan twijfel onderhevig. Zie hof 's-Hertogenbosch 17 december 2002, JOR 2003, 54 en E.A. Brat en S.W. Claassen, Toepasselijkheid Titel 1 Boek 7 BW (koop) of verkoop van aandelen; consequenties voor de overnamepraktijk, Bb 24 juli 2003, nr. 14, p. 108 e.v.

Zie ook Rechtbank Utrecht 14 juni 2006, JOR 2006, 228 en de annotaties daarbij van T.H.M. van Wechem in Actualia Contractspraktijk in Contracteren 2006/4 p. 83 e.v.

Enige twijfel houdt nog de rechtbank Utrecht. Zie de uitspraak van 24 oktober 2007 (LJN: BB6509), waarin de rechtbank zich nog afvroeg of de aard van het vermogensrecht dat uit een aandeel bestaat, 'al dan niet aan een beroep op non-conformiteit in de weg staat'. Deze uitspraak staat inmiddels desondanks alleen.

${ }^{240}$ Het feit dat het om een koop van aandelen gaat, kan de klachttermijn beïnvloeden. Zie Rechtbank Alkmaar 30 januari 2008, LJN BC5954, r.o. 4.2.: "Voldoende aannemelijk is het betoog van [..] dat zij eerst tot onderzoek is overgegaan nadat bij haar het beeld was ontstaan dat de omzetgegevens niet overeenstemden met het beeld dat zij zich op basis van de aan de koop voorafgaande stukken had gevormd. Wanneer zich het moment heeft voorgedaan waarop [..] het ontbreken van de gestelde eigenschap redelijkerwijs had behoren te ontdekken kan niet exact worden vastgesteld, maar in de omstandigheden van dit geval lijkt een periode van zes á zeven maanden na de aandelenoverdracht begrijpelijk."

241 Asser Hijma, 5-I, 333
} 
3. toezeggingen en garanties. Garanties kunnen zowel uitdrukkelijk (schriftelijk en mondeling) als stilzwijgend worden verleend. In geval van toezeggingen en garanties is het reeds de toezegging of garantie zelf die meebrengt dat in geval van 'wangarantie' de verkoper jegens de koper aansprakelijk zal zijn.

In de regel zal de koper op het hem door de verkoper gemelde mogen vertrouwen: hij mag verwachten dat wanneer hem informatie wordt gegeven, deze met de werkelijkheid overeenstemt. De verkoper die een op hem rustende mededelingsplicht heeft geschonden, zal zich in het algemeen niet met succes tegen een beroep op non-conformiteit kunnen verweren, met de stelling dat de koper zelf maar nader onderzoek naar de bewuste eigenschap had moeten verrichten. Net als bij dwaling zal de schending van een mededelingsplicht door de verkoper in het algemeen eventuele nalatigheden aan de zijde van de koper in de schaduw stellen.

Van Wechem ${ }^{242}$ neigt ernaar om bij het leerstuk van conformiteit de nadruk bij de onderzoeksplicht van de koper te leggen. Volgens hem volgt dit uit de tekst van de wet. Hij ziet slechts ruimte voor een mededelingsplicht van de verkoper wanneer dat uit de overeenkomst zou voortvloeien. Aan de hand van de Haviltex-doctrine of aan de hand van regels ter zake van de aanvullende werking van redelijkheid en billijkheid dient dan te worden vastgesteld of er van een mededelingsplicht sprake had moeten zijn. Wanneer partijen afspraken op schrift gesteld hebben, dient volgens hem eerst te worden vastgesteld of die afspraak in de plaats komt van artikel 7:17 doordat in die afspraak van de inhoud van die wetsbepaling wordt afgeweken. Volgens artikel 7:17 dient de zaak de eigenschappen te bezitten die de koper op grond van de overeenkomst mag verwachten. De vraag die dan volgens Van Wechem nog ter beantwoording ligt, is of via uitleg moet worden vastgesteld of partijen van artikel 7:17 hebben willen afwijken (door bijvoorbeeld het contractueel opnemen van een andere definitie van gebrek) of dat artikel 7:17 ook normstellend is binnen de toepassing van de Haviltex-doctrine. Hij is in ieder geval van oordeel dat toepassing van de enkele bepaling van artikel 7:17 niet kan meebrengen dat er een mededelingsplicht aanwezig is. In artikel 7:17 ligt die volgens hem niet besloten. Het gaat volgens hem immers om eigenschappen van de zaak. Niet gedane mededelingen van de verkoper zouden daar niet aan af kunnen doen. Mij dunkt dat deze benadering wat te beperkt is. Zowel het niet doen van mededelingen als het doen van mededelingen kunnen onder omstandigheden immers de uitkomst van onderhandelingen en dus de inhoud van de overeenkomst bepalen. Lid 2 van artikel 7:17 brengt dan denkbaar geen mededelingsplicht mee, maar dat maakt mededelingen van de verkoper of het achterwege laten daarvan niet minder relevant voor de vraag wat de koper als conformiteit mag verwachten ten opzichte van het overeengekomene. In zoverre is de door Van Wechem geconstateerde neiging in literatuur en rechtspraak ${ }^{243}$ om de in het kader van dwaling geformuleerde regels van overeenkomstige toepassing te verklaren bij een beroep van een koper op non-conformiteit, niet zo verbazend.

De conformiteitseis zal met name een rol (kunnen) vervullen bij gebreken, welke men niet behoefde te verwachten in verband met een normaal gebruik. Geen soelaas zal van een beroep op de conformiteitseis kunnen worden verwacht, wanneer de verkoper de koper voorafgaand aan de koop mededelingen heeft gedaan van de gebreken waar het over gaat, dan wel de koper die gebreken voor of uiterlijk bij de koop heeft ontdekt, dan wel op grond van bijzondere omstandigheden van het geval, van de gebreken weet behoorde te hebben. ${ }^{244} \mathrm{lk}$ refereer hierbij ook aan de zogenaamde disclosure letter, waarover meer hierna in hoofdstuk 7.2.

Een vordering tot schadevergoeding - waarop artikel 6:74 lid 1 en 75 van toepassing zijn, zal alleen toewijsbaar zijn, indien de tekortkoming - bestaande uit levering van een non-conforme prestatie - aan de verkoper kan worden toegerekend. ${ }^{245}$

De winstgevendheid van een onderneming werd door de rechtbank te Amsterdam op 13 maart 2002 niet aangemerkt als een eigenschap als bedoeld in artikel 7:17. ${ }^{246}$

Volgens artikel 7:17 lid 5 kan de koper zich er niet op beroepen dat een zaak niet aan de overeenkomst beantwoordt, wanneer hem dit ten tijde van het sluiten van de overeenkomst bekend was of re-

\footnotetext{
${ }^{242}$ Th.M. van Wechem, De verhouding tussen mededelings- en informatieplichten, de betekenis van contractuele afspraken en de rol van artikel 7:17 BW hierbij en kan een beroep op dwaling contractueel worden uitgesloten, Contracteren 2008, p. 19 e.v.

${ }^{243}$ A.W. p. 21

${ }^{244}$ Zie bijvoorbeeld gerechtshof Arnhem 11 april 2006, NJF 2006, 247.

${ }^{245}$ Zie HR 9 januari 1998, NJ 1998, 272 en gerechtshof Leeuwarden 31 augustus 2005, LJN AU1876.

${ }^{246}$ Kenbaar uit HR 7 september 2007, LJN BA2014.
} 
delijkerwijs bekend kon zijn. Wanneer nu kan een koper geacht worden ergens redelijkerwijs mee bekend te zijn? Volgens de memorie van toelichting ${ }^{247}$ zal dit het geval kunnen zijn wanneer de koper redelijkerwijs niet onbekend kon zijn met het gebrek. Het gaat daarbij om gevallen waarin niet met zoveel woorden bewezen kan worden dat de koper iets wist, maar het er toch wel erg dik op ligt dat dit wel het geval was.

Hoewel op overeenkomsten artikel 6:74 e.v. vanzelfsprekend van toepassing zijn, wordt bij koop en verkoop artikel 7:17 als een 'lex specialis' gezien. Derhalve wordt conformiteit wel als element betrokken bij de vraag of er een mededelingsplicht aan de zijde van de verkoper bestaat. Met name wanneer er toezeggingen of garanties zijn gedaan zullen die bijdragen aan het geven van inhoud aan de verwachting welke later kan worden afgemeten als het al dan niet ontbreken van conformiteit. Opvallend is dat het thema van conformiteit wordt betrokken bij de vraag of garanties wel of niet worden nagekomen. De verklaring zal zijn dat artikel 7:17 als een 'lexus specialis' wordt gezien ten opzichte van de algemene bepalingen met betrekking tot niet nakoming. Van Uchelen beschreef het als volgt: "Garanties vullen de conformiteit in en bepalen (na eventuele uitleg conform de Haviltex-formule) wat de koper van de gekochte aandelen en onderneming mocht verwachten (...) wanneer de verkoper vóór het sluiten van de overeenkomst nalaat mee te delen dat bepaalde garanties niet juist zijn (of dat nu bewust gebeurt of niet maakt mijns inziens niet uit), beantwoordt het gekochte niet aan de overeenkomst dan heeft de koper een vordering jegens de verkoper wegens non-conformiteit. Die vordering komt echter oorspronkelijk voort uit het niet nakomen van de mededelingsplicht door de verkoper.,"248 $V a n$ Uchelen schreef het vorenstaande naar aanleiding van een arrest van de Hoge Raad van 23 januari $2004 .{ }^{249}$ In dat arrest ging het om een verkoper die de garantie had gegeven dat met betrekking tot het verkochte die informatie was verschaft die naar geldende verkeersopvattingen door hem ter kennis van de koper behoorde te worden gebracht, waaronder mede begrepen de laatste goedgekeurde jaarrekeningen van de verkochte vennootschappen. Er bleek achteraf sprake van veel afwijking tussen de gepresenteerde cijfers - waarvan de verkoper nadrukkelijk stelde dat die niet meer dan een prognose hadden betroffen - en de actuele cijfers. De Hoge Raad besliste dat mede in het licht van de verplichting welke de verkoper op zich had genomen om de informatie te geven welke naar verkeersopvattingen behoorde te worden gegeven en mede gelet op het feit dat een balansgarantie was gegeven, de weergave van het vermogen en de resultaten van de verkochte vennootschappen bewust onjuist was geweest.

Slaagt een beroep op wanprestatie, dan kan een overeenkomst ontbonden worden, en kan daarnaast schadevergoeding gevorderd worden. Wanneer er sprake is van wederzijdse wanprestatie, kan het zich voordoen dat beide partijen bevoegd zijn de overeenkomst te ontbinden. Een beroep op een opschortingsrecht doet daar niets aan af. Bij de regeling van het opschortingsrecht is door de wetgever niet onder ogen gezien dat het voorkomen dat partijen gehouden zijn tot 'gelijk oversteken', maar onafhankelijk van elkaar op het beslissende tijdstip geen van beide kunnen nakomen. In een zodanig geval moet worden aangenomen dat beide partijen op grond van de tekortkoming in de nakoming van de prestatie van de ander bevoegd zijn tot ontbinding. Het doet er dan niet toe bij welke partij de nakoming het eerst schort, omdat de beantwoording van die vraag alleen maar zin heeft wanneer (ten minste) een van beide partijen wel tot nakoming in staat is, maar die nakoming opschort wegens het niet presteren van de andere partij. ${ }^{250}$

\section{Klachtplicht koper}

\footnotetext{
${ }^{247}$ Kamerstukken II, 27809, nr. 3, p. 6. Zie anderzijds het gerechtshof te 's-Gravenhage, waarin de koper van een huis met de klacht dat het dak lekte, eerst zo'n 7 maanden na de levering bij de verkoper aanklopte. Dat werd te laat bevonden. Het betoog dat eerst door hevige regenval zo'n 5 maanden na de levering de lekkage was gebleken, werd van de hand gewezen op de grond dat het ook voordien al enkele malen hard had gerekend. Zie gerechtshof 's-Gravenhage, 27 maart 2008, NJF 2008, 202.

${ }^{248}$ P.J. van Uchelen, Bestuurdersaansprakelijkheid in geval van schending van de mededelingsplicht bij bedrijfsovername, Ondernemingsrecht 2004-6, p. 230.

${ }^{249}$ LJN AL7051 (Stratex). Zie over deze uitspraak ook P.J. van Uchelen, Bestuurdersaansprakelijkheid ingeval van schending van de mededelingsplicht bij bedrifsovername, Ondernemingsrecht 2004-6, p.229 e.v. en M. Jansen, Pont Eecen N.V./ Stratex B.V., BB 10 juni 2004-12, p. 17 e.v.

250 Zie HR 11 januari 2008, RCR 2008, 23.
} 
In verband met het vorenstaande is artikel 7:23 van belang (klachtplicht koper). Een koper kan geen beroep meer doen op het conformiteitsvereiste, indien hij de verkoper niet binnen bekwame tijd nadat hij heeft ontdekt of redelijkerwijs had behoren te ontdekken dat het afgeleverde niet aan de overeenkomst beantwoordde, aan de koper heeft gemeld. Blijkt aan de zaak een eigenschap te ontbreken die deze volgens de verkoper wel bezat, of heeft afwijking betrekking op feiten die de verkoper kende of behoorde te kennen doch die hij niet heeft meegedeeld, dan moet de kennisgeving binnen bekwame tijd na de ontdekking geschieden. In feite betreft het hier een onderzoeksplicht van de koper na het tot stand komen van de transactie en het voldoen aan de daarbij overeengekomen verbintenissen door de verkoper.

Artikel 7:23 lid 1 heeft de strekking de verkoper te behoeden voor late en moeilijk meer te betwisten klachten, door voor te schrijven dat de koper, op straffe van verval van zijn rechten, zijn klachten tot de verkoper moet richten binnen zo korte termijn als in de gegeven omstandigheden in verband met zijn onderzoeksplicht van hem kan worden gevergd. De verkoper moet erop kunnen rekenen dat de koper met bekwame spoed onderzoekt of doet onderzoeken (bijvoorbeeld met behulp van deskundigen) of de prestatie aan de verbintenis beantwoordt en indien dit niet het geval blijkt te zijn, dat dit met spoed aan de verkoper wordt meegedeeld. Aangenomen wordt dat aan de inhoud en strekking van deze bedoeling geen recht wordt gedaan indien alleen maar aan de verkoper wordt meegedeeld dat er sprake is van gebreken, zonder deze gebreken - zo spoedig als mogelijk is - nader te concretiseren. ${ }^{251}$

Belangrijk is dat rechtsvorderingen en verweren, gegrond op feiten die de stelling zouden rechtvaardigen dat de afgeleverde zaak niet aan een overeenkomst beantwoordt, verjaren door verloop van twee jaren na de overeenkomstig het eerste lid gedane kennisgeving. Dit is een lex specialis ten opzichte van artikel 6:228 jo. artikel 3:52. De koper behoudt de bevoegdheid om aan een vordering tot betaling van de prijs zijn recht op vermindering daarvan door gedeeltelijke ontbinding van de koop of op schadevergoeding tegen te werpen. De termijn loopt niet zo lang de koper zijn rechten niet kan uitoefenen als gevolg van opzet van de verkoper.

Het begrip binnen bekwame tijd wordt ingevuld aan de hand van de omstandigheden als de aard van het gekochte, de waarneembaarheid van het gebrek, de wijze waarop dit aan het licht treedt, de deskundigheid, onderlinge verhouding en juridische kennis van de betrokkenen. ${ }^{252}$ De vraag of de koper binnen bekwame tijd als bedoeld in artikel 7:23 lid 1 heeft gereclameerd over gebreken aan de afgeleverde zaak, kan niet in algemene zin worden beantwoord. Op de koper rust een onderzoeks- en een mededelingsplicht. Niet ongebruikelijk is het dat een periode van twee maanden wordt aangehouden, waarbinnen er moet zijn geklaagd, wil er sprake zijn van bekwame spoed in de zin van artikel 7:23. ${ }^{253}$ Deze termijn geldt in ieder geval als norm in het geval van consumentenkoop (artikel 7:23 lid 1 derde zin). De tijd wordt gerekend vanaf het moment dat een gebrek wordt vastgesteld. ${ }^{254}$ De verjaringstermijn van artikel 7:23 lid 2 geldt voor iedere rechtsvordering van de koper die - en ieder verweer van de koper dat - feitelijk gegrond is op het niet beantwoorden van de afgeleverde zaak aan de overeenkomst, ook indien door de koper op deze grondslag (tevens) een rechtsvordering uit onrechtmatige daad wordt gebaseerd. ${ }^{255}$

Er is in het geval van de toepassing van artikel 7:17 jo. 7:23 lid 1 dus sprake van ook een (ander soort) onderzoeks- en mededelingsplicht. Een koper dient bij het verkrijgen van de zaak een van deze redelijkerwijze te verwachten onderzoek in te stellen voor de beantwoording van de vraag of de hem afgeleverde zaak aan de overeenkomst beantwoordt. Mocht dit niet het geval zijn, dan zal deze in een bekwame tijd nadat hij heeft ontdekt of bij een dergelijk onderzoek had behoren te ontdekken, dat de

\footnotetext{
${ }^{251}$ Zie gerechtshof Leeuwarden 30 januari 2008, LJN BC3421

252 Zie bijvoorbeeld HR 5 april 1968, NJ 1968, 251 (Pekingeenden) en Rechtbank Arnhem 23 mei 2002, kenbaar uit HR 2 juni 2006, LJN AW6612, alsmede N.W.A. Tollenaar, Beschouwingen over artikel 6:89 en 7:23 BW in het bijzonder bij aandelenkoop, NTBR 2005, 74. Zie met name HR 29 juni 2007, RvdW 2007, 636.

${ }^{253}$ Zie voor een recente bevestiging van de gedachte dat de twee maanden een norm is, Rechtbank Amsterdam 5 september 2007, Praktijkgids 2008-1 nummer 2.

254 Zie gerechtshof 's-Hertogenbosch 20 maart 2001, NJ 2002, 67 en gerechtshof 's-Hertogenbosch 31 januari 2006, NJF 2006, 295. In een uitspraak van de Rechtbank Arnhem van 31 oktober 2007 (LJN BB7535) werd het beroep op een klacht drie jaar na oplevering (van een schip) alsnog ontvankelijk geacht. De rechtbank overwoog dat het een klacht betrof die weliswaar drie jaar na de oplevering werd ingediend, "maar die lange duur is inherent aan de aard van het gebrek, zoals dat ook volgt uit het rapport van Studio Yaught, waarin is neergelegd dat de constructie van een schip niet meteen zal bezwijken, maar na verloop van tijd eerst zal vervormen, waardoor een herverdeling van de belasting optreedt". Het werd ook redelijk geacht dat er na het constateren van de gebreken eerst door een deskundig bureau een onderzoek was uitgevoerd. Nadat de resultaten van het onderzoek bekend werden, is er voortvarend van de klacht kennis gegeven aan de leverancier.

255 Zie HR 21 april 2006, NJ 2006, 272
} 
afgeleverde zaak niet aan de overeenkomst beantwoordt, de verkoper daarvan in kennis moeten stellen. In een arrest van 29 juni $2007^{256}$ ging de Hoge Raad in op de vraag met welke termijnen er bij de hiervoor bedoelde onderzoeksplicht en de daarmee denkbaar samenhangende mededelingsplicht hebben te gelden:

"De lengte van de termijn voor het instellen van een onderzoek is afhankelijk van de omstandigheden van het geval. Dat onderzoek dient, gelet op de door artikel 7:23 lid 1 beschermde belangen van de verkoper, door de koper te worden ingesteld en uitgevoerd met de voortvarendheid die gelet op de omstandigheden van het geval in redelijkheid van hem kan worden gevergd. In dat verband kunnen onder meer van belang zijn de aard en de waarneembaarheid van het gebrek, de wijze waarop dit aan het licht treedt en de deskundigheid van de koper. Onder omstandigheden kan voor beantwoording van de vraag of de afgeleverde zaak aan de overeenkomst beantwoordt, een onderzoek door een deskundige nodig zijn (zie ook Parl. Gesch. Boek 7 (Inv. 3, 5 en 6), blz. 157). In beginsel mag de koper de uitslag van dit onderzoek afwachten zonder de verkoper van het onderzoek op de hoogte te brengen. Wanneer echter mag worden verwacht dat met het onderzoek langere tijd is gemoeid of zulks tijdens de loop daarvan blijkt, volgt uit de strekking van artikel 7:23 lid 1 dat de koper aan zijn wederpartij onverwijld kennis dient te geven van dat onderzoek en de verwachte duur ervan.

Wat de lengte van de termijn voor het doen van mededelingen betreft, is voor het geval van consumentenkoop in de derde zin van artikel 7:23 lid 1 bepaald dat kennisgeving binnen een termijn van twee maanden na de ontdekking tijdig is.

In het geval van een niet-consumentenkoop dient de vraag of de kennisgeving binnen bekwame tijd is geschied te worden beantwoord onder afweging van alle betrokken belangen en met inachtneming van alle relevante omstandigheden, waaronder het antwoord op de vraag of de verkoper nadeel lijdt door de lengte van de in acht genomen klachttermijn. Een vaste termijn kan daarbij niet worden gehanteerd, ook niet als uitgangspunt". 257

De Hoge Raad neemt in het arrest van 29 juni 2007 als uitgangspunt dat - waar het de mededelingsplicht van een geconstateerd gebrek betreft - bij consumentenkoop een kennisgeving binnen een termijn van twee maanden na ontdekking als tijdig geldt (r.o 3.3.4.). Dit is gebaseerd op de regel van artikel 7:23 lid 1 derde zin. Over wat in het geval van niet-consumenten koop heeft te gelden wordt gezegd:

"In het geval van niet-consumentenkoop dient de vraag of de kennisgeving binnen bekwame tijd is geschied te worden beantwoord onder afweging van alle betrokken belangen en met inachtneming van alle relevante omstandigheden, waaronder het antwoord op de vraag of de verkoper nadeel lijdt door de lengte van de in acht genomen

\footnotetext{
${ }^{256}$ HR 29 juni 2007, JOR 2007, 260 m.nt. J.J. Dammingh (r.o. 3.3.3).

257 De Rechtbank Groningen besliste op 14 februari 2007 (NJF 2007, 343) dat de strekking van artikel 7:23 is dat de verkoper van een zaak beschermd wordt tegen te late en daardoor moeilijker te betwisten klachten. De termijn die de koper heeft, hangt volgens de rechtbank onder meer af van de mate van waarneembaarheid van het gebrek. Pas als de koper voldoende zekerheid heeft dat een zaak niet aan de overeenkomst beantwoordt, zal hij daarover binnen bekwame tijd bij de verkoper moeten klagen. Zie ook gerechtshof Leeuwarden 30 januari 2008, NJF 2008, 125, waarin werd uitgemaakt dat aan de inhoud en strekking van artikel 7:23 geen recht wordt gedaan indien slechts aan de schuldenaar wordt meegedeeld dat er sprake is van gebreken, zonder deze gebreken zo spoedig als mogelijk is nader te concretiseren. Volgens het hof hangt de lengte van de onderzoekstermijn af van de omstandigheden van het geval. Indien een onderzoek van een deskundige nodig is mag de koper de uitslag van het onderzoek afwachten. De opmerkelijke overweging is echter vooral, dat uit de strekking van artikel 6:23 lid 1 volgt dat de koper aan zijn wederpartij onverwijld kennis dient te geven van het gegeven dat een onderzoek langere tijd vergt dan voorzien. Bovendien moet dan mededeling worden gedaan van de verwachte duur daarvan. In het onderhavige geval werd aangenomen dat niet tijdig was geklaagd. Vergelijk ook hof Den Haag 31 januari 2008, NJF 2008, 122. Na het verkrijgen van een tweede onderzoeksrapport hadden de betrokkenen negen maanden laten verstrijken voordat zij de wederpartij in kennis stelden van het nader onderzoek. Het hof oordeelde dat dit te laat was. Een ander voorbeeld wordt gevonden in de uitspraak van de rechtbank Leeuwarden van 19 maart 2008, NJF 2008, 218. De tijdspanne tussen het eerste moment van het ontdekken van bouwkundige gebreken aan een gekocht hotel in juli 2005 en de melding in april 2006 vormde voor de rechtbank aanleiding de beschermingsgedachte in het belang van de verkoper te laten prevaleren. De rechtbank woog onder meer de aanvankelijk overeengekomen klachttermijn mee (twee maanden), maar ook de aard van een verbouwing welke had plaatsgevonden en de wijze waarop de koper aan het einde van de verbouwing op weinig concrete wijze haar melding had onderbouwd.
} 
klachttermijn. Een vaste termijn kan daarbij niet worden gehanteerd, ook niet als uitgangspunt."

De koper is bevoegd om eerst het advies van een deskundige in te winnen, alvorens hij de verkoper heeft te informeren. Bij een eerste vermoeden hoeft nog niet direct te worden geappelleerd. De klachttermijn neemt een aanvang zodra de koper - denkbaar nadat eerst door een deskundige een onderzoek heeft plaatsgevonden - met voldoende zekerheid weet of er van mag uitgaan, dat de geleverde zaak niet aan de koopovereenkomst beantwoordt. Dat kan het moment zijn waarop een te entameren onderzoek op een ernstig vermoeden gebaseerd is. In het hier voor genoemde arrest van de Hoge Raad van 29 juni lijkt alleen het te verwachten tijdsverloop dat met een onderzoek gemoeid kan zijn te worden bedoeld als aanleiding om wel de verkoper te berichten, maar ik kan mij voorstellen dat de ernst van het vermoeden, lees: de aanleiding voor een onderzoek zodanig kan zijn, dat ook in dat geval niet gewacht mag worden met een kennisgeving aan de verkoper. De Hoge Raad zegt, dat "in beginsel" de uitslag van een onderzoek afgewacht mag worden zonder kennisgeving aan de verkoper. Mij dunkt, dat een bericht aan de verkoper 'voor de zekerheid' nooit weg is, hoewel ik met deze opmerking Drion bedien, waar het de portee van zijn hierna te bespreken bijdrage aan het NJB betreft.

Een toepassing van het vorenstaande deed zich voor bij de aanschaf van een papagaai, die bestemd was om mee te kweken. Dat kweken moest volgens de koopovereenkomst worden gerekend tot het normale gebruik. Na ontvangst van de vogel liet de koper die door een in vogelgeneeskunde gespecialiseerde dierenarts onderzoeken. De vogel werd gezond bevonden. De verkoper werd hiervan mededeling gedaan en dat bleek later het beslissende aspect. Ongeveer een week na het veterinair onderzoek begon de vogel gedragsafwijkingen te vertonen (met een poot over een neer hangende vleugel te stappen). De opnieuw geraadpleegde dierenarts adviseerde om een en ander even aan te kijken en nadat de koper in de maand daarop nog twee maal de dierenarts had gebeld over het zelfde probleem kwam die de vogel bij de koper thuis observeren. Geconstateerd werd dat de vogel een afwijking had die het dier ongeschikt maakte om als kweekvogel te worden ingezet. Na afronding van dat onderzoek werd de verkoper van het gebrek in de overeengekomen conformiteit in kennis gesteld. Het verweer van de verkoper, dat de koper niet tijdig had gereclameerd werd door de rechtbank te Haarlem ${ }^{258}$ gehonoreerd. De rechter meende dat er niet binnen bekwame tijd was geklaagd:

"Bij het bepalen van de termijn die de koper daarvoor ten dienste staat zal zeker rekening mogen worden gehouden met de noodzaak om ter zake deskundig advies in te winnen, voordat hij zijn klacht ter kennis van de verkoper brengt. Maar dat neemt niet weg dat de koper de verkoper in de tussentijd niet zo maar geheel in het ongewisse mag laten, zeker als dat onderzoek de nodige tijd vergt. In zo'n geval zal de koper de verkoper tenminste op de hoogte behoren te brengen van het onderzoek, waarbij hij zich alle rechten voorbehoudt, waarna de uitslag van het onderzoek natuurlijk alsnog met bekwame spoed aan de verkoper moet worden bekendgemaakt."

De koper kan een gebrek dat (eerst) na het uitbrengen van een ontbindingsverklaring aan het licht is gekomen, mede ten grondslag leggen aan zijn stelling dat de tekortkoming van de verkoper ernstig genoeg is om een ontbinding te rechtvaardigen. De Hoge Raad overwoog in het elders vaker genoemde arrest van 29 juni 2007: ${ }^{259}$

"Indien [...] een buitengerechtelijke ontbindingsverklaring is uitgebracht en ten tijde daarvan een bepaald gebrek van de afgeleverde zaak nog niet aan het licht was getreden, zodat dit niet mede aan de ontbinding ten grondslag is gelegd, kan ook dit alsnog aan het licht gekomen gebrek - op zich zelf dan wel in samenhang met de in de ontbindingsverklaring genoemde gebreken - van belang zijn voor de beoordeling of de ontbinding gerechtvaardigd is, mits ook ten aanzien van dit gebrek is voldaan aan de eisen van artikel 6:265 lid 2 en 7:23 BW. Hier is een nieuw gebrek van de afgeleverde zaak aan het licht getreden nadat de procedure aanhangig was gemaakt. In een dergelijk geval kan een ingevolge artikel 6:265 en/of artikel 7:23 BW vereiste verklaring van de koper jegens de verkoper ook besloten liggen in enig processtuk van zijn zijde."

\footnotetext{
${ }^{258}$ Sector Kanton, Kantonrechter te Zaandam 13 december 2007, Prg.. 2008, 68.

${ }^{259}$ RvdW 2007, 634 (r.o. 3.6).
} 
Gelet op het element van bescherming van de verkoper - die er op moet kunnen rekenen dat de koper met bekwame spoed onderzoekt of de prestatie aan de verbintenis beantwoordt - geldt ook het volgende. Wanneer de verkoper een zaak opnieuw aflevert nadat hij daaraan herstelwerkzaamheden heeft verricht op verzoek of na sommatie van de koper, zal bij blijvende gebreken de koper opnieuw met bekwame spoed moeten ageren. Volgens ons hoogste rechtscollege verdient de verkoper ook bescherming tegen te late en daardoor moeilijk te betwisten klachten over door hem verrichte herstelwerkzaamheden. ${ }^{260}$

Voor iedere door de koper in te stellen (feitelijk) op non-conformiteit gebaseerde rechtsvordering geldt dat deze krachtens artikel 7:23 lid 2 aan een verjaringstermijn van slechts twee jaar is onderworpen. Deze termijn vangt aan na de kennisgeving aan de verkoper als bedoeld in artikel 7:23 lid 1. Indien er sprake is van een vordering die feitelijk gegrond is op het niet beantwoorden van de geleverde zaak aan de koopovereenkomst, zal de koper dus na het verstrijken van de bedoelde termijn van twee jaar ook geen vordering meer kunnen instellen op grond van dwaling of onrechtmatige daad. ${ }^{261}$

Ook artikel 7:23 kan contractueel worden uitgesloten, nu er bij de koop en verkoop van aandelen (ook door particulieren) geen sprake is van consumentenkoop (artikel 7:5 lid 1 jo. 6 lid 1). Indien een partij van de hiervoor bedoelde meldingsplicht af wil, zou deze niet alleen artikel 7:23 contractueel moeten zien uit te sluiten, maar tevens artikel 6:89. Er kan anders immers onduidelijkheid ontstaan door de uitsluiting van de lex specialis of partijen niet toch bedoeld hebben wel de algemene regel van artikel 6:89 van toepassing te hebben willen laten blijven. Ook het niet tijdig ageren op grond van artikel 6:89 kan immers tot verlies van rechten aanleiding geven. ${ }^{262}$

Valk is ingegaan op de vraag op wie van partijen de bewijslast rust indien de verkoper aanvoert dat niet tijdig is geprotesteerd, maar de koper beweert dat deze dat wel heeft gedaan. Met verwijzing naar rechtspraak en literatuur bestrijdt hij de overweging van de Hoge Raad in een arrest van 23 november $2007,{ }^{263}$ waarin wordt geconcludeerd dat de koper de plicht heeft te stellen, en bij gemotiveerde betwisting te bewijzen, dat en op welke wijze deze voor op een voor de verkoper kenbare wijze heeft geklaagd over een tekortkoming. Hij meent dat de Hoge Raad het verkeerd ziet omdat de consequentie van de opvatting van de Hoge Raad zou zijn dat de rechter ambtshalve mag en zou moeten toetsen of aan de stelplicht is voldaan als aan beantwoording van de vraag kan worden toegekomen of er feiten zijn gesteld waaruit het verzuim van de schuldenaar voortvloeit. ${ }^{264}$ Valk meent dat het onevenwichtig is om de koper ook de last op te leggen te bewijzen dat hij tijdig heeft geprotesteerd op het gevaar af dat de koper dat niet kan en met lege handen blijft staan, hoezeer deze ook in staat kan zijn om wel te bewijzen dat van een tekortkoming sprake is geweest. Mij dunkt dat het standpunt van de Hoge Raad toch de voorkeur verdient. Indien volstaan zou kunnen worden met de vervulling van de bewijslast dat er van een tekortkoming sprake is geweest, kunnen de door artikel 6:89 en 7:23 lid 1 beoogde doelstellingen van bescherming van de positie van de verkoper, beter worden vergeten. Die dreigt dan immers voor vrijwel onbeperkte tijd geconfronteerd te kunnen worden met vorderingen wegens tekortkoming en opgescheept te raken met de bewijslast om aan te tonen dat de koper binnen bekwame tijd heeft gereageerd.

Drion ${ }^{265}$ vraagt zich af of wij in ons land niet afstevenen op een klaagcultuur, omdat - wanneer de rechter het al dan niet voldaan zijn aan de klachtplicht niet ambtshalve zou mogen toetsen - iedereen die geen verlies van rechten wil riskeren, aantoonbaar zeker moet stellen, dat er tijdig is gereclameerd. Hij constateert in ieder geval dat er sprake lijkt te zijn van een toegenomen bewustzijn waar het de betekenis voor de rechtspraktijk betreft van de artikelen 7:23 en 6:89. Hij formuleert tegelijkertijd een aantal vragen, die volgens hem het overdenken waard zijn, en waar de Hoge Raad in vervolguitspraken aandacht aan zou kunnen schenken: Zo is het hem niet duidelijk waarom in de serie arresten die

\footnotetext{
${ }^{260}$ HR 29 juni 2007, JOR 2007, 259 m.nt. J.J. Dammingh (r.o. 3.4).

261 Zie HR 21 april 2006, NJ 2006, 272.

${ }^{262}$ Zie bijvoorbeeld gerechtshof Amsterdam 29 november 2007, LJN BC2974 (Chipshol) en Hoofdstuk 7.2 hierna.

${ }^{263}$ W.L.Valk, Klachtplicht en bewijslast, NTBR 2008, 2, p. 94 e.v. over HR 23 novemebr 2007, RvdW 2007, 996. Zie over de desbetreffende uitspraak ook J.J. Dammingh in Juridisch Up to Date 14 februari 2008, nr. 3, p.6 e.v.

${ }^{264}$ Volgens HR 20 januari 2006, NJ 2006, 80 is dit niet de bedoeling (r.o. 3.5). Zie aldus ook C.E. Drion, Wie niet klaagt, die niet wint; op weg naar een klaagcultuur?, NJB 2008, nr. 7, p. 375.

${ }^{265}$ A.w. Het door hem genoemde arrest van 29 juli 2007, is gewezen op 29 juni van dat jaar.
} 
elkaar in 2006 en 2007 over de klachtplicht opvolgden ${ }^{266}$ de Hoge Raad verschillende termen gebruikt, waar het gaat om het bekend maken van een klacht (bekwame spoed, terstond en onverwijld). Hij vraagt zich af of er licht zit tussen de daarmee bedoelde normen. Het is jammer dat hij niet uitlegt in welk arrest hij welk begrip heeft gelezen. Volgens mij zit er - om in de termen van de vraagstelling van Drion te spreken - denkbaar inderdaad licht tussen de verschillende termen. De norm blijft echter hetzelfde. Die is dat er - zie de wetsartikelen waarover het hier gaat - binnen bekwame tijd moet worden geklaagd. De Hoge Raad is wat dat betreft volgens mij niet onduidelijk. Een vaste termijn kan niet worden gehanteerd, ook niet als uitgangspunt. ${ }^{267} \mathrm{Bij}$ consumentkoop is de termijn twee maanden, bij niet consumentenkoop gaat het om afweging van alle betrokken belangen en met inachtneming van alle relevante omstandigheden, waaronder het antwoord op de vraag of de verkoper nadeel lijdt door de lengte van de in acht genomen klachttermijn. Het vorenstaande is van overeenkomstige toepassing in gevallen waarin de verkoper naar aanleiding van klachten van de koper het ontbrekende heeft afgeleverd of de afgeleverde zaak heeft hersteld, dan wel vervangen. In het geval van één van beide op 29 juni 2007 gewezen arresten ging het om een particulier, die verschillende deskundigenonderzoeken nodig had om door hem waargenomen gebreken aan een gekocht huis te doen bevestigd te krijgen. Van het eerste rapport was terstond aan de verkoper kennis gegeven. Daarmee was aan de klachtplicht voldaan. De verkoper was gewaarschuwd, dat er vervolgberichten konden volgen. Ter zake daarvan kon volgens de Hoge Raad de soep wat minder heet gegeten worden. Een particuliere koper moet de nodige voortvarendheid betrachten. In het andere op 29 juni 2007 gewezen arrest betrof het over en weer professionele partijen. De Hoge Raad zegt daar (r.o. 3.3) dat op straffe van verval van rechten klachten door de koper tot de verkoper moeten worden gericht "binnen zo korte tijd als in de gegeven omstandigheden in verband met zijn onderzoeksplicht van hem kan worden gevergd." De koper moet met bekwame spoed onderzoeken of de zaak in orde is en dat met bekwame spoed aan de verkoper laten weten. Het betrof in dit geval overigens eveneens een situatie waarin al eerder aan de klachtplicht was voldaan en ook nu ging het nog om de vraag of herstelwerkzaamheden naar behoren waren uitgevoerd. Ik vind niet dat deze uitspraken aanleiding geven tot het stellen van de door Drion opgeworpen vraag, nu uit het arrest van 23 maart 2007 niet iets anders volgde. Dat er tussen - in het geval van het laatst bedoelde arrest - professionele partijen 'met spoed' moet worden geklaagd, levert geen andere instructie op, dan uit de wet of uit de later gewezen arresten volgt, zo is mijn mening. De bedoeling is duidelijk.

De door Drion verder nog gestelde vraag of de artikelen 6:89 en 7:23 moeten worden geacht dwingend recht te bevatten of zelfs als van openbare orde dienen te worden beschouwd, verdient volgens hem zelf gelukkig geen bevestigende beantwoording. Gegeven de aard van de desbetreffende bepalingen die betrekking hebben op privaatrechtelijke verbintenissen tussen private partijen - zou ik een ander antwoord dan ook onjuist vinden. Het rechtsverkeer is gebaat bij vrijheid van handelen en vrije beschikkingsmacht van partijen. Niet valt in te zien waarom - bovendien ook zonder dat de wetgever zelf ter zake enige inclinatie heeft vertoond of vertoont - een inperking van de contractsvrijheid in dit geval geïndiceerd of gerechtvaardigd zou zijn. Anders dan Drion put ik uit het arrest van 23 november 2007 daartoe voor een andere gedachte ook geen enkele aanwijzing, even min als een aanleiding om de door hem geformuleerde vraag te bedenken. Steun voor mijn standpunt wordt gevonden bij Tjittes, die contractuele bescherming van de ene ondernemer jegens de andere ondernemer ook niet gewenst acht. ${ }^{268}$ De laatst genoemde zegt verder:"In een verhouding tussen ondernemers onderling is er in veel gevallen geen sprake van een ongelijke machtspositie. Indien daarvan toch sprake is, waakt primair het mededingingsrecht tegen misbruik daarvan. Het mededingingsrecht, van zowel Europese als nationale origine, zorgt ervoor dat een ongelijke machtspositie niet uitgebuit kan worden." Bij deze gedachtegang past wel enige nuancering, hoewel ik met hem van mening blijf dat er op het hier voor laatst besproken punt geen rol voor de wetgever is weggelegd. Er hoeft in mededingingsrechtelijke termen niet van een probleem sprake te zijn, wil er toch een disbalans kunnen bestaan tussen de positie van verschillende partijen bij een transactie. Misbruik van een situatie of (machts)positie kan ook in andere opzichten spelen dan in termen van verboden marktgedragingen. Niettemin blijft gelden, zoals Tjittes hogerop in zijn artikel ook aangeeft, dat de vrije wilsbepaling (artikel 3:33) de hoofdpijler van ons overeenkomsten recht is en zou moeten blijven.

\footnotetext{
${ }^{266} 20$ januari 2006, NJ 2006, 80; 23 maart 2007, NJ 2007,176; 29 juni 2007, NJ 2007, RvdW 2007, 636; 13 juli 2007, NJ 2007, 408; 29 juni 2007, NJ 2007, RvdW 2007, 634en 23 november 2007, RCR 2008, 14.

${ }^{267}$ R.o. 3.3.4 in het arrest van 29 juni 2007, gepubliceerd in RvdW, 2007, 636.

${ }^{268}$ R.P.J.L. Tjittes, Naar een bijzonder contractenrecht voor ondernemers in Onderneming en 5 jaar nieuw burgerlijk recht, Serie Onderneming en Recht, deel 7, p. 376.
} 
Voor zover er niet sprake is van koop, maar van andersoortige transacties waaruit andersoortige verbintenissen voortvloeien, gelden de algemene bepalingen met betrekking tot rechtsvorderingen (artikel 3:296 e.v.) en vindt de hoofdregel toepassing dat de schuldenaar aansprakelijk is voor een tekortkoming in de nakoming van een overeenkomst, tenzij de tekortkoming niet aan hem kan worden toegerekend (artikel 6:74).

Waar het de relatie betreft tussen de ter zake van artikel 6:89 en 7:23 geldende termijnen enerzijds en de voor toepassing van artikel 6:162 geldende termijnen anderzijds betreft, wordt verwezen naar 5.7 hierna.

\section{Onderzoeksplicht en mededelingsplicht}

Uit het bovenstaande blijkt dat de verhouding tussen onderzoeks- en mededelingsplicht zowel bij wanprestatie als bij dwaling een rol speelt.

Een in het kader van de conformiteitseis nog te noemen uitspraak betreft een vonnis van 26 januari 2005 van de rechtbank te Arnhem. ${ }^{269}$ Het ging daarbij om een zaak waarin sprake was van de verkoop van een onderneming door middel van een aandelenoverdracht waarbij in het rapport van de accountant betreffende die onderneming tot en met 1991 als klant van de onderneming een belangrijke afnemer was genoemd. Het daarop volgende jaar was de omzet bij die afnemer tot een verwaarloosbaar niveau teruggelopen. De overname vond plaats in het jaar waarin het teruglopen van die omzet al kenbaar was, terwijl de verkoper - aldus ook de rechtbank - daar ten onrechte geen melding van had gemaakt. Het verweer van de verkoper dat de koper al voorafgaand aan de overname zelf had kunnen zien dat de afnemer minder kocht, vond geen genade in de ogen van de rechtbank, die overwoog:

"... dat een verkoper die een bepaalde omstandigheid verzwijgt die voor het sluiten van de koop van wezenlijk belang is, zijn koper niet kan tegenwerpen dat hij dit na onderzoek zelf had kunnen ontdekken".

Ik noem verder de overwegingen van de rechtbank, welke relevant zijn in de context van artikel 7:17 BW. Daarbij is het van belang op te merken dat het in confesso was dat het wegvallen van de desbetreffende afnemer niet had geleid tot een te lage waardering volgens de DCF-methode van de door de koper in 1992 overgenomen aandelen.

"Weliswaar kan er vanuit worden gegaan dat in de koopprijs rekening is gehouden met toekomstige inkomsten en winsten, maar ... betekent dat nog niet dat wanneer het wegvallen van de klant geen invloed zou hebben gehad op de prijs van de aandelen, het er ook voor moet worden gehouden dat door dat wegvallen geen schade kan zijn geleden. Het enkele feit dat de koopprijs van de aandelen op zichzelf juist was, neemt niet weg dat de koper op grond van hetgeen de aandelen realiter vertegenwoordigden, mocht verwachten een onderneming te krijgen met een bepaald klantenbestand en een bepaald omzetpotentieel. Wanneer nu, zoals hier, de gekochte zaak niet de eigenschappen bezit die op grond van de koopovereenkomst mochten worden verwacht, dan wordt de omvang van de schade die de verkoper wegens zijn wanprestatie moet vergoeden, niet bepaald of begrensd door de hoogte van de koopprijs die de zaak eigenlijk had moeten hebben, maar door de gevolgen die de wanprestatie voor de koper heeft gehad. De enkele omstandigheid dat de koopprijs van de aandelen op zichzelf juist is geweest, laat dus onverlet dat de koper schade kan hebben geleden door het door de verkoper achtergehouden feit dat de afnemer al enige tijd voor de overname als klant was vertrokken."

Bij de vaststelling van wat een koper omtrent het gekochte heeft mogen verwachten, zal (ook) als uitgangspunt kunnen worden aangehouden dat de koper uitlatingen van de verkoper over het verkochte voor juist mag houden. Desalniettemin kunnen de omstandigheden van het geval tot de conclusie lei-

\footnotetext{
${ }^{269}$ LJN AS8583
} 
den dat de koper ondanks de mededeling van de verkoper toch nader onderzoek ter zake van de eigenschappen van het verkochte had moeten doen. Als relevante omstandigheden noemt A-G Wuijsman in diens conclusie onder een arrest van 25 mei 2007: ${ }^{.70}$

“... onder meer de aard en de inhoud van de mededeling (luidt deze algemeen en globaal of specifiek?), heeft zij het karakter van een toezegging of garantie?), de hoedanigheid van de betrokken partijen (handelen zij beroeps/bedrijfsmatig en zijn zij ter zake kundig of zijn zij een consument zonder bijzondere kennis?), de aard van de zaak waarop de mededeling betrekking heeft (is deze nieuw of oud en reeds gebruikt? Wat kan als regel van de levensduur ervan worden verwacht?)".

De conclusie luidt dat een koper ondanks de mededeling van een verkoper tot het doen van nader onderzoek gehouden kan zijn als resultante van een wegen en waarderen van de relevante omstandigheden van het betreffende geval in onderling verband. Waar het wegen en waarderen van een voorwerp van koop of van omstandigheden als regel een praktische bezigheid betreft, is het onder alle omstandigheden beter om onzekerheid achteraf te vermijden door het doen van (nader) onderzoek of het vragen van (nadere) garanties of vrijwaringen.

Er valt naar mijn oordeel geen vaste regel te benoemen, die inhoudt dat de mededelingsplicht zwaarder weegt dan de onderzoeksplicht of andersom. Het zal steeds van de omstandigheden van het desbetreffende geval afhangen. Het is eerder regel dan uitzondering dat een partij die stelt dat er niet voldaan is aan een mededelingsplicht, de bal terugspeelt door te stellen dat de ander onvoldoende heeft voldaan aan diens onderzoeksplicht. ${ }^{271}$

\section{Dwaling óf wanprestatie?}

Bollen ${ }^{272}$ heeft betoogd dat het tijdstip waarop mededelingen zijn gedaan die hebben geleid tot een onjuiste voorstelling van zaken bij het aangaan van een transactie - anders dan gemeenlijk wordt aangenomen - bepalend is voor de vraag of er een beroep op dwaling dan wel tekortkoming kan worden gedaan. 'Onjuiste' mededelingen die zijn gedaan voor of ten tijde van het sluiten van de overeenkomst zullen volgens hem in beginsel alleen kunnen leiden tot een beroep op dwaling. Het is volgens hem geen automatisme, dat een beroep op een tekortkoming vrijwel steeds ook zal kunnen slagen:

"Wanneer kan een onjuiste mededeling dan enkel leiden tot een dwalingsactie en wanneer tot zowel een dwalings- als een tekortkomingsactie? In het Nederlands recht kan, evenals in het Engels recht, een onderscheid worden gemaakt tussen mededelingen die wel en mededelingen die niet tot de contractsinhoud gaan behoren. Uitgangspunt is dat gedane (onjuiste) mededelingen geen deel van de contractsinhoud gaan uitmaken, zodat enkel een beroep op dwaling openstaat. Slechts wanneer de mededelingen deel zijn geworden van de contractsinhoud en zij blijken onjuist te zijn, dan heeft de teleurgestelde contractant naast een beroep op dwaling contractuele remedies tot zijn beschikking."

Bollen onderscheidt drie categorieën van mededelingen en wel 'blote mededelingen', 'serieuze mededelingen die geen deel zijn gaan uitmaken van de overeenkomst' en 'serieuze mededelingen die wel deel zijn gaan uitmaken van de overeenkomst'. De vraag of een serieuze mededeling deel is gaan uitmaken van de overeenkomst of niet is volgens hem een kwestie van interpretatie. Richtlijn bij de uitleg zal zijn of er als gevolg van een mededeling een verbintenis is ontstaan. In het bevestigende geval kan er een beroep op dwaling worden gedaan maar kan ook tekortkomingsactie worden ingesteld. In het

\footnotetext{
${ }^{270}$ LJN BA2012.

${ }^{271}$ Om slechts één voorbeeld te noemen, zie gerechtshof te 's-Gravenhage 11 november 2005, NJ 2007, 428, waarin koper de gelegenheid kreeg het gekochte te inspecteren, maar onvoldoende grondig kijkt. Na de totstandkoming van de transactie blijkt dat wegens gebreken een gedeelte van de ketelinstallatie en leidingen van de kasverwarming (het gaat om een perceel grond met woonhuis en bedrijfsruimte in de glastuinbouw) moet worden vervangen. Het gerechtshof komt in dit geval tot het oordeel dat de koper onvoldoende aan zijn onderzoeksplicht heeft voldaan (en bovendien onvoldoende concreet feiten heeft gesteld waaruit kan volgen dat de gestelde gebreken reeds ten tijde van de verkoop aanwezig waren).

272 C. Bollen, Onjuiste mededelingen en de samenloop tussen dwaling en wanprestatie: de ene mededeling is de andere niet!, NTBR 2004/9, p. 414 e.v.
} 
ontkennende geval kan alleen een beroep op dwaling worden gedaan en zal de teleurgestelde partij voor schadevergoeding aangewezen zijn op een actie op grond van een onrechtmatige daad. Volgens A-G Langemeijer onder een arrest van de Hoge Raad van 8 februari 2008 kan in het algemeen niet gesteld worden dat bij afwijzing van de grondslag 'dwaling' de grondslag 'wanprestatie' niet meer aan de orde behoeft te komen. Bij de grondslag 'dwaling' gaat de eisende partij volgens hem immers uit van de situatie waarin de overeenkomst is vernietigd of moet worden vernietigd, terwijl bij de grondslag 'wanprestatie/toerekenbare niet-nakoming van de overeenkomst' de eisende partij daarentegen uitgaat van de situatie waarin er een geldige overeenkomst bestaat, zij het dat niet-nakoming grond kan geven tot ontbinding daarvan. ${ }^{273}$

Gewaakt moet worden voor de vergissing die door de eisers werd gemaakt in een zaak die werd beslist door een vonnis van de rechtbank te Dordrecht van 12 oktober $2005{ }^{274}$ De vordering tot vergoeding van schade omdat de verkopers van een huis de koper niet zouden hebben meegedeeld dat de stucplafonds kort voor de verkoop waren overgeschilderd of overgesausd en provisorisch gerepareerd en dat er in het verkochte sprake was van trillingshinder, werd gebaseerd op dwaling. De rechtbank wees de vordering af nu een geslaagd beroep op dwaling - waarvan in casu wel sprake zou kunnen zijn - kan leiden tot (gedeeltelijke) vernietiging van de overeenkomst of tot wijziging van de inhoud daarvan, maar geen recht geeft op schadevergoeding. Waar de eisers zich niet op (gehele of gedeeltelijke) vernietiging van de koopovereenkomst hadden beroepen en ook niet hadden verzocht de gevolgen van de overeenkomst te wijzigen, werd de eis tot betaling van een geldsom afgewezen. Waar de eisers ook tijdens de comparitie van partijen hadden gepersisteerd bij de door hen aangevoerde grondslag van dwaling, zag de rechtbank geen ruimte voor toepassing van artikel $25 \mathrm{Rv}$ en werd de vordering zonder aanvulling van rechtsgronden afgewezen. Partijen moeten kiezen voor de aan hun vordering(en) ten grondslag te leggen kwalificaties, nu die de bepalend kunnen zijn voor de rechtsgevolgen die zij aan hun stellingen kunnen (willen) ontlenen.

\subsection{Onrechtmatige daad}

Op grond van artikel 6:162 is degene die jegens een ander een onrechtmatige daad pleegt, die aan hem kan worden toegerekend, verplicht de schade die de ander daardoor lijdt te vergoeden. Van een onrechtmatig handelen van een partij zou sprake kunnen zijn, wanneer deze een ander valselijk heeft voorgelicht. Het leerstuk van de onrechtmatige daad is vanzelfsprekend vooral relevant, wanneer er geen obligatoire verhouding tussen partijen bestaat. Een verbintenis tot vergoeding van schade kan dan niet op een overeenkomst worden teruggevoerd. Voor zover het al omstreden was of - bij overschrijding van de termijn van twee jaar op grond van artikel 7:23 lid 2-met een beroep op samenloop met onrechtmatige daad alsnog een beroep kon worden gedaan op de voor de onrechtmatige daad geldende verjaringstermijn van vijf jaar, heeft de Hoge Raad die vraag ontkennend beantwoord. ${ }^{275} \mathrm{De}$ Hoge Raad heeft beslist dat artikel 7:23 lid 2 strekt om (ter bescherming van de belangen van de verkoper) te gelden 'voor iedere rechtsvordering van een koper die feitelijk gegrond is op het niet beantwoorden van de afgeleverde zaak aan de overeenkomst', dus ook indien door de koper op deze feitelijke grondslag tevens een rechtsvordering uit onrechtmatige daad wordt gebaseerd.

In het hier bedoelde kader is een uitspraak van belang die de Hoge Raad deed in het kader van een franchiseovereenkomst. ${ }^{276}$ In deze uitspraak werd bepaald dat er op een franchisegever in principe geen verplichting rust een mededeling te doen over de omzet van de onderneming met betrekking tot welke de franchiseovereenkomst gesloten wordt. Wel oordeelde de Hoge Raad dat een franchisegever die een rapport aan een franchisenemer geeft, waarin informatie wordt verstrekt over de omzet van de onderneming, onder omstandigheden onrechtmatig kan handelen, indien de franchisegever weet dat dit rapport ernstige fouten bevat en hij zijn wederpartij niet op deze fouten opmerkzaam maakt.

\footnotetext{
${ }^{273}$ Zie in de conclusie onder 3.12 bij HR 8 februari 2008, LJN BC3880.

Een voorbeeld, waarin na het afwijzen van een vordering wegens dwaling, het gerechtshof toch nog zelfstandig beoordeelt of er wel van wanprestatie wegens non-conformiteit sprake kan zijn: gerechtshof Amsterdam 15 juli 2004, Prg. 2005 (1), nr. 2 m.nt. P. Abas.

${ }^{274}$ Niet gepubliceerd, 12 oktober 2005, Rolnummer 57600 HA ZA 04-2899.

${ }^{275}$ HR 21 april 2006, LJN AW 2582, zie ook Maandblad voor Vermogensrecht, mei 2006, nr. 5, p. 96/97.

${ }^{276}$ HR 25 januari 2002, NJ 2003, 31 (J.M. Paalman / Lampenier). Zie over deze uitspraak ook A. Knigge, Aansprakelijkheid van franchisegevers, Bb 10 juli 2002, nr. 13, p.119 e.v.
} 
De Hoge Raad heeft op 23 november 2007 duidelijk gemaakt dat een beroep op het bepaalde in artikel 6:89 en 7:23 dat er niet, of niet tijdig, aan een klachtplicht werd voldaan, ook opgeld kan doen wanneer de grondslag voor een rechtsvordering niet gebaseerd is op artikel 7:17, maar op een onrechtmatige daad. In de context van artikel 7:23 lid 2 had de Hoge Raad eerder al geoordeeld dat de artikelen 6:89 en 7:23 gelden voor iedere rechtsvordering van de koper die - en ieder verweer van de koper dat feitelijk gegrond is op het niet beantwoorden van de afgeleverde zaak aan de overeenkomst, ook indien door de koper op deze grondslag een rechtsvordering uit onrechtmatige daad wordt gebaseerd. Hetzelfde moet worden aangenomen voor de regel van artikel 7:23 lid 1 en voor 6:89, waarvan artikel 7:23 een precisering vormt. ${ }^{277}$

Zie omtrent een klachtplicht ook hiervoor onder 5.6 en verder hierna in hoofdstuk 7.2.

\subsection{Bedrog en misbruik van omstandigheden}

Binnen het kader van normale commerciële transacties wordt niet uitgegaan van bedrog, ofschoon een onderzoeksplicht ontegenzeggelijk in een aantal gevallen ook ten doel heeft om het gevoel op te doen, dat er niet van bedrog sprake zal zijn. Niettemin wordt het leerstuk van bedrog, evenmin als bedreiging of misbruik van omstandigheden (artikel 3:44 BW) in dit boek buiten beschouwing gelaten.

Wanneer de wederpartij opzettelijk onjuiste mededelingen doet of opzettelijk een feit verzwijgt dat meegedeeld had dienen te worden, kan er sprake zijn van bedrog. ${ }^{278}$ Zie artikel 3:44 lid 3. Aanprijzingen in algemene bewoordingen, ook al zijn ze onwaar, leveren op zichzelf geen bedrog op. Een vuistregel is dan ook dat een gedane mededeling, naarmate deze specifieker is, eerder bedrog kan opleveren wanneer die onjuist blijkt te zijn. Verzwijgen levert slechts bedrog op, wanneer er ter zake een mededelingsplicht bestond. De verkeersopvattingen zijn daarbij beslissend. ${ }^{279}$

De vraag of er sprake is van misbruik van omstandigheden bij de verkoop van een technisch failliete onderneming, vormde in oktober 2007 voorwerp van de uitspraak van de rechtbank te Rotterdam. ${ }^{280}$ De koper, geconfronteerd met een vordering op grond van afgegeven balansgaranties en een vordering tot handhaving van een non-concurrrentiebeding, stelde dat er sprake was geweest van het afdwingen van afspraken, nu hij bij verkoop de onderneming geen andere optie had gehad dan tot verkoop over te gaan teneinde een faillissement af te wenden. De uitspraak leert dat misbruik van omstandigheden in een dergelijke situatie niet snel wordt aangenomen. De rechtbank is er niet één-tweedrie van overtuigd dat er geen alternatieven zouden bestaan naast verkoop aan een derde of een faillissement. Zelfs indien er van een economische dwangpositie sprake is en de wederpartij daarvan op de hoogte is, moet het gaan om het bedingen van voorwaarden die in redelijkheid niet bedongen zouden mogen worden. Daarbij neemt de rechtbank in overweging dat het niet ongebruikelijk is dat er garanties worden verleend, dus zal niet snel gelden dat dergelijke garanties niet mogen worden verlangd. Bovendien overwoog de rechtbank in het hiervoor bedoelde geval dat de verkoper zich ruimhartig had opgesteld bij het verlenen van garanties, toen er naar aanleiding van een due diligence onderzoek vragen omtrent de jaarstukken waren opgekomen. De verkoper zag op dat moment geen bezwaar tegen het afgeven van balansgaranties, nu er op dat punt geen problemen te verwachten zouden zijn. De gevolgtrekking dat er sprake is van misbruik van omstandigheden bij verkoop van een zich in problemen bevindende onderneming, zal door de rechter als gezegd niet gemakkelijk worden aangenomen.

Bestuurdersaansprakelijkheid

\footnotetext{
${ }^{277}$ Zie HR 21 april 2006, NJ 2006, 272.

${ }^{278}$ Zie gerechtshof te Leeuwarden 27 augustus 2003, LJN AJ6840. Het betrof een geschil tussen een koper van 2 bungalows op een recreatiepark en de verkoper daarvan. Na totstandkoming van de koopovereenkomst bleek de koper dat de Gemeente Vlagtwedde in de periode 1951-1958 haar huisvuil had gestort op een locatie waarop een deel van de bij het recreatiepark behorende golfbaan was gelegen. De voormalige vuilstort bevond zich op ten minste 80 meter van de gekochte recreatiebungalows. Niettemin vorderde de koper vernietiging van de koopovereenkomst wegens bedrog c.q. dwaling. Hoewel de verkoper werd geacht bekend te zijn geweest met de aanwezigheid van de voormalige vuilstort, werd niet aangenomen dat er sprake was van opzettelijk onjuiste mededelingen dan wel het opzettelijk verzwijgen van enig feit.

${ }^{279}$ Wel zal het onder omstandigheden nodig zijn dat er wordt doorgevraagd. Met name wanneer er twijfel is aan de juistheid of er twijfel kan zijn omtrent aanprijzingen of mededelingen, is doorvragen vereist. Zie Rechtbank Dordrecht 25 juli 2007, LJN BB0682, r.o. 5.1.

${ }^{280}$ Rechtbank Rotterdam 24 oktober 2007, LJN BB7874.
} 


\section{Artikel 2:9}

Zoals hier voor werd opgemerkt, kan de wens van bestuurders en commissarissen om geen verwijt achteraf gemaakt te krijgen over schending van hun zorgvuldigheidsplicht ten opzichte van de rechtspersoon, een belangrijke reden zijn om niet zonder een behoorlijke due diligence onderzoek een transactie aan te gaan. Een eerste norm betreft in dit opzicht die van artikel 2:9. Elke bestuurder is tegenover de rechtspersoon gehouden tot een behoorlijke vervulling van de hem opgedragen taak. De woorden 'behoorlijke vervulling van de hem opgedragen taak' bevatten een objectiverend element. Van een bestuurder mag worden verwacht dat hij op zijn taak berekend is en deze nauwgezet vervult. ${ }^{281}$ Het nalaten van (voldoende) onderzoek aan de voorkant van het aangaan van een transactie kan onder omstandigheden ernstig verwijtbaar zijn. Het betreft in het voorkomend geval aansprakelijkheid ten opzichte van de 'eigen' rechtspersoon.

Het nalaten van een due diligence onderzoek bij een overname kan wanbeleid van de koper en persoonlijke aansprakelijkheid van bestuurders en commissarissen op grond van onzorgvuldige taakvervulling opleveren. ${ }^{282}$

\section{Elementaire beginselen van behoorlijk ondernemerschap}

Zoals ook eerder gezegd, kan de kwalificatie 'wanbeleid' door de OK een opmaat zijn naar persoonlijke aansprakelijkheid van bestuurders. De Hoge Raad overwoog in dit verband in zijn beschikking van 8 april 2005 in de enquête procedure in het geval van Laurus N.V.:.283

"Indien personen die deel uitmaken van de organen van de rechtspersoon door derden die als gevolg van wanbeleid schade hebben geleden aansprakelijk worden gesteld in een afzonderlijke, op artikel 6:74 en/of artikel 6:162 en/of artikel 2:138/248 BW gebaseerde, procedure, is de vaststelling van de ondernemingskamer dat van wanbeleid van de onderzochte rechtspersoon sprake is - behoudens cassatie - weliswaar bindend voor diegenen die in de tweede procedure van de enquête zijn verschenen en ofwel tot toewijzing van hetgeen verzocht en/of gevorderd is hebben geconcludeerd ofwel daartegen verweer hebben gevoerd, maar dit impliceert niet de persoonlijke aansprakelijkheid van de leden van de organen van de rechtspersoon voor dat wanbeleid. De door de ondernemingskamer vastgestelde feiten staan in een aansprakelijkheidsprocedure ook niet op voorhand vast, zelfs niet behoudens tegenbewijs. Het oordeel van de ondernemingskamer dat van wanbeleid sprake is geweest, kan daarin onder omstandigheden wel de bewijsrechtelijke betekenis hebben dat de rechter, mede gelet op de inhoud van het door de onderzoekers opgestelde verslag en het daarover in de tweede procedure van de enquête gevoerde debat, voorshands bewezen acht dat de aangesproken persoon tegenover de rechtspersoon zijn taak niet heeft vervuld op de wijze waarop een redelijk bekwame en redelijk handelende functionaris die taak in de gegeven omstandigheden had behoren te vervullen."

De OK kan op grond van artikel 2:354 (op verzoek van de rechtspersoon) wel zelf tot een veroordeling van betaling van de kosten van het onderzoek (de kosten van de onderzoeker) aan de rechtspersoon overgaan, indien uit het verslag van de onderzoeker blijkt dat een bestuurder, een commissaris of een ander in dienst van de rechtspersoon verantwoordelijk is voor een onjuist beleid of een onbevredigende gang van zaken van de rechtspersoon. Wat nu, moet men zich voorstellen bij het begrip 'elementaire beginselen van behoorlijk ondernemerschap'?

A-G Wesseling-van Gent in haar conclusie bij HR 21 februari $2003^{284}$ gaat in op 'elementaire beginselen van behoorlijk ondernemingsbestuur of beginselen van verantwoord ondernemerschap'. Voorzover

\footnotetext{
281 Zie HR 10 januari 1997, NJ 1997, 360 (Staleman/Van de Ven) en HR 29 november 2002, JOR 2003, 2 m.nt. Bartman (Schwandt/Berhuizer Papierfabriek). Zie ook J.B. Wezeman, Aansprakelijkheid van bestuurders, Groningse Serie, deel 29.

282 Zie aldus ook H.H. Kersten, Het due diligence onderzoek, O\&F 2003, 58, p. 32. Zie ook F.J.P. van den Ingh, Men gaat deur hovaardy ver boven 't kappetael, Enige bespiegelingen omtrent de financiële draagkracht van kapitaalvennootschappen in Drie Nijmeegse redes, Nijmeegse Serie, deel 59, p. 1 e.v., waar het aansprakelijkheid van bestuurders en commissarissen betreft voor besluitvorming welke tot over- of onderkapitalisatie van de vennootschap keidt.

283 JOR 2005, 119 m.nt. M. Brink.

${ }^{284}$ JOR 2003, 57 (HBG) (onder 2.40 e.v.).
} 
die begrippen, of iets dat daar op lijkt al in rechtspraak van de OK of de HR voorkwamen, ressorteren die onder het begrip wanbeleid. Dit is het begrip dat de wet noemt (artikel 2:355 lid 1). Maeijer ${ }^{285}$ bevestigt dat de OK handelen in strijd met beginselen van behoorlijk ondernemerschap in verband brengt met gedragingen op bedrijfseconomisch en sociaal gebied. De notie heeft betrekking op een beleid ten aanzien van de door de rechtspersoon in stand gehouden onderneming. (Wan)beleid kan ook betrekking hebben op het (onvoldoende) functioneren van de vennootschap als rechtspersoon; beide aspecten kunnen met elkaar verweven zijn. Uit de jurisprudentie blijkt dat meerdere aspecten bij het oordeel dat er sprake is van wanbeleid een rol kunnen spelen, aldus Maeijer (t.a.p.). Mijn mening is dat het steeds van de bijzondere omstandigheden van het geval zal afhangen of er in een voorkomend geval gesproken kan worden van strijd met elementaire beginselen of verantwoord ondernemerschap. Ik zal daarom niet proberen een definitie te formuleren. Inbreuk op elementaire beginselen van verantwoord ondernemerschap kan aan de orde zijn door het ontbreken van zuiverheid van oogmerk, van zorgvuldige voorbereiding, onvoldoende verantwoording, schending van het vertrouwensbeginsel en van het gelijkheidsbeginsel, om maar een aantal mogelijkheden te noemen. A-G Mok in zijn conclusie bij de Ogem uitspraak van de Hoge Raad ${ }^{286}$ onderzoekt de literatuur op het onderwerp wanbeleid en stelt vast:

"De OK heeft in de bestreden beschikking de verschillende onderdelen die zij op wanbeleid heeft onderzocht, in factoren ontleed en is daarbij ten aanzien van de verschillende factoren herhaaldelijk tot de conclusie gekomen dat onzorgvuldig is gehandeld. Soms is ook wel eens de term "laakbaar" en in een enkel geval (r.o. 4.6) "ten zeerste laakbaar" gebruikt. Een combinatie van onzorgvuldigheid en eventuele laakbaarheid in de verschillende elementen brengt de OK dan steeds tot de conclusie dat er sprake is van schending van, danwel handelen in strijd met, "elementaire beginselen van verantwoord ondernemerschap". Dat is, zoals gezegd, de formule die de OK voor wanbeleid pleegt te gebruiken en die ....".

A-G Wesseling-van Gent spreekt naast elementaire beginselen van behoorlijk ondernemerschap ook over 'beginselen van behoorlijk ondernemingsbestuur'. Alsof het al niet ingewikkeld genoeg was. De OK en de HR bedienen zich alleen van het eerst genoemde begrip. Zij wijst op de relatie tussen die beginselen en artikel 2:8. De laatst bedoelde wetsbepaling zou de rechtsgrond opleveren voor de gelding van die hier voor bedoelde begrippen. ${ }^{287}$ Hoewel het geen twijfel leidt dat de OK bij het beoordelen van aan haar voorgelegde situaties ook de norm van artikel 2:8 in haar beschouwingen kan betrekken (en dat, uitdrukkelijk of impliciet, ook regelmatig heeft gedaan), is het belangrijk voor ogen te blijven houden dat de door de OK toe te passen toets er een van een eigen aard is. Prinsen wees hier al op door op te merken, dat enkele strijd met de redelijkheid en billijkheid nog geen wanbeleid hoeft op te leveren. ${ }^{288}$ De plaatsing door de wetgever van het enquêterecht in Boek 2 BW roept weliswaar een natuurlijke neiging op om in het kader van het enquêterecht uitsluitend of vooral in termen van het vennootschapsrecht te denken, maar dat zou te simplistisch zijn. ${ }^{289}$ Wanbeleid kan zich, zoals gezegd, voordoen in veel verschijningsvormen en voorzover die juridisch gekwalificeerd moeten worden, kan er

\footnotetext{
${ }^{285}$ Asser-Maeijer 2-III (nr. 534). Dit naar aanleiding van OK 21 juni 1979, NJ 1980, 71 (Batco). In de Ogem-zaak (HR 10 januari 1990 , NJ 1990, 466) had de OK onderzocht of Ogem onzorgvuldig dan wel laakbaar had gehandeld en of dat handelen van een zo ernstig karakter was dat Ogem in strijd met de hier voor bedoelde elementaire beginselen had gehandeld. De OK kwam tot een bevestigend antwoord op die vraag. De HR achtte het gehanteerde criterium toen niet onjuist. Met dat alles is echter nog geen helder omlijnd beeld van de notie 'handelen in strijd met elementaire beginselen van verantwoord ondernemerschap' gegeven. Met het hier voor genoemde criterium kan dan ook niet worden volstaan.

${ }^{286}$ HR 10 januari 1990, NJ 1990, 466 m.nt. Ma.

${ }^{287}$ Ter ondersteuning van die gedachte verwijst zij naar B.H.A. van Leeuwen, Beginselen van behoorlijk ondernemingsbestuur, IvO, deel 10, p.4. Van Leeuwen spreekt op de genoemde plaats inderdaad over artikel 2:8 als de rechtsgrond voor de gelding van beginselen van 'behoorlijk ondernemingsbestuur'. Hij legt uit, dat die bepaling eist dat zij die deel uitmaken van een orgaan van een rechtspersoon zich jegens elkaar zullen gedragen naar hetgeen door de redelijkheid en billijkheid wordt gevorderd. Dat alles is waar, maar de norm van artikel 2:8 is niet dezelfde norm als die van artikel 2:350 lid 1 (gegronde redenen om aan een juist beleid te twijfelen) of van artikel 2:355 lid 1 (wanbeleid). De A-G wijst er op dat de gedachtevorming nog niet zou zijn uitgekristalliseerd over de verhouding tussen de genoemde beginselen en het begrip wanbeleid. Ten aanzien daarvan merk ik op, dat er over de relatie tussen de strekking van artikel 2:8 (voorheen 2:7) en het begrip wanbeleid eerder toch al wel was nagedacht. Ik verwijs onder meer naar M.J.G.C. Raaijmakers in zijn noot onder OK 20 april 1989, NJ 1991, 205 (Best Golf \& Country Club), AA 1989, p. 850

${ }^{288}$ L.L.M. Prinsen onder OK 27 mei 1999, JOR 1999, 121 (Gucci).

${ }^{289}$ Zie M. Brink, Voortgezette financiering bij joint venture, O\&F, nr. 54, p. 9. Artikel 66 R.O. spreekt over 'het behandelen en beslissen van zaken als bedoeld in Boek 2 BW.' Dat betreft het enquêterecht (artikel 2:344 e.v.). Daardoor wordt niet de inhoud van het begrip wanbeleid ingevuld. Wanbeleid kan zich in allerhande verschijningsvormen voordoen.
} 
sprake zijn van schending van regels op allerhande rechtsgebieden. Zo kan bijvoorbeeld ook het algemene verbintenissenrecht een omstandigheid opleveren bij de beoordeling van vragen omtrent een juist beleid en een goede gang van zaken binnen een rechtspersoon. ${ }^{290}$ Bovendien kan het hier voor bedoelde begrip ook heel goed worden gepast in de sleutel van artikel 2:9, zo zou ik menen. Het is sowieso goed om in het kader van deze paragraaf niet uit het oog te verliezen dat zowel artikel 2:9 (zie hiervoor) als het enquêterecht vooral betrekking hebben op de interne verantwoording, hoewel zoals aangegeven, de resultaten van een enquêteprocedure ertoe kunnen leiden dat vorderingen wegens persoonlijke aansprakelijkheid van betrokkenen zullen resulteren. Eén van de doelstellingen van het enquêterecht is vaststelling bij wie de verantwoordelijkheid berust voor gebleken wanbeleid.

De hiervoor genoemde uitspraak van de Hoge Raad in wat indertijd bekend is geworden als de Ogemaffaire, bevatte ook een waarschuwing aan bestuurders en commissarissen dat een due diligence onderzoek aangewezen kan zijn en bovendien dat een dergelijk onderzoek dan behoorlijk moet worden uitgevoerd. De handelwijze van Bredero bij de overname van de Duitse vennootschap Beton- en Monierbau bleek op een groot aantal punten niet door de beugel te kunnen. Tot de aankoop was besloten vrijwel zonder enige onafhankelijke informatie over de vermogenstoestand van de doelwitvennootschap. Bovendien was een mogelijke verhoging van de koopprijs door Ogem zonder meer aanvaard, terwijl verzuimd was de mogelijkheid van een neerwaartse prijscorrectie te bedingen, ondanks het feit dat het risico van een waardedaling van de doelwitvennootschap geheel voor rekening van Ogem kwam. Vastgesteld werd dat er volstrekt onvoldoende rekening was gehouden met de grote risico's die aan de transactie verbonden waren (r.o. 8.2 en 8.3).

De verwijten welke in het geval van Ogem met betrekking tot de acquisitie van een onderneming waren genoemd, speelden in vergelijkbare zin in de situatie waarin N.V. Verto te Rotterdam ("Verto") te werk was gegaan bij de acquisitie van De Regt Special Cable B.V. (“DRSC") in $1988{ }^{291}$

De verwijten die door Verto zelf en de Vereniging van Effectenbezitters werden gemaakt aan voormalige bestuurders en commissarissen, betroffen het onvoldoende informeren van de raad van commissarissen, het opstellen van een koopovereenkomst door een notaris die tevens instructies ontving van de doelwitvennootschap en het accepteren dat er aanpassingen in het concept werden aangebracht op instructie van de verkoper, het in grote haast tot stand brengen van de koopovereenkomst, het toelaten dat belangrijke garanties uit het concept werden geschrapt en vervangen werden door een summiere balansgarantie, het sluiten van de koopovereenkomst zonder dat verificatie van de intrinsieke waarde van DRSC had plaatsgevonden, het instemmen met een hogere koopprijs dan door de raad van commissarissen was goedgekeurd en het sluiten van de koopovereenkomst zonder due diligence onderzoek, zonder een onderzoek naar de productiefaciliteiten, naar de verwachte rentabiliteit van DRSC en de marktverwachtingen. De voormalige commissaris werd onder meer verweten niet te hebben aangedrongen op een due diligence onderzoek en zelfs niet te hebben geïnformeerd naar de redenen van het achterwege blijven daarvan.

Hoe zeer telkenmale de bijzondere omstandigheden van elk geval bepalend zijn, wordt naar mijn oordeel door de uitspraken in de Verto-zaak bevestigd. De OK had bij beschikking van 5 januari 1995 een onderzoek gelast naar het beleid en de gang van zaken bij Verto. Op 7 maart 1996 deed de OK uitspraak. De overname was in een periode van een maand beklonken. De onderzoekers stelden vast dat een aantal bij overnames zoals de onderhavige veelvuldig toegepaste procedures achterwege waren gebleven of niet uit de verf waren gekomen. Zo was een opdracht aan de eigen accountant om de cijfers te bekijken, vastgelopen omdat deze niet over de desbetreffende gegevens beschikte. Een onderzoek, specifiek gericht op het ontdekken van verborgen verplichtingen, werd niet ingesteld. Er werden geen externe deskundigen zoals fiscaal, juridisch, milieu of technisch geschoolde experts ingeschakeld. Er werd geen analyse gemaakt van de verliezen welke in de voorafgaande jaren door DRSC werden geleden. Gesprekken met het middenkader van DRSC voordat het besluit tot overname werd genomen, werden niet gevoerd. Van een volwaardig due diligence onderzoek was al helemaal geen

\footnotetext{
${ }^{290}$ Zie voor één van meerdere voorbeelden OK 20 mei 1999, JOR 2000, 72 (Versatel).

291 Zie gerechtshof Amsterdam (OK) 5 januari 1995, NJ 1995, 311; gerechtshof Amsterdam (OK) 7 maart 1996, JOR 1996, 23 m.nt. F.J.P. van den Ingh; Rechtbank Rotterdam 12 december 1996, JOR 1997, 50 m.nt. Van Solinge en gerechtshof 'sGravenhage 6 april 1999, JOR 1999, 142 alsmede Th.S. IJsselmuiden in TVVS 1996, nr. 5, p. 146-147 en B. Winters en J. Vossenberg, Aansprakelijkheid van bestuurders en commissarissen ter zake van een mislukte acquisitie; rechtsgevolgen van een verleende decharge, V\&O 1999, nr. 6, p. 66 e.v.
} 
sprake geweest. Gewicht werd toegekend aan het feit dat - zo de hiervoor bedoelde procedures wel zouden zijn toegepast - de uiteindelijke besluitvorming naar alle waarschijnlijkheid niet anders zou zijn uitgevallen. Verto beschouwde de acquisitie van DRSC als een strategische prioriteit (hoewel daar achteraf ook het nodige op af te dingen bleek). Na de acquisitie bleek er sprake van een dramatische ontwikkeling bij DRSC. Volgens Verto was het aangaan van een belangrijke transactie zonder onderzoek van enige betekenis, zonder marktonderzoek en zo goed als geheel op basis van de door de verkoper verstrekte informatie, regelrecht in strijd met elementaire beginselen van verantwoord ondernemerschap en dus was er sprake van wanbeleid.

In de discussie bij de OK werd gebruik gemaakt van een aardige beeldspraak. Gesteld was dat de acquisitie een eenmalige kans was geweest: "De trein gaat voorbij, stap je in of niet, dat was de deal", zo werd gesteld. Verto antwoordde daarop dat het in strijd met elementaire beginselen van verantwoord ondernemerschap moest worden geacht wanneer "men op een rijdende trein stapt, ofschoon je niet weet waar die naar toe gaat".

De voormalige bestuurders en commissarissen weerspraken de bevindingen van de onderzoeker inhoudelijk. Zij stelden dat geabstraheerd moest worden van het feit dat DRSC en Verto later in de problemen waren gekomen. Waar het afgaan op informatie van de verkoper betreft, stelden zij dat zij de onderneming van de verkoper al geruime tijd kenden en naarmate men iets beter kent, de noodzaak tot onderzoeken minder zou worden. Het zou geen wanbeleid zijn om tot op zekere hoogte geloof te hechten aan wat een wederpartij, wiens onderneming men goed kent, meedeelt. Uit de uitspraken blijkt niet dat er uitgebreide garanties werden verkregen of zodanige garanties, dat het achterwege laten van een onderzoek of het accepteren van een oppervlakkig onderzoek gerechtvaardigd zouden kunnen zijn. De voormalige bestuurders en commissarissen voerden zeer inhoudelijk verweer en gingen in op alle door de onderzoekers aangevoerde bezwaren tegen hun handelwijze. Met betrekking tot het verwijt dat er geen due diligence onderzoek had plaatsgevonden, werd opgemerkt dat het in theorie denkbaar was geweest om een oneindige stoet deskundigen los te laten op het overnameplan. "Soms zal dat een goed idee zijn, soms zal dat leiden tot verwijten dat de bedrijfsleiding het juiste moment voorbij heeft laten gaan of probeert het ondernemersrisico op de adviseur af te wentelen".

Als nader excuus werd aangevoerd dat het begrip due diligence pas in het eind van de jaren 80 in Nederland gestalte begon te krijgen en in die tijd nog veel minder gemeengoed was dan thans. Misschien verklaart dit ook dat de voormalige bestuurders en commissarissen in dit geval de dans zijn ontsprongen. Wellicht ook omdat tegenover de betwisting van de feiten en omstandigheden die in het onderzoeksverslag werden genoemd, Verto en de Vereniging van Effectenbezitters later onvoldoende tegenwicht hadden ingebracht. Waar dit ons onderwerp betreft, overwoog de OK dat Verto verweten kon worden dat zij niet voldoende onderzoek had ingesteld. Het hof meende niettemin dat dit gegeven onvoldoende was om tot wanbeleid te concluderen. Daarbij werd in de overwegingen betrokken dat Verto DRSC reeds lange tijd van nabij kende en de beschikking had over een zogenaamde SWOTanalyse (een rapport met sterke en zwakke punten van DRSC, waarbij het hof vergeet te vermelden dat dit een oud rapport betrof) en dat DRSC als een interessante kandidaat werd gekenschetst. Ik kan mij niet voorstellen dat eenzelfde feitencomplex anno 2008 opnieuw tot eenzelfde uitspraak zou leiden. Ontwikkelingen op het punt van due diligence zijn - daarin hadden de voormalige bestuurders en commissarissen van Verto gelijk - sedert het einde van de jaren 80 zodanig geweest, dat het achterwege laten van een behoorlijk due diligence onderzoek bij het aangaan van een transactie onder vergelijkbare omstandigheden als in strijd met elementaire beginselen van behoorlijk ondernemerschap of - om met A-G Wesseling van Gendt te spreken - verantwoord ondernemerschap zou worden gezien. De overwegingen dat de business case zo aantrekkelijk toescheen (een strategische match in temen van diversificatie en synergie) en de schaarste in de markt van kandidaten voor een overname alsmede de aanwezigheid van informatie welke (in belangrijke mate gedateerd was en) uitsluitend van de verkoper afkomstig was, zou anno 2008 niet als voldoende rechtvaardiging worden aanvaard om een due diligence onderzoek achterwege te laten, zo durf ik te stellen. ${ }^{292}$

\footnotetext{
${ }^{292}$ Zo had eerder overigens de OK de overwegingen voor een acquisitie welke door een vennootschap waren aangevoerd 'te licht' bevonden: "Met betrekking tot de verwerving van de aandelen BZN heeft KMZN geen bevredigend antwoord kunnen geven op de vraag welk belang die verwerving (voor deze prijs) voor KMZM zelf heeft. Vast staat dat KMZN zelf geen onderzoek heeft verricht naar die aandelen; integendeel, KMZN is - naar zij ter terechtzitting van 8 april 1993 heeft verklaard - volledig afgegaan op de informatie, verschaft door een relatie van haar wederpartij bij de overeenkomst van koop en verkoop, zonder die informatie ook maar op enige wijze te controleren". Vervolgens wordt geconcludeerd dat het op de weg van de rechtspersoon had gelegen om een zelfstandig onderzoek te (laten) doen. Zie gerechtshof Amsterdam (OK) 27 mei 1993, NJ 1993, 724.
} 
IJsselmuiden heeft kritiek uitgeoefend op de uitspraak van de OK. Hij was van oordeel dat het niet laten uitvoeren van een accountantsonderzoek een beleidsfout betrof waaraan de OK ten onrechte was voorbij gegaan. ${ }^{293}$

Verto en de Vereniging voor Effectenbezitters hebben het er niet bij laten zitten en zijn een procedure begonnen bij de gewone rechter. De zaak eindigde door een uitspraak van het gerechtshof te 'sGravenhage van 6 april $1999 .{ }^{294}$ Van Solinge wijst in zijn noot onder het arrest van het gerechtshof op de bijzondere situatie welke zich in het geval van Verto voordeed. De vraag was of de situatie welke in het hiervoor genoemde citaat uit de Laurus-beschikking blijkt - welke valt terug te voeren op de Ogembeschikking uit 1990 - namelijk dat de vaststelling van wanbeleid nog niet één op één leidt tot civielrechtelijke aansprakelijkheid, in het omgekeerde geval ook zou gelden. De rechtbank te Rotterdam had in het vonnis a quo gemeend dat zij de aansprakelijkheid in het onderhavige geval niet zelfstandig behoefde te toetsen. ${ }^{295}$ Het gerechtshof moest in hoger beroep antwoord geven op de vraag of de vaststelling door de OK dat van wanbeleid van de vennootschap geen sprake was geweest, bindend was in de procedure waarin de gewone rechter moest oordelen of er sprake was van onbehoorlijke taakvervulling door bestuurders en commissarissen in de zin van artikel 2:9 en (in dit geval) 2:149 BW. De vraag was dus of de regel van de Ogem-beschikking ook in de spiegelbeeldige situatie dat de OK geen wanbeleid had vastgesteld, van toepassing was. Het gerechtshof te 'sGravenhage oordeelde dat een gegeven oordeel met betrekking tot wanbeleid of het afwezig zijn daarvan voor de betrokkenen weliswaar bindend was en daarmee bewijsrechtelijk van belang, maar in een latere aansprakelijkheidsprocedure niet zodanig verbindend, dat de rechter niet zelfstandig zal dienen te beoordelen in welke mate er van individuele verwijtbaarheid en aansprakelijkheid van een bestuurder of commissaris sprake is. Het gerechtshof onderzoekt vervolgens zelf de aansprakelijkheidsvraag aan de hand van een drietal verwijten. Opnieuw ontsnappen de voormalige bestuurders en commissarissen de dans. Het verwijt dat de transactie tot stand is gekomen zonder een deugdelijk due diligence onderzoek werd door het gerechtshof als het belangrijkste verwijt beschouwd. Het gerechtshof liet zich eveneens overtuigen door de - in mijn ogen te dunne argumentatie van de voormalige bestuurders en commissarissen dat het een goed bekende onderneming betrof en er over jaarcijfers werd beschikt en een rapport van een consultant dat 'nog redelijk recent was', zodat over voldoende informatie werd beschikt om over te gaan tot aankoop van een onderneming die voor goede synergie-mogelijkheden zou moeten kunnen zorgen. Er waren in het verleden werknemers over en weer bij elkaar te werk gesteld en er zou een groot draagvlak hebben bestaan voor de overname van DRSC. In mijn ogen allemaal mooi en aardig, maar onvoldoende reden om geen due diligence onderzoek uit te voeren.

Het gerechtshof is ook van mening dat het uitgevoerde financiële onderzoek summier was, maar laat zwaarder wegen dat niet vast staat dat het wel uitvoeren van de desbetreffende onderzoeken de later ontstane problemen zou hebben aangetoond. Een merkwaardige redenering in mijn ogen. Het hof sluit af met de overweging dat, gelet op hetgeen de betrokkenen wisten van de markt, de produkten en de bekendheid met DRSC als onderneming, gelet op de voor hen wel beschikbare gegevens op het desbetreffende moment niet een zodanig onverantwoorde beslissing hebben genomen dat hen dit verweten kon worden. Ik vind dat een merkwaardige redenering. Van Solinge stelt in zijn noot onder het arrest terecht dat het omgekeerde ook kan worden beweerd: "Het staat evenmin vast dat deugdelijk financieel onderzoek de latere problemen niet zou hebben aangetoond".

Duidelijker is de uitspraak van de OK van 6 januari $2005^{296}$ in de kwestie van Koninklijke Ahold N.V. te Zaandam ("Ahold"). De aanvragers van de enquête hadden gesteld dat er gegronde twijfels bestonden over de zorgvuldigheid waarmee Ahold het boekenonderzoek met betrekking tot de (toen nog beoogde) acquisitie van US Food Service ("USF") destijds heeft uitgevoerd. Zij wezen erop dat, indien het (juridische) boekenonderzoek destijds juist zou zijn uitgevoerd, aan het licht zou zijn gekomen dat de leverancierscontracten bestonden met clausules over aanzienlijke vooruitbetalingen of dat, als toen door USF gezegd zou zijn dat er geen op schrift gestelde leverancierscontracten bestonden, dit aanleiding had moeten zijn tot een nadere risico-analyse. Een ander aspect van het desbetreffende verwijt had betrekking op de zogenaamde post-closing situatie (namelijk dat Ahold er in ieder geval op

\footnotetext{
293 A.w. p. 147.

294 JOR 1999, 142 m.nt. G. van Solinge.

295 Rechtbank Rotterdam 12 december 1996, JOR 1997, 50 m.nt. G. van Solinge.

296 Gerechtshof Amsterdam (OK) 6 januari 2005, JOR 2005, 6 m.nt. M.W. Josephus Jitta.
} 
had moeten toezien dat die contracten na de acquisitie alsnog geformaliseerd zouden worden). Volgens de verzoekers wees ook de snelheid waarmee de acquisitie had plaatsgevonden, op onzorgvuldigheid van het daaraan voorafgegane onderzoek. De OK oordeelde dat de mate van zorgvuldigheid van het boekenonderzoek voorafgaande aan de acquisitie van USF gegronde redenen opleverden om aan een juist beleid van Ahold te twijfelen:

\begin{abstract}
"Weliswaar heeft zij doen aanvoeren dat in de destijds opgestelde due diligence rapporten "sleutelcontracten" beschreven zijn, maar of dat ook geldt voor leverancierscontracten, is in het midden gelaten. Nu Ahold zich in dit geding op het standpunt heeft gesteld dat het bestaan van dergelijke (op schrift gestelde) contracten tegenover D\&T USA door USF steeds is ontkend (zoals volgens Ahold tegenover D\&T USA door USF ook steeds is ontkend dat er afspraken met leveranciers bestonden die uitmondden in aanzienlijke vooruitbetalingen), moet er voorshands van worden uitgegaan dat in het kader van bedoeld boekenonderzoek geen leverancierscontracten door of namens Ahold zijn ingezien. Dat dergelijke contracten niet van voldoende belang zijn voor het oordeel of een acquisitie als de onderhavige wenselijk is (of dat dergelijke contracten bij due diligence onderzoeken bij een Amerikaanse beursgenoteerde vennootschap niet geproduceerd hoeven of mogen worden) heeft Ahold niet gesteld en lijkt ook - mede gelet op het feit dat Ahold geen specifieke ervaring had op het gebied van de groothandel - voorshands niet aannemelijk. De mogelijkheid dat Ahold destijds wel om (inzage van) leverancierscontracten heeft gevraagd, maar die niet heeft gekregen, met als argument "dat die er niet waren" laat de Ondernemingskamer onbesproken, nu Ahold zulks niet heeft aangevoerd. Voor de duidelijkheid zij nog overwogen dat uit de stellingen van Ahold volgt dat de hiervoor bedoelde mededelingen van USF aan D\&T USA na de acquisitie moeten hebben plaatsgevonden [...] de Ondernemingskamer is van oordeel dat deze gang van zaken inderdaad twijfels oproept over de zorgvuldigheid van het destijds door Ahold uitgevoerde boekenonderzoek met betrekking tot de acquisitie van USF. De brief van Debevoise \& Plimpton LLP van 10 mei 2004 (waarin - kort gezegd - tot het oordeel wordt gekomen dat de ter zake uitgevoerde due diligence onderzoeken afdoende zijn geweest) maakt dat niet anders, reeds niet omdat dat advies op verzoek van Ahold is uitgebracht".
\end{abstract}

De hiervoor laatstgenoemde opmerking van de OK in het genoemde citaat maakt duidelijk dat de opdrachtgever verantwoordelijk is voor de kwaliteit van het onderzoek. Met de door de Hoge Raad ontwikkelde criteria, zoals volgend uit het Hoog-Catharijne arrest, laat de beslissing van de OK zich goed verstaan. In mijn visie is die uitspraak ook een bevestiging van het feit dat sedert de uitspraak in de kwestie rond Verto ook het denken van de OK op het vlak van de normen welke dienen te worden toegepast bij het aangaan van een transactie, zich duidelijk hebben ontwikkeld in de richting van de erkenning dat een due diligence onderzoek een belangrijk element vormt van een acquisitieproces en dat er in het geval van aanwijzingen dat het voorwerp van koop niet goed overzien wordt, nader onderzoek geëigend is.

\title{
Belangenverstrengeling
}

Een aspect dat nog de aandacht verdient bij de uitvoering van due diligence onderzoeken, is de rol welke elk van de daarbij betrokken spelers in het veld hebben. Bij meerdere transacties hebben degenen die de informatie moeten verstrekken - de bestuurders van de doelwitvennootschap - ook een belang bij het uiteindelijke onderhandelingsresultaat. Te denken valt aan de koopprijs welke resulteert. Wanneer betrokkenen ook zelf in de transactie participeren of opties te verzilveren hebben, hebben zij rechtstreeks belang bij het resultaat waarin een waardering van waarden zal resulteren en dus bij de interpretatie van gegevens en de ordering van informatie. Zo is het gebruikelijk dat bij private equity transacties door investeringsmaatschappijen wordt bedongen dat ook het management deel neemt in het kapitaal van de eigen vennootschap ( een zogenaamde carried interest) in de veronderstelling, dat dit management zich dan nog gemotiveerder zal inzetten voor het behalen van goede resultaten door de vennootschap. Afhankelijk van de positie welke commissarissen innemen, kan het een antwoord zijn dat in dergelijke trajecten de commissarissen van meet af aan de regie in handen nemen. De koper dient zich in ieder geval van het gevaar van een belangenverstrengeling in dit soort situaties ter- 
dege bewust te zijn en zich af te vragen hoe vermeden kan worden dat het resultaat van een due diligence onderzoek daardoor kan worden beïnvloed. Hij dient in ieder geval de onderzoekers er op te attenderen dat er bijzondere aandacht dient uit te gaan naar waarderingsgrondslagen en interpretaties van cijfers en feiten. De andere kant van de medaille is dat bij een andersoortige transactie de verkoper ook zal proberen de in zijn geval meest voordelige uitkomst in de onderhandelingen te bereiken. Die heeft immers ook belang bij een voor deze gunstige uitleg van de dingen. Ook dan moet de koper alert zijn op interpretatieverschillen en onterechte rooskleurige voorstellingen van zaken. 


\section{Recente ontwikkelingen in de rechtspraak}

\subsection{Inleiding}

In het voorafgaande deel van dit boek heb ik geprobeerd om niet alleen een inzicht te geven in het fenomeen due diligence, maar ook om te zien welke juridische kwalificaties daar in ons recht bij passen. Ik heb mij in hoofdstuk 4 in eerste instantie beperkt tot de ontwikkelingen in ons recht tot en met het jaar 2000, als de periode waarin de kernelementen van de desbetreffende kwalificaties (de "Obliegenheiten" van de mededelingsplicht en onderzoeksplicht) tot ontwikkeling zijn gekomen. In het hieraan voorafgaande hoofdstuk heb ik een korte schets geprobeerd te geven van de juridische leerstukken die normaliter de achterliggende redenen opleveren voor het (doen) instellen van een due diligence onderzoek. Hierna wil ik aan de hand van rechtspraak en literatuur van de meest recente jaren de ontwikkelingen verder volgen en proberen tot verdergaande gevolgtrekkingen te komen.

\subsection{Casuïstiek}

Aan de hand van een aantal te benoemen thema's in de rechtspraak na het jaar 2000 wil ik zien hoe het leerstuk van de due diligence verder invulling heeft gekregen. Ik rond dit hoofdstuk af met enkele gevolgtrekkingen. Ik realiseer mij dat de keuze van onderwerpen aan de hand waarvan ik probeer het fenomeen due diligence verder een gezicht te laten krijgen, willekeurig genoemd kan worden. Het gaat mij evenwel steeds om het inkleuren van de tekening, waarvan het voorwerp due diligence moet voorstellen. Daarbij komen elementen aan de orde als hierna genoemd. Ik sta bijvoorbeeld stil bij wat ik 'een bijzondere situatie' noem, de situatie waarin men in het geheel niet bedacht hoeft te zijn op adders onder het gras, zodat er sprake kan zijn van verschoonbare onachtzaamheid bij het uitvoeren van een due diligence onderzoek. Ik sta eveneens stil bij de vraag wie er wanneer aanleiding moet zien tot het doen van (nader) onderzoek. Verder vraag ik mij af welke rol de verschillende hoedanigheden van partijen kan worden toegekend en hoe het zit met de stelplicht en bewijslast, wanneer discussies over verdiscontering of verdeling van risico's als gevolg van het wel of niet adequaat uitgevoerd zijn van een due diligence onderzoek te bedenken zijn. Daarnaast komen enkele andere thema's aan de orde.

\section{Verschoonbare onachtzaamheid}

Op grond van artikel 6:228 lid 2 zal voor rekening van de dwalende blijven een dwaling die, in zijn verhouding tot de wederpartij, als onverschoonbaar te kwalificeren is (geschonden onderzoeksplicht). ${ }^{297}$

Het gerechtshof te 's-Gravenhage besliste in een op dwaling gebaseerde zaak op 21 december $1999^{298}$ dat er geen onderzoeksplicht behoeft te worden aangenomen, wanneer het feiten en omstandigheden betreft waarop men (ook als professionele partij) in het geheel niet bedacht behoeft te zijn. Wanneer dat het geval is, is een kwestie van de feitelijke omstandigheden in het bijzondere geval, zodat de Hoge Raad vervolgens geen aanleiding zag om in te grijpen.

Het ging in het desbetreffende geval om de aankoop van een recreatieterrein met daarop bungalows en vakantiehuisjes, waarvoor de huurders de huur bij vooruitbetaling hadden voldaan. De verkoper had dit er niet bij gezegd en kreeg het door de rechtbank en het hof gesanctioneerde verwijt, dat de mededelingsplicht geschonden was.

Deze uitspraak roept gemengde gevoelens op. De koper had de administratie van de verkoper ter beschikking gekregen en was zelf een professionele partij. Huurbetalingen (wijze waarop, tijdstip en dergelijke) lijken toch voor de hand liggende dingen om te bekijken bij een due diligence onderzoek. De verkoper voerde het "Hoog Catharijne-verweer", maar tevergeefs. De portee van deze uitspraak is dat er omstandigheden kunnen zijn, waarin het zelfs een professional vergeven kan worden dat iets over het hoofd gezien is, omdat het een omstandigheid betreft waar ook die professional in het normale geval geen rekening mee hoeft te houden. Ook in de hier voor besproken zaak waren het de bijzondere omstandigheden van het geval die de uitkomst bepaalden. Beslissend was in dit geval het bijzondere

\footnotetext{
${ }^{297}$ Zie Asser-Hijma 5-I, 242.

${ }^{298}$ Kenbaar uit HR 18 januari 2002, LJN AD4924 en G.J.P. de Vries, Mededelings- en onderzoeksplicht bij een vergoedingsaanspraak op grond van dwaling, NTBR 2002/7, p. 341 e.v.
} 
feit dat de verkoper had meegedeeld wat de huuropbrengst was tot en met een bepaalde datum, maar niet dat de huur voor de eerste periode na die datum bij vooruitbetaling al was voldaan. In zoverre kan men ook zeggen dat de koper - al dan niet met verkeerde bedoelingen - op het verkeerde been was gezet.

Mij dunkt dat niet te snel mag worden aangenomen dat er sprake is van een situatie waarin onachtzaamheid verschoonbaar is. De hiervoor genoemde situatie betreft een randgeval. Op zichzelf is het niet ongebruikelijk dat huren vooruit worden betaald en doorvragen in verband daarmee zou niet hebben misstaan. Anderzijds was er de mededeling van de verkoper dat de huuropbrengst tot en met een bepaalde datum was voldaan, waardoor á contrario de indruk was gewekt dat er met betrekking tot de periode na die datum geen huuropbrengst was ontvangen. In combinatie met de wijze van uitleg van overnamecontracten, die meebrengt dat er in beginsel wordt afgegaan op hetgeen in een overeenkomst is vermeld en niet wat daar naar redelijkheid en billijkheid allemaal nog meer (wel of niet) toegerekend kan worden, liep in het onderhavige geval de zaak voor de verkoper goed af. ${ }^{299}$

\section{Opnieuw, de verkeersopvattingen}

Over auto's gesproken, levert de situatie waarmee een mij bekende dealer van auto's te maken kreeg, een goed voorbeeld op over de vraag hoe verkeersopvattingen een rol kunnen spelen. Dit voorbeeld vormt bovendien een mooie brug naar het volgende onderwerp, waar het gaat om de toerekenbare veronderstelling. Wat was het geval? De dealer had zojuist de beschikking gekregen over een voorraad nieuwe auto's van een nieuw type. Het desbetreffende type auto was eerder nog niet op de Nederlandse markt beschikbaar. In één van de eerste dagen nadat de auto in de showroom tentoon is gesteld, koopt een mevrouw een exemplaar zonder een proefrit te maken. Weinig tijd verstrijkt er na de aflevering, wanneer de koopster zich weer meldt om zich te beklagen over een storend geluid tijdens het rijden (volgens de dealer het normale motorgeluid). Treft de koopster blaam, dat zij geen proefrit heeft gemaakt en/of treft de dealer blaam dat deze de auto zonder dat er een proefrit werd gemaakt, heeft verkocht en geleverd? Als het neer zou komen op een beroep op conformiteit, zou de koopster wel eens een probleem kunnen hebben. De auto is immers voor het normale gebruik geschikt en er is geen sprake van door de dealer gewekte verwachtingen, waarin de koopster teleurgesteld kan zijn. Over het motorgeluid is immers in het geheel niet gesproken. Het normale gebruik van een auto is het daarmee rijden. Auto's hebben nu eenmaal verschillende soorten van motorgeluid. Dat motorgeluid doet aan de mogelijkheid van een normaal gebruik conform hetgeen van een auto mag worden verwacht, niet af. Mocht de koopster zich op dwaling beroepen, dan is de vraag of de dealer in verband met hetgeen deze had behoren te weten, zich er niet van had moeten vergewissen, dat de koopster een juiste voorstelling van zaken had. Het is immers naar de verkeersopvattingen ongebruikelijk om een auto te kopen zonder daarin een proefrit te maken, zelfs wanneer het een auto betreft van hetzelfde type, waarover men eerder beschikte. Temeer nu het een nieuw gelanceerd type betrof, had naar mijn oordeel de dealer aan de koopster moeten vragen of zij (voldoende) bekend was met een auto van dit nieuwe type om onder het afzien van het maken van een proefrit de auto te kopen. Wanneer het een auto zou hebben betroffen van eenzelfde type als waarover de koopster eerder had beschikt, is het nog voorstelbaar dat er van een proefrit wordt afgezien. Nu het een nieuw type betrof,

\footnotetext{
299 Zie HR 19 januari 2007, NJ 2007, 63 en HR 29 juni 2007, JOR 2007, 198. Zie daarentegen ook HR 19 oktober 2007, JOR 2008, 23. In het laatstbedoelde geval ging het om de uitleg van een bepaling in een overeenkomst tussen commerciële partijen, waar echter niet bijzonderlijk over onderhandeld was (algemene voorwaarden) of waarbij anderszins duidelijk was gebleken dat de partijen die bij de totstandkoming van de overeenkomst betrokken waren, zich met nadruk met het formuleren van de tekst van de overeenkomst hadden bezig gehouden. De toekomst zal moeten leren of de Hoge Raad inderdaad bedoelt bij de uitleg van overnamecontracten de Haviltex-formule op een eigen wijze toe te passen. Wat mij betreft dient er een waarschuwend woord te worden geuit tegen een al te rigide toepassing van een letterlijke uitleg van overnamecontracten. Dit werd nog eens duidelijk aan de hand van een clausule welke ik onlangs tegenkwam, die erop neerkwam dat een partij bij een aandeelhoudersovereenkomst zich had verbonden om vers eigen vermogen te verschaffen aan een vennootschap, indien die behoefte zou hebben aan een uitbreiding van haar aandelenkapitaal. De zin waarin de verbintenis tot voortgaande financiering was opgenomen, werd onmiddellijk gevolgd door de mededeling dat er een verplichte aanbiedingsplicht zou gelden, indien een aandeelhouder niet bereid of in staat zou zijn om bij te dragen aan een uitbreiding van het eigen vermogen. Nu er tussen partijen een geschil ontstond, vond er overleg plaats tussen de raadslieden van verschillende betrokken partijen. De vraag deed zich voor hoe een petitum diende te worden geformuleerd voor het geval een weigerachtige aandeelhouder in kort geding gedagvaard zou moeten worden. Eén advocaat verdedigde het standpunt dat er primair nakoming van de verbintenis tot voortgezette financiering moest worden gevraagd. De andere visie was dat een dergelijke verbintenis niet op zichzelf staand mocht worden beschouwd, maar moest worden verstaan in de context van de volledige bepaling. Voor sommigen een open deur, voor anderen een valkuil, nu de gedachte dat een overeenkomst letterlijk kan worden genomen, aanleiding kan zijn tot verkeerde interpretaties als hiervoor bedoeld.
} 
wordt het tipping point voor mij gevormd door het feit dat het nu de dealer was die had moeten insisteren op het uitvoeren van een due diligence onderzoek in de vorm van ten minste een proefrit. De toerekenbare veronderstelling - zoals ik dat noem - brengt de situatie in de risicosfeer van de dealer, nu die zich had behoren af te vragen of de koopster wel een juiste voorstelling van zaken had. Een en ander leidt dan tot de toepassing van artikel 6:228 lid 1 sub b.

Niet tegen te spreken valt dat er in het bedrijfsleven sprake is van zekere verkeersopvattingen. Of daartoe gerekend mag worden dat bij overnametransacties de onderzoeksplicht van de koper moet prevaleren boven de mededelingsplicht van de verkoper, wil ik betwijfelen. Ik ben van oordeel dat het aangaan van een transactie zonder het uitvoeren van een behoorlijk onderzoek uitnodigt tot de conclusie dat er van (een mate van) risicoaanvaarding sprake is. Veel meer spreekt mij de hiervoor onder 5.2 weergegeven visie van A-G Huydecoper aan, dat het steeds gaat om de vraag welk argument als doorslaggevend kan worden beschouwd (tipping point) voor de vraag voor wiens rekening de toerekenbare veronderstelling dient te worden gebracht. Huydecoper heeft gezegd dat verkeersopvattingen eerder zullen aanknopen bij de aard van de informatie waaromtrent gedwaald kan zijn: gebrekkige kennis van sommige informatie wordt gerekend tot de risicosfeer van de partij die met miskenning daarvan tot een overeenkomst toetreedt en (gebrekkige) kennis omtrent andere informatie juist niet. ${ }^{300}$

Hiervoor heb ik al betoogd dat de verkeersopvattingen bepalen wat er bij partijen aan veronderstellingen kan leven, naar als in de desbetreffende branche algemeen bekend te veronderstellen bestendig gebruik. Zo zal een onroerend goed dat op één dag meerdere malen van eigenaar wisselt aanleiding moeten zijn om te denken dat er iets mis is. ${ }^{301}$ Wanneer een auto op één dag vaker van eigenaar wisselt, is dat niet terstond aanleiding om te wantrouwen. ${ }^{302}$

\section{Toerekenbare veronderstelling}

Het heeft mijn voorkeur om te spreken over "toerekenbare veronderstelling" om uit te drukken wie van de koper of de verkoper moet worden geacht verantwoordelijkheid te dragen voor een aan de ander toe te rekenen veronderstelling. Die veronderstelling kan de hoedanigheid of omstandigheden betreffen van het voorwerp van de transactie of de kennis welke een partij heeft of moet worden geacht te hebben omtrent de veronderstelling waarin de wederpartij verkeert of kan verkeren. Het voordeel van het gebruik van deze terminologie is, dat de dogmatische discussie over onderzoeksplichten en mededelingsplichten wat minder belangrijk wordt gemaakt. Het hanteren van het begrip "toerekenbare veronderstelling" sluit naar mijn gevoel beter aan bij de werkelijkheid van de vraag welke een rechter te beantwoorden krijgt, wanneer een beroep op dwaling wordt gedaan, danwel op eigenschappen van een zaak waarvan de koper had mogen verwachten dat deze die bezat op grond van hetgeen de verkoper daaromtrent (wel of niet) heeft meegedeeld. Voor zover mij zou worden tegengeworpen dat artikel 7:17 spreekt over het doen van mededelingen door de verkoper en dit niet hetzelfde zou zijn als het nalaten van het doen van mededelingen, maakt de combinatie van die bepaling met de algemene bepalingen betreffende de redelijkheid en billijkheid dat desondanks er ook bij toepassing van artikel 7:17 een risicotoerekening kan plaatsvinden wanneer er wordt gezwegen, terwijl spreken naar redelijkheid en billijkheid verlangd had mogen worden.

Het risico voor het op het verkeerde been zetten van de wederpartij behoort te worden toegerekend aan degene die voor de onjuiste veronderstelling verantwoordelijk kan worden geacht. Dit werd bevestigd in een uitspraak van de rechtbank te Utrecht van 26 juli $2006 .{ }^{303}$ Het gaat om toerekenen van risico, waarbij volgens HR 14 juni $2002^{304}$ de vraag of het veroorzaken (maar ook, het in stand laten, voeg ik daar aan toe) van een onjuiste veronderstelling met (kwade) opzet gebeurt, niet beslissend is. Een gemeente verkocht grond met een bouwplicht in de oprechte veronderstelling dat er geen verontreiniging was. Er werd ook een 'schone grond-verklaring' afgegeven ten behoeve van een bouwvergunning. Er bleek toch sprake van verontreiniging. Dit gegeven rechtvaardigde volgens rechtbank, hof en Hoge Raad de conclusie dat de gemeente jegens een koper van een bouwperceel werd geacht in

\footnotetext{
${ }^{300}$ Zie de conclusie van A-G Huydecoper onder HR 8 december 2006, LJN AY7456.

301 Zie bijvoorbeeld rechtbank Utrecht 26 juli 2006, JOR 2006, 256.

302 Zie rechtbank Rotterdam 15 augustus 2007, Praktijkgids 2007, aflevering 25/26, nummer 179.

${ }^{303}$ Rechtbank Utrecht 26 juli 2006, JOR 2006, 256.

${ }^{304}$ RvdW 2002, 104.
} 
strijd te hebben gehandeld met de passende zorgvuldigheid en dus onrechtmatig te hebben gehandeld.

Een nuancering levert het arrest van de Hoge Raad van 21 juni 2002 op. ${ }^{305}$ Het betrof opnieuw een gemeente die grond verkocht. In dit geval wist de gemeente dat er in de grond olietanks hadden gezeten, die zij had laten verwijderen op één na. Die was leeggezogen en afgevuld met zand. Het verschil met de vorige $z^{2 a a k}{ }^{306}$ is, dat er in dit geval geen discrepantie bestond tussen de door de gemeente aan de koper gegeven indruk en de actuele situatie ter plekke. De kosten van sanering, die de koper op de gemeente wilde verhalen, behoefde de gemeente dus niet voor haar rekening te nemen. De koper was - naar de gemeente wist - vooraf op de hoogte van het bestaan van olietanks en het overblijven van één daarvan. Voor zover het er om ging wat de koper van redelijkerwijze op grond van de overeenkomst mocht verwachten en welke informatie de gemeente redelijkerwijze aan de koper had moeten verschaffen, was volgens het hof en later de Hoge Raad, bepalend wat beide partijen wisten - danwel wat geacht moest worden bekend te zijn - omtrent het verkochte, alles in aanmerking genomen de maatstaven en de algemene kennis ten tijde van het sluiten van de koopovereenkomst. Meegewogen werd dat de gemeente zelf geen aanwijzingen had dat er van verontreiniging sprake was. In zoverre stemt de zaak overeen met de hier voor laatst besproken zaak (waarin de gemeente ook dacht dat er geen verontreiniging (meer) was), maar het verschil zit daar in dat in het geval van de achtergebleven olietank op geen enkele wijze had of kon worden geacht te hebben bijgedragen aan wat ik hier aanduid met 'toerekenbare veronderstelling'.

Het is niet altijd eenvoudig te zeggen wanneer verantwoordelijkheid voor een toerekenbare veronderstelling aan de één en wanneer deze aan de ander moet worden toegerekend. Verkopers van een woonhuis (rijtjeshuis in een rustige en landelijke omgeving) waar de buren 100 tot 200 duiven hielden ('een complete duivenfokkerii' volgens de teleurgestelde koper) stelden zelf van de duiven van de buren nooit last gehad te hebben. Toch was het in dit geval niet zo moeilijk. De voorzieningenrechter in 's-Gravenhage ${ }^{307}$ rekende het de verkoper aan dat die op het inlichtingenformulier bij de NVM-koopakte had ingevuld dat er in de buurwoningen geen huisdieren aanwezig waren. Dat leverde in dit geval de beslissende bijdrage aan de toerekenbare veronderstelling op, dat er een huis werd gekocht, waarin men zonder een continue lawaai van duiven zou kunnen wonen. Of de verkoper zelf van dat lawaai last had gehad, is dan niet (meer) relevant. Wanneer mededelingen worden gedaan zoals op het hiervoor bedoelde inlichtingenformulier bij de NVM-koopakte, zullen die inlichtingen relevant zijn bij de beantwoording van de vraag voor wiens risico de toerekenbare veronderstelling dient te komen. Inlichtingen mogen niet lichtvaardig worden gegeven. Dit wordt nog eens bevestigd in een arrest van de Hoge Raad van 19 september 2003. ${ }^{308}$ Bij een beëindiging van een dienstverband werd door de werkgever aan een werknemer (van 51 jaar met een 20-jarig dienstverband) informatie verschaft, waaruit zou blijken dat er een mogelijkheid bestond voor de werknemer om zijn pensioenopbouw op vrijwillige basis voort te zetten. Die informatie was gebaseerd op een brochure welke door de werkgever aan de werknemer werd overhandigd (terwijl op het moment van het overleg er al een verbeterde procedure beschikbaar was waaruit bleek dat de pensioenopbouw niet mogelijk zou zijn). Gelet op de belangen die voor de werknemer - naar de werkgever had dienen te begrijpen - op het spel stonden bracht de zorgvuldigheid die de werkgever onder de desbetreffende omstandigheden tegenover zijn werknemer in acht behoorde te nemen mee, dat de werkgever tegenover de werknemer geen mededelingen zou doen omtrent een voor deze bestaande mogelijkheid tot toekomstige pensioenopbouw zonder zich van de juistheid van die mededelingen te hebben overtuigd.

Volgens het gerechtshof te 's-Gravenhage, bij arrest van 21 december $1999^{309}$, zal een verkoper eerder een mededelingsplicht hebben, wanneer het omstandigheden betreft, waarop de koper niet bedacht hoeft te zijn, bijvoorbeeld vanwege het ongebruikelijke karakter daarvan. Voor zover er sprake was van een toerekenbare veronderstelling, kon dit worden teruggevoerd naar de uit de processtukken blijkende stelling van de klagende partij dat - het betrof de koop van een bungalowpark - de huur was geïnd tot een bepaalde datum. Vervolgens bleek er sprake te zijn van een factureringssysteem, vol-

\footnotetext{
${ }^{305}$ RvdW 2002, 106.

${ }^{306}$ Waaromtrent G.T.M.J. Raaijmakers, Twee recente arresten over verkopersaansprakelijkheid, WPNR 2002/6507, p. 729-731.

${ }^{307} \mathrm{KG} 2003,183$.

${ }^{308}$ NJ 2005, 234 m.nt JH.

${ }^{309}$ Kenbaar uit HR 18 januari 2002, LJN AD4924. Zie over de desbetreffende uitspraak ook G.J.P. de Vries, Medelings- en onderzoeksplicht bij een vergoedingsaanspraak op grond van dwaling, NTBR 2002-7, p. 341 e.v.
} 
gens het welk ook huur voor de periode na die datum al door de verkoper was ontvangen. Anders dan in het geval van bijvoorbeeld de pensioenoverdracht in het geval van Avery of de kwestie rond Hoog Catharijne ${ }^{310}$ behoefde er in dit geval niet te worden doorgevraagd. Het onderscheidende element betrof hier het inderdaad ongebruikelijke karakter van het factureringssysteem. Het ging om dezelfde uitspraak welke hiervoor eerder werd genoemd onder het hoofd "verschoonbare onachtzaamheid". Dat de scheidslijnen dun zijn, zal wel duidelijk zijn. Het was immers evenzeer denkbaar dat de koper van een recreatiepark zich meer in het bijzonder verdiept in de wijze waarop de huren worden geïncasseerd en zich niet op de enkele mededeling daaromtrent van de verkoper verlaat. Er was kennelijk onvoldoende onderzoek ingesteld in de administratie. Het hof meende niettemin dat - gelet op het ongebruikelijke karakter van het factureringssysteem een en ander de mededelingsplicht van der verkoper niet wegnam. Daar is wat voor te zeggen, indien er inderdaad sprake is van een op zichzelf niet alledaags verschijnsel. De andere kant van de medaille is, dat canonverplichtingen of "hinkende rente" ook geen alledaagse verschijnselen waren en er in die gevallen (Hoog Catharijne en Avery) desondanks het beroep op onkenbaar wegens ongebruikelijkheid, geen genade vond in de ogen van de rechter.

Een fraai voorbeeld van toerekenbare veronderstelling, is te vinden in een arrest van de Hoge Raad van 11 juni 2004, dat betrekking had op veronderstelde non-conformiteit. ${ }^{311}$ Het betrof de aanschaf van een waterkavel door een gemeente. In de onderhandelingsfase had de gemeente in een brief geschreven dat het een kavel betrof, waarbij het water tot 1 meter uit de walkant ongeveer 1 meter diep zou zijn en verder aflopend naar 2 meter diepte. Het geschil tussen partijen ging over de vraag of een afwijking van het gestelde in die brief - waaromtrent in de koopakte of andere documentatie niets was gesteld - non-conformiteit opleverde. De koper had een boot die 1,70 meter diep stak en meende erop te hebben mogen vertrouwen dat de diepte van het water tenminste 2 meter zou zijn, ook in de toekomst. De rechtbank veroordeelde de gemeente om na betekening van het vonnis de overeenkomst na te komen in die zin dat het water tot 1 meter uit de walkant ongeveer 1 meter diep moest blijven en verder schuin moest blijven aflopen naar 2 meter diepte. Het gerechtshof zag het anders en vernietigde het eindvonnis van de rechtbank. De vorderingen van de koper werden alsnog afgewezen. De Hoge Raad meende dat het op de weg van de gemeente had gelegen om mee te delen, dat zij niet voornemens was om ook in de toekomst het water 2 meter diep te houden. Gelet op de inhoud van de eerder genoemde brief, had het volgens de Hoge Raad wel op de weg van de gemeente gelegen om mee te delen dat de koper er in beginsel niet op mocht vertrouwen dat de genoemde waterdiepte ook in de toekomst zou worden gehandhaafd. Door het schrijven van de meerbedoelde brief en het verder onvermeld laten van haar (andere) intenties met het oog op de toekomst, droeg de gemeente bij aan de toerekenbare veronderstelling, dat ook in de toekomst het water een diepte zou houden van 2 meter. De Hoge Raad betrok bij zijn oordeel dat de gemeente als eigenaar en onderhoudsplichtige van het overige water terplekke degene was die de mogelijkheid had de vaargeul in het waterkavel op de meegedeelde diepte van 2 meter te houden.

Met een uitspraak van 14 mei $2004^{312}$ brengt de Hoge Raad weer wat meer duidelijkheid in de verhoudingen in de mededelingsplicht van de verkoper en de onderzoeksplicht van de koper bij een bedrijfsovername, of zoals ik dat bij voorkeur noem, de toerekenbare veronderstelling. De vennootschap M\&M-Beheer II B.V. ("M\&M") heeft alle aandelen gekocht in een besloten vennootschap die als Fiscale Beleggingsinstelling (FBI) was onderworpen aan een zogenaamd 0-tarief voor de vennootschapsbelasting. Kort voor het sluiten van de koopovereenkomst heeft een vertegenwoordiger van M\&M contact opgenomen met de verkoper en hem erop geattendeerd dat de (prijsbepalende) balans geen bedrag aan vennootschapsbelasting vermeldde, waarna verkoper alsnog een voorziening van fl. $37.500,-$ ter zake op de balans heeft opgevoerd. Na de overname is aan de vennootschap een forse aanslag vennootschapsbelasting opgelegd omdat die haar FBI-status had verloren als gevolg van de verkoop van de aandelen aan M\&M (welke laatste vennootschap geen beleggingsvennootschap was). M\&M heeft de verkoper gedagvaard teneinde de schade als gevolg van de belastingaanslag te verhalen. De rechtbank en het hof hebben de vordering van M\&M afgewezen. Het hof heeft daarbij overwogen dat de FBI-status geen centrale rol had gespeeld bij de bepaling van hetgeen beide partijen bij het sluiten van de koopovereenkomst voor ogen stond, zodat het statusverlies binnen de risicosfeer van M\&M moest worden toegerekend. Het had daarom volgens het hof op de weg van M\&M gelegen om haar

\footnotetext{
${ }^{310}$ Zie respectievelijk HR 4 januari 1991, NJ 1991, 254 en HR 22 december 1995, NJ 1996, 300.

${ }^{311}$ HR 11 juni 2004, NJ 2004, 604.

${ }^{312}$ LJN AO1214 (M\&M Beheer).
} 
belangen te beschermen en zij had de verkoper op haar belang in deze moeten attenderen. De informatieplicht van verkoper gaat, aldus het hof, niet zover dat zij M\&M had moeten waarschuwen voor het mogelijk verlies van de FBI-status na verkoop en overdracht van de aandelen. Daarbij heeft het hof nadrukkelijk meegewogen dat M\&M een professionele partij was en dat van haar verwacht mocht worden dat zij zich van voldoende expertise zou voorzien om risico's als de onderhavige te kunnen inschatten. De omstandigheid dat mogelijk beide partijen zich niet hebben bekommerd om de FBI-status achtte het hof onvoldoende om een zwaarder gewicht toe te kennen aan de mededelingsplicht van de verkoper dan aan de onderzoeksplicht van M\&M. Het hof zag in het feit dat beiden zich niet bijzonderlijk hadden begeven in de vragen rond de FBI-status hoogstens een verklaring voor het feit dat naar aanleiding van vragen van M\&M over vennootschapsbelasting te elfder ure in de overnamebalans nog een voorziening ter zake van vennootschapsbelasting was opgenomen. Het beroep op dwaling van de zijde van M\&M werd verworpen met de overweging van het hof dat, indien M\&M al had gedwaald, deze dwaling niet zozeer betrekking had op hetgeen zij heeft gekocht (de aandelen in het kapitaal van de vennootschap), als wel op de FBI-status van de vennootschap. Nu de vennootschap deze status had en M\&M deze status kende, althans in ieder geval had kunnen kennen uit de haar verstrekte gegevens, komt volgens het hof een dergelijke dwaling voor haar risico. Bij twijfel had M\&M nader onderzoek kunnen verrichten, dan wel nadere informatie kunnen vragen, hetgeen zij zou hebben nagelaten.

De Hoge Raad komt tot een ander oordeel. Hij oordeelde dat er op de verkoper een mededelingsplicht rustte en niet zozeer op M\&M een onderzoeksplicht. Daarbij werd met name belang toegekend aan juist het feit dat de verkoper, na daarop door M\&M te zijn geattendeerd, een voorziening voor nog te betalen vennootschapsbelasting in de overnamebalans had opgenomen. Uit dit feit kan volgens de Hoge Raad worden afgeleid dat M\&M van een verkeerde veronderstelling uitging, en wel dat zij niet te maken had met een FBI. Ook wijst de Hoge Raad op de koopakte waarin de vrijwaring, respectievelijk vergoedingsverplichting staat ten aanzien van niet uit de balans blijkende verplichtingen en niet verwerkte belastingaanslagen. Door deze bepalingen heeft verkoper de indruk versterkt dat op de vennootschap geen latente fiscale claim rustte. $\mathrm{lk}$ noem dat dan de toerekenbare veronderstelling in de hand gewerkt hebben dat er geen bijzondere fiscale positie aan de orde was. Ook met betrekking tot het dwalingsberoep van M\&M wijst de Hoge Raad op het opnemen van de post voor betaling van vennootschapsbelasting. De verkoper moet zich er van bewust zijn geweest dat koper geen rekening hield met het feit dat de vennootschap de status van FBI had (als gevolg waarvan de overdracht van de aandelen aan M\&M de onderwerpelijke aanslag tot gevolg zou hebben). Met name dus het contact met de koper over het opnemen van de voorziening voor vennootschapsbelasting had voor de verkoper aanleiding moeten zijn om M\&M op de mogelijke gevolgen van (het verlies van) de FBI-status te wijzen.

De belangrijkste conclusie die uit dit arrest kan worden getrokken is dat in het onderhavige geval de verkoper zich had moeten realiseren dat M\&M denkbaar van een verkeerde veronderstelling uitging, namelijk dat de over te dragen vennootschap niet een FBI was. In een dergelijk geval ontstaat een nadere informatieplicht (zo men wil, mededelingsplicht) bij de verkoper, die immers de meeste kennis over de door haar te verkopen vennootschap pleegt te hebben. Dergelijke kennis moet zij bij kennelijke of anderszins waarneembare of te veronderstellen onkunde van de koper, met de koper delen. Het moet in een dergelijk geval wel gaan om materiële zaken. Er kan een parallel worden getrokken met het bepaalde in artikel 6:228 lid 1 sub b: een overeenkomst is wegens dwaling vernietigbaar, indien de wederpartij (in een dergelijk geval de verkoper) in verband met hetgeen hij omtrent de dwaling wist of behoorde te weten de dwalende (de koper) had behoren in te lichten. Uit dit arrest kan niet worden afgeleid dat van de verkoper een actieve houding wordt verwacht bij het beoordelen van de kennis die bij de koper aanwezig is. Er kan dus geen verplichting voor de verkoper uit worden afgeleid om kennis te nemen van de bevindingen van een due diligence onderzoek van de koper. Doet de koper echter een mededeling op grond waarvan de verkoper kan veronderstellen dat de koper een onjuist beeld van de vennootschap heeft, dan rust op verkoper de verplichting om nader onderzoek te doen.

In een arrest van 2 november 2004 heeft het gerechtshof te Arnhem ${ }^{313}$ zich uitgelaten over de vraag of een mededeling in een koopovereenkomst dat aan de verkoper geen feiten bekend waren, die erop wezen dat het verkochte registergoed een verontreiniging bevatte die nadelig kon zijn voor het door de

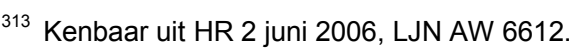


kopers beoogde gebruik, geschonden moest worden geacht wanneer verkoper wel feiten met betrekking tot verontreiniging bekend waren. Het door het hof gegeven antwoord ligt in dit geval voor de hand. Met name waar de verkoper (eigenaar van onroerend goed waarin voorheen een door de verkoper zelf geleid metaal- en constructiebedrijf werd uitgeoefend) van de hoed en de rand wist, had deze volgens het hof een spreekplicht en kon deze zich niet verschuilen achter een verwijzing naar een onderzoeksplicht van de koper. ${ }^{314}$ Het hof overwoog dat het de verkoper bekend was dat het verkochte gebruikt zou gaan worden als woonhuis en bedrijfsruimte. Als voormalig werknemer van het metaal- en constructiebedrijf en in verband met hetgeen ten tijde van de koop in het begin van de negentiger jaren bekend was omtrent de oorzaak van bodemverontreiniging - anders dan deze beweerde - moest de verkoper op grond van de hem bekende voorgeschiedenis ernstig rekening houden met de mogelijkheid dat de bodem met niet-afgegraven grond door het vroegere gebruik ernstig verontreinigd zou zijn. Door alsdan in de koopovereenkomst een verklaring op te nemen dat de verkoper geen feiten bekend waren die erop wezen dat het verkochte registergoed een verontreiniging bevatte die nadelig zou kunnen zijn voor het door de kopers beoogde gebruik, schoot deze toerekenbaar tekort jegens de kopers. Hetgeen de verkoper bekend was omtrent het vroegere gebruik wees, naar deze redelijkerwijs moest beseffen, juist wel op het door hem ernstig in te schatten risico dat het verkochte registergoed een voor het beoogde gebruik nadelige verontreiniging bevatte. Verweer van de verkoper dat de aanwezigheid van ijzerresten op de oprit van het perceel voor de kopers aanleiding had moeten vormen om een eigen onderzoek te laten uitvoeren, vond geen genade in de ogen van het hof. De rechtbank had eerder de verkoper toegelaten tot het bewijs dat er inderdaad ijzerresten op de oprit hadden gelegen ten tijde van het aangaan van de transactie, maar daar wilde het gerechtshof niet van weten. Het vonnis van de rechtbank werd bekrachtigd, maar niet waar het deze bewijsopdracht betrof. Dat onderdeel werd vernietigd. Deze zaak levert een duidelijk voorbeeld op van omstandigheden, waaronder de verantwoordelijkheid voor een onjuiste veronderstelling thuis hoort bij de verkoper. De onderzoeksplicht moest in dit geval wijken voor het gegeven van de mededeling van de voormalig exploitant van het metaal- en constructiebedrijf, ingevolge welke de koper er in redelijkheid niet aan behoefde te twijfelen of de bodem als gevolg van ernstige verontreiniging door de vroegere bedrijfsactiviteiten geschikt zou zijn voor het beoogde gebruik. Het was de combinatie van de hoedanigheid van de verkoper en de door deze gedane mededelingen die de laatstbedoelde verantwoordelijk maakte voor de bij de kopers ontstane verwachting dat er niet van verontreiniging sprake zou zijn.

Wanneer koper noch verkoper weet hebben van gebreken of van een onjuiste veronderstelling omtrent het voorwerp van een transactie, zal er sprake zijn van wederzijdse dwaling. ${ }^{315}$

De toerekenbare veronderstelling kan ook maken dat het risico bij de koper terecht komt. Het hangt er maar van af voor welke veronderstelling aan de zijde van de verkoper die verantwoordelijk kan worden geacht en wat er tegelijkertijd of vervolgens (bijvoorbeeld in termen van een mededelingsplicht) van de verkoper verwacht mag worden. ${ }^{316}$ Wanneer de koper een bepaald risico uitdrukkelijk aanvaard

314 Deze uitspraak vormt een voorbeeld van mijn gedachte dat de algemene opvatting dat bij overnametransacties de onderzoeksplicht van de koper moet prevaleren boven een mededelingsplicht, niet in zijn algemeenheid opgeld kan doen. Niet alleen hebben talloze transacties een gemengd karakter (woonhuis met bedrijfsruimte bijvoorbeeld, of voormalige bedrijfsruimte die voor woonruimte bestemd moet worden), maar veel meer gaat het om de hoedanigheid van partijen.

315 Zie o.m. gerechtshof te 's-Hertogenbosch 6 september 2006, NJF 2006, 67. Bij de (ver)koop van stukken grond was wel onderzoek gedaan naar vervuiling van de grond, maar niet specifiek naar asbestvervuiling. Partijen hadden in 1997 met elkaar onderhandeld over de aankoop van 3 percelen grond en daarna werd een koopovereenkomst gesloten waarbij ondermeer was overeengekomen dat indien bodemonderzoeken daartoe aanleiding gaven partijen de overeenkomst zouden kunnen ontbinden wanneer er zou blijken van ernstige verontreiniging. Uit bodemonderzoeken die daarna plaatsvonden, bleek dat er sprake was van ernstige verontreiniging op 2 percelen doch partijen zagen af van ontbinding van de koopovereenkomst. De percelen zijn in 2000 geleverd. Uit nader onderzoek daarna door de verkoper blijkt dat er ook sprake is van asbestvervuiling. Deze vervuiling was eerder niet uit de bodemonderzoeken gebleken. Het hof oordeelde dat hier geen sprake was van non-conformiteit, maar wel van wederzijdse dwaling. Het hof besloot tot wijziging van de gevolgen van de overeenkomst ter opheffing van het nadeel op voet van artikel 6:230 lid 2 in die zin dat beide partijen het nadeel ieder voor helfte kregen te dragen.

${ }^{316}$ Zie rechtbank Maastricht 13 augustus 2003, LJN AN1928, waar de verkoper zich had gebaseerd op opmerkingen van de koper omtrent diens plannen met het gekochte pand. Zie ook voorzieningenrecht Rechtbank Alkmaar 6 november 2003 , KG 2003, waarin geklaagd werd over gebreken aan een gekocht woonhuis, welke door de koper zelf hadden kunnen worden waargenomen en "indien er twijfel bestond, zelf hadden moeten worden onderzocht", aldus de voorzieningenrechter. Het tekortschieten in de onderzoekplicht maakte in dit geval dat het risico bij de koper terechtkwam. Zie echter ook Rechtbank Middelburg, 17 december 2003, LJN AO0897, waarin het ging om gebreken aan een zeilschip, welke bij nader onderzoek aan het daglicht hadden kunnen komen (volgens de verkoper waren er voldoende duidelijke zichtbare aanwijzingen "op grond waarvan de koper dan wel zijn expert de schroevendraaier had moeten pakken"), maar de Rechtbank toch oordeelde dat de gebreken ten tijde van de koop/verkoop niet (voldoende) zichtbaar waren. Desondanks kwam het risico bij de koper 
bijvoorbeeld of de verkoper zelf met bepaalde risico's niet (volledig) bekend was, zal de toerekenbare veronderstelling al licht aan de zijde van de koper terecht doen komen. ${ }^{317}$

In de lagere rechtspraak is zo een veelheid van uitspraken bekend, waarin de onderzoeksplicht met de mededelingsplicht strijdt om de voorrang. De feitelijke omstandigheden in elk geval zijn vaak bepalend. ${ }^{318}$ Naar mijn mening moeten wij in ieder geval af van de verwarrende vraagstelling of een onderzoeksplicht zwaarder weegt dan een mededelingsplicht of andersom. Het begrip toerekenbare veronderstelling drukt naar mijn gevoel beter uit - of zo men wil, de toerekenbare onjuiste veronderstelling dat er op beide partijen, aan beide zijden van een transactie een zorgplicht rust om rekening te houden met de (kenbare) belangen van de wederpartij. Noem het een zorgplicht. Ik kom daar in mijn slotopmerkingen (hoofdstuk 14) nog op terug.

\section{Onevenwichtige verdeling van deskundigheid}

Veel meer dan zich te baseren op (te) algemene stellingen dat in het bedrijfsleven geldende gebruiken zouden maken dat bij overnametransacties de onderzoeksplicht van de koper moet prevaleren, of andere, vergelijkbare standpunten in te nemen, lijkt mij dat de vraag naar de hoedanigheid van partijen en de daarbij aan hen toe te rekenen veronderstellingen omtrent hetgeen de wederpartij wist, de norm moeten vormen. ${ }^{319}$ In feite speelt deze omstandigheid in het Hoog Catharijne-arrest een rol en in veel andere situaties. De hoedanigheid van partijen bepaalt immers ook welke kennis bij een partij mag worden verondersteld. Dit zal mede de kwaliteit bepalen van een (due diligence) onderzoek dat door een koper wordt ingesteld. Zo is mij de enkele vaststelling dat een ondernemer een "repeat player" zal zijn, te algemeen. Ook voor ondernemers geldt dat die bepaalde transacties voor de eerste keer (en soms de enige keer) doen. Het is dan een te grof raster om de enkele hoedanigheid van ondernemer te verklaren tot een omstandigheid die maakt dat er over ervaring met de dan actuele transactie wordt beschikt. Wel zal van ondernemers over het algemeen een wat zakelijker aanpak en insteek bij transacties worden verwacht dan van een particulier.

terecht. De Rechtbank was niet gebleken dat de verkoper iemand was met bijzondere technische deskundigheid op het gebied van zeilschepen. De Rechtbank kwam tot het oordeel dat de koper het zeilschip had kunnen en moeten (laten) onderzoeken. Hij had een zeiljacht gekocht van meer dan 75 jaar oud, dat gedurende 3 jaar voor de koop op de wal had gelegen. Een deskundige zou waarschijnlijk wel tekenen hebben waargenomen, die aanleiding zouden hebben gegeven tot een waarschuwing of om nader wellicht zelfs destructief onderzoek te plegen. Dat de koper geen gebruik heeft gemaakt van de hem contractueel geboden mogelijkheid om vooraf een keuring te laten plaatsvinden, werd hem in dit geval aangerekend.

317 Zie gerechtshof te Leeuwarden, 12 april 2006, kenbaar uit HR 7 december 2007, LJN BB9421.

318 Zie bijvoorbeeld gerechtshof Amsterdam 15 juli 2004, Praktijkgids 2005/1, nummer 2. Het betrof de vraag of de mededelingsplicht van een veilingverkoper zwaarder woog dan de onderzoeksplicht van de koper bij de aanschaf van een paard. Zowel de koper als de verkoper waren uitgegaan van een 5,5 maand oud medisch rapport. Het betrof de aanschaf van een dressuurpaard. Later bleek dat het paard een aanmerkelijk verhoogd kreupelheidsrisico kende. De koper vernietigde de overeenkomst buiten gerechtelijk. De verkoper betwiste de rechtsgeldigheid daarvan. Volgens het hof was de verkoper geen professionele paardenhandelaar en beschikte deze niet over meer informatie dan een 5,5 maand oud keuringsrapport, zodat niet gezegd kon worden dat deze de koper onjuist had ingelicht. De koper werd verondersteld zich te realiseren dat een 5,5 maand oud rapport niet noodzakelijk de correcte klinische toestand weergeeft van het paard op de dag van aankoop. De koper had derhalve het risico aanvaard dat de toestand van het paard 5,5 maand later anders was, zodat de dwaling voor haar rekening kwam. Zie ook Rechtbank Alkmaar, Sector Kanton, 29 maart 2006, LJN AX4054, waarin een koper van een recreatiewoning met een alleen aan de voorkant vernieuwd dak stelde dat de verkoper diens mededelingsplicht niet was nagekomen. De kantonrechter volgde de eiser hierin niet. Hij was van oordeel dat de koper onvoldoende deugdelijk eigen onderzoek had verricht, terwijl deze daartoe wel in staat was gesteld.

Zie verder gerechtshof 's-Hertogenbosch 6 december 2005, NJF 2006, 271. De onderzoeksplicht van de koper werd verminderd door het verschaffen van een uitdrukkelijke garantie (voor normaal gebruik) van een woonhuis, waarin sprake was van een boktor-aantasting door de verkoper.

319 Zie R.P.J.L. Tjittes, De hoedanigheid van contractspartijen, Kluwer 1994, p. 58 e.v. en over professionaliteit versus verwijtbaarheid ook G.T.M.J. Raaijmakers, Bedrog bij bedrijfsovernames: een gewaarschuwd mens telt voor twee, NTBR 2004, 51, p. 280.

Volgens Raaijmakers is er al langere tijd een zekere tendens en in ieder geval een roep om de factor professionaliteit en risicoverdeling bij de koper zwaarder te laten wegen. Waar enerzijds juist benadrukt wordt dat de regels omtrent mededelingsplicht ook dienen ter bescherming van de onvoorzichtige koper, wordt anderzijds aan de professionele partij een zware eigen verantwoordelijkheid opgelegd. Hij verwijst enerzijds naar HR 10 april 1998, NJ 1998 , 66 (Offringa-Vinck) en vergelijkt verder HR 2 mei 1969, NJ 1969, 344 (Beukinga-Van der Linden), waar de Hoge Raad bijzondere betekenis toekende aan het feit dat de koper 'een betrekkelijk eenvoudige man' was; HR 15 april 1994, NJ 1995, 614 (Oldttimer), waar de Hoge Raad overwoog dat de verkoper beter kon 'sleutelen' dan de koper.

Anderzijds wordt verwezen naar HR 22 december 1995, NJ 1996, 300 (Hoog Catharijne); HR 5 september 2003, NJ 2003, 677 (Kalkman-Baarsma). Ook wordt genoemd HR 1 juni 1990, NJ 1991, 759 (Van Lanschot-Binck) en Asser-Hijma (2001) nr. 337.

Verwezen wordt ook naar HR 18 september 1998, NJ 1988, 818 (KPI-Leba), waar de ene professionele partij niet onder zijn waarschuwingsplicht uitkwam door te wijzen op de professionaliteit van de ander. 
Op meerdere plaatsen in de jurisprudentie komt tot uitdrukking dat de deskundigheid van de betrokken partijen een belangrijke rol speelt bij de vraag welke zin partijen over en weer redelijkerwijs aan elkaars verklaringen en gedragingen mochten toekennen en wat zij te dien aanzien redelijkerwijs van elkaar mochten verwachten. ${ }^{320}$ Een recent voorbeeld wordt gevonden in een arrest van het gerechtshof te Amsterdam van 13 september $2007 .{ }^{321}$ In die uitspraak wordt de kennis van vertegenwoordigers toegerekend aan de bij een aandeelhoudersovereenkomst betrokken partij: "weliswaar kan niet worden vastgesteld dat $[\mathrm{A}]$ c.s. ten tijde van het sluiten van de overeenkomst zelf beschikte over kennis op professioneel niveau aangaande de overname van de onderneming door een andere onderneming en een daar in het verlengde van liggende beursnotering, maar $[\mathrm{A}]$ c.s. heeft zich bij de totstandkoming van de Shareholders' Agreement laten bijstaan dan wel vertegenwoordigen door professionele adviseurs, onder wie zijn advocaat alsmede de toenmalige CEO van Cignal, [X], zodat partijen niet zodanig ongelijkwaardig zijn te achten dat dit van invloed dient te zijn op de uitleg van de overeenkomst".

Niet zelden vangt een beoordeling door de rechter aan met een vaststelling omtrent de hoedanigheid van partijen. ${ }^{322}$

De relevantie van de inschakeling van deskundige adviseurs en de hoedanigheid van een professionele partij komt ook tot uitdrukking in het arrest van de Hoge Raad van 10 oktober $2003 .{ }^{323}$ Het beroep op dwaling van de koper werd verworpen mede op grond van het feit dat de koopovereenkomst betreffende de overname van een onderneming door middel van de koop van alle geplaatste aandelen in het kapitaal van een vennootschap, plaatsvond tussen professionele partijen. De koper had al eerder overnames gedaan. Beide partijen waren bijgestaan door deskundigen (accountants en juristen). Tijdens een beperkt due diligence onderzoek was gebleken dat er op belangrijke punten incorrecte informatie was verstrekt. De koper had daardoor alle aanleiding te twijfelen aan de juistheid van mededelingen van de verkoper. Het had daardoor op de weg van de koper gelegen, als professionele partij, indien zij de transactie toch wilden laten doorgaan, een onbeperkt due diligence onderzoek te eisen en/of garanties te bedingen. Door dit na te laten, heeft de koper welbewust het risico van onjuiste gegevens omtrent de financiële toestand van de doelwitvennootschap aanvaard. Ook het beroep op bedrog werd aldus verworpen.

Onbekendheid van gebreken die na het aangaan van een transactie blijken, kan soms voor rekening van een partij komen, vanwege de deskundigheid van die partij. ${ }^{324}$

Wanneer er geen sprake is van een onevenwichtige verdeling van deskundigheid, dienen partijen er rekening mee te houden dat dit eveneens gevolgen kan hebben voor de wijze waarop de rechter naderhand naar de resultaten van onderhandelingen zal kijken. Vles heeft onder verwijzing naar een tweetal recente uitspraken van de Hoge Raad geconcludeerd dat een door juristen opgestelde en intensief uitonderhandelde, omvangrijke commerciële overeenkomst moet worden uitgelegd naar de meest voor de hand liggende taalkundige betekenis die daaraan gegeven kan worden. De gedachte is dat professionele partijen veel waarde hechten aan zekerheid met betrekking tot de inhoud van de overeenkomst om zodoende de overeengekomen verbintenisrechtelijke risicoverdeling te handhaven. Van veel gebruikte modelbepalingen en andere door juristen met zorgvuldigheid opgestelde bepa-

${ }^{320}$ Vergelijk op het terrein van het bestuursrecht HR 10 augustus 2007, AB 2007, 388, een uitspraak met betrekking tot het Communotaire Douanewetboek. De Hoge Raad sanctioneerde de uitspraak van het hof, waarin het ging om een vergissing van de bevoegde douane-autoriteiten. Overwogen werd dat de belanghebbende die vergissing redelijkerwijs had kunnen ontdekken. Als reden werd genoemd dat de belanghebbende douane expediteur was en professioneel marktdeelnemer, die de vergissing aan de hand van het Publicatieblad eenvoudig had kunnen ontdekken en in geval van twijfel over de betekenis van teksten in het Publicatieblad zelf alle mogelijke opheldering had moeten zoeken om te controleren of deze twijfel gerechtvaardigd was.

321 LJN BC0317 (UPC). Wij zagen eerder dat dit element ook met zoveel woorden speelde in HR 4 januari 1991, NJ 1991, 254 (Avery) en in HR 22 december 1995, NJ 1996, 300 (ABP/FGH).

322 Zie bijvoorbeeld gerechtshof Amsterdam 19 augustus 2004, Prg. 2005 (1), nr. 2 (r.o. 4.6.): "Allereerst is van belang dat gesteld noch gebleken is dat Tuin een professionele paardenhandelaar is..." en HR 29 juni 2007, RvdW 2007, 636, waar wordt aangevangen met de vaststelling dat het onderhavige geding de koop van een huis betreft door een particulier.

323 LJN Al0306 (Dutch Paint), r.o. 331.

324 Zie Rechtbank Alkmaar 24 juni 1999, KG 1999, 183. In r.o. 4.7 wordt overwogen: "Bot's onwetendheid komt bovendien voor haar risico. Als professionele deelnemer op de huizenmarkt heeft zij nadat Hogers, als particuliere koper, vraagtekens had geplaatst ten aanzien van de afwezigheid van asbest in de kruipruimte, gekozen voor een summier en op grond van een eigenhandig genomen monster ingesteld onderzoek." Zie p. 110 onder "evenwichtige verdeling van deskundigheid", HR 29 juni 2007, JOL 2008, 480. 
lingen mag worden uitgegaan dat de tekst van de bepalingen de bedoeling van partijen juist weergeeft. Wel staat volgens de Hoge Raad de mogelijkheid van tegenbewijs open. ${ }^{325}$

\section{Stelplicht en bewijslast}

Bij dwaling en bedrog kan er sprake zijn van vernietigbaarheid (artikel 6:228 lid 1 en 3:44 lid 1). De overeenkomst blijft in stand, wanneer er geen vernietiging wordt gevraagd. Bij gebreke van conformiteit, zal de koper eerst recht kunnen doen gelden op een sanctie, door ter zake na te hebben geklaagd een vordering in te stellen (artikel 7:23 jo. 7:21). Degene die verhaal zoekt voor een vermeend gebrek in een prestatie, zal moeten duidelijk maken waarom er aan het voorwerp van de transactie een gebrek kleefde. De bewijslast ligt in beginsel bij de klager. Dat volgt uit artikel $150 \mathrm{Rv}$ Dit is slechts anders wanneer uit een bijzondere regel of uit de redelijkheid en billijkheid een andere verdeling van de bewijslast voortvloeit. Zo kreeg een verkoper de bewijslast in een geval, waarin een koper van een perceel met opstal een schadevergoeding vorderde van de verkoper op grond van een wanprestatie wegens non-conformiteit. De wanprestatie zou erin hebben bestaan dat voor de oppervlakteverharding gebruik zou zijn gemaakt van gebroken puin maar dat dit na levering grof puin bleek te zijn. ${ }^{326}$ De rechter overwoog dat de koper geen grof puin behoefde te verwachten. Dit zou slechts anders zijn, wanneer de stelling van de verkoper juist zou zijn, dat de koper wist of reden had te vermoeden dat hij grof puin zou krijgen. De rechtbank in Arnhem overwoog op 19 december 2007 dat het aan de verkoper was om te bewijzen dat de koper door een mededeling zijnerzijds wist of reden had te begrijpen dat deze een laag grof puin zou krijgen. ${ }^{327}$

Een uitspraak van de rechtbank te Rotterdam van 17 september $1998^{328}$ bevat een voorbeeld van een gebrek aan bewijs. Partijen maakten met elkaar ruzie over de vraag hoe een post buitenlandse omzetbelasting moest worden verrekend nadat er een geschil was ontstaan over de toepassing van garanties in een overname overeenkomst. De rechtbank verwierp het verweer dat er ter zake afspraken waren gemaakt als onvoldoende feitelijk onderbouwd. ${ }^{329}$ De feitelijke onderbouwing is belangrijk. Een dergelijke wijze van aanpak van de rechter is niet ongebruikelijk. Een recent voorbeeld wordt gevonden in de uitspraak van de rechtbank te Utrecht van 12 december 2007, ter gelegenheid van het geschil tussen de curatoren van Ceteco N.V. en het bestuur, de commissarissen, de moedermaatschappij en de accountant. ${ }^{330}$ De curatoren hadden de bestuurders en commissarissen van Ceteco N.V. verweten dat er met de uitkomsten van uitgevoerde due diligence onderzoeken (ter gelegenheid van de acquisities in het buitenland) niets was gedaan. De rechtbank doet dat verwijt af met de overweging dat de curatoren "slechts" hebben gesteld dat het onbegrijpelijk is dat de commissarissen niet hebben aangestuurd op het op orde brengen van cruciale bedriffsprocessen, alvorens te besluiten tot de integratie van geacquireerde vennootschappen. De rechtbank meende dat onvoldoende was gesteld om

${ }^{325} \mathrm{~N}$, Vles, Toevoeging to the seller's knowledge in commerciële overnamecontracten: een slag om de arm, V\&O november 2007, nr. 11, p. 205. De arresten waarnaar verwezen wordt, zijn HR 29 januari 2007, JOR 2007,166 (Meyer Europe) m.nt. R.P.J.L. Tjittes en HR 29 juni 2007, JOL 2008, 480 (Uni-Invest), onder welke uitspraak R.PJ.L. Tjittes een noot schreef in JOR 2007, 198. Zie ook R.P.J.L. Tjittes, Terug naar de tekst - een herwaardering van de tekstuele uitleg van contracten, WPNR (2007) 6709, p. 421.

326 NJF 2008, 52

327 Een bijzondere vraag is steeds of non-conformiteit ook in de weg staat aan het normale gebruik. Non-conformiteit betekent niet altijd dat er niet desondanks wel normaal gebruik van het gekochte kan worden gemaakt. In het onderhavige geval overwoog de rechtbank (r.o. 4.5) dat onderzocht diende te worden of de aanwezigheid van grof puin in de weg stond aan het gebruikmaken van het perceel voor zelfbewoning met bedrijfsruimte. De rechtbank benoemde een deskundige om te onderzoeken of op het terrein zonder problemen een parkeerplaats kon worden gemaakt met behulp van oppervlakteverharding van betonplaten zonder dat daarvoor het terrein noodzakelijkerwijs tot een meter diep over de gehele oppervlakte ontdaan moest worden van grof puin. Zie in dit verband ook HR 23 november 2007, RCR 2008, 8, waarin het gerechtshof werd verweten niet voldoende te hebben gemotiveerd waarom bodemverontreiniging maakte, dat een tankstation niet die eigenschappen had die de koper mocht verwachten op grond van gedane mededelingen van de zijde van de verkoper (r.o. 5.2).

328 JOR 1999, 4 (r.o. 8.5).

${ }^{329}$ Zie HR 9 juli 2004, RvdW 2004, 94 over de vraag in hoeverre een aanbod van getuigenbewijs gespecificeerd dient te worden, en daarover G.R. Rutgers, Bewijsaanbod in civiele contentieuze zaken, AA 54 (2005), nr. 4, p. 270 e.v., die meent dat er steeds weer zaken onnodig worden verloren omdat de partijen geen, dan-wel onvoldoende bewijs van hun stellingen hebben aangeboden.

330 JOR 2008, 10 m.nt. S.M. Bartman 
de conclusie op te baseren dat op basis van de uitkomsten van de uitgevoerde due diligence onderzoeken in redelijkheid niet had kunnen worden overgegaan tot besluitvorming om in de geacquireerde vennootschappen te investeren.

Het vorenstaande leert niet alleen dat bij gebreke van conformiteit of andere gebreken in de nakoming van een verbintenis, het nodig is dat de vermeende gelaedeerde in actie komt, maar bovendien niet nalaat gemotiveerd diens vordering te onderbouwen. Op een verweer van de andere partij zal gemotiveerd moeten worden ingegaan. Dit werd ook nog eens duidelijk in het arrest van de Hoge Raad in de kwestie Vie d'Or. In geval van dwaling zal moeten worden geadstrueerd dat zonder de aan de ander toe te rekenen verkeerde veronderstelling de transactie niet zou zijn aangegaan.

Bij wijze van voorbeeld kan het geschil tussen Laurus en Vomar worden genoemd, waarin de Rechtbank te Amsterdam oordeelde op 9 januari 2008. Dat geschil had betrekking op de overname van zeven supermarktvestigingen. ${ }^{331}$ Vomar klaagde dat Laurus haar nimmer had geïnformeerd over de achtergrond van een samenwerking tussen Laurus en haar onderhuurder Lidl (te weten dat deze samenhing met het oogmerk een derde (Deen) in de regio buiten de deur te houden) in Venhuizen. Laurus verzuimde Vomar te informeren over de weigering van Lidl om akkoord te gaan met de overgang van de onderhuurovereenkomst. Toch slaagde zij er niet in om ter zake enige schade op Laurus te verhalen, nu volgens de rechtbank zij onvoldoende had aangetoond - hetgeen Laurus als verweer had gevoerd - dat Vomar de supermarkt op de desbetreffende plaats niet zou hebben gekocht, indien zij ermee bekend zou zijn geweest dat Lidl zou vertrekken. Het verschil tussen oorzaak en gevolg hier zorgde voor een goede afloop voor Laurus.

Wanneer de inzet van een geschil de vraag is of een ontbindende voorwaarde is overeengekomen, rust de stelplicht en bewijslast ten aanzien van het bestaan van die voorwaarde op de partij die zich op (het vervuld zijn van) die voorwaarde beroept. ${ }^{332}$ Die vorenstaande conclusie is te ontlenen aan een arrest dat de Hoge Raad wees naar aanleiding van een geschil over de (ver)koop van een 2-tal kantoorpanden. Zowel koper als verkoper waren ervaren vastgoedbeleggers. Volgens de bevestiging van de makelaar van de koper aan de verkoper, wordt op enig ogenblik overeenstemming bereikt over de (ver)koop, waarbij die makelaar vermeldt dat er geen sprake is van ontbindende voorwaarden. Een dag later bericht de verkoper dat deze begrijpt dat er in beginsel overeenstemming bestaat over de (ver)koop, maar dat ter zake een voorbehoud geldt voor "de goedkeuring van zijn makelaar". Weinig later wordt de koper meegedeeld dat de ontbindende voorwaarde was ingetreden. De koper vordert nakoming van de volgens deze gesloten koopoverkomst. Hij stelt dat de ontbindende voorwaarde (in de vorm van het voorbehoud van goedkeuring door de beherend makelaar) eerst achteraf en dus te laat ter sprake is gebracht. De verkoper betoogt dat het voorbehoud wel degelijk (tijdig) is gemaakt en dat de ontbindende voorwaarde inmiddels is ingetreden. De rechtbank oordeelde dat het in de omstandigheden van dit geval en conform de hoofdregel van artikel $177 \mathrm{Rv}$ (thans $150 \mathrm{Rv}$ ) aan de verkoper was om te bewijzen dat deze de door hem gestelde ontbindende voorwaarde tijdig en voldoende duidelijk had bedongen, nu deze zich op de rechtsgevolgen van het intreden van dit omstreden voorbehoud beriep. De rechtbank heeft de verkoper vervolgens tot bewijslevering toegelaten. In het eindvonnis concludeerde de rechtbank dat de verkoper niet in de hem verstrekte bewijsopdracht was geslaagd en werd de verkoper tot schadevergoeding veroordeeld. Het gerechtshof volgde het oordeel van de rechtbank. De Hoge Raad bevestigde dat de hoofdregel van de bewijslastverdeling inhoudt dat de partij die zich beroept op de rechtsgevolgen van door haar gestelde feiten of rechten, de bewijslast van die feiten of rechten draagt. Nakoming van een verbintenis onder ontbindende voorwaarden kan worden gevorderd tenzij de voorwaarde in vervulling is gegaan. Het bestaan van de ontbindende voorwaarde vormt de grondslag van het bevrijdende verweer van de schuldenaar dat de voorwaarde is vervuld. Stelplicht en bewijslast ten aanzien van het bestaan van een ontbindende voorwaarde liggen daarom ook volgens ons hoogste rechtscollege bij de partij die zich op (het vervuld zijn van) een voorwaarde beroept. De conclusie is niet anders, wanneer het niet een ontbindende maar een opschortende voorwaarde betreft ${ }^{333}$.

\footnotetext{
${ }^{331}$ LJN BC3247.

${ }^{332}$ Zie HR 9 september 2005, LJN AT5156.

${ }^{333}$ Zie HR 7 december 2001, NJ 2002, 494 m.nt. DA.
} 
In een arrest van de Hoge Raad van 23 november $2007^{334}$ wordt nog eens bevestigd dat op degene die van oordeel is dat er sprake is van een tekortkoming bij de (nakoming) van een transactie de verplichting rust om ter zake het nodige te stellen en bij gemotiveerde betwisting te bewijzen, en bovendien duidelijk te maken op welke wijze er tijdig en op een voor de wederpartij kenbare wijze is geklaagd over de desbetreffende tekortkoming. Indien de door de verongelijkte partij gestelde feiten door diens wederpartij onvoldoende worden betwist, worden die feiten als vaststaand verondersteld. Er valt dan niets te bewijzen en een bewijsaanbod mag in een zodanig geval worden gepasseerd ${ }^{335}$.

In de praktijk is het niet ongebruikelijk dat er bij met name kleinere transacties slordig wordt omgegaan met het tot stand brengen van documentatie. Partijen hebben vaak een verschillende opvatting over hetgeen voor de ander duidelijk moet zijn. Een voorbeeld wordt gevonden in de uitspraak van de rechtbank te Rotterdam van 13 februari $2008^{336}$. De koper stelde dat de verkoper balansgaranties had afgegeven en dat er op die balansgaranties inbreuk werd gemaakt. Verkoper verweerde zich door te stellen dat dit niet het geval was. De enige documentatie waarover de koper beschikte welke als geformaliseerd kon gelden, was een concept-koopovereenkomst, opgesteld met in de koptekst de vermelding 'conceptversie 20 juli 2005'. Dat stuk vormde de overeenkomst op grond waarvan 2 dochtermaatschappijen van een transportonderneming werden overgenomen. De overeenkomst was door beide partijen bij de verkoper thuis in Spanje geparafeerd en ondertekend. Ofschoon in dat concept bepalingen voorkwamen die erop leken dat de verkoper de grootte en samenstelling van het vermogen volgens de balans van de desbetreffende vennootschappen garandeerde, stuitte de koper op de hardnekkige ontkenning van de verkoper dat deze per saldo een balansgarantie had afgegeven. De rechtbank begeeft zich in interpretatievragen en stelt dat - nu er geen andere aan de totstandkoming van de overeenkomst ontleende of andere voldoende specifieke en concrete feiten en omstandigheden waren gesteld of gebleken, die konden leiden tot de conclusie dat de verkoper in de genoemde bepalingen van de conceptovereenkomst bedoelde balansen had gegarandeerd, de vordering moest worden afgewezen wanneer de koper niet in het bewijs zou slagen dat de situatie anders was. De koper werd een bewijsopdracht verleend en de rechtbank wilde niet treden in de vraag of er sprake was van schending van balansgaranties zo lang het bewijs dat er daadwerkelijk een garantie was verleend, door de koper niet eerst was geleverd.

\section{Verdiscontering / risicoverdeling}

Zo goed als, gebaseerd op artikel 6:101 e.v. er sprake kan zijn van eigen schuld, waar het de verhaalsmogelijkheid van schade betreft, kan bij de risicoverdeling in het kader van een due diligence onderzoek en de gevolgen daarvan betekenis toekomen aan het feit dat er sprake is van een omstandigheid die aan de benadeelde zelf kan worden toegerekend. Sprekende voorbeelden in de rechtspraak zijn de hiervoor besproken casus welke leidde tot de uitspraak van de rechtbank te Amsterdam van 9 januari 2008, maar eerder ook en vooral het arrest van de Hoge Raad van 10 oktober 2003, dat bekendheid kreeg onder de naam Dutch Paint ${ }^{337}$. De professionele koper van een bedrijf geeft het recht prijs om te claimen wegens schending van een mededelingsplicht en zelfs over bedrog, wanneer deze nalaat om een eigen onderzoek te verrichten en om adequaat garanties te bedingen, terwijl deze weet dat zij niet goed en volledig geïnformeerd is. Op deze zaak wordt ook elders in dit boek ingegaan. Relevantie in deze paragraaf is vooral dat de koper een professionele partij was die al eerder overnames had gedaan. Beide partijen waren bijgestaan door deskundigen (accountants en juristen). De koper heeft na het sluiten van een voorovereenkomst een due diligence onderzoek gedaan. Uit dat onderzoek bleek dat informatie die voor het sluiten van de voorovereenkomst aan de koper was verstrekt, op een aantal belangrijke punten niet correct was en wel dat er van een zodanige discrepantie sprake was, dat de koper wilde afzien van de transactie. Zij heeft de koop niettemin doorgezet na opnieuw te

\footnotetext{
${ }^{334}$ LJN BB3733 (r.o. 4.8.4.), maar ook in de conclusie van A-G De Vries Lentsch-Kostense (onder 24.)

${ }^{335}$ Zie DA onder HR 9 juli 2004, NJ 2005, 270 alsmede (onder meer) HR 3 december 2004, NJ 2005, 160 m.nt. MMM.

Zie ook gerechtshof 's-Gravenhage 11 november 2005, NJ 2007, 428 (r.o. 4). In deze uitspraak woog het gerechtshof wel mee dat in de koopovereenkomst was gestipuleerd dat de koop plaatsvond onder de conditie dat het verkochte zich bevond in de staat waarin het zich ten tijde van het sluiten van de koop bevond. Koper had voor het sluiten van de koop onderzoek kunnen verrichten en verkoper had verklaard alle inlichtingen te hebben verschaft, die de koper niet uit eigen hoofde of eigen onderzoek bekend waren of bekend hadden kunnen zijn.

${ }^{336}$ Rechtbank Rotterdam 13 februari 2008, LJN BC6343

${ }^{337}$ LJN AI0306. Zie ook G.T.M.J. Raaijmakers, Bedrog bij bedrijfsovernames: een gewaarschuwd mens telt voor twee, NTBR 2004, 51, p. 277 e.v.
} 
hebben onderhandeld. De koopprijs is daarbij meer dan gehalveerd, maar de verkoper gaf geen garanties meer. De koper was niet gedwongen de koop door te zetten ${ }^{338}$. Na totstandkoming van de definitieve overeenkomst ontdekte koper dat het met de financiële positie van de onderneming van de doelwitvennootschap nog veel slechter was gesteld dan zij dacht. Er blijkt bijvoorbeeld van als voorraad gepresenteerde goederen die van een andere vennootschap bleken te zijn; $5 \%$ hogere loonkosten wegens een wisseling van bedrijfsvereniging; zwarte betalingen aan werknemers en klanten; geflatteerde omzetcijfers door gefingeerde facturen; fiscale naheffingen en boetes; een veel groter negatief resultaat dan verondersteld; een groot deel van de voorraad dat van dermate slechte kwaliteit was, dat het als chemisch afval gold en een waardeloos verfmengsysteem. Volgens de koper was zij op al deze punten verkeerd voorgelicht en zelfs bewust misleid. Zij wil van de overeenkomst af en baseert haar vordering op dwaling en bedrog. Bij de rechtbank Arnhem wordt aanvankelijk een zeker succes behaald, doordat die een bewijsopdracht geeft en in mindering op de gestelde schade een bedrag van ruim NLG 1.000.000,-- toewijst. Het gerechtshof te Arnhem wijst de vorderingen van de koper af en veroordeelt haar om de in reconventie gevorderde (restant)koopprijs te voldoen. Het gerechtshof baseert zich daarbij op de gedachte dat het een koop betreft door middel van een aandelenoverdracht door een professionele partij, die al eerder overnames had gedaan en welke zich liet bijstaan door deskundigen. Het due diligence onderzoek dat na het totstandkomen van een voorovereenkomst was uitgevoerd, leverde belangrijke punten op die als waarschuwing hadden moeten gelden dat er dingen niet klopten. De koper had de koop niettemin doorgezet, zij het na heronderhandeling. Weliswaar was de koopprijs daarbij gehalveerd, maar er was geen sprake meer van enige garantie van de zijde van de verkoper. Onder die omstandigheden kwam volgens het gerechtshof de koper geen beroep toe op de schending van een mededelingsplicht. Zij had immers in haar eigen visie alle aanleiding om te twijfelen aan de betrouwbaarheid van de door de verkoper verschafte informatie en dus alle reden om niet meer op die informatie af te gaan. Zij moest worden geacht de goede en kwade kansen van de gesloten koopovereenkomst te hebben aanvaard. De Hoge Raad sanctioneerde de uitspraak van het gerechtshof en was het ermee eens dat de kans op dwaling in de overeenkomst moest worden geacht in de uiteindelijke overeenkomst te zijn verdisconteerd, in die zin dat die dwaling op grond van de omstandigheden van het geval voor rekening van de koper behoorde te blijven. Ook al had de verkoper diens mededelingsplicht denkbaar geschonden, onder de omstandigheden kwam aan dat gegeven volgens de Hoge Raad geen zelfstandige betekenis meer toe. Het was daarom dan ook niet langer meer relevant met betrekking tot welke aspecten precies de koper zou hebben gedwaald, nu die dwaling voor diens eigen rekening kwam. De stelling dat het binnen het kader van de door redelijkheid en billijkheid beheerste rechtsverhouding in de fase van de voorovereenkomst vereist zou zijn geweest dat de verkoper volledige openheid van zaken zou hebben verschaft met betrekking tot andere zaken dan die reeds aan het licht waren gekomen tijdens het beperkte due diligence onderzoek, strandde omdat in de fase tussen de totstandkoming van de voorovereenkomst en het sluiten van de definitieve overeenkomst de koper alle reden had om aan de juistheid van de verstrekte informatie te twijfelen. De laatstgenoemde had dus maatregelen moeten nemen om te voorkomen dat er van dwaling sprake zou kunnen zijn. Het risico ter zake van de toerekenbare veronderstelling belandde aldus bij de koper ${ }^{339}$. Hoewel dus werd aangenomen dat niet aan de mededelingsplicht was voldaan omdat er wezenlijke informatie was achtergehouden, was het tipping point in de onderhavige zaak het feit dat de koper zich van een en ander bewust was en in die wetenschap willens en wetens had gecontracteerd. Onder die omstandigheden zou het op de weg van de koper hebben gelegen als professionele partij, indien zij de transactie toch wilde laten doorgaan, een onbeperkt due diligence onderzoek te eisen en/of garanties te bedingen. Door dit na te laten is er sprake van risicoaanvaarding en wel in zodanige mate, dat hoewel er aan de vereisten van artikel 6:228 lid 1 op zichzelf voldaan leek - een vordering van de teleurgestelde koper toch schipbreuk leed.

De laatstbedoelde uitspraak levert een voorbeeld op van een situatie waarin de toerekenbare veronderstelling aan beide zijden nadere actie vereiste. De koper wist dat er reden was om aan de juistheid van de verschafte informatie te twijfelen. De verkoper moet hebben geweten dat de verschafte informatie nog steeds niet klopte. In zoverre moet de redelijkheid en de billijkheid uitkomst brengen en die

\footnotetext{
${ }^{338}$ De meningen lopen hier uiteen. De koper zegt dat hij zich genoodzaakt voelde om opnieuw te onderhandelen omdat de verkoper dreigde een beroep te doen op een in de voorovereenkomst opgenomen boetebeding. Het gerechtshof heeft echter aangenomen dat de koper niet gedwongen was de koop door te zetten.

${ }^{339}$ Opmerkelijk is dat de Hoge Raad hier de rechtsgrond van de redelijkheid als zodanig niet weerspreekt.
} 
bepaalde in dit geval dat er meer gewicht aan de onderzoeksplicht werd toegekend dan aan een (voortgezette) mededelingsplicht.

A-G Timmerman (r.o. 3.7.) stelt in zijn conclusie onder het hiervoor besproken arrest de vraag of de verkeersopvattingen kunnen meebrengen dat de koper een eigen onderzoeksplicht heeft en dat het achterwege laten van een eigen onderzoek steeds zal maken dat dwaling voor rekening van de dwalende dient te blijven. Hij merkt echter op dat ook ten aanzien van de onderzoeksplicht geldt, dat op de vraag of en zo ja, in welke mate deze plicht bestaat, geen algemeen antwoord mogelijk is. De draagwijdte wordt steeds in concreto bepaald door de aard van de overeenkomst en de omstandigheden van het geval. Daarbij speelt met name ook het gedrag van de wederpartij een rol. Het gelijk van de A-G wordt bevestigd door de uitspraak van de Hoge Raad van 23 januari 2004, bekend geworden als "Stratex"340. Stratex B.V. ("Stratex") was indirect de enige aandeelhouder van de doelwitvennootschap. Pont Eecen B.V. ("Pont Eecen"), één van de leveranciers van de doelwitvennootschap, onderhandelt over de overname van de aandelen in het kapitaal van de doelwitvennootschap. Tijdens de onderhandeling verstrekte Stratex aan Pont Eecen informatie middels een informatiememorandum, waarin o.a. is opgenomen dat het jaar 1996 naar verwachting zal kunnen worden afgesloten met een gelijk resultaat als behaald in het jaar 1995. Bovendien zou er volgens het informatiememorandum een goede orderportefeuille voorhanden zijn, tegen goede marges. Later wordt ook andere informatie verschaft. Die wijst echter aanmerkelijk slechtere resultaten uit. Pont Eecen onderhandelt desalniettemin door en uiteindelijk komt er een voorovereenkomst tot stand. Volgens die overeenkomst zullen de balans per 30 juni 1997 en de resultaten over de eerste helft van 1997 nog van een goedkeurende accountantsverklaring worden voorzien en behoudt Pont Eecen zich het recht voor die cijfers zelfstandig te (doen) controleren. In de notariële akte van levering wordt een balansgarantie opgenomen, alsmede de mededeling dat de verkoper ervoor instaat met betrekking tot het verkochte die informatie te hebben gegeven die naar de geldende verkeersopvattingen door deze ter kennis van de koper behoort te worden gebracht. Al snel blijkt dat de administratie van de doelwitvennootschap niet op orde is. Als Pont Eecen de jaarstukken over 1996 en 1997 ontvangt, blijken de resultaten van de doelwitvennootschap nog weer veel slechter dan op basis van de aanvullende gegevens door Pont Eecen mocht worden verwacht. De onderneming van de doelwitvennootschap blijkt structureel verliesgevend te zijn. Bovendien zijn er in de groep waartoe de doelwitvennootschap aanvankelijk behoorde, verschuivingen van middelen geweest, die vermogen aan de doelwitvennootschap hebben onttrokken. Pont Eecen vordert van Stratex de volgens haar geleden schade tot een bedrag van NLG 1.500.000,-- te vermeerderen met de wettelijke rente. Dat betreft de primaire vordering. Verder wordt er subsidiair vernietiging van de koopovereenkomst gevraagd op grond van bedrog, met dien verstande dat aan de vernietiging werking zal worden ontnomen met veroordeling van Stratex tot betaling van NLG 1.500.000,-- aan Pont Eecen, te vermeerderen met de wettelijke rente. De primaire vordering slaagt uiteindelijk. Nadat tegen het tussenvonnis van de rechtbank te Arnhem hoger beroep was ingesteld, trekt Pont Eecen bij het gerechtshof te Arnhem aan het kortste einde. Een door Stratex in reconventie ingediende vordering tot betaling van de (restant)koopsom, alsmede tot vergoeding van schade welke Stratex zou hebben geleden als gevolg van ten onrechte gelegde beslagen, werd toegewezen. De Hoge Raad ziet het anders. Mede in het licht van een door Stratex in de koopovereenkomst gegeven balansgarantie en met name wegens de toezegging dat Stratex ervoor instond dat de koper met betrekking tot het verkochte die informatie had gekregen die naar geldende verkeersopvattingen door haar ter kennis van de koper behoorde te worden gebracht, wordt aangenomen dat er bewust een onjuist beeld van het vermogen en de resultaten van de doelwitvennootschap aan Pont Eecen is gegeven. Hierbij speelde een belangrijke rol dat Stratex en (de vertegenwoordiger van) haar bestuurder, hadden behoren te weten dat de gevoerde boekhouding niet in alle opzichten juist en volledig was, zodat de administrateur van de doelwitvennootschap er niet in slaagde de resultaten tijdig boekhoudkundig te verwerken. Ondanks het feit dat in rechte wel kwam vast te staan dat de sterk verslechterde resultaten ook voor Stratex als een onaangename verrassing waren gekomen, werd aangenomen dat er - in de wetenschap dat de administratie niet op orde was - aan Pont Eecen toerekenbaar een verkeerde veronderstelling werd verschaft.

\footnotetext{
${ }^{340}$ HR 23 januari 2004, RvdW 2004, 20.
} 
Binnen de context van de onderhavige paragraaf heeft Jansen ${ }^{341}$ gewezen op het verschil in uitkomst in de onderhavige zaak en dat in de kwestie van Dutch Paint. De Hoge Raad betrekt namelijk niet in zijn oordeel dat de koopovereenkomst niet in de mogelijkheid voorzag om de prijs van de aandelen aan te passen voor het geval de cijfers niet overeen zouden komen met de verwachtingen van Pont Eecen. Daarnaast bevatten de garanties geen bepaling ter zake van de afwikkeling en de financiële gevolgen van eventuele transacties tussen groepsmaatschappijen en de verkoper, waarmee het probleem van de intra-groep betalingen voorafgaande aan de uitvoering van de koopovereenkomst wellicht had kunnen worden voorkomen.

Een ander voorbeeld wordt gevonden in een uitspraak van de rechtbank te Haarlem van 24 maart $2004^{342}$. Het betrof in die zaak de koop van aandelen in het kapitaal van een houdstermaatschappij, die op haar beurt 3 dochtermaatschappijen had. De akte van levering betrof een groot aantal garanties. Voorafgaand aan verkoop en levering van aandelen was ingevolge een voorovereenkomst aan de koper de gelegenheid geboden om een due diligence onderzoek in te stellen. Het betrof een voorovereenkomst met een vergaand bindend karakter. Het due diligence onderzoek betrof een confirmatory due diligence. Afgesproken was dat de overeenkomst zou kunnen worden ontbonden indien na inspectie van de onderneming van de vennootschap in redelijkheid bezien zulke zwaarwegende feiten en omstandigheden aan de koper zouden zijn gebleken dat van deze in redelijkheid niet kon worden verwacht dat de transactie zou worden doorgezet. Binnen de termijn welke ter zake werd afgesproken, werd door de koper geen beroep gedaan op de hiervoor bedoelde ontbindende voorwaarde. Het due diligence onderzoek was niet uitgevoerd. Nadat de aandelen zijn geleverd, roept de koper alsnog de ontbinding van de overeenkomst in met terugbetaling van de koopprijs, een en ander met beroep op de onjuistheid van cijfers in door de verkoper gegarandeerde jaarrekening. De koper betoogde dat er misbruik was gemaakt van zijn veronderstelling dat de accountant van de doelwitvennootschap - die tevens zijn eigen accountant was - de hem aangeleverde omzetbegroting had gecontroleerd, terwijl de verkoper wist dat dit niet het geval was. De verkoper zou bovendien hebben geweten dat de koper lichtzinnig omging met betrekkelijk geringe informatie die voorhanden was en op de juistheid daarvan vertrouwde. De koper was onervaren met overnames van bedrijven en zou op spoed hebben aangedrongen. Deze verweet nu de verkoper dat die de totstandkoming van de koopovereenkomst desalniettemin had bevorderd, hoewel hij wist of had moeten begrijpen dat hij de koper daarvan had dienen te weerhouden.

Waar het de discrepantie tussen de gepresenteerde en de actuele cijfers betrof, was er onvoldoende duidelijkheid. De rechtbank gelastte ter zake een deskundigenbericht. Vooruitlopend op de uitkomst van het deskundigenbericht overwoog de rechtbank voor het geval uit dat deskundigenbericht zou blijken dat er van een nadelige discrepantie sprake zou zijn, dat de verkoper zich in redelijkheid niet zou kunnen beroepen op een bepaling in de koopovereenkomst, volgens welke afstand werd gedaan van het recht om op enige grond ontbinding en/of vernietiging van akte van levering en/of levering te vorderen. In de akte van levering was tevens bepaald dat de overeengekomen opschortende voorwaarden werden geacht per de datum van levering te zijn vervuld. De koper werd evenwel belast met de bewijsopdracht om aan te tonen dat de aan haar voor het ondertekenen van de koopovereenkomst verstrekte omzet- en kostenbegrotingen opzettelijk onjuist waren opgemaakt. De verwijten van de koper kwamen per saldo neer op de stelling dat de verkoper onvoldoende invulling had gegeven aan diens mededelingsplicht. De verkoper verweet de koper diens onderzoeksplicht te hebben verzaakt. De rechtbank overwoog:

"Ten aanzien van de wijze waarop beide plichten zich tot elkaar verhouden in de context van een aandelentransactie als er van in de onderhavige zaak sprake is, stelt de rechtbank het navolgende voorop. De aard van een dergelijke overeenkomst ontslaat de verkoper weliswaar niet van zijn verplichting om de koper te informeren omtrent al hetgeen voor laatstgenoemde van belang is om zich een oordeel te vormen over de waarde van de aandelen in de targetvennootschap, doch juist vanwege de aard van een dergelijke overeenkomst in combinatie met de complexiteit van een dergelijke transactie, kan van de koper worden gevergd dat deze binnen de hem ten dienste staande mogelijkheden een onderzoek instelt naar die aspecten van de targetvennootschap die van invloed zijn op de

\footnotetext{
${ }^{341}$ Zie M. Jansen, Pont Eecen N.V. / Stratex B.V., Bb 2004, nr. 12, p. 117-120.

${ }^{342}$ Rechtbank Haarlem 24 maart 2004, LJN AO8130
} 
waarde van de aandelen. Dat laatste geschiedt doorgaans op basis van een boekenonderzoek. De reikwijdte van de verplichting van de verkoper wordt mede bepaald door hetgeen de verkoper aan onderzoeksinspanningen zijdens de koper mocht verwachten".

De rechtbank meende dat de verkoper er vanuit mocht gaan dat de koper gebruik zou maken van de geboden gelegenheid tot het (doen) instellen van een due diligence onderzoek. De koper betoogde op aanraden van de accountant van het instellen van dat onderzoek te hebben afgezien. Zoals gezegd, bedienden zowel de verkoper als de koper zich van de diensten van dezelfde accountant. De rechtbank was van oordeel dat de inschakeling door de koper van dezelfde adviseur meebracht dat de gevolgen van de door de laatstgenoemde uitgebrachte adviezen voor rekening van de koper moesten blijven. Door af te zien van een serieus due diligence onderzoek en toch in te stemmen met de koop van alle aandelen in het kapitaal van de doelwitvennootschap, had volgens de rechtbank de koper een beroep op schending van de mededelingsplicht van de zijde van de verkoper prijs gegeven. Het risico van eventuele ondeskundigheid van de accountant of enige andere adviseur werd aan de koper toegerekend $^{343}$.

Opvallend is dat de derogerende werking van de redelijkheid en billijkheid door rechters onder omstandigheden wordt toegepast om een beroep op uitsluiting van aansprakelijkheid in een overeenkomst te beletten. In de hiervoor laatst besproken uitspraak van de rechtbank te Haarlem zagen wij daarvan een voorbeeld. Dat ons hoogste rechtscollege in dit opzicht minder scheutig is, blijkt uit een arrest van 13 februari $2004^{344}$. Het gerechtshof meende dat een als standaardbeding in verkoopakten van onroerend goed te beschouwen bepaling dat de verkoper uitsloot in te staan voor verborgen gebreken, in redelijkheid niet kon meebrengen dat een beroep op wanprestatie werd uitgesloten. De Hoge Raad dacht daar anders over:

"Voor zover het ervan zou zijn uitgegaan dat voor de verkoper van een huis op grond van de eisen van redelijkheid en billijkheid jegens de koper een garantieverplichting bestaat dat een degelijke fundering is aangebracht zoals die voorkomt op de van overheidswege goedgekeurde bouwtekening, heeft het Hof miskend dat een dergelijke verplichting niet strookt met het feit dat de verkoper in beginsel voor àlle gebreken die hij niet kende of behoefde te kennen, niet verder instond dan uit de artt. 15.21-15.24 (oud) BWNH voortvloeide. Voor zover het Hof ervan zou zijn uitgegaan dat partijen de garantie dat een gedegen fundering, zoals die voorkomt op de van overheidswege goedgekeurde bouwtekening, daadwerkelijk was aangebracht (eventueel stilzwijgend) waren overeengekomen, heeft het Hof miskend dat zulks nadere motivering behoeft, nu het geen nadere omstandigheden heeft vastgesteld die wijzen op het bestaan van een dergelijke (eventueel stilzwijgend overeengekomen) garantie. Daarbij dient te worden aangetekend dat de omstandigheid dat [eiser] [verweerster] heeft geadviseerd om in verband met de bezichtiging geconstateerde scheuren en betonrot een deskundige te raadplegen, veeleer erop wijst dat [eiser] aan [verweerster] geen verdergaande garanties wilde geven dan in de (toenmalige) wettelijke regeling besloten lag".

Verwezen wordt naar hetgeen in hoofdstuk 7.2 hierna is opgemerkt over de vraag wanneer kennis van een koper kan worden geacht te zijn verdisconteerd in de bepaling van de koopprijs, dan wel in de mate waarin wel of geen garanties en/of vrijwaringen zijn gevraagd. Er is een categorie van gevallen, waarin de koper het risico neemt geen verhaal meer te kunnen zoeken voor gebreken in het voorwerp van de transactie, wanneer er niet terstond wordt geacteerd naar aanleiding van het vaststellen van gebreken. De uitspraak in zake Dutch Paint and Chemical Company B.V., maar ook andere hiervoor genoemde uitspraken maken dat duidelijk. ${ }^{345}$

\footnotetext{
${ }^{343}$ Zoals hoger in dit hoofdstuk is besproken, kan een onevenwichtige verdeling van deskundigheid onder omstandigheden ook tot andere conclusies aanleiding geven.

${ }^{344}$ LJN AM2365

${ }^{345}$ HR 10 oktober 2003, LJN A10306. Zie ook G. Raaijmakers, Bedrog bij bedrijfsovernames: een gewaarschuwd mens telt voor twee, NTBR 2004, 51, p.277 e.v. en in het bijzonder hetgeen deze opmerkt over een verschoonbaarheidseis bij bedrog.
} 


\section{Toerekening}

Met het oog op het onderwerp van toerekenbare veronderstelling, verdient de vraag aandacht of alleen door een partij zelf opgewekte of in het leven gelaten onjuiste veronderstelling relevantie toekomt. Of onder omstandigheden ook de wetenschap van een hulppersoon of gevolmachtigde (in welk laatste geval toerekening wel voor de hand ligt omdat die naar de aard van de volmacht niet voor zich zelf maar voor de volmachtgever optreedt), is niet altijd eenvoudig te geven. De rechtbank te Middelburg meende op 14 april $2004^{346}$ dat bij de beoordeling van de vraag in hoeverre er van toerekening van wetenschap en gedragingen sprake kan zijn aan degene die de hulppersoon heeft ingeschakeld rekening moet worden gehouden met de mate waarin men het onderhouden van de contacten heeft overgelaten aan de hulppersoon. Naarmate de hulppersoon zelfstandiger heeft opgetreden, zal de toerekening eerder worden aangenomen. Verder gelden ten deze alle overwegingen die ook gelden ten aanzien van bevoegde en onbevoegde vertegenwoordiging.

De stand van zaken op het punt van toerekening is samengevat door Hartlief en Tjittes. ${ }^{347}$

Volgens HR 11 maart $2005^{348}$ gaat het erom dat bij de vraag of kennis van een binnen een rechtspersoon werkzame persoon aan die rechtspersoon kan worden toegerekend, de wetenschap van die natuurlijk persoon 'in het maatschappelijk verkeer' kan worden aangemerkt als wetenschap van de rechtspersoon. Dit is ook de norm die al werd toegepast bij de beantwoording van de vraag of gedrag van een natuurlijk persoon kon worden toegerekend aan een rechtspersoon. ${ }^{349}$ Hartlief en Tjittes stellen vast dat de rechtspraak van de Hoge Raad over toerekening van kennis niet heel helder is. Zo heeft de Hoge Raad enerzijds - in het kader van de toetsing of het vanwege opzet of bewuste roekeloosheid van een rechtspersoon naar maatstaven van redelijkheid en billijkheid onaanvaardbaar is dat de rechtspersoon een beroep doet op een exoneratiebeding - ongeclausuleerd geoordeeld dat kennis van de bedrijfsleiding aan de rechtspersoon wordt toegerekend. ${ }^{350}$ De Hoge Raad heeft anderzijds later in algemene bewoordingen geoordeeld dat 'de enkele vaststelling dat iemand gedurende een bepaalde periode bedrijfsleider, directeur of (mede)eigenaar van een onderneming is geweest, onvoldoende is om kennis van deze natuurlijke persoon aan die onderneming toe te rekenen. ${ }^{351}$ Een element bij vragen omtrent toerekening van kennis zal de mate van zeggenschap zijn welke men over de onderwerpelijke transactie heeft in samenhang met de functie welke men uitoefent. ${ }^{352}$ Van een bestuurder mag men zeggenschap aannemen. In het geval van een aandeelhouder, bedrijfsleider of een andere functionaris zullen de feitelijke omstandigheden van het geval een antwoord moeten helpen vinden.

Uit HR 21 september $2007^{353}$ is kenbaar, dat de kennis van een hulppersoon, die niet in een arbeidsrechtelijke verhouding tot een ander staat, niet altijd zonder meer aan de ander kan worden toegerekend. In de desbetreffende zaak ging het om een veilingverkoop van een perceel, waarop de koper een wormenkwekerij wilde beginnen. De verkoper werd daarbij geadviseerd door een deskundige makelaar op het gebied van agrarische bestemmingen. In een twist over de vraag of er sprake was van schending van de onderzoeksplicht (de rechtbank meende dat de koper vooraf zelf het ter plaatse geldende bestemmingsplan had dienen te bekijken) danwel van de mededelingsplicht (de koper meende dat de verkoper had moeten waarschuwen dat voor het kavel een voorbereidingsbesluit op grond van artikel 21 Wet op de ruimtelijke ordening van kracht was), kon het volgens de koper in het midden blijven in hoeverre de verkoper zelf van de belemmering om toestemming te verkrijgen voor het houden van een wormenkwekerij, op de hoogte was. Nu de verkoop middels een deskundige hulppersoon was geregeld - zo meende de koper - had deze hulppersoon de agrarische bestemming waarmee de kavel was aangeprezen, op juistheid behoren te controleren. Volgens het gerechtshof vond de stelling van de koper, dat van de ter zake deskundige hulppersoon van de verkoper had mogen worden verwacht dat deze met het oog op de belangen van de koper de agrarische bestemming op juistheid zou hebben

\footnotetext{
${ }^{346}$ LJN A09310.

${ }^{347}$ T. Hartlief en R.J. Tjittes, Kroniek van het vermogensrecht, NJB 2005/31.

348 JOR 2005, 169.

${ }^{349}$ HR 25 juni 1999, NJ 2000, 33.

${ }^{350}$ HR 31 december 1993, NJ 1995, 389 en HR 12 december 1997, NJ 1998, 208.

${ }^{351}$ HR 5 december 2003, NJ 2004, 506.

352 Zie A-G Timmerman (onder 3.7) in zijn conclusie bij NJ 2004, 506.

${ }^{353}$ LJN BA6238. Vergelijk ook AG-Huydecoper onder 8. in zijn conclusie bij HR 12 oktober 2007, LJN BA7630.
} 
gecontroleerd en dat de koper, behoudens bijzondere omstandigheden, ervan had mogen uitgaan dat dit was geschied, in haar algemeenheid echter geen steun in het recht. ${ }^{354}$

Zie ook hierna in hoofdstuk 13.2.

\section{Bijkomende vereisten}

Schending van de mededelingsplicht of de onderzoeksplicht, is nog geen garantie voor een vernietiging van een overeenkomst of een geslaagde vordering tot nakoming of ontbinding. Wil er sprake zijn van vernietiging van een overeenkomst, dan moet niet alleen vast komen te staan dat er sprake is geweest van schending van een op de wederpartij rustende verplichting, maar moet bovendien komen vast te staan dat de overeenkomst niet tot stand zou zijn gekomen bij een juiste voorstelling van zaken (een juiste veronderstelling). Zie artikel 6:228 lid 2. Wanneer een beroep op non-conformiteit wordt gedaan, terwijl er sprake is van schending van bijvoorbeeld een mededelingsplicht of zelfs het geven van onjuiste inlichtingen (de toerekenbare veronderstelling als uitgangspunt veroorzaakt dat de verkoper toerekenbaar tekort schiet) zal eerst met succes een vordering tegen de verkoper kunnen worden ingesteld, wanneer de zaak niet die eigenschappen bezit die voor een normaal gebruik daarvan nodig zijn volgens de overige elementen van het gestelde in artikel 7:17 lid 2.

Het risico van de toerekenbare veronderstelling, komt eerst voor rekening van de verkoper wanneer bij dwaling de problematiek te wijten is aan een inlichting van de verkoper (tenzij deze mocht aannemen dat de overeenkomst ook zonder deze inlichting zou worden gesloten), danwel indien de verkoper gezwegen heeft waar deze had behoren te spreken of beide partijen van een onjuiste veronderstelling zijn uitgegaan (tenzij de verkoper bij een juiste voorstelling van zaken niet had behoeven te begrijpen dat de dwalende van het aangaan van de overeenkomst had moeten worden afgehouden). Het is niet altijd gemakkelijk vast te stellen wanneer een verkoper behoorde te begrijpen, dat diens wederpartij in dwaling verkeerde. Een voorbeeld wordt gevonden in de uitspraak van het gerechtshof te Leeuwarden van 27 augustus 2003. ${ }^{355}$

Als uitgangspunt geldt dat de conformiteitsgarantie welke door artikel 7:17 in het leven wordt geroepen, betrekking moet hebben op ernstige gebreken die een normaal gebruik in de weg staan. In het geval van een woonhuis werd aangenomen dat een koper van een 17 jaar oud woonhuis moet rekenen met minder ernstige gebreken. De verkoper behoeft daarvoor niet in te staan indien deze gebreken ook hem niet bekend waren. Indien gebreken de verkoper wel bekend zijn, dient hij de koper daarover te informeren. ${ }^{356}$ Onder ernstige gebreken kunnen ook worden begrepen gebreken die niet direct, maar redelijkerwijze wel binnen afzienbare tijd dienen te worden hersteld. Het enkele feit dat een woonhuis zonder concrete overlast kan worden gebruikt betekent nog niet dat er daarom geen sprake kan zijn van ernstige gebreken die het normaal gebruik van een woonhuis in de weg kunnen staan. Wanneer er bijvoorbeeld sprake is van ernstige aantasting van een vloer door betonrot, brengt dat mee dat die vloer redelijkerwijze binnen afzienbare tijd dient te worden hersteld. De herstelkosten zijn in relatie tot de waarde van de woning zodanig hoog, dat dit dan een ernstig gebrek oplevert dat het feitelijk gebruik van het woonhuis in de weg staat, aldus het gerechtshof te Amsterdam in een uitspraak van 5 juli $2001^{357}$, waarbij het ging om de verkoop van recreatiebungalows naast een golfbaan, welke was aangelegd op een voormalige vuilstort. De rechter onderzoekt eerst of er sprake is van zodanige verontreiniging van bodem en/of grondwater, dat er sprake was van risico's voor de volksgezondheid, dan wel anderszins van milieuhygiënische bezwaren. Toen daar onvoldoende van bleek, kon naar het oordeel van de rechter niet worden aangenomen dat er sprake was van een situatie waarin de verkoper had moet begrijpen dat er bij de koper een onjuiste voorstelling van zaken was, causaal om de overeenkomst (niet) aan te gaan. Het kon onder de omstandigheden de verkoper niet worden aangerekend dat deze zich had moeten realiseren dat de koper bij een andere voorstelling van zaken de overeenkomst niet of niet onder dezelfde voorwaarden zou zijn aangegaan.

\footnotetext{
${ }^{354}$ Verwezen werd daarbij naar HR 18 april 1986, NJ 1986, 747 m.nt. G, waarin het een vergelijkbare casus betrof.

${ }^{355}$ LJN AJ6840.

${ }^{356}$ Zie gerechtshof Amsterdam 5 juli 2001, kenbaar uit HR 23 mei 2003, LJN AF6689.

357 Zie gerechtshof Amsterdam 5 juli 2001, kenbaar uit HR 23 mei 2003, LJN AF6689.
} 
In een uitspraak van de rechtbank Arnhem van 24 november $2004^{358}$ wordt een voorbeeld gevonden van een situatie waarin het verkochte niet voldeed aan de verwachting welke door de verkoper was gewekt. Die had meegedeeld dat hem niet bekend was dat in het verkochte - het betrof een woonhuis - asbest was verwerkt. Dit bleek toch het geval te zijn en wel bij enkele riool- en grondleidingen. De koper wilde de koop niet gestand doen. De verkoper vorderde in rechte nakoming van de koopovereenkomst, waarin als gezegd was vermeld dat het aan de verkoper niet bekend was dat in het verkochte asbest was verwerkt. De verkoper had echter na de totstandkoming van de koopovereenkomst de koper een boekje overhandigd met het bestek van de bouwtekeningen waaruit bleek dat bij enkele riool- en grondleidingen asbest was verwerkt. De rechtbank tilde niet zwaar aan de door de verkoper gedane mededelingen en het feit dat die in strijd waren met de wetenschap welke aan de zijde van de verkoper bekend moest worden verondersteld (in de zogenaamde vragenlijst was vermeld dat er geen asbestplaten in het huis aanwezig waren). Voor de rechtbank bleek per saldo de hamvraag of het feit dat er asbest in de woning zat, meebracht dat het gekochte niet aan de overeenkomst beantwoordde. Daarbij achtte zij van belang of door de aanwezigheid van het asbest een normaal gebruik van de zaak als woning onmogelijk was. De rechtbank meende dat dit niet het geval was. Het feit dat er een enkele asbesthoudende buis in een vloer of ondergrond is verwerkt belette volgens de rechtbank het normaal gebruik van het pand als woning niet. Het enkele feit dat de koper perse geen asbest in huis wilde hebben omdat de woning dan later slecht verkoopbaar zou zijn, woog voor de rechtbank onvoldoende zwaar. Hoewel de rechtbank toegaf dat asbest een negatieve naam had en schadelijk kon zijn voor de gezondheid, achtte zij het tevens van algemene bekendheid dat van schadelijkheid geen schade was indien het asbest in vaste vorm is verwerkt en bijvoorbeeld in de constructie van een huis zich op een ontoegankelijke plaats in de vloer of onder de grond bevindt, zoals in casu. Een vordering tot schadevergoeding - waarop de artikelen 6:74 lid 1 en 75 van toepassing zijn, zal alleen toepasbaar zijn indien de non-conformiteit aan de verkoper kan worden toegerekend. ${ }^{359}$

Waar het de vraag betreft wanneer er sprake kan zijn van non-conformiteit bij de koop van aandelen, besliste de rechtbank te Utrecht op 24 oktober $2007^{360}$ dat (op grond van de door eiseres ingenomen stellingen) "niet valt vast te stellen of juist is dat de waarde van de aandelen danwel hun voortbrengend vermogen minder zijn dan ten tijde van de aandelenovereenkomst redelijkerwijs werd of kon worden aangenomen". De rechtbank probeerde daar te stellen dat de onderneming welke door een vennootschap wordt gedreven, zich op velerlei manieren kan aanpassen aan veranderende marktomstandigheden. Een aanpassing in oorspronkelijke bouwplannen betekent nog niet dat 'het voortbrengend vermogen' van de aandelen daarmee ook terstond negatieve bijstelling behoeft. In de zaak waar het hier om ging, had de eiseres volgens de rechtbank onvoldoende gemotiveerd aangevoerd waarom het één ook het ander moest meebrengen.

In de hiervoor laatstgenoemde uitspraak van de rechtbank Utrecht werd evenmin dwaling aangenomen. Het betrof de koop van aandelen in het kapitaal van een vennootschap die zich bezighield met het ontwikkelen van een appartementencomplex in Brazilië. De rechtbank overwoog dat voor de koper de winstgevendheid voor aandeelhouders bepalend leek te zijn geweest bij haar beslissing om de koopovereenkomst aan te gaan en niet de exacte wijze van uitvoering van het bouwproject. "Zij heeft immers geen onroerend goed gekocht, maar aandelen in een vennootschap waarin ontwikkeling van vastgoed was ondergebracht". De vorderingen van de eiseres strandden op het feit dat zij volgens de rechtbank onvoldoende aannemelijk had gemaakt dat alleen de uit het oorspronkelijke bouwplan blijkende specifieke vorm van realisering bepalend was geweest bij de beslissing tot participatie. Ook werd overigens de koper verweten dat zij onvoldoende onderzoek had gedaan. "Zo zij al gedwaald zou hebben ten aanzien van de (on)mogelijkheid van de oorspronkelijk voorgenomen wijze van uitvoering, heeft te gelden dat die dwaling voor haar rekening moet blijven. Zij participeerde immers in planontwikkeling in den vreemde en zij had zich bij het aangaan van de overeenkomst rekenschap moeten geven van de marges van onzekerheid die dergelijke projecten nu eenmaal met zich meebrengen".

\footnotetext{
358 LJN AR8778.

359 Zie HR 9 januari 1998, NJ 1998, 272 en gerechtshof Leeuwarden 31 augustus 2005, LJN AU1876. Zie ook gerechtshof 'sGravenhage 31 januari 2008, NJF 2008, 122, voor een geval waarin de aanwezigheid van een olietank werd geacht de geschiktheid van een pand als woning niet aan te tasten.

360 LJN BB6509.
} 
Wanneer het voornemen voor de koper afwijkt van datgene dat als 'normaal gebruik' kan gelden, doet die er goed aan te stipuleren dat de eigenschappen welke de koper voor het door hem beoogde ge-

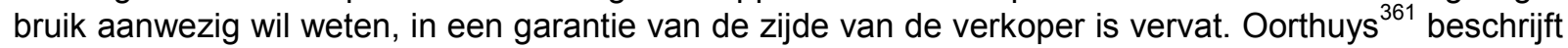
de situatie waarin een koper een erf met een opstal koopt met de gedachte om de opstal te slopen en het erf te splitsen teneinde daarop een 2-tal woningen te bouwen. In de koopovereenkomst was gestipuleerd dat de onroerende zaak bij de eigendomsoverdracht de feitelijke eigenschappen zou bezitten die voor normaal gebruik nodig waren. Wel was gezegd dat de koper voornemens was de onroerende zaak te gebruiken als bouwperceel voor twee half vrijstaande huizen. De verkoper stond echter niet in voor andere eigenschappen dan die welke voor een normaal gebruik nodig waren noch voor de afwezigheid van gebreken die dat normale gebruik zouden belemmeren en die aan de koper kenbaar waren op het moment van het tot stand komen van de koopovereenkomst. Na totstandkoming van de koop, maar voor de levering wordt het gebied waarin de onroerende zaak is gelegen tot beschermd dorpsgezicht verklaard. De sloop- en bouwplannen van de koper kunnen niet doorgaan. De koper wil daarom ontbinding respectievelijk vernietiging van de koopovereenkomst. Het gerechtshof, gesanctioneerd door de Hoge Raad, besliste echter dat de koper aan de overeenkomst niet het recht kon ontlenen dat hem een perceel geleverd zou worden waarmee hij zijn voornemen kon realiseren, nu dat niet uit de tekst van de koopovereenkomst zelf viel af te leiden, noch uit de overige feiten en omstandigheden. Volgens de rechter viel onder 'normaal gebruik' als bedoeld in de koopovereenkomst in beginsel niet tevens de sloop van het verkochte huis gevolgd door nieuwbouw. De mededeling in hetzelfde artikel, dat de koper het kavel wilde gebruiken om daarop 2 huizen te bouwen, deed daaraan niet af, maar werd wel van belang geacht in verband met de mededelingsplicht van de verkoper: als die wist dat de koper het voorgenomen gebruik niet zou kunnen verwezenlijken, had deze de koper moeten informeren. Dat de koper van de gevolgde wijziging van de bestemming ter plekke op de hoogte was geweest, was niet gebleken, aldus de rechter. Oorthuys zag als een van de oorzaken voor de problemen waarmee de koper te maken kreeg, dat deze er niet in slaagde om aan te tonen dat het door hem voorgenomen gebruik van het perceel door de verkoper gegarandeerd was. Alleen op basis van de tekstuele uitleg van de toenmalige standaardovereenkomst (van de NVM), was een dergelijke garantie niet aannemelijk. Inmiddels hebben de NVM, de Consumentenbond en de Vereniging Eigen Huis hun gezamenlijke modelovereenkomst gewijzigd, in die zin dat de desbetreffende bepaling thans zegt dat de onroerende zaak bij de eigendomsoverdracht de feitelijke eigenschappen moet bezitten die nodig zijn voor een normaal gebruik als in de overeenkomst te omschrijven. Niettemin zo waarschuwt Oorthuys is verder niet veel veranderd en wordt in de hiervoor bedoelde standaardovereenkomst nog slechts normaal gebruik gegarandeerd. Hij meent dat de nieuwe redactie van het artikel eerder meer dan minder aanleiding geeft voor de aanname dat het gebruik als opgenomen in het gedeelte dat door partijen zelf is in te vullen (het te omschrijven voorgenomen gebruik) wordt gegarandeerd. Of het aldus beschreven doel nu tot normaal gebruik kan worden gerekend of niet. De waarschuwing is duidelijk. Wanneer een koper zeker wil stellen dat een zaak de eigenschappen bezit die deze nodig heeft voor diens voorgenomen 'abnormale' althans bijzondere gebruik, doet er goed aan om - zonodig in afwijking van het standaardmodel - te stipuleren dat die eigenschappen worden gegarandeerd. Een verkoper op diens beurt dient er rekening mee te houden dat deze mededeling zal moeten doen van gebreken die het door de koper voorgenomen bijzondere gebruik in de weg kunnen staan.

Op de vraag of de aanwezigheid van ernstige bodemverontreiniging in het geval van een verkocht tankstation met verdere aanhorigheden op zichzelf meebracht dat niet voldaan werd aan het vereiste van conformiteit, ging de Hoge Raad in bij de gelegenheid van een arrest van 23 november $2007{ }^{362}$ De vraag was of de aanwezigheid van deze verontreiniging op zichzelf in de weg stond aan het gebruik van het tankstation, terwijl de verontreiniging op zichzelf niet meer betekende dan dat de bodem gesaneerd zou dienen te worden. In het algemeen - en dat werd ook in de onderhavige zaak aangenomen - zijn er met een dergelijke sanering wel belangrijke kosten gemoeid. De Hoge Raad meent dat bij de beantwoording van de vraag of een tankstation ondanks de bodemverontreiniging voldoet aan het conformiteitsvereiste van artikel 7:17, alle van belang zijnde omstandigheden in aanmerking moeten worden genomen, waaronder ook de mededelingen die de verkoper over de zaak heeft gedaan. In het desbetreffende geval had de koopster een aantal stellingen aangevoerd waaruit volgens haar volgde dat het verkochte niet als tankstation bruikbaar was en dat het niet de eigenschappen bezat die

\footnotetext{
${ }^{361}$ A. Oorthuys, HR 23 december 2005, RvdW 2006, 17.

${ }^{362}$ LJN BB3733 (r.0. 5.1. en 5.2.)
} 
zij mocht verwachten op grond van aan haar gedane mededelingen van de zijde van de verkoopster. De Hoge Raad overwoog:

"Het Hof heeft blijk gegeven van een onjuiste rechtsopvatting met betrekking tot artikel 7:17 als het heeft miskend dat het alle van belang zijnde omstandigheden in aanmerking had behoren te nemen, danwel zijn oordeel ontoereikend gemotiveerd door niet op voren bedoelde stellingen van de koopster in te gaan. Daarbij is van belang dat ook indien de aanwezigheid van de bodemverontreiniging niet in de weg zou staan aan het gebruik van het tankstation (zoals het Hof heeft geoordeeld), toch sprake kan zijn van non-conformiteit indien de koopster op grond van mededelingen van de verkoopster de aanwezigheid van bodemverontreiniging niet behoefde te verwachten".

\subsection{Nadere gevolgtrekkingen}

De navolgende gevolgtrekkingen zijn nu mogelijk naar aanleiding van het rechtersrecht dat zich in verband met een due diligence heeft gevormd en waarvan een aantal van de belangrijkste uitspraken hier voor aan de orde kwam: ${ }^{363}$

1. Een contractpartij dient rekening te houden met de gerechtvaardigde belangen van zijn wederpartij. $^{364}$

2. De koper heeft een onderzoeksplicht. Hij dient binnen redelijke grenzen maatregelen te nemen om te voorkomen dat hij contracteert onder de invloed van een onjuiste voorstelling van zaken. ${ }^{365}$ Wanneer de dwalende een deskundige of ondernemer is, rust op deze eerder en een verdergaande onderzoeksplicht dan op de leek of particulier. Indien een ondernemer zich bij het aangaan van een overeenkomst laat bijstaan door een deskundige, zal in de regel op hem een onderzoeksplicht rusten. Met andere woorden: het inschakelen van een due diligence team leidt tot een verzwaarde onderzoeksplicht van de koper.

3. In beginsel geldt dat, wanneer een deskundige faalt, dit voor risico komt van de dwalende partij die hem inschakelde. ${ }^{366}$ Hier passen de nodige nuances. Een professionele partij zal eerder het risico toegerekend krijgen voor de keuze van een deskundige, dan een particulier, van wie in mindere mate mag worden verwacht dat deze in staat is om de deskundigheid van een ingeschakelde partij te evalueren.

4. De verkoper heeft onder omstandigheden een mededelingsplicht. ${ }^{367}$ Of dit het geval is, hangt ook ten aanzien van deze in belangrijke mate af van de wederzijdse professionaliteit en deskundigheid. ${ }^{368}$ Tussen deskundige ondernemers staat voorop dat ieder in beginsel zijn eigen belang nastreeft. Het gaat om de toerekenbare veronderstelling. Ook tussen deskundige ondernemers geldt dat over en weer rekening moet worden gehouden met hetgeen men weet of kan vermoeden dat bij de ander de veronderstelling is omtrent de kennis van het voorwerp van de transactie. Wel zal gelden dat een grotere deskundigheid bij de wederpartij eerder de veronderstelling kan opleveren dat de ander meer weet. ${ }^{369}$

De Hoge Raad neemt aan dat in het Nederlands recht niet een algemene mededelingsplicht van een verkoper kan worden aangenomen ten aanzien van alle consequenties die voor een prijsbepaling relevant zijn, maar besliste vervolgens dat in dit geval een professionele verkoper

\footnotetext{
${ }^{363}$ Mede gebaseerd op M. Wolters, De due-diligenceparadox. Problemen rond due-diligenceonderzoek en garantiebepalingen, in: Contracteren nr. 3, 1999.

364 HR 5 november 1957, NJ 1958, 68, m.nt. LEHR (Baris / Riezenkamp)

${ }^{365}$ HR 5 november 1957, NJ 1958, 68, m.nt. LEHR (Baris / Riezenkamp)

${ }^{366}$ HR 11 april 1986, NJ 1986, 570 (Kelly / Rietvelt). Zie ook R.P.J.L. Tjittes, “De hoedanigheid van contractspartijen”, Kluwer, Deventer 1994, p. 56

${ }^{367}$ HR 19 juni 1959, NJ 1960, 59 (Kantharos van Stevensweert). Volgens ditzelfde arrest wordt wel aangenomen, dat "verkopersdwaling" in het algemeen voor rekening van de dwalende verkoper komt (tenzij de koper deze had behoren in te lichten).

368 HR 1 juni 1990, NJ 1991, 759 m.nt. CJHB (Van Lanschot / Bink). Zie ook J.H. Nieuwenhuis, Een gevaar op de weg, AA 1986, p. 315-321. Vergelijk ook HR 8 september 2006, NJ 2006, 494 (r.o. 3.3.). De laatstbedoelde uitspraak ging over een overeenkomst van opdracht (onderaanneming). De enkele omstandigheid dat een hoofdaannemer voldoende deskundig was om fouten in het ontwerp van het door hem aangenomen werk te onderkennen, ontslaat de onderaannemer niet van zijn verplichting de hoofdaannemer te waarschuwen voor ontwerpfouten die hij kent of behoort te kennen. De hoedanigheid van partijen bepaalt bij het aangaan van een overeenkomst in belangrijke mate welke "Obliegenheiten" kunnen worden geacht op hen te rusten.

${ }^{369}$ HR 15 mei 1981, NJ 1981, 641 m.nt. CJHB (Joba / Gerber)
} 
jegens de professionele koper de plicht heeft om te waarschuwen als zij ziet dat die koper zich van een bepaald probleem niet bewust is, een en ander tegen de achtergrond van een algemene vrijwaring die door de verkoper is gegeven. ${ }^{370}$ Aan deze uitspraak is ook de opvatting ontleend dat een verkoper sowieso een mededelingsplicht heeft als hij weet van een ernstig gebrek en het niet zeker is dat de koper daarvan weet heeft. ${ }^{371}$ Geen schending van een mededelingsplicht wordt aangenomen, wanneer de verkoper zelf niet van een gebrek op de hoogte is. ${ }^{372} \mathrm{Ik}$ herhaal dat het wat mij betreft gaat om de toerekenbare veronderstelling. De hoedanigheid van partijen (meer of minder deskundig, meer of minder ervaren) bepaalt in belangrijke mate welke veronderstelling er bij de wederpartij dient te heersen teneinde zeker te stellen dat er sprake is van een juiste voorstelling van zaken.

5. De koper mag in de regel afgaan op de juistheid van de mededelingen van de verkoper. ${ }^{373}$ Tussen deskundige en professionele ondernemers geldt echter dat men niet klakkeloos op de mededelingen van de andere partij mag afgaan. Naarmate de dwalende partij deskundiger is, weegt zijn eigen onderzoeksplicht zwaarder. Dit volgt uit het arrest Hilders / De Galan. ${ }^{374} \mathrm{De}$ casus was in dit geval als volgt: De Galan had aan Hilders de tip gegeven dat te Rotterdam een pand te koop was, waarvan de bedrijfsruimte was verhuurd tegen een huurprijs van NLG 240.000,--. Naar aanleiding van de tip heeft Hilders het pand gekocht, waarna hij aan De Galan een tipgeld toezegde van NLG 25.000,--. Dit bedrag heeft Hilders vervolgens niet betaald, daartoe stellende dat De Galan hem bepaalde mededelingen had gedaan die achteraf onjuist waren gebleken. Het hof overwoog dat, al zou komen vast te staan dat De Galan voormelde mededelingen aan Hilders heeft gedaan, zulks een beroep op dwaling niet rechtvaardigt. Het hof heeft daartoe in aanmerking genomen dat De Galan van Hilders mocht verwachten dat hij zichzelf zou vergewissen omtrent de juistheid van de mededelingen en de HR oordeelde dat het hof niet had blijk gegeven van een onjuiste rechtsopvatting.

Wanneer de verkoper een deskundige ondernemer is, terwijl de koper een ondernemer is die geen deskundigheid heeft ten aanzien van het onderwerp van de overeenkomst, dan mag de koper in beginsel op de mededelingen van de verkoper afgaan. ${ }^{375}$ Als algemene regel kan worden aangenomen dat hoe stelliger een verklaring gedaan is (hoe ondubbelzinniger), hoe eerder de koper op de juistheid ervan zal mogen afgaan, hoe groter de invloed van die verklaring is op de beschrijving van het object van de koop. ${ }^{376}$

6. Er wordt over getwist of de onderzoeksplicht van de koper zwaarder weegt dan de mededelingsplicht van de verkoper. Er zijn rechters die menen dat de mededelingsplicht van de verkoper in beginsel zwaarder weegt dan de onderzoeksplicht van de koper, ${ }^{377}$ ook van de onvoorzichtige koper. ${ }^{378}$ Naar mijn mening brengen de verkeersopvattingen in overnameland mee dat er in beginsel niet zonder enige vorm van due diligence onderzoek tot het aangaan van een transactie wordt overgegaan.

7. De vraag of de onderzoeksplicht van de dwalende de voorrang had boven de onderzoeksplicht van diens wederpartij, dient steeds naar gelang het geval te worden beantwoord. ${ }^{379}$ De mededelingsplicht van artikel 6:228 lid 1 onder $b$. (het criterium dat in belangrijke mate invulling geeft aan een toerekenbare veronderstelling) strekt volgens de Hoge Raad ter bescherming van een onvoorzichtige contractuele wederpartij tegen de nadelige gevolgen van dwaling. "Dit brengt mee dat niet te spoedig voorrang aan de onderzoeks-/informatieplicht van die partij boven de mededelingsplicht van de andere partij dient te worden gegeven en dat bij een daartoe strekkend oordeel op alle bijzondere omstandigheden van het geval moet worden gelet en

\footnotetext{
370 Zie HR 14 mei 2004, JOL 2004, 248 (M\&M Beheer)

371 Zie G.T.M.J. Raaijmakers, Garanties in het contractenrecht, Themis 2005-3, p. 134

372 Zie NAI 9 juli 2003, TvA 2004, 3

${ }^{373}$ HR 5 november 1957, NJ 1958, 68 m.nt LEHR (Baris / Riezenkamp)

374 HR 13 maart 1981, NJ 1981, 442 m.nt. CJHB (Hilders/De Galan), HR 6 januari 1989, NJ 1989,281 (De Vor/AMRO)

${ }^{375}$ HR 21 januari 1966, NJ 1966, m.nt. GJS (Booy / Wisman).

376 Zie G.T.M.J. Raaijmakers, Garanties in het contractenrecht, Themis 2005-3, p. 126 en 128.

Een aardig voorbeeld levert de uitspraak van de rechtbank te Maastricht van 12 december 2007, Prg.. 2008, 80, waarin wordt beslist dat een koper niet behoeft te twijfelen of een auto de eigenschappen bezit die voor een normaal gebruik nodig zijn, indien een professionele autohandelaar adverteert en stelt dat een tien jaar oude auto 'in zeer goede staat verkeert'.

377 HR 30 november 1973, NJ 1974, 97 m.nt. GJS (Van der Beek / Van Dartel); HR 21 december 1990, NJ 1991, 251 (Van Geest / Nederlof)

378 HR 10 april 1998, RvdW 1998, 84 (Antilliaans zwembad).

${ }^{379}$ Zie HR 19 januari 2007, LJN AZ6541 (Kranendonck / Houthoff Buruma)
} 
deze ook zo volledig en zo nauwkeurig mogelijk moeten worden vastgesteld". ${ }^{380}$ Wanneer zowel de verkoper als de koper ter zake van de toerekenbare veronderstelling een verwijt te maken valt, zal een risicoverdeling het gevolg zijn. ${ }^{381}$

8. Wanneer er aanwijzingen zijn, dat het verschafte of verkregen beeld niet volledig is, dient (nader) onderzoek te worden ingesteld. Het nalaten daarvan kan tot verlies van rechten aanleiding geven. Het behoorlijk (kunnen) uitvoeren van een due diligence onderzoek vergt dat de verkoper die informatie beschikbaar maakt die nodig is om een voldoende beeld van het voorwerp van de transactie te krijgen. De combinaties met de in het navolgende hoofdstuk te bespreken garanties zijn daarom ook van belang. Voor zover niet de garantie kan worden verkregen dat alle informatie welke gewenst of nodig is, zal worden of kan worden verschaft, dient ten minste sprake te zijn van het bedingen van garanties, en zelfs dan dient de vraag te worden gesteld of het desbetreffende gegeven niet aanleiding dient te zijn om van de transactie af te zien.

Deze lijn kan worden getrokken van het Hoog Catharijne-arrest via de uitspraak in de kwestie van Dutch Paint na laatstelijk een uitspraak van de Rechtbank te Haarlem van 5 december $2007 .^{382}$ In deze laatstgenoemde uitspraak betrof het een geval waarin de kopers op grond van een verkennend bodemonderzoek er voorafgaand aan de koop van op de hoogte waren dat de bodem van het perceel in een bepaalde mate verontreinigd was. Achteraf klagen helpt dan niet meer. Volgens de rechtbank rustte op de kopers onder die omstandigheden een onderzoeksplicht naar de werkelijke staat van de bodem. Nu dat nader onderzoek was nagelaten, hadden de kopers het risico aanvaard dat - zoals ook het geval bleek - de bodemverontreiniging erger zou zijn dan ten tijde van de koop op de koop toe genomen was.

9. Er kan sprake zijn van verschoonbare onachtzaamheid, wanneer er bij een al dan niet ingesteld due diligence onderzoek sprake is van zodanig ongebruikelijke omstandigheden dat die niet in een onderzoek zijn betrokken. ${ }^{383}$

De benadering van vraagstukken rond de mededelings- en onderzoeksplicht (due diligence) vertoont grote verwantschap met de benadering welke in de jurisprudentie is gekozen ten aanzien van de uitleg van overeenkomsten. Ik heb daarmee het oog op de zogenaamde Haviltex-maatstaf. ${ }^{384}$ Het komt erop aan welke zin partijen in de gegeven omstandigheden redelijkerwijze aan een afspraak hebben mogen toekennen en wat zij te dien aanzien van elkaar mochten verwachten. Daarbij speelt een rol welke hoedanigheid de betrokken partijen hebben. Waar het gaat om een onderzoeks- of mededelingsplicht gaat het er evenzeer om wat partijen van elkaar mochten verwachten. Dit leidt tot het criterium van de toerekenbare veronderstelling. Wanneer een verkoper weet of moet veronderstellen dat een koper onvoldoende op de hoogte is van het voorwerp van de transactie, danwel over bepaalde omstandigheden twijfelt, ontstaat - alleen al op grond van redelijkheid en billijkheid - een gehoudenheid om te voorkomen dat de ander onder invloed van een onjuiste veronderstelling tot het aangaan van de transactie overgaat. Zie HR 15 november 1958, NJ 1958, 67. De wederkerige gedragingen zullen worden afgestemd op hetgeen de ander zegt. Veronderstelde deskundigheid, ervaring en andere omstandigheden wel of niet de persoon van de wederpartij betreffende, kunnen daarbij mede bepalend zijn voor de inkleuring welke wordt gegeven aan hetgeen evenzeer als een zorgplicht kan worden omschreven.

Er is sprake van een flinterdunne lijn tussen het bestaan van een (vermeende) afspraak en de wijze waarop wordt omgegaan met de uitleg van een dergelijke (vermeende) afspraak enerzijds en anderzijds wat door mij genoemd is als "de toerekenbare veronderstelling" in het geval er nog geen afspraak tussen partijen tot stand is gekomen. Als gezegd kan met betrekking tot de laatstbedoelde situatie worden teruggegrepen op de rechtspraak sedert Baris / Riezenkamp en nadien de Plas/Valburg-doctrine. ${ }^{385}$

\footnotetext{
${ }^{380}$ De Hoge Raad verwijst (in r.o. 3.5 van het arrest van 19 januari 2007) naar HR 10 april 1998, NJ 1998, 666.

381 Zie Rechtbank Amsterdam 7 december 1994, NJ 1995, 265.

382 Zie HR 22 december 1995, NJ 1996, 300 (Hoog Catharijne) en HR 10 oktober 2003, LJN Al0306 (Dutch Paint) en Rechtbank Haarlem 5 december 2007, NJF 2008, 198.

383 Zie HR 18 januari 2002, LJN AD4924.

${ }^{384}$ Zie HR 31 maart 1981, NJ 1981, 635 m.nt. CJHB (Haviltex). Zie laatstelijk HR 20 februari 2004, RvdW 2004, 34 (DSM/Fox), HR 19 januari 2007, NJ 2007, 575 (Meyer/Pontmeyer), HR 29 juni 2007, NJ 2007576 (Derksen/Homburg) en HR 19 oktober 2007, NJ 2007, 565 (Vodafone). R.P.J.L. Tjittes, Uitleg van schriftelijke contracten, RM Themis 2005, p. 2 e.v. en van dezelfde auteur Terug naar de tekst - een herwaardering van de tekstuele uitleg van contracten, WPNR 2007/6709, p. 417 e.v. Zie ook R. Bierenbroodspot, Uitleg van overeenkomsten: maatwerk op basis van Haviltex, O\&F 2008, nr. 1, p. 62. e.v.

${ }^{385}$ HR 18 juni 1982, NJ 1983, 723 (Plas / Valburg)
} 


\section{De NCGC en due diligence}

Een element dat met betrekking tot due diligence relevantie toekomt, is wat door de OK wel is aangeduid als "moderne beginselen van corporate governance", ook al vond het gebruik van dat begrip niet terstond genade in de ogen van de Hoge Raad ${ }^{386}$ en o.m. E.M. Soerjartin, Wie gaat er in het (hoender)hok: de knuppel of de OK? In: Geschriften vanwege de Vereniging Corporate Litigation 2003-2004, p. 109. De vraag is hoe het fenomeen due diligence dient te worden gevat in het vraagstuk van corporate governance. Onder corporate governance valt te verstaan de wijze waarop het bestuur en het toezicht binnen een organisatie is georganiseerd en wordt uitgevoerd.

Opvallend in de NCGC is dat de bepalingen die over risicobeheersing gaan, betrekking hebben op interne risicobeheersings- en controlesystemen en nergens met zoveel woorden wordt gesproken over de noodzaak en het belang van een zorgvuldig due diligence onderzoek in het geval van een voorgenomen overname. ${ }^{387}$ Niet gesproken wordt over het beheersen van risico's bij overnames. Bij de aanbeveling om kerncommissies in te stellen, komt een commissie voor het geval van een voorgenomen overname niet voor. Wellicht dat bedoeld is over de band van de bepalingen van tegenstrijdige belangen ${ }^{388}$ of het goedkeuringsvereiste (II.1.2), volgens hetwelk de randvoorwaarden, die bij een strategie worden gehanteerd ter goedkeuring aan de raad van commissarissen moeten worden voorgelegd, de kwestie aan te (doen) spreken. Zo zijn er meer bepalingen in de NCGC aan te wijzen, die met enige goede wil betrokken kunnen worden op de situatie van een voorgenomen overname. Het is mijn overtuiging, dat het onderwerp van de risico's die samenhangen met het doen van overnames of het aangaan van fusies, alsmede de wijze waarop er ter zake daarvan te werk moet worden gegaan, belangrijk genoeg is om bijzonderlijk te worden geregeld. Bij alle aandacht, die door de NCGC wordt gevraagd voor interne risicobeheersingsprocessen, mag aandacht voor de risico's die met eventuele overname of fusieprocessen samenhangen niet minder zijn. "Due diligence is about managing risk". Het voorschrijven van een kerncommissie uit de raad van commissarissen voor het geval er sprake is van een voorgenomen overname, is wel het minste. Dit zou codificeren, hetgeen in vennootschappen met een goede corporate governance al gebruik is, namelijk dat in het geval van een overname, per saldo het bestuur niet aan het stuurwiel moet zitten, maar (een commissie uit) de raad van commissarissen. Het codificeren van de best practice is een van de doelstellingen van de NCGC.

Door ook op het punt van de in acht te nemen due diligence op de hier voor voorgestelde wijze voor duidelijke richtlijnen te zorgen, kan bovendien in de koop worden meegenomen, dat beslissingen over onredelijke afscheidregelingen of overname bonussen in een kader kunnen worden gepast.

In de speerpuntenbrief van de VEB met betrekking tot 2008 van 28 november 2007 wordt ook benadrukt dat een belangrijk onderdeel van de strategie van ondernemingen het overnamebeleid is en de financiering daarvan. Ik citeer:

"Behalve dat bij majeure transacties goedkeuring aan de aandeelhouders wordt gevraagd, verwacht de VEB dat bij daadwerkelijke (significante) toekomstige overnames aandeelhouders goed worden geïnformeerd. Naast overnamesom, omzet en winst van het overgenomen bedrijf zijn dit zaken als vooruitzichten, verwachte synergievoordelen alsmede impact op de winst per aandeel (nu en later) en het risicoprofiel van de onderneming".

Wil over het vorenstaande op de voorhand met de aandeelhouders gecommuniceerd kunnen worden, dan zal een due diligence onderzoek ook niet kunnen ontbreken, evenmin als dat mag hebben ontbroken wanneer er over overnames niet vooraf maar eerst achteraf met aandeelhouders wordt gecommuniceerd.*

${ }^{386}$ Zie HR 21 februari 2003, JOR 2003, 57 m.nt. M.P. Nieuwe Weme (HBG).

387 Zie II.1.3, II.1.4, III.1.6, III.1.8, en III.5.

${ }^{388}$ Zie Onderhandelen met dubbele petten, FD 20 oktober 2007 naar aanleiding van kritiek van de VEB op de gang van zaken bij de buy out bij Stork N.V.

389 Zie Chr. Davis, New Dimensions in Due Diligence, ICCLR 1997, nr. 7, p. 243 e.v. en ook D.A.M.H.W. Strik, De 'in control'statement, TOP 2008, nr. 8, p. 330-334.

* Inmiddels verscheen na de afsluiting van het manuscript voor dit boek op 4 juni 2008 nog wel het voorstel van de Monitoring Commissie voor toevoegingen aan de Code in het geval van overnames ("VI de positie van het bestuur en de raad van commissarissen bij overnames"). Volgens principe VI.1 moeten het bestuur en de raad van commissarissen aandacht 


\section{Juridische aspecten welke samenhangen met het fenomeen due diligence}

\subsection{Due diligence en garanties}

\section{Garanties - algemeen}

Voor een ampele bespreking van garanties bij overnames, wordt verwezen naar het proefschrift van Raaijmakers uit $2002 .^{390}$ Raaijmakers gaat ook in op het verschil tussen zogenaamde representations and warranties. Naar zijn uitvoerige proefschrift wordt verwezen, alsmede naar zijn meer recente publicatie over garanties in het contractenrecht. ${ }^{391}$

In de Nederlandse overnamepraktijk wordt gesproken over garanties en vrijwaringen. Een scherp onderscheid tussen beide laatstgenoemde begrippen wordt niet altijd aangebracht. Grofweg gezegd zou het onderscheid kunnen worden uitgedrukt door te spreken over "generieke" of "niet-specifieke" garanties enerzijds ("garanties") en specifieke garanties anderzijds ("vrijwaringen"). Een voorbeeld van een generieke garantie is een balansgarantie of de garantie dat een doelwitvennootschap over alle nodige vergunningen wordt beschikt. Een vrijwaring is dan een specifieke garantie, een verzekering welke de ene partij aan de andere partij geeft van het bestaan of van een feit waarop de andere partij zich mag verlaten. Een vrijwaring kan gezien worden als een vorm van een verzekering, dat de ander op de desbetreffende verklaring mag vertrouwen zonder ter zake (nader) onderzoek te behoeven te verrichten. De strekking van een garantie is het aangaan van een verbintenis om de wederpartij schadeloos te stellen voor het verlies dat deze kan opdoen, wanneer het toegezegde ontbreekt of onjuist blijkt te zijn.

Raaijmakers concludeert meer in het algemeen dat garanties geen vast omlijnd rechtsbegrip zijn met vaste kenmerken en vooraf bepaalde rechtsgevolgen. Volgens hem belichamen garanties risicoverdelingsafspraken, maar niet per definitie. Ze hebben geen vooraf bepaalbare inhoud en rechtsgevolgen. Het zijn praktijkfiguren die steeds weer moeten worden uitgelegd om vast te stellen wat hun belang is voor de onderlinge rechtsverhouding. Wat mij betreft zijn garanties zo goed als de formulering waarin die gevat zijn en als het verhaal dat kan worden gevonden op degene die de garanties afgeeft. ${ }^{392} \mathrm{Bij}$ de uitleg van garanties zullen alle daarvoor in aanmerking komende omstandigheden moeten worden meegewogen om vast te stellen wat partijen voor ogen stond bij het tot stand komen van de desbetreffende formuleringen. Daarbij zullen de hoedanigheden van partijen en hetgeen zij (derhalve) van elkaar hadden te verwachten en mochten verwachten, een belangrijke rol spelen.

Het feit dat er in de rechtspraak een tendens valt waar te nemen om garanties in overname-overeenkomsten - nu die over het algemeen tussen professionele partijen tot stand zullen zijn gekomen - betrekkelijk strikt uit te leggen, valt te ver buiten het onderwerp van dit boek om meer aandacht te krijgen

besteden aan de wijze waarop bij een overnamebod het overnameproces zal worden begeleid. Volgens principe VI.6 op het moment dat het bestuur van een vennootschap ten aanzien waarvan een overnamebod is aangekondigd of uitgebracht, het verzoek ontvangt van een derde (potentieel) concurrerende bieder op dezelfde wijze inzage te krijgen in de gegevens van de vennootschap als de bieder, bespreekt het bestuur het verzoek onverwijld met de raad van commissarissen.

390 G.T.M.J. Raaijmakers, Garanties bij overnames, Boom 2002, zie in het bijzonder p. 95 e.v. en de door hem genoemde literatuur. Zie ook o.m. A. Hammerstein, Garanties zijn geen garanties, in Onderneming en 5 jaar nieuw burgerlijk recht, Serie Onderneming en Recht, deel 7, p. 389 e.v. en M.M. Tuytel, (Balans)garanties, V\&O 2001, p. 174-179.

${ }^{391}$ G.T.M.J. Raaijmakers, Garanties in het contractenrecht, RM Themis 2005-3, p. 124-138.

$\left({ }^{*}\right) \mathrm{Na}$ de datum van het afsluiten van de tekst voor dit boek verscheen een bijdrage van R.J. Tjittes die het verdient dat daar toch melding van wordt gemaakt: De uitleg van garanties en vrijwaringen in overnamecontracten in Geschriften vanwege de Vereniging van Corporate Litigation 2007-2008, p. 113 e.v.

392 De rechter verlangt over het algemeen dat garanties duidelijk geformuleerd moeten zijn, willen die de grondslag vormen voor een veroordeling tot vergoeding van schade. Zie bij wijze van voorbeeld Rechtbank Rotterdam 13 februari 2008, LJN BC6343, waarin de rechtbank vooralsnog oordeelde (er volgde een bewijsopdracht), dat het verband tussen afgegeven balansgaranties en de identiteit van tussen partijen voorafgaand aan de transactie uitgewisselde financiële gegevens (concept-balansen) onvoldoende was aangetoond (r.o. 5.4 e.v.). 
dan de constatering daarvan. ${ }^{393}$ Wat relevant is voor het onderwerp van dit boek, is dat een due diligence onderzoek een belangrijke opmaat is naar het bespreken en voorwerp van onderhandeling maken van garanties en vrijwaringen in de transactie-documentatie. ${ }^{394}$

Garanties hebben een belangrijke betekenis waar dit het onderwerp van het boek betreft. Zowel door het vragen als door het opnemen van garanties in de (concept)documentatie voor de vastlegging van een transactie, doet degene die de garanties voorstelt mededeling aan diens wederpartij omtrent zijn wensen en verwachtingen ten aanzien van het voorwerp van de transactie. Het vragen van garanties maakt duidelijk dat de koper ter zake van het voorwerp van koop wil (kunnen) weten dat deze vrij is van de risico's waartegen deze zich wil beschermen door het vragen van de garanties. Dit vult mede in wat partijen (over en weer) van elkaar verwachten en willen kunnen verwachten. De verkoper weet daardoor wat de veronderstelling aan de zijde van de koper is. In de praktijk werkt een en ander ook aldus uit. Wil een verkoper iets niet garanderen, dan zal hij openheid moeten verschaffen en/of het geven van een garantie weigeren. Dit waarschuwt de koper, die - al naar gelang de omstandigheden van het geval - van de transactie kan afzien of andere voorwaarden kan bedingen.

\section{Disclosure letter}

De onderwerpen welke voorwerp worden gemaakt van garanties, lopen veelal in de pas met de onderwerpen welke onderdeel uitmaken van het due diligence onderzoek. Dezelfde lijst van onderwerpen passeert gebruikelijk de revue. ${ }^{395}$ Het proces van onderhandeling over garanties gaat veelal gepaard met het verstrekken van bijzondere informatie over onderwerpen, waarvan de verkoper weet of kan vermoeden dat de koper daar relevantie aan zal toekennen, maar welke de verkoper buiten de te verstrekken garanties wil houden. Die onderwerpen worden dan bekend gemaakt en neergelegd in wat een disclosure letter wordt genoemd. Aldus wordt voorkomen dat de verkoper achteraf verwijten kunnen treffen dat er onvoldoende openheid is betracht. De in de disclosure letter bekend gemaakte feiten en omstandigheden worden dan uitgezonderd van de werking van garanties en eventuele vrijwaringen. Vanzelfsprekend zal de koper met de hem aldus bekend gemaakte gegevens opnieuw naar de prijs kijken, welke deze bereid is te betalen. Over het algemeen zal de verkoper zo vroeg mogelijk in het onderhandelingsproces die onderwerpen, waarvan hij de gevoeligheid kan begrijpen, aan de orde stellen om te vermijden dat er na de initiële prijsonderhandelingen door de koper gebruik zal worden gemaakt van de desbetreffende feiten of omstandigheden en deze die als een waardedrukkend feit zal betrekken bij de onderhandelingen. Vanzelfsprekend dient het systeem van de disclosure letter ook de transactie. Als gezegd kan de verkoper zich aldus beschermen tegen verwijten achteraf omtrent onvoldoende openheid. De disclosure letter maakt een onlosmakelijk onderdeel uit van het totale due diligence onderzoek. Men kan echter zeggen dat het veel meer een aanvulling vormt op het due diligence onderzoek. Tegelijkertijd met of tijdens de due diligence procedure zal de disclosure letter in concept voorwerp van de (concept-)transactiedocumentatie uitmaken en niet zelden is de uiteindelijke versie van de disclosure letter bedoeld om die elementen, welke (ook) tijdens het due diligence onderzoek naar voren komen, die de verkoper niet wil garanderen. ${ }^{396}$ In de praktijk vormt het opstellen van een disclosure letter nog wel eens een sluitstuk van de onderhandelingen. Het blijt een vraag van onderhandelingstechniek voor met name de verkoper, wanneer de volledige inhoud van de disclosure letter inzet van de besprekingen wordt gemaakt. De verkoper zal in de disclosure letter immers zoveel mogelijk informatie willen opnemen, waarmee de uitzondering op de garanties in omvang toeneemt.

\footnotetext{
${ }^{393}$ R.P.J.L. Tjittes, Uitleg van schriftelijke contracten, RM Themis 2005, p. 2 e.v. en van dezelfde auteur Terug naar de tekst een herwaardering van de tekstuele uitleg van contracten, WPNR 2007/6709 p. 417 e.v.

${ }^{394}$ Hoewel het due diligence onderzoek een belangrijke stap vormt in de procedure betreffende een transactie betekent dit nog niet dat er al een zodanig stadium in de onderhandeling is bereikt dat het gerechtvaardigd vertrouwen mag bestaan dat enige overeenkomst tot stand zal komen, zelfs niet wanneer de verschillen tussen partijen ogenschijnlijk niet erg groot zijn. De bespreking van nadere voorwaarden volgt - tenzij er sprake is van een confirmatory due diligence - immers eerst nadat de uitslag van het due diligence onderzoek bekend is geworden. Vergelijk HR 29 februari 2008, LJN BC1855 (Shell Nederland Verkoopmaatschappij).

395 Zie over soorten van garanties ook J.L. Burggraaf, Garanties bij overnames, Dossier 1996, nummer 24, p. 80 e.v.

396 Zie voor een voorbeeld Rechtbank Leeuwarden 19 maart 2008, NJF 2008, 218, waarin de navolgende clausule wordt genoemd: "Verkopers zijn ermee bekend dat de juistheid en volledigheid van de garanties essentieel zijn voor de bereidheid van koper om deze overeenkomst aan te gaan onder de voorwaarden zoals hierin vermeld. Aan de verkoper zijn geen feiten of omstandigheden bekend die niet vóór de overdrachtsdatum ter kennis van koper zijn gebracht en waarvan redelijkerwijs moet worden aangenomen dat de kennisneming daarvan door koper van invloed zou zijn geweest op de bereidheid van koper om de overeenkomst aan te gaan".
} 
Als gezegd zal de koper bij elk onderwerp dat aan de disclosure letter wordt toegevoegd - afhankelijk van de stand van de dingen - proberen een waarde aan dat onderwerp toe te kennen en een verdiscontering op de koopprijs toe te passen.

Op de vraag hoe het zit wanneer een koper voorafgaand aan het tot stand komen van een transactie ervan op de hoogte is dat er één of meer dingen die in een garantie zullen worden opgenomen, niet in overeenstemming met die garantie zijn, wordt hierna nog ingegaan. Daaraan voorafgaand wil ik in veel algemenere zin eerst nog stil staan bij de relatie tussen garanties en een due diligence onderzoek.

\section{Gelden garanties onverminderd een uitgevoerd onderzoek?}

In de overnamepraktijk is het regelmatig een voorwerp van discussie tussen de bij de onderhandeling betrokken partijen of de uitvoering van een due diligence onderzoek beperkingen moet meebrengen waar het de te verschaffen garanties betreft. De verkoper wil zich bij voorkeur zo weinig mogelijk gecommitteerd weten aan garanties en zal de informatie welke uit het due diligence onderzoek verkregen kon worden, aanvoeren als reden om minder garanties te hoeven verlenen. De koper zal betogen dat hij weliswaar een onderzoek heeft ingesteld, maar desondanks niet weet welke dubbele bodems er kunnen zijn, waartussen zich toch nog verrassingen kunnen bevinden. De verkoper zal zich willen vrijwaren van dwalingsacties en proberen zoveel mogelijk de tijdens een due diligence onderzoek opgedane kennis in de tekst van een overeenkomst te verwerken als bevestiging dat deze de koper naar behoren heeft ingelicht.

Van Dunné heeft naar mijn oordeel terecht verdedigd dat er geen omslag dient plaats te vinden bij een eigen onderzoek van de koper, met het verspelen van een dwalingsactie als gevolg. De consequentie van het tegengestelde standpunt zou zijn dat aspirant-kopers aangeraden moet worden om geen onderzoek te doen in de onderhandelingsfase, en dat kan volgens hem niet de bedoeling zijn van het recht op dit punt. Het voorkomen van miskopen door eigen onderzoek in te stellen, is een maatschappelijk belang dat nagestreefd moet worden. ${ }^{397}$

Mijn eigen standpunt is dat een due diligence onderzoek wordt uitgevoerd ter informatie van de koper. Weliswaar voldoet de verkoper in zekere mate aan een plicht tot het verschaffen van inlichtingen door het bieden van de gelegenheid om een onderzoek in te stellen, maar daarmee is voor de koper op geen manier zekerheid verkregen dat de getoonde informatie ook volledig is. Dit betekent dat in ieder geval een garantie, dat de verschafte informatie alle informatie betreft, welke voor de koper van aandelen of activa relevant is, een gerechtvaardigde wens van een koper zal betreffen. Om misverstanden te vermijden over de vraag welke informatie de desbetreffende koper relevant acht, kunnen ook op bijzondere deelterreinen garanties worden gevraagd. Wanneer de verkoper de overtuiging heeft dat alle relevante informatie aan de koper bekend is gemaakt, behoeft het afgeven van een dergelijke garantie ook geen probleem op te leveren. De dynamiek van onderhandelingen over een overname, maken dat hetzelfde argument vaak wordt teruggespeeld. Wanneer de overtuiging bestaat dat het onderzoek toereikend is geweest, is het vragen van een garantie niet meer nodig. De koper zal in het verzet tegen het verlenen van een garantie een aanleiding voor (hernieuwde) onzekerheid of achterdocht putten en insisteren op het verkrijgen van de gevraagde garantie. Per saldo telt in mijn ogen dat de verkoper de onderneming kent en behoort te kennen en derhalve - ondanks een uitgevoerd due diligence onderzoek - begrip zou moeten tonen voor de wens van de koper om een zorgvuldige beslissing te nemen, ondersteund door verkregen garanties. Niettemin bepaalt in de praktijk de machtsbalans de uitslag van de onderhandelingen. Het hangt er maar vanaf hoe graag de koper de transactie wil laten doorgaan of hoe nodig die is binnen het kader van diens ondernemingsstrategie, en omgekeerd, hoe graag de verkoper zijnerzijds de transactie wil laten doorgaan, danwel hoe zeer de verkoper om geld verlegen zit.

Het is de vraag in hoeverre een contractuele bepaling dat een eventueel uitgevoerd due diligence onderzoek geen afbreuk kan doen aan gegeven garanties, in rechte het beoogde resultaat zal opleveren. In de meest recente literatuur blijkt van een verschil van opvatting over een antwoord op deze vraag tussen Van Dunné en Raaijmakers. Van Dunné is sceptisch over de juridische waarde van een afspraak als hiervoor bedoeld. Hij ziet dergelijke afspraken als 'vrij tekeningsbedingen' en wijst op de jurisprudentie waaruit de betrekkelijkheid van exoneratieclausules en soortgelijke afspraken blijkt, om te

\footnotetext{
397 J.M. van Dunné, Onderzoeks- en spreekplichten bij bedrijfsovername, in: Onderneming en 5 jaar Nieuw Burgerlijk Recht, Serie Onderneming \& Recht, deel 7, p. 399 e.
} 
concluderen dat 'de speelruimte die vrij tekeningsbedingen in het kader van due diligence onderzoek bieden, dus beperkt is'. 398

Raaijmakers is minder sceptisch. Hij meent dat het niet gaat om een onder omstandigheden onredelijke beperking van de aansprakelijkheid van de verkoper, maar om het stipuleren van volstrekt legitieme afspraken. 'Partijen proberen slechts tot uitdrukking te brengen dat zij beogen de desbetreffende risico's voor rekening van de verkoper te laten komen, no matter what, en dat de koper slechts onderzoek heeft verricht voor zijn eigen gemoedsrust zonder aan dat principe afbreuk te willen doen'.

Raaijmakers ziet niet in wat daartegen het bezwaar is. De grote lijnen van die opvatting kunnen wat mij betreft worden gevolgd. Raaijmakers ziet garanties doorgaans als risicoverdelingsafspraken waarmee nadere invulling wordt gegeven aan de prestatieplicht van de verkoper. De verkoper is dan niet van zijn verplichting gekweten door de enkele levering van het goed. Hij is verplicht een goed te leveren dat geen van de - met de garanties geïdentificeerde - gebreken vertoont. Doet hij dat niet, dan pleegt hij wanprestatie. De garanties hebben aldus de functie van het nauwkeurig vastleggen welke risico's voor rekening van de koper of de verkoper zijn. ${ }^{399}$ Mij dunkt dat het hiervoor aan de orde gestelde onderwerp van de toerekenbare veronderstelling echter voor een nuance zorgt. De door Raaijmakers gehuldigde opvatting kan slechts worden onderschreven in zoverre er sprake is van een door de verkoper bewust aanvaard risico. De nuance zie ik in het geval de koper weet dat er van gebreken sprake is, waarmee de gegeven garantie niet in overeenstemming is. Behalve wanneer er dan sprake is van een inspanningsverbintenis om te zorgen dat er alsnog aan de garantie zal worden voldaan in de toekomst, dient een koper de toerekenbare veronderstelling tot zijn verantwoordelijkheid te rekenen om te verifiëren of de verkoper zich bewust is van het feit dat deze een garantie verleent die op het moment van het verlenen daarvan niet spoort met de actuele situatie van de gegarandeerde toestand. Een behoorlijke omgang tussen contractspartijen blijft onderdeel van de in de pre-contractuele fase passende redelijkheid en billijkheid. De toerekenbare veronderstelling is in dat opzicht een niet te veronachtzamen factor, waarbij de zorgplicht van beide partijen om te vermijden dat er sprake is van een onjuiste voorstelling, gewicht moet blijven toekomen. Dat is mijn mening. Kijken we naar de situatie in de rechtspraak van dit moment, dan zien we het volgende.

Dat de afspraken tussen partijen bepalend zijn omtrent de vraag in hoeverre een uitgevoerd due diligence onderzoek afbreuk kan doen aan gegeven garanties, kwam nog eens tot uitdrukking in een uitspraak van de rechtbank te Rotterdam van 19 november $1998:^{400}$

"In het algemeen kan een door de koper verricht due diligence onderzoek niet afdoen aan een door de verkoper gegeven balansgarantie. Gedaagde heeft echter gesteld dat eiser bij de uitsluitingen van de gegeven garantie uitdrukkelijk heeft bepaald (...) dat de garantie niet gold voor feiten die in het due diligence onderzoek naar voren waren gekomen. Derhalve is van belang in hoeverre dat onderzoek zich (mede) heeft uitgestrekt tot de problematiek omtrent de fiscaal compensabele verliezen".

De Best ${ }^{401}$ noemt als antwoord op de in de aanhef van deze paragraaf genoemde vraag:

"De uit het Hoog Catharijne arrest afgeleide regel dat de koper zich onder bepaalde omstandigheden niet op een door de verkoper afgegeven garantie kan beroepen omdat hij de onjuistheid daarvan op grond van het due diligence onderzoek had kunnen kennen, zal in het algemeen alleen een rol kunnen spelen bij niet-specifieke garanties, zoals een garantie omtrent volledige informatieverschaffing. In het geval dat dergelijke niet-specifieke garanties zijn afgegeven, kan het voor koper nuttig zijn om een bepaling op te nemen die de invloed van het due diligence onderzoek op de afdwingbaarheid van de garantie uitsluit. De meeste schrijvers achten dergelijke bepalingen geldig. Het is echter aannemelijk dat een

398 Zie G.T.M.J. Raaijmakers, Garanties in het contractenrecht, Themis 2005-3, p. 135-136. Zie over de toetsing van exoneraties naar aanleiding van HR 26 oktober 2007, RvdW 2007, 923. Zie recent M.M. van Rossum, Overzicht Actualiteiten vermogensrecht, Juridisch Up to Date 2008, nr. 10, p. 4-5.

399 Zie ook M. Bax, De rol van garanties in de overnamepraktijk, V\&O juni 2003, nummer 6, p. 94 e.v., die niet alleen ingaat op het begrip garantie, maar ook op denkbare acties die een koper van een 'gebrekkige' onderneming ten dienste (kunnen) staan.

400 JOR 1999, 31

401 E.A. de Best, Bepalingen omtrent de invloed van due diligence onderzoek op de afdwingbaarheid van garanties, V\&O september 2004, nr. 9, p. 155 
dergelijke bepaling niet een koper zal beschermen die op grond van het due diligence onderzoek rechtens bekend is met de onjuistheid van de garantie".

Rechters zijn niet gauw bereid om bekendheid met gebreken te vergeven, wanneer er een beroep op een garantie wordt gedaan. Een voorbeeld vormt de uitspraak van de rechtbank te Rotterdam van 28 november $2007 .^{402}$

Het geschil ging over de vermeende schending van een balansgarantie, welke luidde dat de balans een getrouw en duidelijk beeld gaf van de grootte van het vermogen van de vennootschap per de overnamedatum en van de verdeling van actief- en passiefposten. Na de koop bleek er verschil te bestaan in de omvang van de voorraden.

De rechtbank overwoog:

"Wat de schending van garanties betreft die de koper mede aan zijn vordering ten grondslag legt, geldt het volgende. Voor de koop was al duidelijk dat er een verschil van inzicht bestond omtrent de waarde, althans de in de balans opgenomen waarde van de handelsvoorraad, waarbij men zich van de zijde van de koper op het standpunt heeft gesteld dat de voorraad (zo goed als) niets waard was. Onder deze omstandigheden komt de koper geen beroep toe op de in de leveringsakte opgenomen algemene garantie dat de balans een getrouw en duidelijk beeld geeft van de grootte van het vermogen van de vennootschap noch op het bepaalde in artikel 2:249 BW, en hem komt in dit verband evenmin een beroep toe op de in de koopovereenkomst opgenomen garantie dat de verkoper geen relevante informatie heeft verzwegen, omdat hij al gerede twijfel koesterde omtrent het verschil tussen de vermelde historische kostprijs van de voorraad en de actuele waarde daarvan. Een en ander zou mogelijk anders kunnen zijn indien afzonderlijk 'de waarde' van de voorraad was gegarandeerd, maar daarvan is geen sprake".

In zoverre volgt de rechtbank te Rotterdam de opvatting welke De Best in het hiervoor genoemde citaat verwoordde.

Men kan zich tenslotte nog afvragen of een benadeelde koper een veroordeling tot vergoeding van een waardeverschil op grond van non-conformiteit zou kunnen instellen, wanneer die niet kan worden gebaseerd op het schenden van een specifieke garantie ten aanzien van een bepaald onderwerp. Ook in dat geval zal een rechter bij de beoordeling van de vraag of de onderneming de eigenschappen bezat die de koper ervan mocht verwachten, dienen te kijken naar de wel gegeven garanties en de omstandigheden van het concrete geval.

Een niet ongebruikelijke clausule in transactie-documentatie teneinde om te gaan met de hiervoor bedoelde problematiek, luidt wel als volgt:

\section{"Partijen komen expliciet overeen dat:}

(i) een beroep van de koper op garanties door de verkoper niet kan worden afgeweerd met een beroep op enige kennis die de koper bij het aangaan van deze overeenkomst had of zou kunnen hebben, met dien verstande dat geen inbreuk op de garanties geacht zal worden te bestaan voor zover de feiten of omstandigheden die een garantie onjuist of onvolledig doen zijn, bij de koper op de datum van ondertekening van deze overeenkomst bekend waren of hadden moeten zijn op basis van een eerste zorgvuldige lezing van de due diligence informatie omdat zij daar ondubbelzinnig en zonder nader onderzoek uit blijken; en (ii) met de garantie en risicoverdeling is beoogd die is verdisconteerd in de transactie en die inhoudt dat (de schadelijke gevolgen van) inbreuken, uitzonderingen en afwijkingen op de garanties met inachtneming van de overige bepalingen in deze overeenkomst steeds geheel en uitsluitend voor rekening van de verkoper komen".

Nu een garantie de strekking heeft om de aan- of afwezigheid van bepaalde gebeurtenissen of feiten te verzekeren, is er sprake van tekortkoming van de zijde van de verkoper, ook wel vergeleken met non-conformiteit, wanneer naderhand blijkt dat de garantie niet in overeenstemming is met de actuele

${ }^{402}$ LJN BB9319 (r.o. 7.11 en 7.12) 
situatie. Kennis van de koper als resultaat van een ingesteld due diligence onderzoek of als gevolg van de bekendgeving van feiten of gebeurtenissen door de verkoper middels de hiervoor bedoelde disclosure letter, zullen over het algemeen in de weg staan aan het inroepen van een garantie door de koper. Als steeds geldt, dat het achterwege laten van een (adequaat) due diligence onderzoek de koper kan worden tegengeworpen. Hierna zal worden ingegaan op de vraag hoe de koper zich dient te gedragen wanneer tijdens of na een uitgevoerd due diligence onderzoek deze bekend raakt met feiten of gebeurtenissen die voorwerp zijn of kunnen zijn van een garantie. Naarmate garanties of mededelingen van een verkoper ondubbelzinniger zijn, zal het excuus dat er geen (nader) due diligence onderzoek is uitgevoerd, eerder opgeld doen.

\section{Naar beste wetenschap?}

Raaijmakers ${ }^{403}$ gaat ook nog in op de vraag in hoeverre de gebruikelijke slagen om de arm van 'to the best of my knowledge'-clausules de waarde van garanties beïnvloeden. Waar degene die de garantie met die toevoeging afgeeft, veelal van oordeel zal zijn dat de angel uit een gegeven garantie is gehaald (en alleen maar hoeft te verklaren dat hij niets achter houdt), menen degenen die de garantie verkrijgen veelal dat de betrokkene ook nog een eigen verantwoordelijkheid had en eerst zeker heeft moeten stellen dat diens verklaring juist is. ${ }^{404}$ Raaijmakers wijst op het arrest Ernst \& LattenCrombag. ${ }^{405}$ Het ging daarbij om een vastgoedmaatschappij welke een woning verkocht aan twee leken-kopers. Deze maakten zich ongerust over de ontwikkelingen onder het bestemmingsplan en vroegen aan de directeur van de vastgoedmaatschappij die hen de woning probeerde te verkopen, hoe het daarmee zat. Deze antwoordde dat het onroerend goed 'bij zijn weten' niet in een bestemmingsplan viel. Achteraf bleek dat wel degelijk het geval te zijn. Volgens het bestemmingsplan zou er zelfs een weg door de tuin van de woning worden gelegd. De kopers wilden daarop de overeenkomst vernietigen wegens dwaling. Het gerechtshof oordeelde dat de toevoeging 'bij zijn weten' zoveel onzekerheid liet, dat de kopers zelf nader onderzoek hadden moeten instellen. De Hoge Raad liet dit oordeel in stand en voegde er nog aan toe dat ook de deskundigheid van de verkoper hieraan geen afbreuk deed, nu er geen algemene regel is dat een ter zake kundig onroerend goedhandelaar zelf eerst onderzoek behoort in te stellen om na te gaan of het door hem aangeboden onroerend goed in een bestemmingsplan ligt. Zelf vind ik de uitkomst van de laatstbedoelde uitspraak niet erg bevredigend, nu juist van ter zake kundig onroerend goedhandelaren naar verkeersopvattingen volgens mij wél kan worden verwacht dat die zelf onderzoek hebben gedaan naar de toekomstige bestemming van het door hun aangeboden perceel. Niet zelden zal die bestemming aanleiding zijn om een perceel in de verkoop te doen. Dat ik het niettemin niet altijd bij het rechte eind heb, blijkt ook wel uit de uitspraak van de Hoge Raad in de zaak Christiaansen / Van Dijk. ${ }^{406}$ Als rechter-plaatsvervanger werkte ik mee aan de uitspraak van de rechtbank, welke uiteindelijk geen genade vond in de ogen van de Hoge Raad. Waar ging het om? Het betrof de verkoop van een woonboerderij. Voor de koop maakten partijen gebruik van de model-koopovereenkomst van de NVM. In artikel 5.1 daarvan was bepaald dat het goed overgedragen werd in de staat waarin het zich bevond. Artikel 5.3 van diezelfde overeenkomst bepaalde vervolgens dat de onroerende zaak de feitelijke eigenschappen bezat die voor een normaal gebruik nodig waren. In artikel 5.4 stond dat het aan de verkoper niet bekend was 'dat de onroerende zaak enige verontreiniging bevat die ten nadele strekt van het in lid 3 omschreven gebruik door de koper'. Achteraf bleek de grond bij de oude schuur op het perceel vervuild te zijn en wel zodanig dat de grond gesaneerd diende te worden om een schone grondverklaring te krijgen die Van Dijk nodig had om de bouwvergunning te krijgen waarmee hij de schuur wilde ombouwen, zodat hij daarin vee kon gaan houden. De wens om vee te houden was voor hem één van de redenen geweest om de woonboerderij te kopen. In rechte komt vast te staan dat dit ombouwen van de schuur onder 'normaal gebruik van de woning' valt, zodat de volgende vraag was of het gebruik op basis van artikel 5.4 niet toch voor rekening van de koper komt. In cassatie voerde Christiaansen aan dat dit inderdaad het geval was, aangezien artikel 5.4 gezien moest worden als een inperking van de strekking van de garantie die is vervat in artikel 5.3. De Hoge Raad dacht daar anders over. Die overwoog dat niet gezegd kon worden 'dat lid 4 van artikel 5 geen andere uitleg

\footnotetext{
403 T.a.p.

${ }^{404}$ Zie ook J.M. Barendrecht en E.J.A.M. van den Akker, Informatieplichten van dienstverleners, Den Haag 1999, p. 171 e.v.

${ }^{405}$ HR 18 april 1986, NJ 1986, 747.

${ }^{406}$ HR 28 januari 2000, NJ 2000, 575. Zie over deze problematiek ook A.G. Huydecoper in zijn conclusie onder HR 23 januari 2004, LJN AL7051.
} 
toelaat dan dat de garantie, die in lid 3 van artikel 5 wordt gegeven, niet zou gelden voor het geval van een aan Christiaansen niet bekende verontreiniging'. Het oordeel van het hof dat artikel 5.4 op 'geen enkele wijze' afbreuk deed aan lid 3, was niet onbegrijpelijk, zo vervolgde de Hoge Raad.

Raaijmakers ${ }^{407}$ bespreekt deze zaak en wijst erop dat in het algemeen zal gelden dat met de toevoeging dat een partij de juistheid van een feit slechts garandeert 'naar zijn beste weten', de garantie sterk van karakter verandert. Niet langer is het een bepaling die een contractuele risicoverdeling tot stand brengt, maar een bepaling die veel meer betrekking heeft op onderlinge informatie-uitwisseling: de garanderende partij verklaart dat zij niets heeft achtergehouden. De garantie krijgt daardoor het karakter van een verklaring over haar wetenschap ten aanzien van bepaalde feiten. In beginsel zal de toevoeging daarmee impliciet wel degelijk een risicoverdelingskarakter hebben in de zin dat de garanderende partij ermee aangeeft dat hij niet bereid is het risico voor zijn rekening te nemen. Volgens Raaijmakers mag de toevoeging 'naar zijn beste weten' niet snel worden opgevat als een verplichting voor de garanderende partij om zelf eerst gedegen onderzoek naar het desbetreffende risico uit te voeren, alvorens deze een dergelijke uitspraak doet. Anders wordt de betreffende toevoeging al snel weg geredeneerd, zo meent hij. Daarmee zou anders de wetenschap van de garanderende partij worden uitgebreid met 'behoren te weten'. Zonder concrete aanleiding dat partijen dit voor ogen stond, dient dat volgens hem niet te snel te worden aangenomen.

De vraag hoe de toevoeging "to the best knowledge of" in een bepaalde situatie uitgelegd moest worden was inzet van de procedure die eindigde in een uitspraak van de Hoge Raad van 7 september $2007 .{ }^{408} \mathrm{Bij}$ de verkoop van de aandelen in het kapitaal van BComponents Holdings BV ("BCC") kwam verkoper Kon. Philips Electronics N.V. ("Philips") met koper Phoenix Acquisition Company Sarl ("Phoenix") onder meer het navolgende overeen:

\section{"As of the Closing Date Seller represents and warrants to Purchaser as follows: \\ Section 3.18 Absence of Change(...) to the Knowledge of Seller, since December 31 1997 the Business has been operated in the ordinary course of the business and has not suffered a Material Adverse Change (...)".}

In de koopovereenkomst was een verplichting voor Philips opgenomen om aan Phoenix melding te maken van ontwikkelingen welke zich zouden voordoen tussen de datum van ondertekening van de overeenkomst en Closing, die zouden meebrengen dat één van de garanties of vrijwaringen niet zou worden nagekomen.

Phoenix stelde dat er voorafgaand aan de Closing met betrekking tot BCC sprake was geweest van gebeurtenissen die als Material Adverse Change - in de zin van de definitie die in de koopovereenkomst was opgenomen ${ }^{409}$ - hadden voorgedaan, waarvan Philips ten onrechte geen melding zou hebben gemaakt. Er bleek in het desbetreffende geval volgens de rechtbank sprake van voorafgaand aan de datum van de Closing - "een wezenlijke, naijlende, verslechtering van de resultaten van het verkochte bedrijf die het gevolg is van een reeds eerder gemelde gebeurtenis, zoals de Azië-crises (die, MB) moet worden aangemerkt als een Material Adverse Change waarover de koper moet worden geïnformeerd." De rechtbank te Amsterdam wees echter niettemin de vordering van Phoenix tot vergoeding van schade af, omdat de resultaten waar het om ging ten tijde van de Closing niet bij Philips bekend waren en er derhalve van Philips niet verlangd kon worden dat zij daarvan bij de Closing mededeling zou doen.

Ook het gerechtshof overwoog dat een aanzienlijk lagere EBITDA over 1998 dan verwacht voor Philips aanleiding had moeten vormen de aanwezigheid van een Material Adverse Change te veronderstellen. Desondanks bekrachtigde het hof het vonnis van de rechtbank:

\footnotetext{
407 a.w., p. $136-137$

408 JOR 2007, 291 m.nt. R.P.J.L. Tjittes. Zie ook N. Vles, De toevoeging to the seller's knowledge in commerciële overnamecontracten: een slag om de arm, V\&O november 2007, nr. 11, p. 203 e.v.

${ }^{409}$ Een Material Adverse Change was gedefinieerd als "an occurance or event or combination thereof that would reasonably be expected to have a material Adverse Effect". "Material Adverse Effect shall mean an effect that is materially adverse to the business, financial condition or results of operations of the Business as a whole". Zie ook D.A.H.W. Strik, Aspecten van schadevergoeding bij inbreuk op garanties in overnamecontracten, in: Geschriften vanwege de Vereniging Corporate Litigation 2003-2004, p. 393 e.v.
} 


\begin{abstract}
"Voor aansprakelijkheid van Philips is evenwel ingevolge art. III.3.18 vereist dat zij "Knowledge" had van de aanwezigheid van een Material Adverse Change. Niet door feiten gesteund wordt de stelling van Phoenix dat die "Knowledge" bij Philips op of vóór de datum van Closing bestond, vanwege haar bekendheid met de gerealiseerde EBITDA over 1998. Ook uit de omstandigheid dat de prognose van de EBITDA voor het jaar 1999 in aanzienlijke mate werd bijgesteld, blijkt niet dat Philips "Knowledge" had dat zich vóór de Closing een material Adverse Change had voorgedaan. Evenmin kan worden gezegd dat Philips deze wetenschap wel zou hebben verkregen, wanneer zij een "reasonable enquiry" had laten uitvoeren. De door Phoenix gestelde, en door haar als "Pre-Closing-gebeurtenissen" aangeduide, voorvallen leveren geen Material Adverse Change op in de zin van de tussen partijen gesloten overeenkomst. De door Philips gegeven Material Adverse Change-garantie is dus niet geschonden. Philips heeft evenmin haar mededelingsplicht geschonden en zij heeft ook niet een onjuist of vals "Officer's Certificate" afgegeven."
\end{abstract}

Philips had als verweer gevoerd, dat zij aan haar contractuele mededelingsplicht had voldaan. Voor zover de verslechtering van de markt als gevolg van de Azië-crises als Material Adverse Change in de zin van de koopovereenkomst diende te worden gekwalificeerd, had zij daarvan in oktober 1998 mededeling gedaan en waren de gevolgen van die verslechtering in november 1998 in een verlaging van de koopprijs verdisconteerd. Volgens Philips konden de resultaten van BCC over december 1998 niet zelfstandig als Material Adverse Event worden gekwalificeerd. Zij stelde ten tijde van de Closing van de resultaten over december 1998 geen kennis te hebben gedragen.

De inzet van het geschil tussen Phoenix en Philips raakte aan een vraag die wat de overnamepraktijk betreft nog op een antwoord van ons hoogste rechtscollege wachtte. Het ging er per saldo om of de uitleg van het "Knowledge-criterium" mee dient te brengen dat met dit begrip niet alleen wordt gedoeld op de feitelijke wetenschap van de desbetreffende garantiegever, maar ook op de wetenschap die deze (en haar functionarissen) had(den) behoren te hebben nadat zij een van hen redelijkerwijs te verwachten onderzoek zouden hebben verricht. De Hoge Raad kwam in cassatie niet aan een antwoord op deze vraag toe. Nu het hof de door Phoenix aan het contractuele begrip "Knowledge" gegeven uitleg had verworpen, achtte de Hoge Raad zich aan de door het hof gegeven uitleg gebonden, omdat 'de uitleg van een overeenkomst overwegend feitelijk van aard is en het aangevoerde middel niet aangaf welke specifieke rechtsregel(s) het hof daarbij zou hebben geschonden'. Nu het gerechtshof de vraag of er aan een verklaring omtrent het begrip "Knowledge" een "reasonable enquiry" vooraf diende te gaan in haar overwegingen aandacht had besteed, achtte de Hoge Raad het niet onbegrijpelijk dat volgens het hof onder "Knowledge" uitsluitend feitelijke wetenschap van de desbetreffende Philips-functionarissen diende te worden verstaan. De hier besproken uitspraak leert derhalve dat onder omstandigheden het begrip "Knowledge" uitsluitend feitelijk en niet (mede) normatief dient te worden opgevat. Indien de uitleg die als normatief kan gelden, gewenst wordt, zullen partijen dit in de tekst van de in een overeenkomst op te nemen clausule tot uitdrukking moeten brengen. De lotgevallen van Phoenix - die haar vordering zag stranden op een strikt grammaticale uitleg van een Engelstalige tekst - staan in de jurisprudentie op het terrein van fusies en overnames niet op zichzelf. ${ }^{410} \mathrm{Bij}$ het antwoord op de vraag welke zin partijen in gegeven omstandigheden over en weer redelijkerwijze mochten toekennen aan bepaalde woorden in een overeenkomst en wat zij te dien aanzien redelijkerwijze van elkaar mochten verwachten, dient volgens de Hoge Raad als uitgangspunt beslissend gewicht te worden toegekend aan de meest voor de hand liggende taalkundige betekenis van die woorden, gelezen in het licht van de overige, voor de uitleg relevante bepalingen van de overeenkomst. De Hoge Raad let daarbij op de aard en strekking van de overeenkomst. Mede van gewicht kan zijn dat bij de totstandkoming van een overeenkomst bijstand werd verleend door (juridisch) deskundige raadslieden. Het vorenstaande betekent overigens niet dat de zogenaamde Haviltex-doctrine door ons hoogste rechtscollege volstrekt verlaten is. ${ }^{411}$ Als uitgangspunt blijft gelden dat de vraag hoe in een schriftelijke overeenkomst de verhouding tussen partijen geregeld is, niet alleen kan worden beantwoord op grond van een zuiver taalkundige uitleg van

\footnotetext{
${ }^{410}$ Zie HR 19 januari 2007, NJ 2007, 575 (Meyer Europe / PontMeyer) en HR 29 juni 2007, NJ 2007, 576 m.nt. M.H. Wissink (Derksen / Homburg).

411 Zie HR 19 oktober 2007, NJ 2007, 565 (r.o. 3.4 en 3.5). Zie ook HR 20 februari 2004, NJ 2005, 493 m.nt. Du Perron (DSMChemie / Fox).
} 
de bepalingen van de overeenkomst. Voor de beantwoording van die vraag komt het eveneens aan op de zin die partijen in de gegeven omstandigheden over en weer redelijkerwijs aan deze bepalingen mochten toekennen en op hetgeen zij te dien aanzien redelijkerwijs van elkaar mochten verwachten. De rechten en verplichtingen van partijen ten opzichte van elkaar worden niet alleen bepaald door hetgeen zij uitdrukkelijk zijn overeengekomen, doch ook door de redelijkheid en billijkheid die hun rechtsverhouding beheerst. Mede daardoor wordt de inhoud van de rechtsverhouding bepaald. Op grond van die rechtsverhouding moeten partijen hun gedrag mede laten bepalen door de gerechtvaardigde belangen van de wederpartij. Laatstbedoelde overwegingen golden met name daar waar de woordelijke tekst van de overeenkomst een bepaald gedrag niet verbood, maar in het desbetreffende geval toch kon meebrengen dat een gedraging ingevolge de overeenkomst niet geoorloofd was, nu de betrokkene "wist of had behoren te beseffen dat dit gebruik in de overeenkomst niet was verdisconteerd" en dat het desbetreffende gebruik de contractspartij onaanvaardbaar zou benadelen. In de laatstbedoelde uitspraak is de scheidslijn tussen de bepaling van de inhoud van de overeenkomst en de vraag hoe een overeenkomst ten uitvoer gelegd moet worden, erg dun. Niettemin formuleerde de Hoge Raad in het laatstbedoelde geval de rechtsvraag aldus, dat het erom ging hoe in een schriftelijke overeenkomst de verhouding tussen partijen was geregeld. Het antwoord op die vraag mocht in dat geval volgens ons hoogste rechtscollege niet alleen worden gebaseerd op een zuiver taalkundige uitleg van de bepalingen van de overeenkomst. Door de vraag naar de zin die partijen in de gegeven omstandigheden over en weer redelijkerwijs aan de desbetreffende bepalingen mochten toekennen relevant te achten, wordt de grens overgestoken naar de uitleg van hetgeen partijen redelijkerwijs van elkaar mochten verwachten bij de tenuitvoerlegging van de overeenkomst. In zijn noot onder het arrest Derksen/Homburg ${ }^{412}$ heeft Wissink erop gewezen dat de conclusie uit de arresten Meyer Europe/PontMeyer en Derksen/Homburg kan zijn dat de Hoge Raad de feitenrechters de vrijheid laat om een in beginsel taalkundige uitleg te kiezen. ${ }^{43}$

Het zou naar mijn oordeel een vergissing zijn aan de hiervoor laatstgenoemde arresten de indruk te ontlenen dat nu de tekst van de overeenkomsten tussen professionele partijen die met behulp van deskundigen tot stand zijn gekomen, uitsluitend of in hoofdzaak letterlijk moeten worden uitgelegd. De taalkundige uitleg in een dergelijk geval is een uitgangspunt. Veel meer zie ik de lijn die de Hoge Raad gekozen heeft als van bewijsrechtelijke betekenis. Er moet tegenover een taalkundige uitleg heel wat worden gesteld, wil de rechter ervan kunnen worden overtuigd dat met de desbetreffende tekst partijen iets anders hebben bedoeld. Ik herinner mij deel te hebben uitgemaakt van een scheidsgerecht dat een zaak kreeg voorgelegd waar partijen tot in de nacht hadden onderhandeld en nog een wijziging in een garantiebepaling hadden afgesproken. De documentatie werd ten kantore van de advocaat van één van partijen nog aangepast om de volgende morgen te worden ondertekend. $\mathrm{Na}$ ondertekening bleek dat de afgesproken aanpassing in een belangrijke bepaling niet was doorgevoerd. Beide partijen hadden voor ondertekening nog snel naar de beoogde wijzigingen gekeken, maar één wijziging was daarbij over het hoofd gezien. Middels getuigenbewijs kon worden vastgesteld dat de wijziging inderdaad bedoeld was. Ondanks de andersluidende tekst werd de werkelijke bedoeling van partijen door arbiters als inhoud van de verbintenis tussen partijen geoordeeld. Dit is slechts één voorbeeld dat als waarschuwing kan strekken om al te eenvoudig aan te nemen dat het recht vatbaar is om in formules te worden gegoten die universeel toepasbaar zijn.

\section{Nogmaals garanties en het due diligence onderzoek}

Ook de hier voor laatst besproken jurisprudentie maakt duidelijk dat het formuleren van garanties en vrijwaringen in overname- en andere overeenkomsten, zeker wanneer die in de Engelse taal worden gesteld, bijzondere nauwkeurigheid vereist. De omvang en aard van een due diligence onderzoek, evenals de resultaten daarvan, spelen daarbij vaak een bepalende rol. Indien een uitputtend onderzoek kan of zal plaatsvinden, zal een koper wellicht met minder vergaande toezeggingen op het punt van garanties en vrijwaringen genoegen nemen, dan wanneer er voorafgaand een minder diepgaand beeld van het voorwerp van een transactie kan worden verkregen. Uiteindelijk bepalen echter meerdere factoren de inhoud van de afspraken, die uiteindelijk in de documentatie worden vastgelegd en waarop partijen aangewezen zijn wanneer er zich na het aangaan van een transactie nog geschil

\footnotetext{
${ }^{412}$ HR 29 juni 2007, NJ 2007, 576 m.nt. M.H. Wissink.

${ }^{413}$ Zie M.H. Wissink, a.w. en de door deze genoemde rechtspraak en literatuur.
} 
voordoet. Het machtsevenwicht tussen partijen in de onderhandelingen, de omvang van de behoeftewens of noodzaak om een transactie wel of niet te doen slagen, de bekwaamheid van de onderhandelaars die zijn ingezet en dergelijke factoren bepalen mede in welke richting in het spanningsveld van de tegengestelde belangen van partijen de balans doorslaat. Veelal wordt in de documentatie uitgedrukt welke mate van onderzoek mogelijk is (geweest) en in hoeverre zulk onderzoek heeft plaatsgevonden ${ }^{414}$ De hier voor aangesproken vraag in hoeverre het uitvoeren van een vorm van een due diligence onderzoek afbreuk doet of wat partijen betreft afbreuk kan doen aan gegeven garanties, kan het best worden opgelost door het maken van duidelijke afspraken daarover. De verkoper zal zich daarbij op het standpunt stellen, dat door het bieden van de gelegenheid tot het instellen van een onderzoek, (in belangrijke mate) aan de mededelingsplicht is voldaan en garanties dus niet meer nodig zijn. Vrijwaringen zullen naar aanleiding van de uitkomst van een onderzoek nog kunnen worden opgenomen in de transactie documentatie. De koper zal onzeker zijn over de vraag of een onderzoek wel alles aan het licht kan brengen en desondanks (uitgebreide) garanties willen opnemen. Ondanks het maken van afspraken over de betekenis welke bekendheid van gegevens naar aanleiding van een due diligence onderzoek mag worden toegekend, zal een verkoper zich tegen een eventuele vordering achteraf willen verweren daar te stellen dat een koper zich naar redelijkheid en billijkheid niet mag beroepen op de gevolgen van gebreken, waarvan deze het bestaan voorafgaand aan het aangaan van de transactie kende. Om die reden is er inmiddels de nodige jurisprudentie ontstaan over de vraag of een verkoper aanspraak kan maken op het inzien van een verslag van een uitgevoerd due diligence onderzoek - die hierna nog zal worden besproken - en is de hier voor genoemde benadering van Van Dunné ook weer niet volledig van betekenis ontbloot.

Zoals hier voor al is aangegeven, zullen partijen zich er in de context van overnameovereenkomsten rekenschap van moeten geven, dat de aard van garantiebepalingen volgens de jurisprudentie te onzent meebrengt, dat er geen vastomlijnde betekenis aan het begrip garantie kan worden toegekend.

In HR 4 februari $2000^{415}$ werd dit nog eens bevestigd. In de lijn van de Haviltex-doctrine stelt de Hoge Raad in de desbetreffende uitspraak dat de vraag welke aard en strekking garantiebepalingen hebben, moet worden beantwoord door de uitleg ervan, "waarbij het aankomt op de zin die partijen bij de overeenkomst in de gegeven omstandigheden over en weer redelijkerwijs daaraan mochten toekennen en op hetgeen zij redelijkerwijs te dien aanzien van elkaar mochten verwachten". Ook deze vaststelling benadrukt het belang van een duidelijke considerans en een duidelijke beschrijving van de wijze waarop in de eigen visie van partijen de gevolgen van het uitvoeren van een onderzoek de toepassing van bepalingen omtrent garanties kunnen beïnvloeden.

De gedachte dat het achterwege laten van een regeling omtrent de invloed op garanties van bekendheid met bepaalde gegevens de meeste opties open laat om achteraf te kunnen ageren, is niet noodzakelijk een goede gedachte. Indien er helemaal geen onderzoek is uitgevoerd, kan dat op zich zelf in de meeste gevallen als een verweer en niet ten onrechte - zeker waar het een professionele partij betreft - tegen geworpen worden. Voorzover er wel sprake is geweest van enige vorm van onderzoek, zal een verwijt zich al licht laten denken dat er onvoldoende zorgvuldig uitvoering is gegeven aan de onderzoeksplicht, dan wel dat de gebreken waarover men zich beklaagt vooraf bekend waren of bekend hadden behoren te zijn.

\section{Eigen wetenschap?}

Een tussenvonnis van de rechtbank te Rotterdam van 17 september 1998 bevat een aanwijzing dat de rechter onder omstandigheden in eigen wetenschap van de koper omstandigheden kan vinden om een verkoper niet volledig aan eenmaal gegeven garanties te houden. ${ }^{416}$ In juridische termen komt het er in dergelijke situaties op neer dat het in strijd wordt geacht met de redelijkheid en billijkheid om zich op gegeven garanties te beroepen (artikel 6:2 jo. 2:248) wanneer bij het accepteren van die garanties er

\footnotetext{
${ }^{414}$ Een voorbeeld van een clausule, waarin de beperking van de informatie waarover kon worden beschikt, benoemd wordt, is: "For the avoidance of doubt, during the due diligence investigations carried out by the Purchaser, the Purchaser has only studied the matters appearing on the face of the Data Room Information and the Purchaser has not studied any 'reference-toreference information' which has not been made available as part of the Data Room Information. In connection thereto, the Parties acknowledge and confirm that where matters which do not appear on the face of the Data Room Information and where reference is made to a (particular part of a) document, such matter or reference and (particular part of a) document shall be deemed not to be disclosed to the Purchaser in respect to the Warranties"

${ }^{415}$ NJ 2000, 562 m.n. JBMV, zie r.o. 3.3.

${ }^{416}$ Zie rechtbank Rotterdam 17 september 1998, JOR 1999, 4 (r.o. 8.4.).
} 
bekendheid was met het feit dat die niet overeenstemden met de werkelijke situatie. Erg duidelijk is de hier voor bedoelde uitspraak overigens niet. De koper (Van der Wiel Drachten Holding B.V., hierna: "Van der Wiel") had aan haar vordering tegen de verkoper (De Vries Joure Holding B.V., hierna: "De Vries") ten grondslag gelegd dat de laatstgenoemde haar garantieverplichtingen niet was nagekomen. Verkoper De Vries beriep zich erop dat koper Van der Wiel volledig op de hoogte was geweest van de financiële situatie bij de doelwitvennootschap, mede omdat haar directeur, de heer E. van der Wiel, indertijd in een operationele rol betrokken zou zijn geweest bij zowel de doelwitvennootschap als de onderneming van De Vries. Die bijzondere wetenschap werd overigens niet aangenomen door de rechter nu in ieder geval ten tijde van de verkoop de heer Van der Wiel niet langer de beweerdelijke betrokkenheid had. Op enig ogenblik had de heer Van der Wiel wel de feitelijke leiding over de doelwitvennootschap gehad, maar gesteld - en onvoldoende weersproken - was dat ten tijde van de transactie de heer Van der Wiel niet langer de feitelijke leiding over de doelwitvennootschap had. Hij was op het desbetreffende moment nog slechts indirect aandeelhouder. Uit die omstandigheid volgde volgens de rechtbank niet dat Van der Wiel voor en op de datum van de transactie volledig op de hoogte was van de financiële situatie bij de doelwitvennootschap. De rechtbank overweegt vervolgens: "In ieder geval kunnen hieraan op zichzelf geen argumenten worden ontleend voor de stelling dat De Vries wat betreft door Van der Wiel genoemde specifieke kritiek op de jaarrekening 1993 en de prognoses voor 1994 niet aan haar verklaringen en garanties kan worden gehouden. Dit kan anders zijn wanneer Van der Wiel met betrekking tot die specifieke kritiekpunten meer van belang zijnde wetenschap had dan welke zij kon putten uit de door De Vries verstrekte informatie, doch hiervan is niets gesteld noch gebleken". De vraag rijst wat de rechtbank zou hebben gedaan wanneer Van der Wiel wel over specifieke informatie had beschikt met betrekking tot de kritiekpunten welke deze later uitte om een beroep te doen op de gegeven garanties.

De vraag over welke informatie een partij beschikt bij het aangaan van een transactie, is in alle stadia van een overnametraject of van een andersoortige transactie van belang. Wij hoeven bij andersoortige transacties maar te denken aan het rumoer dat is ontstaan naar aanleiding van de vraag of verzekeraars bij het aangaan van polissen van levensverzekering wel voldoende openheid van zaken hebben betracht, de zogenaamde woekerpolis-discussie. ${ }^{417}$

Hierna zal worden ingegaan op de vraag of het beschikken over kennis van gebreken in het voorwerp van de transactie op het moment van het aangaan daarvan, tot het verspelen van het recht om achteraf te klagen, kan leiden.

\subsection{Meldplicht tijdens en na due diligence?}

\section{Algemeen}

Waar het gaat om de beantwoording van de in de aanhef van deze paragraaf geformuleerde vraag, kan allereerst worden gewezen op het belang van het gestelde in artikel 7:17 lid 5 en in artikel 6:228 lid 1 sub b. Volgens artikel 7:17 lid 5 kan een koper zich niet op een gebrek in een zaak beroepen wanneer de zaak niet aan de overeenkomst beantwoordt, wanneer dit gebrek hem ten tijde van het sluiten van de overeenkomst bekend was. In artikel 6:228 lid 1 sub 2 krijgt de verkoper het recht een overeenkomst te vernietigen wanneer de koper heeft nagelaten om de verkoper in te lichten waar het aangelegenheden betreft waarvan de koper wist of behoorde te weten dat dit bij de verkoper ter gelegenheid van het aangaan van de overeenkomst welke de transactie tot stand bracht een onjuiste veronderstelling in het leven riep of liet bestaan, al naar gelang het geval. Het niet melden door de koper van een aanleiding voor een onjuiste veronderstelling aan de zijde van de verkoper kan meebrengen dat er onder omstandigheden aan de zijde van de koper niet van dwaling kan worden gesproken. Duidelijk zal zijn, dat bewijsrechtelijke vragen steeds relevant zullen zijn wanneer er geen melding heeft plaatsgevonden door de koper van door deze in de voorfase van een transactie geconstateerde gebreken.

Zowel tijdens als na afloop van een due diligence onderzoek kan het belangrijk zijn om geconstateerde gebreken te melden. Wanneer dit wordt nagelaten, wordt het risico aanvaard dat men in een voorko-

\footnotetext{
${ }^{417}$ Zie de Aanbeveling Ombudsman Financiële Dienstverlening ((KiFiD, 4 maart 2008) en de daarop gevolgde brief van de Minister van Financiën aan de Tweede kamer van 11 maart 2008 (n.a.v. TK 2006-2007, 29507, nr. 39).
} 
mend geval tegengeworpen krijgt, te hebben ingestemd met het bestaan van de desbetreffende gebreken, dan wel geacht te worden de gevolgen daarvan te hebben verdisconteerd in de afgesproken prijs. ${ }^{418}$ Het melden van gebreken is bovendien belangrijk met het oog op termijnen waar dit rechtsvorderingen tot vernietiging van rechtshandelingen betreft. Te denken valt aan vernietiging van een overeenkomst op grond van een beroep op dwaling, maar ook wanneer het vermeende non-conformiteit betreft. De verjaring van rechtsvorderingen tot vernietiging van een overeenkomst op grond van dwaling vangt aan, 3 jaar nadat de bevoegdheid om deze vernietigingsgrond in te roepen, aan degene aan wie deze bevoegdheid toekomt, ten dienst is komen te staan. Met een beroep op artikel 3:55 lid 1 kan de wederpartij stellen dat de bevoegdheid om een beroep op vernietiging van een rechtshandeling te doen, vervallen is wanneer degene aan wie die bevoegdheid toekomt, de rechtshandeling heeft bevestigd nadat de verjaringstermijn een aanvang heeft genomen. Kennis van een gebrek en het onvermeld laten daarvan, kan derhalve leiden tot de aanname dat de overeenkomst is bevestigd. De wil tot bevestiging kan uitdrukkelijk (mondeling of schriftelijk) aan de wederpartij kenbaar worden gemaakt, maar kan ook stilzwijgend geschieden. Uit gedragingen kan ook een verklaring worden afgeleid. ${ }^{419}$ In het geval van dwaling, vangt de verjaringstermijn van 3 jaar aan nadat de dwaling is ontdekt. ${ }^{420}$ Hetzelfde geldt ter zake van de rechtsvorderingen tot vernietiging van rechtshandelingen op grond van bedrog of misbruik van omstandigheden. Wanneer het non-conformiteit betreft speelt vernietiging niet, maar vindt artikel 7:21 toepassing (recht op nakoming). Onder omstandigheden - zo kan ik mij voorstellen - zal een verkoper met succes kunnen stellen te hebben gemeend dat de koper het gebrek had geaccepteerd, dan wel deze geacht moest worden dit te hebben verdisconteerd in de koopprijs, wanneer het duidelijk is dat de koper voorafgaand aan tot stand komen van de transactie van het gebrek kennis droeg.

Op 23 november 2007 schiep de Hoge Raad duidelijkheid in de discussie over de vraag of een op artikel 6:89 en 7:23 gestoeld verweer alleen kan opgaan, voor zover de vorderingen van de wederpartij (uitsluitend) zijn gebaseerd op een contractuele relatie tussen partijen (toerekenbare tekortkoming en dwaling), maar niet voor zover de (desbetreffende) vorderingen zijn gebaseerd op onrechtmatige daad. ${ }^{42}$

De Hoge Raad overwoog:

"In de context van artikel 7:23 lid 2 BW heeft de Hoge Raad in zijn arrest van 21 april 2006, nummer C05/047, NJ 2006, 272 geoordeeld dat de hier bedoelde bepalingen gelden voor iedere rechtsvordering van de koper die - en ieder verweer van de koper dat - feitelijk gegrond is op het niet-beantwoorden van de afgeleverde zaak aan de overeenkomst, ook indien door de koper op deze grondslag een rechtsvordering uit onrechtmatige daad wordt gebaseerd. Hetzelfde moet worden aangenomen voor de regel van artikel 7:23 lid 1 en voor artikel 6:89, waarvan artikel 7:23 een precisering vormt'.

De afgelopen jaren heeft de rechtspraak op het punt van de klachtplicht van artikel 6:89 en 7:23 een vlucht genomen. ${ }^{422}$ Zie ook hoofdstuk 5.6 hiervoor. De relevantie van het voldoen aan een klachtplicht kan niet wordt onderschat. De Hoge Raad heeft volstrekt duidelijk gemaakt dat de bepaling van artikel 6:89 en 7:23 lid 1 ertoe strekt dat de schuldenaar die een prestatie heeft verricht, zal worden beschermd, omdat deze erop moet kunnen rekenen dat de schuldeiser met bekwame spoed onderzoekt

${ }^{418}$ Zie bijvoorbeeld Rechtbank Haarlem 9 januari 2008, LJN BC3247 (Laurus/Vomar).

${ }^{419}$ Zie artikel 3:37 lid 1.

${ }^{420}$ Zoals laatstelijk bevestigd door HR 8 februari 2008, LJN BC3880.

421 Zie LJN BB3733 (r.o. 4.8.2.). A-G De Vries Lentsch-Kostenes gaat in haar conclusie bij dit arrest in op het probleem van samenloop: "Zie over deze kwestie uitvoerig Tjittes, De klacht- en onderzoeksplicht bij ondeugdelijke prestaties, RM Themis 2007, p. 15 e.v., nummer 9. Tjittes is van oordeel dat in het kader van artikel 7:23 lid 1 BW ook de vordering wegens nonconformiteit gegrond op onrechtmatige daad komt te vervallen in geval niet aan de "klachtplicht" is voldaan; hij verwijst in dat verband naar HR 21 april 2006, NJ 2006, 272, waarin Uw Raad oordeelde dat het tweede lid van artikel 7:23 BW ook geldt voor rechtsvorderingen die op onrechtmatige daad zijn gebaseerd indien door de koper op de grondslag dat de afgeleverde zaak niet aan de overeenkomst beantwoordt (tevens) een rechtsvordering uit onrechtmatige daad wordt gebaseerd. Hijma (Asser-Hijma 5-I, 2001, nr. 559) is als ik het goed zie een andere opvatting toegedaan op grond dat voor een vordering uit onrechtmatige daad een ander (aanvullend) feitencomplex geldt dan voor non-conformiteit en (zo voeg ik hieraan toe met het oog op het door Hijma als "moederartikel" aangeduide artikel 6:89 BW) voor het leveren van een gebrekkige prestatie in het algemeen".

${ }^{422}$ Zie onder meer HR 23 maart 2007, LJN AZ3531; HR 29 juni 2007, LJN AZ4850; HR 29 juni 2007, LJN AZ7617; HR 13 juli 2007, LJN BA3520 en HR 23 november 2007, LJN BB3733.

Zie ook C.E. Drion, Wie niet klaagt, die niet wint?, NJB 2007/7. 
of de prestatie aan de verbintenis beantwoordt en dat de laatstgenoemde - indien dit niet het geval blijkt te zijn - zulks eveneens met spoed aan de schuldenaar meedeelt. ${ }^{423}$

Op degene die meent dat er bij of na het voltooien van een transactie sprake is van een gebrek in de prestatie, zal een verplichting rusten ter zake het nodige aan te voeren en bij gemotiveerde betwisting te bewijzen, waarbij - zie hiervoor - komt dat er op een voor de wederpartij kenbare wijze tijdig zal moeten zijn geklaagd over de desbetreffende tekortkoming. ${ }^{424}$

\section{Meldplicht tijdens due diligence?}

Een in de praktijk voorkomend vraagstuk is of tijdens het uitvoeren van een due diligence onderzoek er melding dient te worden gemaakt van de ontdekking van gebreken. Nu zal dit onder omstandigheden wel gebeuren, omdat bevindingen tijdens een due diligence onderzoek aanleiding kunnen zijn tot het vragen van garanties of vrijwaringen, maar noodzakelijk is dat niet. Zoals we hiervoor zagen, kan het in het eigen belang van de onderzoeker en diens opdrachtgever zijn, dat er wel melding wordt gemaakt van geconstateerde gebreken.

Cohen Henriquez heeft er op gewezen ${ }^{425}$ dat er onder omstandigheden voor een koper een spreekplicht kan bestaan, wanneer deze wist wat de verkoper niet wist en naar eisen van redelijkheid en billijkheid gehouden was om die kennis met de verkoper te delen. Het lijkt ook alleszins redelijk een dergelijke mededelingsplicht op de verkoper te laten rusten, gegrond op de (pre-)contractuele redelijkheid en billijkheid. De hiervoor gestelde vraag heeft echter ook betrekking op tijdens een due diligence onderzoek door de koper verworven wetenschap, die wel bij de verkoper bekend is, maar die in een vervolgtraject relevantie kan toekomen (zoals bij de nakoming van garantieverplichtingen).

Zo is het een vraag of ingevolge artikel 7:23 lid 1 een meldplicht kan worden aangenomen, zo lang de zaak niet is afgeleverd. Artikel 7:24 lid 2 verbindt consequenties aan kennis bij een koper, welke voorafgaand aan de aflevering van een goed bestond, maar die wetsbepaling (artikel 7:24 lid 2 sub a.) ziet met name op consumentenkoop. De vraag was of middels de schakelbepaling van artikel 7:47 een adequate remedie ter zake van het hiervoor bedoelde vraagstuk kon worden geboden. ${ }^{426}$ De Hoge Raad heeft op 13 juli 2007 in dit opzicht overigens klare wijn geschonken:

"De artikelen 6:89 en 7:23 BW berusten op de gedachte dat een schuldenaar erop moet kunnen rekenen dat de schuldeiser met bekwame spoed onderzoekt of de prestatie aan de verbintenis beantwoordt en dat hij, indien dit niet het geval blijkt te zijn, zulks eveneens met spoed aan de schuldenaar meedeelt (Parl. Gesch. Boek 6, blz. 316-317). Bedoeld onderzoek zal in de regel pas kunnen plaatsvinden nadat de prestatie is geleverd. De in genoemde bepalingen besloten liggende onderzoeksplicht en mededelingsplicht kunnen derhalve in beginsel niet betrokken worden of de periode voorafgaande aan het moment dat de schuldenaar zijn prestatie verricht. Dat stemt ook overeen met hetgeen de minister heeft opgemerkt tijdens de parlementaire behandeling van het wetsvoorstel tot aanpassing van Boek 7 BW aan Richtlijn 99/44/EG (...).

Het voorgaande kan anders liggen indien de schuldenaar voorafgaande aan het moment van levering aan de schuldeiser gelegenheid biedt tot een inspectie van de af te leveren zaak, in welk geval de schuldeiser in de regel ter zake van de door hem bij deze inspectie ontdekte gebreken terstond zal hebben te protesteren (Parl. Gesch. Boek 6, blz. 317), maar een zodanig geval doet zich hier niet voor. Noch de omstandigheid dat het hier gaat om de koop van een vermogensrecht als bedoeld in artikel 7:47 BW, noch de omstandigheid dat de non-conformiteit niet meer vóór het moment van levering kon worden hersteld, brengt mee dat de tijd waarbinnen aan de (onderzoeks- en) mededelingsplicht voldaan moest worden, reeds voor de levering van het erfpachtrecht een aanvang heeft genomen".

\footnotetext{
${ }^{423}$ HR 23 maart 2007, LJN AZ3531 (r.o. 4.3) en HR 23 november 2007, LJN BB3733 (r.o. 4.8.3).

424 Zie HR 23 november 2007, LJN BB3733 (r.o. 4.8.4).

${ }^{425}$ E. Cohen Henriquez, Spreken is zilver, zwijgen is fout, NJB 8 mei 1976, p. 630. Hij baseert zijn standpunt op HR 19 juni 1959, NJ 1960, 59 (Kantharos).

${ }^{426}$ Zie HR 13 juli 2007 , LJN BA3520 (r.o. 4.1.2.)
} 
Bij toepassing van artikel 6:89 moet eerst sprake zijn van een prestatie, alvorens er een beroep op een gebrek in de prestatie kan worden gedaan. ${ }^{427}$ Het vorenstaande betekent dat er eerst van rechtsverlies door niet-protesteren sprake zou zijn, wanneer er niet geklaagd zou worden nadat de transactie is voltooid. Het lijkt mij, dat er geen algemene meldplicht kan worden aangenomen. Niemand verplicht een (potentiële) koper om melding te maken van gebreken welke deze tijdens een due diligence onderzoek in het voorwerp van de transactie ontwaart. Bij het aangaan van een overeenkomst zal de bij de koper bestaande kennis worden verondersteld te zijn verdisconteerd. Kennis van een gebrek op de voorhand zou immers tot de conclusie moeten leiden dat de transactie niet zou moeten worden aangegaan danwel tot een aanpassing van de prijs zou hebben moeten leiden. Indien geen van beiden heeft plaatsgevonden en achteraf door de koper een beroep wordt gedaan op een gebrek, dat deze kende of behoorde te kennen, zal een vordering van een koper stranden op de derogerende werking van de redelijkheid en billijkheid. In dit kader spelen de algemene bepalingen van het BW een rol. ${ }^{428}$

In het goederenrecht speelt in ieder geval artikel 3:11 een rol. Het artikel geeft een algemene regel voor die gevallen, waarbij in het vermogensrecht aan de goede of kwade trouw van een persoon rechtsgevolgen verbonden zijn, wanneer iemand niet te goeder trouw is. lemand is niet te goeder trouw wanneer hij de feiten of het recht die hem wordt tegengeworpen, kende (subjectief criterium) of wanneer hij die feiten of het recht weliswaar niet kende, maar hij deze feiten of het recht had behoren te kennen (objectief criterium). De vraag is over welk rechtsgevolg het dan moet gaan binnen de context van een due diligence onderzoek of een transactie in vervolg daarop. Mij dunkt dat de relevantie van de genoemde wetsbepaling vooral daarin bestaat dat een verkrijger zal (willen) stellen te goeder trouw te zijn geweest bij het verkrijgen van goederen, terwijl de aangesproken partij zich zal verweren door te stellen dat de koper een gebrek kende of had behoren te kennen. Ook komt ten deze artikel 6:248 lid 1 en 2 betekenis toe. Op grond van artikel 6:2 lid 1 kan wellicht een soort pre-contractuele meldplicht worden aangenomen, maar tijdens de fase van een due diligence onderzoek kan ook nog niet van de hoedanigheden van schuldeiser en schuldenaar worden gesproken, zodat het omgaan met het vraagstuk van een meldplicht tijdens due diligence naar mijn mening benaderd moet worden volgens de hiervoor genoemde visie.

De waarde van het argument dat in een overeenkomst, waarop een transactie zal zijn gebaseerd, de bij de koper bestaande kennis verondersteld kan worden te zijn verdisconteerd, blijkt ook uit het arrest van de Hoge Raad in de zaak van Dutch Paint and Chemical Company B.V. ${ }^{429}$ Het betrof een kwestie waarin een beroep werd gedaan op dwaling, danwel bedrog, nu de verkoper van aandelen er door de koper van werd beticht op diverse punten essentiële informatie te hebben verzwegen voorafgaand aan het tot stand komen van de koopovereenkomst. Men nam aan dat er sprake was van het opzettelijk verzwijgen van informatie. Het gerechtshof wilde daar niet aan en oordeelde dat er tevergeefs een beroep werd gedaan op zowel dwaling als schending van een op redelijkheid en billijkheid gebaseerde mededelingsplicht als op bedrog. Het hof overwoog onder meer, dat de aandelentransactie had plaatsgevonden tussen professionele partijen, van wie de koper al eerder overnames had gedaan. Beide partijen waren bijgestaan door deskundigen, te weten accountants en juristen. De koper had na het sluiten van de voorovereenkomst een onderzoek bij de doelwitvennootschap laten doen. Uit dat onderzoek bleek dat de informatie die de verkoper voor het sluiten van de voorovereenkomst aan de koper had verstrekt, op een aantal belangrijke punten niet correct was en wel in die mate dat de koper, naar zij stelde, wilde afzien van de transactie. De koper heeft de koop niettemin doorgezet, zij het na heronderhandelingen; daarbij is de koopprijs meer dan gehalveerd maar werden door de verkoper geen garanties meer gegeven. De koper was volgens het hof niet gehouden om de koop door te zetten. Op die gronden werd geconcludeerd dat de koper bewust het risico had genomen dat de waarde van de doelwitvennootschap kon tegenvallen:

\footnotetext{
${ }^{427}$ Aldus ook de Hoge Raad in HR 23 maart 2007, LJN AZ3531 (r.o. 4.3) en HR 13 juli 2007, NJ 2007, 408. Zie ook W.L. Valk, Klachtplicht en bewijslast, NTBR 2008, 2, p. 94, die stelt dat “(...) de in artikel 6:89 en artikel 7:23 besloten liggende onderzoeksplicht en mededelingsplicht kunnen in beginsel niet betrokken worden op de periode voorafgaand aan het moment dat de schuldenaar zijn prestatie verricht".

${ }^{428}$ Zie voor een auteur die van oordeel is dat een koper er verstandig aan doet om kennis van een opgedaan gebrek tijdens een due diligence onderzoek met de verkoper te delen en ter zake een vrijwaring te verlangen of een verlaging van de koopprijs te bedingen: E.A. de Best, Bepalingen omtrent de invloed van due diligence onderzoek op de afdwingbaarheid van garanties, V\&O september 2004, nr. 9, p. 155.

${ }^{429}$ HR 10 oktober 2003, LJN Al0306. Zie ook G.T.M.J. Raaijmakers, Bedrog bij bedrijfsovernames: een gewaarschuwd mens telt voor twee, NTBR 2004, 51, p.277 e.v.
} 
“... hoewel zij wist dat de door de verkoper verstrekte informatie op zijn minst onvolledig was, heeft zij aan het doorgaan van de transactie geen voorwaarden verbonden, bijvoorbeeld door het bedingen van een onbeperkt due diligence onderzoek of van de bij overnametransacties gebruikelijke garanties; zij heeft in tegendeel de reeds in de voorovereenkomst bedongen garanties laten vallen".

Onder die omstandigheden kwam de koper ook geen beroep toe op schending van een mededelingsplicht door de verkoper. De koper had immers in haar eigen visie alle aanleiding om te twijfelen aan de betrouwbaarheid van de door de verkoper verschafte informatie en dus alle reden om niet meer op die informatie af te gaan.

"Naar het oordeel van het Hof moet worden aangenomen dat de koper bewust de goede en kwade kansen van de gesloten koopovereenkomst heeft aanvaard".

De Hoge Raad sanctioneert het oordeel van het hof. Op voet van artikel 6:228 lid 2 en de omstandigheden van het geval is naar het oordeel van de Hoge Raad terecht geoordeeld dat de koper, wetende dat de verkoper haar (minst genomen) onvolledig informeerde, bewust heeft afgezien van het krijgen van volledige informatie of van (verdere) garanties en in plaats daarvan een substantiële korting op de koopprijs heeft bedongen, en aldus bewust het risico heeft genomen dat de waarde van de doelwitvennootschap kon tegenvallen en de goede en kwade kansen van de gesloten koopovereenkomst heeft aanvaard.

"In dit oordeel ligt besloten dat de koper de kans op dwaling in de overeenkomst heeft verdisconteerd in die zin dat die dwaling op grond van de omstandigheden van het geval voor rekening van de dwalende behoort te blijven".

Doordat het beroep op de dwalingsgrond van artikel 6:228 lid 1, onder b., werd verworpen, kwam het beroep op een eventuele schending door de verkoper van diens mededelingsplicht geen zelfstandige betekenis meer toe.

Het hiervoor laatstbedoelde arrest bevestigt dat in ieder geval partijen die met elkaar een voorovereenkomst hebben gesloten, tot elkaar in een door redelijkheid en billijkheid beheerste rechtsverhouding zijn komen te staan "op basis waarvan het op de weg van de verkoper had gelegen de koper volledige openheid van zaken te verschaffen, ook met betrekking tot andere zaken dan die reeds aan het licht waren gekomen tijdens het beperkte onderzoek door de koper, waaruit reeds bleek dat de financiële positie van de doelwitvennootschap slechter was dan voorgesteld in de voorovereenkomst".

Door de koper werd gesteld dat de verkoper deze op de redelijkheid en billijkheid gebaseerde mededelingsplicht had geschonden en derhalve schadeplichtig was. De Hoge Raad benadrukte dat het hof niet had geoordeeld dat op de verkoper geen mededelingsplicht zou hebben gerust, maar dat - zelfs aannemende dat de verkoper wezenlijke informatie had achtergehouden - de koper zich hiervan bewust was geweest en in die wetenschap willens en wetens had gecontracteerd en zich derhalve niet na het sluiten van de koopovereenkomst kon beroepen op de schending van die mededelingsplicht.

"Dit oordeel, waarin besloten ligt dat de koper door toch de overeenkomst te sluiten een beroep op de schending van de mededelingsplicht heeft prijs gegeven, geeft geen blijk van een onjuiste rechtsopvatting, is niet onbegrijpelijk en behoeft geen nadere motivering".

Wanneer een verkoper slechts een beperkt onderzoek toestaat en bovendien op belangrijke punten blijkt incorrecte informatie te verstrekken, moet er voldoende aanleiding zijn om te twijfelen aan (alle) mededelingen van de verkoper. Volgens de rechter had het aldus op de weg van de koper gelegen om als professionele partij, indien zij de transactie toch wilde laten doorgaan, een onbeperkt due diligence onderzoek te eisen en/of garanties te bedingen. Door dit na te laten wordt wel bewust het risico van onjuiste gegevens aanvaard. Dan kan niet worden volgehouden dat de koper door (opzettelijk) onjuiste mededelingen van de verkoper en/of door het (opzettelijk) verzwijgen door de verkoper van relevante gegevens is bewogen tot het aangaan van de koopovereenkomst. 
Indien er al een eerste fase van een transactie is doorgemaakt, zoals bijvoorbeeld het tekenen van een Letter of Intent of transactiedocumentatie welke nog niet definitief is afgewikkeld met het oog op nog te verkrijgen toestemmingen of door andere oorzaken, kan er (tussentijds) ook nog van gebreken blijken. ${ }^{430}$ Grosso modo zal dan hetzelfde gelden als hiervoor weergegeven.

Een partij zal tijdens de uitvoering van een transactie niet moeten aarzelen met het melden van gebreken. In een situatie waarin de eerste fase van een transactie al was doorgemaakt, zonder dat er van door een koper vastgestelde problemen melding was gemaakt aan de verkoper - en de bij die eerste fase behorende betalingen zelfs zonder protest waren verricht - verspeelde volgens de rechter de koper het recht om in een latere fase, achteraf terug te komen op geconstateerde gebreken, die ook op de eerdere fasen betrekking hadden. ${ }^{431}$ In die zaak overwoog de Rechtbank:

"Door na te laten ... aanzienlijke verschillen met naam en toenaam bij Laurus ter sprake te brengen nog voordat de derde tranche ... werd overgedragen en niet metterdaad op de rem te gaan staan teneinde eerst de verdere afwikkeling van de overdracht aan de orde te stellen, heeft Vomar zand in de ogen van Laurus gestrooid".

Door niet terstond of tijdig de ander van geconstateerde gebreken in kennis te stellen, kan bij de ander het gerechtvaardigd vertrouwen worden gewekt dat men instemde en bleef instemmen met hetgeen volgens de opvatting van de andere partij ten aanzien van een transactie was afgesproken of tussen partijen werd geaccepteerd.

In herinnering geroepen wordt nog de visie van de Hoge Raad, dat onder omstandigheden voor de beantwoording van de vraag of een afgeleverde zaak aan de overeenkomst beantwoordt (lees: met analoge toepassing van het leerstuk van de redelijkheid en billijkheid, zal beantwoorden) een koper de uitslag van een onderzoek waarbij een deskundige moet worden ingeschakeld, mag afwachten zonder de verkoper van het onderzoek op de hoogte te brengen. "Wanneer echter mag worden verwacht dat met het onderzoek langere tijd is gemoeid, of zulks tijdens de loop daarvan blijkt, volgt uit de strekking van artikel 7:23 lid 1 dat de koper aan zijn wederpartij onverwijld kennis dient te geven van het onderzoek en de verwachte duur ervan." ${ }^{432}$

\section{Material Adverse Change}

Gebruikelijk is het om in een emissieprospectus en in ieder geval in een prospectus ter gelegenheid van een openbaar bod clausules op te nemen die de betrokkene toestaan om van de transactie af te zien indien zich na een bepaald moment een wijziging voordoet in de omstandigheden, die een (volstrekt) ander licht op de transactie werpt. Dergelijke clausules komen ook in transactie documentatie voor bij wat grotere overnames of bij overnames waar op basis van een verschil in tijd tussen de beschikbare jaarcijfers en de definitieve overnamebalans nog veranderingen in de situatie kunnen optreden. Material Adverse Change clausules zijn dus met name daar relevant - ook bij onderhandse transacties - waar er sprake is van een tijdverloop tussen het moment van het aangaan van verbintenissen en het moment van de uitvoering daarvan. Allerhande andere oorzaken dan hiervoor genoemd kunnen maken dat het moment tussen de ondertekening van een overeenkomst en de uitvoering daarvan niet samenvallen. Te denken valt bijvoorbeeld ook aan het verkrijgen van goedkeuring van mededingingsautoriteiten, het uitstaan van een (anderszins) onherroepelijke bieding of het nog niet voltooid zijn van een due diligence onderzoek. Te onderscheiden van de gevolgen welke kunnen worden verbonden aan een andere uitkomst van een due diligence onderzoek dan gewenst of verwacht, is de situatie waarin zich tussen het moment van het aangaan van een verbintenis en het uitvoeren daarvan een wijziging in de omstandigheden voordoet die de waarde van de transactie (sterk) negatief beïnvloedt. De partij die door die wijziging in de omstandigheden in diens positie geraakt dreigt te worden, zal dan de transactie om die reden niet meer of niet meer onder dezelfde voorwaarden willen doorzetten. Teneinde zich tegen die situatie te beschermen, zal gebruik (moeten) worden gemaakt van Material Adverse Change clausules. Dergelijke clausules kunnen bovendien een rol vervullen, wanneer trans-

\footnotetext{
${ }^{430}$ Vergelijk onder 1.10 in de conclusie van de P-G bij HR 7 september 2007, LJN BA2014.

${ }^{431} \mathrm{Rb}$. Amsterdam 9 januari 2008, LJN BC3247 (Laurus / Vomar).

${ }^{432}$ HR 29 juni 2007, LJN AZ7617.
} 
acties onder voorwaarden worden aangegaan, voor de vervulling waarvan de medewerking van derden nodig is. Denk aan de financiering van de transactie door een bank of anderen, die zich nog niet onvoorwaardelijk en ongeacht een wijziging in omstandigheden, gecommitteerd hebben om de acquisitiefinanciering te verschaffen.

Van Schooten ${ }^{433}$ heeft aandacht besteed aan de vraag hoe een koper of andere betrokkenen kunnen omgaan met een relevante wijziging van de omstandigheden bij gebreke van Material Adverse Change clausules. Hij stelt de vraag of toepassing van artikel 6:258 of 7:17 uitkomst kan bieden. Gevraagd kan immers worden de overeenkomst te wijzigen of geheel of gedeeltelijk te ontbinden wanneer ongewijzigde instandhouding naar maatstaven van redelijkheid en billijkheid niet door de wederpartij mag worden verwacht. De rechter moet daarbij terughoudendheid betrachten. ${ }^{434}$ Artikel 6:258 ziet enkel op onvoorziene omstandigheden die door de betrokkenen niet uitdrukkelijk of stilzwijgend in hun overeenkomsten zijn verdisconteerd. Het moet daarbij gaan om omstandigheden die zij niet hebben voorzien. Waarin partijen kunnen worden geacht te hebben voorzien, moet door uitleg van de overeenkomst worden vastgesteld op grond van de Haviltex-doctrine. Niet van belang is of partijen de wijziging van de omstandigheden hebben voorzien of hadden kunnen voorzien. Het komt erop aan of zij met het plaatsvinden van die wijziging van omstandigheden rekening hebben gehouden bij het tot stand komen van de overeenkomst. Hoe meer de mogelijkheid van een wijziging van omstandigheden in de rede lag, des te eerder zal worden aangenomen dat partijen daarmee ook rekening zullen hebben gehouden. Het moeten wijzigingen in de omstandigheden betreffen die zich voordoen na het sluiten van de overeenkomst. Van Schooten benadrukt dat artikel 6:258 geen soelaas biedt in geval de wijziging van de omstandigheden heeft plaatsgevonden voorafgaand aan het tot stand komen van de overeenkomst, maar bijvoorbeeld na de datum van de laatste balans waarop de koper zich heeft gebaseerd. In een geval als laatstbedoeld, zal een beroep op dwaling moeten worden gedaan. Een andere oplossing zou gezocht kunnen worden in de toepassing van artikel 7:17 op grond van de stelling dat hetgeen is of moet worden geleverd, niet (meer) beantwoordt aan de overeenkomst. De mogelijkheid om op artikel 7:17 een beroep te doen, zou de wens in het leven kunnen roepen dat artikel niet buiten toepassing te verklaren (hetgeen in transacties tussen professionele partijen wel regelmatig gebeurt, zeker waar het de koop en verkoop van aandelen betreft). Degene die bedenkt dat deze met het oog op eventuele onvoorziene omstandigheden voor het moment van effectuering van de transactie toch artikel 7:17 van toepassing wil laten blijven, doet er beter aan om zich sterk te maken voor de opneming in de overeenkomst van Material Adverse Change clausules. Een Material Adverse Change clausule is in feite een opschortende of ontbindende voorwaarde. Van Schooten beveelt aan dat bij het sluiten van een overeenkomst partijen bij zichzelf te rade moeten gaan welke concrete gewijzigde omstandigheden zij aanleiding willen laten zijn om de transactie niet langer te (hoeven) effectueren of consumeren of slechts onder andere voorwaarden. Hij wijst op het dilemma voor bijvoorbeeld de koper, die moeten kiezen tussen enerzijds een specifiek geformuleerde wijziging van de omstandigheden, waarop in voorkomende gevallen met meer kans op succes een beroep kan worden gedaan, maar waaronder ook veel wijzigingen niet zullen vallen, en anderzijds een algemeen geformuleerde wijziging van de omstandigheden, waarop in voorkomende gevallen met minder kans op succes een beroep kan worden gedaan, maar die vaker zal zien op hetgeen in de toekomst zou kunnen gebeuren. Indien het enigszins mogelijk is, zou een combinatie van beiden de uitkomst moeten bieden. Een andere praktische aanbeveling is om een Material Adverse Change clausule in het geval van acquisitiefinanciering af te stemmen op de afspraken welke gelden in de documentatie die met de kredietverschaffer tot stand wordt gebracht.

Het is opvallend dat er in ons land anders dan door de hiervoor genoemde auteurs aan Material Adverse Change clausules zo weinig aandacht is geschonken. Het belang daarvan rechtvaardigt meer aandacht.

\footnotetext{
${ }^{433}$ M.R. van Schooten, Material Adverse Change / Material Adverse Events, Contracteren 2008, p. 8 e.v. en de door hem genoemde rechtspraak

Literatuur is er in ons land nauwelijks. Eerder werd al verwezen naar D.A.H.W. Strik, Aspecten van schadevergoeding bij inbreuk op garanties in overnamecontracten, in: Geschriften vanwege de Vereniging Corporate Litigation 2003-2004, p. 393 e.v.

Ook gaat P.J.L.Tjittes in zijn noot onder HR 7 september 2007, JOR 2007, 291 in op Material Adverse Change clausules. De laatstbedoelde uitspraak leert lessen over de uitleg van een Material Adverse Change clausule. Het draaide in die zaak om de vraag of de koper van aandelen aanspraak kon maken op een schadevergoeding danwel vermindering van de betaalde koopprijs op grond van een gegeven garantie dat geen Material Adverse Change had plaatsgevonden. In het desbetreffende geval hadden partijen een Material Adverse Change clausule in hun overeenkomst opgenomen. De rechter legde die clausule restrictief uit.

${ }^{434}$ Van Schooten, a.w., verwijst naar HR 20 februari 1998, NJ 1998, 493 (Briljant Schröders / ABP).
} 


\section{Meldplicht na due diligence?}

Voor de beantwoording van de vraag of ten aanzien van de vraag of gebreken, die middels een due diligence onderzoek (of nadien) zijn geconstateerd, moeten worden gemeld aan de wederpartij, wordt verwezen naar het gestelde in hoofdstuk 5 hiervoor (klachtplicht). De rechtspraak biedt voorbeelden van situaties, waarin een te late melding tot verlies van rechten leidde. Elders in dit boek hebben wij voorbeelden gezien van verlies van rechten doordat er niet of te laat werd gereageerd naar aanleiding van gebreken. Duidelijk is ook dat bij het aangaan van een transactie op basis van gedateerde informatie, eveneens verlies van rechten kan ontstaan. De koper van een dressuurpaard, die de koopbeslissing baseerde op een rapport van een klinisch en röntgenologisch onderzoek van het paard dat op het moment van het tot stand komen van de transactie 5,5 maand oud was, poogde bijvoorbeeld vergeefs wegens dwaling zich van de overeenkomst te bevrijden toen na aanschaf bleek dat er denkbaar een verhoogd risico van kreupelheid aanwezig was. ${ }^{435}$

\subsection{Opschortende of ontbindende voorwaarde}

Een due diligence onderzoek zal vrijwel steeds bedoeld zijn als een waarborg tegen teleurstellingen. Dit betekent dat er veelal al in de eerste afspraken opgenomen zal zijn dat de uitslag van een due diligence onderzoek bepalend zal zijn voor de vraag of de onderzoekende partij gebonden wil zijn aan een kapitaalmarkttransactie of een andere transactie. De onderzoekende partij zal daarom als opschortende of ontbindende voorwaarde in een letter of intent, term sheet of de documentatie of overeenkomst met betrekking tot de transactie zelf, opnemen dat gebondenheid aan de gemaakte afspraken eerst zal gelden (bij een opschortende voorwaarde) of niet langer zal gelden (bij een ontbindende voorwaarde) wanneer de uitslag van het due diligence onderzoek niet tot tevredenheid stemt. Het zo formuleren van een voorwaarde dat deze degene die de voorwaarde bedingt ook de door die gewenste bescherming zal bieden, is nog niet eenvoudig. Wanneer bovendien - hetgeen vaak het geval is - het antwoord op de vraag of er wel of niet sprake is van de vervulling van de voorwaarde te zeer wordt overgelaten aan de discretie van degene die de voorwaarde heeft bedongen, kan deze te maken krijgen met een beroep op artikel 6:23. Zie hierna onder 7.4. Het meer objectiveren van de normen waaraan wel of niet voldaan dient te zijn, blijkt in de praktijk niet zelden aanleiding te geven tot procedures. Het is niet ongebruikelijk om een objectivering te zoeken in het noemen van een bedrag. Wanneer er uit een due diligence onderzoek een afwijking blijkt ten opzichte van de eerder gepresenteerde gegevens van een hoger bedrag, dan treedt een voorwaarde wel of niet in vervulling. Waarderingskwesties zullen dan evenwel gemakkelijk tot een dispuut aanleiding geven. Voorbeeld valt te vinden in een uitspraak van de rechtbank te Arnhem van 19 maart 2008. ${ }^{436}$ In die zaak was het de koper volgens de gemaakte afspraak toegestaan de overeenkomst te ontbinden indien de uitkomsten van het due diligence onderzoek in belangrijke mate afweken van de tot de ondertekening van de overeenkomst aan de koper verstrekte informatie. Onder "in belangrijke mate afwijken" werd in dat verband verstaan verschillen welke gezamenlijk of individueel (een belang vertegenwoordigen dat) een bedrag van $€ 75.000$ te boven ging. Uiteindelijk bleek er van een verschil sprake te zijn van $€ 74.000$. Nu daar weer andere factoren tegenover leken te staan blijkens het due diligence rapport, ontstond een discussie over de vraag of er sprake was van een verschil in visie op de betekenis van bepaalde factoren. Bovendien geldt ook bij de toepassing van een clausule met een ontbindende of een opschortende voorwaarde in de vorm van een in een bedrag uitgedrukte norm, dat een beroep daarop naar redelijkheid en billijkheid niet onaanvaardbaar mag zijn.

\subsection{Potestatieve voorwaarde}

Men kan zich afvragen of een opschortende of ontbindende voorwaarde als hiervoor bedoeld eigenlijk niet een zogenaamde potestatieve voorwaarde is (artikel 6:23). ${ }^{437}$ Men spreekt van een potestatieve voorwaarde als de partij die bij de niet-vervulling van een voorwaarde belang heeft, belet of teweegbrengt dat deze wordt vervuld. In het geval dat het de uitoefening van het recht om de overeenkomst wel of niet te ontbinden afhankelijk is gesteld van de inhoud van het due diligence rapport of de (niet)

\footnotetext{
${ }^{435}$ Zie gerechtshof Amsterdam 15 juli 2004, Prg. 2005 (1), nr. 2 m.nt. P. Abas

${ }^{436}$ LJN BC8052, r.o. 4.16.

${ }^{437}$ Zie J.D.A. den Tonkelaar, Opschortende en ontbindende voorwaarden, 1994, p. 94 e.v.
} 
vervulling van een opschortende voorwaarde, is het aan de koper om in de beoordeling van het wel of niet vervuld zijn van deze voorwaarde te treden. Afhankelijk van de wijze waarop een voorwaarde is geformuleerd, zou derhalve een opdrachtgever van het onderzoek een overeenkomst kunnen ontbinden of de ontbinding kunnen veroorzaken of het (niet) in vervulling gaan van een opschortende voorwaarde door vervulling van de voorwaarde te beletten of teweeg te brengen. ${ }^{438}$

Als de opdrachtgever door het teweeg brengen of beletten van de vervulling van een voorwaarde kan veroorzaken dat de rechtsgevolgen van een overeenkomst niet intreden of deze overeenkomst kan (doen) ontbinden, kan het onder omstandigheden - afhankelijk van de redelijkheid en billijkheid - zo zijn dat aan het (niet) vervuld zijn van de voorwaarde geen rechten kunnen worden ontleend. Het is - gelet op het vorenstaande - van belang om een voorwaarde en de rechtsgevolgen daarvan zorgvuldig te formuleren in een overeenkomst. Waar artikel 6:23 een regel van aanvullend recht betreft, is het mogelijk dat partijen overeenkomen die regel buiten toepassing te verklaren. Artikel 6:248 blijft van toepassing, evenals artikel 6:2, maar een duidelijke partijafspraak zal de ruimte voor onduidelijkheid en twist in elk geval kunnen beperken.

Hierbij teken ik aan dat er een niet te veronachtzamen verschil bestaat tussen de formuleringen van artikel 6:2 lid 2 en 6:248 lid 2 enerzijds en artikel 6:23 anderzijds. Communis opinio is dat de regels van artikel 23 moeten worden beschouwd als een toepassing van het beginsel van de redelijkheid en billijkheid als in de eerste twee genoemde artikelen neergelegd. ${ }^{439}$

Volgens artikel 6:2 lid 2 en 6:248 lid 2 geldt evenwel formeel een strenger criterium. De gevolgen van een tussen partijen geldende regel moeten naar maatstaven van redelijkheid en billijkheid onaanvaardbaar zijn, wil toepassing van deze wetsbepalingen mogelijk zijn. Artikel 6:23 is een specialis, waarin het criterium van onaanvaardbaarheid niet geldt. Daar is dus een mildere vorm van redelijkheid en billijkheidstoets beoogd door de wetgever. Dit betekent dat artikel 6:23 een ruimere toepassing kan vinden dan artikel 6:2 lid 2 en 6:248 lid $2^{440}$

\section{Subject to board approval}

Wat er geldt binnen het kader van de redelijkheid en billijkheid is steeds afhankelijk van de omstandigheden van het geval, met name van de aard en strekking van de bepaling zowel ook als van de desbetreffende voorwaarde en van de belettende of teweegbrengende handeling. ${ }^{441}$

Ook de toepassing van een opschortende of ontbindende voorwaarde in de vorm van een zogenaamde subject to board approval-clausule zal steeds voorwerp van toetsing kunnen zijn aan de hand van de norm redelijkheid en billijkheid. ${ }^{442}$ Vranken $^{443}$ meent dat er minder ruimte is voor toetsing van een subject to board approval-clausule aan de redelijkheid en billijkheid. Volgens hem mag een dergelijk voorbehoud ten volle worden uitgeoefend, zo lang dit maar tijdig en duidelijk is gemaakt. Volgens De Kluiver kan een subject to board approval-clausule dubieus zijn doordat een (rechts)persoon na een onderhandelingsproces, waarin de wederpartij zich op velerlei wijze heeft gecommitteerd, zelf alle vrijheid voorbehoudt om een overeenkomst wel of niet te accepteren en onder dreiging van het onthouden van goedkeuring de onderhandelingen kan 'openbreken'. Wat De Kluiver betreft is een dergelijke clausule derhalve rechtstreeks vatbaar voor toetsing aan de redelijkheid en billijkheid. ${ }^{444}$

Schaafsma en Elsenga hebben aan de hand van een rechtspraakanalyse een aantal aanbevelingen voor de praktijk geformuleerd, die erop neer komen dat een voorbehoud in een zo vroeg mogelijk stadium van de onderhandelingen uitdrukkelijk en schriftelijk moet worden gemaakt en in diverse con-

\footnotetext{
${ }_{438}$ Zie verder over de toepassing van artikel 6:23 in het vennootschapsrecht M.C. Schepel, Beliën/Provincie Brabant; potestatieve voorwaarde? V\&O november 1997, afl. 11, p. 123 e.v. en de door hem genoemde rechtspraak en literatuur. 439 Zie Asser/Hartkamp \& Sieburgh 6-I*-2008, t.a.p.

440 (vervallen).

441 Zie HR 21 juni 1996, NJ 1996, 698, voor een geval waarin de redelijkheid en billijkheid zich ertegen verzette dat een partij ten behoeve van wie een ontbindende voorwaarde (financieringsclausule) in een koopovereenkomst was opgenomen, zich op het niet vervuld zijn van die voorwaarde beriep. Zie ook Prg. 1996, 17, 4593. De betrokkene had zich onvoldoende ingespannen om de financiering te verkrijgen, waarbij er strikt genomen niet eens sprake was geweest van 'beletten 'in de zin van artikel 6:23

442 Zie L. Timmerman in TVVS 1987, p. 129-130 over VHS/Schell (Rechtbank Rotterdam) en verder HR 4 juni 1976, NJ 1977, 336; HR 27 januari 1984, NJ 1984, 545; President Rechtbank Breda 24 december 1987, KG 1988, 56; President Rechtbank Haarlem 10 oktober 1989, KG 1989, 390; HR 27 november 1992, NJ 1993, 287; HR 24 maart 1995, NJ 1997, 569 en hof Arnhem 26 augustus 2003, JOR 2003, 250 (waarover ook in Juridisch Up to Date 11 maart 2004, nr. 5, p. 18 e.v.)

${ }^{443}$ J.B.M. Vranken, Mededelings- , informatie- en onderzoeksplicht in het verbintenissenrecht, p. 108 e.v.

${ }^{444}$ H.J. de Kluiver, Onderhandelen en privaatrecht, p. 24.
} 
ceptstukken zou moeten worden herhaald. Ook dient volgens hen voorkomen te worden dat de onderhandelaar de schijn wekt dat het orgaan waarvan de toestemming is vereist, de vereiste toestemming zal geven danwel dat de vereiste toestemming slechts een formaliteit is. Het orgaan waarvan de toestemming is vereist, zou zich moeten onthouden van bemoeienis met de onderhandelingen. Hoe groter de afstand tussen de onderhandelaar en het goedkeurende orgaan, hoe beter. Het is soms beter om een subject to contract-clausule af te spreken dan een subject to board approval-clausule, met name wanneer er sprake is van weinig afstand tussen de onderhandelaar en degene die uiteindelijk de toestemming moet geven. Ter vermijding van problemen raden zij aan dat schriftelijk wordt bedongen dat het goedkeurende orgaan ook zonder nadere motivering toestemming mag onthouden. Tenslotte zou niet met de uitvoering van een overeenkomst moeten worden begonnen alvorens het orgaan dat de goedkeuring zou moeten verlenen, die goedkeuring heeft verleend. ${ }^{445}$

Het leerstuk van de potestatieve voorwaarde is naar mijn mening ondanks het vorenstaande onderbelicht in de schaarse rechtspraak die er over subject to board approval-clausules voorhanden is. ${ }^{446}$ Een subject to board approval-clausule heeft over het algemeen de bedoeling om contractuele binding niet onvoorwaardelijk te maken, maar soms ook om aanspraak op schadevergoeding wegens afgebroken onderhandelingen uit te sluiten. ${ }^{447}$ Het gaat in gevallen als hier bedoeld niet om de in de rechtspraak ontwikkelde regel in zake afgebroken onderhandelingen, maar het komt neer op (vooral) de vraag of de afbrekende partij naar maatstaven van redelijkheid en billijkheid een beroep mag doen op subject to board approval-clausule. ${ }^{448}$ In de literatuur wordt wel verdedigd dat een voorbehoud als een goedkeuringsbeding in het geval van voortgezette onderhandelingen door de feiten kan worden achterhaald. ${ }^{49}$ Een beroep op een subject to board approval-clausule (beding) kan naar maatstaven van redelijkheid en billijkheid onaanvaardbaar zijn. De bijkomende omstandigheden zullen veelal de vraag helpen beantwoorden of een beroep naar maatstaven van redelijkheid en billijkheid te rechtvaardigen valt. De rechtbank te Rotterdam accepteerde een 'interne beleidswijziging', die zich zou hebben voorgedaan nadat er in materieel opzicht over een overeenkomst volledige overeenstemming was bereikt, als rechtvaardiging voor het bestuur van Texaco om toch geen goedkeuring aan die overeenkomst te hechten. ${ }^{450}$

445 Zie A.C. Schaafsma en O.S. Elsenga, Afgebroken onderhandelingen; de betekenis van een voorbehoud toestemming (vennootschappelijk) orgaan, V\&O februari 2004, nr. 2, p. 29 e.v. en de aldaar genoemde rechtspraak en literatuur. Een subject to contract clausule komt erop neer dat wordt afgesproken dat er eerst van gebondenheid van partijen sprake zal zijn, wanneer er zijdens beide partijen ondertekende vastlegging zal zijn van de gemaakte afspraken. In combinatie daarmee wordt dan overeengekomen dat tot het moment van die ondertekening elk van de partijen vrij is om zonder nadere motivering de onderhandelingen te beëindigen, zonder dat de ander ter zake daarvan in een voorkomend geval enig recht zal (kunnen) doen gelden of vergoeding van schade of van enige andere vergoeding.

${ }^{446} \mathrm{Op}$ de discussie over wel of niet bevoegde vertegenwoordiging ga ik niet in. De vraag of een subject to board approval onbevoegdheid van de onderhandelaar meebrengt, laat ik derhalve rusten. Ik ga uit van onderhandelaars die bevoegd zijn om rechtshandelingen aan te gaan. Aspecten van vertegenwoordigingsmacht blijven derhalve buiten bespreking.

447 Zie HR 14 mei 1993, NJ 1993, 446. In de onderhandelingen over een aandelentransactie wordt als voorwaarde opgenomen dat de ondernemingsraad van de doelwitvennootschap positief zal adviseren. Uiteindelijk doet de ondernemingsraad dat niet. De koper stelde dat de verkoper zich onvoldoende had ingespannen om een positief advies van de ondernemingsraad te bevorderen. De rechtbank honoreerde deze stellingen en veroordeelde tot het betalen van een schadevergoeding. Het gerechtshof zag dit anders en overwoog dat weliswaar voor de bestuurder van de onderneming uit de overeenkomst 'verplichtingen voortvloeiden onder meer met betrekking tot het verkrijgen van een gunstig advies van haar ondernemingsraad', maar stelde vervolgens vast dat de ondernemingsraad op basis van eigen onderzoek en na het horen van alle betrokkenen tot een negatief advies was gekomen. Onder die omstandigheden achtte het hof een beroep op het voorbehoud dat de ondernemingsraad positief zou adviseren, acceptabel.

${ }^{448}$ Met het oog op het onderwerp van dit boek, een weigering om in te stemmen naar aanleiding van de gebleken uitkomst van een due diligence onderzoek. De hiervoor genoemde vraag wordt besproken in de context van artikel 6:23.

449 Zie de conclusie van AG Hartkamp bij HR 24 november 1995, 1996, 162 en de door hem genoemde literatuur.

450 Zie over de zogenaamde subject to contract-voorwaarde HR 24 november 1995, NJ 1996, 162 (Daily Mirror). Zie ook rechtbank Rotterdam 21 november 2007, LJN BC0215. De rechtbank interpreteerde daarbij strikt het voorbehoud dat 'de directie' de overeenkomst moest goedkeuren: "Indien het al juist zou zijn dat Texaco een functionele organisatiestructuur heeft, heeft nog steeds als uitgangspunt te gelden dat met 'directie' de in het handelsregister als zodanig aangeduide personen worden bedoeld. Dit is alleen anders indien (...) op grond van uitlatingen danwel gedragingen van de zijde van Texaco er gerechtvaardigd op mocht vertrouwen dat in casu het begrip 'directie' een andere betekenis zou hebben. Dat er sprake is geweest van dergelijke uitlatingen danwel gedragingen aan de zijde van Texaco, is echter gesteld noch gebleken". Zie voorts rechtbank Amsterdam 4 juli 2007 RCR 2008, 21 en HR 26 oktober 2007 (artikel 81 r.o.), RCR 2008 , 2 (Roompot/De Efteling) m.n. de conclusie van A-G Spier het gerechtshof te 's-Hertogenbosch had als volgt overwogen: "Efteling heeft de onderhandelingen (...) afgebroken wegens het ontbreken van goedkeuring van de raad van commissarissen. Gelet op het feit dat partijen een dergelijk beding zijn overeengekomen (...) is het in het onderhavige geval niet zozeer de vraag of Efteling de onderhandelingen mocht afbreken (zie daarover recentelijk HR 12 augustus 2005 , NJ 2005, 467), maar moet worden beoordeeld of Efteling zich naar maatstaven van redelijkheid en billijkheid op dat beding mag beroepen (vgl. gerechtshof Arnhem 26 augustus 2003, JOR 2003, 250)". Naar het oordeel van het hof had de Efteling voldoende aannemelijk gemaakt dat zij een bijzonder belang had bij een ruime change of control-bepaling in de 
De voorzieningenrechter van de rechtbank te 's-Hertogenbosch woog alle omstandigheden van het geval mee toen een transactie over de verkoop van een onroerend goed niet dreigde door te gaan omdat de raad van bestuur gebruik maakte van een subject to board approval-clausule. ${ }^{451}$ De rechter formuleerde als rechtsvraag "of gelet op (a) de feiten en omstandigheden van de zaak, op (b) hetgeen feitelijk was voorgevallen, op (c) de gevolgtrekkingen die daaruit moeten worden getrokken, en (d) op meer in het bijzonder [...] het beding, het onthouden door de raad van bestuur van Essent van definitieve goedkeuring aan het onderhandelingsresultaat, onaanvaardbaar is."

In het ampel en goed gemotiveerde vonnis, ${ }^{452}$ komt onder meer de navolgende overweging voor, die ook een zekere algemene gelding kan toekomen:

"Reeds de omstandigheid dat zij het beroep op het goedkeuringsvoorbehoud zonder opgave van redenen heeft gedaan, maakt zulks in de omstandigheden dat zij zich (1) verregaand en in toenemende mate aan het door haarzelf voorgestelde onderhandelingstraject had gecommiteerd, (2) daardoor bij [...] het vertrouwen heeft gewekt om met haar in dat traject (en niet: in een nader traject) tot een overeenkomst te komen en (3) daartoe haar bekwame onderhandelaar een objectief goed onderhandelingsresultaat tot stand heeft laten brengen, naar maatstaven van redelijkheid en billijkheid onaanvaardbaar."

De rechter in 's-Hertogenbosch onderzocht bij gebreke van een nadere toelichting van de zijde van Essent ook nog (naar het lijkt ambtshalve, hoe ver zorgvuldigheid niet kan gaan) of er niet toch gegronde redenen zouden kunnen worden bedacht waarop goedkeuring geweigerd had kunnen worden. Die konden niet worden gevonden in de bepaling van het voorwerp van koop (daarover was geen misverstand), ook niet in de persoon van de koper (die was eerder al gegoed bevonden) en evenmin in de persoon van de notaris. Toen de rechtbank ook geen onvoorziene omstandigheden kon aanwijzen (als bedoeld in HR 14 juni 1996, NJ 1997, 481), werd geconcludeerd dat de weigering van de raad van bestuur om het onderhandelingsresultaat van haar vertegenwoordigers goed te keuren, 'naar maatstaven van redelijkheid en billijkheid rechtens onaanvaardbaar was en zonder gevolg moest blijven.' Hogerop in het vonnis was al afgerekend met de stelling van Essent, dat het simpelweg om een voorwaarde ging die nu eenmaal niet vervuld was:

\begin{abstract}
"Voor zover Essent heeft willen betogen dat het simpelweg om een voorwaarde zou gaan die nu eenmaal niet vervuld is, faalt dat betoog omdat ten deze sprake is van een potestatieve voorwaarde, die geen (opschortende of ontbindende) voorwaarde in de zin van artikel 6:21 BW is (vgl. Brunner in punt 2 van zijn noot onder HR-24-03-1995, NJ $1997 / 596^{453}$, Beliën/Prov. Brabant). Het gaat hier niet om goedkeuring door een derde (overheid, vakbond, deskundige of dergelijke) maar om een wilsverklaring van Essent zelf."
\end{abstract}

Hoewel het een, als gezegd, goed gemotiveerde uitspraak van de rechter te 's-Hertogenbosch betrof, verdient het een en ander nog wel wat nuancering. De opmerking van Brunner in zijn noot onder het arrest waarnaar hiervoor wordt verwezen met betrekking tot een potestatieve voorwaarde is wat te kort door de bocht. Brunner merkte op dat er geen sprake zou zijn geweest van een overeenkomst onder voorwaarde, omdat er niet sprake zou zijn geweest van een toekomstige onzekere gebeurtenis. Die visie kan niet zo algemeen (meer) worden toegepast als de rechter deed. Het door Brunner ingenomen standpunt was op het moment dat de rechter in 's-Hertogenbosch zijn vonnis schreef in de literatuur ook al van kritische kanttekeningen voorzien (omdat hij ten onrechte geen onderscheid zou hebben gemaakt tussen de verschillende organen van de Provincie). ${ }^{454}$ De regels van artikel 6:23 moeten, zoals ook in het artikel is uitgedrukt, worden beschouwd als een toepassing van het beginsel van de redelijkheid en billijkheid, dat onder andere is neergelegd in artikel 6:2 en 6:248. Artikel 6:23 lid 1 ziet op

overeenkomst welke partijen wilde sluiten, terwijl de Roompot de voorkeur had voor een minder vergaande change of control-bepaling. Ook hier waren het de bijkomende omstandigheden, die de subject to board approval-clause overeind hielden.

${ }^{451}$ Rechtbank 's-Hertogenbosch 14 april 2008, LJN BD0037.

452 Zulks in tegenstelling tot een vonnis dat ruim een week later over een vergelijkbare rechtsvraag wordt gewezen door de rechtbank te Utrecht (23 april 2008, LJN BD0116), waarin bij een voorbehoud voor de goedkeuring van Laurus bij de overname van een supermarkt het niet aangetoond zijn van die goedkeuring maakte dat er geen binding werd aangenomen. ${ }^{453}$ Betreft HR 24 maart 1995, NJ 1997, 569 (MB).

${ }^{454}$ Zie M.C. Schepel, Beliën/Provincie Brabant;potestatieve voorwaarde? In V\&O 1997, nr. 11, p. 123-124. 
de vraag of een verhindering van de vervulling van een voorwaarde niet zonder rechtsgevolg moet blijven, wanneer de partij die bij de niet vervulling belang had, de vervulling heeft belet. Volgens lid 2 van die wetsbepaling geldt een voorwaarde als niet vervuld, wanneer de partij die bij de vervulling belang had, de vervulling zelf heeft teweeg gebracht. In beide gevallen echter alleen wanneer de redelijkheid en billijkheid dat verlangt. In het geldende recht is het minder van belang om te twijfelen over de vraag of men wel met een voorwaarde van doen heeft. Dit komt door de erkenning van de beperkende werking van de redelijkheid en billijkheid (artikel 6:2 lid 2 en 6:248 lid 2; vergelijk ook artikel 6:258), waardoor ook buiten de door artikel 6:23 getrokken grenzen een beroep op het (niet) vervuld zijn van de voorwaarde kan worden afgesneden, met name in verband met gedragingen van degene die dit beroep doet (rechtsverwerking). Ook bevat het huidige recht meer regels die evenzeer als een toepassing van de beperkende werking van de redelijkheid en billijkheid zijn te beschouwen en een beroep op artikel 6:23 overbodig maken. ${ }^{455}$

Een algemene regel voor de toepasselijkheid van artikel 6:23 is niet te geven. Het volstaat dat er sprake van moet zijn dat er in verband met de doel en strekking van de overeenkomst volgens de eisen van de redelijkheid en billijkheid sprake is van een onterechte bewerkstelliging van het vervullen van een voorwaarde danwel het beletten van het vervuld worden van een voorwaarde.

Niet alle rechters nemen aan dat het inroepen van de gevolgen van een subject to board-approvalclausule steeds heeft te gelden als een potestatieve voorwaarde, of, zoals Brunner in zijn hier voor genoemde noot naar mijn mening al te makkelijk concludeerde, dat er in dergelijke gevallen niet van een voorwaarde kan worden gesproken. Het enkele feit dat een partij die bij de (niet) vervulling van een voorwaarde belang had de (niet) vervulling daarvan heeft veroorzaakt of belet - al naar gelang het geval - maakt nog niet dat de voorwaarde wel of niet als (niet) vervuld heeft te gelden. Het is op zich juist dat de wijze waarop een voorwaarde is geformuleerd kan maken dat er niet van een voorwaarde kan worden gesproken, ${ }^{456}$ maar afgezien daarvan moet er zoals gezegd sprake zijn van strijd met de redelijkheid en billijkheid, wil artikel 6:23 toepassing kunnen vinden. In het geval van rechtspersonen brengt de redelijkheid en billijkheid ook mee, dat ondanks het bestaan van de procuraleer gerespecteerd wordt dat een dergelijk instituut bestaat uit meerdere organen, die hun eigen functie in die rechtspersoon hebben te vervullen en - hetgeen even zo zwaar moet mee tellen naar mijn mening waarvan heeft te gelden dat in een normaal geval de wederpartij van een rechtspersoon zich van dat gegeven bewust is of behoort te zijn. Het instemmen met een bepaling in een overeenkomst die meebrengt, dat de vertegenwoordigers van een rechtspersoon waarmee men onderhandelt voor de goedkeuring van het eindresultaat nog de goedkeuring van een (ander) orgaan binnen de rechtspersoon nodig zullen hebben, betekent de acceptatie van de realiteit dat er in de interne organisatie van de andere partij van meerdere lagen van besluitvorming sprake is en de gedachte dat de begrippen "partij" (als genoemd in artikel 6:23) en "de rechtspersoon" waarmee men onderhandelt in die omstandigheden zonder nuancering als één en hetzelfde mogen worden beschouwd, kan dan in redelijkheid en billijkheid niet worden volgehouden. Als "partij" heeft dan zo men wil een meerkoppige draak te gelden, namelijk zowel degene met wie de onderhandelingen worden gevoerd àls de rechtspersoon met wie de overeenkomst uiteindelijk zal worden aangegaan. Afhankelijk van het stadium waarin de onderhandelingen zich bevinden heeft men dan te doen met de ene of de andere kop van de draak. De draak is pas verslagen, wanneer alle koppen zijn gesneld. Het is duidelijk dat in de jurisprudentie wordt gezocht naar een passende manier om aan de behoeften van de rechtspraktijk tegemoet te komen zonder de dogmatiek al te ver uit het oog te verliezen.

De rechtspraak op het gebied van de subject to board approval-clausule overziende, kom ik tot de slotsom dat het volume van de ruimte om zonder veel motivering gebruik van die clausule te maken, in belangrijke mate zal worden bepaald door de vraag of en in hoeverre en op welke wijze de personen die deel uitmaken van het orgaan, dat de bevoegdheid is toegekend om een transactie alsnog af te wijzen betrokkenheid hebben gehad in het voortraject van de transactie. Naarmate die betrokkenheid groter is, zal de ruimte om zonder veel toelichting een transactie niet door te laten gaan door op de desbetreffende clausule een beroep te doen, afnemen. De gedragingen van verschillende organen binnen een rechtspersoon gelden in beginsel ten opzichte van derden als aan de rechtspersoon toe te rekenen.

\footnotetext{
${ }^{455}$ Zie Asser/Hartkamp \& Sieburgh 6-I* 2008, nr.182.

${ }^{456}$ Asser/Hartkamp \& Sieburgh 6-I* 2008, nr.182.
} 
De waarschuwing die al het vorenstaande oplevert, is dat de formulering van een subject to board approval-clausule van veel waarde is. Daarin zal bij voorkeur ook worden gestipuleerd in hoeverre er wel of niet een motiveringsplicht mag worden aangenomen van het orgaan aan de goedkeuring waarvan uiteindelijk de transactie wordt onderworpen. De hiervoor door Schaafsma en Elsenga geformuleerde vuistregels blijven verder actualiteitswaarde houden.

Voor zover de regel ter zake van de potestatieve voorwaarden door partijen niet buiten toepassing is verklaard, is het mogelijk de voorwaarde dat een due diligence onderzoek een naar het oordeel van de partij die daartoe opdracht heeft gegeven, bevredigende uitslag zal vertonen, toch zo te formuleren dat die regel niet snel tot een beroep op de potestatieve voorwaarde kan leiden. Dit kan gebeuren door als voorwaarde op te nemen dat het uit te voeren due diligence onderzoek niet tot uitkomsten zal leiden, die informatie opleveren die niet in overeenstemming is met de gepubliceerde informatie betreffende de doelwitvennootschap, danwel anderszins voor de opdrachtgever van het due diligence onderzoek van zodanige betekenis kunnen worden geacht, dat van die in redelijkheid niet kan worden gevergd de transactie doorgang te laten vinden. ${ }^{457}$

Ook kan - in het geval van koop - door een uitdrukkelijke verwijzing naar artikel 7:45 soms een meer passende oplossing worden bereikt. Door een zo duidelijk mogelijke maatstaf te formuleren - in het bijzonder bij toepassing van een confirmatory due diligence - wordt het karakter van een koop op proef als intentie van partijen tot uitdrukking gebracht. Zijn er objectieve wegingsfactoren afgesproken, dan biedt dit de verkoper zekere waarborgen tegen grillig gedrag aan de zijde van de koper. Wanneer er sprake is van een voorwaardelijke koopovereenkomst gesloten met een subjectieve maatstaf, moet een serieus onderzoek worden gedaan en kan niet op willekeurige gronden van de transactie worden afgezien. Volgens artikel 7:45 jo. 6:23 is dan wel een zekere normering van het gedrag van de koper aan de orde, maar zal een toets naar redelijkheid en billijkheid van het gedrag van de koper een belangrijker rol spelen. ${ }^{458}$

Terwijl de notie 'koop op proef' niet direct lijkt te passen bij de koop van een onderneming of een onderdeel daarvan (al dan niet in de vorm van een aandelen of activa passiva transactie) is de toepassing van dit leerstuk niet helemaal ondenkbaar, wanneer dit de fase betreft tot de afronding van een confirmatory due diligence. Zo goed als het niet ongebruikelijk is dat het management van een onderneming voorafgaand aan het definitief worden van een transactie al door de koper wordt overgenomen, kan ook worden voorzien in afspraken die tijdens de proefperiode in management door de koper voorzien. Gaat de koop niet door, dan wordt het management weer overgedragen. Over de gevolgen van tijdens de interim periode te treffen beslissingen, zijn dan gebruikelijk vooraf afspraken gemaakt.

Het kan ook aanbeveling verdienen om bij het stipuleren van de mogelijkheid van een due diligence onderzoek van tevoren duidelijk vast te leggen dat het niet naar behoren kunnen uitvoeren van een due diligence onderzoek aanleiding kan zijn om een transactie niet door te zetten. ${ }^{459}$ Tui zag af van de overname van de ATR-vennootschappen (Exel Aviation Group) omdat de uitkomst van het due diligence onderzoek uitwees dat de kwaliteit en de omvang van de beschikbare informatie onvoldoende was om de risico's van de ATR-vennootschappen te inventariseren. Het due diligence onderzoek had toen al plaatsgevonden. Beter dan te verwijzen naar de uitkomst van het due diligence onderzoek zou gezegd kunnen worden dat het due diligence onderzoek niet naar behoren kon worden uitgevoerd.

\subsection{Bestuurdersaansprakelijkheid}

\footnotetext{
${ }^{457}$ Zie bijvoorbeeld de hiervoor genoemde uitspraak van de Rechtbank Arnhem van 19 maart 2008, LJN BC8052 (r.o. 216), waarin een clausule wordt genoemd van de navolgende inhoud: "De overeenkomst zal, mits met inachtneming van het volgende, ontbonden (kunnen) worden indien de uitkomst van het door de koper ingestelde - zogenaamde 'due diligence'onderzoek een minder positief beeld geeft van de aangelegenheden van de Vennootschap dan door verkoper aan koper meegedeeld, met dien verstande dat geringe afwijkingen niet geacht worden een minder positief beeld dan voornoemd te geven. Koper kan slechts ontbinden indien de uitkomsten van het due diligence onderzoek in belangrijke mate afwijken van de tot de ondertekening van deze overeenkomst aan koper verstrekte informatie. Onder "in belangrijke mate afwijken" wordt in dit verband verstaan verschillen welke gezamenlijk of individueel (een belang vertegenwoordigen dat) een bedrag van $€$ 75.000 (...) te boven gaan (gaat)." Of het zo handig was om een bedrag van $€ 75.000$ te noemen was de vraag. De onderhavige zaak ging erover dat verkoper betwiste dat er een verschil van meer dan $€ 75.000$ was gebleken (het zou $€ 74.000$ zijn geweest). De kwestie van de potestatieve voorwaarde speelde in deze uitspraak nadrukkelijk, nu de rechtbank bij de beoordeling van de wijze waarop gebruik was gemaakt van de ontbindende voorwaarde de redelijkheid en billijkheid duidelijk betrok. Het vonnis kwam tot een bewijsopdracht aan de koper.

${ }^{458}$ Zie Asser-Hijma 5-I, nr. 113, waarin nader wordt ingegaan op het verschil - of liever gezegd, de aansluiting - tussen de toepassing van artikel 7:45 en 6:23.

${ }^{459}$ Zie OK 1 november 2005, JOR 2005, 297.
} 
De Hoge Raad heeft zich in een arrest van 23 januari $2004^{460}$ uitgelaten over de aansprakelijkheid van een enig aandeelhouder statutair directeur van een vennootschap waarvan werd aangenomen dat bij de verkoop van een 2-tal dochtermaatschappijen de mededelingsplicht door de verkopende vennootschap werd geschonden. Er was een onjuist beeld van het vermogen en de resultaten van de dochtermaatschappijen gegeven. In het verlengde daarvan werd door de Hoge Raad 'in beginsel op dezelfde gronden' aangenomen dat deze onrechtmatig tegenover de koper had gehandeld, omdat hij via zijn houdstermaatschappij enig aandeelhouder en statutair bestuurder was van de verkoper en bij de voorbereiding en het besluiten van de desbetreffende transactie blijkens de tussen partijen gewisselde stukken ten nauwste betrokken was. De Hoge Raad plaatste die conclusie in het licht van de conclusie dat er bij de verkoop bewust een onjuist beeld van de vermogende resultaten van de dochtermaatschappijen van de verkoper was gegeven. Jansen ${ }^{461}$ heeft zich afgevraagd wat door de Hoge Raad zou kunnen zijn bedoeld met de term 'in dit licht'. Hij concludeert dat de aansprakelijkheid van de directeur groot aandeelhouder gelegen zal zijn geweest in het feit dat deze namens de verkoper de verplichting tot informatieverstrekking aanging, terwijl hij, gezien zijn nauwe betrokkenheid, wist dat de verkoper die verplichting niet kon nakomen. Jansen vraagt zich af of daarmee voldaan werd aan alle voorwaarden die krachtens jurisprudentie aan een persoonlijke aansprakelijkheid in dit kader worden gesteld. Nu de koper haar schade als gevolg van de handelwijze van de directeur groot aandeelhouder op de verkoper kon verhalen, zou er geen sprake zijn van een schuldeiser die als gevolg van de gedragingen van de groot aandeelhouder met lege handen achterblijft. Volgens Jansen werden in het arrest van 23 januari 2004 daarom de gronden voor persoonlijke aansprakelijkheid opgerekt. Bestuurders dienen er derhalve rekening mee te houden dat in een overnametraject de grenzen ruimer getrokken kunnen worden.

Van Uchelen ${ }^{462}$ zegt dat de redenering van de Hoge Raad overeenkomt met de redenering in de arresten van HR 14 november 1997, NJ 1998, 270 (Henkel) en HR 18 januari 2002, NJ 2002, 96 (Textile), waarin werd bepaald dat wanprestatie door een rechtspersoon onder omstandigheden kan meebrengen dat de bestuurder op grond van onrechtmatige daad aansprakelijk is ten opzichte van de benadeelde indien hem te dier zake een persoonlijk verwijt treft. Voorzienbaarheid van de wanprestatie (in het hiervoor besprokene genoemd: bewustheid) alsmede nauwe betrokkenheid van de bestuurder bij de transactie zijn de elementen die bij de vaststelling of van een persoonlijk verwijt sprake is, een belangrijke rol spelen. Aansprakelijkheid speelt volgens Van Uchelen wanneer er sprake is van het bewust geven van een onjuist beeld. Indien van bewustheid geen sprake is moet volgens hem betwijfeld worden of het verwijt dat een bestuurder gemaakt wordt, in de gegeven omstandigheden als voldoende ernstig kwalificeert. Door in het onderhandelingsproces onjuiste gegevens te verschaffen kan het zich voordoen dat jegens de koper niet de vereiste zorgvuldigheid is betracht. Een bestuurder dient zich er immers bewust van te zijn dat de verkeerde voorstelling van een financiële toestand van een doelwitvennootschap ertoe kan leiden dat de koper een te hoge prijs voor de aandelen of een onderneming betaalt. In dat geval kan gesteld worden dat een bestuurder onrechtmatig handelt jegens een koper wegens strijd met een zorgvuldigheidsnorm. Van Uchelen meent dat in het laatstbedoelde geval het criterium voor verwijtbaarheid niet het 'voldoende ernstig persoonlijk verwijt' zou moeten zijn (zoals voor bestuurdersaansprakelijkheid is vereist), maar wellicht een minder strenge norm gehanteerd zou kunnen worden. ${ }^{463}$

\subsection{Kosten van het due diligence onderzoek}

De kosten van een due diligence onderzoek komen - behoudens anders luidende afspraken tussen partijen - voor rekening van degene die tot het doen uitvoeren van het onderzoek de opdracht geeft.

\footnotetext{
${ }^{460}$ LJN AL7051 (Stratex).

${ }^{461}$ M. Jansen, Pont Eecen N.V./Stratex B.V., BB 10 juni 2004-12, p. 17 e.v

${ }^{462}$ P.J. van Uchelen, Bestuurdersaansprakelijkheid ingeval van schending van de mededelingsplicht bij bedrijfsovername, Ondernemingsrecht 2004-6, p.229 e.v.

${ }^{463} \mathrm{Bij}$ het verstrekken van jaarstukken binnen het kader van de informatieverschaffing kan ook aan aansprakelijkheid op grond van artikel 2:249 worden gedacht. Volgens Asser-Maeijer 2 III nummer 324 en J.B. Wezeman, Aansprakelijkheid van bestuurders, T 87, kunnen kopers van aandelen in een vennootschap, die zich door een onjuiste voorstelling van zaken tot aankopen hebben laten verleiden een beroep doen op de bepaling van artikel 2:249, met name omdat zij ten tijde van de misleiding nog duidelijk derden waren.
} 
Ondanks het maken van afspraken over de betaling van kosten, kan daar een probleem over ontstaan. Dit kan met name gebeuren wanneer partijen er in hun afspraken niet op geanticipeerd hebben dat de dingen niet altijd zo verlopen als men zou willen.

Nog onbekend met de uitspraak van de Hoge Raad van 12 augustus $2005^{464}$ oordeelde de rechtbank te Middelburg op 14 april 2004, dat - ondanks de partij afspraak dat partijen de kosten van het due diligence onderzoek gezamenlijk en gelijkelijk zouden dragen - het deel van de ander bij wijze van schadevergoeding volledig gedragen moesten worden door de partij die verantwoordelijk werd gehouden voor het afbreken van de onderhandelingen over de transactie. ${ }^{465}$

De rechtbank achtte het aannemelijk dat het niet meedelen van belangrijke financiële gegevens - die eerst in het kader van het due diligence onderzoek aan het licht kwamen - reden voor het niet doorgaan van de transactie was. De wederpartij had volgens de rechtbank moeten begrijpen dat de bekendheid met die gegevens voor de ander van essentieel belang was om het onderhandelingsproces voort te zetten en verdere kosten te maken, terwijl er overigens redelijkerwijs geen toegang tot die gegevens verkregen kon worden. De rechtbank meende dat het niet (tijdig) bekend maken van de desbetreffende gegevens onder de omstandigheden een onrechtmatige daad opleverde.

${ }^{464}$ Over de ruimte om onderhandelingen af te breken: RvdW 2005, 93.

465 LJN AO9310. 


\section{Due diligence in de kapitaalmarkt}

\subsection{Due diligence en de beursvennootschap}

\section{Openbaar bod}

Is een koper voornemens een beursgenoteerde vennootschap over te nemen dan zal hij een openbaar bod op de uitstaande aandelen van deze vennootschap doen. Het aandelenkapitaal is gemeenlijk sterk verspreid. Er is niet één verkoper. De koper weet niet precies wie de verkopers zijn. De koper is bij het overnemen van de doelwitvennootschap voor het verkrijgen van inzicht in de onderneming - naast de openbaar beschikbare informatie - afhankelijk van het bestuur van de doelwitvennootschap. ${ }^{466}$ Het bestuur kan het bod als vijandelijk betitelen en elke medewerking weigeren. Garanties kunnen er praktisch gesproken niet worden gevraagd. Voor zover de garanties door de vennootschap zelf zouden (moeten) worden gegeven, zullen niet alleen de regels van artikel 2:98c spelbreker kunnen zijn, maar zouden na een geslaagde acquisitie de kosten voor nakoming van de garanties indirect voor rekening van de koper zelf komen.

De koper zal zich bij een openbaar bod dienen te conformeren aan de op 28 oktober 2007 in werking getreden wet tot uitvoering van de dertiende EG-richtlijn betreffende het openbaar overnamebod, alsmede aan het op deze wet gebaseerde Besluit openbare biedingen Wft ("Bob"). ${ }^{467}$ Uitgangspunt is het verbod van artikel 5:74 Wft een openbaar bod uit te brengen zonder dat voorafgaand aan het bod een biedingsbericht algemeen verkrijgbaar is gesteld dat is goedgekeurd door de AFM. In de systematiek van de Wft vormt deze bevoegdheid van de AFM het aanknopingspunt voor de toepasselijkheid van de Nederlandse biedingsregels. Waar onder het oude recht een voorgenomen openbaar bod diende te worden aangekondigd als de verwachting gerechtvaardigd was dat tussen de bieder en de doelwitvennootschap overeenstemming zou worden bereikt, dient thans een openbaar bod onverwijld te worden aangekondigd als de bieder en de doelwitvennootschap - al dan niet voorwaardelijk - overeenstemming hebben bereikt. ${ }^{468}$ Een openbaar bod geldt echter ook als aangekondigd indien de bieder concrete informatie over de inhoud van het voorgenomen bod openbaar heeft gemaakt, zoals de naam van de doelwitvennootschap in combinatie met een voorgenomen prijs. Gevolg van een aankondiging van een openbaar bod is dat de biedingsprocedure, inclusief de in de Wft en het Bob neergelegde termijnen, beginnen te lopen en het toezicht van de AFM aanvangt. Binnen 4 weken na aankondiging dient de bieder bekend te maken of, en zo ja, wanneer hij een aanvraag tot goedkeuring van het biedingsbericht bij de AFM zal indienen. ${ }^{469}$ In het biedingsbericht dient - overeenkomstig de voorschriften voor het opstellen van een prospectus - die informatie beschikbaar te komen die voor een redelijk geïnformeerde en zorgvuldig handelende persoon van belang is voor het vormen van een verantwoord oordeel over het in het betreffende biedingsbericht beschreven openbaar bod. ${ }^{470}$ Het biedingsbericht dient niet méér gedetailleerde informatie te bevatten dan de informatie die in een zogenaamd certain funds persbericht is opgenomen. In een certain funds persbericht omschrijft de bieder de wijze waarop hij zorg draagt voor het kunnen opbrengen van de vergoeding om het bod gestand te kunnen doen en/of welke maatregelen zijn getroffen in verband met enige andere vorm van vergoeding om het bod gestand te kunnen doen. ${ }^{41}$ Voor een bieder geldt verder nog de verplichting tot openbaarmaking van koersgevoelige informatie voor zover het informatie betreft die "rechtstreeks op hem betrekking heeft of verband houdt met het voorgenomen, aangekondigde of uitgebrachte openbaar bod". Doelstelling hierbij is dat de koersgevoelige informatie beschikbaar komt die voor een redelijk geïnformeerde en zorgvuldig handelende persoon van belang is voor het vormen van een verantwoord oordeel over het

\footnotetext{
${ }^{466}$ Zie ook G.T.M.J. Raaijmakers, Due diligence bij onderhandse bedrijfsovername en openbare biedingen, Juridisch Up To Date 9 september 1999 , p. 12 e.v.

${ }^{467}$ Wet van 24 mei 2007 tot uitvoering van richtlijn nr. 2004/25/EG van het Europese Parlement en de Raad van de Europese Unie van 21 april 2004 betreffende het openbaar overnamebod, Staatsblad 2007, 202; Besluit Openbare biedingen Wft, Staatsblad 2007, 329.

468 Ingevolge art. 4 lid 4 Bob kan deze mededeling nooit worden uitgesteld met een beroep op een rechtmatig belang van de uitgevende instelling als bedoeld in art. 5:59 lid 3 sub a Wft (publicatie van voorwetenschap).

${ }^{469}$ M.C. Schouten, Inwerkingtreding nieuwe regels betreffende het openbaar bod op effecten, Bb 2008, 18, p. 69-72.

470 Dit kunnen dus ook adviezen van bijvoorbeeld advocaten betreffen. Zie 'veelgestelde vragen openbare biedingen' op de website van de AFM (www.afm.nl). De informatievereisten zijn uitgebreid ten opzichte van het 'oude' art. 9i Bte 1995.

471 Zie art. 7 lid 4 en 5 Bob.
} 
(mogelijke) openbaar bod en daarmee de goede werking van de financiële markten en de bescherming van de spelers op die markten. ${ }^{472}$ Deze laatstgenoemde verplichting om koersgevoelige informatie openbaar te maken, brengt ons bij de vraag welke verplichtingen gelden indien in een eerder stadium mededelingen worden gedaan met betrekking tot het bod. ${ }^{473}$ Immers, net als de koper van een niet beursgenoteerde vennootschap wil ook de koper van een beursgenoteerde vennootschap weten wat er gekocht wordt en of er geen problemen zijn bij de over te nemen vennootschap. De koper vindt bij het houden van een due diligence onderzoek dan ook de regels omtrent voorwetenschap op zijn weg (artikel 46 e.v. Wte, als laatstelijk gewijzigd door inwerkingtreding van de Wft en het Besluit Marktmisbruik Wft). ${ }^{474}$ Er kan sprake zijn van voorwetenschap zo lang er sprake is van niet-publiekelijk bekend gemaakte informatie, die invloed op de prijs van de aandelen kan doen gelden. Dit laatste kan ook relevant zijn waar het gaat om de koop/verkoop van aandelen in een dochtermaatschappij van een beursgenoteerde vennootschap. Die koop/verkoop kan immers ook invloed doen gelden op de koers van de aandelen in een houdstervennootschap. ${ }^{475}$

\section{Openbaar bod en voorwetenschap}

$\mathrm{Er}$ is in het beleid van de AFM ruimte om bij grootaandeelhouders van de doelwitvennootschap te informeren naar hun bereidheid om op een eventueel bod in te gaan. Dit blijkt uit Beleidsregel 03-01 van de AFM inzake het polsen van (potentiële) aandeelhouders. ${ }^{476}$ Blijkens het Besluit van 17 december 1988 van het Ministerie van Financiën ${ }^{477}$, een AMvB op grond van artikel 46 lid 4 Wte 1995, als aangepast bij Besluit van 20 mei $2003^{478}$ werden transacties in het kader van een voorgenomen openbaar bod of emissie uitgesloten van het verbod op handel met voorwetenschap. ${ }^{479}$ Dit is onverkort blijven gelden na invoering van de Wft. Voornoemde regel is in het Besluit Marktmisbruik Wft - een AMvB op grond van artikel 5:56 lid $6 \mathrm{Wft}$ - opgenomen in artikel 2 sub d. ${ }^{480}$

De Beleidsregel Polsen Grootaandeelhouders is op 10 mei 2004 door de AFM ingetrokken. De Beleidsregel werd vervangen door een zogenaamde 'interpretatie', waarin de strekking van de Beleidsregel - voor zover niet gedekt door het eerder genoemde Besluit van het Ministerie van Financiën - werd overgenomen. De interpretatie moet denkbaar worden gezien als een wetsinterpreterende beleidsregel. ${ }^{481}$ De interpretatie legt nog eens uit bij welke transactie het polsen van grootaandeelhouders naar de mening van de AFM niet valt onder het verbod van artikel 46a Wte 1995 (thans art. 5:57 Wft). Ge-

472 Zie 'veelgestelde vragen openbare biedingen' op de website van de AFM (www.afm.nl).

473 M.C. Schouten, Inwerkingtreding nieuwe regels betreffende het openbaar bod op effecten, Bb 2008, 18, p. 71.

${ }^{474}$ Met ingang van 1 januari 2007 is de belangrijkste wet- en regelgeving die van toepassing is op Marktmisbruik ('Regels ter voorkoming van marktmisbruik en voor het optreden op markten in financiële instrumenten') in hoofdstuk 5.4 van de Wft en in het Besluit Marktmisbruik Wft opgenomen. Zie artikel 5:53 e.v. Wft. Zie tevens Staatsblad 2006, 510 en Staatsblad 2005, 467.

475 In HR 4 april 2006 (LJN AU 4658) is nog eens overwogen dat regels met betrekking tot voorwetenschap ook gelden waar het optietransacties betreft in effecten gedurende de periode waarin een due diligence onderzoek plaatsvindt met het oog op eventuele deelname of overname van de desbetreffende instelling, voordat het voornemen tot deelname of overname openbaar is gemaakt. De Rechtbank Amsterdam beslist op 26 januari 2005 (JOR 2005, 96) dat de AFM geen directe toezichthoudende taak heeft op nakoming van de verplichting van een beursgenoteerde vennootschap tot openbaarmaking van koersgevoelige informatie. Het directe toezicht is opgedragen aan Euronext. De omstandigheden dat AFM aan Euronext op grond van artikel 6 lid 1 Wte 1995 een aanwijzing kan geven wanneer de AFM vaststelt dat een beursgenoteerde instelling zich niet houdt aan de beursregels, maakt dit volgens de rechtbank niet anders.

476 Beleidsregel 03-01 van de AFM inzake de toepassing van artikelen 46 en $46 a$ Wte bij het polsen van (potentiële) aandeelhouders in het kader van het verrichten van transacties, Stcrt. 2003, 71, p. 17.

477 Staatsblad 1988, 717.

478 Staatsblad 2003, 224

479 Het tipverbod ex artikel 46a Wte 1995 (thans artikel 5:57 Wft) biedt, in tegenstelling tot het verbod op handel met voorwetenschap ex artikel 46 Wte 1995, niet de mogelijkheid om bepaalde situaties uit te sluiten. In de Nota van Toelichting bij het Besluit merkte de Minister echter op dat het polsen van grootaandeelhouders in het kader van het voorbereiden van een openbaar bod of een emissie van effecten valt binnen het kader van het werk, beroep of functie van de polser en als zodanig niet wordt bestreken door het tipverbod van artikel 46a Wte 1995. Blijkens de toelichting bij artikel 3 in de Nota van Toelichting bij het Besluit Marktmisbruik Wft is ook dit onverkort blijven gelden. Op grond van artikel 5:57 lid $3 \mathrm{Wft}$ is het echter wel mogelijk om bij AMvB (Besluit Markmisbruik Wft) regels te stellen met betrekking tot de gevallen waarin en de omstandigheden waaronder sprake is van meedelen in het kader van de normale uitoefening van werk, beroep of functie.

480 Staatsblad 2006, 510.

481 B.F.H. Rumora-Scheltema, Het polsen van grootaandeelhouders, V\&O november 2004, nr. 11, p. 189 e.v., die erop wijst dat op de website van de AFM te lezen is dat aan de interpretatie geen rechten kunnen worden ontleend en dat die niet bindend is. Zij stelt dat het per saldo om niet meer dan een toelichting gaat. Voorstellen voor een wijziging van hoofdstuk 5.3 Wft kunnen - indien tot wet verheven - het identificeren van groot aandeelhouders helpen vergemakkelijken wanneer de eerste drempelwaarde op $3 \%$ zou worden gesteld. Zie M.M. van den Broek, op weg naar grotere transparantieverplichtingen voor aandeelhouders in beursgenoteerde ondernemingen, TOP 2008, nummer 2, p. 55 e.v. 
dacht dient te worden aan alle transacties waarbij het voor de polser van belang is om te weten wat de mening van de grootaandeelhouder zal zijn. Het moet gaan om een transactie die ofwel onderworpen is aan goedkeuring van de aandeelhoudersvergadering ofwel waarop de grootaandeelhouder(s) direct of indirect invloed kan (kunnen) uitoefenen. Naar de mening van de AFM draagt het polsen van grootaandeelhouders in deze situaties bij aan een goed functioneren van de effectenmarkten en de positie van beleggers op die markten en is derhalve in overeenstemming met het doel van de Wte 1995. Onder die omstandigheden meent de AFM dat een dergelijk polsen beschouwd kan worden als handelen uit hoofde van werk, beroep of functie en dus niet valt onder het tipverbod van artikel 46a Wte 1995.

De polsende partij heeft de verantwoordelijkheid dat de kring van personen die beschikt over de verstrekte informatie, zo beperkt mogelijk dient te blijven. Deze verantwoordelijkheid wordt als onlosmakelijk verbonden gezien met het polsen van (potentiële) aandeelhouders of zij bereid zijn hun medewerking te verlenen aan de totstandkoming van een transactie. Het komt voor dat de polsende partij met de benaderde (potentiële) aandeelhouders afspraken maakt over de geheimhouding van de verstrekte informatie, inhoudende dat de (potentiële) aandeelhouder deze informatie niet aan derden mag verstrekken alsmede een stand still overeenkomst afsluit, inhoudende dat de (potentiële) aandeelhouder gedurende de periode waarin de informatie geacht moet worden niet openbaar en koersgevoelig te zijn, geen transacties zal verrichten in aandelen van de vennootschap. Verwezen wordt ook naar de Memorie van Toelichting bij het Ontwerp voor de Wet Marktmisbruik ${ }^{482}$ :

"Tenslotte wordt voorzien in de grondslag voor een algemene maatregel van bestuur, waarin zal worden bepaald wanneer sprake is van meedelen in het kader van de normale uitoefening van werk, beroep of functie. In deze algemene maatregel van bestuur zal in ieder geval worden opgenomen dat een bieder die voornemens is een openbaar bod uit te brengen, en die om die reden bestaande (groot)aandeelhouders polst of zij bereid zijn bij een eventueel uit te brengen bod hun aandelen aan te bieden, handelt in de normale uitoefening van zijn werk, beroep of functie ${ }^{\text {A83 }}$.

Dit polsen dient dan wel beperkt te blijven tot de (groot)aandeelhouders waarvan het voor de bieder noodzakelijk is te weten of deze aandeelhouders op het bod ingaan. Een vergelijkbare overweging is te vinden in de Nota van Toelichting bij het Besluit Marktmisbruik Wft:

"Waar in dit onderdeel en onderdeel E sprake is van aandelen en (groot)-aandeelhouders wordt tevens gedoeld op andere financiële instrumenten respectievelijk rechthebbenden op financiële instrumenten. In de praktijk is het echter gebruikelijk om de begrippen aandelen en (groot)aandeelhouders te hanteren. Bij dit gebruik wordt hier aangesloten. Degene die voornemens is een openbaar bod op aandelen uit te brengen en om die reden bestaande (groot)aandeelhouders polst of zij bereid zijn bij een eventueel uit te brengen bod hun aandelen aan te bieden, handelt in de normale uitoefening van zijn werk, beroep of functie. Voor een dergelijke persoon is het immers van belang om te weten of een voorgenomen openbaar bod kans van slagen heeft. Om die reden is een dergelijk handelen, mits aan bepaalde voorwaarden wordt voldaan, niet in strijd met het verbod om koersgevoelige informatie aan derden mee te delen, zoals verwoord in artikel 5:57, eerste lid, onderdeel a, van de Wet en is deze situatie in artikel 3 uitgezonderd. De (groot)aandeelhouder die door de bieder over het bod is benaderd, komt daardoor ook over voorwetenschap te beschikken. Het polsen heeft voor de bieder weinig zin als de desbetreffende (groot) aandeelhouder niet aan de bieder kan aangeven of hij al dan niet op het bod zal ingaan. Omdat het begrip transactie van artikel 5:56, eerste lid van de Wet in de praktijk ruim wordt uitgelegd, zou aangenomen kunnen worden dat de toezegging van een (groot)aandeelhouder het begin van een transactie is en dus verboden is op grond van artikel 5:56, eerste lid van de Wet. Teneinde

\footnotetext{
482 TK 2004-2005, 29827, nr. 3, p. 9.

${ }^{483}$ Verwezen wordt ook naar overweging 29 van de Richtlijn Marktmisbruik, Richtlijn 2004/72/EG van de Europese Commissie van 29 april 2004 tot uitvoering van Richtlijn 2003/6/EG van het Europese Parlement en de Raad, wat gebruikelijke marktpraktijken, de definitie van voorwetenschap met betrekking tot van grondstoffen afgeleide instrumenten, het opstellen van lijsten van personen met voorwetenschap, de melding van transacties van leidinggevende personen en de melding van verdachte transacties betreft, PB EU L 72 .
} 
zeker te stellen dat het doen van een toezegging door een (groot)aandeelhouder aan de bieder is toegestaan, is het doen van een toezegging in dit onderdeel uitgezonderd van het verbod van gebruik maken van voorwetenschap onder voorwaarde dat de (groot)aandeelhouder schriftelijk specificeert aan de bieder hoeveel aandelen hij zal aanbieden. Met ondermeer deze schriftelijke verklaring kan de bieder inzichtelijk maken dat het polsen noodzakelijk was. Voor de duidelijkheid zij opgemerkt dat in het geval de (groot)aandeelhouder door de doelvennootschap (de vennootschap die voorwerp is van een mogelijke bieding) gepolst wordt, de toezegging om op het bod in te gaan aan de bieder wordt gedaan, al dan niet door tussenkomst van de doelwitvennootschap. Aan de bieder is immers de toezegging om op het bod in te gaan gericht en met de bieder wordt de uiteindelijke transactie gesloten. De uitzondering in dit onderdeel richt zich dan ook op de toezegging aan de bieder. De bieder kan door het polsen van (groot)aandeelhouders voorwetenschap verkrijgen. Door in het biedingsbericht, conform de regels voor openbare biedingen, op te nemen welke (groot)aandeelhouders reeds te kennen hebben gegeven voor hun financiële instrumenten het bod te zullen aanvaarden, wordt de koersgevoelige informatie hieromtrent openbaar gemaakt en geldt het transactieverbod niet langer voor de bieder. Daarnaast wordt opgemerkt dat het in de praktijk voorkomt dat een bieder onderdeel uitmaakt van een concern en dat tijdens het biedingsproces een ander onderdeel van het concern of een nieuw op te richten onderdeel van het concern formeel het bod uitbrengt. Ook komt het voor dat het polsen van (groot)aandeelhouders door de doelvennootschap plaatsvindt. Hetgeen in het onderstaande wordt opgemerkt voor een bieder, geldt tevens voor het andere of nieuwe onderdeel van het concern en voor de doelvennootschap die de (groot)aandeelhouders polst. Hoewel een emissie niet specifiek wordt genoemd, is deze situatie vergelijkbaar met een overnamebod". 484

Met betrekking tot emissie wordt terzelfder plekke gesteld:

"Voor een toezegging door een (groot)aandeelhouder of een potentiële (groot)-aandeelhouder die in het kader van een voorgenomen emissie of herplaatsing door een (vertegenwoordiger van een) uitgevende instelling gepolst wordt of hij in zal gaan op die emissie of herplaatsing, geldt hetzelfde als in de toelichting op onderdeel $d$ is gesteld. Omdat niet alleen bestaande (groot)aandeelhouders gepolst worden in het kader van een voorgenomen emissie of herplaatsing, maar soms ook toekomstige (groot) aandeelhouders, is de uitzondering ook van toepassing op een potentiële (groot) aandeelhouder. Ook voor onderdeel e. geldt dat het polsen noodzakelijk moet zijn en dat de toezegging gespecificeerd vastgelegd moet worden in een schriftelijke verklaring aan de uitgevende instelling. Zo lang geen vastlegging van de toezegging heeft plaatsgevonden, is niet voldaan aan de uitzonderingsvereisten en is het verbod van het gebruik maken van voorwetenschap van toepassing op een (groot)aandeelhouder of een potentiële (groot) aandeelhouder".

"Het transactieverbod van artikel 5:56 van de Wet op het financieel toezicht blijft onverkort gelden voor andere transacties door de (groot)aandeelhouders en potentiële (groot)aandeelhouders dan de in onderdeel e. en onderdeel d. hiervoor genoemde transacties. Ook het verbod van artikel 5:57 van de Wet op het financieel toezicht blijft onverkort van toepassing op de (potentiële) (groot)aandeelhouder die door de bieder en de uitgevende instelling over het bod onderscheidenlijk de emissie of herplaatsing is benaderd. In de praktijk worden overigens geheimhoudingsovereenkomsten en "stand-still overeenkomsten ${ }^{\text {,485 }}$ gesloten om gehoudenheid aan het mededelingsverbod te benadrukken en om voortijdige publiciteit over bijvoorbeeld de overname tegen te gaan.

${ }^{484}$ Staatsblad 2006, 510, p. 28-29.

${ }^{485}$ Een stand-still overeenkomst betreft een afspraak dat een potentiele overnemer gedurende een zekere periode geen nieuwe posities zal innemen, zolang besprekingen tussen de besturen van de betrokken ondernemingen worden gevoerd. Niet altijd wordt duidelijk genoeg bepaald hoelang zo'n stand-still overeenkomst gelding heeft. Zie rechtbank Dordrecht 23 maart 2000 , LJN AA5229. Waar banken betrokken zijn, zullen die veelal bezwaar maken tegen het aan het (doen) aanvaarden van standstill overeenkomsten (door hun cliënte), nu zij vanzelfsprekend niet voor slechts een partij optreden (behoudens het geval waarin de bank zelf voornemens is een openbaar bod uit te brengen). 
De biedende en uitgevende instellingen mogen alleen onder de hiervoor genoemde onderdelen $d$. en e. genoemde omstandigheden (potentiële) (groot)aandeelhouders polsen. De bieder, de uitgevende instelling en de (potentiële) (groot)aandeelhouders mogen, beschikkende over voorwetenschap, geen transacties verrichten tenzij de voorwetenschap openbaar is gemaakt."

Dat met het polsen van grootaandeelhouders uiterste zorgvuldigheid dient te worden betracht, mag inmiddels duidelijk zijn. Enkel en alleen onder de hiervoor genoemde omstandigheden en voorwaarden valt het polsen van grootaandeelhouders naar de mening van de AFM niet onder het verbod van artikel 46a Wte 1995 (art. 5:57 Wft). Buiten deze gevallen zou men terughoudend moeten zijn met het verstrekken van koersgevoelige informatie aan grootaandeelhouders en dient de kring van personen die over koersgevoelige informatie beschikt zo beperkt mogelijk te blijven. In dit kader kan gewezen worden op de bezwaren van de VEB tegen het conceptvoorstel corporate governance, waarin de mogelijkheid wordt geïntroduceerd voor beursfondsen de identiteit van hun aandeelhouders op te vragen bij banken die de aandelen van deze aandeelhouders in bewaring hebben. Volgens de VEB werkt het stimuleren van direct één op één contact tussen de onderneming en grotere aandeelhouders het selectief verstrekken van koersgevoelige informatie in de hand. ${ }^{486}$

In de literatuur wordt verschillend gedacht over de vraag in hoeverre het de verkoper vrijstaat om koersgevoelige, niet-openbare informatie aan de koper te verstrekken en in hoeverre de koper, voorzien van zulke wetenschap een bod op de aandelen mag uitbrengen (waarover hierna meer). ${ }^{487} \mathrm{Blij-}$ kens de parlementaire geschiedenis bij artikel 46 e.v. Wte $1995^{488}$ zal er in beginsel geen sprake zijn van gebruik van voorwetenschap wanneer een partij een positie in aandelen opbouwt met het doel de doelwitvennootschap over te nemen middels een openbaar bod. De overnemende partij beschikt per definitie over voorwetenschap. De niet-openbare kennis welke door een due diligence onderzoek is verkregen, is zeker voorwetenschap. Die wordt relevant, wanneer die kennis niet wordt omgezet in een openbaar bod op aandelen. Zo lang niet-openbare informatie relevant kan zijn voor de koersvorming zou degene die van die informatie kennis draagt zich moeten onthouden van het innemen van posities (het uitvoeren van transacties). Waar eerder het vooraf vragen van een ruling of een pre-clearance aan het Openbaar Ministerie of de AFM uitkomst kon bieden, ligt thans de verantwoordelijkheid bij de marktpartijen zelf. De regelgeving omtrent voorwetenschap zou naar de mening van de AFM voldoende duidelijkheid scheppen.

Het bestuur van een doelwitvennootschap moet goed weten waar het aan begint voordat het instemt met het verschaffen van niet-openbare informatie. Het wel of niet toestaan van een due diligence onderzoek kan velerlei consequenties meebrengen. In het geval er uiteindelijk een vijandige overname volgt en er sprake is van informatie welke niet volledig blijkt te kloppen, zal dat niet zonder gevolgen blijven. Schuldigen zullen worden aangewezen. Concurrentievoorsprong kan worden verloren. Volgt er geen overname, dan kunnen de kwetsbare plekken van een onderneming zichtbaar zijn geworden. Werknemers in sleutelposities kunnen op het idee komen dat er bij een concurrent minder te vrezen valt dan zij hadden gedacht of kunnen vroeger of later, direct of indirect benaderd worden doordat er over hun plaats en vooruitzichten bij de eigen onderneming inzicht is verkregen door de gegadigde voor de onderneming. Wanneer het bekend wordt dat er sprake is van een due diligence onderzoek en hierbij doet het er niet toe of er van een vriendelijke of vijandige overname sprake is - en de koper ziet van de overname af, zou dit als een openbaar brevet van ondeugdelijkheid van de onderneming van de vennootschap gezien kunnen worden. Dit kan voor het bestuur van een doelwitvennootschap reden zijn om niet mee te werken aan het uitvoeren van een due diligence onderzoek wanneer een voornemen van een openbaar bod eenmaal bekend is geworden.

De wens om een due diligence onderzoek uit te voeren, kan een belangrijke prikkel zijn voor gegadigden om met het bestuur van de onderneming op goede voet te blijven. Ook overigens de wens om met het kader van een onderneming te kunnen spreken, de toegang die normaliter zal worden geblok-

\footnotetext{
${ }^{486}$ Zie VEB vreest voor privacy aandeelhouders, OpMaat Ondernemingsrecht 2008/118.

487 Zie A.N. Krol, V\&O, februari 2000, p. 26 e.v., I.A. Stratenus, V \& O, mei 2000, p. 83 e.v. en H.V. Oppelaar, Ondernemingsrecht 2000/10, p. 270.

488 TK $91 / 92 \mathrm{~K}, 22340$ nr. 8.
} 
keerd, wanneer er van een als vijandig te kwalificeren situatie sprake is. ${ }^{489}$ Zo liet Eric Knight, managing director van de voormalige activistische VNU-aandeelhouders Knight Vinke Asset Management, tijdens een vergadering van de Vereniging van Corporate Litigation op 19 mei 2006 weten, dat vooral voorkomen moet worden dat een overnamebod als vijandig zal worden bestempeld, omdat anders de toegang tot bedrijfsinformatie wordt afgesloten. ${ }^{490}$

Het wel of niet mogen uitvoeren van een due diligence onderzoek verwordt soms tot zelfstandige inzet van een overnamegevecht. Dit gebeurde in de strijd tussen Getronics en Ordina over de zeggenschap in PinkRoccade. In een zogenaamde bidding war verhoogde Getronics haar bod, op voorwaarde dat Ordina geen due diligence onderzoek zou mogen uitvoeren. Als PinkRoccade Ordina toestemming zou geven een due diligence onderzoek te laten verrichten, zou Getronics haar bod intrekken. Als reactie op de verhoging van het bod van Getronics verhoogde Ordina haar indicatieve bod en verlangde het recht om een due diligence onderzoek te mogen uitvoeren. Uiteindelijk stond het bestuur van PinkRoccade onder zware druk van de aandeelhouders het Ordina toe om een due diligence onderzoek uit te voeren. Getronics trok zich niet terug, maar Ordina na uitvoering van het due diligence onderzoek wel. $^{491}$

In het geval van een controlled auction kan de verkoper het onderzoeksproces (aanvankelijk) redelijk zelf in de hand houden. Waarborgen om te voorkomen dat de ins en outs van de onderneming voor alle branchegenoten en anderen openlijk bekend worden, zijn dan nog meer dan anders noodzakelijk. Er wordt in zulke gevallen vaak - al dan niet met behulp van investeringsbanken of fusiebemiddelaars - een zogenaamde long list gemaakt van alle denkbare gegadigden voor de vennootschap, de onderneming of een of meer onderdelen. Na zekere tijd wordt die teruggebracht tot een short list met namen van partijen die bereid en in staat zouden kunnen zijn om tot een transactie te geraken en die uit strategisch of ander oogpunt (zoals zorg voor continuïteit) aanvaardbaar zijn. De verkoper stelt een lijst op met voorwaarden van aanbieding (waaronder verkoopcondities en soms een concept-koopovereenkomst). De geselecteerde partijen (soms ook alle namen op de long list) worden uitgenodigd om een aanbieding te doen. Bij die uitnodiging gaat soms al direct een bid book (zie hierna), waar dan bij wordt gezegd, dat die partijen die van hun interesse doen blijken een bid book zullen kunnen ontvangen, al dan niet afhankelijk van het antwoord op de vraag of zij in de ogen van de aanbieder zullen kwalificeren naar gelang de genoemde prijsindicatie en de voorgestelde wijzigingen in de door de verkoper genoemde verkoopvoorwaarden. De AFM is van opvatting dat de verstrekking van niet-openbare informatie in het geval van een controlled auction in het informatiememorandum niet is toegestaan. Het verstrekken van zulke informatie aan een beperkt aantal overgebleven gegadigden zou minder zwaarwegend worden opgevat. Ook hier is het vooraf vragen van een ruling of een pre-clearance aan het Openbaar Ministerie of de AFM geen gangbare praktijk meer. Een controlled auction wordt wel gebruikt bij de verkoop van zowel een beursgenoteerde als een niet openbare vennootschap.

\section{Non-disclosure and abstention agreement}

Het is aan te raden dat in alle hiervoor bedoelde gevallen tussen de doelwitvennootschap en potentiële gegadigden een zogenaamde non-disclosure and abstention agreement ("NDAA") zal worden overeengekomen. Een NDAA is niet alleen een geheimhoudingsovereenkomst, maar ook feitelijk een stand still agreement. Het verbod om posities in te nemen, houdt verband met artikel 5:56 Wft (voorheen artikel 46 Wte 1995). Een enkele uitzondering op het innemen van posities is toegelaten. De wetgever had eerder al bij KB van 17 december $1998^{492}$ in artikel 1, aanhef en onder c, bepaald dat het verbod bedoeld in artikel 46 eerste lid Wte niet van toepassing is op het verrichten of bewerkstelligen van een transactie die noodzakelijk is om te kunnen voldoen aan een verplichting tot levering van aandelen of certificaten van aandelen.

In de Nota van Toelichting bij dit Besluit stond in de paragraaf "algemeen" onder meer het volgende:

\footnotetext{
${ }^{489}$ Zie hierover onder meer M. Brink, Wanneer is een overnamebod 'vriendelijk'?, Bank- en Effectenbedrijf 1998/11, p. 26 e.v. en G. van Solinge en M.P. Nieuwe Weme, Gedragsregels in zake een openbaar bod op aandelen, Serie Onderneming \& Recht, deel 16, p. 95 e.v.

490 Zie Ondernemingsrecht 2006-13, p. 481.

491 Zie Ondernemingsrecht 2006-13, p. 491.

492 Koninklijk Besluit van 17 december 1998, houdende bepalingen ter uitvoering van artikel 46, vierde lid van de Wet toezicht effectenverkeer 1995.
} 
"Als achtergrond blijt evenwel gelden dat een niet-rechtvaardig verschil in kennisniveau tussen de verschillende marktpartijen niet behoort te worden uitgezonderd van het verbod. In dit kader zijn bijvoorbeeld transacties in effecten gedurende de periode waarin een zogenaamd due diligence onderzoek plaatsvindt met het oog op eventuele deelname in of overname van de desbetreffende instelling, niet gerechtvaardigd alvorens het voornemen tot deelname of overname openbaar is gemaakt. Ook is het inkopen van eigen aandelen niet uitgezonderd. Indien inkoop van eigen aandelen toch gewenst is, zal, alvorens de inkoop plaatsvindt, deze informatie openbaar worden gemaakt.

De toelichting op artikel 1, onderdeel c van het genoemde Besluit vermeldde onder meer het volgende:

"Voorts is het verrichten van transacties in effecten om te voldoen aan een leveringsverplichting uitgezonderd. Het gaat daarbij bijvoorbeeld om het voldoen aan de uit een personeelsregeling voortvloeiende verplichting in het kader van de uitoefening van opties (...). Er zijn evenwel ook transacties denkbaar die noodzakelijk zijn om te kunnen voldoen aan leveringsverplichtingen uit andere hoofde. (...) Aangezien deze transacties uitsluitend van het verbod zijn uitgezonderd voor zover deze transacties bij ongewijzigde omstandigheden noodzakelijk zijn om aan de desbetreffende verplichting te voldoen, zal de rechtspersoon, vennootschap of instelling deze noodzaak moeten kunnen aantonen. Zij zal derhalve moeten aantonen dat door de transactie het aantal effecten waarover de rechtspersoon al dan niet op termijn beschikt, de totale (potentiële) voorraad benodigd ter voldoening aan de leveringsverplichting, niet te boven gaat" ${ }^{493}$

Richtlijn 89/592/EEG (en artikel 5:56 lid $2 \mathrm{Wft}$ ) verbiedt transacties van ingewijden met als oogmerk om het vertrouwen van de beleggers in de secundaire effectenmarkt te beschermen en aldus de goede werking van deze markt te verzekeren. Artikel 2 van de Richtlijn verbiedt personen die met name vanwege hun hoedanigheid als lid van de bestuursorganen of vanwege de uitoefening van hun werk, hun beroep of hun functie beschikken over voorwetenschap, dat wil zeggen concrete informatie die niet openbaar is gemaakt en die aanwijsbaar invloed zou kunnen hebben op de koers van één of meer effecten, van deze informatie gebruik te maken door deze effecten te verwerven of te vervreemden. Ter beperking van het aantal personen dat van dergelijke informatie gebruik zou kunnen maken door de effecten waarop deze informatie betrekking heeft te verwerven of te vervreemden, voorziet artikel 3 van de Richtlijn eveneens in een verbod voor de in artikel 2 genoemde personen om voorwetenschap aan derden mee te delen. Dit verbod is evenwel niet absoluut. Volgens artikel 3 sub a geldt het verbod niet voor de mededeling die een persoon in het kader van de normale uitoefening van zijn werk, beroep of functie verricht (vergelijk te onzent artikel 5:56 lid 2 sub c Wft). Deze regel dient restrictief te worden uitgelegd. De mededeling van voorwetenschap is slechts gerechtvaardigd indien zij strikt noodzakelijk is voor de uitoefening van het werk, beroep of functie en het evenredigheidsbeginsel eerbiedigt. ${ }^{494}$

\section{Eigen voorwetenschap en voorwetenschap over zichzelf}

Hiervoor werd in het kader van openbare biedingen reeds opgemerkt dat in de literatuur discussie bestaat over de vraag in hoeverre het de verkoper vrijstaat om koersgevoelige, niet-openbare informatie aan de koper te verstrekken en in hoeverre de koper, voorzien van zulke wetenschap een bod op de aandelen mag uitbrengen. ${ }^{495}$ Ook buiten het kader van openbaar biedingen is het interessant bij deze discussie stil te staan. Aangegeven werd dat de overnemende partij per definitie over voorwetenschap beschikt. Deze voorwetenschap betreft zogenaamde 'eigen voorwetenschap' nu de voorwetenschap is ontstaan door, en bestaat uit, het voornemen van degene die de transactie zelf wil aangaan. Eigen voorwetenschap is al vanaf de invoering van artikel 336a Sr, de voorloper van artikel $46 \mathrm{Wte}$ en ons huidige 5:56 Wft, uitgezonderd van het verbod van gebruik van voorwetenschap bij transacties in fi-

\footnotetext{
${ }^{493}$ Beide overwegingen zijn tevens opgenomen in de Nota van Toelichting bij het huidige Besluit Marktmisbruik Wft. Zie Staatsblad 2006, 510, pagina 26 en 28.

${ }^{494}$ Zie HvJ EG 22 november 2005, JOR 2006, 49.

495 Zie A.N. Krol, V\&O, februari 2000, p. 26 e.v., I.A. Stratenus, V \& O, mei 2000, p. 83 e.v. en H.V. Oppelaar, Ondernemingsrecht 2000/10, p. 270.
} 
nanciële instrumenten zoals bedoeld in artikel 5:56 Wft. ${ }^{496}$ Ingevolge artikel 5:56 lid $1 \mathrm{Wft}$ is het primair ingewijden verboden gebruik te maken van voorwetenschap door een transactie in financiële instrumenten te verrichten of te bewerkstelligen. Ingevolge lid 3 is het secundair ingewijden verboden gebruik te maken van voorwetenschap door een transactie in financiële instrumenten te verrichten of te bewerkstelligen wanneer zij weten of redelijkerwijs moeten vermoeden dat zij over voorwetenschap beschikken.

Men mag eigen voorwetenschap niet verwarren met voorwetenschap over zichzelf. Voorwetenschap over zichzelf betreft, in tegenstelling tot eigen voorwetenschap, niet de voorgenomen transactie maar andere koersgevoelige en niet-openbare informatie zoals de binnen de beursgenoteerde aanwezige informatie over een op komst zijnd openbaar bod. Advocaat-generaal Wortel beargumenteert in zijn conclusie bij het Cardio Control-arrest ${ }^{497}$ dat eveneens gedacht worden aan plannen voor een (actieve of passieve) overname of fusie, het vooruitzicht een cruciaal octrooi of merkrecht te verwerven of kwijt te raken, of de wetenschap dat externe financiers aanvullende zekerheid verlangen. Voorwetenschap over zichzelf ziet volgens hem op situaties waarin de betrokkene, zijnde een emittent of een functionaris daarvan, over vertrouwelijke en koersgevoelige informatie over de eigen kansen en mogelijkheden beschikt. Bij voorwetenschap over zichzelf geldt in beginsel niet de hiervoor genoemde exceptie.

De vraag rijst wat de reikwijdte van de exceptie van eigen voorwetenschap is. Hiervoor is het Cardio Control-arrest van belang, al kan deze uitspraak op verschillende manieren worden gelezen. ${ }^{498}$ Een verdachte plaatste berichten op een op beleggers gerichte chatbox. Deze berichten konden de indruk wekken dat één of meer partijen op grote schaal aandelen Cardio Control aan het opkopen waren. De beleggers wisten echter niet dat verdachte zelf de enige koper van grotere aantallen in het fonds was en de aandelen vaak op dezelfde dag kocht én verkocht. De rechtbank Amsterdam heeft de verdachte vrijgesproken van handel met voorwetenschap. ${ }^{499}$ Het hof oordeelde dat er wel degelijk sprake was van handel met voorwetenschap. Volgens het hof betrof het voorwetenschap over zichzelf nu de wetenschap van de verdachte verder ging dan alleen de wetenschap over de voorgenomen transactie. Immers, verdachte heeft door het verspreiden van leugenachtige berichten in combinatie met het op grote schaal uitvoeren van tegengestelde aan- en verkopen op de beurs, getracht de koers van het aandeel Cardio Control in voor hem gunstige zin te beïnvloeden. Dit handelen van verdachte was ten tijde van het uitvoeren van de transacties niet in volle omvang openbaar. ${ }^{500}$ De Hoge Raad heeft anders geoordeeld: nu de hiervoor genoemde omstandigheden (de in de bewezenverklaring als bijzonderheden opgenomen concrete feiten) door de verdachte zelf zijn geschapen, dient zijn wetenschap daaromtrent te worden aangemerkt als wetenschap omtrent zijn eigen voorgenomen effectentransacties. Op grond hiervan werd de verdachte dan ook vrijgesproken van handel met voorwetenschap. Lamp interpreteert de uitspraak van de Hoge Raad als volgt: indien in een bepaalde casus is gehandeld met voorwetenschap, waarbij de voorwetenschap zowel wetenschap over voorgenomen eigen transacties betreft en andere feiten die strikt genomen niet onder de exceptie van voorwetenschap vallen, valt het gehele feitencomplex onder eigen voorwetenschap indien en voor zover de andere feiten in het verlengde liggen van de $a b$ initio wens om via voorgenomen transacties te profiteren van de eigen geschapen voorwetenschap. Het beginpunt moet liggen bij de kennis van een eigen aan- of verkoopplan. ${ }^{501}$ Het bovenstaande kan aldus worden samengevat dat het verbod op gebruik van voorwetenschap niet in de weg staat aan het uitvoering geven aan een eigen voornemen tot het aangaan van transacties, indien dat voornemen niet zelf veroorzaakt wordt door informatie die voorwetenschap oplevert. ${ }^{502}$ Voorwetenschap die is verkregen naar aanleiding van een due diligence onderzoek - verricht vanuit de wens een transactie aan te gaan - zal derhalve weinig problemen opleveren. Dit is anders indien men reeds vóór het verrichten van een due diligence onderzoek beschikt over koersgevoelige informatie en op basis daarvan voornemens is een transactie aan te gaan. In dat geval dient men erop bedacht te zijn dat geen sprake is van exceptie van eigen voorwetenschap.

\footnotetext{
${ }^{496}$ R. Lamp, Eigen voorwetenschap en aanverwante kwesties, Ondernemingsrecht 2008, 4, p. 153.

${ }^{497}$ Zie HR 6 februari 2007, RF 2007, 19 en JOR 2007/73, nr. 23.

${ }^{498}$ R. Lamp, Eigen voorwetenschap en aanverwante kwesties, Ondernemingsrecht 2008, 4, p. 152-159.

499 Rb. Amsterdam 3 juli 2003, JOR 2003/205.

${ }^{500}$ Hof Amsterdam 12 juli 2005, JOR 2005/298.

${ }^{501}$ R. Lamp, Eigen voorwetenschap en aanverwante kwesties, Ondernemingsrecht 2008, 4, p.158.

502 Zie Kamerstukken II 1997/98, 25 095, nr. 8, p. 8 en R. Lamp, Eigen voorwetenschap en aanverwante kwesties, Ondernemingsrecht 2008, 4, p.153.
} 


\section{Kosten emissie due diligence aftrekbaar}

Op 22 maart 2006 heeft het Amsterdamse gerechtshof bevestigd dat de kosten van een due diligence onderzoek ter gelegenheid van een emissie van aandelen als kosten ter vergroting van het kapitaal van de vennootschap ten laste van de winst van de desbetreffende belastingplichtige konden komen. ${ }^{503}$ Het hof overwoog dat er bij wijze van hoofdregel vanuit kan worden gegaan dat de kosten die worden gemaakt ter vergroting van kapitaal van een vennootschap ten laste van de winst van die vennootschap kunnen komen. Voor zover dit niet reeds volgde uit hetgeen is bepaald in artikel 7 van de Wet op de inkomstenbelasting 1964 in samenhang met artikel 8 van de Wet op de vennootschapsbelasting 1969 is dit, om twijfel uit te sluiten, nadrukkelijk bepaald in artikel 9, eerste lid, aanhef en onderdeel e van de Wet op de vennootschapsbelasting 1969 (tekst 1994-1995). In de zaak waarin het hof oordeelde, was het niet een geschil dat overige met de emissie verband houdende kosten, zoals kapitaalbelasting, prospectuskosten en dergelijke, maar ook de kosten van due diligence en juridisch advies, aftrekbaar zijn. ${ }^{*}$ Hierna in hoofdstuk 11 zal dieper worden ingegaan op fiscale aspecten van due diligence, meer in het bijzonder op de vertrouwelijkheid van fiscale due diligence rapportages.

\subsection{Aansprakelijkheid in de primaire markt}

In hoofdstuk 1 is het 'verschil' tussen due diligence bij kapitaalmarkttransacties en due diligence bij onderhandse bedrijfsovernames kort de revue gepasseerd. Een belangrijk verschil tussen voornoemde transacties is de mate van professionaliteit van de partijen die bij de transactie betrokken zijn. Dit is van invloed op de zorgvuldigheidsnormen die bij het verrichten van een due diligence in acht dienen te worden genomen en op de aansprakelijkheid die voortvloeit bij het niet in acht nemen van die zorgvuldigheidsnormen. De hiervoor bedoelde zorgvuldigheidsnormen vindt men terug in verschillende regelgeving - ingevoerd ter implementatie van Europese richtlijnen - om transparantie op de kapitaalmarkt te bevorderen ter bescherming van de minder of niet professionele partij die bij de transactie betrokken is (de belegger). Zo kan op de primaire markt gedacht worden aan de regelgeving op grond van de Prospectusrichtlijn. ${ }^{504}$

Vóór de implementatie van de Prospectusrichtlijn werden vragen naar aansprakelijkheid van een uitgevende instelling, van een lead manager en eventuele andere bij een prospectus betrokkenen terug gevoerd op de algemene regels betreffende onrechtmatige daad (artikel 162 e.v.) en (met name) de artikelen 6:194 e.v. (misleidende reclame). Daarnaast is er denkbaar een grond te vinden voor aansprakelijkheid in de regels betreffende toerekenbare niet nakoming, maar daarvan zal alleen sprake kunnen zijn, wanneer er van een verbintenisrechtelijke rechtsverhouding tussen de betrokkenen sprake is. Zo speelde begin 90 -jaren in ons land een geruchtmakende zaak die vragen naar prospectusaansprakelijkheid prangend onder de aandacht bracht, bekend als de Coop-affaire. Amsterdam-Rotterdam Bank N.V. (de "Bank") had als lead manager haar medewerking verleend aan een tweetal emissies van obligaties door Coopag Finance B.V. De obligaties werden gegarandeerd door Co-op AG ("Co-op"), de moedermaatschappij van Coopag Finance B.V. Voor ieder van de desbetreffende emissies was een prospectus opgemaakt, waarin onder meer de jaarstukken van Co-op waren opgenomen. Niet lang na plaatsing van de tweede emissie verschenen er in de pers negatieve berichten over Co-op als gevolg waarvan er een sterke koersdaling optrad. De obligatiehouders die zich benadeeld voelden richtten een vereniging op en die sprak de Bank aan op de grond dat de prospectussen misleidende mededelingen bevatten. De vereniging stelde de bank als uitgever van de prospectussen aansprakelijk voor de door haar leden geleden en te lijden schade. De kwestie is aan-

503 Gerechtshof Amsterdam 22 maart 2006, LJN AV5473.

* Inmiddels heeft de Hoge Raad de uitspraak van het hof van 22 maart 2006 gesanctioneerd. Zie HR 9 mei 2008, LJN AZ7382 (Samas). De Hoge Raad oordeelde dat in artikel 9 lid 1 aanhef en letter e van de Wet op de vennootschapsbelasting 1969 is bepaald dat bij het bepalen van de winst mede in aftrek komen de oprichtingskosten, alsmede de kosten van wijziging van het kapitaal. Deze bepaling heeft volgens de wetsgeschiedenis ten doel iedere twijfel over aftrekbaarheid van die kosten uit te sluiten, aldus de Hoge Raad. Tot de in mindering op de winst te brengen kosten behoren alle aan het syndicaat betaalde provisies voor bij een emissie van aandelen verrichte dienstverlening. Hieronder valt ook een in het kader van de begeleiding aan het emissiesyndicaat verstrekte vergoeding voor een door dat syndicaat afgegeven garantie voor het welslagen van de emissie tegen een vastgestelde emissiekoers. Ook die vergoeding wordt immers verstrekt voor dienstverlening ten behoeve van de uitbreiding van het kapitaal van de emitterende vennootschap. De omstandigheid dat de gegeven garantie ertoe kan leiden dat de te emitteren aandelen uiteindelijk (gedeeltelijk) bij het emissiesyndicaat zullen worden geplaatst, doet daar niet aan af. De opbrengsten voor het emissiesyndicaat behoren tot de belaste winst bij het emissiesyndicaat.

${ }^{504}$ Richtlijn 2003/71/EG van 4 november 2003 (PbEU L 345). 
leiding geweest voor een serie rechterlijke uitspraken, ${ }^{505}$ die uiteindelijk resulteerden in een vaststellingsovereenkomst tussen de vereniging en de Bank, ingevolge welke de Bank benadeelde obligatiehouders een schadeloosstelling betaalde. Blom ${ }^{506}$ bespreekt de Due diligence circulaires, die in de periode waarin de Co-op affaire zich voordeed waren verspreid door wat toen de Vereniging voor de Effectenhandel heette. Een belangrijk bestanddeel van de aan de Bank gemaakte verwijten betrof dat de bank onvoldoende eigen onderzoek had gedaan. Lees: geen genoegzaam due diligence onderzoek had verricht.

Uit het hiernavolgende overzicht van aansprakelijk van de bij een prospectus betrokken partijen, zal blijken dat ook na de implementatie van de Prospectusrichtlijn (en na de invoering van de Wft) voornoemde aansprakelijkheidsgronden relevant zijn gebleven. ${ }^{507}$

\section{Prospectusaansprakelijkheid: de effectenuitgevende instelling}

Ingevolge de verbodsbepaling van artikel 5:2 Wft - welke bepaling voortkomt uit de implementatie van de Prospectusrichtlijn - dient de uitgevende instelling bij de aanbieding van effecten een prospectus algemeen beschikbaar te stellen. ${ }^{508}$ De Prospectusrichtlijn heeft het vaststellen van de minimumvereisten in artikel 7 gedelegeerd aan de Europese Commissie, welke hieraan gevolg heeft gegeven door middel van een Verordening. ${ }^{509}$ De artikelen 4 tot en met 20 van deze Verordening bevatten voor verschillende categorieën van effecten bouwstenen en schema's met betrekking tot de informatie die ten minste dient te worden opgenomen in het prospectus. ${ }^{510}$ Ter implementatie van voornoemde Prospectusrichtlijn- en Verordening werden onder de 'oude' financiële toezichtwetgeving (Wte) de artikelen $1 \mathrm{~h}$ tot en met 6a Besluit toezicht effectenverkeer (Bte) ingevoerd. Voornoemde artikelen zijn met de invoering van de 'nieuwe' financiële toezichtwetgeving (Wft) vervangen door de volgende artikelen:

- $\quad$ de artikelen 5:12 tot en met 5:19 Wft (procedure inzake het opstellen van het prospectus en de in het prospectus op te nemen gegevens);

- $\quad$ de artikelen 5:20 tot en met 5:22 Wft (reclame-uitingen, algemeenverkrijgbaarstelling van het prospectus en geldigheidsduur van het prospectus);

- $\quad$ artikel 5:23 Wft (informatieverplichtingen na goedkeuring van het prospectus);

- $\quad$ artikel 5:24 Wft (doorlopende informatieverplichtingen).

Uitgangspunt is dus art. 5:2 Wft: de uitgevende instelling dient een prospectus algemeen beschikbaar te stellen. ${ }^{511}$ Het prospectus is een document waarmee de rechtspersoon zich in de regel richt tot het publiek met een eenzijdig aanbod tot het nemen (kopen) of ruilen van effecten. Het geeft een omschrijving van alle financiële en andere gegevens van de uitgevende instelling, de aard en inhoud van de aangeboden effecten en de daaraan verbonden rechten en plichten en de identiteit en inrichting van de uitgevende instelling. ${ }^{512}$ Ratio van de verplichting een prospectus uit te geven, is bescherming van de integriteit en betrouwbaarheid van de financiële markt. Het dient op essentiële punten juist en volledig te zijn. ${ }^{513}$

\footnotetext{
${ }^{505}$ Rb. Amsterdam 30 oktober 1991, kenbaar uit Hof Amsterdam 27 mei 1993, NJ 1993, 682; HR 2 december 1994, NJ 1996, 246 m.nt. D.W.F. Verkade en Rechtbank Amsterdam 28 augustus 1996, JOR 1996/108 en Hof Amsterdam 18 december 1997, genoemd in TVVS 1998, p. 89 m.nt. Winter.

${ }^{506}$ Zie M.A. Blom, Prospectusaansprakelijkheid van de lead manager, Nijmeegse reeks, deel 53, p. 121 e.v.

507 Zie C.M. Grundmann-van de Krol, Koersen door het effectenrecht, Den Haag: Boom Juridische uitgevers, p. $472-477$ en C.M. Grundmann-van de Krol, Koersen door de Wet op het financieel toezicht, Den Haag: Boom Juridische uitgevers, p. 538-541.

${ }^{508} \mathrm{Zie}$ over prospectusaansprakelijkheid o.m. M.A. Blom, Prospectusaansprakelijkheid van de lead manager, Nijmeegse Serie, deel 53; A.F.J.A. Leijten, V\&O 1996, p. 114; H.F.C. Schoordijk, Prospectusaansprakelijkheid, een garantieverplichting?, in Onderneming en 5 jaar nieuw burgerlijk recht, Serie Recht en Onderneming, deel 7, p. 329 e.v.; G.T.J. Hoff, De lessen van het Coop-arrest, zelfde bundel, p. 347 e.v. Zie ook L. van Braak, Van Kannenbier tot Coop: een overzicht van prospectusaansprakelijkheid in $L T$ Verzamelde 'Groninger' opstellen aangeboden aan Vino Timmerman, Groningse serie, deel 44, p. 15 e.v. en G. van Solinge, Doorbraak van prospectusaansprakelijkheid in A-T-D, Opstellen aangeboden aan Prof. Mr. P. van Schilfgaarde, p. 417 e.v.

${ }^{509}$ Verordening nr. 809/2004 van 29 april 2004 ter uitvoering van de Prospectusrichtlijn 2003/71/EG (PbEU L. 149) en Verordening nr. 1787/2006 van 4 december 2006 tot wijziging van Verordening nr. 809/2004 (PbEU L. 337).

${ }^{510}$ F.G.B. Graaf en R.A. Stegeman, Wet op het financieel toezicht, Deventer: Kluwer 2007, p. 730.

511 Behoudens de uitzonderingen genoemd in artikel 5:3 en 5:4 Wft en de vrijstellingen genoemd in de Vrijstellingsregeling Wft (Vr. Wft).

512 M.J.G.C. Raaijmakers, Ondernemingsrecht, Deventer: Kluwer 2006, p. 357.

513 S. Perrick en V.P.G. de Serière, Effecten (algemeen deel), Serie Bank en effectenrecht, Deventer: Kluwer 1991, p. 103 en R.E. de Rooy, Emissies op de Nederlandse markt, Deventer: Kluwer 2003, p. 9.
} 
Ondanks de regel dat in beginsel geen contractuele rechtsverhouding bestaat tussen belegger ${ }^{514}$ en $^{-1}$ uitgevende instelling, wordt wel gesteld dat voor voornoemde eis een contractuele grondslag bestaat; de inschrijvende belegger moet er op kunnen vertrouwen dat datgene wat in het prospectus staat ook daadwerkelijk wordt aangeboden. Het prospectus is relevant voor haar rechtspositie gezien de prijsvorming van de aangeboden effecten voor een belangrijk deel gebaseerd is op de informatie die het prospectus verschaft. In deze visie zou een belegger die inschrijft op een emissie een overeenkomst tot uitgifte van aandelen aangaan waarbij het prospectus relevante mededelingen geeft over het onderwerp van de overeenkomst. Indien de inhoud van het prospectus op relevante onderdelen afwijkt van de werkelijke situatie, kan dit aanleiding geven voor acties in de contractuele sfeer. Zo zou de belegger ingevolge art. 6:74 schadevergoeding en ontbinding kunnen vorderen uit toerekenbare tekortkoming in de nakoming of ingevolge art. 6:228 een beroep kunnen doen op dwaling en vernietiging kunnen vorderen. ${ }^{515}$ Bovendien zou een beroep op het conformiteitsvereiste van art. 7:17 jo 7:47 openstaan, welke artikelen analoog toegepast kunnen worden op de uitgifte van effecten. Immers, de overeenkomst tot uitgifte van effecten vertoont gelijkenis met de koopovereenkomst. ${ }^{516}$ De redenering die hiervoor gevolgd kan worden, is dat een aandeel een vermogensrecht is en de bepalingen inzake koop analoog van toepassing zijn op vermogensrechten voor zover dit in overeenstemming is met de aard van het recht. Interessant is stil te staan bij de vraag in hoeverre beleggers zich kunnen beroepen op het conformiteitsvereiste; dit houdt verband met hetgeen de inschrijvende belegger mag verwachten. Gezien de ruime werking van art. 7:17 kan de belegger zich op het conformiteitsvereiste beroepen indien sprake is van gebreken aan het aandeel, zoals beperking van het stemrecht, beperking van het recht op dividend, pandrecht en beslag op aandelen. De belegger mag immers verwachten dat het aandeel de eigenschappen bezit die voor normaal gebruik nodig zijn. Een belegger zal zich met name op het conformiteitsvereiste willen beroepen indien er gebreken kleven aan de onderneming die wordt gedreven door de vennootschap waarin de aandelen zijn gekocht. Gedacht kan worden aan een onderneming die kort na de koop in financiële moeilijkheden komt te verkeren, aan voor de vennootschap bedreigende aansprakelijkheden en aan een ongezonde balans. Mag de belegger tevens verwachten dat de aan de aandelen verbonden onderneming de eigenschappen bezit die voor normaal gebruik nodig zijn? In de literatuur is discussie ontstaan of de conformiteitsregel wel van toepassing kan zijn op de onderneming, aangezien het aandeel het object van de koop is en niet de daarmee verbonden onderneming. Volgens sommigen is de conformiteitsregel alleen van toepassing indien bij een aandelenkoop de onderneming zelf het oogmerk van de koop is, en niet bij de aankoop van effecten door een particuliere belegger. ${ }^{517}$ Elders in dit boek wordt dezelfde vraag aan de orde gesteld naar aanleiding van uitspraken van rechters naar aanleiding van de koop van aandelen in een onderhandse transactie. Anderen stellen dat het irrelevant is of de belegger het oogmerk heeft de onderneming te kopen; het aandeel blijft het object van de koop. De opgewekte verwachtingen - welke eveneens op de onderneming betrekking hebben - zijn wél relevant. Zo kan worden gesteld dat er niet voor niets een uitgebreide beschrijving van de onderneming wordt gegeven bij een beursgang. Het voorgaande in aanmerking nemende, kan er ten aanzien van de effectenuitgevende instelling aanleiding bestaan voor acties in de verbintenisrechtelijke sfeer. In de praktijk worden de hierboven genoemde acties echter zelden gehanteerd. ${ }^{518}$ Hierop zal ik later terugkomen.

Door de wat onzekere status van een verbintenisrechtelijke rechtsverhouding in het geval van een kapitaalmarkttransactie zal aansprakelijkheid voor een misleidend prospectus in de regel gebaseerd zijn op onrechtmatige daad. ${ }^{519}$ De financiële toezichtwetgeving geeft een aantal specifieke normen die ertoe strekken dat het prospectus volledig en correct moet zijn. ${ }^{520}$ Overtreding van die normen is onrechtmatig. Misleidende mededelingen zijn bovendien maatschappelijk onbetamelijk. De algemene norm is terug te vinden in art. 6:162 en meer in het bijzonder in de bepalingen over misleidende re-

\footnotetext{
514 Gemakshalve noem ik de niet-professionele partij bij kapitaalmarkttransacties "beleggers".

515 J.W.P.M. van der Velden, Gronden van prospectusaansprakelijkheid, Aansprakelijkheid in beroep, bedrijf of ambt 2003 , p. 673-676.

516 Zie J.E. Tielens, Zijn de banken aansprakelijk voor schade van World Online-beleggers?, NJB 2002, p. 745 en J.W.P.M. van der Velden, Gronden van prospectusaansprakelijkheid, Aansprakelijkheid in beroep, bedrijf of ambt 2003 , p. 675 .

517 M.P.P. de Planque, conformiteitsvereiste bij overnames, Vennootschap en Onderneming 2000, p. 186-188.

518 J.W.P.M. van der Velden, Gronden van prospectusaansprakelijkheid, Aansprakelijkheid in beroep, bedrijf of ambt 2003 , p. 696-697.

${ }^{519}$ A.G. Maris en S.A. Boele, Prospectusaansprakelijkheid, TVVS 1994, p. 143

${ }^{520}$ Gedacht kan worden aan de normen genoemd in artikel 5:12 tot en met 5:23 Wft, zoals eerder weergegeven.
} 
clame van art. 6:194. Bij de actie uit onrechtmatige daad van art. 6:162 zal de belegger moeten bewijzen dat de uitgevende instelling verwijtbaar heeft gehandeld. Hij dient in dit kader te bewijzen dat de uitgevende instelling verantwoordelijk was voor het prospectus, dat het prospectus onjuist of onvolledig was en dat de uitgevende instelling dit wist of behoorde te weten. ${ }^{521}$ Tevens dient de belegger het causale verband tussen de onrechtmatige gedraging en de schade aan te tonen en moet er voldaan zijn aan het relativiteitsvereiste van art. 6:163. Art. 6:194 bepaalt dat degene die omtrent goederen of diensten een mededeling openbaar maakt of laat maken, onrechtmatig handelt indien deze mededeling in een of meer opzichten misleidend is. Onder 'openbaar maken' valt tevens het publiceren van samengestelde teksten waarin reeds eerder openbaar gemaakte mededelingen zijn opgenomen. ${ }^{52}$ De stelplicht met betrekking tot de misleiding en toerekenbaarheid rust op de belegger, de bewijslast op de uitgevende instelling. De bewijslast ten aanzien van causaliteit en schade ligt echter bij de belegger. ${ }^{523}$ Ingevolge art. 6:195 lid 1 is vereist dat de uitgevende instelling de inhoud en inkleding van het prospectus geheel of ten dele zelf heeft bepaald of doen bepalen. ${ }^{524}$ Art. 6:195 lid 2 biedt de mogelijkheid voor de belegger schadevergoeding te vorderen indien schuld dan wel verwijtbaarheid aanwezig is bij de uitgevende instelling.

\section{Prospectusaansprakelijkheid: de lead manager van de emissie-begeleidende banken}

De rechtsverhouding van de lead manager van de emissie-begeleidende banken tot de belegger op de primaire markt kan onder omstandigheden gekenmerkt worden door een verbintenisrechtelijke grondslag, met name wanneer uit het prospectus blijkt dat de lead manager met de uitgevende instelling overeen is gekomen dat zij de stukken overneemt en doorplaatst aan de inschrijvende beleggers. Uit een dergelijke verklaring zou de inschrijvende belegger af kunnen leiden dat hij contracteert met de lead manager bij wie hij op de emissie inschrijft. ${ }^{525}$ Deze zienswijze biedt openingen voor acties in de verbintenisrechtelijke sfeer.

Waar de lead manager een zekere verantwoordelijkheid heeft ten aanzien van de deugdelijkheid van de inhoud van het prospectus, kan zij aangesproken worden op grond van onrechtmatige daad ex art. 6:162. ${ }^{526}$ De Hoge Raad heeft een emissieprospectus aangemerkt als door de lead manager openbaar gemaakte mededelingen in de zin van art. 6:194. ${ }^{527}$ Voor de vereisten van beide grondslagen verwijs ik hiervoor naar prospectusaansprakelijkheid: de effectenuitgevende instelling. Opgemerkt dient te worden dat de lead manager zich kan disculperen voor informatie die niet van deze afkomstig is door uitdrukkelijk te kennen te geven dat deze een bepaalde tekst niet heeft samengesteld en daarvoor niet instaat. ${ }^{528}$ Hiermee wordt bereikt dat de bewijslastomkering van art. 6:195 niet ten aanzien van het gehele prospectus geldt. De aansprakelijkheid voor onrechtmatig handelen wordt daardoor niet uitgesloten. ${ }^{52}$ In de literatuur wordt overigens de waarde betwijfeld van de door de Hoge Raad bedoelde mogelijkheid de omkering van de bewijslast teniet te doen. Immers, de verdeling van de bewijslast dient - uiteindelijk - afhankelijk te zijn van de deskundigheid van partijen en de (processuele) billijkheid van de bewijslast. ${ }^{530}$

Prospectusaansprakelijkheid: (verbintenisrechtelijke) acties jegens de uitgevende instelling en de lead manager

\footnotetext{
${ }^{521}$ J.W.P.M. van der Velden, Gronden van prospectusaansprakelijkheid, Aansprakelijkheid in beroep, bedrijf of ambt 2003, p. 677.

${ }^{522}$ HR 2 december 1994, NJ 1996, 246, r.o. 4.1 (ABN AMRO/Vereniging Coopag).

${ }^{523}$ M.A. Blom, Prospectusaansprakelijkheid van de lead manager, Deventer: Kluwer 1996, p. 197.

524 Dit kan zelfs het geval zijn indien in die tekst opgenomen mededelingen van een of meer anderen afkomstig zijn, tenzij het voorbehoud is opgenomen dat degene die de tekst openbaar maakt daarin op niet mis te verstane wijze tot uitdrukking brengt dat bepaalde mededelingen niet van hem afkomstig zijn en dat hij niet voor de juistheid van die van een of meer anderen afkomstige mededelingen instaat. Zie bovenstaand arrest r.o. 4.3.

525 J.W.P.M. van der Velden, Gronden van prospectusaansprakelijkheid, Aansprakelijkheid in beroep, bedrijf of ambt $2003, \mathrm{p}$. 676 en 692.

${ }^{526}$ Het bankensyndicaat dat de introductie begeleidt, treedt in het prospectus duidelijk naar voren vanwege de namen en logo's waardoor het prospectus op het publiek over kan komen als een publicatie van het bankensyndicaat. Zie J.W.P.M. van der Velden, Gronden van prospectusaansprakelijkheid, Aansprakelijkheid in beroep, bedrijf of ambt 2003, p. 679 .

${ }^{527}$ HR 2 december 1994, NJ 1996, 246 r.o. 4.1 (ABN AMRO/Vereniging Coopag).

${ }^{528}$ HR 2 december 1994, NJ 1996, 246, r.o. 4.3 (ABN AMRO/Vereniging Coopag).

${ }^{529}$ Zie J.W. Winter, Ontwikkelingen in het effectenverkeersrecht, NV 1996, p. 30 en C.J.H. Jansen, E.R. Schreuder en H.L.E. Verhagen, Prospectusaansprakelijkheid, Amsterdam: NIBE-SVV, p. 70-72.

${ }^{530}$ C.J.H. Jansen, E.R. Schreuder en H.L.E. Verhagen, Prospectusaansprakelijkheid, Amsterdam: NIBE-SVV, p. 70 en 84.
} 
Hoewel er denkbaar tussen de uitgevende instelling en de belegger geen verbintenisrechtelijke rechtsverhouding bestaat, kan - zoals hierboven reeds werd aangegeven - een misleidend prospectus toch aanleiding geven voor acties in de verbintenisrechtelijke sfeer. Deze verbintenisrechtelijke acties worden als gezegd in de praktijk echter nauwelijks gehanteerd. Een aanspraak jegens de uitgevende instelling is weinig interessant omdat door de aanspraak de effecten zelf minder waard worden, zo die überhaupt nog iets waard zijn door mogelijke financiële problemen. In dat geval zal de belegger de voorkeur hebben een kapitaalkrachtige derde aan te spreken zoals de lead manager van de emissiebegeleidende banken wanneer deze de stukken over heeft genomen en doorgeplaatst heeft aan de inschrijvende belegger. ${ }^{531}$ Echter, ook ten aanzien van de lead manager worden verbintenisrechtelijke acties in het kader van misleidende prospectussen nauwelijks gehanteerd. ${ }^{532}$ Reden hiervoor zou kunnen zijn dat artikel 6:195 de benadeelde belegger een verlichting van de bewijslast biedt. ${ }^{533}$ Verbintenisrechtelijke acties zouden wel voordelen kunnen bieden aan de misleide belegger. Zo hoeft er bij de actie tot vernietiging en ontbinding geen discussie gevoerd te worden over de hoogte van de schade maar kunnen de stukken geretourneerd worden tegen aanschafprijs. Daarnaast is voor ontbinding op grond van tekortkoming niet vereist dat de tekortkoming aan de vervreemdende partij kan worden toegerekend. Nadeel van ontbinding en vernietiging is dat beleggers verplicht zijn hun effecten te retourneren wanneer de actie - doorgaans na vele jaren - slaagt. Indien beleggers hun stukken al hebben verkocht en de koers van de effecten weer gestegen is tot boven de uitgiftekoers, leidt de ongedaanmakingsverplichting zelfs tot verlies. Remedie voor dit nadeel zou kunnen zijn het naast elkaar vorderen van verschillende verklaringen voor recht. Op iedere gevorderde verklaring dient te worden beslist. Zo kan een verklaring voor recht worden gevraagd inhoudende dat beleggers op de primaire markt bevoegd zijn de koopovereenkomst te vernietigen op grond van dwaling dan wel te ontbinden op grond van tekortkoming in de nakoming. Gelijktijdig kunnen verklaringen voor recht worden gevorderd inhoudende dat de wederpartij aansprakelijk is tot schadevergoeding uit hoofde van art. 6:194, 6:162 of 6:74. De belegger kan aan het einde van de procedure nog kiezen of hij vernietigt, ontbindt of schadevergoeding vordert. ${ }^{534}$

Gezien het bovenstaande berust een aanspraak vanwege een misleidend prospectus in de regel dus op misleidende reclame of op onrechtmatige daad. Omdat art. 6:195 de bewijslast omkeert ten aanzien van de juistheid van het prospectus en de toerekenbaarheid zal deze actie de voorkeur genieten. ${ }^{535}$ Art. 6:195 kent echter geen bewijslastomkering ten aanzien van de causaliteit en schade. Bij het causaal verband tussen de misleiding en de verwerving van effecten kan de vraag gesteld worden in hoeverre het prospectus invloed heeft gehad op de beslissing van de belegger om de effecten te nemen. Indien de belegger het prospectus tevoren niet heeft ingezien, de misleidende mededeling niet heeft opgemerkt of enkel is afgegaan op het feit dat een bepaalde bank als lead manager betrokken was, is het onwaarschijnlijk dat de mededeling een rol heeft gespeeld bij zijn beslissing. Indien de belegger echter is afgegaan op een koersstijging als reactie op de misleidende mededeling, is wel denkbaar dat hij heeft gekocht op basis van de misleidende mededeling in het prospectus. ${ }^{536}$

Met betrekking tot de causaliteit is ook de geldigheidsduur van het prospectus van belang: kan een belegger die een jaar na uitgifte van het prospectus effecten koopt en vervolgens schade lijdt, stellen dat deze schade het gevolg is van een misleidende mededeling in het prospectus? Het prospectus is bedoeld om gebruikt te worden bij gelegenheid van een bepaalde aanbieding. In dit opzicht is het onwaarschijnlijk dat de belegger op de secundaire markt nog een beroep kan doen op art. 6:194. Bovendien blijkt uit art. 5:21 en 5:22 Wft dat een prospectus op de dag van uitgifte begint te verouderen. Naarmate de tijd verstrijkt zal de belegger dan ook minder op het prospectus af mogen gaan. Daarnaast zou een verouderd prospectus een omstandigheid kunnen zijn die meegenomen dient te worden

\footnotetext{
${ }^{531}$ M.E. Franke, Aansprakelijkheid voor misleidende informatie in een emissieprospectus, Bedrijfsjuridische berichten, 1989 , p. 273-274 en C.J.H. Jansen, E.R. Schreuder en H.L.E. Verhagen, Prospectusaansprakelijkheid, Amsterdam: NIBE-SVV, p. 40.

532 Zie J.W.P.M. van der Velden, Gronden van prospectusaansprakelijkheid, Aansprakelijkheid in beroep, bedrijf of ambt 2003 , p. 676 en 692

533 C.J.H. Jansen, E.R. Schreuder en H.L.E. Verhagen, Prospectusaansprakelijkheid, Amsterdam: NIBE-SVV, p. 29.

534 J.W.P.M. van der Velden, Gronden van prospectusaansprakelijkheid, Aansprakelijkheid in beroep, bedrijf of ambt 2003 , p. 693-694.

535 Overigens zij hier opgemerkt dat de lead manager zich kan disculperen voor informatie die niet van hem afkomstig is waardoor de bewijslastomkering niet ten aanzien van het hele prospectus geldt.

${ }^{536}$ Zie M.A. Blom, Prospectusaansprakelijkheid van de lead manager, Deventer: Kluwer 1996, p. 153-154. Overigens kan een belegger denkbaar op grond van artikel 843a Rv overlegging van een due diligence rapport vragen van de lead manager.
} 
in het kader van art. 6:101 (eigen schuld). ${ }^{*}$ Tot slot is de aard van de mededeling van belang voor de vraag naar de geldigheidsduur van een prospectus. ${ }^{537}$

Daarnaast speelt de vraag naar de hoogte van de schade, welke doorgaans gezocht wordt in de sfeer van koersdaling. Hier speelt veelal het probleem dat de koerdaling eveneens door andere factoren zoals een algehele daling van het beursklimaat of bij obligaties een wijziging van de rentestand veroorzaakt kan zijn. ${ }^{538}$

\section{Prospectusaansprakelijkheid: de accountant}

De relatie tussen de belegger en de accountant wordt mijns inziens niet gekenmerkt door een verbintenisrechtelijke grondslag. De overeenkomst van opdracht in de zin van titel 7 van boek 7 zou als een verbintenisrechtelijke grondslag kunnen worden gezien. Bij die laatstbedoelde rechtsverbinding is echter de rechtspersoon de opdrachtgever en niet de belegger.

In geval een accountant een goedkeurende verklaring verstrekt bij misleidende financiële verantwoording ten gevolge waarvan beleggers schade hebben geleden, kan deze derhalve enkel aangesproken worden op grond van art. 6:162. ${ }^{539}$ Voor een geslaagde actie dient voldaan te zijn aan de vereisten van art. 6:162 en het relativiteitsvereiste van art. 6:163. De toetsingsmaatstaf is de 'redelijk bekwaam en handelend vakgenoot'. De accountant dient zich ervan bewust te zijn dat de door hem afgegeven verklaring over een jaarrekening in het prospectus wordt opgenomen en dat deze mede de grondslag zal vormen van beslissingen van beleggers over de aankoop van effecten. ${ }^{540}$ Valt de individuele belegger onder het begrip benadeelde zoals bedoeld in art. 6:163? Benadeelden zijn volgens de literatuur 'degenen van wie de accountant, op het moment dat hij de jaarstukken opstelt of controleert, weet dat zij zullen afgaan op de desbetreffende stukken en op die basis zullen handelen' of 'belanghebbenden in de zin van art. 999 Rv', waarbij als criterium geldt 'bescherming van alle belangen van al degenen voor wie het onderzoek naar de getrouwheid van de jaarrekeningen is voorgeschreven'. ${ }^{441}$ Volgens deze criteria zouden beleggers onder het begrip benadeelden kunnen vallen. De wet gaat ervan uit dat voldaan is aan het relativiteitsvereiste tenzij het tegendeel wordt bewezen. Hiermee komt de bewijslast op de accountant te rusten. De bewijslast met betrekking tot de schade en causaliteit rusten op de belegger. Onzeker is of de accountant ook aangesproken kan worden op grond van de bepalingen omtrent misleidende reclame - welke de bewijslast omkeren ten aanzien van de misleiding en toerekenbaarheid - indien zijn verklaringen in een prospectus niet juist zijn. ${ }^{542}$ Wel wordt gesteld dat de accountant zorgplichten heeft ten opzichte van derden tot wie het prospectus zicht richt en wel voor wat betreft hetgeen met het prospectus wordt beoogd te worden verhandeld. ${ }^{543}$

\section{Prospectusaansprakelijkheid: bestuurders en commissarissen}

Zie voor eigen schuld ook het hierna te bespreken arrest van de Hoge Raad van 30 mei 2008, LJN BD2820.

${ }^{537}$ Betreft de mededeling bijvoorbeeld naar hun aard fluctuerende gegevens, dan zal de belegger er betrekkelijk snel niet meer van uit mogen gaan dat hij op het prospectus af mag gaan.

${ }^{538}$ M.A. Blom, Prospectusaansprakelijkheid van de lead manager, Deventer: Kluwer 1996, p. 154-158.

539 HR 9 juni 1995, RvdW 1995, 129 (Finad/Worst) en J.W.P.M. van der Velden, Gronden van prospectusaansprakelijkheid, Aansprakelijkheid in beroep, bedrijf of ambt 2003, p. 685.

540 C.J.H. Jansen, E.R. Schreuder en H.L.E. Verhagen, Prospectusaansprakelijkheid, Amsterdam: NIBE-SVV, p. 19. De accountant zal in het normale geval ook niet zonder het vragen van vrijwaringen of het bedingen van exoneraties - in ieder geval in de relatie met diens opdrachtgever - toestemming geven voor het noemen van een verklaring of zelfs maar zijn naam in een prospectus.

541 Zie A.T. Bolt en J. Spier, "De uitdijende reikwijdte van de aansprakelijkheid uit onrechtmatige daad", in: Preadvies Nederlandse Juristen Vereniging, Zwolle: Tjeenk Willink 1996, p. 157

542 De discussie in de literatuur spitst zich vooral toe op 'het openbaar maken dan wel openbaar laten maken'. Indien een accountant toestaat dat zijn verklaring in het prospectus wordt opgenomen, is er sprake van 'openbaar laten maken' in de zin van art. 2:194. Echter, 'openbaar laten maken' kan ook worden verstaan als 'doen publiceren'. De parlementaire geschiedenis geeft voorbeelden waarin degene die 'laat openbaar maken' de misleidende reclame-uitingen 'doet publiceren'. De parlementaire geschiedenis laat zich echter niet expliciet uit over de vraag of het toestaan van publicatie onder 'laten openbaar maken' kan worden begrepen. Zie J.W.P.M. van der Velden, Gronden van prospectusaansprakelijkheid, Aansprakelijkheid in beroep, bedrijf of ambt 2003, p. 686-689 en M.A. Blom, Prospectusaansprakelijkheid van de lead manager, Deventer: Kluwer 1996, p. 71.

${ }^{543}$ E.J.A.M. van den Akker, Beroepsaansprakelijkheid ten opzichte van derden, uitgave vanwege het Schoordijk Instituut, Den Haag: Boom Juridische uitgevers 2001, p. 79. 
De vraag is wel opgekomen of bestuurders en/of commissarissen van uitgevende instellingen of begeleidende syndicaten eveneens aansprakelijk gesteld kunnen worden voor een misleidend prospectus krachtens artikel 6:194. In 2002 heeft de Europese Commissie in het kader van een (destijds) nieuwe prospectusrichtlijn een voorstel gedaan welke inhield dat aansprakelijkheid voor het prospectus zou moeten berusten bij de leidinggevende en toezichthoudende organen van (onder andere) de uitgevende instelling. Dit voorstel is echter verworpen: door de lidstaten hoeft geen wettelijke basis te worden gecreëerd voor persoonlijke aansprakelijkheid van bestuurders en commissarissen ${ }^{544}$ Wel zouden bestuurders en commissarissen aansprakelijk gesteld kunnen worden op grond van artikel 6:162. In 1928 oordeelde de Hoge Raad al dat een bestuurder een onrechtmatige daad pleegt wanneer deze tegen beter weten in een geheel scheve voorstelling van zaken geeft van de staat van zaken van de vennootschap, en daardoor een derde beweegt om in deze vennootschap aandelen te nemen. ${ }^{545}$ Vervolgens werd in 1958 geoordeeld dat wanprestatie, gepleegd in de kwaliteit van orgaan van een rechtspersoon, niet in de weg staat aan persoonlijke aansprakelijkheid op grond van onrechtmatige daad. ${ }^{546}$ Met andere woorden: de handelende bestuurder kan zich niet verschuilen achter aansprakelijkheid van de rechtspersoon die hij vertegenwoordigt, om zich aan persoonlijke aansprakelijkheid te onttrekken indien hij persoonlijk verwijtbaar betrokken is bij de schadeveroorzakende handeling. Opgemerkt dient te worden dat de relevantie van beide uitspraken bij beursvennootschappen aanzienlijk is verminderd door de uitgebreide Wft- en beursregulering. Denkbaar zou kunnen zijn dat een bestuurder of commissaris van de vennootschap een persoonlijk verwijt kan worden gemaakt ingeval hij in het prospectus informatie laat opnemen waarvan hij weet of zou behoren te weten dat deze onjuist of onvolledig is. Ook treft een bestuurder of commissaris een persoonlijk ernstig verwijt ingeval hij niet actief bij de samenstelling van het prospectus was betrokken maar wel wist van de misleiding en er niet tegen optrad. ${ }^{547}$

Overigens zijn bestuurders en commissarissen ingevolge artikel 2:139 hoofdelijk aansprakelijk jegens derden - waaronder beleggers - indien door de jaarrekening of tussentijdse cijfers die bekend zijn gemaakt of door het jaarverslag een misleidende voorstelling van zaken van de toestand van de vennootschap gegeven wordt en tengevolge van die misleiding schade is geleden. Indien de bestuurder dan wel commissaris bewijst dat de misleiding niet aan hem te wijten is, is hij niet aansprakelijk. ${ }^{548}$ Het verschil met art. 6:194 schuilt mijns inziens in de functie van het prospectus om het publiek voor te lichten, zodat niet lichtzinnig of op grond van verkeerde of onvolledige informatie wordt ingegaan op een aanbieding van effecten. ${ }^{549}$ Hoewel (ook) de jaarrekening een disclosure functie bezit - de jaarrekening geeft inzicht in de vennootschap aan aandeelhouders en potentiële investeerders - dient de jaarrekening met name de rekening- en verantwoordingsplicht voor gevoerd beheer en bestuur. ${ }^{550}$

\section{Prospectusaansprakelijkheid: administratiefrechtelijke aansprakelijkheid}

De jurisprudentie die ontwikkeld is in het kader van de misleidende reclameregeling van art. 6:194 is niet alleen van belang voor de civielrechtelijke prospectusaansprakelijkheid, maar eveneens voor de administratiefrechtelijke (prospectus)aansprakelijkheid.

Ingevolge art. 5:20 lid 1 sub b Wft mag een reclame-uiting niet onjuist of misleidend zijn. Grundmannvan de Krol merkt hierover het volgende op:

"Onder het civiele recht geldt reeds de eis dat een reclame-uiting niet onjuist of misleidend mag zijn. De reden dat gekozen is voor het tevens in de Wft opnemen van de in artikel 15 lid 3 Prospectusrichtlijn neergelegde eis dat de reclame-uiting niet onjuist of misleidend mag zijn - met het gevolg dat bij niet-naleving de AFM kan optreden - is waarschijnlijk daarin gelegen dat de Prospectusrichtlijn in artikel 21 de lidstaten verplicht een centrale

\footnotetext{
${ }^{544}$ C.J.H. Jansen, E.R. Schreuder en H.L.E. Verhagen, Prospectusaansprakelijkheid, Amsterdam: NIBE-SVV, p. 18.

${ }^{545}$ HR 25 november 1927, NJ 1928, p. 364 (Kretzschmar/Mendes de Leon).

${ }^{546}$ HR 31 januari 1958, NJ 1958, 251 (Van Dullemen/Sala).

547 G. van Solinge, Doorbraak van prospectusaansprakelijkheid, in: A-T-D, Opstellen aangeboden aan Prof. Mr. P. van Schilfgaarde, Deventer: Tjeenk Willink 2000, p. 424.

${ }_{548}^{5}$ Noot Raaijmakers bij HR 2 december 1994, AA 1995, 44, p. 224 (ABN AMRO/Vereniging Coopag).

${ }^{549}$ M.A. Blom, Prospectusaansprakelijkheid van de lead manager, Deventer: Kluwer 1996, p. 6.

${ }^{550}$ M.J.G.C. Raaijmakers, Vennootschaps- en rechtspersonenrecht, Deventer: Gouda Quint 2000, p. 497.
} 
bevoegde autoriteit aan te wijzen die verantwoordelijk is voor het zeker stellen dat de ter uitvoering van de Prospectusrichtlijn vastgestelde bepalingen worden toegepast. Aangenomen mag worden dat de AFM in de uitoefening van haar taak om toezicht uit te oefenen op de naleving van de reclame-bepalingen rekening houdt met de jurisprudentie die ontwikkeld is in het kader van artikel 6:194 BW inzake misleidende reclame. ${ }^{, 551}$

\section{Enkele uitspraken}

De mededelingsplicht van financiële instellingen is niet beperkt tot het verrichten van een due diligence onderzoek en het verslag doen daarvan. In ieder geval moet er verantwoordelijkheid worden gedragen voor de voorstelling van zaken, die in of door een prospectus in het leven wordt geroepen. Dit leert een uitspraak van het gerechtshof Amsterdam van 3 mei 2007 (WorldOnline) ${ }^{552}$ Deze zaak draaide om de verkoop door de houdstervennootschap van Nina Brink in augustus 1999 van aandelen WorldOnline tegen een prijs van USD 6,04 per aandeel. Op 22 februari 2000 heeft WorldOnline bekend gemaakt naar de beurs te gaan. ABN AMRO en Goldman Sachs waren joint global coordinator, joint lead manager en joint book runner voor de introductie op de Amsterdamse Effectenbeurs. Het voorlopig prospectus is op 3 maart 2000 gepubliceerd en 16 maart 2000 definitief geworden. De introductieprijs was EUR 43, -- per aandeel. De VEB en de Stichting VEB - Actie - WOL ("de Stichting") hebben een vordering ingesteld namens gedupeerde beleggers, gebaseerd op uitlatingen dat de houdstermaatschappij van Nina Brink een ander belang had dan in werkelijkheid.

De rechtbank heeft als volgt geoordeeld:

- Voor recht verklaard dat WorldOnline door uitlatingen die Nina Brink op 1 maart 2000 heeft gedaan en door het niet corrigeren van die uitlatingen en nadien in de media verschenen berichten omtrent het (ongewijzigde) belang van Nina Brink, onrechtmatig heeft gehandeld jegens beleggers in aandelen WorldOnline, die op de beursintroductie hebben ingeschreven of na de beursintroductie, uiterlijk op 3 april 2000, aandelen WorldOnline hebben gekocht;

- WorldOnline veroordeeld aan de Stichting alle schade te vergoeden die de deelnemers door voormelde onrechtmatige daad hebben geleden, op te maken bij staat.

In hoger beroep wordt de Stichting niet-ontvankelijk verklaard. Zulks op grond van meerdere redenen. De akte van cessie is niet geproduceerd en de cessionarissen zijn onvoldoende geïdentificeerd. Ook van lastgeving aan de Stichting kon de Stichting onvoldoende doen blijken. De procedure wordt derhalve voortgezet tussen de VEB enerzijds en anderzijds WorldOnline, ABN AMRO en Goldman Sachs. De VEB wordt op grond van artikel 3:305a toegelaten als volledig rechtbevoegde vereniging die blijkens haar statuten tot doel heeft de belangen van beleggers te behartigen. Het verweer dat haar achterban onvoldoende gelijksoortig is om de zaak voor een collectieve actie in aanmerking te doen komen, wordt afgewezen:

"VEB komt in deze zaak op voor de belangen van beleggers die in de periode van 17 maart 2000 tot en met 3 april 2000 aandelen WorldOnline hebben verworven (hierna: de Beleggers) en - zo is zeer kort samengevat de stelling van VEB - voor of bij de aankoop daarvan door WorldOnline, ABN Amro en/of Goldman Sachs zijn misleid waardoor de beleggers schade hebben geleden. Dat is een voldoende gelijksoortig belang om VEB in een collectieve actie op voet van artikel 3:305a BW te kunnen ontvangen. Dat er tussen de beleggers onderling aanmerkelijke verschillen zijn in onder meer professionaliteit, mate van geïnformeerdheid, zorgvuldigheid bij het nemen van de beleggingsbeslissing en omvang van het geleden koersverlies, alsmede dat sommige van hen geen natuurlijk persoon maar een rechtspersoon zijn, kan daaraan niet afdoen. Dat zijn immers omstandigheden waarmee bij de bepaling van een eventueel toe te kennen schadevergoeding in een door ieder van de beleggers aan te spannen vervolgprocedure rekening kan worden gehouden".

\footnotetext{
${ }^{551}$ C.M. Grundmann-van de Krol, Koersen door de Wet op het financieel toezicht, Den Haag: Boom Juridische uitgevers, p. 121122.

552 LJN BA4343.
} 
Een verwijt betrof onvolledigheid van het prospectus. Daarin werd niet vermeld dat Nina Brink in het verleden betrokken was geweest bij de financiële ondergang van een aantal ondernemingen. Het verweer was dat er ten tijde van de beursgang geen wettelijke of andere regel een uitgevende instelling ertoe verplichtte in het prospectus informatie op te nemen over een faillissement, waarbij een bestuurder in het verleden betrokken is geweest.

Het hof is van oordeel dat zowel de positieve als negatieve elementen van iemands carrière moeten worden genoemd. Zonder aan het beknopte karakter van de beschrijving van de loopbaan van Nina Brink af te doen, was het eenvoudig mogelijk geweest vollediger te zijn.

Het hof wijst het verwijt van de hand, dat in het prospectus onvoldoende duidelijk tot uitdrukking zou zijn gebracht dat de holding van Nina Brink kort voor de beursgang haar aandelen had verkocht. Hoewel er veel te doen is geweest over het woord "transferred", moet het voor het hof voor een gemiddeld geïnformeerde omzichtige en oplettende gewone belegger, die de Engelse taal voldoende machtig is en kennis heeft genomen van het prospectus, duidelijk zijn geweest dat Nina Brink een groot deel van haar aandelenbezit voor de beursgang van de hand had gedaan. Het verwijt dat de prijs waartegen Nina Brink had verkocht, niet in het prospectus werd vermeld, leidt uiteindelijk niet tot een veroordeling. De ten tijde van de beursgang geldende regelgeving verlangde niet dat dergelijke informatie zou worden genoemd, maar slechts dat het prospectus informatie gaf omtrent de financieel-economische situatie van de uitgevende instelling, waartoe verkoop door derden van aandelen van de uitgevende instantie niet kan worden gerekend. Ook al is die derde voorzitter van de raad van bestuur. Wel meent het hof dat de omstandigheid dat de voorzitter van de raad van bestuur door het aanvaarden van een zeer lage prijs tot uitdrukking brengt zelf weinig vertrouwen te hebben in de toekomst van het bedrijf, vermelding behoefde. Een prijsvergelijking was echter niet eenvoudig (door een tevens afgesproken winstdelingsregeling), zodat per saldo het niet vermelden van de prijs in het prospectus niet tot onjuiste informatievoorziening heeft geleid.

Een volgend verwijt betrof het beeld dat in de media in stand was gelaten, dat Nina Brink over een ruim aandelenbezit beschikte en dat zij niet voornemens was bij de beursgang aandelen te verkopen. Met de rechtbank is het hof van oordeel dat beleggers relevante informatie is onthouden, waar het gaat om de verkoop door de holding van Nina Brink enige maanden voor de beursgang. Het hof overweegt:

\begin{abstract}
"Daaruit kan immers blijken in welke mate Nina Brink, herhaaldelijk en onweersproken aangeduid als het boegbeeld van WorldOnline, vertrouwen had in haar eigen onderneming. Dat klemt in dit geval temeer daar WorldOnline tot dan nog zeer verlieslatend was en een belegging in aandelen WorldOnline louter gebaseerd was op gunstige toekomstverwachtingen. Uit de omstandigheid dat Nina Brink een substantieel deel van haar aandelen WorldOnline had verkocht, had mogelijk afgeleid kunnen worden dat zij zelf geen vertrouwen had in deze onderneming".
\end{abstract}

De opmerkingen van Nina Brink worden aan WorldOnline toegerekend. Zij trad op als bestuursvoorzitter en zegsvrouwe, teneinde informatie te geven over en belangstelling te wekken voor de op handen zijnde beursgang. Die mededelingen vallen onder het bereik van artikel 6:194 (omtrent aangeboden goederen en diensten).

Opvallend is nog dat het hof meent dat een belegger een koopbeslissing in belangrijke mate zal hebben gebaseerd op publiciteit in de media en niet op de exacte inhoud van het prospectus:

"In veel gevallen zal deze belegger geen kennis hebben genomen van het prospectus, ook al niet omdat - zoals VEB onbestreden heeft opgemerkt - dit slecht verkrijgbaar was, hetgeen een omstandigheid is die WorldOnline behoorde te betrekken bij haar afweging al dan niet naast het prospectus nadere informatie te verstrekken".

Ook ABN AMRO en Goldman Sachs hadden de verplichting een juist beeld van WorldOnline te geven in het prospectus en te voorkomen dat het juiste beeld werd verstoord door misleidende presentaties in de pers: 
"In dat verband mag van hen worden verlangd dat zij bijvoorbeeld de leiding van WorldOnline deugdelijk hadden geïnstrueerd en de persconferentie van 1 maart 2000 zodanig hadden begeleid, dat er bij Nina Brink geen onzekerheid was opgetreden wat nu wel en wat niet aan journalisten mocht worden meegedeeld, vooruitlopend op het verschijnen van het prospectus".

Andere verwijten, zoals het niet voldoende specifiek vermelden van de emissieopbrengst of het noemen van een conversiekoers bij het omzetten van leningen geven het hof geen aanleiding tot een veroordeling. Anders is dit met het bericht in het prospectus dat een vennootschap in Zweden was gekocht, terwijl dit feitelijk niet het geval was. Relevant is met name nog de navolgende overweging van het hof:
"Het Hof neemt het uitgangspunt dat koersmanipulatie niet is toegestaan, maar dat deze regel een uitzondering kent in het geval een syndicaat voor zijn rekening maatregelen treft, gericht op een stabiele prijsvorming met het oog op het in stand houden van de adequate functionering van de effectenmarkt ten behoeve van beleggers en de uitge- vende instelling."

Per saldo komt het erop neer dat door de onduidelijkheid die Nina Brink heeft gecreëerd omtrent haar aandelenbezit in WorldOnline ten tijde van de beursgang, hetgeen aan WorldOnline wordt toegerekend en waartegen ABN AMRO en Goldman Sachs als begeleiders van die beursgang onvoldoende zijn opgetreden, door onvolledige informatie over de loopbaan van Nina Brink in het prospectus op te nemen, door een dochtervennootschap in het definitief prospectus te vermelden terwijl deze niet tot het WorldOnline-concern mocht worden gerekend, en doordat WorldOnline een aantal suggestieve persberichten heeft uitgegeven waartegen ABN Amro en Goldman Sachs evenmin zijn opgetreden, hebben WorldOnline, ABN AMRO en Goldman Sachs een meer optimistisch beeld gecreëerd van de waarde en de toekomstverwachtingen van de onderneming van WorldOnline dan gerechtvaardigd was. Beleggers zijn daarop afgegaan en in zoverre misleid. WorldOnline, ABN AMRO en Goldman Sachs worden geacht onrechtmatig te hebben gehandeld jegens de beleggers.

In de volgende uitspraak van het gerechtshof Arnhem van 16 oktober $2007^{553}$ overweegt het hof onder meer dat het enkele feit dat er optimistische en achteraf als té optimistisch gebleken uitlatingen zijn gedaan, onvoldoende is om de betrokken uitlating als onjuist en/of misleidend te kwalificeren. Het arrest van het hof betreft het hoger beroep van het eindvonnis van de rechtbank Arnhem in de zaak van een groot aantal vermeend gedupeerde beleggers enerzijds en Baan Company N.V. ("Baan") en een drietal andere vennootschappen ("Vanenburg") anderzijds. ${ }^{554}$ De rechtbank had de vordering afgewezen - kort gezegd - omdat de vorderingen onvoldoende onderbouwd waren, nu er niet was overgegaan om per eiser jegens één of meer specifieke gedaagden een onderbouwing van de op onrechtmatige daad gebaseerde vorderingen te geven, die zodanig was, dat de stellingen, mits bewezen, de vordering zouden kunnen dragen. De verwijten betroffen schending van een mededelings- en informatieplicht, waardoor beleggers zouden zijn gedupeerd. Ook was op grond van artikel 843a Rv incidenteel gevorderd dat inzage zou worden verschaft in een aantal transacties, notulen van vergaderingen en van de raad van bestuur en de raad van commissarissen en dergelijke. Alle vorderingen waren door de rechtbank afgewezen. De vordering was gebaseerd op verwijten omtrent koersmanipulatie. Relevante informatie zou zijn achtergehouden. De beleggers stelden dat zij andere transacties op andere tijdstippen zouden zijn aangegaan zonder de onjuiste of misleidende mededelingen zijdens Baan en Vanenburg. Nadat de rechtbank bij tussenvonnis de eisers de mogelijkheid had geboden om hun vorderingen nader te onderbouwen en te preciseren, zijn de vorderingen afgewezen.

Het hof gaat op een technisch juridische wijze in op de verhouding tussen de verschillende vorderingen welke zijn ingesteld. De eerste vordering betrof een veroordeling tot betaling van schadevergoeding. Wanneer die vordering zou zijn geslaagd, was het de bedoeling dat er een zogenaamde schadestaatprocedure zou volgen. Het hof overweegt dat voor toewijzing van de eerste vordering ten gunste van elke afzonderlijke appellant het wel nodig is dat ten aanzien van elke individuele appellant aan de vereisten van artikel 6:162 (onrechtmatige daad) respectievelijk 6:212 (ongerechtvaardigde ver-

\footnotetext{
${ }^{553}$ LJN BB5511

${ }^{554}$ Rechtbank Arnhem 23 maart 2005, JOR 2005/140 (X e.a./Baan Company NV c.s.).
} 
rijking) wordt voldaan. Omdat het uitspreken van een veroordeling tot schadevergoeding, op te maken bij staat - een minder ver strekkende vordering is dan de primaire vordering waaraan geen strenge eisen worden gesteld - zou volgens het hof wat de vereisten van causaal verband en schade betreft, reeds voldoende zijn dat de mogelijkheid van schade als gevolg van de onrechtmatige daad aannemelijk is. Wel blijft voor het uitspreken van een dergelijke veroordeling noodzakelijk dat de veroordeelde aansprakelijk kan worden gehouden "dat wil zeggen dat hij jegens de individuele gelaedeerde ten gunste van wie een dergelijke veroordeling zou moeten worden uitgesproken, verwijtbaar onrechtmatig heeft gehandeld of de (onrechtmatige) handeling volgens de verkeersopvattingen voor zijn rekening komt".

Voor zover de vordering was gebaseerd op ongerechtvaardigde verrijking, geldt voor toewijzing van die vordering dat naast aannemelijkheid van de mogelijkheid van schade ook aan alle vereisten moet worden voldaan die voortvloeien uit artikel 6:212. Het hof onderzoekt vervolgens eerst of de vordering - die verder strekt - wegens ongerechtvaardigde verrijking voor toewijzing in aanmerking komt. Er wordt dan ingegaan op het verwijt van de eisers, dat Baan bij voortduring optimistisch en achteraf gebleken té optimistische opmerkingen had gedaan omtrent de gang van zaken. Het hof overweegt dat het enkele feit dat er optimistische en achteraf als té optimistisch gebleken uitlatingen zijn gedaan, onvoldoende is om de betrokken uitlating als onjuist en/of misleidend te kwalificeren. In zoverre wordt er iets anders ingestoken dan door de Hoge Raad in het arrest in de zaak van WorldOnline.

Niettemin zit er iets in de overweging van het hof, waar wordt opgemerkt:

"Daarbij moet in aanmerking worden genomen dat het niet erom gaat of de gedane mededelingen achteraf bezien te optimistisch zijn geweest, maar of op het moment dat mededelingen werden gedaan over toekomstige ontwikkelingen, feiten en/of omstandigheden, bekend of redelijkerwijs voorzienbaar waren op grond waarvan de betrokken mededeling met betrekking tot die toekomstige ontwikkelingen niet houdbaar, althans te optimistisch en daardoor onjuist en/of misleidend waren."

Opnieuw vallen de eisers in het zwaard van de onvoldoende onderbouwing van hun vordering.

Ter zake van de verwijten over het achterhouden van informatie met betrekking tot twee intra-concerntransacties (ter zake waarvan het verwijt van belangenverstrengeling werd gemaakt) overweegt het hof:

"In de eerste plaats geldt in zijn algemeenheid dat de door de eisers aangehaalde passages slechts onderdelen zijn van publicaties (die op hun beurt veelal weer een selectie zijn van hetgeen daadwerkelijk aan de verslaggever is meegedeeld). Aldus kan op het enkele aanhalen van die fragmenten nimmer het verwijt worden gebaseerd dat die fragmenten onvolledig zijn, of dat betrokkenen daarmee zijn tekort geschoten in op hen rustende informatie- of mededelingsplichten. Voorts geldt met betrekking tot de twee transacties dat deze wel degelijk in de jaarrekening .... stonden beschreven, evenals dat het transacties met "related parties" betrof, en dat deze derhalve voor iedereen kenbaar waren".

In het onderhavige arrest wordt ook de activa/passiva-transactie in feite gesanctioneerd, welke erop neer kwam dat de activa en passiva van Baan werden overgedragen aan Invensys Plc tegen een vergelijkbaar bedrag als de aandelenwaarde van dat moment. Het hof overweegt:

"Voor zover de eisers hebben betoogd met het vorenstaande tevens Vanenburg uit dien hoofde aansprakelijk te stellen, constateert het Hof dat de eisers geen daarop gerichte vordering hebben ingesteld, maar voegt het daaraan volledigheidshalve toe dat in het voorgaande reeds besloten ligt dat een dergelijke vordering ook jegens Vanenburg niet zou kunnen slagen, omdat de betrokken crediteuren van Baan door de gewraakte handelingen geenszins in hun verhaalsmogelijkheden zijn benadeeld".

Daarmee werd gesanctioneerd dat Invensys de activa/passiva kocht voor hetzelfde bedrag als waarmee een openbaar bod had kunnen worden gedaan op alle uitstaande aandelen. Door vervolgens Baan te liquideren en de opbrengst voor de activa/passiva aan aandeelhouders uit te keren, werd een 
vergelijkbaar resultaat behaald als bij het doen slagen van een openbaar bod. De vordering wegens ongerechtvaardigde verrijking wordt afgewezen, nu de één verrijkt moet zijn ten koste van de ander. Dat gegeven was door de eisers onvoldoende geconcretiseerd. Al met al zijn er de nodige lessen te trekken uit de gebeurtenissen in deze zaak voor advocaten die - onvoldoende voorbereid - vorderingen namens gedupeerde beleggers willen instellen.

Interessant is de volgende uitspraak van de Hoge Raad waarin bij beantwoording van de vraag of een brochure misleidend is in de zin van artikel 6:194 BW wordt uitgegaan van de vermoedelijke verwachting van een gemiddeld geïnformeerde, omzichtige en oplettende gewone consument. Bij de vraag naar de mate van eigen schuld in het kader van de omvang van de schadevergoedingsplicht wordt echter de ervaren zakenman als maatman genomen. ${ }^{555}$

Een besloten vennootschap heeft de naamloze vennootschap HSI opgericht met het oogmerk om door middel van dochtervennootschappen een stuk grond en een thermale bron in Spanje te ontwikkelen ("het Project"). Naar aanleiding van een brochure - waarin TMF als financieel adviseur wordt genoemd - hebben twintig beleggers ("de Investeerders") zich bereid gevonden te investeren in het Project door deelname in het kapitaal van HSI. In de brochure was een door TMF opgestelde begroting van de financiering, de kosten en de baten van het Project opgenomen. Deze brochure bleek achteraf te rooskleurig te zijn. HSI slaagde er namelijk niet in het Project uit te voeren.

De Investeerders vorderen schadevergoeding. TMF heeft volgens hen onrechtmatig gehandeld nu zij onder meer misleidende mededelingen als bedoeld in artikel 6:194 en 6:195 openbaar heeft gemaakt. Het hof is van mening dat de brochure wellicht voor het gemiddeld publiek misleidend zou kunnen zijn aangezien van de brochure twee pagina's een artists impression geven, op drie pagina's de historische achtergronden van de bron en de bedoelding van het Project worden geschetst en de financiële prognose voor het Project en de exploitatieprijzen van vergelijkbare projecten slechts twee pagina's beslaan. Van de Investeerders - die allen (onbestreden) ervaring in de zakenwereld hebben - mag echter toch worden verwacht dat zij weten wat de waarde van prognoses is en dat zij, indien zij enige aarzeling hadden over de haalbaarheid van het project, dit bij de presentatie daarvan aan de orde hadden gesteld, aldus het hof. Volgens de Investeerders verliest het hof hier uit het oog dat de uitgever van een brochure als de onderhavige gehouden is daarin volledige en niet-misleidende mededelingen te geven en dat, zo hij aan die verplichting niet heeft voldaan, het onvolledige of misleidende karakter van de brochure niet wordt weggenomen door de mogelijkheid dat beleggers, die ervaring in de zakenwereld hebben, vragen kunnen stellen of nadere mededelingen kunnen krijgen. De Hoge Raad is het hiermee eens:

"Bij beantwoording van de vraag of de brochure misleidend is in de zin van artikel 6:194 $B W$ had het hof behoren uit te gaan van de vermoedelijke verwachting van een gemiddeld geïnformeerde, omzichtige en oplettende gewone consument tot wie de brochure zich richt of die zij bereikt. De omstandigheid dat de Investeerders ervaring in de zakenwereld hebben behoort derhalve bij de beantwoording van de hiervoor bedoelde vraag geen gewicht in de schaal te werpen, nu het hof niet heeft vastgesteld dat de kring van personen tot wie de brochure zich richtte of die zij heeft bereikt uitsluitend bestaat uit personen die ervaring in de zakenwereld hebben."

Het hof blijft consequent. Bij de vraag naar de mate van eigen schuld in het kader van de omvang van de schadevergoedingsplicht acht het hof aannemelijk dat de schade van de Investeerders mede is ontstaan doordat zij, ervaren zakenmensen, hebben nagelaten zich deugdelijk te informeren. Bij goede lezing van de brochure moet voor hen kenbaar zijn geweest dat met name de door TMF gegeven prognose niet was gefundeerd op deugdelijk, verifieerbaar, cijfermateriaal. Het hof stelt de mate waarin de aan ieder van partijen toe te rekenen omstandigheden hebben bijgedragen tot de door de Investeerders geleden schade dan ook vast op de verhouding 50:50. Naar mening van de Investeerders is

\footnotetext{
Hoge Raad 30 mei 2008, LJN BD2820.

${ }^{555}$ Zie in dit verband eveneens M. Brink, De Maatman bij Corporate Governance, Geschriften vanwege de Vereniging Corporate Litigation 2004-2005, Deventer: Kluwer 2005, p. 91-97.
} 
vermindering op de voet van artikel 6:101 van de schadevergoedingsplicht wegens onrechtmatig handelen als bedoeld in artikel 6:194 op de grond dat de schade mede een gevolg is van de aan de benadeelde toe te rekenen omstandigheid dat die nagelaten heeft zich deugdelijk te informeren, rechtens slechts toelaatbaar indien die benadeelde een professionele belegger is. De Hoge Raad deelt deze mening niet en neemt hier een 'andere maatman' als referentiekader:

\begin{abstract}
"Het hof mocht de omstandigheid dat de Investeerders ervaren zakenmensen zijn van belang achten voor zijn oordeel dat de door de Investeerders geleden schade mede een gevolg is van hun nalatigheid dat zij louter zijn afgegaan op de in de brochure opgenomen informatie zonder zich deugdelijk te informeren, hoewel voor hen bij goede lezing kenbaar moet zijn geweest dat met name de door TMF gegeven prognose niet was gefundeerd op deugdelijk, verifieerbaar cijfermateriaal."
\end{abstract}

\title{
8.3 Aansprakelijkheid in de secundaire markt
}

Zoals reeds aan de orde kwam bij de aansprakelijkheid op de primaire markt, is de mate van professionaliteit van partijen die bij een transactie betrokken zijn van invloed op de zorgvuldigheidsnormen die bij het verrichten van een due diligence onderzoek in acht dienen te worden genomen en op de aansprakelijkheid die voortvloeit bij het niet in acht nemen van die zorgvuldigheidsnormen. De hiervoor bedoelde zorgvuldigheidsnormen vindt men voor de secundaire markt - de markt waar de aangeboden effecten worden verhandeld - terug in de regelgeving op grond van de Markets in Financial Instruments Directive (MiFID). ${ }^{556}$ De zorgplichten kwamen al eerder aan de orde in paragraaf 11 van hoofdstuk 2 alsmede in paragraaf 4 van hoofdstuk 5 .

\section{Aansprakelijkheid van beleggingsondernemingen bij overtreding van de vergunningplicht}

Op de secundaire markt zijn beleggingsondernemingen actief om ten behoeve van beleggers beleggingsdiensten te verlenen. ${ }^{557}$ In deel $1 \mathrm{Wft}$ (algemeen deel) is in de definitiebepaling aangegeven wat verstaan moet worden onder 'verlenen van beleggingsdiensten'. De omschrijving van beleggingsdiensten is ontleend aan de omschrijving van effectenbemiddelaar (artikel 1 sub b Wte) en de omschrijving van vermogensbeheerder (artikel 1 sub c Wte) in de Wte. Er is geen materiële wijziging beoogd ten opzichte van de Wte. ${ }^{558}$ In het hiervoor genoemde deel 1 zijn tevens enkele reikwijdtebepalingen opgenomen die aangeven welke (onder)delen van de Wft niet van toepassing zijn op welke categorie(en) financiële ondernemingen waaronder ook een beleggingsonderneming wordt verstaan (artikel 1.1 Wft). In deel $2 \mathrm{Wft}$ (markttoegang) is vervolgens aangegeven welke categorieën financiële ondernemingen een vergunning nodig hebben om toegang te krijgen tot de financiële markten en aan welke eisen voldaan moet zijn om een vergunning te krijgen. Daarbij is verwezen naar bepaalde regels uit de delen 3 en $4 \mathrm{Wft}$, welke betrekking hebben op prudentiële regels respectievelijk gedragsregels waaraan voldaan moet worden om daadwerkelijk werkzaam te zijn op de financiële markten (lopend toezichteisen). ${ }^{559}$

De vergunningeisen voor een beleggingsonderneming zijn opgenomen in artikel 2:99 Wft. Dit artikel bepaalt dat de AFM een vergunning verleent indien de aanvrager van de vergunning aantoont dat zal worden voldaan aan de regels ten aanzien van de deskundigheid (artikel 4:9 Wft), de betrouwbaarheid (artikel 4:10 Wft), de integere bedrijfsuitoefening (artikel 4:11 Wft) en inrichting van de bedrijfsvoering (artikel 4:14 Wft), het minimum aantal dagelijks beleidsbepalers (artikel 4:83 Wft) en de plaats van waaruit zij hun werkzaamheden verrichten (artikel 4:84 Wft), de zeggenschapstructuur (artikel 4:13 $\mathrm{Wft}$ ), de te treffen maatregelen ter bescherming van de rechten van cliënten (artikel 4:87 Wft), het te voeren beleid ter voorkoming van belangenconflicten (artikel 4:88 Wft) en het minimum eigen vermogen (artikel 3:53 Wft). Voornoemde gedragsregels zijn verder uitgewerkt in het Besluit gedragstoezicht

\footnotetext{
${ }^{556}$ Markets in Financial Instruments Directive, 2004/39/EG van 21 april 2004 (PbEU L 145).

${ }^{557}$ Het begrip beleggingsonderneming vervangt het begrip effecteninstelling uit de Wte.

${ }^{558}$ Zie F.G.B. Graaf en R.A. Stegeman, Wet op het financieel toezicht, Deventer: Kluwer 2007, p. 208.

559 Zie C.M. Grundmann-van de Krol, Koersen door de Wet op het financieel toezicht, Den Haag: Boom Juridische uitgevers, p. 335.
} 
financiële ondernemingen Wft (Bgfo), het Besluit prudentiële regels Wft en in de Nadere regeling gedragstoezicht financiële ondernemingen Wft (Nrgfo Wft). ${ }^{560}$

Overtreding van de vergunningplicht kan leiden tot (doorbraak van) aansprakelijkheid op grond van onrechtmatige daad. De vraag rijst of het vergunningstelsel van de $\mathrm{Wft}$ aan het relativiteitsvereiste voldoet. Strekt schending van het verbod om te handelen zonder vergunning tot bescherming tegen door een belegger geleden schade? Uit lagere rechtspraak (ontwikkeld onder de Wte) blijkt dat voldaan is aan het relativiteitsvereiste gezien het vergunningstelsel van de Wte mede ten doel had het beschermen van beleggers. ${ }^{561} \mathrm{Bij}$ invoering van de Wte is het beschermen van beleggers tegen malafide aanbiedingen, onvoldoende informatie en ondeskundig optreden door effectenbemiddelaars immers een belangrijk en zelfstandig doel geweest. ${ }^{562}$ Wel zou ten aanzien van het relativiteitsvereiste (en causaliteitsvereiste) onderscheid gemaakt kunnen worden tussen formele schendingen van effectenrechtelijke regels (afwezigheid van de formele vergunning) en materiële schendingen (het handelen zonder materieel te voldoen aan de vergunningvereisten dan wel regels voor vergunninghouders). Niet zozeer de formele schending zou onrechtmatig zijn, maar de materiële schending. ${ }^{563}$

\section{Aansprakelijkheid van beleggingsondernemingen bij overtreding van de gedragsrege/s}

In tegenstelling tot de uitgevende instelling worden contractuele acties bij beleggingsondernemingen wél gehanteerd. ${ }^{564}$ Uit jurisprudentie van de Hoge Raad (eveneens ontwikkeld onder de Wte) blijkt dat overtreding van specifieke gedragsregels mede bepalend is voor de mate van contractuele aansprakelijkheid van een effecteninstelling voor door een particuliere belegger geleden verliezen. ${ }^{565}$ Deze regels strekken immers 'onmiskenbaar mede ter bescherming van de belangen van de cliënt' en zijn van invloed op de vraag hoe en in hoeverre de betrokken effecteninstelling tekortgeschoten is in de vereiste zorgplicht en aansprakelijk is voor (een deel van) de door de cliënt geleden verliezen. ${ }^{566}$ De Hoge Raad gaat nog verder door aan te geven dat een effecteninstelling in beginsel ook in strijd handelt met haar contractuele zorgplicht indien zij op expliciet verzoek van de belegger afwijkt van een mede ter bescherming van de belegger gestelde regel. ${ }^{567}$ Gelet op deze uitspraken kan gesteld worden dat de Hoge Raad steun geeft aan de mogelijkheid voor beleggers voor verbintenisrechtelijke acties, hetgeen - zoals bleek bij beschrijving van verbintenisrechtelijke acties jegens de uitgevende instelling en de lead manager - voordelen met zich meebrengt. Tevens blijkt uit deze uitspraken dat de Hoge Raad waarde hecht aan de bescherming van de belegger bij verwijzing naar de gedragsregels. Hier wordt echter de vraag opgeworpen of de gedragsregel, die uiteindelijk strekt ter bescherming van de belangen van de belegger maar zo ver verwijderd is van de verbintenisrechtelijke relatie tussen de beleggingsonderneming en de belegger, nog wel mede de omvang van de verbintenisrechtelijke zorgvuldigheid zou moeten bepalen. ${ }^{568}$

${ }^{560}$ C.M. Grundmann-van de Krol, Koersen door de Wet op het financieel toezicht, Den Haag: Boom Juridische uitgevers, p. 362363. Zie ook de reader Markets in Financial Instruments Directive: in 82 vragen door de MiFID op de website van de AFM (www.afm.nl).

${ }^{561}$ Rechtbank Assen 25 februari 1997, JOR 1997, 55, Rechtbank Haarlem 27 oktober 1998, JOR 1999, 12, Hof Amsterdam 13 augustus 1998 (n.g.) en Hof Den Haag 24 september 2003, JOR 2004, 135.

${ }^{562}$ Rechtbank Assen 25 februari 1997, JOR 1997, 55.

${ }^{563}$ C.M. Grundmann-van de Krol, Koersen door het effectenrecht, uitgave vanwege het Schoordijk Instituut, Den Haag: Boom Juridische uitgevers 2006, p. 473-480 en C.M. Grundmann-van de Krol, Koersen door de Wet op het financieel toezicht, Den Haag: Boom Juridische uitgevers, p. 542-544. De uitspraak van het Hof Amsterdam van 13 augustus (zie hierboven) zou als voorbeeld van een formele schending kunnen dienen. Hier werd verzuimd aan te geven op grond van welke bijzondere omstandigheden de bestuurder aansprakelijk gesteld kon worden. Er werd pas na twee jaar geageerd toen voor de belegger een nadelig saldo ontstond. De uitspraak van het Hof Den Haag van 24 september (zie eveneens hierboven) kan als voorbeeld van een materiële schending dienen. Daarin werden de Wte regels als 'schutznormen' beschouwd waarop de belegger zich kan beroepen.

${ }^{564}$ Zie bijvoorbeeld klachtencommissie DSI 23 april 2002, JOR 2002, 119 waarin een overeenkomst van huurkoop van aandelen op grond van art. 6:228 BW werd vernietigd mede vanwege het feit dat onjuiste informatie zou zijn verschaft.

${ }^{565}$ HR 23 mei 1997, NJ 1998, 192 (Rabobank/Everaars)

${ }^{566}$ HR 26 juni 1998, NJ 1998, 660 (Rabobank/Klundert).

${ }^{567}$ HR 11 juli 2003, JOR 2003, 199 (Kouwenberg/Rabobank).

568 C.M. Grundmann-van de Krol, Koersen door het effectenrecht, uitgave vanwege het Schoordijk Instituut, Den Haag: Boom Juridische uitgevers 2006, p. 481-483 en C.M. Grundmann-van de Krol, Koersen door de Wet op het financieel toezicht, Den Haag: Boom Juridische uitgevers, p. 544-546. 


\section{Artikel 3:40 BW en artikel 1:23 Wft}

Ten tijde van de toepasselijkheid van de Wte heeft in de rechtspraak en literatuur discussie bestaan of overeenkomsten gesloten met een effecteninstelling die in strijd met de Wte handelt zonder vergunning, civielrechtelijk aantastbaar zijn. Bij het opstellen van diverse ver- en gebodsbepalingen heeft de wetgever slechts bij enkele bepalingen stilgestaan of overtreding behalve een bestuursrechtelijke of strafrechtelijke sanctionering, tevens een civielrechtelijk effect zou moeten hebben. In de wet zelf of in de toelichting vindt men dan een aanwijzing dat de geldigheid van rechtshandelingen die in strijd zijn met de betreffende bepalingen niet op grond van art. 3:40 aangetast kan worden. Hierbij gaat het vooral om effectenrechtelijke bepalingen die betrekking hebben op vennootschapsrechtelijke relaties. ${ }^{569}$ Art. 3:40 zou derhalve gezien kunnen worden als een civielrechtelijk middel tot effectenrechtelijke normering.

In de meeste uitspraken werd geoordeeld dat overtreding van de vergunningplicht leidt tot vernietigbaarheid dan wel nietigheid van de gesloten overeenkomst op grond van art. 3:40 lid 2 en tot niet gebondenheid van de belegger jegens de effecteninstelling aan de ter uitvoering van die overeenkomst aangegane effectentransacties (herstel in de financiële toestand van voor het sluiten van de overeenkomst). ${ }^{570}$ Uitgangspunt van art. 3:40 lid 2 is immers dat strijd met een dwingende wetsbepaling tot nietigheid of vernietigbaarheid leidt, tenzij de betreffende bepaling niet de aard en strekking heeft de geldigheid van daarmee strijdige rechtshandelingen aan te tasten, art 3:40 lid 3. De vraag is gerezen of niet art. 3:40 lid 1 in het geding is. Bij het verlenen van effectendiensten zonder de vereiste vergunning verplicht de overeenkomst namelijk tot het verrichten van een rechtshandeling die door de wet verboden is. ${ }^{571}$ De overeenkomst is nietig, tenzij als gevolg van een wijziging van de maatschappelijke opvattingen de verbodsbepaling de strekking heeft verloren om een daarmee strijdige dienstverlening nietig te doen zijn. Tevens zijn vraagtekens geplaatst bij de verstrekkende reikwijdte die aan nietigheid toegekend is. ${ }^{572}$

De Wft heeft inmiddels meer duidelijkheid gegeven omtrent de toepassing van art. 3:40. In artikel 1:23 Wft is opgenomen: 'de rechtsgeldigheid van een privaatrechtelijke rechtshandeling, welke is verricht in strijd met de bij of krachtens deze wet gestelde regels, is niet uit dien hoofde aantastbaar, behalve voor zover in deze wet anders is bepaald'. Uit de toelichting blijkt dat artikel 1:23 Wft de toepasselijkheid van art. 3:40 lid 2 uitsluit. Toepasselijkheid van art. 3:40 lid 1 is in het wetsvoorstel niet uitgesloten. ${ }^{573}$ Reden hiervoor is dat de beoordeling van strijdigheid met de openbare orde of de goede zeden om een inhoudelijke beoordeling van de rechtshandeling vraagt waardoor er voor de rechter - in tegenstelling tot art. 3:40 lid 2 - ruimte is om een beoordeling te maken of in het betreffende geval aantasting van de rechtshandeling redelijk is. ${ }^{574} \mathrm{Nu}$ toepasselijkheid van art. 3:40 lid 2 is uitgesloten, zullen beleggers hun toevlucht moeten nemen tot andere actiemogelijkheden zoals een actie op grond van dwaling, wanprestatie of onrechtmatige daad. In de toelichting bij bovenstaand voorstel is opgemerkt dat voldaan is aan het relativiteitsvereiste van art. 6:163 indien schade is geleden als gevolg van een overtreding van het voorstel. ${ }^{575}$

\footnotetext{
${ }^{569}$ C.M. Grundmann-van de Krol, Koersen door het effectenrecht, uitgave vanwege het Schoordijk Instituut, Den Haag: Boom Juridische uitgevers 2006, p. 461.

570 Zie bijvoorbeeld Hof Amsterdam 14 januari 1999, JOR 1999, 35 (Cogenius) en Rechtbank Roermond 17 mei 2001, JOR 2001, 134 (Gerrits/Rila).

${ }^{571}$ C.M. Grundmann-van de Krol, Koersen door het effectenrecht, uitgave vanwege het Schoordijk Instituut, Den Haag: Boom Juridische uitgevers 2006, p. 477.

572 C.M. Grundmann-van de Krol, Verboden effectendienstverlening: van zwart-wit naar zacht grijs?, JORplus 2003, p. 89.

${ }^{573}$ Kamerstukken II 2005/06, 29 708, nr. 19, p. 395.

${ }^{574}$ Kamerstukken II 2005/06, 29708 , nr. 19, p. 395.

${ }^{575}$ Kamerstukken II 2005/06, 29 708, nr. 19, p. 393. Zie C.M. Grundmann-van de Krol, Koersen door het effectenrecht, uitgave vanwege het Schoordijk Instituut, Den Haag: Boom Juridische uitgevers 2006, p. 495 en C.M. Grundmann-van de Krol, Koersen door de Wet op het financieel toezicht, Den Haag: Boom Juridische uitgevers, p. 528-531.
} 


\title{
9. Vragen rond de uitvoering van een due diligence onderzoek
}

\author{
9.1 Uitvoering onderzoek en waarborgen
}

\section{Algemeen}

Het voorwerp en de inhoud van het onderzoek zullen vóór alles dienen te worden besproken en te worden overeengekomen tussen de opdrachtgever van het onderzoek en degene die het onderzoek moet toestaan. Eerder in dit boek is er daarbij gesproken over het belang van duidelijkheid. Hierna zal nog worden ingegaan op vragen als naar hoor en wederhoor, geheimhouding, en dergelijke. In dit hoofdstuk zal worden ingegaan op de uitvoering van het onderzoek zelf.

Het is voor een due diligence onderzoek van belang of de onderzoekers wel of niet op de hoogte zijn van het doel dat met de transactie wordt nagestreefd. Afhankelijk van het doel van de transactie zullen de onderzoekers zich op de beschikbare informatie concentreren. Er zijn twee momenten waarop de onderzoeker het onderzoek kan afbakenen:

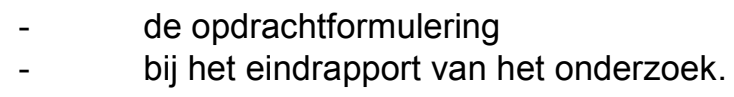

\section{De opdrachtformulering}

Door voordat het onderzoek begint duidelijkheid te verkrijgen over het doel van het onderzoek, voorkomt men dat de onderzoekers de nadruk verkeerd of niet op het juiste onderdeel leggen. Tevens moet op voorhand duidelijk zijn met welke intensiteit de onderzoekers het onderzoek uit moeten voeren. Moet het een zeer diepgaand onderzoek zijn of kan worden volstaan met het bekijken van hoofdpunten? Is het de bedoeling dat er ook eigen opvattingen worden gegeven en/of denkbare verbeteringen of nodig geachte veranderingen worden aangedragen? Als de opdrachtformulering op bovenstaande punten een antwoord geeft dan is voor de betrokken partijen duidelijk wat op welke wijze onderzocht gaat worden en wat niet en hoe er zal worden gerapporteerd. Voor onderdelen die buiten het bereik van de opdrachtformulering vallen, kan de onderzoeker achteraf niet aangesproken worden. Ook is het goed om afspraken te maken over de lay-out van het rapport (format).

Vlaar en Ezinga ${ }^{576}$ stellen dat voor een heldere opdrachtformulering het nodig is dat over de volgende zaken duidelijkheid wordt verkregen:

- $\quad$ de aard en de structuur van de transactie waar het om gaat;

- $\quad$ de doelstelling van het onderzoek;

- $\quad$ de overeengekomen werkzaamheden;

- $\quad$ de wijze van rapporteren (ik voeg daar aan toe ook het beantwoorden van de vraag aan wie er zal worden gerapporteerd en voor wie het rapport ter beschikking zal komen);

- de verschillende procedures in zake deadlines, benadering van personeel en management, toegang tot informatie, enz.

Zij menen dat het ook goed is van meet af aan te proberen - dus al in de voorbereidende gesprekken met de opdrachtgever - eventuele deal breakers te identificeren.

\section{Het eindrapport van het onderzoek}

In het eindrapport van het onderzoek zullen de onderzoekers duidelijk moeten aangeven welke stukken zij ter inzage aan de doelwitonderneming hebben gevraagd en welke zij hebben ontvangen. Hiermee is aangegeven op welke informatie het onderzoek is gebaseerd en welke informatie buiten beschouwing is gebleven. Van belang is ook dat de onderzoekers aangeven waarom bepaalde onderdelen wel/niet zijn onderzocht. Doel van deze handelswijze is dat de opdrachtgever weet welke stukken de onderzoekers onder ogen hebben gehad en belangrijker nog, welke niet. Mochten er na het tot stand komen van de transactie problemen ontstaan, dan kunnen de onderzoekers met het rapport aantonen dat zij niet de beschikking hadden over de stukken waaruit de problemen te voorzien waren

\footnotetext{
${ }^{576}$ N.W. Vlaar en A. Ezinga, Het due diligence-onderzoek en de rol van de accountant, MAB december 1997, p. 637.
} 
geweest. Op stukken die de onderzoekers niet hebben gezien kunnen zij niet aangesproken worden. Naar aanleiding van het rapport had de opdrachtgever desgewenst verder bij de doelwitvennootschap moeten informeren of een nader onderzoek moeten opdragen.

Het is gebruikelijk om een due diligence rapport te voorzien van een zogenaamde management summary. Dit is een kernachtige opsomming van de belangrijkste bevindingen, bij voorkeur op niet meer dan één of enkele bladzijden gesteld.

\section{Aan wie wordt de opdracht verleend?}

Er is in het verleden wel misverstand ontstaan over de vraag aan wie nu een opdracht tot het doen van een deskundigenonderzoek (want zo kan een due diligence onderzoek toch worden gekwalificeerd) werd gegeven. De opdrachtgever dient zich af te vragen met wie de overeenkomst van opdracht wordt aangegaan. Dit is vooral van belang in verband met aansprakelijkheidsvragen. ${ }^{577}$

In veel gevallen bestaat een due diligence team uit deskundigen van verschillende achtergronden. Het is verstandig om iemand te benoemen die het due diligence proces begeleidt en bewaakt, zeker bij wat meer omvangrijke transacties. Die projectleider zal allerhande logistieke zaken tot zijn verantwoordelijkheid rekenen, zoals overleg met de adviseurs van de doelwitvennootschap, het beleggen van coördinatievergaderingen met het eigen team, het aanleggen van een zogenaamde parties list (een overzicht van alle contactgegevens van alle leden van het team en andere betrokken partijen) en de voortgang stimuleren en bewaken. Niet ongebruikelijk is dat de projectleider een zogenaamd deal memorandum opstelt, waarin de hoofdlijnen van de voorgenomen transactie zijn uiteengezet, zodat elk van de leden van het due diligence team een goed en uniform beeld heeft van die transactie. Zo maakt het ook verschil of er sprake is van een activa-passiva transactie bijvoorbeeld of een aandelenkoop. De projectleider zal het contactpunt zijn wanneer er vragen rijzen of andere problemen ontstaan. Hij zal ook bewaken dat er niet onnodig kosten worden veroorzaakt. De opdracht wordt evenwel steeds aan alle leden van het team verleend. De projectleider is één van de opdrachtnemers.

\section{Inzage vooraf?}

Hoe wenselijk of verstandig is het om een due diligence rapport vooraf ter inzage te verschaffen? Op deze plaats wordt die vraag geplaatst in de (rechts)betrekking tussen de koper en de verkoper. Of een onderzoeker - die in een rechtsbetrekking staat tot alleen de opdrachtgever - zich iets aan een noodzaak tot hoor en wederhoor gelegen moet laten liggen wordt hierna (onder 9.4) aangesproken.

De hier voor bedoelde vraag kan niet in zijn algemeenheid worden beantwoord. Het gaat bij de beantwoording allereerst of er sprake is van een vendor due diligence of niet. Verder zal de visie op de hier genoemde vraagstelling verschillen al naar gelang dit de visie van de koper dan wel de verkoper betreft.

Waar de koper betreft, zal het geen vendor due diligence betreffen.

De koper kan het verschaffen van inzage minder gewenst achten omdat - zeker wanneer het een behoorlijk compleet rapport betreft - dit diens mogelijkheden om na het tot stand komen van de transactie zich te beklagen over een gebrek in de mededelingsplicht, zal beperken. Te bedenken valt dat het voor de koper niet raadzaam is om vooraf een afschrift van het rapport aan de verkoper ter hand te stellen wanneer het niet zeker is dat het een behoorlijk compleet rapport betreft. Indien de inhoud van het rapport niet erg volledig of specifiek is, zal dit de verkoper helpen aan argumenten om achteraf te stellen dat bepaalde feiten moeten worden geacht gezien te zijn en begrepen te zijn geweest in de formuleringen in het rapport, of in ieder geval van het onderzoek deel hebben uitgemaakt. De andere kant van de medaille is dat een rapport dat in (te) algemene termen gesteld is, achteraf natuurlijk toch

\footnotetext{
577 Zie voorzieningenrechter Rechtbank Amsterdam 10 januari 2008, LJN BC3099, waarin een vordering tegen PricewaterhouseCoopers Advisory N.V. werd afgewezen op grond van de overweging dat de desbetreffende deskundige werd geacht een overeenkomst van opdracht te hebben gesloten en niet PricewaterhouseCoopers Advisory N.V. zelf. De tegen PricewaterhouseCoopers Advisory N.V. ingestelde vordering werd om die reden niet-ontvankelijk verklaard. Het feit dat de rapportage van de deskundige was gesteld op papier van PricewaterhouseCoopers Advisory N.V. en ook de factuur door die organisatie was verzonden, maakte dat in de ogen van de rechter niet anders.
} 
voor problemen in de discussie over de onderzoeks- en mededelingsplicht kan zorgen, ook wanneer het niet vooraf ter inzage is verschaft.

Een evident voordeel van het vooraf ter inzage verschaffen van een due diligence rapport aan de verkoper, is dat eventuele discussie punten vroegtijdig kunnen worden gesignaleerd en kunnen worden aangesproken, ook in verband met het bespreken en vaststellen van garanties en vrijwaringen. Gelet op de stand van de rechtspraak op het punt van de exhibitieplicht (zie hoofdstuk 11) kan het in het algemeen niet veel kwaad om een afschrift van een due diligence rapport aan de verkoper ter hand te stellen. Indien het tot een geschil komt over garanties of vrijwaringen achteraf, zal een rechter zoals wij nog zullen zien al licht geneigd zijn te gelasten dat een exemplaar van het rapport wordt overgelegd. Door pro-actief in te spelen op de situatie dat er niet aan kan worden ontkomen, kan een rapport ook zo worden ingericht, dat het presentabel is op een wijze die de koper niet te zeer voor problemen achteraf kan stellen. Adviezen en feiten kunnen bijvoorbeeld worden gescheiden, er kunnen opmerkingen over beperkingen worden opgenomen waar het de compleetheid betreft en ook op andere wijze kan aldus richting worden gegeven aan hetgeen de koper wenst dat voorwerp zal of kan zijn van de documentatie die in een eventueel dispuut met de verkoper achteraf een rol zal (kunnen) spelen.

Het kan belangrijk zijn om het moment goed te kiezen waarop een exemplaar van een due diligence rapport aan de verkoper ter hand zal worden gesteld. Denkbaar is dat dit juist voor of juist na de afronding van de prijsonderhandelingen te doen. Ook in dit kader kan de overweging gelden om niet één maar meerdere rapporten te (laten) maken. De verkoper hoeft niet te weten van meerdere exemplaren of daarover de beschikking te krijgen. Aan de inhoud van een rapport dat wel aan de verkoper ter beschikking wordt gesteld, zullen als gezegd de nodige eisen gesteld moeten worden op het punt van duidelijkheid en volledigheid. Mijn mening is dat afschrift van een due diligence rapport niet zonder voorwaarden aan de verkoper ter hand gesteld zou moeten worden. Van de verkoper mag daarbij bijvoorbeeld worden verlangd, dat die de inhoud van het rapport verifieert en bevestigt of bijvoorbeeld de inventarisatie van onderzochte documenten wel of niet compleet is. De verkoper zou ook op zich moeten nemen om andere gebreken in de inhoud niet onaangesproken te laten.

Waar het de verkoper betreft, zal ook gelden dat die voorwaarden kan en wellicht ook zou moeten stellen aan het aannemen van een afschrift van een due diligence rapport. De verkoper zou moeten willen weten of het een afschrift van het volledige rapport betreft of van een geschoonde of separate versie. De verkoper laadt met het accepteren van een afschrift van het due diligence rapport een aantal verantwoordelijkheden op zich. Het accepteren zal voor deze in ieder geval een aantal (rechts)gevolgen mee (kunnen) brengen. Het rapport zal moeten worden bestudeerd. Het nalaten daarvan zal niet kunnen vermijden dat naderhand de verkoper zal worden geacht met de inhoud bekend te zijn. Daarmee ontstaat voor de verkoper ook de verplichting om de inhoud te verifiëren en de koper op onjuist- of onvolledigheden te attenderen, wanneer daarvan sprake zou zijn. De verkoper wordt als deze niet oppast mede verantwoordelijk voor het vaststellen van de omvang van de onderzoeksplicht of onderzoeksbehoefte van de koper. Moet de verkoper op zaken in gaan, die ook al onder garanties zijn aangesproken, maar niet in dezelfde zin als in het due diligence rapport of in hoeverre roept het ontvangen van een afschrift van het due diligence rapport een noodzaak op om meer te verklaren, dan in de onderhandelingen overigens is of zou kunnen worden verlangd?

Evident is dat het voor de verkoper zekere voordelen kan hebben om - bij voorkeur voorafgaand aan de transactie - inzage te krijgen in het due diligence rapport. De inzage kan de verkoper helpen aan een inzicht in de visie van de koper op de doelwitvennootschap en indien er sprake is van een onjuiste veronderstelling, kan er nog worden gecorrigeerd. Verwijten achteraf over het niet of niet volledig voldoen aan een mededelingsplicht kunnen worden voorkomen.

Een vendor due diligence of pre-acquisition onderzoek is over het algemeen bedoeld om door (alleen) de verkoper zelf te worden gebruikt, evenzo als een due diligence onderzoek dat door de koper wordt uitgevoerd bedoeld is voor diens eigen informatievoorziening. De eerste zaak op grond van artikel 843a, waarin om de productie van een vendor due diligence rapport wordt gevraagd, moet ik nog tegen komen. Waar op grond van dat wetsartikel alleen om afgifte van bepaalde bescheiden gevraagd kan worden nu dat artikel niet bedoeld is als grondslag voor zogenaamde fishing expeditions zal een koper die afgifte wenst van een vendor due diligence er wel van op de hoogte moeten zijn dat er een dergelijk onderzoek is uitgevoerd door de verkoper.

Niet zelden wordt een rapport dat is opgesteld naar aanleiding van een eigen onderzoek door de verkoper wel gebruikt in onderhandelingen of al op de voorhand - bij de uitnodiging om een bod uit te 
brengen - geproduceerd. Niet ongebruikelijk is het om een rapport van een vendor due diligence met zoveel woorden of in een geparafraseerde vorm onderdeel te doen uitmaken van de documentatie die wordt toegezonden aan potentiële gegadigden (bidbook) in het geval van een gecontroleerde veilingverkoop (controlled auction). Overhandiging aan een (potentiële) koper van een rapport dat het resultaat is van een eigen onderzoek door de verkoper kan veel tijd besparen bij het tot stand brengen van een transactie. Het toezeggen dat de inhoud van dat rapport (al dan niet aangevuld met de inhoud van een (nadere) disclosure letter) een volledig en accuraat beeld van de (onderneming van de) doelwitvennootschap geeft, al dan niet aangevuld met (aanvullende) garanties en/of vrijwaringen, kan dan de doorlooptijd van een transactie aanzienlijk bekorten.

\subsection{Kwaliteitswaarborgen}

Kwaliteitswaarborgen zijn moeilijk te krijgen, nu in veel gevallen geobjectiveerde maatstaven voor het vergelijken van de kwaliteit van due diligence onderzoeken ontbreekt. Voor accountants gelden een aantal regels, die van toepassing zijn zowel bij een quick scan, een review en een beperkt of volledig rapport.

Als gevolg van de herziening van de gedrags- en beroepsregels en de invoering van de Wta (ingangsdatum 1 oktober 2006) is met ingang van 1 januari 2007 voor accountants een aantal nieuwe verordeningen en nadere voorschriften van kracht geworden ${ }^{578}$ Een aantal andere verordeningen en nadere voorschriften is inmiddels door de bestuurder van NIVRA en NOVAA vastgesteld. Er zijn nog delen van regelgeving in ontwikkeling. ${ }^{579}$

Ingevolge de nieuwe structuur is er sprake van normen voor accountantsorganisaties en van normen voor individuele accountants. Normen voor individuele accountants zijn te vinden in de Wet op de Registeraccountants (en de Wet op de accountants-administratieconsulenten) en in de zogenaamde Verordening Gedragscode (VGC). Ingevolge die laatstgenoemde verordening zijn de navolgende nadere voorschriften gesteld:

- $\quad$ nadere voorschriften permanente educatie;

- $\quad$ nadere voorschriften onafhankelijkheid;

- $\quad$ nadere voorschriften voor accountantskantoren en accountantsafdelingen; en

- $\quad$ nadere voorschriften voor controle en overige standaarden.

Met betrekking tot transactiegerelateerde werkzaamheden gelden de NV COS nummer $5500 \mathrm{~N}$ en voor opdrachten tot het verrichten van specifiek overeengekomen werkzaamheden geldt NV COS nummer $4400 .^{580}$

NV COS nummer $5500 \mathrm{~N}$ (Transactiegerelateerde adviesdiensten) van het NIVRA bevat een standaard met als doel grondslagen en essentiële werkzaamheden vast te stellen en aanwijzingen te geven omtrent de vaktechnische verantwoordelijkheid van de beroepsbeoefenaar (dit geldt voor zowel de registeraccountant alsook voor de accountant-administratieconsultent) ten aanzien van de uitvoering van een opdracht tot het verlenen van transactiegerelateerde adviesdiensten.

De standaard ziet op adviesdiensten met betrekking tot een voorgenomen transactie van een opdrachtgever, in het algemeen met een derde partij. Als voorbeelden worden genoemd: kapitaalmarkttransacties, uitgifte / verkoop of koop van aandelen, overname of verkoop van ondernemingen of onderdelen daarvan, het verstrekken of ontvangen van financieringen, herfinancieringen, securisaties, fusies, allianties en soortgelijke activiteiten (inl. onder 2).

Accountants dienen rekening te houden met zorgvuldigheidsverplichtingen, welke oorspronkelijk zijn terug te voeren naar artikel 11 GBR (ook artikel 11 van de GBAA), welke regelingen inmiddels echter niet meer van toepassing zijn. Volgens artikel 11 GBR moest de registeraccountant slechts mededeling doen omtrent de uitkomst van zijn arbeid voor zover zijn deskundigheid en de door hem verrichte

\footnotetext{
${ }^{578}$ Inmiddels is er sprake van wijziging van de Wta teneinde te komen tot implementatie van richtlijnnummer 206/43/EG van het Europees Parlement en de raad van de Europese Unie van 17 mei 2006. Op het moment van afsluiten van de tekst voor dit boek bevond die wetswijziging zich in het stadium van de Derde Nota van wijziging. Zie TK 2008-2009, 31 270, nr. 16.

579 Onder meer de Nadere voorschriften onafhankelijkheid interne accountant, Nadere voorschriften onafhankelijkheid overheidsaccountants en Nadere voorschriften accountantsafdelingen.

580 Zie de artikelen A-130.4 tot en met A-130.7 Verordening Gedrags Code (VGC) en nummer 4400 en 4500 van de Nadere voorschriften Controle- en overige Standaarden (Opdrachten tot het verrichten van overeengekomen specifieke werkzaamheden met betrekking tot financiële informatie).
} 
werkzaamheden daarvoor een deugdelijke grondslag vormden. Hij moest er zorg voor dragen dat zodanige mededelingen een duidelijk beeld gaven van de uitkomsten van zijn arbeid. Inmiddels is per 1 januari 2007 de GBR vervangen door een tweetal gedragsverordeningen, de Verordening Gedragscodes voor Registeraccountants en de Verordening Gedragscode voor Accountant-Administratieconsulenten. Beide gedragscodes komen qua inhoud vrijwel overeen. Het NIVRA is lid geworden van de International Federation of Accountants ( "IFAC") en heeft uit die hoedanigheid de verplichting om standaarden van de IFAC in de eigen regelgeving te implementeren. Onderdeel daarvan is onder meer de Code of Ethics. Deze laatste code wordt met de Verordening Gedragscode voor Registeraccountants ingevoerd. Bij de opmaak van de Verordening Gedragscode voor Accountant-Administratieconsulenten is eveneens uitgegaan van de inhoud van de Code of Ethics van de IFAC. Zorgvuldigheidsverplichtingen zoals eerder neergelegd in de GBR, zijn nu te vinden in artikel A-130 van allebei de hiervoor genoemde Verordeningen Gedragscode. Geheimhouding is te vinden in artikel A-140 van beide gedragscodes en de formuleringen van de beide bepalingen zijn vrijwel identiek.

Accountants dienen bij het uitvoeren van een due diligence opdracht nu dus rekening te houden met de zorgvuldigheidsnormen welke in de hier genoemde gedragscodes zijn genoemd. Verder hebben zij rekening te houden met de regelingen welke in de plaats zijn gekomen - eveneens per 1 januari 2007 - voor de Richtlijnen voor de Accountantscontrole, namelijk de Verordening op de Kwaliteitstoetsing voor Registeraccountants en NV COS 220 betreffende kwaliteitsbeheersing voor controles van historische financiële informatie. Waar het dossiervorming betreft, dienen zij acht te slaan op de NV COS 230 betreffende controledocumentatie. De navolgende aanbevelingen zijn wel gepubliceerd in de literatuur. $^{581}$

Bij het vaststellen van de opdrachtvoorwaarden zou aandacht moeten worden besteed aan ondermeer:

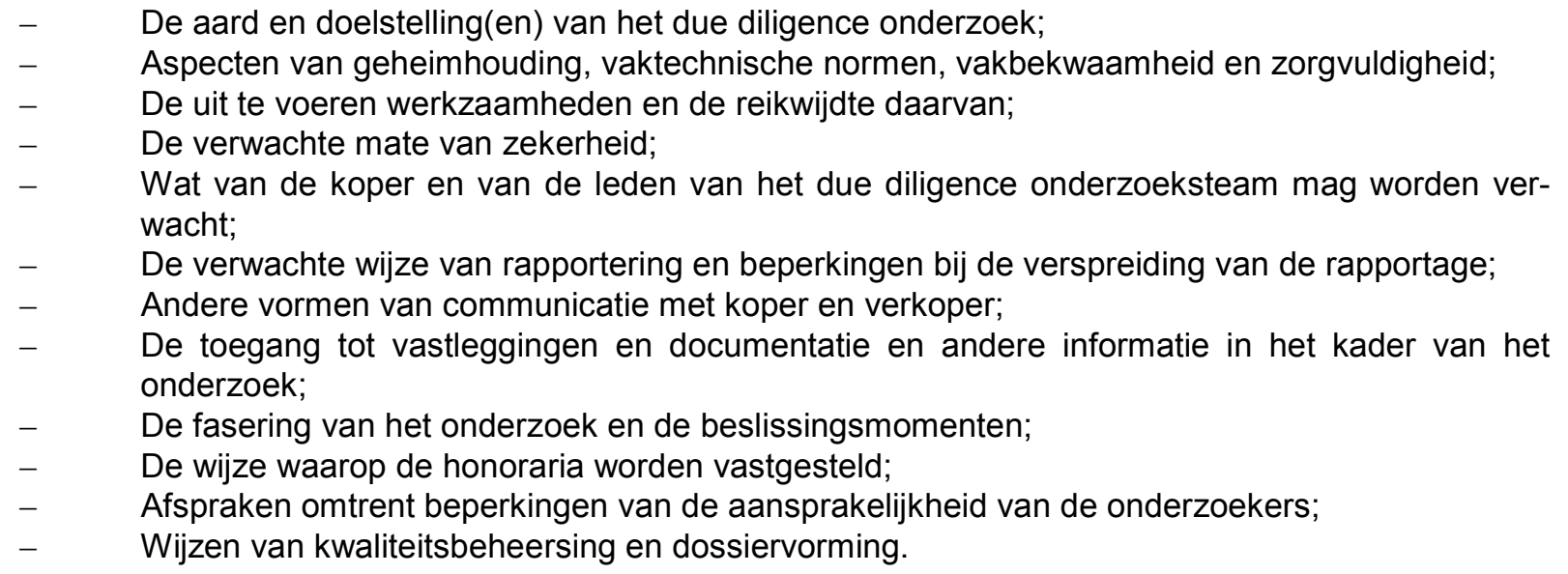

In tegenstelling tot een controle van de jaarrekening, waarbij de accountant nagaat of er sprake is van een 'getrouw beeld' in aansluiting op de door hem ingeschatte verwachtingen over wat van belang is voor de besluitvorming van de gebruikers van de jaarrekening, 'het materieel belang ${ }^{\text {,582 }}$, vereist een due diligence onderzoek meestal een diepgaander geheel van werkzaamheden op een beperkter terrein. Verschuiving in resultaten en onjuiste inschattingen van balansposten kunnen zich direct doorvertalen in andere berekeningen van de overnamewaarde danwel tot een andere besluitvorming leiden bij de overname. ${ }^{583}$

Zoals dat voor alle deskundigen, die bij het uitvoeren van een due diligence onderzoek worden betrokken, geldt, geldt voor accountants in het bijzonder dat rekening moet worden gehouden met de denkbare wens van een verkoper van een onderneming om de onderzochte informatie zo florissant mogelijk voor te doen stellen (bijvoorbeeld activa, omzet en inkomende cash flows zo hoog mogelijk, passiva, kosten en uitgaande cash flows zo laag mogelijk). Waar er tussen partijen veelal voorafgaand aan het aanvangen van het due diligence onderzoek al afspraken bestaan omtrent een overwogen

\footnotetext{
${ }^{581}$ F.B.M. Deckers RA, GBR en Richtlijnen bij due diligence, Accountancy News, 1 december 2000, p. 9

${ }^{582}$ Zie NV COS 320 (materieel belang in de accountantscontrole).

${ }^{583}$ Zie F.B.M. Deckers RA, t.a.p., p. 10
} 
transactie, dient de accountant ook rekening te houden met de voor deze geldende richtlijnen met betrekking tot verbonden partijen. ${ }^{584}$

Voor een accountant zal het uitvoeren van een due diligence onderzoek over het algemeen mede gelden als werkzaamheden met betrekking tot financiële informatie. ${ }^{585}$ Niettemin kan er vanzelfsprekend ook gerapporteerd (moeten) worden over niet-financiële informatie. Waar de accountant bij het verrichten van werkzaamheden ingevolge een dergelijke opdracht alleen maar verslag doet van feitelijke bevindingen uit hoofde van de overeengekomen werkzaamheden, wordt door hem geen zekerheid verschaft omtrent de getrouwheid van de financiële informatie. De opdrachtgevers zullen op basis van het rapport zelf een oordeel moeten vormen omtrent de bevindingen die in het rapport zijn weergegeven en hun eigen conclusies moeten trekken uit de door de accountant verrichte werkzaamheden.

Inmiddels is door het NIVRA - zoals gezegd - een bijzondere richtlijn vastgesteld met betrekking tot zogenaamde transactiegerelateerde dienstverlening. Transactiegerelateerde adviesdiensten worden niet beschouwd als assurance-opdrachten of opdrachten tot het verrichten van overeengekomen specifieke werkzaamheden. Informatie verkregen ten behoeve van het adviesproces, wordt niet gecontroleerd of beoordeeld als bedoeld in het stramien voor assurance-opdrachten. Bij opdrachten tot het verlenen van transactiegerelateerde adviesdiensten levert de accountant adviesdiensten met betrekking tot een voorgenomen transactie van de opdrachtgever, in het algemeen met een derde partij. Deze transacties kunnen bestaan uit kapitaalmarkttransacties, uitgifte of koop van aandelen, overname of verkoop van ondernemingen of onderdelen daarvan, het verstrekken of ontvangen van financieringen, herfinancieringen, securisaties, fusies, allianties en soortgelijke activiteiten. De opdracht tot het uitvoeren van een transactiegerelateerde adviesdienst kan samenlopen met werkzaamheden met een assurance-karakter of met een opdracht tot het verrichten van overeengekomen specifieke werkzaamheden. Essentieel zal het steeds zijn dat in de opdrachtbevestiging en in de rapportage door de accountant een duidelijk onderscheid wordt aangebracht tussen de verschillende diensten. Binnen het kader van dit werk is een sprekend voorbeeld van een transactiegerelateerde adviesdienst een due diligence onderzoek. Een belangrijk element is dat bij het verlenen van transactiegerelateerde adviesdiensten de accountant het bijzondere belang van de opdrachtgever vertegenwoordigt, tenzij het tegendeel uitdrukkelijk wordt vermeld. De eis van onpartijdigheid (artikelen A-120.1 en A-120.2 VGC, voor zowel registeraccountants als accountant-administratieconsulenten) blijft onverminderd van toepassing. Waar een opdracht tot het verlenen van een transactiegerelateerde adviesdienst elementen bevat die voldoen aan de definitie van assurance-opdrachten of van overeengekomen specifieke werkzaamheden, behoeft niet noodzakelijk te worden voldaan aan de vereisten welke worden gesteld door NV COS. ${ }^{586}$ Voor assurance-opdrachten of overeengekomen specifieke werkzaamheden, zo lang voor de oordelen, standpunten of uitspraken waaraan een gebruiker zekerheid zou kunnen ontlenen, geldt elk van de onderstaande punten:

a. deze oordelen, standpunten of uitspraken zijn slechts van ondergeschikte betekenis binnen de gehele opdracht;

b. het gebruik van elk schriftelijk rapport dat wordt verstrekt, is uitdrukkelijk beperkt tot slechts de beoogde, bij de transactie betrokken gebruikers;

c. op grond van een schriftelijke afspraak met de beoogde gebruikers is de opdracht niet bedoeld als een assurance-opdracht of opdracht tot het verrichten van overeengekomen specifieke werkzaamheden; en

d. de opdracht wordt in het rapport van de accountant niet aangemerkt als een assurance-opdracht of opdracht tot het verrichten van overeengekomen specifieke werkzaamheden.

${ }^{584}$ In dit kader zijn relevant de richtlijnen welke vermoedelijk zullen opgenomen onder NV COS 300-499 (risico-inschatting en het inspelen op ingeschatte risico's). Verwezen kan worden naar NV COS 315 en 330 . Ook verwijs ik naar NV COS 550 (verbonden partijen).

585 Volgens NV COS nummer 4400 betreft een opdracht tot het verrichten van specifieke werkzaamheden zaken als het uitvoeren van bepaalde werkzaamheden met betrekking tot afzonderlijke aspecten van financiële gegevens (bijvoorbeeld crediteuren, debiteuren, aankopen bij verbonden partijen en de verkoop en resultaten van een onderdeel van de entiteit), een deel van de financiële overzichten (bijvoorbeeld de balans) of zelfs een volledige set van financiële overzichten.

586 NV COS nummers 3000-3699 betreffen assurance opdrachten, anders dan opdrachten tot controle of beoordeling van historisch financiële informatie. 
Volgens punt 28 van NV COS nummer 5500N (Transactiegerelateerde adviesdiensten) van het NIVRA geldt het navolgende:

Teneinde de gebruikers in staat te stellen de aard en omvang van de uitgevoerde adviesdiensten te beoordelen, dient, in geval een schriftelijk rapport wordt uitgebracht, dit rapport naast de uitkomsten van de uitgevoerde adviesdienst mede te bevatten:

a. opschrift;

b. geadresseerde (dit zal doorgaans de opdrachtgever zijn die de accountant heeft aangetrokken om de overeengekomen adviesdiensten uit te voeren);

c. de beschrijving van het doel waarvoor de opdracht tot het verlenen van de transactiegerelateerde adviesdienst is uitgevoerd;

d. de vermelding dat de opdracht is uitgevoerd conform de voorwaarden van de opdracht en overeenkomstig de richtlijn met betrekking tot transactiegerelateerde adviesdiensten;

e. een kopie van de opdrachtbevestiging of een samenvatting van de daarin opgenomen opdracht en eventuele belangrijke wijzigingen daarin (belangrijke veranderingen in de oorspronkelijke aard en omvang van de opdracht gedurende het onderzoek moeten schriftelijk worden vastgelegd in een gewijzigde of aanvullende opdrachtbevestiging of in de rapportage);

f. in de opdrachtbevestiging genoemde adviesdiensten die niet werden uitgevoerd onder opgave van redenen voor het niet-uitvoeren daarvan;

g. een beschrijving van de bevindingen;

h. de vermelding van de beperkingen in en condities met betrekking tot de verspreiding van het rapport;

i. datum van het rapport;

j. naam en adres van de accountantsorganisatie.

Met betrekking tot de verspreiding van het rapport stelt punt 30 van NV COS $5500 \mathrm{~N}$ dat het accountants slechts toegestaan is op verzoek van de opdrachtgever inzage in een rapport te verschaffen aan andere gebruikers, indien vooraf de voorwaarden voor inzage (waaronder in ieder geval begrepen een beperking van verdere verspreiding) met de opdrachtgever en met de andere gebruikers zijn overeengekomen en de gebruikers inzicht is gegeven in de omvang van de uitgevoerde adviesdienst. Indien er beperking in de onafhankelijkheid bestaat ten opzichte van de doelonderneming of de opdrachtgever stelt de accountant de andere gebruikers daarvan in kennis.

\subsection{Uitvoering onderzoek}

Het is niet onverstandig - en in de meeste gevallen zal dit gebeuren - dat er een werklijst wordt gemaakt voor het uitvoeren van een due diligence onderzoek. In de matrix kunnen dan de aandachtsgebieden worden weergegeven die relevant zijn voor het uitvoeren van het onderzoek. In die matrix wordt aangegeven wie verantwoordelijk is voor het verkrijgen en beoordelen van de benodigde informatie, op welke wijze dat zal gebeuren en wie vanuit de doelwitvennootschap het aanspreekpunt is. Er worden afspraken gemaakt over de centrale coördinatie en waar dit praktisch is, worden aanspreekpunten per afdeling of per doctrine benoemd. Het is geen overbodige luxe om al in een LOI vast te leggen dat de uitvoering van een due diligence onderzoek zal worden voorafgegaan door een regie zitting. Dat is een bijeenkomst van alle betrokken adviseurs en (vertegenwoordigers van) de betrokken partijen zelf, waarin afspraken worden gemaakt over de wijze waarop een onderzoek zal worden georganiseerd en zal worden uitgevoerd.

De inventarisatie van acties en aandachtspunten zal veelal het resultaat zijn van voorafgaand overleg met de opdrachtgever. Te bedenken valt het als gezegd ook om aan de vertegenwoordiger van de doelwitvennootschap te vragen of deze bijzondere punten van zorg heeft (mogelijke deal breakers, synergiemogelijkheden en dergelijke). Het opmaken van een verslag van het desbetreffende gesprek kan waarde hebben in het controledossier, wanneer achteraf blijkt dat er wel bekendheid verondersteld had mogen worden met bijzondere aandachtspunten.

Het bewaren van aantekeningen en concepten voor het due diligence rapport, is eveneens aan te raden. Een accountant zal spontaan een controledossier aanhouden. Juristen en andere professionals zijn daar niet altijd aan gewend. 
Het is verstandig van tevoren met de opdrachtgever afspraken te maken over de wijze waarop gerapporteerd zal worden (de zogenaamde format). Een en ander hangt vanzelfsprekend samen met de diepgang welke het onderzoek volgens de opdrachtgever moet hebben. Niet alle opdrachtgevers zitten te wachten op een telefoonboek-dik verslag.

Als eerder opgemerkt, zijn coördinatievergaderingen tussen de verschillende, bij het onderzoek betrokken disciplines, voorafgaand aan de start van het onderzoek uiterst zinvol. Ofschoon dit extra investering in tijd en energie vergt, is het aan te raden die coördinatievergadering ten kantore van de doelwitvennootschap te doen plaatsvinden. Het zien van de fysieke omvang van de inhoud van de dataroom, de situatie ter plekke en andere voor de uitvoering van het onderzoek relevante gegevens, kunnen tot het besparen van tijd later leiden.

Vlaar en Ezinga ${ }^{587}$ inventariseren de werkzaamheden, die door het due diligence team zullen moeten worden uitgevoerd en onderscheiden de na te noemen fasen bij de uitvoering. Te coördineren is in ieder geval:

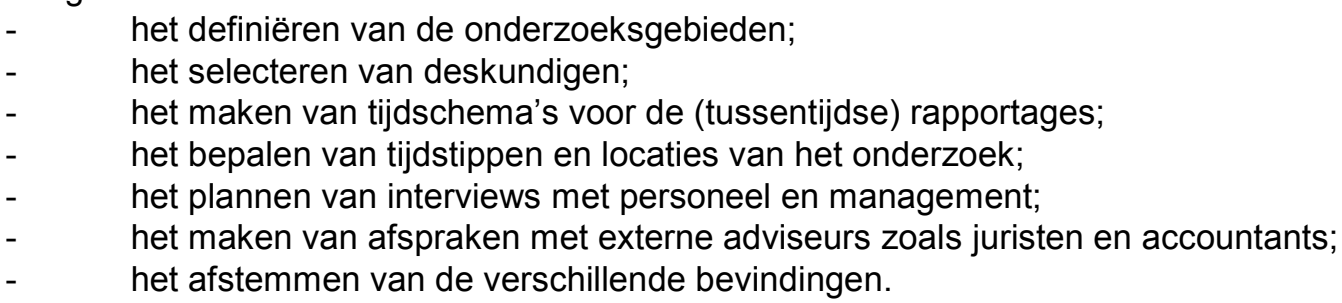

Zoals ik hier voor opmerkte, is een in mijn ogen belangrijk element nog het afstemmen van de te gebruiken format voor het inventariseren van gegevens, het weergeven daarvan en het uitbrengen van een rapportage.

Gebruikelijk wordt er één projectmanager aangewezen, die de coördinatie van het hele onderzoek op zich neemt. Deze onderhoudt de contacten met alle betrokkenen, bewaakt het tijdpad en regelt verder alles wat er logistiek en anderszins voor een succesvolle en tijdige voltooiing van het onderzoek nodig is of kan zijn. De werkverdeling tussen de opdrachtgever en de projectmanager is door Vlaar en Elzinga als volgt in kaart gebracht. Hun inzichten ter zake zijn als volgt:

Stap 1: De opdrachtgever en de projectmanager bepalen samen de opdracht (opdrachtformulering).

Stap 2: De projectmanager voert een quick scan uit en bekijkt of onderzoek naar aanvullende aspecten noodzakelijk is.

Stap 3: De opdrachtgever beslist op basis van de bevindingen of de due diligence wordt voortgezet (beslissingsmoment).

Stap 4: In overleg met de projectmanager worden zo nodig de aard en diepgang van het onderzoek aangepast.

Stap 5: Op basis van de te beoordelen aspecten wordt het werk over de medewerkers en de interne en/of externe adviseurs verdeeld (samenstellen onderzoeksteam).

Stap 6 en 7: De projectmanager stuurt de teamleden aan, draagt zorg voor de communicatie met de opdrachtgever en heeft een belangrijke rol in de financiële vertaling van de gesignaleerde risico's (veldwerk).

Stap 8 en 9: In deze fasen adviseert de projectmanager de opdrachtgever over de gevolgen van de gesignaleerde mogelijkheden en risico's (rapportering en beslissingsmoment, gevolgd door debriefing). Hij kan bijvoorbeeld adviseren over:

- $\quad$ aanpassingen in de prijs;

- $\quad$ het laten opnemen in de transactie documentatie van specifieke garanties en waarborgen;

- $\quad$ vereiste organisatorische aanpassingen;

- $\quad$ het al dan niet laten doorgaan van de transactie.

De hier voor genoemde inventarisaties zijn indicatief. Tussen en tijdens de verschillende stappen moet soms veel moeite worden gedaan om een en ander goed te laten verlopen of in werkbare vormen te

\footnotetext{
${ }^{587}$ N.W. Vlaar en A. Ezinga, Het due diligence-onderzoek en de rol van de accountant, MAB december 1997, p. 637-638.
} 
vatten. Alleen al de uitdaging om verschillende disciplines zo te laten werken en rapporteren, dat de uitkomsten allemaal over dezelfde doelwitvennootschap lijken te gaan, is groot. Een zorgvuldige voorbereiding en planning van een due diligence onderzoek is een belangrijke voorwaarde niet alleen voor een goede uitvoering van een due diligence onderzoek, maar mag ook op grond van artikel 7:401 van de onderzoeker als opdrachtnemer worden verwacht. Zo goed als het ondernemen van een due diligence onderzoek kan gelden als zorgvuldigheidsnorm bij het aangaan van een transactie, geldt een goede voorbereiding als norm voor het aanvaarden en in uitvoering nemen van een opdracht tot het uitvoeren van een due diligence onderzoek.

Aan de zijde van doelwitvennootschap stelt de uitvoering van een due diligence onderzoek ook de nodige eisen, niet alleen in logistiek opzicht, maar ook in termen van zorgvuldigheid. Op verschillende plaatsen in dit boek is gewezen op de noodzaak van goede afspraken over geheimhouding, het tegengaan van gebruik van voorwetenschap, het beschermen van strategische belangen, zoals een afspraak dat er gedurende zekere tijd geen gebruik van te onderzoeken gegevens mag worden gemaakt als de transactie niet doorgaat en er geen personeelsleden in dienst zullen worden genomen. Het bijeenbrengen van de gegevens die nodig zijn om de ander in staat te stellen een röntgen foto van de doelwitvennootschap en haar onderneming te maken, is niet zelden ook een heel werk. In hoofdstuk 10 hierna wordt nader ingegaan op de verschillende aspecten welke samenhangen met het bewaken van het bedrijfsdebiet van de doelwitvennootschap.

Zonder pretentie van volledigheid noem ik ter afsluiting van de onderhavige paragraaf een aantal richtlijnen - waarvan een aantal hoger op in deze paragraaf al aan de orde kwam - die bij het uitvoeren van een due diligence onderzoek (kunnen) verdienen:

1. Er moet op worden toegezien dat er zowel aan de zijde van het due diligence team als aan de zijde van de opdrachtgever en aan de zijde van de doelwitvennootschap één iemand is die weet wat iedereen moet doen en (later) aan het doen is. Er moet (ook) bij de doelwitvennootschap één aanspreekpunt zijn voor vragen.

2. Er moeten duidelijke afspraken zijn over de bedoeling van het onderzoek en die afspraken moeten ook met de vertegenwoordigers van de doelwitvennootschap zijn afgestemd.

3. Wijzigingen in scope en aanpak dienen steeds tussentijds met de opdrachtgever te worden afgestemd en schriftelijk te worden vastgelegd. Zijn derden betrokken bij de initiële afspraken, dan dienen die met de wijziging in te stemmen.

4. De onderzoekers moeten duidelijke afspraken maken over de eigen positie. Aan wie wordt er gerapporteerd, is hoor en wederhoor voorzien, hoe vaak, wie krijgt het rapport ter inzage, exoneratie en dergelijke en er moet worden zeker gesteld dat die relevante afspraken ook met de vertegenwoordigers van de doelwitvennootschap zijn afgestemd.

5. Alle leden van het due diligence team dienen precies te begrijpen wat de scope van het onderzoek is (diepgang, volledigheid, voorwerp van onderzoek en dergelijke). Dit moet waar mogelijk gecoördineerd worden met andere due diligence teams (fiscalisten, accountants of advocaten bijvoorbeeld, al naar gelang het geval).

6. Het moet (eerst) met de opdrachtgever en (daarna) met alle leden van het due diligence team worden besproken op welke wijze het onderzoek zal worden uitgevoerd, en ook hoe er zal worden gerapporteerd (format). Dit moet waar mogelijk ook met andere due diligence teams gecoördineerd worden.

7. De uitvoering van het onderzoek start met een kick-off meeting. Daarbij moeten de koper en verkoper en vertegenwoordigers van elke discipline van het due diligence team aanwezig zijn.

8. Met de leden van het due diligence team moeten harde afspraken worden gemaakt over het gebruik maken van de format en er moet worden gezorgd voor software of andere middelen om de uitkomsten van de door een ieder te verrichten werkzaamheden snel en eenvormig te verwerken.

9. Met de doelwitvennootschap moeten duidelijke afspraken worden gemaakt over de inhoud en inrichting van een dataroom. Zeker moet worden gesteld dat al het gewenste onderzoeksmateriaal daar in wordt samengebracht.

10. Goede afspraken moeten worden gemaakt over vertrouwelijkheid (geheimhouding) en goede spelregels moeten worden afgesproken over de toegang tot informatie en over het overnemen of meenemen daarvan (dataroom protocol?). 
11. Van te voren - als de tijd dat toestaat - dient de coördinator van het due diligence team zich er van te vergewissen dat al het benodigde materiaal in de dataroom aanwezig is, om te voorkomen dat het gehele due diligence team voor twee multo-mappen op pad gaat.

12. Er moet worden voorzien in een voldoende aantal medewerkers. Het is beter om te downsizen gaande het due diligence proces, dan er nieuwe medewerkers bij te moeten betrekken en die te moeten inwerken.

13. Indien de doelwitvennootschap niet in staat is om tijdig een data-room in te richten, dan kan ondersteuning worden aangeboden onder het afspreken van waarborgen voor vertrouwelijkheid. Met name bij kleinere doelwitvennootschappen wil deze hulp nog wel eens welkom zijn, ook om te helpen duidelijk maken wat voor een soort gegevens benodigd zijn.

14. Er moet worden gezorgd voor de benodigde logistiek (computers, nietmachines, markers, en dergelijke), zodat niet behoeft te worden aangevangen met een strooptocht in de organisatie van de doelwitvennootschap naar kantoorbenodigdheden.

15. In de agenda's van de leden van het due diligence team dient sprake te zijn van een ruime en flexibele planning. Overwogen kan worden om bij de planning ten minste de helft van de tijd te reserveren voor overleg, voorbereiding, rapportage, hoor- en wederhoor (als van dit laatste sprake moet zijn).

16. De leden van het due diligence team dienen ter bestemder plekke tijdig en voldoende geïntroduceerd zijn. Alle leden van het due diligence team dienen zich er van bewust te zijn dat de doelwitvennootschap zo weinig mogelijk overlast moet worden bezorgd tijdens het uitvoeren van het onderzoek. Het is belangrijk dat iedereen zich in het contact met vertegenwoordigers van de doelwitvennootschap ook correct gedraagt en zich als vragende en niet als instructie-gevende partij opstelt.

17. Tijdens de uitvoering van het onderzoek dient regelmatige onderlinge afstemming in het due diligence team plaats te vinden, maar ook met de coördinatoren van andere due diligence teams (bijvoorbeeld fiscaal, accountantstechnisch, milieu) om dubbel werk te voorkomen en elkaar te wijzen op aandachtspunten.

18. Met name in het MKB is vaak de betrokkenheid van de accountant bij diens cliënt groot. Dit kan de onafhankelijkheid van de accountant bij het onderzoek beïnvloeden ${ }^{588}$ Hiermee moet rekening worden gehouden.

19. Er dient niet alleen naar documenten maar ook naar de organisatie te worden gekeken (toont het goed georganiseerd; is het opgeruimd?) en naar de mensen.

20. Met de opdrachtgever moet eerst een concept-rapport worden besproken en met deze dient te worden nagegaan of deze alleen onderzoeksresultaten gerapporteerd wil krijgen of ook suggesties voor oplossingen. De definitieve lay-out van de gewenste rapportage (bijvoorbeeld één bladzijde met management informatie en overall conclusies, een kort rapport of een (erg) uitgebreid rapport) moet worden besproken.

21. Met de opdrachtgever moet worden besproken hoe te handelen wanneer gegevens blijken te ontbreken of antwoorden op vragen (nog) niet gegeven kunnen worden.

22. Achteraf moet met het due diligence team worden geëvalueerd 'what went well" en "what did not go well". ${ }^{89}$ Die lessen kunnen worden meegenomen naar een volgend onderzoek.

\section{$9.4 \quad$ Hoor en wederhoor}

De kwestie van hoor en wederhoor ligt genuanceerd. In beginsel zal het om gewone zorgvuldigheidsnormen gaan. Niet voor alle deskundigen die bij een due diligence onderzoek betrokken zijn, gelden bijzondere regels, die de kwestie van hoor en wederhoor voor die deskundige relevant maken. In beginsel staat de beantwoording van de vraag of er van hoor en wederhoor sprake zal zijn, alvorens een due diligence rapport zal worden uitgebracht, ter discretie van partijen. Normaliter zal het bestuur van de doelwitvennootschap verwachten en er aanspraak op maken dat er geen due diligence rapport zal worden uitgebracht, alvorens er over bevindingen van de deskundige met het bestuur van die doelwitvennootschap is gesproken. Toch verdient het aanbeveling om bij het maken van afspraken over het doen uitvoeren van een due diligence onderzoek, dit onderwerp nadrukkelijk aan de orde te stellen. Omgekeerd geldt deze aanbeveling ook voor degene die een due diligence onderzoek doet uitvoeren.

\footnotetext{
${ }^{588}$ R.W.A. Eradus en D.B.C. Contzé, Due diligence in het MKV, een vak apart? (www.bdo.nl).

589 www/www ("what went well" / "what went wrong")
} 
Wanneer die niet bedoelt om de voorlopige bevindingen te laten bespreken met het bestuur van de doelwitvennootschap, dan kan dat maar beter met zoveel woorden tot uitdrukking worden gebracht bij het maken van afspraken.

Vanzelfsprekend heeft het bespreken van de voorlopige bevindingen met het bestuur van de doelwitvennootschap zin - hetgeen eerder regel dan uitzondering zal zijn, ongeacht de vraag of partijen aan deze kwestie op de voorhand aandacht hebben besteed - nu dat de kwaliteit van het rapport uitsluitend ten goede kan komen. Het risico van verkeerde interpretaties of misverstanden wordt daardoor immers beperkt.

Een deskundige zal over het algemeen zelf geneigd zijn hoor en wederhoor toe te passen. ${ }^{590}$

In een reeks van uitspraken heeft de Raad van Tucht voor Registeraccountants en, in hoger beroep, het College van Beroep voor het Bedrijfsleven (waaronder de bekende uitspraak in de zaak van oudburgemeester Bram Peper tegen KPMG), geoordeeld dat een accountant die onderzoek doet naar een derde, onder omstandigheden niet aan zijn opdrachtgever mag rapporteren zonder eerst hoor en wederhoor toe te passen. ${ }^{591}$

Deze regel geldt in ieder geval, als het commentaar van de derde op de voorlopige bevindingen van de accountant essentieel is om tot een deugdelijke grondslag voor de rapportage te komen. De verplichting tot toepassing van hoor en wederhoor is dus sterker aanwezig indien de accountant moet begrijpen dat bij een ongunstige rapportage voor de derde grote belangen op het spel staan. In dat geval moeten de grondslagen van de bevindingen van de accountant helder zijn en uit zijn (al dan niet tussentijdse) rapportage ook blijken. Aard en doel van de rapportage spelen bij de vraag in hoeverre hoor en wederhoor moet worden toepast, een belangrijke rol.

Inmiddels heeft het NIVRA aanbevelingen vastgelegd voor de wijze waarop moet worden omgegaan met zogenaamde persoonsgerichte accountantsonderzoeken. ${ }^{592}$ Een persoonsgericht onderzoek is een onderzoek waarbij accountants in het kader van een opdracht gegevens verzamelen, analyseren en/of controleren, alsmede daarover rapporteren in zake het functioneren, het handelen, of nalaten van handelen van betrokkene $(\mathrm{n}){ }^{593}$

Tussen accountants onderling gold voorheen artikel 33 GBR. Nu de GBR niet langer van toepassing is, moet worden nagegaan of er vervangende bepalingen zijn te vinden in de Verordening Gedragscode Registeraccountants en de Verordening Gedragscode Accountant-administratieconsulenten. Voor de openbare accountants is in hoofdstuk B1-203 van de Verordening Gedragscode een bepaling opgenomen met betrekking tot second opinions. In die bepaling is hoor en wederhoor genoemd als voorbeeld van een waarborg die in acht genomen kan worden om een bedreiging van niet te verwaarlozen betekenis voor de naleving van het fundamentele beginsel van deskundigheid en zorgvuldigheid ongedaan te maken of terug te brengen tot een aanvaardbaar niveau. Ook bij een bedreiging van niet te verwaarlozen betekenis van een ander fundamenteel beginsel - te denken is aan objectiviteit - kan het toepassen van hoor en wederhoor een adequate waarborg zijn. Voor zover in jurisprudentie nog naar artikel 33 GBR wordt verwezen, houdt dit verband met het feit dat de aangelegenheden waarover in die tuchtzaken werd geklaagd, zich voordeden in de periode waarin niet de Verordening Gedragscode maar de GBR (nog) van toepassing was. De huidige status is derhalve dat er - anders dan in de GBR - geen formele verplichting kan worden aangewezen voor het toepassen van hoor en wederhoor tussen accountants en accountant-administratieconsulenten. Wel kan de verplichting tot naleven van de fundamentele beginselen welke door de Verordening Gedragscode worden nagestreefd, ertoe leiden dat het toepassen van hoor en wederhoor als waarborg kan gelden voor het terugbrengen tot een aanvaardbaar niveau - of het wegnemen van een bedreiging van niet te verwaarlozen betekenis - voor

\footnotetext{
${ }^{590}$ Zie bijvoorbeeld onder 2.3 in Rb. Amsterdam 6 februari 2008, LJN BC7179. In de desbetreffende zaak week overigens later na het uitbrengen van het rapport door de deskundige - de rechtbank op bepaalde punten van het oordeel van de deskundige af, hetgeen steeds mogelijk blijft. Toepassen van hoor en wederhoor, maakt dit laatste echter minder voor de hand liggend.

591 CBB 31 augustus 1999, AB 1999/473, AWB 97/1418; CBB 14 maart 2000, AB2000/245, AWB 98/1320 en 98/1348; CBB 12 april 2001, LJN AB1303, AWB 99/950; CBB 12 maart 2002, LJN AE0760, AWB 01/690; CBB 13 juni 2002, LJN AE4057, AWB 01/527 en 01/534; CBB 5 november 2002, LJN AF1513, AWB 02/331; CBB 5 februari 2004, LJN AO3797, AWB 02/1838; CBB 10 februari 2004, LJN AO4456, AWB 03/136; CBB 9 september 2004, LJN AR2770, AWB 03/583; CBB 30 november 2004, LJN AR8302, AWB 03/866 en 03/855; CBB 25 januari 2005, LJN AS4440, AWB 03/1207.

${ }^{592}$ Gedragsrichtlijn in zake persoonsgerichte accountantsonderzoeken.

${ }^{593}$ Hoewel op het moment van afsluiten van het manuscript voor dit boek de gedragsrichtlijn van toepassing was, had zich tevens het besluit binnen het NIVRA gevormd om de richtlijn opnieuw aan een evaluatie te onderwerpen en denkbaar te veranderen. Het is dus niet uit te sluiten dat op enige termijn deze richtlijn weer zal worden gewijzigd.
} 
de voor iedere registeraccountant verplichte naleving van de hiervoor bedoelde fundamentele beginselen.

De vraag of een deskundige tegen diens wil medewerking dient te verlenen aan een verzoek tot verduidelijking van het deskundigenrapport kwam aan de orde in een procedure bij de voorzieningenrechter te Amsterdam. ${ }^{594}$ In die procedure ging het om de vraag of een procespartij kon weigeren medewerking te verlenen aan het gezamenlijk met diens wederpartij doen van een verzoek aan een deskundige om het door die uitgebrachte rapport op een bepaald punt te verduidelijken. In het desbetreffende geval werd de afweging gemaakt dat de gewenste verduidelijking zou kunnen voorkomen dat er over het punt van de onduidelijkheid tussen partijen (verder) zou moeten worden geprocedeerd. Wanneer niet zou worden meegewerkt aan een gemeenschappelijk verzoek aan de deskundige, zou die deskundige later op verzoek van de rechter uiteindelijk toch de gezochte inlichtingen moeten verschaffen. Het alternatief zou zijn dat er een nader of alternatief voorlopig deskundigenrapport zou worden gevraagd. De rechter was van oordeel dat dit de procesgang onnodig zou vertragen. Waar de deskundige had aangegeven bereid te zijn om antwoord te geven wanneer hij van beide partijen een verzoek daartoe zou ontvangen, werd de weigering van de wederpartij om mee te werken aan het geven van een opdracht aan de deskundige om inlichtingen te verschaffen, als onrechtmatig beoordeeld. ${ }^{595}$

\subsection{Questionnaire}

Uitgebreide vragenlijsten en zogenaamde check lists zijn commercieel verkrijgbaar. Ik verwijs onder meer naar www.diomo.com, maar ook naar www.duediligencechecklist.com en www.construx.com.

\subsection{Forensische accountants}

Voor zover er bij due diligence werkzaamheden al van forensische activiteiten sprake kan zijn, geldt dat de forensisch accountant onder omstandigheden slechts kan beschikken over een van de advocatuur afgeleid verschoningsrecht. ${ }^{596}$ Dit geldt echter uitsluitend wanneer de opdracht aan de forensisch accountant of deskundige is verstrekt door een advocatenkantoor. Indien de opdrachtverstrekking rechtstreeks van de opdrachtgever komt en de opdrachtgever geen verschoningsrecht toekomt, zal de forensisch accountant geen beroep kunnen doen op het verschoningsrecht. Waar in tegenstelling tot een due diligence rapport een forensisch rapport vrijwel nooit een advies zal bevatten, zal in beginsel ook geen beroep kunnen worden gedaan op algemene beginselen van behoorlijk bestuur, wanneer bijvoorbeeld de fiscus inzage in een rapport verlangt. ${ }^{597}$

\section{$9.7 \quad$ Settlement deed}

In de praktijk is het niet ongebruikelijk om aan de hand van de uitkomst van een due diligence onderzoek de gevolgen van de uitkomst van dat onderzoek met elkaar te regelen. Het vermijden van inhoudelijke procedures; het verifiëren van de actuele omvang van activa of passiva welke zijn overgedragen of het toepassen van (verrekeningen op) de koopprijs, het zijn allemaal onderwerpen die partijen met elkaar kunnen regelen. De vaststellingsovereenkomst waarin de desbetreffende afspraken worden vastgelegd wordt dan wel als settlement deed aangeduid. De benaming moet benadrukken dat de gevolgen van eventuele discrepanties welke naar aanleiding van het due diligence onderzoek zijn gebleken, tussen partijen zijn geregeld. ${ }^{598}$

Belangrijk is vanzelfsprekend de inhoud van een settlement deed. In het geschil dat eindigde met de uitspraak van de rechtbank Haarlem van 24 maart $2004^{599}$ blijkt dat het tot stand komen van een

\footnotetext{
${ }^{594}$ Voorzieningenrechter rechtbank Amsterdam 10 januari 2008, LJN BC3099

${ }^{595}$ Voorzieningenrechter Rechtbank Amsterdam 10 januari 2008, LJN BC3099 (r.o. 4.4) De rechter nam aan dat de deskundige de nadere toelichting gratis zou verschaffen: "Voor ruim Euro 55.000 mogen partijen toch wel een rapport met een helder en eenduidig antwoord verwachten".

${ }^{596}$ Zie HR 29 maart 1994, NJ 1994, 552 en HR 12 maart 1997, BNB 1997/146.

597 Zie omtrent de hier aangesproken problematiek, B.G.H. de Ruiter, Due-diligence rapporten buiten spel, Weekblad Fiscaal Recht 6665, 6 april 2006, p. 372.

${ }^{598}$ Zie voor een voorbeeld Rechtbank Rotterdam 30 mei 2007, LJN BB6044 (r.o. 3.1. onder h.).

${ }^{599}$ LJN AO8130 (r.o. 6.2.)
} 
settlement deed nog niet altijd alle geschillen definitief de wereld uit helpt. Het betrof een kwestie waarin koper en verkoper hadden geprobeerd alle geschillen naar aanleiding van een koopovereenkomst van aandelen definitief en tegen algehele kwijting te regelen. Toen de koper een vordering instelde tegen de verkoper op grond van toerekenbare niet-nakoming, danwel dwaling of bedrog, probeerde de verkoper zich te verweren door te verwijzen naar het bestaan van de vaststellingsovereenkomst. De rechtbank stelde vast dat de vaststellingsovereenkomst geen kwijtingsregeling bevatte en een bepaling ontbeerde die strekte tot een definitieve beslechting van de geconstateerde geschillen. In tegendeel. In de vaststellingsovereenkomst werd de mogelijkheid van nieuwe meningsverschillen en de regeling daarvan juist open gehouden doordat werd opgemerkt dat in het geval van nieuwe discussies de inhoud van de vaststellingsovereenkomst onverbindend zou zijn en partijen gehouden zouden zijn de oorspronkelijke overeenkomst onverminderd na te komen. Dat in de considerans van die vaststellingsovereenkomst werd gezegd dat de afspraken werden gemaakt 'ter finale oplossing van alle (mogelijke) discussiepunten', deed aan het vorenstaande volgens de rechtbank niet af.

Niet ongebruikelijk is het om een zogenaamde escrow voorwerp van de afspraken te maken. ${ }^{600} \mathrm{De}$ escrow houdt in dat een gedeelte van de koopsom wordt achtergehouden door de koper of in handen van een derde wordt geplaatst (bijvoorbeeld de derdengeldrekening van een notaris) om te dienen voor verhaal in het geval er een beroep moet worden gedaan op garanties of er ingevolge de settlement deed sprake is van verrekening met de koopprijs. ${ }^{601}$

\section{$9.8 \quad$ Verklaring van de wijze van prijsbepaling}

Zoals elders opgemerkt, komen veel vragen naar aanleiding van de nakoming van bepalingen in overnameovereenkomsten aan de orde in arbitrageprocedures. Het is eerder regel dan uitzondering dat in overnameovereenkomsten arbitrage wordt overeengekomen bij wijze van geschillenregeling. Het voordeel van arbitrage is vooral (naast het niet-openbare karakter van de procedure) dat deskundige scheidslieden kunnen worden aangezocht die ervaring hebben op het gebied van fusies en overnames. Veronderstelde inbreuken op garanties, vragen van non-conformiteit en dergelijke passeren dan de revue. In veel van die procedures speelt de vraag of bij het bepalen van een koopsom rekening is gehouden met bepaalde omstandigheden. Niet zelden worden in procedures door de koper de desbetreffende omstandigheden opgevoerd als reden om de stelling te rechtvaardigen dat er sprake is van een inbreuk op garanties of om anderszins te stellen dat er sprake is van non-conformiteit. De verkoper zegt niet zelden juist te hebben ingestemd met een bepaalde koopprijs om (alsdan) door de verkoper genoemde redenen, terwijl de koper zegt zich van die overwegingen niet bewust te zijn geweest, ${ }^{602}$ of andersom, stelt de koper juist met een prijs te hebben ingestemd op grond van omstandigheden, waarvan de verkoper zegt zich niet bewust te zijn geweest. Het is daarom van belang in een settlement deed of bij voorkeur eerder al in de documentatie waarin een transactie wordt vastgelegd, aandacht te besteden aan de vraag welke overwegingen voor ieder der partijen bepalend zijn geweest bij de vaststelling van de koopprijs. Eerst wanneer die omstandigheden voor de wederpartij kenbaar zijn, kan achteraf naar die omstandigheden worden verwezen, wanneer de gevolgen van non-conformiteit of een inbreuk op garanties aan de orde komen. ${ }^{603}$

\footnotetext{
${ }^{600}$ Volgens de New International Webster's Comprehensive Dictionary of the English Language een escrow is "an instrument under seal, placed in the hands of a third person for delivery to the grantee on some condition, the instrument being of no effect until delivery".

601 Zie voor een voorbeeld HR 9 juni 1995, NJ 1995, 692 (Finad / Worst), waar slechts een voorschot op de koopprijs was betaald en het restant van de koopprijs was achtergehouden.

602 Zie bijvoorbeeld ook in de gewone rechtspraak Rechtbank Utrecht 24 oktober 2007. LJN BB6509 (r.o. 4.5.): "Zij (de koper, $\mathrm{MB}$ ) heeft bovendien onvoldoende concreet weersproken dat met dergelijke factoren rekening is gehouden bij de vaststelling van de koopprijs van de aandelen".

603 Zie in dit verband HR 19 juni 1959, NJ 1960, 59 m.nt .HB (Kantharos van Stevenweert: '(...) naar redelijke, in het verkeer gangbare opvattingen geeft degene, die aan hen toebehorende zaak tegen een contraprestatie van de hand doet, daarmee de kans prijs dat de zaak achteraf hoedanigheden zal blijken te bezitten, waarvan hij ten tijde van de verkoop geen vermoeden kon hebben'. Door de overwegingen welke bij de prijsbepaling spelen wel te benoemen, is er achteraf in ieder geval een richtsnoer.
} 


\section{Aspecten van geheimhouding}

\section{$10.1 \quad$ Algemeen}

Voorafgaande aan het plaatsvinden van het due diligence onderzoek zullen partijen over en weer afspraken willen maken over de wijze waarop een due diligence onderzoek zal worden uitgevoerd. Belangrijk punt hierbij is dat de doelwitvennootschap de voor de koper vereiste informatie slechts onder strikte voorwaarden zal willen verstrekken. De doelwitvennootschap zal haar commerciële positie niet in gevaar willen brengen. Zij moet rekening houden met het mislukken van de transactie, totdat zeker is dat een en ander zal doorgaan. De gesprekspartner van vandaag kan immers morgen nog steeds of weer een concurrent zijn. De in het traject voorafgaande aan de transactie bedoelde geheimhouding, wordt in dit hoofdstuk besproken onder het hoofd "Geheimhouding". Het betreft geheimhouding welke van de koper wordt verlangd door de verkoper. De geheimhouding wordt verlangd ten opzichte van derden en de eigen bestuurders, commissarissen en werknemers van de koper voor zover die in de commerciële praktijk hun voordeel met de te verkrijgen kennis zouden kunnen doen. In dit hoofdstuk wordt ook stilgestaan bij de geheimhouding waarop de verkoper (ook) moet kunnen rekenen wanneer er door de koper adviseurs worden ingeschakeld om een due diligence onderzoek uit te voeren.

In hoofdstuk 11 wordt ingegaan op de vraag of in de fase na het tot stand komen van de transactie de middels een due diligence onderzoek verkregen informatie door de koper ten opzichte van de verkoper geheim gehouden kan worden. Daarmee wordt de situatie aangesproken waarin het nu de koper zelf is die geheimhouding wenst. Zo goed als de verkoper in de fase voorafgaand aan de transactie - maar ook daarna nog - er belang bij heeft dat vertrouwelijke bedrijfsinformatie niet in handen komt van partijen, die daar oneigenlijk gebruik of zelfs misbruik van kunnen maken, wil de koper voorkomen dat na het voltooien van de transactie de tijdens een due diligence onderzoek verkregen informatie (oneigenlijk) gebruikt kan worden. De koper heeft in het normale geval een due diligence onderzoek uitgevoerd om zelf een (eigen) beeld te vormen van de (onderneming van de) doelwitvennootschap en niet om die informatie later door de verkoper tegen zich te doen gebruiken wanneer hij een beroep wil doen op garanties. De koper kan onder omstandigheden belang hebben bij vertrouwelijkheid waar het de inhoud van een eenmaal uitgebracht due diligence rapport betreft. Ik bespreek de laatst bedoelde situatie onder het hoofd "Exhibitieplicht". Of ondanks de aanvaarding van een verplichting om informatie betreffende een doelwitvennootschap geheim te houden, vertrouwelijkheid altijd gewaarborgd zal zijn - ook ten opzichte van anderen dan alleen de verkoper met wie de koper zich in een rechtsbetrekking bevindt - hangt af van de toepassing van de wettelijke regeling met betrekking tot de exhibitieplicht. In zoverre komen ook vragen rond een verschoningsrecht van de verschillende bij een transactie betrokkenen in het volgende hoofdstuk aan de orde.

Het hier voor gemaakte onderscheid tussen geheimhouding en exhibitieplicht is niet absoluut. Het onderscheid gaat bijvoorbeeld niet op wanneer de koper er weet van heeft dat er een vendor due diligence is uitgevoerd.

Het gemaakte onderscheid tussen geheimhouding enerzijds en exhibitieplicht anderzijds (waarbij onder exhibitieplicht ook het verschoningsrecht wordt meegenomen) kan echter goed dienst doen om beide onderwerpen gescheiden van elkaar te behandelen.

Van de verkrijger van vertrouwelijke informatie kan niet worden gevraagd dat die geheimhouding blijft betrachten, wanneer de informatie anders dan door diens toedoen of door het toedoen van diens adviseurs van algemene bekendheid wordt. In de geheimhoudingsovereenkomst welke veelal bij de aanvang van de besprekingen tussen partijen zal worden voorgelegd door degene van wie verlangd wordt dat die vertrouwelijke informatie verschaft, zullen veelal ook uitzonderingen zijn opgenomen voor de gevallen waarin door rechterlijke of andere autoriteiten gegevens worden verlangd ofwel langs andere weg - en niet door gebruikmaking van wanprestatie van een derde - de desbetreffende informatie toch wordt verkregen.

De verschaffer van informatie doet er in elk geval goed aan om in een zo vroeg mogelijk stadium goede afspraken te maken over de omstandigheden waaronder vertrouwelijke informatie aan welke personen zal worden verschaft en ook welk gebruik zal zijn toegestaan. Ook is het nodig dat wordt na- 
gedacht over de verbintenis van adviseurs of anderen dan de ontvanger van de informatie zelf, nu deze zich veelal voor de beoordeling van een transactie zal voorzien van adviezen van derden, die derhalve over dezelfde informatie zullen komen te beschikken. Belangrijke onderwerpen in een geheimhoudingsovereenkomst zijn de benoeming van die informatie welke als vertrouwelijk zal worden beschouwd en wat er zal gebeuren indien een transactie geen doorgang vindt. Moeten alle gegevensdragers dan worden vernietigd of geretourneerd? De naleving van de in een geheimhoudingsovereenkomst op te nemen verbintenissen zal niet altijd eenvoudig te controleren en daarom evenmin eenvoudig te sanctioneren zijn.

Het geheimhouden van gegevens welke worden onderzocht tijdens een due diligence onderzoek, zal steeds een belangrijk voorwerp van zorg zijn. Gebruikelijke afspraken zijn dat uitsluitend diegenen die zich gebonden weten (al dan niet uit hoofde van hun beroep) aan een geheimhoudingsplicht, toegang zullen krijgen tot vertrouwelijke gegevens van de onderzochte onderneming. In de gemaakte afspraken staat gebruikelijk dat al die gegevens geheim moeten worden gehouden, die niet al in het publiek domein bekend zijn of anders langs openbare bronnen verkrijgbaar zijn.

Op 22 juni 2007 speelde de vraag omtrent de strekking van een geheimhoudingsbeding bij de Hoge Raad. ${ }^{604}$ Het betrof een zaak waarin een vertrekkende directeur-grootaandeelhouder had afgesproken strikte geheimhouding te betrachten met betrekking tot alle gegevens respectievelijk bijzonderheden betreffende de onderneming (van de vennootschap) of een met haar gelieerde onderneming en zich in het algemeen te zullen onthouden van iedere handeling of gedraging welke kon leiden tot schade voor de vennootschap of een met haar gelieerde onderneming. De betrokkene overhandigde kort na zijn vertrek een klantenlijst aan een concurrent, waarmee hij een managementovereenkomst aanging. De vennootschap stelde dat dit een inbreuk op de geheimhoudingsverplichting vormde. Zij wenste ontbinding van de beëindigingsovereenkomst met de directeur-grootaandeelhouder en vorderde de overeengekomen boete met schadevergoeding. Het gerechtshof te 's-Hertogenbosch en de Hoge Raad beschouwden het gebruik van de klantenlijst van de vennootschap als een schending van de overeengekomen geheimhoudingsplicht. Volgens het Gerechtshof moest de afgesproken geheimhoudingsverplichting aldus worden uitgelegd, dat het uitgangspunt was dat het moest gaan om de bescherming van (bedrijfsspecifieke) gevoelige / vertrouwelijke bedrijfsinformatie, "die als deze buiten het bedrijf bekend (gemaakt) wordt, schade veroorzaakt". Daarbij moeten het gegevens en bijzonderheden betreffen, volgens het Gerechtshof, die voor de concurrentie daadwerkelijk geheim zijn. De Hoge Raad overwoog als volgt:
"(...) het Hof kennelijk tot uiting heeft gebracht dat reeds door het bekend worden van die informatie buiten het bedrijf, sprake is van het teloorgaan van de vertrouwelijkheid van de bedrijfsinformatie en daarmee van een voor dat bedrijf schadelijke situatie in die zin dat derden ten nadele van het bedrijf van die informatie zouden kunnen profiteren. Het door het Hof (...) geformuleerde uitgangspunt houdt dus niet in dat pas sprake is van schending van een geheimhoudingsplicht indien (gebleken is dat) daadwerkelijk schade is veroor- zaakt door het bekend worden van de vertrouwelijke bedrijfsinformatie buiten het bedriff".

Er werd in het onderhavige geval schending van de geheimhoudingsverplichting aangenomen. Van der Korst ${ }^{605}$ duidt op een onderscheid tussen:

a. verhandelbare bedrijfsgeheimen, dat wil zeggen geheime informatie die los van de onderneming handelswaarde bezit (zoals knowhow, recepturen, klantenlijsten); en

b. 'incidentele' bedrijfsgeheimen, die louter relateren aan de onderneming waarvan openbaarmaking de onderneming kan schaden (zoals overnamebesprekingen, voorgenomen introductie van een nieuw product, juridische procedures) en

c. beide vormen van bedrijfsgeheimen.

Volgens hem gaan in de hiervoor genoemde uitspraak het gerechtshof en de Hoge Raad er zonder nadere toelichting vanuit dat een geheimhoudingsbeding (ook) betrekking heeft op verhandelbare be-

\footnotetext{
${ }^{604}$ Zie HR 22 juni 2007, NJ 2007, 343 en daarover P.J. van der Korst, Contractuele bescherming bedrijfsgeheimen, Ondernemingsrecht 2008-3, p. 127-128. 
drijfsgeheimen. Van der Korst acht dat op grond van een algemeen gestelde geheimhoudingsverplichting - zoals in de onderhavige zaak het geval was - niet concludent. Volgens de desbetreffende bepaling was het de betrokkene wel toegestaan in dezelfde branche als de vennootschap werkzaam te blijven. Volgens hem duidden de bewoordingen van de geheimhoudingsverplichting veel meer op incidentele bedrijfsgeheimen dan op verhandelbare bedrijfsgeheimen als klantenlijsten. Niettemin is de strekking dat ter gelegenheid van een due diligence onderzoek er bij het formuleren van een geheimhoudingsverplichting geen onduidelijkheid over mag blijven bestaan, dat de beide vormen van door Van der Korst bedoelde bedrijfsgeheimen voorwerp moeten zijn van een geheimhoudingsverplichting, wil toegang tot bedrijfseigen informatie aan de onderzoekers worden gegeven.

Het beroepsgeheim is wel omschreven als "de plicht van een hulp- of dienstverlener om te zwijgen over al datgene wat hij te weten is gekomen in de uitoefening van zijn beroep". Het betreft een plicht. Het beroepsgeheim betreft evenzeer een recht dat de cliënt toekomt. Voor bijvoorbeeld de advocaat of notaris geldt dat de cliënt het prijsgeven van dat recht niet kan afdwingen. Evenmin kan de cliënt de advocaat of notaris ontslaan van zijn plicht tot geheimhouding. ${ }^{606}$ Artikel $272 \mathrm{Sr}$ stelt het schenden van het beroeps- of ambtsgeheim strafbaar. Het artikel noemt diegene strafbaar, "die enig geheim waarvan hij weet of redelijkerwijs moest vermoeden dat hij uit hoofde van zijn (vroegere) ambt, beroep of wettelijk voorschrift verplicht is om te bewaren, opzettelijk schendt".

De geheimhoudingsplicht kan worden doorkruist door de in ons land bestaande getuigplicht (zie bijvoorbeeld $165 \mathrm{Rv}$ in civiele zaken en artikel 213en $215 \mathrm{~Sv}$ in strafzaken), maar dit komt aan de orde bij de bespreking van de de exhibitieplicht in hoofdstuk 11 hierna. Ook de toepassing van de Wet melding ongebruikelijke transacties kan tot een doorbreking van een geheimhoudingsplicht aanleiding zijn, zoals wij hierna in hoofdstuk 11 nog zullen zien.

\subsection{Concurrentiepositie}

Bij aanvang van de onderhandelingen kan in een geheimhoudingsovereenkomst maar bijvoorbeeld ook in een LOI worden overeengekomen dat het gedurende de onderhandelingen niet is toegestaan om met een derde in onderhandeling te treden over een eventuele samenwerking. Op deze manier zullen zowel koper als verkoper zich ervan proberen te verzekeren dat er onderhandeld kan worden zonder de dreiging van concurrentie. Een dergelijke afspraak noemt men wel een exclusiviteitsbeding.Een bijzonder element bij het afspreken van een exclusiviteitsbeding is het moment waarop aan de exclusiviteit een einde komt. Dit moet duidelijk bepaald zijn. ${ }^{607}$

\subsection{Verbod overnemen van personeel}

Al dan niet in de hiervoor bedoelde geheimhoudingsovereenkomst is het zinvol afspraken te maken over een verbod van de onderzoekende vennootschap om personeelsleden van de doelwitvennootschap aan te nemen binnen een bepaalde tijd na het afbreken van onderhandelingen. De onderzoeker zal immers een goed beeld krijgen van de sleutelfiguren binnen de onderzochte organisatie en zou in de verleiding kunnen komen om één of meer van die sleutelfiguren een aanbod te doen om over te stappen. Het in dienst (kunnen) nemen van bepaalde in de onderneming van de doelwitvennootschap werkzame personen kan een acquisite van de doelwitvennootschap overbodig maken.

\subsection{Sanctionering}

Een geheimhoudingsbeding kan als hiervoor opgemerkt worden gesanctioneerd met een boeteclausule. In de praktijk maakt men in combinatie met een beding als hiervoor bedoeld ook nog wel eens de afspraak dat de opdrachtgever binnen zekere tijd niet tot een soortgelijke transactie met een ander zal overgaan, wanneer de transactie geen doorgang vindt.

Hiervoor werd al gesproken over een non-disclosure en de abstention agreement (NDAA). Bij gewone transacties zal een desbetreffende overeenkomst in veel gevallen als "geheimhoudingsovereenkomst"

\footnotetext{
${ }^{606}$ Zie F.A.W. Bannier e.a., Beroepsgeheim en verschoningsrecht, SDU 2008, p. 3.

${ }^{607}$ Zie voor een geval waarin onduidelijkheid voor problemen aanleiding vormde: President rechtbank Dordrecht, 23 maart 2000 , JOR 2000, 80 (HBG / Boskalis).
} 
(confidentiality and non-disclosure agreement) worden aangeduid. De inhoud van een overeenkomst als hiervoor bedoeld moet tevens inhouden dat informatie ook geheim wordt gehouden (of juist) wanneer de gesprekken afgebroken zouden worden. Niet ongebruikelijk is het in - evenzo als dat in een LOI wel gebeurt - om ten aanzien van een of meer bepalingen over een te komen dat die na het einde van de overeenkomst hun gelding tussen partijen zullen behouden.

\subsection{Positie adviseurs en derden}

Er is hiervoor in hoofdstuk 8 al op gewezen dat het nodig is om aandacht te besteden aan de positie van adviseurs en andere derden. Veelal bestaat er een noodzaak om afspraken over geheimhouding en dergelijke te maken met behulp van de opdrachtgever, de wederpartij en/of de doelwitvennootschap, nu de rechtsverhouding tussen deze en gene veelal niet rechtstreeks bestaat (bijvoorbeeld de door de onderzoekers geraadpleegde deskundigen of werknemers van de onderzoekers).

Waar het de positie van adviseurs en derden betreft die over vertrouwelijke informatie komen te beschikken door de uitvoering van een due diligence rapport of die een dergelijk rapport in handen krijgen, moet rekening worden gehouden met de regels van fiscaal- en burgerlijk procesrecht, die - zoals wij hierna in hoofdstuk 11 zullen zien - in deze context van belang zijn.

Het is niet altijd gemakkelijk om te bepalen wie een derde is. Ten aanzien van partijen die voorafgaand of tijdens het tot stand komen van een transactie daarmee niets van doen hebben (gehad), zal dat niet zo moeilijk zijn aan te nemen. Ingewikkelder wordt het wanneer het partijen betreft die gebruikelijk intensief bij het tot stand komen van een transactie betrokken worden. Te denken valt aan bankiers, fusiebemiddelaars, advocaten, notarissen, belastingadviseurs en accountants. De meeste van die beroepsbeoefenaars hebben een geheimhoudingsplicht, in de meeste gevallen gebaseerd op eigen beroeps- en gedragsregels. ${ }^{608}$ Ten opzichte van de partijen zelf die de transactie voor hun rekening en risico aangaan, zijn deze adviseurs evenals andere adviseurs derden. Ook de bedrijfsmakelaar of fusiebemiddelaar is een derde. Op de voor deze adviseurs geldende geheimhoudingsplicht wordt hierna nog nader ingegaan.

Een vraag die niet direct met geheimhouding te maken had, maar voortkwam uit het feit dat een bedrijfsmakelaar (fusiebemiddelaar) zichzelf mede als partij beschouwde bij een transactie, betrof die of de makelaar in ondernemingen (die optrad voor de verkoper), aanspraak kon maken op vergoeding van kosten of betaling voor het mislopen van courtage in het geval een koopovereenkomst die was gesloten onder de ontbindende voorwaarde van een positieve uitslag van een due diligence onderzoek, ontbonden werd. De koper stelde dat het due diligence onderzoek informatie had opgeleverd welke ruimschoots rechtvaardigde dat deze van de koop afzag. Er werd een beroep gedaan op de ontbindende voorwaarde. De koper eiste bovendien een vergoeding voor de gemaakte kosten van ruim $€ 80.000$, stellende dat de verkoper onjuiste en onvolledige informatie had verschaft en daarmee had gehandeld in strijd met de redelijkheid en billijkheid die de rechtsverhouding tussen de koper en de verkoper beheerste. De verkoper was het met dit alles in het geheel niet eens. Volgens deze rechtvaardigde de uitkomst van het due diligence onderzoek de ontbinding van de overeenkomst niet. De bedrijfsmakelaar was het daar graag mee eens. Hij miste $€ 115.000$ aan provisie door het niet doorgaan van de transactie. Of de koper met het oog op de gemaakte afspraken de ontbindende voorwaarden jegens de verkoper mocht inroepen achtte de rechtbank voorwerp van nader feitelijk onderzoek. De vordering van de makelaar werd echter afgewezen, omdat het mislopen van de courtage geen gevolg was van de schending van een zorgvuldigheidsnorm door de beoogde koper. De stelling van de makelaar dat een niet-gerechtvaardigd beroep op de ontbindende voorwaarden tegenover de verkoper onrechtmatig was jegens de makelaar, werd door de rechtbank in haar algemeenheid niet als juist beschouwd, alleen daarom al niet omdat de rechtbank geen zorgvuldigheidsnorm aanwezig achtte die de koper tegenover de makelaar van haar onderhandelingspartner in acht had te nemen. ${ }^{609}$

\footnotetext{
${ }^{608}$ Dit geldt voor advocaten, notarissen, belastingadviseurs, accountants en octrooigemachtigden. Waar advocaten en andere adviseurs behoren tot één samenwerkingsverband, gelden de Richtlijnen m.b.t. samenwerkingsverbanden van advocaten en andere (erkende) beroepsbeoefenaren van de Nederlandse Orde van Advocaten. Waar het notarissen en accountants betreft, kan gelden dat die als partij adviseur optreden. Zij hebben ook in die hoedanigheid een geheimhoudingsplicht. Zie verder in hoofdstuk 11

${ }^{609}$ Rechtbank Arnhem, 19 maart 2008, LJN BC8052.
} 


\subsection{Geheimhoudingsplicht adviseurs}

De belangrijkste adviseurs die in de regel bij een transactie zijn betrokken, zijn bankiers, fusiebemiddelaars, accountants, belastingadviseurs, advocaten en notarissen. Hierna wordt bezien of die adviseurs sowieso een geheimhoudingsplicht hebben of dat er met die adviseurs bijzondere afspraken over geheimhouding dienen te worden gemaakt wanneer die bij de uitvoering van een due diligence onderzoek worden betrokken.

Bij het vertrouwen op een (wel of niet op grond van de wet of op grond van gedragsregels van beroepsorganisaties geldende) geheimhoudingsplicht van bij een due diligence onderzoek betrokken adviseurs, moet wel steeds in het oog worden gehouden wat de sanctie is in het geval van schending van die geheimhoudingsplicht. Strafrechtelijke of deontologische sancties baten een partij die de dupe is geworden van schending van een geheimhoudingsplicht niet waar dit de schade betreft die het gevolg van zo' schending kan zijn. Het is daarom dat het aanbeveling kan verdienen om met de partij die de desbetreffende adviseurs inschakelt afsrpaken te maken over de toepasselijkheid van een boete of gefixeerde schadevergoeding welke door de opdrachtgever van die adviseurs verschuldigd zal worden door het enkele feit dat één van de door die partij ingeschakelde adviseurs zich niet aan de (gewenste) verplichting tot geheimhouding houdt. Een beroep op artikel 6:171 zal niet altijd volstaan, nu niet in alle gevallen zal kunnen worden aangenomen dat een adviseur bedrijfsmatig zijn werk verricht. ${ }^{610}$

Wanneer voorzien wordt in een duidelijk geformuleerde verbintenis waarin de aansprakelijkheid voor hulppersonen bij de betrokken opdrachtgever wordt gelegd, moet in de verhouding tussen die opdrachtgever en diens adviseurs dan middels regres of anderszins maar worden uitgevochten waar de rekening voor de schade uit eindelijk terechtkomt. Het is dan de opdrachtgever van de desbetreffende adviseur(s) die in de relatie tot die adviseur kan klagen over toerekenbare tekortkoming ingevolge de overeenkomst van opdracht, al dan niet na het doormaken van een voorafgaande tuchtrechtelijke of andere procedure. Dit is voor de gelaedeerde veruit te verkiezen boven het anders voor een verhaal van schade denkbaar noodzakelijk traject om een tuchtrechtelijke klacht te moeten indienen tegen de adviseur van de wederpartij en dan bij de gewone rechter hebben te voldoen aan het bewijzen van een causaal verband, schending van de Schutznorm en het moeten procederen over de vastelling van de omvang van de schade.

\section{Bankiers}

Wij kennen in Nederland geen bankgeheim. De algemene bankvoorwaarden 1995 spreken evenmin over een verplichting voor bankiers om de hen ter kennis komende zaken geheim te houden. Hoogstens zou een dergelijke verplichting kunnen worden afgeleid uit de door artikel 2 van die voorwaarden door banken op zich genomen verplichting om bij de dienstverlening 'de nodige zorgvuldigheid' in acht te nemen. De boodschap is in ieder geval dat het raadzaam is om met een bankier die wordt ingeschakeld bij (de voorbereiding van) een transactie goede afspraken op schrift te stellen over geheimhouding. Helemaal wanneer er een beursgenoteerde onderneming in het spel is, is het ook belangrijk om ter bescherming van de eigen positie - in aanvulling op de bestaande wettelijke bepalingen omtrent voorwetenschap - duidelijk af te spreken hoe er binnen de bank zal worden omgegaan met te verkrijgen informatie. De bank zal vrijwel altijd een probleem hebben om te verklaren dat er nergens binnen de bank posities in het desbetreffende fonds zullen worden ingenomen, nu dat voor andere cliënten van de bank in andere afdelingen desondanks gewenst kan zijn. Ook het inschakelen van derden door de bank moet worden aangesproken. Te meer waar in het overleg tussen de Nederlandse Vereniging van Banken en de Consumentenbond in het kader van het overleg in de Commissie Con-

\footnotetext{
${ }^{610}$ Zie T\&C, aantekening 2 sub c) onder artikel 6:171. Met de tendens bij advocatenkantoren om zich te organiseren in de rechtsvorm van een naamloze vennootschap, zal in het geval van in die rechtsvorm georganiseerde kantoren overigens eerder dan voorheen van een bedrijfsmatige activiteit kunnen worden gesproken wanneer er een opdracht tot het uitvoeren van een due diligence onderzoek wordt aanvaard. De andere kant van de hier bedoelde tendens is dat advocaten die tot een kantoor behoren dat zich in de rechtsvorm van een naamloze vennootschap heeft georganiseerd, op persoonlijke titel opdrachten plegen te aanvaarden. Zie ook r.o. 3..4 in HR 25 januari 2002, RvdW 2002, 22 (Lampenier).
} 
sumentenaangelegenheden van de SER er over artikel 3 van de algemene bankvoorwaarden (waarin voor het geval van inschakeling van derden een aansprakelijkheidsbeperking is opgenomen) geen overeenstemming kon worden bereikt. Tussen de genoemde partijen kon over de meeste van de in de algemene bankvoorwaarden opgenomen bepalingen wel overeenstemming worden bereikt. ${ }^{611} \mathrm{Er}$ mag niet lichtvaardig worden aangenomen dat de contacten tussen een bankier en diens relatie ipso facto onder een geheimhoudingsplicht van de bankier ressorteert.

\section{Fusiebemiddelaars}

Evenmin als bankiers kennen fusiebemiddelaars een geheimhoudingsplicht. Bij de inschakeling van een fusiebemiddelaar moeten daarom afspraken gemaakt worden over de in acht te nemen geheimhouding. Evenals bij bankiers - maar dit geldt ook bij andere beroepsgroepen - moet niet vergeten worden om in de te maken afspraken tevens te betrekken dat in te schakelen hulpersonen zich aan een gelijke geheimhoudingsverplichting dienen te verbinden. Het tot stand brengen en handhaven van een geheimhoudingsverplichting in de kring van mensen die over vertrouwelijke informatie komen te beschikken is een verplichting die gelegd moet worden op de eerste opdrachtnemer. Kantoorgenoten en adviseurs van de fusiebemiddelaar moeten eveneens aan een geheimhoudingsplicht gebonden worden. Dit geldt als gezegd voor alle adviseurs die bij een transactie betrokken raken. Ook de kantoorgenoten van accountants, advocaten, belastingadviseurs en anderen door hen te raadplegen personen dienen aan een geheimhoudingsplicht gebonden te zijn of te worden.

\section{Accountants}

Een accountant ${ }^{612}$ is wel verplicht tot geheimhouding, ingevolge de in de beroepsgroep geldende Verordening Gedragscode ("VGC"). De geheimhouding betreft "het niet bekend maken van vertrouwelijke informatie die de accountant in het kader van zijn beroepsmatig en zakelijk optreden heeft verkregen, tenzij hij is gemachtigd tot bekendmaking over te gaan of op grond van een wettelijk voorschrift dan wel beroepshalve daartoe een recht of plicht bestaat." ${ }^{613}$ Tevens is de accountant verplicht de vertrouwelijke informatie niet te gebruiken om zichzelf of een derde te bevoordelen. ${ }^{614} \mathrm{Om}$ de geheimhoudingsplicht effect te geven dient de accountant maatregelen te nemen om te waarborgen dat zijn ondergeschikten en hulppersonen zich hieraan ook conformeren. ${ }^{615}$

Hoewel de bovengenoemde geheimhoudingsverplichting ingevolge de VGC in zijn algemeenheid van toepassing is, wordt hiernaar ook expliciet verwezen in de nadere voorschriften omtrent transactiegerelateerde diensten (NV COS 5500N), waarvan de bepalingen ook op een due diligence zien. ${ }^{616}$ De geheimhoudingsplicht in het kader van een due diligence opdracht, wordt dus met nadruk van belang geacht en dient expliciet te worden gehandhaafd. In de NV COS $5500 \mathrm{~N}$ wordt de accountant voorts geïnstrueerd om vertrouwelijkheid ten opzichte van andere partijen dan de opdrachtgever te waarborgen, door onder meer:

gebruik te maken van uit verschillende personen samengestelde opdrachtteams; procedures in te voeren die voorkomen dat andere, werkzaam binnen dezelfde accountantsorganisatie, toegang kunnen krijgen tot bepaalde informatie. Hierbij is onder meer te denken aan het gebruik maken van afzonderlijke opdrachtteams, werkzaam op verschillende locaties en/of aan intern beveiligde archivering van de specifieke gegevens van de cliënt;

duidelijke richtlijnen te geven aan het opdrachtteam met betrekking tot de beveiliging en de geheimhouding van specifieke gegevens;

een geheimhoudingsverklaring te laten tekenen door de medewerkers van de accountantsorganisatie;

\footnotetext{
${ }^{611}$ Andere uitzonderingen betroffen artikel 10 (aansprakelijkheid voor verkeerde uitvoering van betalingsopdrachten) en 31 (algemene aansprakelijkheidsbeperking).

${ }^{612}$ De verplichting is van toepassing op zowel registeraccountants als accountants-administratieconsulenten.

${ }^{613}$ Art. A-140.1 sub a onder 1 VGC.

${ }^{614}$ Art. A-140.1 sub a onder 2 VGC.

${ }^{615}$ Art. A-140.5 VGC.

${ }^{616}$ Paragraaf 12 sub d van NV Cos 5500N (Transactiegerelateerde adviesdiensten).
} 
door een senior-functionaris van de accountantsorganisatie, die bij geen van de desbetreffende cliënten en opdrachten is betrokken, periodiek te laten beoordelen of de waarborgen juist worden toegepast.

Naast al deze maatregelen is het de accountant slechts toegestaan op verzoek van de opdrachtgever inzage in het rapport te verschaffen aan derden. Dit mag deze desondanks alleen maar doen wanneer hij vooraf voorwaarden voor inzage met de opdrachtgever en de derden is overeengekomen en de derden inzicht is gegeven in de omvang van de uitgevoerde onderzoeken. ${ }^{617}$

Uitzonderingen op de geheimhoudingsplicht vormen verplichtingen voortvloeiend uit wettelijke voorschriften, zoals de Wet toezicht accountantsorganisaties en de Wet MOT. Op vordering van de AFM kan dus wel openheid worden verzocht en deze dient te worden gegeven in het kader van de toezichtwetgeving. Ook indien vermoedelijk sprake is van witwaspraktijken geldt de geheimhoudingsplicht uiteraard niet. Voordat een accountant een besluit neemt over de bekendmaking op grond van een wettelijk voorschift, dient hij onder meer de belangen van alle partijen af te wegen, de relevante informatie af te wegen en zich te vergewissen dat de ontvanger van de informatie de juiste is. ${ }^{618}$

Voor zover het de relatie tussen een accountant en de fiscus betreft, wordt verwezen naar hoofdstuk 11 hierna.

\section{Belastingadviseurs}

Er is geen wettelijke regeling van een geheimhoudingsplicht voor belastingadviseurs. Wel hebben twee van de drie van de mij bekende beroepsorganisaties een geheimhoudingsplicht neergelegd in hun gedragsregels. De Nederlandse Orde van Belastingadviseurs ("NOB") heeft in mei 2006 een vernieuwde brochure uitgebracht over de geheimhoudingsplicht van de belastingadviseur. ${ }^{619}$ Het betreft een uitgebreide nota van de NOB op grond van artikel 8 van het Reglement Beroepsuitoefening van die organisatie, waarin aan een belastingadviseur een geheimhoudingsplicht wordt opgelegd betreffende alles wat hem in de uitoefening van zijn beroep als belastingadviseur wordt toevertrouwd. Verlangd wordt dat een lid van de NOB alle mogelijke voorzorgsmaatregelen zal nemen om aan deze geheimhoudingsplicht te kunnen voldoen. Deze verplichting heeft gevolgen voor de fiscale dossiervorming en voor de wijze waarop op verzoeken tot het verstrekken van informatie dient te worden gereageerd. Zoals opgemerkt, hebben belastingadviseurs geen wettelijk verschoningsrecht. Het is een belastingadviseur daarom niet mogelijk om gemotiveerd te weigeren om informatie te verstrekken aan de Belastingdienst. Een vergelijkbare beperking van de geheimhoudingsplicht geldt ook ten opzichte van andere overheidsinstanties en bijvoorbeeld de rechter. In civilibus zal een belastingadviseur zich in de regel steeds op zijn geheimhoudingsplicht op grond van het Reglement Beroepsuitoefening beroepen, evenals op de (veronderstelde) afspraken van een zelfde strekking ingevolge de overeenkomst van opdracht met diens cliënt. Verder regelt de Nederlandse Federatie van Belastingadviseurs ook een geheimhoudingsplicht in art. 12 van haar Reglement voor de Beroepsuitoefening. ${ }^{620}$ Het College Belastingadviseurs kent geen dergelijke bepaling.

\section{Advocaten}

De advocaat behoort tot de klassieke beroepsgroepen, zoals ook de arts, geestelijke en notaris, die een beroepsgeheim kennen. De geheimhoudingsplicht van een advocaat is (nog) niet rechtstreeks wettelijk geregeld, maar al wel op de wet gebaseerd. Er geldt voor de advocaat op grond van artikel 46 Advocatenwet jo. regel 6 van de Gedragsregels 1992 een voor deze beroepsgroep bindende regel over een geheimhoudingsverplichting. De geheimhoudingsplicht ziet op de informatie die aan de advocaat in die hoedanigheid is toevertrouwd. Geheimhouding moet worden betracht van alle kennis omtrent de cliënt, onafhankelijk van de vraag hoe die informatie is verkregen, van de cliënt zelf, van derden of anderszins. Wanneer een juiste uitvoering van de aan een advocaat opgedragen taak naar diens oordeel een gebruik van de hier voor bedoelde kennis ten opzichte van derden verlangt, mag

\footnotetext{
${ }^{617}$ Paragraaf 30 van NV COS 5500N.

${ }^{618}$ Art. A-140.8 VGC

${ }^{619}$ De geheimhoudingsplicht van de belastingadviseur, Nederlandse Orde van Belastingadviseurs, Red. H. Koller e.a., 6 mei 2006 (zie www.nob.nl).

${ }^{620}$ Reglement voor de Beroepsuitoefening, Nederlandse Federatie van Belastingadviseurs (zie www.fb.nl)
} 
een advocaat die kennis openbaren voorzover de cliënt die het betreft daartegen geen bezwaar maakt en een en ander in overeenstemming is met een goede beroepsuitoefening (artikel 6 lid 2 van de Gedragsregels). Kantoorgenoten zijn gebonden aan dezelfde geheimhoudingsplicht. Om de geheimhouding te waarborgen dient de advocaat de geheimhoudingsplicht van zijn ondergeschikten verbintenisrechtelijk vast te leggen (artikel 33 Gedragsregels). De geheimhoudingsplicht duurt voort tot na beëindiging van de werkzaamheden. Zoals eerder is opgemerkt, is ingevolge art. $272 \mathrm{Sr}$ schending van een beroepsgeheim strafbaar.

\section{Notarissen}

De notaris heeft wel een wettelijke geheimhoudingsplicht, neergelegd in art. 22 Wet op het notarisambt. De notaris is verplicht tot geheimhouding ten aanzien van al hetgeen waarvan hij kennisneemt uit hoofde van zijn werkzaamheid als zodanig. Ook voor personen werkzaam onder zijn verantwoordelijkheid, zoals onder meer de kandidaat-notaris, geldt deze verplichting. De geheimhoudingsplicht strekt zich uit tot na beëindiging van de werkzaamheden. Voor notarissen geldt naast deze wettelijke verplichting ook een beroepscode. In art. 7 van de Verordening beroeps- en gedragsregels van de Koninklijke Notariële beroepsorganisatie houdt in dat een notaris zich niet van zijn geheimhoudingsplicht kan laten ontslaan, behoudens vermoedens van misdrijven in georganiseerd verband. In dit kader geldt uiteraard ook de Wet MOT. Deze komt in hoofdstuk 11 nog aan de orde. De notaris is, evenals de advocaat, op grond van art. $272 \mathrm{Sr}$ strafbaar bij schending van de geheimhoudingsplicht.

\section{Bedrijfsjuristen}

Tenzij een bedrijfsjurist tevens als advocaat is ingeschreven - en deze in het laatst bedoelde geval ingevolge artikel regel 6 van de Gedragsregels voor advocaten 1992 tot geheimhouding verplicht is over bijzonderheden van door hem behandelde zaken en diens personeel een gelijke geheimhouding heeft opgelegd - moet ook die gelijkelijk met andere personeelsleden van de koper middels afspraken met de koper aan geheimhouding worden gebonden. ${ }^{621}$

\section{Andere adviseurs}

Voor zover bestuurders of andere vertegenwoordigers van vakorganisaties bij het inzetten of uitvoeren van een due diligence onderzoek betrokken worden, geldt de regeling van artikel 7 juncto 4 van de SER Fusiegedragsregels 2000. Die regeling wordt door de SER Geschillencommissie Fusiegedragsregels ruim geïnterpreteerd. ${ }^{622}$

\section{Doelwitvennootschap zelf en curator}

Is een doelwitvennootschap een derde wanneer een bank opdracht aan een accountant geeft om een onderzoek in te stellen naar de vermogenspositie en het toekomstperspectief van die doelwitvennootschap? ${ }^{623}$ In een uitspraak van de voorzieningenrechter in Leeuwarden verlangde een curator van de bank van een aantal gefailleerde vennootschappen afgifte van een onderzoeksrapport dat het resultaat was van een opdracht van een bank aan een accountant en dat grondslag had gevormd voor de opzegging van de kredietfaciliteit. De bank beriep zich op de omstandigheid dat in haar afspraken met de accountant (in dat geval PricewaterhouseCoopers ("PWC")) was overeengekomen (artikel 6.3 van de algemene voorwaarden van PWC) dat zij een rapport, advies of een andere uiting van de accountant niet aan derden zou openbaren zonder toestemming van die accountant, tenzij er sprake zou zijn van een wetsbepaling, voorschrift of andere beroepsregel die de bank tot openbaarmaking zou verplichten. PWC wilde de bank alleen toestemming geven voor terhandstelling van het rapport, wanneer de curator PWC vooraf wilde vrijwaren tegen enige aansprakelijkheid in verband met het opstellen van het rapport. De curator wilde die vrijwaring niet afgeven. De curator stelde als grondslag voor zijn vordering, dat de vennootschappen naast de bank als mede-opdrachtgever van het door PWC verrichte onderzoek hadden te gelden en dat hij uit dien hoofde als curator van die vennootschappen recht op on-

\footnotetext{
${ }^{621}$ Zie ook de Verordening op de praktijkuitoefening in dienstbetrekking van de Nederlandse Orde van Advocaten.

${ }^{622}$ Zie laatstelijk Geschillencommissie Fusiegedragsregels 7 januari 2008, JOR 2008, 32.

${ }^{623}$ Voorzieningenrechter Rechtbank Leeuwarden, 6 juli 2005, LJN AT 9151
} 
voorwaardelijke afgifte van het opgemaakte rapport had. Hij stelde dat het onderzoek mede ten behoeve van die vennootschappen had plaatsgevonden, dat die vennootschappen hun volledige medewerking aan de totstandkoming van het rapport hadden verleend en dat de kosten van het onderzoek indirect aan de vennootschappen waren doorberekend (de bank had de kosten van het uitgevoerde onderzoek in rekening-courant doorberekend en ten laste gebracht van de desbetreffende vennootschappen).

De curator meende dat de hier voor bedoelde vennootschappen niet als derden konden worden aangemerkt in de zin van de algemene voorwaarden van PWC. Overigens was de curator wel bereid om zijnerzijds de geheimhoudingsclausule uit de algemene voorwaarden van PWC ook in acht te nemen. De bank stelde dat er geen gronden voor afgifte waren, nu de failliete vennootschappen niet als medeopdrachtgever zouden kunnen worden aangemerkt. De opdracht was uitgegaan van de bank en het onderzoek werd ook verricht ten behoeve en in het belang van de bank. De vennootschappen waren op basis van de bankvoorwaarden gehouden hun medewerking aan het onderzoek te verlenen en op basis van diezelfde voorwaarden had de bank de kosten van het onderzoek, die de bank aan PWC had voldaan, aan de vennootschappen kunnen doorberekenen, maar een en ander maakte de vennootschappen volgens de bank niet tot mede-opdrachtgever. Waar PWC de bank bovendien niet ontslagen had van de geheimhoudingsverplichting, stelde de bank jegens PWC wanprestatie te zullen plegen, wanneer zij het rapport uit handen zou geven.

De voorzieningenrechter zag de failliete vennootschappen naast de bank niet als mede-opdrachtgever van het door PWC verrichte onderzoek.

"Uit de stukken blijkt genoegzaam dat de bank alleen en namens zichzelf de betreffende opdracht aan PWC heeft verstrekt, dat slechts vertegenwoordigers van de bank en PWC de in verband daarmee opgestelde schriftelijke overeenkomst hebben getekend en dat PWC alleen aan de bank haar rapport en bijbehorende rekening heeft gestuurd".

Niet gesteld en ook niet gebleken zou zijn, dat de vennootschappen zich ook maar enig moment mede als opdrachtgever zouden hebben geprofileerd of anderszins als zodanig beschouwd werden of benaderd waren. De voorzieningenrechter meende dat - indien dit anders zou zijn geweest - de curator ook aan PWC had kunnen vragen om afgifte van het rapport, danwel PWC in rechte had kunnen betrekken. Dat had de curator niet gedaan.

De voorzieningenrechter meende dat desondanks het rapport door de bank aan de curator moest worden afgestaan. De voorzieningenrechter overwoog daartoe:
"Met voormelde feiten en omstandigheden is naar het oordeel van de voorzieningenrechter in redelijkheid niet verenigbaar en strijdig met de haar betamende zorgvuldigheid dat de bank aan haar kredietnemer, die, het zij herhaald, op verzoek van de bank onderwerp van onderzoek is geweest, daaraan heeft meegewerkt en dat onderzoek ook, zij het indirect, heeft betaald, het van dat onderzoek opgemaakte rapport onthoudt, en evenzeer dat de bank kennisneming van dat rapport weigert aan de curator, die nadien met het beheer en de vereffening van de boedel van de inmiddels in staat van faillissement verkerende vennootschappen is belast".

Het beroep op de algemene voorwaarden van PWC ging volgens de voorzieningenrechter niet op, nu de desbetreffende vennootschappen - en in hun kielzog de curator - bezwaarlijk als derden in de zin van de bepaling van de algemene voorwaarden konden worden aangemerkt en bovendien de curator te kennen had gegeven dat hij die bepaling bij afgifte van het rapport wilde respecteren en tevens wilde laten gelden. Onder die omstandigheden was de curator niet gehouden om een vrijwaringsverklaring af te geven. "Laatstbedoelde verklaring heeft immers een veel verdergaande strekking dan voormelde bepaling uit de algemene voorwaarden van PWC". De voorzieningenrechter overwoog tenslotte: 


\begin{abstract}
"Ook het door de bank benadrukte belang dat een kredietnemer van de bank erop moet kunnen vertrouwen dat aan de bank verstrekte informatie vertrouwelijk blijtt, kan de bank in dit geval niet baten, omdat ten deze juist de - curator als ten deze vertegenwoordiger van de - kredietnemer van de bank wil weten welke informatie de bank over haar heeft en dus juist die vertrouwenspositie zou moeten meebrengen dat de bank terzake opening van zaken geeft'.
\end{abstract}

\title{
10.7 Dataroom en locatie
}

De opdrachtgever zal in het kader van het onderzoek bepaalde gegevens van de doelwitvennootschap in willen zien. De doelwitvennootschap zal willen voorkomen dat deze gegevens op straat komen te liggen en zal proberen om de inzage in de gegevens zo strak mogelijk in te kaderen. Daarom kunnen de gegevens veelal alleen worden ingezien in een dataroom. Een dataroom is in het normale geval een afgesloten ruimte waar de door de doelwitvennootschap geselecteerde gegevens kunnen worden ingezien door de onderzoekers van de opdrachtgever. ${ }^{624}$ Over het gebruik van deze dataroom zijn allerlei afspraken mogelijk. Zo kan worden overeengekomen dat de dataroom slechts een aantal uren per dag toegankelijk zal zijn. Ook kan overeengekomen worden welke documenten wel en welke niet gekopieerd mogen worden. Tevens kan overeengekomen worden dat slechts een beperkt aantal mensen tegelijkertijd in de dataroom aanwezig mag zijn, al dan niet onder toezicht van een medewerker van de doelwitvennootschap. Deze afspraken worden vastgelegd in het zogenoemde dataroom protocol.

Het is raadzaam om een dataroom index (wat ook wel datalijst heet) te maken. Dat betekent een inventarisatie van welke informatie in de dataroom ter beschikking van de onderzoekers is gesteld.

Aandacht verdient het feit dat het aanwezig zijn van zogenaamd privileged material (informatie welke normaliter onder de geheimhoudingsplicht of het verschoningsrecht van adviseurs valt bijvoorbeeld) in de dataroom door sommige partijen kan worden uitgelegd als het prijsgeven van het 'geprivilegieerde' karakter daarvan. Het is belangrijk om in het dataroom protocol terzake duidelijkheid te scheppen. Overeengekomen moet worden, dat het voorhanden zijn van informatie in de dataroom niet betekent, dat anderszins als zodanig te kwalificeren informatie niet langer geprivilegieerd zou zijn. ${ }^{625}$

Niet zelden wordt er een verbinding gelegd tussen de informatie welke op de zogenaamde dataroom index voorkomt en de inhoud van de dataroom zelf enerzijds en door de verkoper te verschaffen garanties anderzijds. De koper zal niet zelden aandringen op garantie dat de in de dataroom ter beschikking gestelde informatie volledig is en de inhoud daarvan juist. Teneinde een beter gevoel te krijgen bij de inhoud van de dataroom en de wijze waarop naar die inhoud moet worden gekeken, wordt in de praktijk wel voorafgaand aan het accepteren van toegang tot de dataroom geïnsisteerd op het doornemen van een vragenlijst met de bedrijfsjurist van de doelwitvennootschap.

Toegang tot een dataroom wil nogal eens tot zelfstandige onderhandelingen leiden. Zo is het mij bekend dat Goldman Sachs International in Londen medewerkers alleen een dataroom wil laten binnengaan, wanneer degene die verantwoordelijk is voor de dataroom die medewerkers wil toezeggen dat zij onder geen omstandigheid persoonlijke aansprakelijkheid zullen hebben te vrezen (bijvoorbeeld omdat zij op grond van een wettelijke verplichting informatie moeten verstrekken of anderszins betrokken zouden bedreigen te raken bij geschillen tussen de verkoper en de koper). De desbetreffende medewerkers zien zich soms ook geconfronteerd met verplichtingen jegens derden, waardoor volledige geheimhouding lastig te beloven is. De verkoper zal steeds de afweging moeten maken of deze desondanks de betrokkene tot de dataroom wil toelaten.

Hier voor - in hoofdstuk 2 (onder 2.9) - is al het nodige gezegd over de locatie van een dataroom. $\mathrm{Er}$ wordt verwezen naar hetgeen daar is opgemerkt over de betekenis van de situationering van een data-

\footnotetext{
${ }^{624}$ Zie hierover ook P. Gelderman en F. Modderman, Dataroom als middel nog vaak onderschat (electronische dataroom maakt snel furore) in Fusie \& Overname juni 2004, p. 7 e.v.

${ }^{625}$ Vergelijk ook r.o. 18 in de conclusie van A-G Vellinga onder HR 24 januari 2006, LJN AU4666: "De klacht dat geen beroep meer kan worden gedaan op het verschoningsrecht omdat de informatie die volgens de advocaat verborgen dient te blijven al naar buiten is gebracht en derhalve geen voorwerp van geheimhouding meer vormt, faalt eveneens."
} 
room in verband met een denkbare behoefte om de (voorbereiding van) onderhandelingen over een transactie geheim te houden.

\subsection{Wet bescherming persoonsgegevens}

Per 1 september 2001 is de Wet bescherming persoonsgegevens ("Wbp") in werking getreden. Ingevolge deze wet mogen slechts uit bij het College bescherming persoonsgegevens ("CBP") aangemelde persoonsgegevensverwerkingen, persoonsgegevens worden verstrekt. Daarbij heeft het College bescherming persoonsgegevens uitgemaakt dat persoonsgegevens alleen mogen worden verstrekt indien:

\footnotetext{
- $\quad$ de opdrachtgever een verzoek heeft ingediend ter verkrijging van de persoonsgegevens;

- de opdrachtgever heeft aangetoond dat het noodzakelijk is over deze persoonsgegevens te beschikken; en

de opdrachtgever heeft de kring van het aantal personen die inzage in de persoonsgegevens verkrijgen zoveel mogelijk beperkt.
}

Het in het kader van een due diligence verstrekken van persoonsgegevens kwalificeert als een verwerking van persoonsgegevens in de zin van de Wbp. Hierbij is te denken aan de gebruikelijke personeelsgegevens (adres, telefoonnummer, sofinummer, pasfoto en dergelijke), maar bijvoorbeeld ook aan andere databestanden. Verstrekking mag alleen wanneer kennisneming van de inhoud daarvan gewenst of noodzakelijk is en nadat aan de hier voor genoemde voorwaarden is voldaan. Een inbreuk op het recht op eerbiediging van de persoonlijke levenssfeer levert in beginsel een onrechtmatige daad op. De aanwezigheid van een rechtvaardigingsgrond kan een inbreuk het onrechtmatige karakter ontnemen. Of zulk een rechtvaardigingsgrond zich voordoet, kan alleen worden beoordeeld in het licht van de omstandigheden van het geval door tegen elkaar af te wegen enerzijds de ernst van de inbreuk op het recht op de eerbiediging van de persoonlijke levenssfeer en anderzijds de belangen die met de inbreukmakende handelingen redelijkerwijs kunnen worden gediend. ${ }^{626}$

De Wbp is voor de financiële sector uitgewerkt in de Gedragscode Verwerking Persoonsgegevens Financiële Instellingen. ${ }^{627}$ Zelfs indien er met toestemming van betrokkene bij een due diligence gezocht zou worden naar gegevens betreffende personen, behoeft onder omstandigheden de doelwitvennootschap geen kopieën af te geven van interne notities die de persoonlijke gedachten van medewerkers van de doelwitvennootschap bevatten en uitsluitend zijn bedoeld voor intern overleg en beraad. ${ }^{628}$ Een en ander is anders, wanneer de betreffende notities in het bestand zijn opgenomen.

Relevant in het kader van het vorenstaande is ook het onderwerp van de informatietechnologie in het algemeen. Te denken valt aan de risk-management-achtige aspecten van de informatietechnologie, zoals default settings in systemen, gekozen parameters, gedefinieerde formats en integriteitsconstraints in databases, security levels, passwords, cc's van emails, log-files, en dergelijke. Dit soort due diligence zal gedaan moeten worden door EDP-auditors en soms zelf door forensische informatici. Het zal van het soort onderneming afhangen en het soort van zekerheid dat de opdrachtgever in wiens belang het onderzoek wordt uitgevoerd, verlangt, of, en met welke diepgang, een en ander bekeken zal mogen en kunnen worden. Er wordt ook wel gesproken over due moral diligence wanneer het een onderzoek betreft naar de zogenaamde self-monitoring capability van een onderneming. ${ }^{629}$

\footnotetext{
${ }^{626}$ Zie HR 31 mei 2002, NJ 2003, 589

${ }^{627}$ De Wbp geeft een overkoepelende regeling voor uiteenlopende situaties, die in een aantal sectoren nadere concretisering behoefde (TK 1997-1998, 25 892, nr 3, p.11-12). De concretisering welke in de financiële sector heeft plaatsgevonden is te vinden in Staatscourant 3 februari 2003, nr. 23, p. 16. Het betreft een gedragscode die is opgesteld door de Nederlandse Vereniging van Banken en het Verbond van Verzekeraars en een nadere aanvulling geeft aan bepalingen van de Wbp. Het CBP heeft op voet van artikel 25 Wbp op 27 januari 2003 verklaard dat deze gedragscode, gelet op de bijzondere kenmerken van de financiële sector, een juiste uitwerking vormt van de Wbp en de andere wettelijke bepalingen betreffende de verwerking van persoonsgegevens.

${ }^{628}$ Zie HR 24 januari 2003, NJ 2003, 491 en artikel 2 lid 2, onder a. Wbp.

${ }^{629}$ Zie J. van den Hoven, Informatietechnologie en rekenschap: due moral diligence, de Accountant nr. 4/dec. 1999, p. 239 e.v.
} 


\section{$10.9 \quad$ Document management}

Ook met het oog op een eventueel due diligence onderzoek in de toekomst of teneinde op transparante en efficiënte wijze invulling te kunnen geven aan een informatie of verantwoordingsplicht, is het formuleren en ten uitvoer leggen van een duidelijk documenten beheerbeleid belangrijk. Daarbij wordt onderscheid gemaakt naar soorten van documenten (gegevensdragers, strategisch of andere betekenis en dergelijke). Er worden checklists opgesteld voor de wijze waarop er moet worden omgegaan met verplicht te bewaren documenten, vrijwillig te bewaren documenten en met nieuw aan te maken documenten. ${ }^{630}$ Eens in de zoveel tijd wordt er grote schoonmaak gehouden. De betekenis van de verschillende stukken wordt dan opnieuw tegen het licht gehouden en al naar gelang een wettelijke plicht om te bewaren, een strategisch of andere noodzaak om (wel of juist niet) te bewaren, wordt een en ander dan vernietigd of digitaal of anderszins toegankelijk opgeslagen.Een en ander sluit ook aan bij het gestelde in II.1.3 van de NCGC, waarin wordt verlangd, dat er een op de vennootschap toegesneden systeem van interne risicobeheersing en ter controle zal zijn, dat onder meer een systeem van monitoring en rapportering zal omvatten.

Document management kan ook bepalend zijn voor de wijze waarop per saldo de inhoud van een dataroom er uit kan komen te zien. Een goed documentbeheer en rapportagesysteem maakt de voorbereiding en/of uitvoering van een due diligence onderzoek aanzienlijk minder bezwarend voor een organisatie, dan wanneer - zoals in de praktijk nog vaak het geval is - er enorm moet worden geïnvesteerd in tijd en energie om een beetje behoorlijke dataroom tot stand te brengen.

De informatietechnologie zal steeds meer bepalend worden bij de opslag en terbeschikkingstelling van informatie. Dit roept volgens Van den Hoven ook morele vragen op, mede in verband met de persoonlijke levenssfeer. ${ }^{61}$ Het gaat daarbij om een verantwoorde omgang met gegevens, informatie en kennis"(...) aangezien verantwoordelijkheid nemen en rekenschap afleggen kennis en informatie veronderstellen, worden veel van deze vragen thans geformuleerd in termen van de technologie die ons informatie en kennis kan verschaffen. De cruciale vraag verschuift van 'Wie heeft wat wanneer gedaan?' naar 'Wie wist wat en wanneer, en wie wist wat niet en waarom niet?'. Het verkrijgen van informatie of het juist niet verkrijgen van informatie is uiteraard in toenemende mate een kwestie geworden van toegang, uitsluiting, selectie en beveiliging in een elektronische of systeemomgeving."

De rol van EDP-auditors ook op het terrein van de due diligence zal in de toekomst dan ook alleen maar groter worden. Van den Hoven vraagt daarom aandacht voor de noodzaak om, alvorens men tot de bouw van een nieuw systeem overgaat, of een oud systeem migreert, een analyse te maken van accountability-structuur van de oude toestand van de organisatie en die van de gewenste nieuwe toestand en de informatierelaties te beschrijven in het licht van verantwoordelijkheden.

Mede in het kader van vragen rond exhibitieplicht voor gewone vennootschappen - maar in ieder geval voor beursgenoteerde vennootschappen en in het bijzonder voor die vennootschappen, die ook een notering van een Amerikaanse beurs hebben, door de toegenomen belangstelling van regelgevers voor het inventariseren en beheersbaar doen zijn van ondernemingsrisico's ${ }^{632}$ - geldt dat het onderwerp van document management zich in toenemende mate in belangstelling zal mogen verheugen. ${ }^{633}$

\footnotetext{
${ }^{630}$ Bijvoorbeeld: is aanmaak wel nodig, moeten er wel zoveel mensen een kopie ontvangen? Schriftelijke verslagen mogen alleen feiten bevatten. Als rapporten meningen bevatten, moeten die van een motivering zijn voorzien. Na een vergadering moeten alle notities en andere aantekeningen achter gelaten worden en worden vernietigd. E-mail bestanden moeten eens in de zoveel tijd worden geschoond, etc.

${ }^{631}$ M.J. van den Hoven, Informatietechnologie en rekenschap: due moral diligence, De Accountant nr. 4/december 1999, p. 239 e.v.

632 Zie bijvoorbeeld II.1, II.1.3, II.1.4, III.1.6, III.1.8 van de NCGC.

${ }^{633}$ Zie bijvoorbeeld J. Kelly en P. Li, Document Management, confronting your skeletons, in PLC June 1997, p. 39 e.v.
} 


\section{Verplichting tot het openbaren van de resultaten van een due diligence onderzoek?}

\subsection{Algemeen}

De koper van een onderneming kan er in het algemeen niet op rekenen dat de inhoud van het due diligence rapport vertrouwelijk blijft, althans niet wanneer partijen daar inzage in verlangen die gerechtigd zijn een beroep te doen op artikel 843a Rv. Ook ten opzichte van de fiscus zal vertrouwelijkheid niet altijd gewaarborgd zijn. Tenslotte hangt het er vanaf wie de auteur is van een due diligence rapport.

Een klassiek verschoningsrecht komt toe aan bijvoorbeeld notarissen ${ }^{634}$ en advocaten ${ }^{635}$, maar niet aan accountants ${ }^{636}$ of belastingadviseurs. ${ }^{637}$ Tegenover de fiscus hebben belastingadviseurs en accountants wel een informeel verschoningsrecht. ${ }^{638}$ Aangenomen wordt dat het aan een getuige toekomende verschoningsrecht voorrang heeft boven waarheidsvinding. Het is aan de getuige die het betreft, om te beslissen of deze een beroep doet op het hem of haar op grond van een geheimhoudingsplicht toekomende verschoningsrecht. Uiteindelijk zal een rechter (moeten) beslissen of dit beroep al dan niet gegrond is. ${ }^{639}$ De adressant van het fiscale of accountantsadvies heeft een afgeleid verschoningsrecht. ${ }^{640}$

Medewerkers van verschoningsgerechtigden zoals de secretaresse en de juridisch medewerker van een advocaat hebben ook een afgeleid verschoningsrecht.

Afgezien van of in aanvulling op het bestaan van een verschoningsrecht kunnen obligatoire afspraken gemaakt worden over de geheimhouding. Keizer ${ }^{641}$ wijst erop dat het verweer, dat het bestaan van een verbintenisrechtelijke geheimhoudingsplicht jegens de adviseurs een gewichtige reden zou vormen om niet te hoeven overgaan tot overlegging van een due diligence rapport op grond van artikel 843a lid 4 $\mathrm{Rv}$, in het algemeen weinig kans van slagen heeft. De rechter blijkt niet snel bereid in te zien welk te respecteren belang de adviseur heeft bij het weigeren van zijn toestemming.

Hierna zal worden ingegaan op de omvang van vertrouwelijkheid in civilibus en in fiscalibus. In fiscalibus zijn vooral twee uitspraken van belang, die hierna worden besproken. Die benadrukken het belang van de vraag of er sprake is van een gecombineerd onderzoeksrapport of een rapport per discipline, terwijl het ook relevant is of een rapport uitsluitend feitelijke gegevens bevat of tevens adviezen.

Het onderscheid tussen adviezen enerzijds en bevindingen of waarnemingen anderzijds werd ook relevant geacht door de rechtbank te Rotterdam in een uitspraak van 19 mei 2004. ${ }^{642}$ De rechtbank overwoog naar aanleiding van een verzoek tot afgifte van een rapport van een partij-deskundige, dat het maatschappelijk belang meebrengt dat een partijexpert vrijelijk en zonder vrees voor openbaarmaking zijn opdrachtgever van advies moet kunnen dienen. Dit rechtvaardigde een weigering tot afgifte van het rapport van de deskundige aan de wederpartij "voor zover deze stukken echter een feitelijk/vaststellend deel bevatten met de bevindingen en waarnemingen van de expert", diende deze feitelijke/vaststellende (delen van) de stukken wel aan de wederpartij te worden afgegeven.

\footnotetext{
${ }^{634}$ HR 25 september 1992, NJ 1993, 467

${ }^{635}$ HR 22 juni 1984, NJ 1985, 188

${ }^{636}$ HR 14 juni 1985, NJ 1986, 175

${ }^{637}$ HR 21 november 1986, NJ 1987, 318 en HR 23 september 2005, JOR 2005, 264, m.nt. P.J. van der Korst.

${ }^{638}$ Zie L.H.E. Muller in WFR 2005/3

639 Zie HR 20 januari 2006, LJN AU 4529

640 Zie President Rechtbank Utrecht, 7 september 1999, JOR 2000, 42 en conclusie AG inzake een uitspraak van de Hoge Raad (LJN AR6468, nummers 38809 en 388810) en P. van der Korst in diens noot onder Hof 's-Hertogenbosch 28 september 2004, JOR 2005, 23

${ }^{641}$ A. Keizer, Exhibitieplicht bij overnamegeschillen, V\&O 2008, nr. 3, p. 56. onder verwijzing naar Rechtbank Breda 14 januari 2004, JOR 2004, 70 en W.P. Wijers \& A.J. Haasjes, Exhibitie in het (Onderneming)recht, O\&F 2006, p. 54.

${ }^{642}$ Rechtbank Rotterdam 19 mei 2004, NJ Feitenrechtspraak 2004, 526.
} 


\subsection{Exhibitieplicht in fiscalibus}

\section{Algemeen}

Relevante wetsartikelen in fiscalibus zijn te vinden in de AWR. ${ }^{643}$ Eenieder is gehouden desgevraagd aan de inspecteur de gegevens en inlichtingen te verstrekken welke voor de belastingheffing te zijn aanzien van belang kunnen zijn. Boeken, bescheiden en andere gegevensdragers of de inhoud daarvan - dit ter keuze van de inspecteur - waarvan de raadpleging van belang kan zijn voor de vaststelling van de feiten welke invloed kunnen uitoefenen op de belastingheffing, moeten beschikbaar worden gesteld. Gelijke verplichtingen gelden voor een derde bij wie zich gegevens of gegevensdragers bevinden van degene die gehouden is deze, of de inhoud daarvan, aan de inspecteur voor raadpleging beschikbaar te stellen. Een weigering om te voldoen aan de hiervoor bedoelde verplichtingen ten behoeve van de belastingheffing van derden, kan alleen worden ingeroepen door bekleders van een geestelijk ambt, notarissen, advocaten en apothekers op grond van de omstandigheid dat zij uit hoofde van hun stand, ambt of beroep tot geheimhouding verplicht zijn. Het moet dan dus wel gaan om personen die zich kunnen beroepen op een (wettelijk) verschoningsrecht als hiervoor bedoeld.

\section{Verschoningsrecht bij belastingadviseurs}

Hierna zal nog worden ingegaan op een mededeling van de Staatssecretaris van Financiën van 5 januari 1994, ${ }^{644}$ op grond waarvan de Belastingdienst het op zich had genomen ter zake van het verrichten van derdenonderzoek van belastingadviseurs geen inzage van de aan cliënten verstrekte adviezen en met cliënten gevoerde correspondentie te vragen. Die mededeling van de Staatssecretaris uit 1994 is inmiddels ingetrokken naar aanleiding van een tweetal arresten van de Hoge Raad ${ }^{645}$ waarin werd beslist dat de Inspecteur geen inzage dient te krijgen in door derden opgestelde fiscale rapporten (zoals due diligence rapporten), die bedoeld zijn om de fiscale positie van de belastingplichtige te belichten of hem daarover te adviseren. Op die arresten wordt hierna nog ingegaan.

Er worden in de brochure van de NOB drie soorten verschoningsrecht onderscheiden:

het afgeleide verschoningsrecht:

een belastingadviseur hoeft geen inzage te geven in correspondentie met advocaten, notarissen en andere personen die een (wettelijk) verschoningsrecht hebben. Ook adviezen en/of overzichten die de belastingadviseur op verzoek van een advocaat of andere algemene verschoningsgerechtigde uitbrengt, behoeven niet ter beschikking te worden gesteld. ${ }^{646}$

Het afgeleide verschoningsrecht kan worden geëffectueerd door een opdracht van een (wettelijk) verschoningsgerechtigde aan de belastingadviseur. Vervolgens dienen dan gescheiden dossiers te worden aangehouden terzake van de door de (wettelijk) verschoningsgerechtigde ter beschikking gestelde informatie en met de (wettelijk) verschoningsgerechtigde gevoerde vertrouwelijke correspondentie. De belastingadviseur moet dan rechtstreeks factureren aan de (wettelijk) verschoningsgerechtigde. ${ }^{647} \mathrm{De}$ (wettelijk) verschoningsgerechtigde bepaalt of en in

\footnotetext{
${ }^{643}$ Zie de artikelen 47, 48, 49 en 53a. Zie hierover J.A. Booij, Fiscale due diligence-rapporten niet meer veilig voor fiscus?, Ondernemingsrecht 2000/3, p. 71 e.v. en de door deze genoemde literatuur en rechtspraak. Zie ook de recente uitspraak van de Hoge Raad (21 maart 2008, LJN BA8179) waarin het werd gesanctioneerd dat de Belastingdienst naar aanleiding van gegevens in gestolen microfiches een nader onderzoek instelde naar verzwegen bankrekeningen. Ook mochten de bankgegevens die de belastingplichtigen onder druk aan de Belastingdienst hadden verstrekt worden gebruikt voor het opleggen van boetes. De rekeninghouders werden in het ongelijk gesteld waar dit hun stelling betrof dat het onjuist was dat zij onder bedreiging met straf gedwongen waren aan hun eigen veroordeling mee te werken. De Hoge Raad vond het bovendien goed dat er in het onderhavige geval een langere navorderingstermijn van 12 jaar werd gehanteerd in de gevallen waarin pogingen waren gedaan om vermogen buiten het zicht van de Belastingdienst te houden.

${ }^{644}$ Besluit 10DGM4, V-N 1994, p. 456 e.v.

645 BNB 2006, 21 en V-N 2005, 46.5

${ }^{646}$ Zie bijvoorbeeld HR 29 maart 1994, NJ 1994, 552; HR 12 maart 1997, BNB 1997, 146 en HR 12 februari 2002, NJ 2002, 440

${ }^{647}$ Vergelijk HR 29 maart 1994, NJ 1994, 552
} 
hoeverre de voor hem door de belastingadviseur uitgevoerde opdracht al dan niet onder zijn(wettelijk) verschoningsrecht valt; ${ }^{648}$

het informele verschoningsrecht:

gebaseerd op het fair play-beginsel van de algemene beginselen van behoorlijk bestuur. Zoals wij nog zullen zien heeft ons hoogste rechtscollege beslist dat rapporten en andere geschriften van derden - voor zover zij ten doel hebben de fiscale positie van de belastingplichtige te belichten - niet met toepassing van artikel 47 AWR door de Belastingdienst kunnen worden opgevraagd;

(3) het afgeleide informele verschoningsrecht:

welke eveneens gebaseerd is op het hier voor bedoelde fair play-beginsel. Belastingplichtigen die worden bijgestaan door personen die over een informeel verschoningsrecht beschikken, zoals de belastingadviseur, hoeven evenmin met een beroep op het afgeleide informele verschoningsrecht de aan hen verstrekte vertrouwelijke correspondentie (met name adviezen en fiscale rapporten) aan de Inspecteur te geven voor inzage wanneer deze daarom zou verzoeken.

Omdat het niet de bedoeling is dat de overheid de burger de mogelijkheid ontneemt om voor zijn belangen op te komen of die mogelijkheid extra bemoeilijkt, wordt het tot een beginsel van behoorlijk bestuur gerekend dat geen inzage mag worden geëist in stukken van derden die zijn opgesteld met het doel om de belastingplichtige te adviseren over diens fiscale positie. Aangegeven is al dat het om deze reden denkbaar is dat documenten worden gesplitst of geschoond. Van belang is dat derden die de desbetreffende stukken in handen krijgen, zich op eenzelfde standpunt zouden kunnen stellen als de belastingadviseur.

Het is op grond van de hiervoor genoemde omstandigheden dat belastingadviseurs door hun beroepsorganisatie wordt aanbevolen de dossiers zo in te richten dat de onderdelen van het dossier die wel beschikbaar zijn voor inzage door de Belastingdienst, voldoende afgezonderd zijn van de fiscale rapporten en het advies- of correspondentiedossier. De brochure geeft terzake een aantal dossierinstructies. Belastingadviseurs in loondienst zullen zich mogelijk niet op het informele verschoningsrecht kunnen beroepen.

WID en $M O T^{649}$

De Wet identificatie bij Dienstverlening ("WID”), de Wet Melding Ongebruikelijke Transacties ("MOT") en een daarop gebaseerde AMvB van 24 februari 2003 hebben belangrijke gevolgen voor de geheimhouding van de belastingadviseur. De belastingadviseur heeft een identificatie- en meldplicht. Het Bureau Financieel Toezicht (het "BFT") van de NOB is aangewezen als toezichthouder op naleving van de identificatie- en meldplicht. Het BFT is bevoegd inlichtingen te vorderen en inzage in zakelijke gegevens en bescheiden te vorderen en hiervan kopieën te maken.

Een belastingadviseur is op basis van artikel 2, derde lid en artikel 4, derde lid van de hier voor bedoelde AMvB niet verplicht het BFT inzage te geven in dossiers die betrekking hebben op:

- $\quad$ werkzaamheden van de belastingadviseur ter bepaling van de rechtspositie van de cliënt;

- $\quad$ werkzaamheden van de belastingadviseur die verband houden met procesvertegenwoordiging van de cliënt; en

het geven van advies door de belastingadviseur voor, tijdens en na een rechtsgeding of het geven van advies over het instellen of vermijden van een rechtsgeding.

Ook daarom is het belangrijk voor een belastingadviseur om voor deze werkzaamheden afzonderlijke dossiers in te richten.

Het informele verschoningsrecht werd aanvankelijk gebaseerd op de hiervoor al genoemde inmiddels ingetrokken mededeling van de Staatssecretaris van Financiën uit 1994. Deze mededeling wordt hierna onder 11.5 verder besproken. De kwestie van het gescheiden aanleggen en/of beschikbaar hebben van dossiers met betrekking tot een due diligence onderzoek kwam rechtstreeks aan de orde

\footnotetext{
${ }^{648}$ Vergelijk HR 12 februari 2002, NJ 2002, 439
}

${ }^{649}$ Zie ook onder 11.7 hierna. 
in een procedure welke de Belastingdienst voerde tegen een verzekeraar in ons land, die weigerde een due diligence rapport aan de Belastingdienst ter hand te stellen. ${ }^{650}$

\section{De Fortis-uitspraak ${ }^{651}$}

In een kort geding dat Fortis N.V. ("Fortis") tegen de Belastingdienst aanspande, kwam de vraag op of Fortis gehouden kon worden een due diligence rapport, dat was opgemaakt ter gelegenheid van de acquisitie van MeesPierson, aan de Belastingdienst ter hand te stellen. Naar aanleiding van het kort geding is de vraag actueel geworden of er een gecombineerd rapport van een due diligence onderzoek opgesteld zou moeten worden of dat er per discipline een apart rapport opgesteld moet worden. Beantwoording van de laatstbedoelde vraag bepaalt onder omstandigheden of een rapport wel of niet aan de Belastingdienst ter hand moet worden gesteld. De aanbevelingen welke zijn te vinden in de brochure van de NOB van mei 2006 zijn terug te voeren naar deze uitspraak.

De Belastingdienst verzocht Fortis om inzage in een aantal stukken. Fortis stemde hiermee in maar weigerde een haar uitgebracht due diligence onderzoek alsmede een memorandum inzake de belastingpositie van Fortis te overleggen. Hiertoe voert Fortis aan dat deze documenten niet van belang zijn voor de vaststelling van feiten welke van invloed kunnen zijn op de belastingheffing. Daarnaast voerde Fortis aan dat beide documenten adviezen en beschouwingen bevatten, op welke de Belastingdienst geen aanspraak kon maken. Fortis heeft wel het definitieve memorandum overgelegd. Het verschil met het concept memorandum is dat de adviserende passages zijn weggelaten.

De president oordeelde dat Fortis niet gehouden was om het concept-memorandum af te geven. Met betrekking tot het due diligence rapport overwoog de president dat Fortis gelet op de aard van een dergelijk rapport voorshands onvoldoende aangetoond had dat het rapport een stuk van louter adviserende aard was. Fortis was gehouden het due diligence rapport ter inzage te verschaffen nu het Fortis dan wel KPMG bekend was dat stukken, die geen fiscale adviezen bevatten door de staat kunnen worden opgevraagd en de omstandigheid dat het feitencomplex en de fiscale adviezen niet waren gesplitst maar in een zelfde rapportage werden verweven, een omstandigheid was die voor risico van Fortis diende te komen.

De lering die uit de hier besproken uitspraak werd getrokken, is dat als een onderneming op voorhand niet wenst dat een due diligence rapport op enig ogenblik aan de belastingdienst zou moeten kunnen worden afgegeven de onderneming en haar adviseurs er verstandig aan doen omtrent de feiten en de adviezen los van elkaar te (laten) rapporteren. Als de due diligence onderzoeker in zijn rapport een scheiding aanbrengt tussen feiten en adviezen dan kan de belastingdienst, voor zover fiscaal relevant, slechts inzage in de feiten eisen, waar het overigens adviezen betreft die onder een beroepsgeheim zouden kunnen vallen, zoals van een advocaat. ${ }^{652}$

\section{Inlichtingen}

Zoals hiervoor onder 11.2 al opgemerkt, is eenieder volgens artikel 47 AWR gehouden waar het de belastingheffing te zijnen aanzien betreft, aan de Inspecteur die gegevens en inlichtingen te verstrekken welke voor de belastingheffing van belang kunnen zijn en boeken, bescheiden en de inhoud van andere gegevensdragers - zulks ter keuze van de Inspecteur - ter beschikking te stellen waarvan de raadpleging van belang kan zijn voor de vaststelling van de feiten welke invloed kunnen uitoefenen op de belastingheffing. De sanctie is omkering van de bewijslast (artikel 54 AWR) of zelfs strafvervolging op grond van artikel 68 of 69 AWR.

De belastingplichtige dient toe te laten dat kopieën, leesbare afdrukken of uittreksels worden gemaakt van voor de raadpleging beschikbaar gestelde gegevensdragers of de inhoud daarvan (artikel 49 lid 2

\footnotetext{
${ }^{650}$ Voor een inhoudelijke bespreking van de meld- en indentifcatieplicht van advocaten, wordt verwezen naar R. van der Hoeven en J.C. Visser, Identificatie- en meldplicht van de advocaat, Een frontale aanval op de gehiemhoudingsplicht en het verschoningsrecht, NJB 2003, p. 1124 e.v.

${ }^{651}$ President Rechtbank Utrecht, 7 september 1999, KG 1999, 284. Zie hierover ook J.A. Booij, Fiscale due diligence rapporten niet meer veilig voor fiscus? Ondernemingsrecht 2000-3, p. 71 e.v.

${ }^{652}$ Zie bijvoorbeeld Rechtbank Amsterdam 4 juli 2007, RCR 2008, 21, r.o. 5.2.
} 
AWR). Indien de boeken en bescheiden van de belastingplichtige zich niet bij de belastingplichtige zelf bevinden doch bij een derde (bijvoorbeeld de belastingadviseur, accountant of advocaat), dan is die derde verplicht in deze documenten op vordering van de Ontvanger inzage te verlenen (artikel 48 AWR). Het is dus niet zo dat de advocaat, de belastingadviseur of de accountant deze gegevens onder zich kan houden en vervolgens een beroep kan doen op het (afgeleide) verschoningsrecht. Bijvoorbeeld jaarstukken en daarmee samenhangende accountantsrapporten die worden bewaard in een dossier van een advocaat, zullen op vordering van de belastingdienst ter inzage moeten worden gegeven. Het is daarom inderdaad verstandig dat professionele dienstverleners zoals advocaten en notarissen hun cliëntendossiers opdelen in de dossiers waarin feitelijke stukken zitten (die zo aan de belastingdienst kunnen worden afgegeven) en stukken waarvoor het verschoningsrecht geldt. Het verschoningsrecht geldt als eerder opgemerkt alleen voor bekleders van een geestelijk ambt, notarissen, advocaten, procureurs, artsen en apothekers (artikel 53a AWR). Nogmaals wordt benadrukt dat het verschoningsrecht niet geldt voor gegevensdragers en andere documenten van de cliënt die zich in het dossier van de advocaat of notaris bevinden.

Het probleem kan wel zijn, dat het onderscheid tussen advisering en het verslag van feiten niet altijd goed te maken zal zijn.

Naast een onderscheid in feiten en advisering zou er wellicht ook een scheiding moeten worden aangebracht tussen de rapportages van de juridische, de economische, de financiële en de fiscale due diligence. Mocht de belastingdienst één van de onderzoeksrapporten opeisen dan hoeft zij geen inzage in de overige rapporten te krijgen.

\section{Voor wie is het rapport bestemd?}

Een due diligence rapport heeft het karakter van een advies, ook al heeft het per saldo betrekking op feitelijke constateringen. Het is geen legal opinion (dat is een juridische vaststelling) en kan ook niet als garantie worden gekwalificeerd. Het rapport zal - tenzij er terzake andere afspraken zijn gemaakt - in opdracht van de cliënt van de onderzoeker(s) worden opgesteld. De relatie tussen de cliënt en de onderzoeker wordt beheerst door afspraken tussen die beide partijen en soms door de wet (bijvoorbeeld de Wet op het Notarisambt) en tuchtrecht. Tussen de onderzoeker(s) en de wederpartij van de opdrachtgever of andere derden bestaat geen contractuele relatie.

Voor de onderzoeker kan het zin hebben om te stipuleren dat het due diligence rapport alleen voor de opdrachtgever of met name genoemde partijen bestemd is. Indien de ontvanger van het rapport zich niet aan de genoemde beperking wenst te conformeren, zou deze het rapport niet moeten behouden, maar voorafgaand aan het tot stand komen van de transactie dienen te retourneren, met het verzoek om aanpassing of bijstelling van de gemaakte afspraken. ${ }^{653}$ Een derde, die buiten de kring van benoemde en overeengekomen ontvangers bestaat, zou door zich op de inhoud van een rapport te verlaten, er rekenschap van dienen te geven dat het informatie betreft, die verkregen kan zijn door toerekenbare tekortkoming van de geadresseerde. Mochten er gebreken in het rapport voorkomen, dan is er voor die derde in dat geval geen aanspraak ingevolge toerekenbare niet-nakoming door de onderzoeker(s), nu er geen contractuele band bestaat en, denkbaar, evenmin uit onrechtmatige daad, nu de ontvanger niet zou mogen beschikken over het rapport en het niet bestemd was om deze daar op te doen vertrouwen.

Het heeft voor een onderzoeker ook om andere redenen veel zin om vooraf zijn opdracht en positie duidelijk te maken - zowel naar zijn opdrachtgever toe als tegenover derden met wie er in verband met het onderzoek in contact wordt getreden - nu dat deze in de gelegenheid stelt om vragen over diens eigen positie te beantwoorden, bijvoorbeeld wanneer hem om een afschrift van het rapport wordt gevraagd door anderen dan de opdrachtgever of er verwijten zouden kunnen komen over de omvang of diepgang van het onderzoek. Zie in dit verband ook een uitspraak van de Hoge Raad van 25 januari $2002^{654}$ over de vraag of een onderzoeker - niet ondergeschikte van de opdrachtgever - kan worden

\footnotetext{
${ }^{653}$ Vergelijk M. Brink en G.T.M.J. Raaijmakers, Beroepsaansprakelijkheid en legal opinions, in: Beroepsaansprakelijkheid, Ars Aequi Libri 1996, p. 60-61.

654 HR 25 januari 2002, RvdW 2002, 22, r.o. 3.4. (Lampenier): "Wel zal de franchisegever die een rapport, zoals hiervoor bedoeld, aan zijn wederpartij verschaft, onder omstandigheden onrechtmatig handelen, indien hij weet dat dit rapport ernstige
} 
geacht het onderzoek uit te voeren binnen het kader van de bedrijfsuitoefening van de opdrachtgever en als hulppersoon van de opdrachtgever kan worden aangemerkt (artikel 6:171). Het antwoord op die vraag is mede bepalend voor de vraag of onzorgvuldigheid van de onderzoeker aan de opdrachtgever kan worden toegerekend. ${ }^{655}$

\section{Hoge Raad 23 september $2005^{656}$}

In twee inhoudelijk vrijwel identieke zaken ging het onder meer over de vraag of de Inspecteur recht heeft op inzage in een door externe accountants opgesteld due diligence rapport. Het rapport zou zijn opgesteld met het oog op een management buy-out van de grootaandeelhouder. De belanghebbende (degene die met de Inspecteur in gesprek was) had het rapport doen opstellen onder meer voor de vaststelling van de juiste vervreemdingsprijs. De belanghebbende weigerde aan de Inspecteur de inzage. De vraag moest worden beantwoord welke partij in fiscalibus de bewijslast droeg. De Inspecteur stelde dat de last, om de onjuistheid van een aanslag te bewijzen, op de belanghebbende rustte, zulks wegens het niet (ter inzage) verstrekken van inlichtingen(dragers). Het Gerechtshof te Amsterdam achtte deze omkering van de bewijslast echter niet gerechtvaardigd, waartoe het in beide zaken overwoog:
"Belanghebbende heeft geweigerd desgevraagd een due diligence rapport aan de In- specteur ter inzage te verstrekken. Het Hof acht het aannemelijk dat het due diligence rapport, zoals dat bij een dergelijk rapport gebruikelijk is, informatie kan bevatten van feitelijke aard. Naar het oordeel van het Hof kan derhalve de raadpleging van even be- doeld rapport van belang zijn voor de vaststelling van feiten welke invloed kunnen uit- oefenen op de belastingheffing ten aanzien van belanghebbende. Ingevolge artikel 47, eerste lid, aanhef en onderdeel b., van de Algemene wet inzake Rijksbelastingen (hierna: AWR) diende belanghebbende het due diligence rapport aan de Inspecteur voor raadpleging ter beschikking te stellen. Gelet evenwel op het bepaalde in paragraaf 32, tweede lid, van de Leidraad AWR, welke bepaling door de Staatssecretaris van Fi- nanciën is gehandhaafd, blijkens zijn mededeling van 5 januari 1994, nummer 10DGM4, VN1994, bladzijde 456, lijkt het ervoor te kunnen worden gehouden dat de Staatssecretaris van Financiën met betrekking tot een rapport als het onderhavige due diligence rapport, heeft beoogd de inlichtingenplicht van artikel 47 AWR te beperken. Onder deze omstandigheid acht het Hof het niet redelijk om aan de weigering van be- langhebbende het due diligence rapport voor raadpleging aan de Inspecteur ter be- schikking te stellen, in dit geval het gevolg te verbinden van de 'zogenaamde omkering' van de bewijslast, welk gevolg in het algemeen aan een dergelijke weigering is verbon- den". ${ }^{657}$

De Staatssecretaris ging in cassatie. Hij betwistte dat paragraaf 32, tweede lid van de Leidraad AWR ertoe leidt dat de niet-verstrekking van een due diligene rapport niet tot omkering van de bewijslast leidde.

fouten bevat en hij zijn wederpartij niet op deze fouten opmerkzaam maakt. Op deze grond zou kunnen worden aangenomen dat de franchisegever verplicht is de door zijn wederpartij geleden schade te vergoeden. Zodanige aansprakelijkheid kan ook bestaan indien sprake is van onrechtmatig handelen door personen voor de gevolgen van wier fouten degene die het rapport aan zijn wederpartij verschafte, op grond van de art. 6:170-6:172 BW aansprakelijk is. De vraag of Lampenier op grond van onrechtmatige daad jegens Paalman aansprakelijk is, is in cassatie echter niet aan de orde. Niet gesteld is dat het door Lampenier aan Paalman verschaffen van het door B \& O opgemaakte rapport als onrechtmatige daad van Lampenier zelf moet worden aangemerkt. Evenmin is aangevoerd dat zich in het onderhavige geval een aansprakelijkheid als bedoeld in artikel 6:172 voordoet. Het oordeel van het Hof ... tenslotte dat Lampenier niet op grond van de artt. 6:170 danwel 6:171 BW voor de gevolgen van, eventuele, ondeugdelijkheid van het $B$ \& O-rapport jegens Paalman aansprakelijk kan worden gehouden, wordt in cassatie niet bestreden."

${ }^{655}$ Zie A. Knigge, Aansprakelijkheid van franchisegevers, Bb 10 juli 2002,13 , p. 119 e.v. Zie ook S.C. de Lange, Exhibitieplicht in overnamegeschillen, Fusie \& Overname juli 2006, p. 13 e.v.

656 JOR 2005, 264, m.nt. P.J. van der Korst (LJN AR 6468 en AU 3140).

Zie ook P. van der Korst in diens noot onder JOR 2005, 23; A. Verhulst en J.P. van Niekerk, Fiscus etaleert informatiehonger, Fusie \& Overname, maart 2005, p. 30 e.v. en B.G.H. de Ruyter, Due-diligence rapporten buiten spel, Weekblad Fiscaal Recht 6665,6 april 2006, p. 369 e.v.

657 Zie voor commentaar op de hiervoor bedoelde uitspraak J.A.R. van Eijsden in WFR 2003/6530, p. 844 e.v. 
A-G Wattel concludeert tot vernietiging van het arrest van het Hof. Gelet op het belang van de desbetreffende overwegingen, noem ik de relevante overwegingen van de $A G$ hierna integraal:

\begin{abstract}
"4.1
In onderdeel 6 van de bijlage bij deze conclusie ga ik in op het vertrouwen dat belanghebbenden rechtstreeks kunnen ontlenen aan de (oorspronkelijk in paragraaf 32 , tweede lid Leidraad AWR en later in een handhavende mededeling) gepubliceerde beleidsregel waarin de fiscus zijn bevoegdheidsuitoefening ex artikel 47 AWR normeert, met name ten aanzien van inzage en informatievorderingen jegens belastingadviseurs en accountants terzake van hun adviezen aan en correspondentie met de belastingplichtige. Zoals daar betoogd, is mijns inziens voor de vraag of het vertrouwen gerechtvaardigd is dat het gevorderde niet verstrekt hoeft te worden, beslissend wat het intrinsieke karakter van het document is: beschrijvend danwel (fiscaal) risico-analyserend en adviserend. Het Hof heeft die maatstaf niet aangelegd, maar geoordeeld dat het ervoor lijkt te kunnen worden gehouden dat de Staatssecretaris de inzage bevoegdheid van de fiscus heeft beoogd te beperken met betrekking tot due diligence rapporten. Ik meen dat het Hof aldus geen zichtbare maatstaf heeft aangelegd voor de vraag of rechtens relevant vertrouwen is gewekt door de beleidsmededeling van de Staatssecretaris, zodat ofwel niet na te gaan is of zijn oordeel rechtskundig juist is, ofwel zijn oordeel (anderszins) aan motiveringsgebrek lijdt. Het Hof had zich het rapport moeten laten overleggen om zich omtrent het beschrijvende danwel fiscaal-analyserende karakter ervan een oordeel te vormen. Een due diligence rapport lijkt mij overigens - met het Hof - in het algemeen, mede gezien zijn functie en benaming (rapport), intrinsiek voor een groot deel beschrijvend van aard te zijn en dus in beginsel ter inzage verstrekt te moeten worden. Indien de conclusie moet zijn dat het rapport beide karakters heeft (zowel beschrijving als fiscaal-juridische analyse), zal het mijns inziens in beginsel eveneens ter inzage verstrekt moeten worden, zowel door de opsteller als door de cliënt.
\end{abstract}

\title{
4.2
}

De Hof-uitspraak moet daarom mijns inziens worden vernietigd. Anders dan de Staatssecretaris verbind ik daaraan echter niet het gevolg dat in de verwijzingsprocedure de bewijslast zal zijn omgekeerd wegens het niet-verstrekken van het rapport. Het verwijzingshof zal de aard van het rapport moeten beoordelen en zal nog steeds tot dezelfde conclusie kunnen komen als in de thans aangevallen uitspraak. Indien het verwijzingshof bevindt dat het rapport niet onder het beleidsmatige verschoningsrecht van de belastingadviseur / accountant valt, zal het moeten beoordelen of de ernst van de nietverstrekking de sanctie van omkering van de bewijslast terzake van alle geschilpunten rechtvaardigt (evenredigheidsbeginsel). Het Hof heeft in de aangevallen uitspraak dat oordeel (niet-overlegging is niet ernstig genoeg) geveld zonder kennis te nemen van het rapport, en het slechts onderbouwd met verwijzing naar het beleidsmatige verschoningsrecht van de accountant. Dat is echter, zoals bleek, mijns inziens onvoldoende onderbouwing. Het Hof zal bij die beoordeling zowel acht moeten slaan op de belangen van de Inspecteur bij verwerving van informatie die van belang is voor de belastingheffing (het Hof zal daartoe marginaal het belang voor de belastingheffing van de in het rapport gerapporteerde feiten dienen te beoordelen), als op de belangen van de belanghebbende bij het niet-verstrekken van het rapport, dat immers veel fiscale analyse kan bevatten, waaronder worst case scenario's en adviezen, die - indien afzonderlijk gerapporteerd - op grond van de genoemde beleidsregel niet ter inzage verstrekt zouden behoeven te worden.

4.3

Gezien de nog steeds heersende rechtskundige onduidelijkheid omtrent het karakter van due diligence rapporten in het licht van het beleidsmatige verschoningsrecht van accountants en belastingadviseurs, meen ik dat indien het Hof in dit pioniergeval tot de bevinding komt dat het rapport kwalitatief ongeveer even beschrijvend als adviserend is, en indien de risico-analyses / adviezen eenvoudig kunnen worden gescheiden van de feitelijke rapportage, het zorgvuldigheidsbeginsel meebrengt dat de belanghebbende alsnog de gelegenheid krijgt het rapport, desnoods onder rechterlijk toezicht, te split- 
sen. De rechter kan de belanghebbende verzoeken die splitsing binnen een te stellen termijn te doen verrichten door de opstellers van het rapport. ${ }^{3658}$

Op 23 september 2005 besliste de Hoge Raad de kwestie. Ik noem de dragende overweging hierna:

"3.2 Het eerste middel stelt aan de orde of een inspecteur gelet op het bepaalde in artikel 47 van de Algemene Wet inzake rijksbelastingen (hierna: AWR) een belastingplichtige kan vragen een aan deze uitgebracht zogenoemd due diligence rapport over te leggen en of de weigering om daaraan gevolg te geven, leidt tot omkering van de bewijslast. Voor de beslissing van het onderhavige geschil is het antwoord op deze vragen niet van belang, omdat de weigering van belanghebbende om de ... bedoelde verslagen te verstrekken, in dit geval al tot omkering van de bewijslast leidt.

Gelet op het belang van de eerste vraag in andere geschillen zij er evenwel op gewezen dat het tot de algemene beginselen van behoorlijk bestuur te rekenen beginsel van fair play zich ertegen verzet dat een inspecteur van zijn bevoegdheid ex artikel 47 AWR gebruik maakt om kennis te krijgen van rapporten en andere geschriften van derden voor zover zij ten doel hebben de fiscale positie van de belastingplichtige te belichten of hen daaromtrent te adviseren. Deze overweging geldt ook voor de onderdelen van die geschriften die met dat doel gegevens van feitelijke of beschrijvende aard bevatten. De resterende (niet op dat doel betrekking hebbende) onderdelen dienen wel - desgevraagd - te worden verstrekt, waartoe het nodig kan zijn dat het document wordt gesplitst of geschoond".

Van der Korst heeft in zijn noot onder de hiervoor bedoelde uitspraak in JOR 2005 erop gewezen dat de keuze voor het fair play beginsel veroorzaakt dat niet met zekerheid te zeggen valt of de door de Hoge Raad in fiscalibus aangelegde norm ook geldt voor andere bestuursorganen (als omschreven in artikel 1:1 AWR), zoals NMa, AFM en OPTA. De algemene beginselen van behoorlijk bestuur hebben, zoals de omschrijving al aangeeft, een algemene werking maar het fair play-beginsel is niet vastgelegd in de Algemene Wet Bestuursrecht en heeft in de jurisprudentie en de literatuur geen scherpe afbakening. Bovendien is het - aldus Van der Korst - denkbaar dat het door de Hoge Raad in civilibus gehanteerde begrip fair play is ingekleurd door een opmerking van de Minister in het parlement bij de totstandkoming van de Algemene Wet Rijksbelastingen, ${ }^{659}$ waarin de navolgende passage voorkomt:

\begin{abstract}
"Maar aan de andere kant acht ik het niet fair ... dat inzage zou worden geëist van de correspondentie en adviezen, die accountants of belastingconsulenten aan hun cliënten verstrekken. Ik zou gaarne aan de Belastingdienst een uitdrukkelijke aanwijzing geven, welke er hier op neer komt, dat inzage van door belastingconsulenten en accountants verstrekte adviezen en gevoerde correspondentie niet behoeft te worden verstrekt. In de wet kunnen wij dat niet opnemen, omdat men in het onzekere tast ten aanzien van degene, die er onder zouden vallen, omdat - zoals ik zei - op het ogenblik nog iedereen zich accountant of belastingconsulent mag noemen."
\end{abstract}

Hij wijst op het belang van het feit dat de Hoge Raad de vertrouwelijkheid van fiscale due diligence rapportages van toepassing acht op gegevens van feitelijke of beschrijvende aard die met het doel van advisering zijn opgenomen. Dat daar in civilibus nog wel eens anders over wordt gedacht door lagere rechters, komt hierna aan de orde onder 11.3.

\title{
Verschoningsrecht bij bedrijfsfiscalisten
}

De brochure van de NOB van mei 2006 "De Geheimhoudingsplicht van de Belastingadviseur" 660 bevat de volgende opmerkingen met betrekking tot de positie van bedrijfsfiscalisten, waar het een informeel verschoningsrecht betreft.

\footnotetext{
${ }^{658}$ A. Verhulst en J.P. van Niekerk, Fiscus etaleert informatiehonger, Fusie \& Overname maart 2005, p. 30 e.v.

${ }^{659}$ Handelingen der Staten-Generaal 1951-1952 II p. 1940.

${ }^{660}$ Zie hiervoor onder 11.3.
} 


\begin{abstract}
"Naar de mening van de Commissie die deze brochure heeft geschreven, kan de bedrijfsfiscalist zich niet beroepen op het informeel verschoningsrecht. Immers, de Hoge Raad heeft in de arresten van 23 september 2005 uitdrukkelijk overwogen dat het moet gaan om "... rapporten en andere geschriften van derden ...". De bedrijfsfiscalist heeft in wezen te maken met twee soorten advieswerk, te weten: het schrijven van eigen adviezen (hiervoor geldt zoals hiervoor aangegeven volgens de Commissie geen verschoningsrecht) en het schrijven van samenvattingen van andere adviezen (bijvoorbeeld van een externe belastingadviseur). Het is zeer de vraag of met betrekking tot het schrijven van samenvattingen van adviezen van een externe belastingadviseur een verschoningsrecht van toepassing is. Dit is tot op heden helaas onduidelijk. Dit geldt overigens ook voor bedrijfsfiscalisten die vanuit een 'eigen' entiteit adviseren over een groepsmaatschappij (bijvoorbeeld de holding). Betoogd zou dan immers kunnen worden dat een derde (ten opzichte van de holding) het advies heeft geschreven en derhalve het verschoningsrecht van toepassing zou moeten zijn. Onduidelijk is of deze opvatting juist is".
\end{abstract}

\title{
Verschoningsrecht bij accountants
}

Accountants en belastingadviseurs hebben geen klassiek verschoningsrecht. ${ }^{661}$ Een accountant-belastingconsulent komt evenmin een verschoningsrecht toe. ${ }^{662}$ Wel heeft de beroepsgroep met de fiscus afspraken gemaakt over de gevallen waarin de fiscus inzage mag vorderen van stukken die de accountant onder zich heeft.

De op 5 januari 1994 gepubliceerde mededeling van de Staatssecretaris van Financiën met betrekking tot de inzage in correspondentie en adviezen van belastingadviseurs en accountants ${ }^{663}$ betrof een beleidsmaatregel met betrekking tot de AWR van de navolgende inhoud:

"Ten aanzien van de verplichtingen met betrekking tot de belastingheffing van derden (artikel 49) beperkt het tweede lid van artikel 53 de mogelijkheid zich op een geheimhoudingsplicht te beroepen tot de uitoefenaren van bepaalde zelfstandige beroepen. Hiertoe behoren niet accountants en belastingconsulenten. Van hen dient echter geen inzage te worden geëist van de in de uitoefening van hun beroep aan cliënten verstrekte adviezen en met cliënten gevoerde correspondentie".

De hiervoor bedoelde beleidsmaatregel is gevolgd door afspraken tussen de Directeur-Generaal der Belastingen en de beroepsorganisaties van accountants op 27 september 1994, die zijn vastgelegd in de Gedragscode Openbare Accountants - Belastingdienst ${ }^{664}$. De mededeling (het besluit) van 5 januari 1994 is bij besluit van 25 januari 2007 ingetrokken omdat dit het belang had verloren na het hiervoor genoemde arrest van de Hoge Raad van 23 september $2005 .{ }^{665}$ De op 27 september 1995 vastgestelde gedragscode betreft afspraken ter zake van de controle-activiteiten van de Belastingdienst bij leden van het Nederlands Instituut van Registeraccountants en de Nederlandse Orde van Accountants-administratieconsulenten. De gedragsregels gelden wanneer een ambtenaar van de belastingdienst, belast met het uitvoeren van een controle, in het wettelijk kader inzage vordert in de controledossiers van de openbare accountant. De gedragscode ziet alleen op die dossiers die de openbare accountant aanlegt in het kader van zijn controlewerkzaamheden. Een controledossier is dan het systematisch geheel van documenten en vastleggingen inzake de controlewerkzaamheden die door een openbare accountant zijn uitgevoerd. Een due diligence rapport valt daar niet onder, althans niet voor zover het uit andere bestanddelen bestaat dan alleen controlebevindingen. Als rapportage van controlebevindingen gelden alle stukken en rapporten waarin de openbare accountant aan de leiding van de onderneming en/of het toezichthoudend orgaan mededeling doet over zijn controlebevindingen. Daarbij valt te denken aan de brief met controlebevindingen, de management letter (fiscale adviezen voor-

\footnotetext{
${ }^{661}$ Zie J.A. Booij, Fiscale due diligence rapporten niet meer veilig voor fiscus?, Ondernemingsrecht 2003, p. 71 e.v.

${ }^{662}$ Zie HR 21 november 1986, NJ 1987, 318

${ }^{663}$ Besluit nr. 10DGM4, V-N 1994, p. 456.

${ }^{664}$ Besluit Directeur-Generaal Belastingdienst namens de Staatssecretaris van Financiën, 27 september 1994, nr. AFZ94/4517M, VN1995/27.

${ }^{665}$ Besluit van 25 januari 2007, nr. CPP2006/2715M, Stcrt. 24 naar aanleiding van HR 23 september 2005, JOR 2005, 264 m.nt. P.J. van der Korst.
} 
komend in de management letter behoeven niet ter inzage te worden verstrekt). De gedragscode geldt niet in het kader van een strafrechtelijk onderzoek. Volgens de hier bedoelde afspraken kan de ambtenaar van de belastingdienst inzage verlangen in (delen van) het controledossier van de openbare accountant, of in de rapportage van de controlebevindingen. Er zijn procedure-afspraken gemaakt die zullen gelden wanneer een dergelijke inzage gewenst wordt. De code regelt welke onderdelen van een controledossier ter inzage dienen te worden verstrekt. Het betreft:

a. Analyse van het controle-object (bedrijfsbeschrijving en beschrijvingen van de Administratieve Organisatie en interne beheersingsmaatregelen $(\mathrm{AO} / \mathrm{IC})$;

b. Opzet van de accountantscontrole te onderscheiden in:

- werkprogramma's;

- $\quad$ uit te voeren overige controlewerkzaamheden.

c. Bevindingen terzake van de controle, in te delen in:

- $\quad$ bevindingen met betrekking tot de AO/IC (o.a. proceduretests);

- controlebevindingen. Indien de ambtenaar door feiten gestaafde vermoedens heeft dat een bepaalde post in een financiële verantwoording of andere cijfermatige opstelling, fiscale onjuistheden vertoont, kan hij terzake inzage vragen in de controlebevindingen van de openbare accountant;

- $\quad$ rapportage van de controlebevindingen aan de leiding van de onderneming en/of het toezichthoudend orgaan; en

- het accountantsverslag.

De openbare accountant is niet gehouden inzage te verlenen in het fiscale dossier, waarin fiscale correspondentie, fiscale adviezen en fiscale beschouwingen zijn opgeborgen.Desgevraagd moet de accountant aan de ambtenaar van de Belastingdienst wel een nadere toelichting op de dossierstukken geven. Waar zich in de controledossiers van een openbare accountant stukken bevinden van de belastingplichtige, heeft de ambtenaar van de Belastingdienst de bevoegdheid die stukken in te zien. Wel stelt de ambtenaar de belastingplichtige wiens stukken het betreft, daarvan in kennis. Zijn het stukken die eerst bij de belastingplichtige zelf kunnen worden ingezien, dan moet de ambtenaar de belastingplichtige eerst in de gelegenheid stellen zelf die stukken te verstrekken. Verder bevat de gedragscode een geschillenregeling. ${ }^{66}$

De hiervoor genoemde uitspraak van de Hoge Raad heeft in ieder geval geleid tot de conclusie dat het in strijd met het fair play beginsel zou zijn, wanneer de inspecteur vertrouwelijke gegevens en rapporten zou opvragen. Dit geldt niet alleen wanneer dit zou gebeuren bij de belastingadviseur, maar ook wanneer dit zou gebeuren bij de belastingplichtige zelf.

\subsection{Exhibitieplicht in civilibus}

\section{Algemeen}

In civilibus is er sprake van een toenemend aantal uitspraken, dat gebaseerd is op de regeling in het Wetboek van Burgerlijke Rechtsvordering met betrekking tot de openbaring en overlegging van gegevens. Ik wijs op de artikelen 21, 22, $29^{667}, 162$ en 843a Rv. ${ }^{668}$

De wetsbepaling welke tot dusverre in verband met het moeten bekend maken van gegevens uit een due diligence onderzoek tot de meeste rechterlijke uitspraken heeft geleid, is ongetwijfeld artikel 843a $\mathrm{Rv}^{669} \mathrm{Er}$ kan een beroep op die wetsbepaling worden gedaan door degene die over informatie wil ko-

\footnotetext{
${ }^{666}$ De gedragscode is een beleidsregel in de zin van artikel 1.3, vierde lid, Algemene wet bestuursrecht en vormt recht in de zin van artikel 79 Wet op de rechterlijke organisatie. De Belastingdienst is eraan gebonden.

${ }^{667}$ Artikel 29 Rv moet worden gelezen in verband met artikel $272 \mathrm{Sr}$.

${ }^{668}$ Een artikel dat eveneens met exhibitieplicht te maken heeft, maar buiten het onderwerp van dit boek valt, is artikel 3:15j. Dit artikel bepaalt dat erfgenamen de boekhouding van de erflater kunnen inzien, deelgenoten in een gemeenschap de boekhouding betreffende de gemeenschap, vennoten de boekhouding van de vennootschap en schuldeisers in het geval van een faillissement of toepassing van een schuldsaneringsregeling de boekhouding van de failliet onderscheidenlijk degene ten aanzien van wie de schuldsaneringsregeling van toepassing is. Voorwaarde is dat er voldoende belang bij die inzage bestaat. Zie J.A.C. van Veersen, Exhibitieplicht ex artikel 3:15j BW; een ondergeschoven kindje, V\&O januari 2006, nr. 1, p. 6 e.v.

${ }^{669}$ Zie H. Uittien, Gedwongen verstrekking van due diligence-rapportages, in: TOP januari 2007, p. 19 e.v.
} 
men te beschikken wanneer deze een rechtmatig belang heeft bij inzage, het verkrijgen van een afschrift of een uittreksel. De houder van dergelijke gegevens dient niet nodeloos te worden lastig gevallen. Het moet gaan om gegevens welke bijzonderlijk kunnen worden aangeduid. Dit kan ook onderhandse aktes, foto's, films, geluidsbanden en computergegevens betreffen. Voorwaarde is dat expliciet wordt aangegeven om welke bescheiden het gaat. ${ }^{670}$ Het moet verder gaan om gegevens welke betrekking hebben op een rechtsbetrekking van degene die over de gegevens beschikt enerzijds en de verzoeker of diens rechtsvoorgangers anderzijds. ${ }^{671}$ Van der Korst wijst er in zijn proefschrift ${ }^{672}$ op, dat in de lagere jurisprudentie regelmatig een ruime uitleg wordt gehanteerd van de voorwaarde dat het moet gaan om een rechtsbetrekking tussen de betrokken partijen en derhalve niet om correspondentie, rapportage en andere bescheiden, gewisseld tussen degene die over de informatie beschikt (of de verzoeker) en een derde. ${ }^{673}$ Zeker in de lagere rechtspraak wordt al snel aangenomen dat een due diligence rapport een document is dat betrekking heeft op de rechtsbetrekking tussen partijen, ook wanneer een due diligence rapport nadrukkelijk op verzoek van alleen één van beide partijen is opgemaakt en alleen aan de opdrachtgever van de onderzoeker(s) ter beschikking is gesteld. ${ }^{674}$ Wanneer in een letter of intent of overname-overeenkomst afspraken zijn gemaakt omtrent het uitvoeren van een due diligence onderzoek, wordt dan aangenomen dat de rechtsbetrekking waarop de weergave van de resultaten van het due diligence onderzoek betrekking heeft, de rechtsbetrekking tussen partijen is, zoals die is voortgevloeid uit de desbetreffende overeenkomst. Niet zelden wordt het ook van belang geacht dat garanties en/of vrijwaringen, zoals die in de uiteindelijke documentatie worden opgenomen, mede het gevolg kunnen zijn van de resultaten van een due diligence onderzoek. Voor de uitleg van de desbetreffende bepalingen kan het dan van belang zijn in hoeverre voorafgaand aan het tot stand komen van de documentatie ieder van de partijen op de hoogte was van de exacte situatie. Ik kom daar nog op terug. Een due diligence rapport - dat is de uitgangssituatie - wordt door rechters al snel gezien als een bescheid dat de rechtsbetrekking tussen de koper en de verkoper aangaat, zodat de kwalificatie van bepaalde bescheiden in artikel 843a lid $1 \mathrm{Rv}$ daarop van toepassing wordt geacht. In de literatuur is inmiddels het nodige over artikel $843 a$ Rv gezegd. ${ }^{675}$

\section{Jurisprudentie artikel 843a Rv}

In een uitspraak van 12 september 2007 vat de rechtbank Utrecht - in een vonnis, waarin lezenswaardige algemene beschouwingen voorkomen onder r.o. 3.4 tot en met 3.15 - de vier hoofdvoorwaarden samen waaraan een vordering op grond van artikel $843 a \mathrm{Rv}$ moet voldoen:

- $\quad$ rechtmatig belang;

${ }^{670}$ Volgens de rechtbank Utrecht 12 september 2007, JOR 2007, 265 is het voldoende dat de gevorderde gegevens voor de gedaagde (en de rechter) voldoende bepaalbaar zijn, niet of die tot in het grootste detail nader kunnen worden gepreciseerd. Van der Korst wijst erop dat jurisprudentie over deze bepaaldheideis niet consistent is. Verwezen wordt naar de door hem in zijn noot genoemde jurisprudentie.

671 Zie HR 18 februari 2000, NJ 2001, 259.

${ }^{672}$ P.J. van der Korst, Bedrijfsgeheimen en transparantieplichten, Nijmeegse Serie, deel 92, p. 95. Zie met name ook de nrs. nrs. 1.6.2. $\mathrm{b} ; 2.2 .2 ; 6.2 .5$ en 9.4.2.

${ }^{673}$ Zie echter Voorzieningenrechter Rechtbank Rotterdam 25 november 2004, NJF 2005, 2, welke overwoog dat als rechtsbetrekking niet alleen dient te worden aangemerkt de tussen twee partijen bestaande overeenkomst, maar tevens de rechten en verplichtingen die als gevolg van de uit hoofde van die overeenkomst gedane prestaties zijn ontstaan tussen één van de partijen en een derde, nu de rechten van de derde mede werden bepaald door de inhoud van de overeenkomst tussen de partijen bij die overeenkomst.

${ }^{674}$ Zie Rechtbank Amsterdam 24 januari 2007, LJN-nummer AZ7826 en rechtbank Utrecht 12 september 2007, JOR 2007, 265 m.nt. P.J. van der Korst.

${ }^{675}$ Zie onder meer P.J.M. von Schmidt auf Altenstadt, Opening van zaken, TCR 2002, nr. 1, p. 8 e.v.; B.T.M. van der Wiel, De exhibitieplicht (te) terughoudend opgevat, NbBW 2004, nr. 4, p. 58 e.v.; M.M. van den Broek, Gedwongen overlegging due diligence rapport, V\&O 2004, nr. 7/8, p. 122 e.v; .; K.I.A. Middelkoop, Due diligence rapporten: plicht tot overleggen?, V\&O 2005, nr. 11, p. 196 e.v.; Teuben, De verplichting tot het overleggen van stukken ex art. 843a Rv, Maandblad voor Vermogensrecht 2006, nr. 12, p. 218 e.v. J. Ekelmans, De exhibitieplicht in de praktijk: de ruime mogelijkheden tot opvragen van bescheiden, TCR 2005, 3;

W.P. Wijers en A.J. Haasjes, Exhibitieplicht in het (ondernemings)recht, O\&F 2006, nr. 71, p. 49 e.v; J. Ekelmans, Een onbalans in de eindbalans: de exhibitieplicht revisited, TCR 2006, nr. 4, p. 101 e.v. en van dezelfde auteur, De exhibitieplicht in kort bestek. Een practische leidraad bij het opstellen en beoordelen van vorderingen tot verstrekking van bescheiden op grond van art. 843a Rv, Zutphen 2007; J.R. Sijmonsma, Art. 843a Wetboek van Burgerlijke Rechtsvordering ont(k)leed, Nijmegen 2007; J. Ekelmans, Art. 843a Wetboek van Burgerlijke Rechtsvordering ont(k)leed, TCR 2008, 2, p. 65-66; H. Aittien, Gedwongen verstrekkingen van due diligence rapportages, TOP januari 2007, p. 19 e.v.; A. Keizer, Exhibitieplicht bij overnamegeschillen, V\&O maart 2008, nr. 3, p. 53 e.v.; J.M. Barendrecht en W.A.J.P. van den Reek, Exhibitieplicht en bewijsbeslag, WPNR 94/6155, p. 739 e.v. en J.R. Sijmonsma, Exhibitieplicht in kort bestek, TCR 2008, 2, p. 60 e.v. 
- $\quad$ bescheiden aangaande een rechtsbetrekking, waarbij de eiser en de gedaagde of de rechtsvoorgangers van de eiser partij zijn;

- bepaalde bescheiden;

- $\quad$ van degene die deze bescheiden te zijner beschikking of onder zijn berusting heeft.

De rechtbank overweegt wat het rechtmatig belang betreft, dat dit niet uitsluitend ziet op verstrekkingen van bescheiden in het kader van een gerechtelijke procedure, maar tevens op verstrekking buiten rechte. Dat de wetgever bedoeld heeft zogenaamde 'fishing expeditions' te voorkomen, betekent volgens de rechtbank ook weer niet dat het begrip 'rechtmatig belang' beperkter moet worden uitgelegd dan noodzakelijk is voor het bereiken van dat doel. ${ }^{676}$

Veel te ver, vind ik, gaat de uitspraak van de rechtbank (r.o. 3.19) als zou ingevolge vaste jurisprudentie een partij bij een overeenkomst, waarin overeengekomen wordt om een due diligence onderzoek te verrichten, op grond van artikel $843 \mathrm{a} R \mathrm{v}$ recht op verstrekking van het rapport van het betreffende onderzoek hebben. De enige troost ten opzichte van die in mijn ogen te ongenuanceerde vaststelling is, dat de rechtbank in de volgende regel zegt dat om die reden de vordering in de onderhavige zaak - die betrekking had op de rapportages met bijlagen, van de personen die de due diligence hadden uitgevoerd en het due diligence rapport van de accountant - "in beginsel" voor toewijzing vatbaar was. Mij dunkt dat tenminste steeds opnieuw volgens de voorwaarden welke toepasselijk zijn, moet worden onderzocht of er een exhibitieplicht bestaat, ook wanneer dit betrekking heeft op due diligence bescheiden. Dit raakt ook aan de hierna te bespreken vraag of artikel 843a Rv dwingend recht is (zie hierna).

Het gerechtshof te Arnhem heeft op 13 februari 2007 terecht als uitgangspunt geformuleerd, "dat op grond van artikel 843a Rv Van een algemeen recht op inzage van bescheiden jegens degeen die deze bescheiden te zijner beschikking of onder zijn berusting heeft, geen sprake is" ${ }^{677}$ Een vordering tot inzage, afschrift van bepaalde bescheiden kan (maar hoeft niet te) worden toe gewezen indien aan alle voorwaarden van het eerste lid van die bepaling is voldaan.

Het is een kwestie van visie op het totaal van de rechtsmaatregelen die in het Wetboek van Burgerlijke Rechtsvordering worden genoemd of uitsluitend het tegengaan van een zogenaamde fishing expedition aanleiding kan zijn voor het afwijzen van een vordering op grond van artikel 843a van dat wetboek, wanneer overigens is voldaan aan de vereisten, die toewijzing van een vordering mogelijk maken. ${ }^{678}$

Mij dunkt dat een rechter ook moet letten op de aard van de bescheiden en andere gegevensdragers waar het om gaat - ook wanneer die wel voldoende concreet zijn aangeduid - en de rechtsbetrekking tussen partijen in ruimere zin. Ook moet naar mijn mening meetellen, wat partijen terzake van de desbetreffende bescheiden van elkaar mochten verwachten, en bijvoorbeeld, afgesproken hebben. Niet vergeten mag worden dat - ofschoon het een bijzonder exhibitieplicht betreft - de bepaling van artikel 843a Rv past binnen het stelsel van de in ons land gekende processuele mededelingsplichten waarbij bescheiden en dergelijke niet behoeven te worden geproduceerd, zolang maar wordt geaccepteerd dat de rechter aan de weigering die gevolgen kan verbinden die hem geraden voorkomen. Het feit dat de bijzondere exhibitieplicht ziet op het produceren van bescheiden en andere gegevensdragers binnen en buiten rechte, leid ik af dat er aan de desbetreffende wetsbepaling een stevige privaatrechtelijk component zit. Dit behoort mee te wegen bij de manier waarop wij kijken naar de ruimte welke er is voor het maken van partij afspraken over het wel of niet aanspraak (mogen) maken op de productie van bescheiden en informatie en voor de verwachtingen welke op grond van redelijkheid en billijkheid wel of niet mochten bestaan. Anders dan Van der Korst ${ }^{679}$ meen ik derhalve dat - ook wanneer aan de vereisten van artikel $843 \mathrm{a}$ lid $1 \mathrm{Rv}$ is voldaan - er de nodige ruimte voor de rechter is en moet zijn om een vordering gelet op alle omstandigheden van het geval toch af te wijzen.

\footnotetext{
${ }^{676}$ Van der Korst legt in zijn noot onder het vonnis van de rechtbank Utrecht uit, dat het begrip 'fishing expeditions' niet gedefinieerd is maar ontleend is aan de Angelsaksische rechtspraktijk. Volgens Black's Law Dictionary (West Publishing Co.) wordt eronder begrepen "using the courts to find out information beyond the fair scope of the law suit". Artikel 843a Rv mag daarvoor dus niet worden misbruikt. Zie over fishing expeditions ook B. Winters en J. Vossenberg, Vissen in het enquêterecht, V\&O april 2005, nr. 4, p. 62 e.v.

677 JOR 2007, 136 (r.o. 3.2).

${ }^{678}$ Dit is de opvatting van P.J. van der Korst blijkens zijn noot onder Gerechtshof Arnhem 13 februari 2007, JOR $2007,136$.

${ }^{679}$ A.w.
} 
Wat verder opvalt in de hiervoor besproken uitspraak van de rechtbank te Utrecht van 12 september 2007 is dat verschillende soorten due diligence onderzoeken (het door in dit geval OPG Groothandel zelf uitgevoerde due diligence onderzoek) onder één noemer wordt gebracht met het door externe adviseurs uitgevoerde onderzoek. De rechtbank meende dat onvoldoende gemotiveerd was betwist dat er sprake was van verschillende onderzoeken en derhalve werden beide onderzoeken gebracht onder de noemer van het in de voorovereenkomst (Heads of Agreement) overeengekomen due diligence onderzoek. Ik heb er eerder al op gewezen dat rechters (te) weinig boodschap lijken te hebben aan de zelfstandige positie van adviseurs (zie hier voor onder 11.1).

Over de vraag hoe concreet moet zijn aangegeven om welke bescheiden het gaat, huldigen de rechtbank van Utrecht en het gerechtshof te Arnhem blijkens de beide hier voor laatst besproken uitspraken duidelijk verschillende opvattingen. De rechtbank te Utrecht schildert naar mijn mening in bepaalde opzichten met een te dikke kwast, zoals ik hier voor al aangaf.

Verder trekt de rechtbank in Utrecht de cirkel wel erg ruim waar het gaat om het ter beschikking of onder berusting hebben van bescheiden. In r.o. 3.28 zegt de rechtbank in feite dat voor een veroordeling om stukken te produceren voldoende is dat men de beschikking over de desbetreffende bescheiden kan krijgen. Tamelijk ver gaat het in mijn ogen ook dat de rechtbank uit de gang van zaken rond de overname afleidt dat aan de zijde van de overnemende partij als groep is geopereerd in die zin dat uit de overname voortvloeiende rechten en verplichtingen van de ene tot de groep behorende vennootschap (OPG Deelnemingen) na de overname aan een andere tot de groep behorende vennootschap worden overgedragen (OPG Groothandel) danwel worden uitgeoefend door een andere tot de groep behorende vennootschap (OPG Groep) dan de rechthebbende (OPG Groothandel). Onder die omstandigheden vereenzelvigde de rechtbank alle betrokken partijen en kende OPG Groothandel geen beroep toe op een verschil in rechtspersoonlijkheid. OPG Groothandel had gesteld dat het betreffende due diligence onderzoek was verricht in opdracht van haar moedermaatschappij (OPG Groep) en niet van haar zelf. De voorovereenkomst was tot stand gekomen tussen een zustermaatschappij van OPG Groothandel, OPG Deelnemingen, en de wederpartij. OPG Deelnemingen had haar rechten en verplichtingen uit de overeenkomst overgedragen aan OPG Groothandel. Volgens de rechtbank was het dus het recht van OPG Groothandel om opdracht te geven voor het uitvoeren van het due diligence onderzoek. Nu zij dat had overgelaten aan haar moedermaatschappij, kon zij zich volgens de rechtbank er niet op beroepen dat de bescheiden met betrekking tot het due diligence onderzoek haar niet ter beschikking stonden of onder haar berusting waren. Het feit dat OPG Groothandel intern recht had op afgifte van de bescheiden die op het onderzoek betrekking hadden jegens haar moedermaatschappij, maakte volgens de rechtbank niet dat OPG Groothandel niet kon worden beschouwd als degene die niet de beschikking had over de betreffende stukken.

De inzet van de procedure was een verschil van mening tussen partijen over het antwoord op de vraag of een bepaling in de koopovereenkomst moest worden uitgelegd als een garantie (standpunt OPG Groothandel) danwel als een bepaling waarmee partijen de uitkomst van het due diligence onderzoek, dat gedeeltelijk pas werd uitgevoerd nadat de overname reeds beslag had gekregen, nog in de koopprijs tot uitdrukking kon komen (standpunt Quigley c.s.). In de omstandigheid dat volgens de rechtbank de uitleg van die bepaling moet plaatsvinden aan de hand van het zogenaamde Haviltex-criterium, ziet de rechtbank aanleiding om te rechtvaardigen dat het due diligence rapport van de wederpartij moet worden geproduceerd. Volgens de rechtbank moet de uitleg plaatsvinden aan de hand van alle omstandigheden van het geval, waaronder de vraag op welke wijze een partij van de in de overeenkomst opgenomen mogelijkheid tot het uitvoeren van een due diligence onderzoek gebruik heeft gemaakt (diepgaand onderzoek of niet), en of zij daarmee bepaalde risico's voor lief heeft genomen danwel heeft beoogd deze door middel van garanties af te dekken. Na te hebben vastgesteld dat zij van oordeel is dat deze diepgang in ieder geval niet uit het overgelegde conceptrapport van de accountant valt af te leiden, stelt de rechtbank vast dat niet duidelijk is geworden wat het bereik van het onderzoek was. De door de eiser gevraagde stukken zouden meer duidelijkheid over de diepgang van het due diligence onderzoek kunnen brengen. Deze door de rechtbank gegeven rechtvaardiging snijdt naar mijn oordeel geen hout. Of er nu wel of niet een diepgaand onderzoek is geweest en of OPG Groothandel wel of niet bepaalde risico's heeft willen aanvaarden, behoeft helemaal niet bepalend te zijn voor het antwoord op de vraag of een bepaling in de koopovereenkomst moet worden uitgelegd als een garan- 
tie. Voor zover dit wel het geval is, blijkt dat naar mijn oordeel onvoldoende uit het vonnis. Meer hout snijdt de overweging van de rechtbank (r.o. 3.23) dat de diepgang van een uitgevoerd onderzoek niet alleen van belang kan zijn voor de uitleg van de hier voor meer bedoelde bepaling in de koopovereenkomst, maar tevens voor de uitleg van de tussen partijen gesloten vaststellingsovereenkomst. OPG meende overigens dat de zogenaamde Settlement Deed slechts betrekking had op het beslechten van kleine verschillen van mening over de uitkomsten van het due diligence onderzoek. Dat de rechtbank hier het naadje van de kous wil weten, laat zich beter voorstellen.

Een sprekende uitspraak is die van het Gerechtshof te 's-Hertogenbosch van 28 september 2004 . $^{680}$ Het ging daarbij om een overname van aandelen, waarbij naderhand wegens vermeende schending van de overeengekomen garanties en het verzwijgen van relevante gegevens, een vordering werd ingesteld. De verkoper verweerde zich door een incidentele vordering in te stellen tegen de koper, welke erop gericht was een voorlopige voorziening te verkrijgen, inhoudende dat de koper een afschrift van het ten tijde van de overname uitgebrachte due diligence rapport aan de verkoper zou overhandigen. De verkoper wilde op die manier komen te beschikken over documentatie waaruit zou kunnen blijken dat de koper ten tijde van de transactie op de hoogte was van gegevens, waarmee deze later stelde onbekend te zijn geweest. De rechtbank wees de vordering toe met dien verstande dat het due diligence rapport ter griffie van de rechtbank zou dienen te worden gedeponeerd, zodat de verkoper dit zou kunnen inzien. De koper stelde hoger beroep in tegen het vonnis van de rechtbank. Het ging alleen nog om de principiële vraag, nu de verkoper inmiddels van het rapport had kennis genomen.

Relevant is dat de opdracht tot het due diligence onderzoek door de koper was verstrekt. De verkoper stond buiten die overeenkomst van opdracht. Het rapport was niet aan de overname-overeenkomst gehecht en de verkoper heeft voorafgaande aan de totstandkoming van de overname-overeenkomst geen inzage in het rapport gevraagd.

Het Hof overwoog evenwel dat het rapport betrekking had op de rechtsbetrekking tussen de koper en de verkoper, zoals die was voortgevloeid uit de tussen partijen eerder overeengekomen intentieverklaring (welke intentieverklaring voorafging aan de overnameovereenkomst). Het due diligence onderzoek was overeengekomen in de intentieverklaring. Het Hof overwoog, dat slechts voor zover het rapport tevens adviezen bevatte van de accountant aan de koper met betrekking tot de overname, gezegd zou kunnen worden dat het rapport geen betrekking had op de rechtsbetrekking tussen de koper en de verkoper, maar op de rechtsbetrekking tussen de accountant en de koper.

Het verweer dat ook zonder dat het rapport aan de verkoper ter beschikking zou worden gesteld, een behoorlijke rechtsbedeling gewaarborgd zou zijn, vond geen genade in de ogen van het Hof. Niet alleen - zo meende het Hof - zou uit het rapport kunnen blijken waartoe het onderzoek zich had uitgestrekt en wat in het kader daarvan al dan niet desgevraagd door de verkoper aan de koper was meegedeeld, maar bovendien was sedert de overnametransactie 7 jaar verlopen. De inhoud van een getuigenverklaring kon dan niet meer als alternatief gelden voor inzage van het rapport. ${ }^{681}$

In de meer genoemde uitspraak van de rechtbank te Utrecht van 12 september 2007 - waarvan overigens op het moment van afsluiten van dit manuscript was aangekondigd dat hoger beroep zou worden ingesteld - werd met betrekking tot het alternatief van bewijslevering door middel van getuigen, danwel het gelasten van een deskundigenbericht het navolgende opgemerkt:

"Met dit verweer miskent OPG Groothandel dat aan bewijslevering door middel van het horen van getuigen danwel het gelasten van een deskundigenbericht pas wordt toegekomen, indien de rechter van oordeel is dat beide partijen hun stellingen voldoende hebben gemotiveerd. In dit kader wordt van Quigley c.s. verwacht dat zij de stellingen van OPG Groothandel, alsmede de bescheiden waarop deze zich beroept (waaronder het rapport van $K P M G)$, voldoende gemotiveerd weerlegt. Door de gevraagde bescheiden wordt hij daartoe in staat gesteld (het pluraris en singularis wordt nog wel eens door elkaar gehaald, MB). Daarbij komt dat de onderhavige feiten zich ruim zes jaar geleden hebben voorge-

\footnotetext{
680 Gerechtshof 's-Hertogenbosch 28 september 2004, JOR 2005, 23 m.nt. P.J. van der Korst.

${ }^{681}$ Zie ook Rechtbank Amsterdam 24 januari 2007, LJN AZ7826, waar - zo laat die uitspraak zich lezen - wat minder dan zeven jaar was verlopen, maar de rechtbank toch van oordeel was dat de inhoud van een getuigenverklaring afhankelijk is van wat een getuige zich herinnert en de kans bestaat dat na enig tijdsverloop niet meer alle details zijn onthouden.
} 
daan en het horen van getuigen in verband met het noodzakelijkerwijs teruglopen van het geheugen niet gelijk gesteld kan worden met de inhoud van bescheiden die destijds zijn opgemaakt. Bovendien zijn de stukken niet alleen nodig als bewijs voor het standpunt van Quigley c.s. in conventie, maar tevens als bewijs voor het bestaan van een vorderingsrecht in reconventie. In de reconventionele procedure gelden eventuele getuigenverklaringen van Quigley c.s. zelf in beginsel als partij-getuige verklaringen, terwijl bescheiden in beginsel volledig tot bewijs kunnen dienen. Tenslotte zijn deskundigenonderzoeken kostbaar en tijdrovend en verdient het uit oogpunt van een goede procesorde in beginsel de voorkeur om - indien het bewijs ook door middel van overlegging van bescheiden kan worden geleverd - het gelasten van een deskundigenonderzoek te voorkomen. Bovendien kan een deskundigenonderzoek ook in die zin niet gelijk gesteld worden met verstrekking van stukken, dat Quigley c.s. in beginsel geen recht heeft op inzage in bescheiden waarover de deskundige in het kader van zijn onderzoek kan beschikken."

In de zaak die speelde voor het Gerechtshof te 's-Hertogenbosch en eindigde met het arrest van 28 september 2004, slaagde evenmin het verweer dat het rapport tevens passages van adviserende aard zou bevatten, waardoor het rapport hoogstens bij een notaris zou moeten worden neergelegd, waarna de notaris bepaalde mededelingen zou kunnen doen aan de verkoper. Het Hof overwoog wat dit betreft:

"De koper is in gebreke gebleven aan te geven in welke mate bedoelde adviserende passages in het rapport voorkomen en in hoeverre het mogelijk is deze op controleerbare wijze onleesbaar te (laten) maken in het aan verkoper ter beschikking te stellen exemplaar van het rapport, bijvoorbeeld door een notaris die ook het vertrouwen van de verkoper geniet."

Indien er geen verweer wordt gevoerd tegen de productie van een due diligence rapport, moet een vordering tot overlegging worden toegewezen. De rechter mag niet ambtshalve één of meer verweren - of de uitzonderingen van artikel 843a lid $4 \mathrm{Rv}$ - toepassen, nu hij daarmede in strijd zou komen met artikel $24 \mathrm{Rv}$ (de rechter zou daarmee buiten de door partijen aangevoerde grondslag treden). Slechts op een daartoe strekkend verweer mag de rechter beslissen of er gewichtige redenen zijn die zich verzetten tegen overlegging en of redelijkerwijs kan worden aangenomen dat een behoorlijke rechtsbedeling ook zonder overlegging is gewaarborgd. ${ }^{682}$

Tenslotte speelde nog de discussie of deponering ter griffie het mogelijk zou maken dat concurrenten toch inzage zouden nemen in gevoelige informatie. Het Hof maakt met dat verweer korte metten door te stellen dat dit niet opgaat voor zover met gevoelige informatie wordt gedoeld op de passages van adviserende aard, waarover de koper onvoldoende duidelijkheid had verschaft. "Voor zover de koper daarbij op iets anders doelt, is niet duidelijk wat zij daarmee bedoelt".

In de genoemde uitspraak van het Gerechtshof te 's-Hertogenbosch van 28 september 2004 werd de verkoper overigens een verbod opgelegd om de gegevens die haar uit het due diligence rapport bekend werden, aan derden mee te delen.

\section{Voorwaarden blijkens jurisprudentie}

Per saldo komt het erop neer dat voor een succesvol beroep op een exhibitieplicht ex artikel 843a Rv voldaan moet zijn aan de navolgende cumulatief toepasselijke voorwaarden:

De eiser of verzoeker moet een rechtmatig belang hebben bij inzage, uittreksel of afschrift; Het moet om "bepaalde bescheiden" gaan. De desbetreffende bescheiden moeten bijzonderlijk worden genoemd, evenals de reden waarom inzage vereist is. ${ }^{683}$ Onder bepaalde bescheiden worden als gezegd ook andere gegevensdragers verstaan, zoals film, foto, computergegevens, geluidsbanden en CD-rom;

\footnotetext{
682 Zie HR 6 oktober 2006, LJN AX7774

${ }^{683}$ Zie voor een voorbeeld, waarin het verzoek als te algemeen geformuleerd werd beschouwd, Hof 's-Gravenhage 22 november 2007, NJF 2008, 3.
} 
- $\quad$ De eiser of verzoeker moet partij zijn bij een rechtsbetrekking waarop de desbetreffende gegevens betrekking hebben. Het is nodig dat de eiser of verzoeker of diens rechtsvoorganger zelf partij bij die rechtsbetrekking is (geweest). ${ }^{684}$ De jurisprudentie is verdeeld over de vraag of een (vermeende) rechtsbetrekking uit een onrechtmatige daad ook kwalificeert als een rechtsbetrekking tussen partijen; ${ }^{685}$

- $\quad$ Degene van wie de bescheiden worden verzocht, moet die bescheiden wel tot zijn beschikking of onder zijn berusting hebben;

- $\quad$ Degene van wie de bescheiden worden verlangd, is niet gehouden die bescheiden over te leggen als daarvoor gewichtige redenen zijn;

Er moet geen alternatieve wijze van informatieverschaffing bestaan. Als een behoorlijke rechtsbedeling ook zonder verschaffing van de gevraagde bescheiden gewaarborgd is, behoeven die niet te worden verstrekt. ${ }^{686}$

Er is dus geen onbeperkt recht op inzage, afschrift of uittreksel. Het rechtmatig belang dat betrekking moet hebben op bepaalde bescheiden, moet zijn ingegeven door redenen die eventuele gewichtige redenen aan de zijde van de houder van de gegevens in belangrijkheid overtreffen. ${ }^{67}$ Een partij die een beroep doet op het bestaan van een gewichtige reden zal dit gemotiveerd kenbaar dienen te maken. Het meest voorkomende verweer in deze is dat er belang bij bestaat om vertrouwelijke (bedrijfs)informatie niet in de openbaarheid te doen komen. ${ }^{688}$ Verschillende mogelijkheden doen zich voor om vertrouwelijkheid te waarborgen. Zo kan een rapport bij een notaris worden gedeponeerd die kan verifiëren of er sprake is van passages van feitelijke of adviserende aard, danwel gegevens kan rapporteren zonder naamvermelding of andere informatie welke als schadelijk voor de concurrentiepositie kunnen worden beschouwd. Uitsluitend indien degene die over de betrokken bescheiden beschikt, gewichtige redenen heeft om inzage of afgifte te weigeren, zal die weigering gerechtvaardigd kunnen worden. Afgifte of inzage behoeft niet te worden verschaft, indien dit niet nodig is voor een behoorlijke rechtsbedeling. De hoofdvordering hoeft niet volledig onderbouwd te worden en hoeft niet voldoende duidelijk te zijn. Aan de hand van de opgevraagde informatie kan immers een inschatting worden gemaakt van de kansen in een bodemprocedure. ${ }^{689}$ Kan eenvoudig middels getuigenbewijs een behoorlijke rechtsbedeling worden bereikt, dan is gedwongen inzage of afschrift van bepaalde bescheiden niet nodig. De rechter zal een belangenafweging maken. ${ }^{690}$

De rechter bepaalt zo nodig op welke wijze de inzage, afschrift of uittreksel zal worden verschaft. Hij kan bijvoorbeeld ook een derde aanwijzen om inzage te nemen en een afschrift of uittreksel te maken. Dit zal vooral iemand moeten zijn die tot geheimhouding verplicht is, zoals een advocaat, notaris of arts. Concurrentieoverwegingen bijvoorbeeld kunnen rechtvaardigen dat er niet meer informatie wordt verschaft dan strikt nodig of de informatie wordt verschaft op een wijze die gevaar voor verspreiding meebrengt.

\footnotetext{
684 Zie HR 18 februari 2000, NJ 2001, 259.

${ }^{685}$ Zie Gerechtshof 's-Gravenhage 22 november 2007, LJN-nummer BB8556, waarin de rechtsbetrekking waarop degene die inzage in een aannemingsovereenkomst wilde, volgens het Hof was gebaseerd op een onrechtmatige daad. De betrokkenen hadden niet gesteld dat zij of hun eventuele rechtsvoorgangers partij waren bij de aanbesteding waarop het door hen opgevorderde bescheid, de (schriftelijke) aannemingsovereenkomst, betrekking had en overigens was dat ook niet gebleken. De rechtbank Utrecht overweegt (r.o. 3.11) met een verwijzing naar de parlementaire geschiedenis dat ook een rechtsbetrekking uit onrechtmatige daad als een rechtsbetrekking in de zin van artikel 843a Rv moet worden beschouwd.

686 Zie ook P.S. Bakker, de grenzen van de exhibitieplicht in Practisch Procederen 2007/5, p. 143 e.v. Zie ook J.F. Sijmonsma, enkele aspecten van de inzageplicht van art. 843a Rv, praktisch procederen 2005/5, p. 145 e.v. Sijmonsma concludeert dat de reikwijdte van artikel $843 a \mathrm{Rv}$ nog steeds niet volledig is uitgekristalliseerd en dat alle knelpunten nog niet zijn opgelost. "Niet de minste daarvan zijn de vragen of een niet-verschoningsgerechtigde gehouden is om inzage te verstrekken in stukken die door een verschoningsgerechtigde zijn opgesteld, wat nu precies de inhoud is van het begrip 'gewichtige redenen' en of het huidige stelsel een zekere vorm van bewijsbeslag toelaat."

687 Zoals blijkt uit A.I.M. van Mierlo, m.m.v. F.M. Bart, Parlementaire geschiedenis: herziening van het burgerlijk procesrecht voor burgerlijke zaken, Kluwer 2002, p. 157, heeft de wetgever de nadere invulling van 'gewichtige redenen' willen overlaten aan de rechtspraak.

688 Zie bijvoorbeeld Rechtbank Breda 14 januari 2004, JOR 2004, 70. In die zaak meende de rechter de kwestie van de vertrouwelijkheid op te lossen door deponering te gelasten ter griffie van de rechtbank. Aldus kon volgens de rechter worden voorkomen dat het rapport ongecontroleerd kon worden gekopieerd en verspreid.

689 Voorzieningenrechter 's-Gravenhage 23 oktober 2003, JOR 2004, 136

690 Zie HR 31 mei 2002, NJ 2003, 589.
} 
De rechtbank Amsterdam stelde in een uitspraak van 13 april 2005 vast ${ }^{691}$ dat een verkoper recht had op het kennis nemen van de resultaten van een due diligence onderzoek, maar voegde daaraan toe dat de eiser in de desbetreffende zaak niet duidelijk had gemaakt of het feitelijke en adviserende deel van het rapport zou zijn te scheiden, zodat niet kon worden vastgesteld of het ter beschikking stellen van het rapport aan een notaris, een werkbare optie was. Overigens wordt (ook) in die zaak aan het bezwaar dat het rapport uitsluitend geadresseerd was aan en bestemd was voor de opdrachtgever, door de rechtbank voorbij gegaan. De gedaagde had het verweer gevoerd dat die met PricewaterhouseCoopers, die in dit geval het due diligence rapport had opgesteld, had afgesproken het rapport uitsluitend voor eigen gebruik te bestemmen en niet aan anderen ter inzage te zullen verschaffen. De rechtbank passeert als gezegd dat verweer. Zij zegt niet in te zien waarom PricewaterhouseCoopers goedkeuring zou onthouden. Daarmee maakt de rechtbank zich er gemakkelijk vanaf.

Omdat het niet als een werkbare optie werd gezien bepaalde gedeelten van het due diligence rapport wel en andere gedeelten niet voor inzage aan te wijzen (nu een dergelijke verdeling moeilijk werd geacht), besluit de rechtbank in dit geval dat het rapport ter inzage moet worden verschaft op basis van een aan de eiser op voet van artikel $29 \mathrm{Rv}$ op te leggen mededelingsverbod. Artikel $29 \mathrm{Rv}$ zegt dat het partijen verboden is aan derden mededelingen te doen omtrent het verhandelde op een terechtzitting met gesloten deuren of een terechtzitting waarbij slechts bepaalde personen zijn toegelaten, danwel andere gegevens uit een procedure, indien de rechter dit heeft bepaald. In eenzelfde procedure werd niet toegestaan dat ook een due diligence rapport van de hand van de advocaten in de desbetreffende zaak, ter inzage zou worden verschaft. Het geschil tussen partijen ging over schade en inbreuk op garanties en betrof volgens de rechtbank cijfermatige kwesties. Inzage in het rapport van de accountant zou wat dat betreft moeten kunnen volstaan. De eiser werd geacht onvoldoende te hebben aangedragen om te rechtvaardigen dat ook het juridische due diligence rapport ter inzage zou moeten worden verschaft. Dit was in lijn met eerdere jurisprudentie al gebleken. ${ }^{692} \mathrm{Ik}$ noem hierna uit de uitspraak van de rechtbank in Amsterdam een citaat, dat een les inhoudt voor diegene die middels een verzoek op grond van artikel $843 a \mathrm{Rv}$ toegang tot informatie wenst te verkrijgen:

"Gesteld noch gebleken is hoe het due diligence dossier precies is samengesteld en uit welke onderdelen dit bestaat. Aan de vordering tot afgifte van al deze documenten ligt de stelling van Aegon ten grondslag dat Dexia in dit geding inzage dient te geven in de mate waarin zij in het kader van het due diligence onderzoek bepaalde risico's in de onderneming van Labouchere heeft onderkend of heeft kunnen onderkennen, opdat mede aan de hand daarvan kan worden beoordeeld of Dexia zich op dwaling kan beroepen en kan worden vastgesteld welke betekenis aan de door Aegon gegeven warranties moet worden toegekend. In het licht van onder meer HR 22 december 1995, NJ 1996, 300 is de aan het due diligence onderzoek ontleende en te ontlenen wetenschap van Dexia in beginsel relevant voor de beoordeling van haar vordering door de rechtbank. Daarom kan van Dexia in beginsel worden gevergd dat zij daarover ten aanzien van elk van de door haar gestelde gebreken nadere informatie verstrekt in dit geding. De vraag welke concrete informatie omtrent de inhoud en uitkomst van het due diligence onderzoek Dexia in dit geding moet verschaffen, hangt echter af van alle omstandigheden van het geval, waaronder in ieder geval de afspraken die partijen omtrent doel en strekking van het due diligence onderzoek, de vertrouwelijkheid daarvan en het vervolgtraject hebben gemaakt, de rol die de verschafte informatie in het onderhandelingsverloop heeft gespeeld en de uitleg van de overeenkomst met bijlagen, waaronder de hiervoor geciteerde artikelen over de betekenis van de informatie in de dataroom. Daarop heeft het debat tussen partijen zich in hoofdzaak en in het kader van dit incident nog onvoldoende toegespitst. De vraag naar de omvang van de informatieplicht van Dexia als eisende partij in dit geding vergt dan ook een integrale beoordeling door de rechtbank, na een daarop toegespitst debat tussen partijen. Eerst wanneer de omvang van de informatieplicht van Dexia is vastgesteld, kan de rechtbank toekomen aan de vraag welke documenten Dexia dient over te leggen en overgaan tot toetsing per onderdeel van de opgevorderde documenten aan de vereisten en uitzonderingen van artikel 843a Rv. De conclusie moet luiden dat bij de hui-

\footnotetext{
${ }^{691}$ Rechtbank Amsterdam 13 april 2005, JOR 2005, 142.

${ }^{692}$ Zie bijvoorbeeld Rechtbank Amsterdam 3 november 2004, JOR 2004, 326.
} 
dige stand van het processuele debat nog niet gezegd kan worden dat de primaire vordering tot afgifte van bescheiden geheel of op onderdelen op de grondslag van artikel 843a Rv toewijsbaar is".

Niet alle rechters trekken de lijnen van het speelveld even wijd wanneer het gaat om de verplichting om documenten te verschaffen als in de eerder genoemde uitspraak van de rechtbank te Utrecht gebeurde. Artikel 843a spreekt niet voor niets over bepaalde bescheiden en er is geen misverstand over dat daarmee wordt gedoeld op verbijzonderd aan te geven bescheiden.

In geval er sprake is van procedures rond de afgifte due diligence rapporten, doet degene die dit betreft er goed aan aandacht te besteden aan de vraag of de rechter een uitspraak wel bij voorraad uitvoerbaar moet verklaren. Gaat het immers om het verschaffen van informatie die als concurrentiegevoelig kan worden beschouwd, dan zal het kwaad zijn geschied wanneer er door de voorzieningenrechter bij voorraad wordt toegestaan.

\section{Verschoningsgerechtigden in civilibus}

Diegenen die geen geheimhoudingsplicht hebben, komen uiteraard ook niet in aanmerking zich op een verschoningsrecht te beroepen. Een verschoningsrecht is het recht om af te zien van het afleggen van een getuigenis voor een rechter of jegens anderen. De in het vorige hoofdstuk besproken mogelijkerwijs bij een due diligence betrokken (beroeps)groepen van bankiers en fusiebemiddelaars blijven hier buiten beschouwing. Zij kennen geen verschoningsrecht. Met betrekking tot belastingadviseurs en accountants is hierboven bij de exhibitieplicht in fiscalibus al het nodige opgemerkt. Hierna zal daarom nog alleen op het verschoningsrecht van de notaris, advocaat en bedrijfsjurist in civilibus worden ingegaan.

Meer in het algemeen gesproken vindt een verschoningsrecht erkenning in artikel $218 \mathrm{~Sv}$ waar dit het strafrecht betreft en in artikel 165 lid 2 sub b Rv waar het burgerlijk recht gaat. Van het optreden als getuige in civilibus kunnen zich volgens de laatst bedoelde wetsbepaling diegenen verschonen die tot geheimhouding verplicht zijn uit hoofde van hun ambt, beroep of betrekking, (alleen) waar dit hetgene betreft dat hen in de desbetreffende hoedanigheid is toevertrouwd.

\section{Notarissen en advocaten}

Zoals is opgemerkt hebben een notaris en een advocaat een geheimhoudingsplicht op grond van respectievelijk de Wet op het notarisambt en de Gedragsregels voor advocaten 1992. Hun verschoningsrecht van de getuigplicht in civilibus is te vinden in art. 165 lid 2 sub b Rv. Het criterium dat hierin is neergelegd luidt als gezegd, dat een verschoningsrecht bestaat uitsluitend voor 'hetgeen hun in hoedanigheid is toevertrouwd.' In welke mate een verschoningsrecht gerespecteerd zal worden, is om die reden afhankelijk van de omstandigheden. De rechter zal slechts marginaal toetsen om niet al te zeer in te breken op de vertrouwelijkheid van de informatie waar het om kan gaan. ${ }^{693}$

In een uitspraak van 1 maart $1985^{694}$ bepaalde de Hoge Raad dat het verschoningsrecht als een in $\mathrm{Ne}-$ derland algemeen geldend rechtsbeginsel wordt gezien. De reden waarom wordt door de Hoge Raad als volgt geformuleerd:

"De grondslag van dit verschoningsrecht moet worden gezocht in een in Nederland geldend algemeen rechtsbeginsel dat meebrengt dat bij zodanige vertrouwenspersonen het maatschappelijk belang dat de waarheid in rechte aan het licht komt, moet wijken voor het maatschappelijk belang dat een ieder zich vrijelijk en zonder vrees voor openbaarmaking van het besprokene om bijstand en advies tot hen moet kunnen wenden."

In de zaak die tot de uitspraak van 1 maart 1985 leidde, ging het om een verhoor door een rechter-commissaris in het geval van een surseance van betaling (van Ogem N.V.) Gelet op de door de Hoge Raad genoemde grondslag voor het verschoningsrecht kon niet worden

aanvaard dat de omstandigheid dat het verhoor van de rechter-commissaris plaatsvond op verzoek van de bewindvoerders in de surseance van de belanghebbende vennootschappen, de geheimhoudingsplicht en

\footnotetext{
${ }^{693}$ Zie HR 6 maart 1987, NJ 1987, 1016.

${ }^{694}$ Hoge Raad 1 maart 1985, NJ 1986, 173, RvdW 1985, 52 (Ogem / Notaris Maas)

${ }^{695}$ Zie onder meer Hoge Raad 29 juni 2004, NJ 2005, 273; Hoge Raad 24 januari 2006, NJ 2006.109.
} 
het verschoningsrecht zou kunnen worden opgeheven. Dit gold ook indien deze vennootschappen de notaris uit zijn geheimhoudingsplicht zouden hebben ontslagen. Een andere opvatting zou er immers toe leiden dat het oordeel omtrent de geloofwaardigheid van hen die zich tot de betreffende vertrouwenspersoon hebben gewend, ongunstig zou kunnen worden beinvloed door hun weigering hem uit zijn geheimhoudingsplicht te ontslaan, zodat de vrees dat zij daardoor naderhand tot een zodanig ontslag zouden worden genoopt hen ervan zou kunnen weerhouden de hulp van die vertrouwenspersoon in te roepen of zich vrijelijk tegenover hem uit te spreken, aldus ons hoogste rechtscollege.

De gedachte dat bij de vraag wat als aan de notaris toevertrouwd heeft te gelden een algemeen onderscheid gemaakt kan worden tussen vertrouwelijke en minder vertrouwelijke gegevens en dat het verschoningsrecht alleen de eerste categorie zou betreffen, werd in de hier voor laatst genoemde uitspraak door de Hoge Raad van de hand gewezen. Die gedachte miskent dat het verschoningsrecht ten doel heeft clienten en andere belanghebbenden zekerheid te geven dat zij vrijelijk met de notaris kunnen spreken. Die zekerheid zou door het maken van zulk een onderscheid op onaanvaardbare wijze worden aangetast. Wel is waar dat het verschoningsrecht van de notaris in zoverre niet absoluut is, dat zich zeer uitzonderlijke omstandigheden laten denken waarin het belang dat de waarheid aan het licht komt ook ten aanzien van datgene waarvan de wetenschap hem als zodanig is toevertrouwd - moet prevaleren boven het verschoningsrecht.

De hier voor genoemde grondslag voor het verschoningsrecht werd door de Hoge Raad bevestigd in een uitspraak van 25 september $1992 .^{696}$ In dat en een later arrest van 13 januari 2006 werd de bovenstaande regel genuanceerd. ${ }^{697}$ Als de kwestie die in geschil is de vraag betreft of een overeenkomst tussen partijen wel of niet tot stand is gekomen, bestaat er terzake van de beantwoording van die vraag in beginsel geen verschoningsrecht. Zijn er mededelingen gedaan in het vertrouwen dat de desbetreffende mededelingen geheim zouden blijven tot het moment dat de afspraken door de notaris schriftelijk zouden worden vastgelegd en deze vastlegging blijt uit, dan kan een notaris onder omstandigheden weer wel een beroep doen op zijn verschoningsrecht. Ik citeer uit het arrest van 25 september 1992:

"Wanneer een notaris, zoals hier, door twee partijen die hebben onderhandeld over een transactie en daarbij een bepaalde mate van overeenstemming hebben bereikt, wordt ingeschakeld om aan hen bijstand te verlenen door het ontwerpen en bespreken van een of meer notariele akten waarin de beoogde transactie wordt vastgelegd en uitgewerkt, zal het van de omstandigheden afhangen of hetgeen de onderhandelende partijen aan de notaris hebben medegedeeld als aan hem toevertrouwd heeft te gelden. Dit is in elk geval niet zo wanneer de onderhandelingen tot overeenstemming hebben geleid, die onder leiding van de notaris is vastgelegd, ongeacht of dit in een notariele akte is geschied of in een onder de leiding van de notaris tot stand gekomen onderhandse akte dan wel in een notariele verklaring, zoals bijv. bedoeld in art. 37 Kadasterwet. De notaris zal dan terzake van die totstandkoming en de uitleg van de transactie moeten getuigen, aangenomen dat het, zoals hier, een geschil tussen partijen betreft. In het midden kan blijven wat geldt indien partijen de notaris hebben medegedeeld dat de transactie voor derden of voor een bepaalde derde verborgen moet blijven en zijn getuigenis in een geschil met deze derde(n) verlangd wordt.

In beginsel kan evenmin van een dergelijk "toevertrouwen" gesproken worden wanneer partijen hun mededelingen gedaan hebben ter vastlegging onder leiding van de notaris in een stuk als voormeld, doch zonder dat het tot vastlegging is gekomen. Ontstaat naderhand een geschil over de vraag of de overeenstemming waarbij van deze mededelingen werd uitgegaan, inderdaad bestond, dan zal de notaris zich derhalve in beginsel niet kunnen verschonen. Maar het kan anders zijn, bijv. wanneer het gaat om mededelingen die gedaan zijn in het vertrouwen dat ze geheim zouden blijven tot de transactie ten behoeve van beide partijen behoorlijk in een akte zou zijn vastgelegd of wanneer die vastlegging is uitgebleven als gevolg van de vertrouwelijke voorlichting van de notaris over de consequenties van de transactie voor partijen of voor een van hen. Ook kan de tenslotte niet

\footnotetext{
${ }^{696}$ NJ 1993, 467 m.nt. HJS (Van Eijk / Tomol Investments),

${ }^{697}$ NJ 2006, 480 m.nt. G.R. Rutgers.
} 
vastgelegde overeenstemming bereikt zijn als gevolg van pogingen van de notaris om partijen tot elkaar te brengen, die zich in het vertrouwen van geheimhouding hebben afgespeeld en ter zake waarvan de notaris zich derhalve eveneens als getuige verschonen kan, wanneer een der partijen zich voor de vastlegging alsnog terugtrekt. Tenslotte kan zich voordoen dat geen overeenstemming wordt bereikt. In dat geval zal de notaris verschoningsrecht hebben."

Het vorenstaande maakt duidelijk dat de scheidslijnen dun zijn. Een en ander brengt mee dat in beginsel slechts de notaris wiens getuigenis wordt gevraagd, in detail kan beoordelen welk van de in het citaat onderscheiden gevallen zich voordoet, zodat in de eerste plaats aan zijn oordeel moet worden overgelaten of zich een situatie voordoet die onder zijn verschoningsrecht valt. Wat betreft de beoordeling door de rechter geldt dat deze zich op het standpunt zal moeten stellen dat, naar de aard van het verschoningsrecht meebrengt, de opgegeven vragen niet behoeven te worden beantwoord, zolang de rechter aan redelijke twijfel onderhevig acht of die beantwoording naar waarheid zou kunnen geschieden zonder dat geopenbaard wordt wat verborgen dient te blijven. ${ }^{698}$

Het vorenstaande werd door de Hoge Raad in de hier voor bedoelde uitspraak van 13 januari 2006 benadrukt:

"Bij de beoordeling van het middel wordt vooropgesteld dat alles waarvan de wetenschap aan een notaris als zodanig is medegedeeld, heeft te gelden als aan hem toevertrouwd, waarbij het in beginsel aan de notaris zelf moet worden overgelaten om te beoordelen of hetgeen aan hem is medegedeeld heeft te gelden als aan hem toevertrouwd. De aard van het verschoningsrecht brengt mee dat de opgegeven vragen niet behoeven te worden beantwoord, zolang de rechter aan redelijke twijfel onderhevig acht of die beantwoording naar waarheid zou kunnen geschieden zonder dat geopenbaard wordt wat verborgen dient te blijven."

De in het arrest uit 1992 genoemde regel werd verduidelijkt:

"Uit een en ander volgt dat zich weliswaar niet een van de situaties voordeed waarop de Hoge Raad in het hiervoor vermelde arrest doelde, maar dat het onderhavige geval daarmee wel in zoverre is te vergelijken dat naar aanleiding van de vastlegging van de tussen partijen bereikte overeenstemming, door een der partijen mededelingen zijn gedaan ter vastlegging onder leiding van de notaris in de door hem opgestelde conceptakten, doch zonder dat het tot vastlegging is gekomen. Het gaat in dit geval klaarblijkelijk ook niet om mededelingen van De Wit (of van Kuijper) die gedaan zijn in het vertrouwen dat zij geheim zouden blijven tot de transactie ten behoeve van beide partijen behoorlijk in een akte zou zijn vastgelegd. Integendeel, het was in de gegeven situatie, waarin partijen niet meer "on speaking terms" waren, de kennelijke bedoeling dat hetgeen De Wit aan Feikema (de notaris in kwestie, MB) mededeelde door deze aan Kuijper zou worden doorgegeven. Onder deze omstandigheden behoefde het nadere, in het arrest ontbrekende, motivering dat die aldus inhet telefoongesprek slechts doorgegeven mededeling zou kunnen gelden als aan de notaris in diens hoedanigheid toevertrouwd. De klachten van het middel treffen doel, voorzover in het oordeel van het hof besloten ligt dat het verschoningsrecht van Feikema ook op die doorgegeven mededeling betrekking hebbende vragen omvat. Wel verdient hierbij opmerking dat vragen die betrekking hebben op hetgeen Feikema van De Wit heeft vernomen maar niet aan Kuijper heeft doorgegeven wel onder het verschoningsrecht kunnen vallen, indien dat kan gelden als aan Feikema in diens hoedanigheid toevertrouwd. Met betrekking tot vragen daaromtrent zal voor de notaris opnieuw de mogelijkheid openstaan zich naar gelang van de inhoud van deze vragen op zijn verschoningsrecht te beroepen."

De hier voor genoemde regels zijn direct van toepassing op de notaris, maar kunnen naar analogie ook van belang zijn bij de advocaat. Bannier merkt op dat bij de beantwoording van de vraag of een

\footnotetext{
${ }^{698}$ Zie ook HR 1 maart 1985, NJ 1986, 173, r.o. 3.5; 7juni 1985, NJ 1986,174; en 22 nov. 1991, NJ 1992, 315, r.o. 3.3.
} 
advocaat in een getuigenverhoor zich met recht op een verschoningsrecht kan beroepen, ook niet zonder oog voor nuances kan worden beantwoord. ${ }^{699}$

Ook met het oog op toepassing van het verschoningsrecht in het kader van een due diligence onderzoek of bij vragen naar aanleiding daarvan, is van belang dat in onderhandelingen met derden moet worden bezien in hoeverre informatie aan de notaris of advocaat in hoedanigheid is toevertrouwd. Of een advocaat zich kan beroepen op zijn verschoningsrecht is afhankelijk van de vraag of de onderhandelingen tot een rechtens afdwingbare afspraak hebben geleid. Wanneer dit het geval is, geldt de inhoud van de besprekingen niet als vertrouwelijk. Het besprokene is dan ook niet te scharen onder de geheimhoudingsplicht en het daaraan verbonden verschoningsrecht van de advocaat. Aangenomen wordt dan dat er geen vertrouwelijkheid (meer) is beoogd en de advocaat kan dan worden gehouden te verklaren over het verloop van de besprekingen zolang het besprokene verband heeft met de tot standkoming of de inhoud van de overeenkomst. Hebben de besprekingen niet geleid tot rechtens afdwingbare resultaten, dan is de inhoud van de gesprekken strikt vertrouwelijk. ${ }^{700}$

Tegenover derden hebben een notaris en een advocaat een verschoningsrecht indien informatie met betrekking tot een transactie of daaraan verbonden feiten kunnen worden beschouwd als aan hem toevertrouwd in het vertrouwen dat de desbetreffende informatie geheim zou blijven. De vertrouwelijkheid van die informatie moet op een vergelijkbare wijze als in het geval van een notaris worden afgeleid uit de aard van de transactie en uitingen van partijen bij de transactie. ${ }^{701}$

Van het verschoningsrecht van de klassieke verschoningsgerechtigden wordt door de wetgever overigens steeds meer afgesnoept. De WID en de Wet MOT zijn hiervan voorbeelden. De Wet MOT komt hierna in 11.7 aan bod.

\section{Bedrijfsjurist in dienstbetrekking}

Naar Nederlands recht wordt een advocaat in dienstbetrekking onder voorwaarden gelijkgesteld met een externe advocaat waar dit het verschoningsrecht betreft. In verband hiermee is de Verordening op de praktijkuitoefening in dienstbetrekking van toepassing. ${ }^{702}$ Een belangrijke voorwaarde voor de toepasselijkheid van het (in het Nederlands procesrecht geldende) verschoningsrecht is dat er een zogenaamd Professioneel Statuut is opgesteld (artikel 3 lid 3 van voornoemde Verordening). Dit heeft doorgaans de vorm van een overeenkomst, waarin de werkgever onder meer verklaart de vrije en onafhankelijke beroepsuitoefening van de advocaat in dienstbetrekking te eerbiedigen. Hiermee wordt beoogd de onafhankelijkheid van de advocaat in dienstbetrekking te waarborgen en wanneer aan de genoemde voorwaarde is voldaan, geldt waar het de inhoud van de dossiers van de advocaat in dienstbetrekking betreft in beginsel het verschoningsrecht. "In beginsel", want door ontwikkelingen op Europees niveau is voor de bedrijfsjurist in dienstbetrekking een minder sterke positie op het punt van het verschoningsrecht het gevolg, dan van toepassing voor de advocaat- niet bedrijfsjurist.

Het Europees Gerecht van Eerste Aanleg besloot op 17 september 2007 dat het legal privilege (verschoningsrecht) in Europese kartelprocedures niet van toepassing is op interne correspondentie tussen bedrijfjuristen die zijn ingeschreven bij een nationale balie (te onzent als "Cohen-advocaten' aangeduid) en andere personen van het bedrijf waar de bedrijfsjurist werkt. ${ }^{703}$ De Europese rechter zet de Nederlandse mededingingswetgeving op dit punt aan de kant. Op grond van artikel 51 Mededingingswet kan de toezichthouder geen inzage vorderen van geschriften betreffende mededingingsrechtelijke regels tussen advocaten in dienstbetrekking en de onderneming. Deze laatst bedoelde wetsbepaling wordt door het Akzo Nobel-arrest buiten spel gezet. In de uitspraak volgt het Gerecht in Eerste Aanleg de lijn van het HvJ EG, die al werd uitgezet in de zogenaamde AM \& S uitspraak in $1982 .{ }^{704}$ In die uitspraak heeft het Hof van Justitie uitgemaakt dat een advocaat die gebonden is aan zijn cliënt door middel van een arbeidsovereenkomst geen beroep kan doen op zijn verschoningsrecht. De inhouse counsel - ad-

\footnotetext{
${ }^{699}$ F.A.W. Bannier et al., Beroepsgeheim en verschoningsrecht, Den Haag: Sdu Uitgevers, 2008 p.38

${ }^{700}$ HR 12 december 1958, NJ 1961, 270 m.nt. D.J.V. en Hoge Raad 22 juni 1984, NJ 1985, 188 m.nt. W.H.H.

${ }^{701}$ HR 11 maart 1994, NJ 1995, 3 (Kilbarr Corporation-Holan / Teeuwen).

${ }^{702}$ Verordening op de praktijkuitoefening in dienstbetrekking, Strct. 1997, 75.

${ }^{703}$ Europees Gerecht van Eerste Aanleg, 17 september 2007, Akzo Nobel Chemicals Ltd. et al. v. Europese Commissie, T125/03 en T-253/03. ()

${ }^{704}$ Hof van Justitie van de EG, 18 mei 1982, AM \& S Europes Ltd v. Europese Commissie, C-155/79.
} 
vocaat in dienstbetrekking - is volgens het Hof van Justitie en nu dus ook het Europees Gerecht van Eerste Aanleg, niet onafhankelijk en kan zich derhalve niet beroepen op het legal privilege, het verschoningsrecht.

Er moet rekening worden gehouden met een verschil tussen het nationale recht en het Europese recht. Indien de Nma op eigen initiatief een onderzoek start, valt de correspondentie tussen bedrijfsadvocaat en onderneming wel onder het verschoningsrecht (art. 51 Mededingingswet jo. Art. 5:17 Awb). Start de Nma een onderzoek op verzoek van de Europese Commissie, dan bestaat een dergelijk verschoningsrecht dus niet op grond van boven besproken Europese rechtspraak. ${ }^{705}$

Degene die een due diligence rapport onder zich heeft en verschoningsgerechtigd is, behoeft in beginsel een due diligence rapport niet op vordering van een derde uit handen te geven. Elders is besproken hoe de situatie is wanneer bescheiden van de hand van verschoningsgerechtigden zich bij de koper zelf bevinden. Zoals wij zagen, kunnen zich onder die bescheiden adviezen bevinden van verschoningsgerechtigden, die niet onder alle omstandigheden - ook op vordering van de verkoper op last van de rechter niet - zullen behoeven te worden geproduceerd. ${ }^{706} \mathrm{Er}$ zijn uitzonderingen op de hiervoor genoemde regel. In zeer bijzondere omstandigheden kan het belang van de waarheidsvinding prevaleren boven het belang van de bescherming van de inhoud van communicatie tussen de koper en een verschoningsgerechtigde. ${ }^{707}$ Wanneer er voldoende indicaties zijn dat een ander zwaarwegend belang geschaad zou kunnen worden, kan dat ook aan een beroep op de geheimhoudingsplicht in de weg staan. $^{708}$

\subsection{Gevolgtrekkingen}

Middelkoop ${ }^{709}$ vat het vorenstaande samen als volgt: voor fiscale geschillen geldt op grond van artikel 53a AWR dat 'klassieke geheimhouders', zoals advocaten, notarissen en belastingambtenaren, zich kunnen beroepen op een verschoningsrecht. Voor hun cliënten geldt een afgeleid verschoningsrecht.

Daarnaast geldt voor fiscale geschillen op grond van het hier voor genoemde arrest van de Hoge Raad van 23 september 2005 een informeel verschoningsrecht voor belastingadviseurs en belastingconsulenten. Cliënten van adviseurs waarvoor een informeel verschoningsrecht geldt, kunnen zich ook beroepen op een afgeleid verschoningsrecht. In civielrechtelijke geschillen geldt dat op grond van artikel 843a lid 3 Rv de betrokken adviseurs zich kunnen verschonen als zij een beroep kunnen doen op het verschoningsrecht van artikel 165 lid 2 sub b Rv (wel: advocaten, notarissen en belastingadviseurs, maar niet: registeraccountants, belastingadviseurs en accountants, belastingconsulenten). De vraag blijft vooralsnog onbeantwoord of in civiele procedures eveneens een beroep op een afgeleid verschoningsrecht kan worden gedaan op grond van artikel 843a lid $3 \mathrm{Rv}$ of dat alleen een beroep op andere gronden, zoals in lid 1 en lid 4 van artikel 843a Rv genoemd, mogelijk is. Adviseurs waarvoor geen verschoningsrecht op grond van artikel 843 a lid $3 \mathrm{Rv}$ geldt, kunnen in civilibus evenmin een beroep doen op een beleidsregel waarin een informeel verschoningsrecht is opgenomen. Voor hun cliënten is daarom geen afgeleid verschoningsrecht van toepassing.

Middelkoop stelt de vraag waarom voor fiscale geschillen wel een (afgeleid) informeel verschoningsrecht van toepassing wordt geacht en voor civielrechtelijke geschillen niet. Het antwoord op die vraag zou zijn dat de relatie tussen de fiscus en een privaat persoon anders is dan de relatie tussen twee private personen. De fiscus is als orgaan dat belasting heft, gebonden aan wettelijke dwangmiddelen. Het zou als onrechtvaardig kunnen gelden dat de fiscus zich buiten de grenzen van de door de wet genoemde dwangmiddelen zou kunnen begeven doordat adviezen van accountants of belastingconsulenten (rechtstreeks) bij of van hun cliënten opgevraagd kunnen worden. Verder geldt het fair play beginsel voor private partijen niet. In civielrechtelijke procedures is een verschoningsrecht van toepassing voor adviseurs die een beroep kunnen doen op artikel 843a lid $3 \mathrm{Rv}$ en geldt voor hun cliënten mogelijkerwijs een afgeleid verschoningsrecht. Voor adviseurs waarvoor geen verschoningsrecht van toe-

\footnotetext{
${ }^{705}$ M.M. Slotboom en L. Heringa, 'AKZO Nobel / Commissie: Teleurstellende uitspraak Europees Gerecht voor bedrijfsjuristen', Juridisch up to date, 25 oktober 2007, pp. 19-23.

${ }^{706}$ Zie bijvoorbeeld ook Rechtbank Zutphen 7 mei 2003 , NJ 2003, 480 r.o. 7.9.

${ }^{707}$ Zie HR 1 maart 1985, NJ 1986, 173, r.o. 3.6.

${ }^{708}$ Zie HR 20 april 2001, NJ 2001, 600, r.o. 3.7.

${ }^{709}$ K.I.A. Middelkoop, Due diligencerapport: plicht tot overleggen? ,V\&O november 2005, 11, p. 197 e.v.
} 
passing is geldt voor hun cliënten ook geen afgeleid verschoningsrecht. Met betrekking tot due diligencerapporten geldt dat alleen succesvol een beroep op een (afgeleid) verschoningsrecht kan worden gedaan wanneer alleen die feiten die niet bestaan uit adviezen geproduceerd behoeven te worden. Adviseurs en hun cliënten die geen gebruik kunnen maken van een (afgeleid) verschoningsrecht zullen in civilibus een verweer tegen een vordering tot afgifte moeten baseren op andere gronden, zoals de gronden genoemd in artikel 843a lid 1 en $4 \mathrm{Rv}$. Slaagt dat beroep niet, dan zal het al gauw zo zijn, dat due diligence rapport aan de wederpartij moeten worden overgelegd.

\subsection{Recht op toegang tot informatie na overdracht daarvan}

De hiervoor genoemde uitspraak van de Rechtbank te Amsterdam van 3 november 2004 ging over de overname door Dexia Banque Internationale à Luxembourg SA en Dexia Bank Belgium SA ("Dexia") van Aegon van de aandelen in het kapitaal van Labouchere Holding N.V. Voorafgaand aan de overname was Dexia in de gelegenheid gesteld een due diligence onderzoek uit te voeren. Aegon had stukken ter beschikking gesteld in een dataroom. Ook in dit geval was het zo, dat de koper vervolgens de zeggenschap verwerft over een vennootschap en haar onderneming en daarmede in het bezit raakt van de administratie van de onderneming. Ontstaat er dan later een conflict over de tenuitvoerlegging van de overnameovereenkomst (bijvoorbeeld een inbreuk op een garantie of een warranty), dan zal het voor de verkoper lastig zijn zich te verweren, wanneer die geen toegang heeft tot de administratie van de onderneming welke zich inmiddels in handen van de koper bevindt. De uitspraak in de zaak tussen Dexia en Aegon heeft geleerd dat het aan te bevelen is dat een verkoper ofwel een afschrift van (ten minste) die informatie welke zich in de dataroom bevindt, behoudt danwel stipuleert dat deze toegang krijgt tot die informatie welke nodig is om zich te verweren tegen een eventuele vordering achteraf op grond van de overnameovereenkomst of op een andere grond. In ieder geval zo lang de periode loopt, waarin een beroep op garanties of warranties door de koper mogelijk is. ${ }^{710}$

In de hier voor laatst bedoelde zaak stelde de eisers dat zij ter onderbouwing van de aanwezigheid van een rechtmatig belang de verlangde bescheiden nodig hadden voor de onderbouwing van hun verweer tegen de stelling dat zij zich schuldig zouden hebben gemaakt aan fraude door in de boekhouding fictieve omzet te boeken. Volgens hen dienden zij te beschikken over de betreffende stukken, nu zij aan de hand daarvan konden bepalen of ter zake een kostprijs was geboekt. Ook zeiden zij te willen beschikken over de gevraagde bescheiden om een reconventionele vordering te onderbouwen, voor zover het betrof de uitleg van garanties in de koopovereenkomst en betreffend een geschil over een zogenaamd resultaatafhankelijk deel van de koopprijs. De rechtbank meende in dit geval dat de correspondentie in het kader van de onderhandelingen waren gevoerd die hadden geleid tot de overeenkomst relevant kon zijn voor de uitleg van de bepalingen van die overeenkomst en dat aan het vereiste van een rechtmatig belang was voldaan.

\subsection{Artikel 843a Rv dwingend recht?}

Ik ben met Ekelmans van oordeel dat er afspraken moeten kunnen worden gemaakt over de vraag of een due diligence rapport wel of niet geproduceerd zal moeten worden. ${ }^{711}$ Volgens hem kunnen partijen in een obligatoire relatie (zoals de koopovereenkomst bij een overname) de discussie over de vraag welke stukken tot hun eigen domein moeten blijven behoren voorkomen door afspraken te maken over de bewijsrechtelijke betekenis van stukken, zoals het due diligence rapport. Zo'n afspraak kan volgens hem behelsen dat de inhoud van een eventueel due diligence onderzoek geen invloed heeft op de vraag of vorderingen ingesteld kunnen worden wegens inbreuk op garanties. Zo lang die afspraken geen betrekking hebben op rechten die niet ter vrije bepaling van partijen staan, acht hij die afspraken bindend. Hij verwijst daarbij naar artikel $153 \mathrm{Rv}$. Mij dunkt dat het tussen partijen duidelijk moet worden gestipuleerd dat er sprake is van (de bedoeling van) een bewijsovereenkomst, wil een eenvoudige clausule in de documentatie uitgelegd kunnen worden als het afzien van de rechten die worden gegeven door artikel 843a Rv. De wens van de koper om artikel 843a Rv buiten werking te stellen zal in de meeste gevallen immers zijn ingegeven door de wens om geen bewijs tegen zichzelf te hoeven aandragen in het geval er een vordering zou worden ingesteld in het geval van een inbreuk

\footnotetext{
${ }^{710}$ Zie Rechtbank Utrecht 12 september 2007, JOR 2007, 265 m.nt. P.J. van der Korst.

711 J. Ekelmans, De exhibitieplicht in kort bestek, p. 43.
} 
op garanties. De verkoper zal niet gemakkelijk met een dergelijke bepaling instemmen. Mocht dit toch het geval zijn, dan houdt die afspraak in dat in een voorkomend geval het tegenbewijs door middel van het opvragen van een due diligence rapport niet geleverd kan worden. Het instellen van een vordering op grond van artikel 843a Rv wordt uitgesloten. Nu zal elke verkoper het te ver vinden gaan om de mogelijkheid van het leveren van tegenbewijs op de voorhand prijs te geven. Wel kan de inhoud van het due diligence rapport buiten handen van een verkoper worden gehouden door met die af te spreken dat deze de bevoegdheid die hem gegeven wordt op grond van artikel 843a lid 1Rv niet zal gebruiken. Mede door de verbinding met artikel 7:900 is een dergelijke afspraak naar mijn oordeel rechtsgeldig. De bewijsovereenkomst kan worden vergeleken met een vaststellingsovereenkomst en er staat niets aan in de weg om met betrekking tot een in de toekomst denkbare situatie een vaststellingsovereenkomst aan te gaan. ${ }^{712}$ Het wel of niet ter beschikking willen of moeten stellen van een due diligence rapport betreft niet het bewijs van feiten waaraan het recht gevolgen verbindt die niet ter vrije bepaling van partijen staan. Vanzelfsprekend kan de rechter aan een dergelijke clausule onder omstandigheden - en het feit dat een due diligence rapport niet in een procedure wordt geproduceerd als gevolg van een afspraak als hier voor bedoeld - wel overeenkomstig de intentie van artikel 21, 22 en $162 \mathrm{Rv}$ aan dat gegeven dan de gevolgen verbinden die hij geraden acht. De verkoper die ondanks een afspraak dat het due diligence rapport niet tot zijn beschikking zal komen, toch een vordering op grond van artikel 843a lid $1 \mathrm{Rv}$ instelt, doet er goed aan zich tevens te beroepen op de algemene beginselen van redelijkheid en billijkheid en voldoende redenen aan te voeren om te rechtvaardigen dat de derogerende werking van de redelijkheid en billijkheid meebrengt dat hij aan de desbetreffende afspraak niet (langer) gebonden zal zijn. Zonder dat die grondslag wordt aangevoerd, zal de rechter die zich rekenschap geeft van artikel $24 \mathrm{Rv}$ de gemaakte afspraak naar mijn oordeel hebben te respecteren. ${ }^{713}$

Ekelmans heeft erop gewezen dat een afgezwakte vorm van een afspraak dat een due diligence rapport niet geproduceerd zal behoeven te worden in een eventuele procedure over garanties ook in een mengvorm kan voorkomen door de afspraak dat de inhoud van een eventueel due diligence onderzoek geen invloed zal hebben op de vraag of vorderingen ingesteld kunnen worden wegens een inbreuk op garanties en/of welke betekenis aan dat rapport in die situaties zal mogen worden toegekend. ${ }^{714}$ Een en ander kan in verband worden gelezen met de opvatting van sommige auteurs dat het verstrekken van garanties een kwestie van risicoverdeling is welke ter vrije beschikking van partijen staat en dat zelfs garanties, waarvan zowel de verlener als de verkrijger zich realiseren dat die (op het moment van het aangaan van de transactie) (nog) niet kunnen worden nagekomen, een rechtsgeldige afspraak opleveren.

\subsection{Wet Melding Ongebruikelijke Transacties ${ }^{715}$}

De voor ons onderwerp relevante artikelen in de Wet Melding Ongebruikelijke Transacties ("Wet MOT") zijn artikel 12, 18 en 19. Volgens artikel 12 kunnen de gegevens die een meldende adviseur heeft verstrekt, niet de grondslag van een opsporingsonderzoek of vervolging opleveren van wit wassen door de melder of personen die voor deze werken. Artikel 18 regelt dat degene die de gegevens van een melder ontvangt, deze voor geen ander doel mag gebruiken dan voor de uitoefening van de taken welke de wetgever aan de betrokkene heeft opgedragen. ${ }^{716}$ Artikel 19 verlangt van degene die een melding verricht, dat deze hiervan geen melding maakt aan de betrokkene(n). Dit wil zeggen dat

\footnotetext{
712 Zie over de relatie tussen de vaststellingsovereenkomst en de bewijsovereenkomst M. van Zijst, De vaststellingsovereenkomst in strijd met dwingend recht, p. 54-55.

713 Zie niet in dezelfde termen, maar wel over de grenzen van de exhibitieplicht N.J. Margetson, De grenzen van de exhibitieplicht, PP 2007/5, p. 143 e.v.

714 J. Ekelmans, De exhibitieplicht in de praktijk: de ruime mogelijkheden tot het opvragen van bescheiden, TCR 2005, nr. 3, p. 66-67.

715 Op 10 oktober 2007 is bij de Tweede Kamer een wetsontwerp ingediend met de bedoeling om een integratie te bewerkstelligen tussen de Wet melding ongebruikelijke transacties en de Wet identificatie dienstverlening. Kamerstukken II, 2007-2008, 31 238, 1-3. Zie verder K. Werkhorst, Wet MOT en witwassen; jurisprudentie biedt volop kansen voor beleid , in Tijdschrift voor Financieel Recht, nr. 11/12, november/december 2007, p. 350 e.v.

716 De NOB-brochure van mei 2006, De geheimhoudingsplicht van de belastingadviseur, noemt op p. 16 daarvan een uitspraak van de Rechtbank Amsterdam met betrekking tot de vraag of de Wet Openbaarheid van Bestuur een inbreuk kan maken op het gestelde in artikel 18 van de Wet MOD: Rechtbank Amsterdam, Sector Bestuursrecht Algemeen d.d. 2 mei 2005 , nr. AWB 04/819 WOB. Deze uitspraak staat alleen. De uitkomst was dat andere gegevens dan persoonsgegevens wel verstrekt zouden moeten worden. Het is te vroeg om aan deze uitspraak algemene gelding toe te kennen.
} 
een verrichte melding niet bekend mag worden gemaakt aan de opdrachtgever van degene die een due diligence onderzoek uitvoert en stuit op een transactie welke ingevolge de Wet MOT voor melding in aanmerking komt. Waar dit bijvoorbeeld advocaten, accountants en belastingadviseurs betreft, staan de artikelen 18 en 19 Wet MOT eraan in de weg dat de Belastingdienst inlichtingen vraagt of inzage verlangt in bescheiden van bijvoorbeeld het Meldpunt Ongebruikelijke Transacties. Ook met het oog op de toepassing van de Wet MOT kan het voor een adviseur aanbeveling verdienen om eventuele dossiers over een melding gescheiden te houden van de belastingdossiers, danwel die in een dossier van een advocaat te doen bewaren. Artikel 19 lid 1 Wet MOT zegt dat de geheimhouding verplicht is "behoudens voor zover uit de doelstelling van deze wet de noodzaak tot bekendmaking voortvloeit". Dit betekent dat binnen het kader van een strafrechtelijk onderzoek bijvoorbeeld er wel ruimte is om bepaalde gegevens, die voorwerp van een melding zijn geweest, aan het openbaar ministerie bekend te maken (of aan de FIOD, wanneer die is ingeschakeld).

Eind 2001 is een zelfstandig witwasartikel in het Wetboek van Strafrecht opgenomen, dat er kort gezegd op neer komt dat iemand zich schuldig kan maken aan witwassen wanneer hij weet dat geld of andere geldmiddelen afkomstig zijn uit een misdrijf. ${ }^{717}$

Een due diligence onderzoeker doet er goed aan bij het aannemen van zijn opdracht te stipuleren dat hij in een voorkomend geval een melding ingevolge de Wet MOT zal verrichten wanneer hij bij de uitvoering van het onderzoek kennis krijgt van gegevens welke van een dergelijke melding voorwerp dienen te zijn.

Een advocaat dient er zich van bewust te zijn dat de op handen zijnde wetswijziging terzake van de WID en de wet MOT zal bevestigen, dat het beroepsgeheim van de advocaat alleen geldt voor het domein van procesvoering en dat opdrachten tot verlening van juridisch advies daar niet onder vallen. Dit blijkt uit de antwoorden van de ministers van justitie en financiën, welke op 2 april $2008^{718}$ werden gegeven op vragen van de VVD-fractie over het wetsvoorstel ter implementatie van de Europese witwasrichtlijnen. ${ }^{719}$ Een advocaat die een due diligence onderzoek uitvoert, treedt niet op ter verdediging van de belangen of vertegenwoordiging van zijn cliënt in rechte. Hetzelfde geldt ten aanzien van belastingadviseurs en notarissen. Ik citeer: Uit de nota naar aanleiding van het verslag van 2 april 2008 naar aanleiding van het wetsvoorstel tot wijziging van de WID en de Wet MOT (p. 17):

"De leden van de VVD-fractie vroegen zich af waarom een vrijstelling ontbreekt voor de advocatuur terzake van juridisch advies. In artikel 1 tweede lid, van het voorstel is met betrekking tot dit onderwerp geregeld dat de verplichting uit het voorstel niet geldt voor belastingadviseurs, advocaten en notarissen "voor zover deze voor een cliënt werkzaamheden verrichten betreffende de bepaling van diens rechtspositie, diens vertegenwoordiging en verdediging in rechte, het geven van advies, het geven van advies voor, tijdens en na een rechtsgeding of het geven van advies over het instellen of vermijden van een rechtsgeding". Bij het uitvoeren van de genoemde werkzaamheden vallen belastingadviseurs, advocaten en notarissen niet onder de verplichting van het voorstel. Deze beroepsgroepen vallen alleen onder het voorstel voor zover zij specifieke werkzaamheden, zoals het assisteren bij de aan- of verkoop van onroerend goed of het oprichten van vennootschappen, verrichten. Dit is in lijn met de jurisprudentie van het Hof van Justitie van de EG. Volgens het Hof houden deze laatstgenoemde activiteiten "naar hun aard geen verband met een rechtsgeding

\footnotetext{
${ }^{717}$ Wet van 6 december 2001, Staatsblad 2001, 606. Artikel 420 bis, eerste lid, Wetboek van Strafrecht.

${ }^{718}$ Zie TK 2007-2008, 31237 en 31238 nummer 6 wijziging van de wet identificatie bij dienstverlening en de Wet ongebruikelijke Transacties ter uitvoering van richtlijnnummer 2005/60/EG van het Europees Parlement en de raad van de EU van 26 oktober 2005 tot voorkoming van het gebruik van het financiële stelsel voor het witwassen van geld en de financiering van terrorisme (PBEUL 309) en ter uitvoering van richtlijn 2006/70 van de Commissie van de Europese Gemeenschappen van 1 augustus 2006 tot vaststelling van uitvoeringsmaatregelen van richtlijn 2005/60/EG van het Europees Parlement en de raad wat betreft de definitie van politiek prominente personen en wat betreft de technische criteria voor vereenvoudigde klantenonderzoeksprocedures en voor vrijstellingen op grond van operationele of zeer beperkte financiële activiteiten (PBEUL 2014). Samenvoeging van de Wet Identificatie bij Dienstverlening en de Wet ongebruikelijke Transacties (Wet ter voorkoming van witwassen en financieren van terrorisme).

${ }^{719}$ Verwezen werd naar een uitspraak van het HvJ EG van 26 juni 2007 (zaak C-305/05), volgens welk de verplichting voor advocaten in de Europese witwasrichtlijnen om witwaspraktijken te melden, niet in strijd komt met artikel 6 EVRM. Dit is overigens wettelijk door het Belgisch grondwettelijk Hof op 23 januari 2008 (Arrest 10/2008 onder rolnummer 3064 en 3065 ) anders geoordeeld. Dat Hof oordeelde dat de vrijstelling voor de advocatuur ook geldt voor opdrachten tot juridisch advies.
} 
en vallen zij dus buiten de werkingssfeer van het recht op een eerlijk proces" (Arrest van het Hof van Justitie (Grote Kamer) van 26 juni 2007 in de zaak C-305/-5) (verzoek om prejudiciële beslissing ingediend door het Arbitragehof-België)). De benadering van het voorstel met betrekking tot de juridische beroepsgroepen sluit aan bij deze uitspraak van het Hof van Justitie ${ }^{\text {720 }}$

\subsection{Due diligence en mediation}

Een belangrijk element van mediation is de overeengekomen vertrouwelijkheid. Deze is gewaarborgd in een door partijen en de mediator ondertekende mediationovereenkomst. Door het ondertekenen van de overeenkomst verklaren de partijen zich te houden aan de geheimhoudingsplicht. Onder die geheimhoudingsplicht valt alle informatie die tijdens de mediation is gegeven, tenzij partijen anders overeenkomen. Het gaat om informatie over het verloop van de mediationprocedure, de daarbij door partijen ingenomen standpunten, gedane voorstellen, mondeling of schriftelijk, direct of indirect, tijdens de mediation door partijen verstrekte informatie en/of stukken die door een partij zijn gemaakt, getoond, geciteerd of geparafraseerd. De geheimhoudingsplicht geldt niet als de desbetreffende partij onafhankelijk van de mediation zelf al over de informatie beschikte of daarover had kunnen beschikken. ${ }^{721}$

Mediation kan overigens toch een rol vervullen in het kader van complicaties welke zich tussen partijen kunnen voordoen in verband met due diligence. In een kwestie waar sprake was van een confirmatory due diligence verschilden partijen omtrent de aanpassing van de koopprijs. Het systeem dat gekozen was, ging er vanuit dat er na het tot stand komen van de transactie een inventarisatie zou worden gemaakt van de overgedragen activa. Bij gebleken verschillen zou een correctie op de koopprijs worden toegepast. Partijen twistten met elkaar over de omvang van de toe te passen correctie op de koopprijs. De rechtbank Amsterdam in een vonnis van 9 januari $2008^{722}$ overwoog:

"Gelet op het voorgaande ligt het voor de hand dat partijen nu eerst middels mediation trachten tot een vergelijk te komen ten aanzien van de vraag in hoeverre de koopprijs neerwaarts dient te worden bijgesteld naar aanleiding van de door de bouwkundigen op de activalijsten genoteerde (en niet-genoteerde) bevindingen, waarbij van een maximale bijstelling van $€ 646.383,--$ sprake zal kunnen zijn. Het lijkt aangewezen een ervaren bouwkundige als mediator aan te zoeken. Desgewenst kan de rechtbank daarbij behulpzaam zijn met suggesties omtrent de persoon van de bouwkundige.

Voor het geval mediation (om wat voor reden ook) niet tot een oplossing leidt, zal de rechtbank een comparitie van partijen gelasten teneinde zich terzake nader te laten voorlichten. Het is dan van belang dat ook de bouwkundigen ter comparitie verschijnen om hun aantekening op de activalijsten per supermarkt toe te lichten. Mogelijk wordt ter comparitie een bewijsopdracht verstrekt".

Met de suggestie van de rechtbank om een ervaren bouwkundige als mediator aan te zoeken, raakte de rechtbank aan een in mediationland gevoelige kwestie: moet de mediator tevens materie-deskundige zijn? De beantwoording van die vraag valt buiten het bestek van dit boek.

\footnotetext{
${ }^{720}$ Zie Rechtbank Rotterdam 18 maart 2008 LJN-BC7312, waarin wordt vastgesteld dat een belastingadviseur niet onder een van het toezicht uitgesloten beroepsgroep valt, wier handelen of nalaten onderworpen is aan tuchtrechtspraak als bedoeld in artikel $17 \mathrm{c}, 3^{\mathrm{e}}$ lid, van de Wet MOT, zoals advocaten, notarissen en accountants. Deze uitspraak werd gedaan onder het geldende recht op 18 maart 2008.

${ }^{721}$ P. de Wolf en M. Spliet, Mediation en vertrouwelijkheid in het Burgerlijk recht - enkele practische tips, Trema mei 2005, 5, p. 215 e.v. en A.N. Labohm, Het belang van de mediation overeenkomst, Tijdschrift voor Mediation 2002, nr. 2 , p. 32 e.v., die wijst op de noodzaak dat een mediator zich rekenschap geeft van de noodzaak tot geheimhouding en aanbeveelt dat een mediator daarom nooit een mediation zou moeten aanvangen alvorens een mediationovereenkomst is getekend, waarin afspraken over geheimhouding zijn voorzien.

${ }^{722}$ LJN BC3247 (Laurus / Vomar).
} 


\title{
12. Due diligence en de ondernemingsraad
}

\subsection{Artikel 25 WOR}

Waar een due diligence onderzoek gebruikelijk samenhangt met een transactie van enige importantie, zal al gauw artikel 25 WOR relevant zijn. De OR dient door de ondernemer in de gelegenheid te worden gesteld advies uit te brengen over elk door deze voorgenomen besluit van belangrijke economische betekenis als in die wetsbepaling genoemd. Gaat het om een besluit waarop artikel 25 WOR van toepassing is, dan dient er rekenschap van te worden gegeven, dat ook het verstrekken en formuleren van een adviesopdracht aan een deskundige buiten de onderneming betreffende één van die aangelegenheden, adviesplichtig is. Dit kan betekenen dat het verlenen van een opdracht tot het uitvoeren van een due diligence met het oog op een besluit als bedoeld in artikel 25 WOR lid 1 sub a tot en met $m$ denkbaar voorwerp moet zijn van een adviesaanvrage aan de OR, ook al is het nog niet op de voorhand zeker dat een transactie na uitvoering van het due diligence onderzoek ook doorgang zal vinden. Artikel 25 lid 1 sub n WOR spreekt over het verstrekken en formuleren van een adviesopdracht aan een deskundige buiten de onderneming betreffende één der aangelegenheden als genoemd in artikel 1 lid a tot en met $m$ en niet over een voorgenomen besluit met betrekking tot één van die aangelegenheden.

\subsection{Artikel 26 WOR}

De Ondernemingskamer deed op 20 oktober 2005 een interessante uitspraak. ${ }^{723}$ Die uitspraak betrof het beroep van een OR tegen een besluit om een dochtervennootschap - die ingevolge een aanwijzing van de Europese Commissie moest worden vervreemd - te verkopen aan een partij die door de OR als een minder gewenst koper werd gezien. De bezwaren van de OR werden als volgt geformuleerd:

(i) Er was geen sprake van een voldoende uitgewerkt businessplan;

(ii) Er was geen sprake van een professionele (in het advies zelf wordt dit begrip overigens niet genoemd) analyse van de (verschillende) culturen van de te fuseren organisaties;

(iii) Het te verwachten verlies aan klanten als gevolg van de transactie was (te) groot;

(iv) Er was geen draagvlak voor de transactie bij het management van $\mathrm{SSH}$; en

(v) Gevreesd moest worden dat als gevolg van de transactie de samenwerking met een bestaande partij zou eindigen, waarmee innovatiemogelijkheden zouden komen te vervallen.

Interessant is de overweging van de OK die betrekking heeft op de vraag of een due diligence naar cultuurverschillen als voorwaarde kan gelden voor besluitvorming:

\begin{abstract}
"Hoewel de ondernemingsraad op zich mogelijk wel het gelijk aan zijn zijde heeft met de stelling dat 'fusies vaak mis gaan vanwege cultuurverschillen', kan niet worden aanvaard dat een besluit als het onderhavige niet kan worden genomen alvorens 'een professionele analyse' heeft plaatsgevonden van de culturen van de (te fuseren) organisaties. Er kan weliswaar aanleiding bestaan voor het uitvoeren van een dergelijke analyse, maar zonder zo een analyse is een besluit dan niet (om die reden) kennelijk onredelijk in de zin van artikel 26 lid 5 WOR. De OK is van oordeel dat de aanzet die is gegeven met het hiervoor in 2.37 genoemde stuk (een stuk met het opschrift "aanpak gewenste cultuur nieuwe organisatie Falck-Prened versie $0.1, \mathrm{MB}$ ) dat tijdens het voortgezette overleg van de OR met Facilicom op 23 juni 2005 aan de OR is overhandigd (en kort toegelicht) en waarover, aldus Gennessen, blijkens de notulen van dat overleg, na de overname 'direct overleg dient plaats te vinden', als voldoende response op de zorgen van de OR op dit vlak valt te beschouwen".
\end{abstract}

In het hiervoor bedoelde geval liep het verkeerd af voor de OR. Niettemin laten zich situaties denken, waarin de in het hiervoor bedoelde citaat door de OK bedoelde aanzet niet is gegeven om wel in te

\footnotetext{
${ }^{723}$ Zie ARO 2005, 191.
} 
gaan op cultuurverschillen, of toch onvoldoende diepgaand, waardoor een besluit zonder genoegzame due diligence naar eventuele cultuurverschillen, toch als kennelijk onredelijk zou kunnen kwalificeren in de zin van artikel 26 lid 5 WOR. ${ }^{724}$

${ }^{724}$ Een discussie tussen de ondernemer en de ondernemingsraad moet wel gebaseerd zijn op de grondslag van een adviesaanvraag of een convenant. In andere gevallen kan het bezwaar van een ondernemingsraad dat er onvoldoende onderzoek wordt gedaan naar alternatieven, worden beschouwd buiten de bevoegdheid van de ondernemingsraad te vallen. Zie OK 19 februari 2008, ARO 2008, 73. 


\section{Beroepsaansprakelijkheid en exoneratie}

\subsection{Aspecten van aansprakelijkheid}

Bij overnames is het due diligence onderzoek een belangrijk instrument waarmee de opdrachtgever zich inzicht kan verschaffen in de (onderneming van de) doelwitvennootschap. Het belang van een grondig onderzoek is derhalve aanzienlijk.

Door de grote belangen en de daarmee samenhangende denkbare financiële consequenties is de aansprakelijkheid van de onderzoekers een meewegend belangrijk thema. De mate van aansprakelijkheid van de onderzoekers is mede afhankelijk van hetgeen de opdrachtgever van de onderzoekers mocht verwachten. Derhalve is het van belang dat zowel opdrachtgever als onderzoeker beseffen dat de mogelijkheden die het due diligence onderzoek biedt niet oneindig zijn.

Een due diligence onderzoek kan niet uitsluiten dat er na de overname toch nog onverwachte feiten boven water komen. Het due diligence onderzoek kent verschillende beperkingen welke voor een groot deel zijn gelegen in een tweetal omstandigheden:

- De aard van het onderzoek is mede afhankelijk van de opdrachtomschrijving.

Het is voor het due diligence onderzoek van belang of de onderzoekers wel of niet op de hoogte zijn van het doel dat met de overname wordt nagestreefd. Afhankelijk van het doel van de overname zullen de onderzoekers hun blik richten. Verder is het van groot belang hoe de omvang en de diepgang van het onderzoek is bepaald, alsmede welke afspraken er zijn gemaakt over de wijze van rapporteren.

- De medewerking van de doe/witonderneming is vereist.

Bij een due diligence onderzoek zijn de onderzoekers uiteindelijk afhankelijk van hetgeen zij van de zijde van de doelwitvennootschap (de verkoper) aangeleverd krijgen. In bepaalde gevallen is het voor de onderzoeker niet mogelijk vast te stellen of en in hoeverre het aangeleverde materiaal compleet is. De onderzoekers kunnen derhalve slechts een oordeel geven over hetgeen zij gezien hebben en over hetgeen er op hun bijzonderlijk verzoek nog nader is aangeleverd. Van het overige hebben de onderzoekers geen kennis en hiervan vindt de opdrachtgever dan ook niets terug in het rapport.

De $\mathrm{Ru}^{725}$ heeft er gelet op het vorenstaande terecht op gewezen, dat de bedoelde afhankelijkheid van de onderzoekers van de medewerking van de doelwitvennootschap een niet onbelangrijke beperking oplevert. Een door de wederpartij af te geven garantie dat de verstrekte informatie juist en volledig is, doet daar, zo benadrukt hij, niet aan af: "Noch een accountant, noch een advocaat is een fraude-rechercheur." Een en ander - in samenhang met het feit dat wel verstrekte informatie slechts eenduidig kan worden geïnterpreteerd - brengt mee dat de betekenis van een due diligence rapport beperkingen kent. Zowel de opdrachtgever als de opdrachtnemer dienen hiervan doordrongen te zijn. Het rapport kan niet meer betekenen dan een ondersteuning van de opdrachtgever bij diens besluitvorming.

Of de onderzoekers inderdaad alle relevante gegevens aangereikt zullen hebben gekregen in de dataroom of - bijvoorbeeld naar aanleiding van gerichte vragen, anderszins, is een vraag die in het bijzonder aangesproken dient te worden in de relatie tussen de opdrachtgever en de aandeelhouders en/of vertegenwoordigers van de onderzochte onderneming. Het wordt gebruikelijk niet tot de verantwoordelijkheid van de onderzoekers gerekend om te bedingen dat zij een volledig inzicht verschaft hebben gekregen. Overigens zal een en ander tevens afhangen van de verder tussen de opdrachtgever en diens wederpartij gemaakte afspraken. ${ }^{726}$ Lang niet alle onderzoeken zijn bedoeld als een volledig on-

\footnotetext{
${ }^{725}$ C.F de Ru, Due diligence- onderzoek en beroepsaansprakelijkheid, V\&O, december 1995, afl. 12, p. 126 e.v.

${ }^{726}$ Een willekeurig voorbeeld van een clausule voor een juridische due diligence, waarin allerhande beperkingen zijn opgenomen is: "_ [name firm] has been instructed by__through__ [name and address], to conduct a high level legal due diligence exercise on ___ ("the Target"), in connection with the proposed asset acquisition by a newly to be established
} 
derzoek. Volgens De Ru brengt de hier voor bedoelde afhankelijkheid van de medewerking van de doelwitvennootschap mee, dat onderzoekers slechts 'naar beste weten' en onder verwijzing naar geraadpleegde bronnen hun bevindingen weergeven. Het is in hun belang steeds duidelijk aan te geven waar de beperkingen liggen. Zo is het even belangrijk om aan te geven wat niet is onderzocht. Wat de onderzoeker(s) betreft, zal het er - net als bij het afgeven van een legal opinion - om draaien of die de nodige zorgvuldigheid in acht hebben genomen. ${ }^{727}$

De Hoge Raad bood in $1992^{728}$ duidelijkheid over de maatstaf welke daarbij telt. Daaruit blijkt dat het enkele feit dat een beroepsbeoefenaar onjuist handelt of een onjuist advies geeft, op zich zelf nog geen civielrechtelijke aansprakelijkheid in het leven behoeft te roepen. Aansprakelijkheid ontstaat pas wanneer een redelijk bekwaam handelend vakgenoot in de gegeven omstandigheden anders gehandeld zou hebben. ${ }^{729}$

De maatstaf van "redelijk bekwaam en redelijk handelend vakgenoot" als norm voor aansprakelijkheid geldt ingevolge vaste rechtspraak en de heersende mening in de literatuur algemeen voor alle soorten beroepsbeoefenaren. ${ }^{730}$

Bij het beoordelen van de strekking en betekenis van een due diligence onderzoek zal veel afhangen van de hiervoor bedoelde omstandigheden. Bij de vraag hoe ver de aansprakelijkheid van de onderzoekers strekt, zal met deze omstandigheden rekening worden gehouden. Vanzelfsprekend past het binnen de professionaliteit van de onderzoekers dat zij wel naar de gebruikelijk als belangrijk aan te merken informatie vragen. Wanneer het gaat om gegevens op het bestaan waarvan zij niet bedacht hoeven te zijn, zal het minder snel een verwijt opleveren dan wanneer zij daar niet naar gevraagd hebben, aldus de Hoge Raad in een uitspraak van 18 januari $2002:^{731}$

\section{"Dit oordeel sluit een onderzoeksplicht uit, omdat geen onderzoeksplicht kan worden aangenomen ten aanzien van feiten en omstandigheden waarop men (ook als profes- sionele partij) in het geheel niet bedacht hoefde te zijn".}

Omgekeerd zullen er omstandigheden zijn, waarin er bijzondere redenen zijn om wel de nodige vragen te stellen en een onderzoek in te stellen. Denk aan een specifiek gebruik in het verleden van een onroerende zaak, waardoor een bepaalde mate van verontreiniging te verwachten is ${ }^{732}$ Raaijmakers

company (" by Target at agreements as disclosed in the data room. Furhtermore we raised several

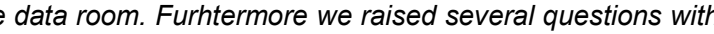
"). We understand that the subsidiary of the Target will not form part of the transaction contemplated Our investigation is limited to the documents that were present in the data room at the premises of the , the Netherlands, which was visited by Messrs. and financial director. In this report we shall, insofar as possible, refer to the written information we have examined. If we do not specifically refer to a certain document, the stated information, assumptions, facts, etc. will have been based on oral information provided to us during the course of our investigation. We do not know whether we have been provided with all relevant contracts. We have assumed the correctness and completeness of the documents and all other information provided to us. Where we had well founded reasons to question the correctness of the information, we indicate our doubts while explicitly cautioning about aspects of the relevant matters that were investigated by us. We did not make an independent investigation into documents merely referred to in the documents received.

We have assumed that the agreements we reviewed are legally valid and binding. If an agreement stipulates that certain acts took place in the past, we assumed that these acts have in fact taken place. Furthermore, we assumed that copies of the documents we reviewed conformed to the originals thereof, and, to the extent that the documents we reviewed were in draft form, that such documents were indeed executed in conformity with such draft documents.

The main objectives of our investigation have been to identify material legal matters that will need specific attention of when making the decision to acquire the assets of - L is qualified to advise on Dutch and

European Union Law only. To the extent that foreign law is applicable to the reviewed documents, we have reviewed such documents only on the basis of their face value. We are not qualified to give any tax opinion in relation to the documentation disclosed in the data room in documentation: Our due diligence investigation was limited to the review of the following

${ }^{727}$ M. Brink en G.T.M.J. Raaijmakers, Beroepsaansprakelijkheid en legal opinions in: Beroepsaansprakelijheid, Ars Aequi Libri 1996, p. 53 e.v., die afsluiten met de opmerking, dat "the best of men are but men at best" om uit te drukken dat van onderzoekers ook geen wonderen verwacht mogen worden.

${ }^{728}$ Zie HR 26 april 1991, NJ 1991, 455. Een deurwaarder had onjuist advies gegeven, maar dat leverde geen wanprestatie op. Zie HR 28 juni 1991,NJ 1992, 420 m.nt. JBMV voor een geval waarin wel wanprestatie van een advocaat werd vastgesteld.

729 Zie voor toepassing van deze norm op de advocatuur recentelijk Gerechtshof Arnhem, 8 januari 2008, LJN-nummer BC 7551 (r.o. 4.5).

730 Aldus Vranken in zijn noot onder HR 28 juni 1991, NJ 1992, 420 en de door hem genoemde rechtspraak en literatuur.

731 LJN AD4924, r.o. 2.23

732 Hof Amsterdam, 16 oktober 1997, nr. 396/96, M\&R jurisprudentie 1999, nr. 718, p. 149 e.v.

Literatuur: Y. Borrius, Mededelings- en onderzoeksplicht bij (ver)koop van verontreinigde grond, in: Contracteren, 2001/4, $\mathrm{p}$. 86 e.v. en G.T.M.J. Raaijmakers, Twee arresten over verkopersaansprakelijkheid, WPNR 02/6507, p. 729 - 731. 
maakt in WPNR aan de hand van door hem genoemde jurisprudentie ${ }^{733}$ duidelijk dat het niet gemakkelijk is om grenzen te bepalen omtrent de omvang van een mededelingsplicht aan de zijde van een verkoper. Het ging daarbij om twee bijna identieke zaken en twee volstrekt verschillende uitkomsten van gerechtelijke procedures. De omvang van de mededelingsplicht is belangrijk voor het antwoord op de vraag of en in welke mate er een onderzoeksplicht moet worden verondersteld.

In het algemeen geldt dat op degene die in overnamesituaties stelt schade te hebben geleden als gevolg van een handelen of nalaten van een derde (zoals een accountant) een stelplicht zal rusten. ${ }^{734}$

Beroepsfouten kunnen zich in veel vormen voordoen. De misslagen die zich in het geval van een due diligence onderzoek laten denken zijn vooral het niet opmerken van zaken die verborgen werden gehouden (voor zover die toch opgemerkt hadden kunnen worden), of die niet verborgen waren (binnen of buiten het eigen deskundigheidsgebied en het verkeerd interpreteren of onjuist vastleggen van bevindingen). Waar het een juridisch onderzoek betreft, zal niet mogen worden afgegaan op samenvattingen of verwijzingen. Steeds moet naar de originele documenten en de daarin genoemde en daarbij behorende bijlagen worden gekeken. Bij het financieel onderzoek gelden vergelijkbare zorgvuldigheidsnormen. Is er sprake van onzekerheden in balansposten of van verschuivende panelen in waarderingsgrondslagen, dan moet dat gesignaleerd worden. Een valkuil voor een onderzoeker is het om in een dergelijk geval zelf oplossingen te gaan bedenken. Niet vertrouwd moet worden op eenzijdig door de verkoper opgestelde overnamebalans en daarin gehanteerde waarderingsgrondslagen.

Een woord van waarschuwing is op zijn plaats, waar het de noodzaak betreft om een due diligence onderzoek te laten uitvoeren door deskundigen die terzake ervaring hebben. Er kunnen omstandigheden zijn waarin ervaring en bijzondere deskundigheid vereist zijn, bijvoorbeeld door de complexiteit van hetgeen er te onderzoeken is of om andere redenen. Zoals op meer terreinen, is het moeilijk om te beoordelen of de deskundige deskundig is. ${ }^{735}$ In de praktijk zal een opdrachtgever veelal vooraf willen weten over welke ervaring een onderzoeker beschikt. Op het terrein van medische keuringen, wordt wel gebruik gemaakt van een zogenaamde disclosure statement. ${ }^{736}$ In een disclosure statement wordt van de deskundige gevraagd zijn track record te noemen. Zoals elders in dit boek is aangegeven, is het in het geval van een due diligence onderzoek belangrijk met de betrokkene te hebben afgestemd omtrent de eigen visie op de aard van het onderzoek en de wijze waarop dit zou dienen te worden uitgevoerd. Kortom, 'de visie' moet overeenstemmen. Het is belangrijk om een ervaren onderzoeker de leiding van het onderzoek te geven. Soms wordt uit overwegingen van kosten gekozen voor een onbekende adviseur, zonder veel te weten van diens echte ervaring op het terrein van het due diligence onderzoek. Niets is echter zo duur als een slechte adviseur.

\section{Aansprakelijkheid onderzoeker, mogelijkheden tot beperking}

De onderzoeker heeft diverse mogelijkheden om aansprakelijkheid te beperken. Bij deze mogelijkheden moet - afgezien van het zo nauwgezet mogelijk uitvoeren van een onderzoek - onderscheid worden gemaakt tussen:

1. de mogelijkheid om het onderzoek af te bakenen (het voorwerp van de aansprakelijkheid);

2. de mogelijkheid om de aansprakelijkheid zelf te beperken.

\section{Afbakenen onderzoek}

Zoals hierboven al is aangegeven, zijn er verschillende omstandigheden die tot gevolg hebben dat het onderzoek beperkingen kent. Er zijn twee momenten waarop de onderzoeker hetgeen waarvoor hij aansprakelijk zou kunnen worden gehouden, kan afbakenen. De onderzoeker doet er goed aan in ieder geval voor duidelijkheid te zorgen over de afspraken met betrekking tot:

\footnotetext{
${ }^{733}$ HR 14 juni 2002, RvdW 2002, 104 (Gemeente Boarnsterhim/ Heideveld c.s.) en HR 21 juni 2002, RvdW 2002, 106 (Van den Akker/ Gemeente Helmond)

${ }^{734}$ HR 9 juni 1995, NJ 1995, 692.

${ }^{735}$ Zie Chr.H. Van Dijk, Hoe te beoordelen of de deskundige deskundig is?, NTBR 2007/10, p. 434 e.v.

${ }^{736}$ Zie A.J. Akkermans en J.L. Smeehuijzen, Disclosure statement, versie augustus 2005, www.rechten.vu.nl/iwmd-ProjectenVraagstellingen-disclosurestatement.
} 
- $\quad$ de opdrachtformulering;

- $\quad$ de te verwachten inhoud van het eindrapport van het onderzoek.

\section{De opdrachtformulering}

Door voordat het onderzoek begint duidelijkheid te creëren over het doel van het onderzoek, voorkomt men dat de onderzoekers de nadruk niet of niet op het juiste onderdeel leggen. Tevens moet op voorhand duidelijk zijn met welke intensiteit (omvang en diepgang) de onderzoekers het onderzoek uit moeten voeren. Moet het een zeer diepgaand onderzoek zijn of kan worden volstaan met een quick scan of een dataroom review? Het moet duidelijk zijn aan wie de rapporteurs moeten rapporteren en op welke wijze deze persoon informatie wenst te ontvangen. Moet het rapport een verslag zijn van het volledige onderzoek of wenst de opdrachtgever slechts een verslag van die onderdelen die mogelijk problematisch kunnen zijn?

\section{Het eindrapport van het onderzoek}

In het eindrapport van het onderzoek zullen de onderzoekers duidelijk moeten aangeven welke stukken zij van de doelwitvennootschap (de verkoper) hebben gevraagd en welke zij hebben ontvangen. Hiermee is aangegeven op bestudering van welke stukken het onderzoek is gebaseerd en welke stukken (eventueel) buiten beschouwing zijn gebleven. Van belang is ook dat de onderzoekers aangeven waarom bepaalde onderdelen wel/niet zijn onderzocht. Doel van deze handelswijze is dat de opdrachtgever weet welke stukken de onderzoekers onder ogen hebben gehad en belangrijker nog welke stukken of onderwerpen niet zijn bekeken. Mochten er na de transactie problemen ontstaan, dan kunnen de onderzoekers met het rapport aantonen dat zij niet de beschikking hadden over de stukken waaruit de problemen te voorzien waren geweest. Op stukken die de onderzoekers niet hebben gezien kunnen zij niet afgerekend worden, tenzij het niet onderkennen van (de mogelijkheid van) het bestaan van bepaalde stukken de onderzoekers kan worden aangerekend. ${ }^{737}$ Naar aanleiding van het rapport moet een opdrachtgever desgewenst verder bij de wederpartij informeren of zou deze aan de onderzoeker terzake een nadere onderzoeksopdracht moeten geven.

Met de hiervoor bedoelde wijze van aanpak kan de onderzoeker niet de aansprakelijkheid zelf afbakenen maar wel het speelveld beperken waarop zich vragen over de aansprakelijkheid kunnen voordoen.

\section{Verspreiding van het rapport}

In NV COS nummer 5500N (onder 30) wordt voorgeschreven dat een accountant slechts op verzoek van de opdrachtgever inzage in het rapport zal verschaffen aan andere gebruikers indien vooraf de voorwaarden voor inzage (waaronder in ieder geval begrepen een beperking van verdere verspreiding) met de opdrachtgever en met de andere gebruikers zijn overeengekomen en de gebruikers inzicht is gegeven in de omvang van de uitgevoerde adviesdiensten. Dit kwam hier voor al aan de orde.

Het rapport zal veelal geadresseerd zijn aan een beperkte kring van betrokkenen die zich met instemming van de uitbrenger van het rapport op de inhoud daarvan mogen baseren. Naar mijn oordeel constitueert de door de opsteller van het rapport genoemde beperking van de kring van diegenen, die zich volgens de opsteller van het rapport op de inhoud daarvan mogen verlaten, een overeenkomst van geheimhouding wanneer diegene aan wie het rapport gericht is, na lezing daarvan dit behoudt. De desbetreffende beperking is een voorwaarde welke de opsteller van het rapport met zijn opdrachtgever (en eventueel de geadresseerde) wil overeenkomen. Hij stipuleert dat het rapport niet voor anderen bestemd is. Indien de ontvanger van het rapport zich niet aan de genoemde beperking wenst te conformeren, zou deze het rapport niet moeten behouden, maar voorafgaand aan het totstandkomen van de transactie dienen te retourneren. ${ }^{738}$

\footnotetext{
${ }^{737}$ Vergelijk de situatie, welke leidde tot HR 22 december 1995, NJ 1996, 300 (Hoog Catharijne).

${ }^{738}$ Vergelijk M. Brink en G.T.M.J. Raaijmakers, Beroepsaansprakelijkheid en legal opinions, in: Beroepsaansprakelijkheid, Ars Aequi Libri 1996, p. 60-61.
} 
Zoals hier voor onder 9.2 duidelijk is geworden, betekent een clausule als geldend voor accountants ingevolge NV COS nummer $5500 \mathrm{~N}$ of een clausule als hiervoor laatstbedoeld in een due diligence rapport, nog niet dat daarmee het rapport niet in handen van derden terecht kan komen.

\section{De mogelijkheid om de aansprakelijkheid zelf te beperken}

De aansprakelijkheid zelf kan de onderzoeker beperken door een exoneratiebeding in de opdrachtbevestiging op te nemen, danwel algemene voorwaarden voorwerp van de opdrachtbevestiging te maken. ${ }^{739}$ Ook kan worden gedacht aan het overeenkomen van vrijwaringen. Wessels constateerde in 1995 dat de totstandkoming en een rechtsverhouding waarin juridische advisering wordt verleend, nog maar weinig schriftelijk werd vastgelegd. Inmiddels is dat bij de kantoren die zich met (grotere) commerciële transacties bezig houden wel veranderd. Wat bij accountants al langer gebruikelijk was is nu ook door veel advocatenkantoren overgenomen, en wel het aanvaarden van een opdracht middels een schriftelijk vastlegging van de afspraken (een zogenaamde engagement letter) met toezending en van toepassing verklaring van algemene voorwaarden. Wessels: "Een groot aantal van de modaliteiten van de opdrachtverlening kan (...) in individuele of algemene advies- of dienstverleningsvoorwaarden nader worden afgebakend. Art. 7:400 lid 2 biedt hiertoe alle ruimte. Uiteraard krijgen dergelijke verbintenisrechtelijke condities rechtens hun specifieke inhoud door bijvoorbeeld uitleg ervan. Uiteraard kunnen zij tevens worden getoetst aan de geoorloofdheidsgrenzen die ons rechtsstelsel kent, zoals art. 3:40 (strijd met de wet, openbare orde en goede zeden), art. 6:248 lid 2 (gezien maatstaven van redelijkheid en billijkheid 'onaanvaardbaarheid' van een dergelijke conditie) dan wel art. 6:233 onder a (onredelijke bezwarendheid van een standaardconditie)."

In een exoneratiebeding / algemene voorwaarden kan de onderzoeker met de opdrachtgever overeenkomen dat de aansprakelijkheid is beperkt tot een bepaald soort vorderingen, en/of tot een bepaald bedrag. Bijvoorbeeld tot het maximaal door de beroepsaansprakelijkheidsverzekering van de uitvoerder(s) van het onderzoek uit te keren bedrag of het maximum of een veelvoud van de verzonden declaraties. Evident is het dat de onderzoeker zich zal (willen) voorzien van een beroepsaansprakelijkheidsverzekering die als basis kan gelden voor te maken exoneratie-afspraken. Het bestaan van een dergelijke verzekering levert voor de afnemers van de diensten van de onderzoeker een geruststellende gedachte op. Niettemin behoren onderzoekers bij een voorgenomen transactie te worden ingeschakeld vanwege hun deskundigheid en niet vanwege de (veronderstelde) omvang van de door hun beroepsaansprakelijkheidsverzekering geboden dekking tegen beroepsfouten.Voor wat betreft een dergelijke afspraak in algemene voorwaarden, leveren de zogenaamde grijze en zwarte lijst (een wettelijk begrip, dat in bepaalde gevallen aan de toepasselijkheid van bedingen in een overeenkomst die de aansprakelijkheid beperken, in de weg kan staan) geen probleem op. Deze lijsten zijn alleen van toepassing als de opdrachtgever een natuurlijk persoon/consument is. Met betrekking tot een due diligence onderzoek zal de opdrachtgever als regel een rechtspersoon zijn.

Afhankelijk van de positie welke de onderzoeker inneemt ten opzichte van de opdrachtgever, kan het mogelijk zijn om een vrijwaring te bedingen tegen alle vorderingen van derden die voortvloeien uit of samenhangen met de onderzoeker ingevolge de opdrachtverlening verrichte werkzaamheden. Normaliter zal er in een dergelijke vrijwaring een uitzondering worden genoemd terzake van opzet of bewuste roekeloosheid.

Zowel advocaten als accountants en belastingadviseurs zijn ingevolge de voor hen toepasselijke deontologie gehouden zich te voorzien van een verzekering tegen de gevolgen van beroepsaansprakelijkheid. ${ }^{740}$ Beroepsregels - of andere regels - staan er niet in aan de weg, dat buiten het bedrag van

\footnotetext{
${ }^{739}$ Zie omtrent de mogelijkheden van begrenzing van aansprakelijkheid B. Wessels, Risicobeheer bij advisering, Preadvies van de Nederlandse Vereniging van Ondernemingsrechtadviseurs 1995 (hoofdstuk 2.7 Begrenzing door contractuele voorwaarden, p. 60 e.v.) en door hem genoemde rechtspraak en literatuur.

${ }^{740}$ Zie voor advocaten: Verordening op de beroepsaansprakelijkheid 1991 als laatstelijk gewijzigd op 28 november 2003 van de Nederlandse Orde van Advocaten (artikel 2 en 3 en over exoneratie artikel 7); voor accountants: de Nadere Voorschriften inzake de continuïteit van de beroepsuitoefening door de openbaar accountant van 1 juli 2004, ook voor NOvAA (artikel 2
} 
het eigen risico middels een exoneratiebeding aansprakelijkheid wordt uitgesloten voor die schade waarvoor de beroepsaansprakelijkheids verzekering geen aanspraak op uitkering geeft. De Verordening op de beroepsaansprakelijkheid van de Nederlandse Orde van Advocaten schrijft in artikel 7 daarvan nog voor dat advocaten afspraken met een cliënt over exoneratie schriftelijk moeten vastleggen.

\section{'Onderaanneming’}

Niet ongebruikelijk is het om bij due diligence onderzoeken gebruik te maken van de diensten van anderen. Evenmin is het ongebruikelijk om daarbij van die anderen verklaringen te vragen, die degene die het due diligence onderzoek uitvoert, moeten vrijwaren tegen aansprakelijkheid welke gebaseerd is op de verklaringen van de degene die bij het uitvoeren van het due diligence onderzoek zijn ingeschakeld. Degene die een due diligence onderzoek verricht met inschakeling van anderen, zal er goed aan doen om in het due diligence rapport tot uitdrukking te brengen welke werkzaamheden wel door de opdrachtnemer zelf zijn uitgevoerd en terzake van welke bevindingen uitgegaan is van het resultaat van de inspanningen van anderen. In dergelijke omstandigheden zal het steeds verstandig zijn om de instemming van de opdrachtgever te verkrijgen bij het inschakelen van derden. Voor zover er algemene voorwaarden van toepassing worden verklaard, zal het duidelijkheid in de rechtsverhoudingen kunnen opleveren, wanneer de afspraken in die algemene voorwaarden ook van toepassing zullen worden verklaard met betrekking tot de werkzaamheden welke in opdracht van de opdrachtnemer worden uitgevoerd door derden. Langs die weg zullen denkbaar ook vragen van toepasselijk recht en de bevoegde rechter in geval van problemen achteraf kunnen worden geregeld. Wessels ${ }^{741}$ heeft, geredeneerd vanuit de positie van de ingeschakelde derde (die onder aannemer - lees: hulppersoon van de opdrachtnemer bij een due diligence onderzoek zal zijn) onder verwijzing naar artikel 6:74 e.v. aanbevolen, in een voorkomend geval een vrijwaring van de opdrachtnemer (de hoofd aannemer van de opdracht) te vragen.

In een arrest van 25 januari $2002^{742}$ ging het over een situatie waarin er onjuiste marktinformatie bleek te staan in een rapport dat door een franchisegever aan een kandidaat franchisenemer ter hand was gesteld, maar welk rapport niet door de franchisegever zelf was opgesteld. De Hoge Raad overwoog:
"...zal de franchisegever die een rapport, zoals hiervoor bedoeld, aan zijn wederpartij verschaft, onder omstandigheden onrechtmatig handelen, indien hij weet dat dit rapport ernstige fouten bevat en hij zijn wederpartij niet op deze fouten opmerkzaam maakt. Op deze grond zou kunnen worden aangenomen dat de franchisegever verplicht is de door zijn wederpartij geleden schade te vergoeden. Zodanige aansprakelijkheid kan ook be- staan indien sprake is van onrechtmatig handelen door personen voor de gevolgen van wier fouten degene die het rapport aan zijn wederpartij verschafte, op grond van de art. 6:170-6:172 BW aansprakelijk is."

Aansprakelijkheid voor hulppersonen op grond van artikel 6:76 of 6:171 geldt volgens A-G Wesselingvan Gent ook tijdens de pre contractuele fase en daar is vanzelfsprekend ook van alles voor te zeggen. Het laat zich denken dat schade die zich - zoals in het geval van de hier voor genoemde franchise overeenkomst - in de fase voorafgaand aan het tot stand komen van een overeenkomst is veroorzaakt, zich eerst na de tot stand koming van de overeenkomst openbaart.

\section{Moeilijke bewijsopdracht}

In het algemeen gesproken zal het een opdrachtgever niet licht vallen om zich te verhalen op een opdrachtnemer, wanneer die in de ogen van de opdrachtgever diens werk niet goed zou hebben gedaan. Zoals ik hier voor al opmerkte, zal er in ieder geval sprake moeten zijn van duidelijke afspraken bij de

e.v.) en voor belastingadviseurs: Reglement Beroepsuitoefening Nederlandse Orde van Belastingadviseurs van 11 juni 2002 en nadere toelichting van december 2006.

${ }^{741}$ B. Wessels, Risicobeheer bij advisering, Preadvies van de Nederlandse Vereniging van Ondernemingsrechtadviseurs 1995, tijdens het debat over zijn preadvies, p. 90.

742 NJ 2003, 31 m.nt. JBMV (Lampenier). 
aanvang van de opdracht. Hoe meer er vast ligt over de omvang van de werkzaamheden, de wijze waarop die uitgevoerd zouden moeten worden en het verwachte eindresultaat, des te meer referentiekader zal er voorhanden zijn, om de uiteindelijke resultaten aan af te meten. Bij gebreke daarvan - en zelfs bij het wel bestaan van goede afspraken - zal de hindernis van het aantonen van het causale verband tussen schade en eventuele gebreken in de werkzaamheden van de opdrachtnemer, niet eenvoudig genomen zijn. Möller wijst op het belang van goede afspraken in verband met de uitleg van het schadebegrip in overnamecontracten. ${ }^{743}$ De bewijslast met betrekking tot het causaal verband tussen schade en de gebeurtenis waarop de aansprakelijkheid is gebaseerd, zo volgt uit de hoofdregel van artikel $150 \mathrm{Rv}$ rust in beginsel op de benadeelde eiser. Die is het die in beginsel zal moeten bewijzen dat er tussen de desbetreffende gebeurtenis en de gestelde schade een conditio sine qua non verband bestaat. Over het conditio sine qua non verband als minimum vereiste dat over het algemeen aan het causaal verband gesteld wordt, volgt hierna meer. Zou de bedoelde hindernis al genomen kunnen worden, dan is het nog maar de vraag welke schade voor vergoeding in aanmerking zal komen. $^{744}$

\subsection{Aansprakelijkheid belastingadviseur / accountant}

\section{Wtaa en Accountantskamer}

Op 4 december 2007 is bij de Eerste Kamer een gewijzigd wetsvoorstel voor de Wet tuchtrechtspraak accountants ("Wtaa") ingediend. ${ }^{745}$ De kernpunten van het wetsvoorstel zijn, dat alle beroepsmatige gedragingen van accountants direct aan de orde kunnen worden gesteld bij de Accountantskamer te Zwolle (artikel 22). De klager moet in het klaagschrift wel melden of de klacht eerst is voorgelegd aan de instantie die het NIVRA of de NOVAA daartoe bij of krachtens verordening heeft aangewezen. Als dat niet gebeurd is, kan de voorzitter van de Accountantskamer de klacht ter behandeling aan die instantie toesturen. Dit betreft een discretionaire bevoegdheid. De Accountantskamer maakt onderdeel uit van de rechtbank te Zwolle-Lelystad. De keuze is op deze instantie gevallen, nu die inmiddels goede ervaringen heeft opgedaan met het medisch tuchtrecht. Als waarborg voor de onafhankelijkheid van de Accountantskamer is bepaald dat die in meerderheid zal worden gevormd uit juristen. Accountants maken als deskundige een minderheid uit van de desbetreffende kamer. Klachten dienen binnen drie jaar na constatering van het gewraakte handelen of nalaten bij de Accountantskamer te worden aangebracht. Verder is er een verjaringstermijn van zes jaar.

De voorzitter van de Accountantskamer kan een zaak zonder zitting afdoen indien de klacht hem 'kennelijk niet ontvankelijk, kennelijk ongegrond of van onvoldoende gewicht' voorkomt. Dat kan ook bij gegrond bevinding van de klacht met oplegging van een maatregel van waarschuwing, berisping of een geldboete van maximaal $€ 225,--$. Tegen een dergelijke uitspraak is binnen zes weken verzet mogelijk. $\mathrm{Bij}$ verzet komt de uitspraak te vervallen en wordt de zaak alsnog in een gewone procedure behandeld. De door de Accountantskamer op te leggen maatregelen zijn uitgebreid: waarschuwing, berisping, geldboete, tijdelijke doorhaling en (definitieve) doorhaling. De sanctie van geldboete is nieuw en wordt door de wetgever beschouwd als een effectieve sanctie. Het maximum is een geldboete ter grootte van de derde categorie als bedoeld in artikel 23 lid $4 \mathrm{Sr}$.

Beroep van de uitspraak van de Accountantskamer is mogelijk bij het College van Beroep voor het Bedrijfsleven. $^{746}$

\section{Accountants}

Voor accountants en accountants-adminstratieconsulenten gelden voorschriften met betrekking tot het rapport van bevindingen. Waar dit transactiegerelateerde adviesdiensten (zoals een due diligence) betreft, dient het rapport volgens paragraaf 28 van NV COS $5500 \mathrm{~N}$ ten minste de navolgende informatie te bevatten:

\footnotetext{
${ }^{743}$ J.M. Möller, De uitleg van het schadebegrip in overnamecontracten, V\&O 2008, 2, p. 31 e.v.

744 Zie hier omtrent ook A.G. Castermans, De medelingsplicht in de onderhandelingsfase, Kluwer 1992, p. 134 e.v. Zie ook Rechtbank Alkmaar 30 januari 2008, LJN BC5954. De rechtbank concludeerde dat de gevorderde schadevergoedingen niet onder het begrip 'schade' vielen.

745 EK 2007-2008, 30397 B. Inmiddels verscheen het Voorlopig verslag (op 19 februari 2008).

${ }^{746}$ Zie onder meer E.C.A. Nass, Tuchtrechtspraak voor accountants, Ondernemingsrecht 2007, 125, p. $427-429$ en T. van Wijngaarden, Juridisch Up to Date, 20 december 2007, p. 16 e.v.
} 
- opschrift;

- $\quad$ geadresseerde;

- $\quad$ de beschrijving van het doel waarvoor de opdracht tot het verlenen van de transactiegerelateerde adviesdiensten is uitgevoerd;

de vermelding dat de opdracht is uitgevoerd conform de voorwaarden van de opdracht en overeenkomstig de Standaard met betrekking tot transactiegerelateerde adviesdiensten;

- een kopie van de opdrachtbevestiging of een samenvatting van de daarin opgenomen opdrachten en eventuele belangrijke wijzigingen daarin;

de aard van de opdracht met inbegrip van het gegeven dat de adviesdiensten niet worden uitgevoerd in het kader van een assurance-opdracht en dat derhalve geen zekerheid wordt verstrekt omtrent de getrouwheid van de informatie;

- $\quad$ in de opdrachtbevestiging genoemde adviesdiensten die niet werden uitgevoerd onder opgave van redenen voor het niet uitvoeren daarvan;

- $\quad$ een beschrijving van de bevindingen;

- $\quad$ de vermelding van de beperkingen in en condities met betrekking tot de verspreiding van het rapport;

- datum van het rapport;

- $\quad$ naam en adres van de beroepsbeoefenaar.

Wanneer het opdrachten tot het verrichten van specifieke werkzaamheden met betrekking tot financiële informatie betreft, gelden de navolgende vereisten voor het uitbrengen van een rapport (NV COS nummer 4400, onder 18):

- opschrift;

- $\quad$ geadresseerde (dit zal doorgaans de opdrachtgever zijn die de accountant heeft aangetrokken om de overeengekomen specifieke werkzaamheden uit te voeren);

- $\quad$ identificatie van de specifieke financiële of niet-financiële informatie waarop de overeengekomen specifieke werkzaamheden toegepast zijn;

- $\quad$ de vermelding dat de met de ontvanger overeengekomen werkzaamheden zijn uitgevoerd;

- $\quad$ de vermelding dat de opdracht is uitgevoerd overeenkomstig de desbetreffende standaard: opdrachten tot het verrichten van overeengekomen specifieke werkzaamheden met betrekking tot financiële informatie (4400) of met betrekking tot transactiegerelateerde activiteiten (5500N);

- $\quad$ indien van toepassing, de vermelding dat de accountant niet onafhankelijk van de entiteit is;

- $\quad$ de beschrijving van het doel waarvoor de overeengekomen specifieke werkzaamheden zijn uitgevoerd;

- $\quad$ de beschrijving van de uitgevoerde specifieke werkzaamheden;

- $\quad$ de beschrijving van de feitelijke bevindingen van de accountant waaronder voldoende details van de gevonden fouten en afwijkingen;

- $\quad$ de vermelding dat geen controle of beoordelingsopdracht is uitgevoerd en dat derhalve geen zekerheid wordt verstrekt;

- $\quad$ de vermelding dat indien de accountant aanvullende werkzaamheden, een controle- of een beoordelingsopdracht zou hebben uitgevoerd, wellicht andere onderwerpen zouden zijn geconstateerd die voor rapportering in aanmerking zouden zijn gekomen;

- $\quad$ de vermelding dat de verspreiding van het rapport is beperkt tot degene met wie de uit te voeren werkzaamheden zijn overeengekomen;

- $\quad$ de mededeling (indien van toepassing) dat het rapport alleen betrekking heeft op de gespecificeerde elementen, posten, onderwerpen of aangegeven financiële en niet-financiële informatie en dat het onderhavige financiële overzicht van de entiteit als geheel niet onder de reikwijdte van het rapport valt;

- datum van het rapport;

- $\quad$ adres van de accountant; en

- $\quad$ ondertekening (naam accountant met vermelding naam accountantspraktijk).

Voorschriften als hiervoor genoemd, welke door accountants in acht moeten worden genomen bij het uitbrengen van een rapport, geven aanwijzingen die ook richtinggevend zouden kunnen zijn voor andere beroepsbeoefenaars, die een due diligence rapport uitbrengen. Het gaat immers om zorgvuldig- 
heidsnormen die vrijwel allemaal eveneens aandacht verdienen bij het uitvoeren van een due diligence onderzoek door vertegenwoorrdigers van andere diciplines.

Slagter constateerde in 1996 dat de rechtspraak over aansprakelijkheid van accountants in ons land geen duidelijke lijn te zien geeft. ${ }^{747}$ Inmiddels is in de jurisprudentie mede door een uitspraak van de Hoge Raad van 13 oktober 2006 meer lijn in die rechtspraak te ontdekken. ${ }^{748}$

In een geval waarin een belastingadviseur werd verweten verkeerd te hebben geadviseerd over de aftrekbaarheid van restauratiekosten van een tweetal monumentenpanden, werd aansprakelijkheid aangenomen. ${ }^{749}$ De rechtbank meende dat de schade bestond in alleen een bedrag gelijk aan de door de koper van de monumentenpanden gederfde belastingaftrek (alleen het belastingnadeel derhalve). Het gerechtshof en de Hoge Raad zijn het niet met de rechtbank eens. In het geval van een onjuist advies zou moeten worden vastgesteld of de koper zonder dat advies wel tot aankoop van de panden zou zijn overgegaan. Indien dit laatste zou komen vast te staan, moet de vermogensschade worden gesteld op het nadelige verschil tussen de financiële situatie waarin de koper na aankoop en restauratie verkeerde en de financiële situatie waarin deze zou hebben verkeerd indien hij niet - of op andere wijze tot die aankoop zou zijn overgegaan:

"Niet valt in te zien waarom ${ }^{750}$ dit verschil zou moeten worden gesteld op het bedrag van
het belastingnadeel dat voortspruit uit het ontbreken van de aftrekmogelijkheid. Deze
mogelijkheid bestond immers noch bij aankoop en restauratie noch wanneer van een en
ander werd afgezien."

De hiervoor laatst genoemde zaak, betrof een verwijt aan de eigen (belasting)adviseur. De rechtsgrond zal dan zijn wat tegenwoordig toerekenbare niet nakoming heet van verbintenissen uit een overeenkomst van opdracht. Wanneer (vermeende) schade het gevolg is van een handelen of nalaten van een derde, zal degene die schade wil verhalen een vordering moeten baseren op het leerstuk van de onrechtmatige daad. ${ }^{751}$ Een voorbeeld in de rechtspraak wordt gevonden in het geschil tussen Financierings- en Administratiekantoor Finad B.V. ("Finad") en Worst Accountants B.V. ("Worst"), dat eindigde met een arrest van de Hoge Raad van 9 juni $1995 .{ }^{752}$ Worst was de accountant van de verkoper van aandelen in het kapitaal van een drietal vennootschappen. Finad kocht de aandelen, mede gebaseerd op de cijfers welke waren opgesteld door Worst. Finad had een aanbetaling op de koopprijs voldaan en constateerde later dat de jaarrekening welke door Worst was opgesteld en als verantwoordelijke accountant door hem was ondertekend ernstige gebreken vertoonde. Het eigen vermogen van de gekochte vennootschap bleek zelfs negatief. Finad vorderde schade bij de rechtbank te Haarlem. De rechtbank wees de vordering af. Het verweer van Worst werd gehonoreerd dat eerst van enige schade aan de zijde van Finad sprake kon zijn als vaststond dat de aanspraken van Finad op de verkoper die de juistheid van de cijfers had gegarandeerd - niet zou kunnen worden gerealiseerd. Het Gerechtshof te Amsterdam velde het vonnis van de rechtbank in hoger beroep. De norm welke door Worst zou zijn overtreden aldus het hof zou de norm zijn die ertoe strekte dat Finad van de juiste vermogenspositie van de vennootschap op de hoogte zou zijn gesteld, zodat zij kon bepalen of, en zo ja voor welke prijs en onder welke voorwaarden, zij de aandelen zou kopen. De aard van het door Finad aan Worst gemaakte verwijt bracht mee dat Finad jegens Worst slechts aanspraak zou kunnen maken op schade die zij had geleden doordat zij bij de aankoop op de door Worst verstrekte informatie was afgegaan. Tot die schade behoorde in beginsel niet de winst die Finad van de transactie mocht verwachten: zou Finad door Worst juist zijn geïnformeerd en als gevolg daarvan de transactie niet zijn aangegaan, dan zou zij deze winst evenmin hebben behaald. Volgens A-G Mok (103.1.5 van diens conclusie) kon Finad daarom slechts aanspraak maken op het negatief, niet het positief contractsbelang. Finad betoogde dat haar schade er in het bijzonder in was gelegen dat zij zich zonder de onjuiste informatie niet zou hebben begeven in een transactie met de achteraf gebleken risico's van verhaal, althans niet zonder afdoende zekerheid te hebben bedongen. Worst behoefde echter niet voor het

\footnotetext{
747 Zie W.J. Slagter, Het due dliligence onderzoek en aansprakelijkheid van de accountant, Dossier 1996, nummer 24, p. 56 e.v.

${ }^{748}$ HR 13 oktober 2006, JOR 2006, 296 m.nt. H. Beckman.

749 Zie HR 3 april 1992, NJ 1992, 396.

750 In het arrest (r.o. 3.4) wordt "waarin" gezegd, maar dat zal een schrijffout zijn.

751 Zie ook artikel 6:172.

${ }^{752}$ HR 9 juni 1995, NJ 1995, 692 m.nt. PvS. Zie ook M.J.G.C. Raaijmakers, Finad/Worst, AA 44 (1995) 12, p. 959 e.v.
} 
verhaalrisico in te staan. Finad had zich op het standpunt gesteld dat zij als schade op Worst kon verhalen het gehele bedrag waarmede het (uit de jaarstukken blijkende) eigen vermogen van de doelwitvennootschappen verminderd bleek ten gevolge van omissies in de jaarstukken (verminderd met een bedrag dat kon worden verhaald op een nog niet uitbetaald gedeelte van de koopprijs). Door als verantwoordelijk accountant jaarstukken op te stellen en te ondertekenen waarop ook Finad als koper mocht afgaan, maar waarin belangrijke onvolkomenheden voorkwamen waardoor de vermogenspositie van de doelwitvennootschappen gunstiger werd voorgesteld dan in werkelijkheid verantwoord was, handelde Worst jegens Finad onrechtmatig.

De door Worst geschonden norm strekt ertoe dat Finad als koper van aandelen niet zou worden misleid omtrent de vermogenspositie van de doelwitvennootschappen, maar niet daartoe dat Worst jegens haar ervoor zou hebben ingestaan dat - in het onderhavige geval - een vordering van de doelwitvennootschappen op een andere vennootschap verhaalbaar zou zijn of dat in de jaarrekeningen genoemde debiteurenposten zouden kunnen worden geïnd. Dergelijke verplichtingen rusten krachtens de overnameovereenkomst wellicht wel op de verkoper maar dat betreft dan verplichtingen van een geheel andere aard en berusten op een andere grondslag dan de op een (veronderstellenderwijs aan te nemen) onrechtmatige daad gebaseerde schadevergoedingsverplichting van Worst. Het feit dat de verkopers geen verhaal bleken te bieden voor schade, leidde niet tot aansprakelijkheid van Worst, nu niet was gesteld of was gebleken dat dit laatste het gevolg was van een aan Worst te verwijten fout. Voor zover Finad bedoelde te stellen dat zij als gevolg van de onjuiste informatie een te hoge prijs had betaald voor de aandelen, kreeg zij het verwijt dat haar vordering in zoverre onvoldoende gemotiveerd was. Zij had met het oog daarop een genormaliseerde balans dienen te overleggen en op grond daarvan aan te geven welke feiten en omstandigheden schade hadden veroorzaakt. Teruggegrepen wordt op het hiervoor genoemde arrest van 3 april 1992. Finad kon van Worst hoogstens het nadelig verschil vorderen tussen de financiële situatie waarin zij als koopster van de aandelen ten gevolge van die aankoop was komen te verkeren, en die waarin zij zou hebben verkeerd wanneer zij niet tot de aankoop van de aandelen zou zijn overgegaan. Daarbij werd mede in de beschouwing betrokken - op grond van de Poot/ABP-doctrine ${ }^{753}$ - dat in beginsel aandelen in het vermogen van de aandeelhouder niet de negatieve waarde vertegenwoordigen, omdat behoudens bijzondere omstandigheden de aandeelhouder niet aansprakelijk is voor schulden van de vennootschap. Daaruit volgt dat het voor de vraag of en in hoeverre Finad nadeel had geleden waarvan zij - uitgaande van waardering van de aandelen uitsluitend op basis van het eigen vermogen van de vennootschap volgens de jaarstukken vergoeding kon vorderen, het vooral aankwam op de door haar uiteindelijk voor die aandelen betaalde prijs. In de overnameovereenkomst was een verrekeningsbeding opgenomen voor uiteindelijke waardeverschillen. De vordering van Finad strandde op het feit dat Finad terzake daarvan onvoldoende gegevens had verstrekt. Finad was zich consequent en exclusief blijven baseren op de haar als juist voorgedragen schadeberekening maar had ondertussen onvoldoende gegevens verstrekt om tot een andere schadeberekening te komen. Zo bleef het uiteindelijk onduidelijk hoe bij de aanpassing van de koopprijs, gegeven het negatieve vermogen van de overgenomen vennootschappen, het tussen partijen afgesproken verrekeningsbeding was uitgelegd en toegepast. ${ }^{*}$

Volgens de controlestandaarden van het NIVRA met betrekking tot transactiegerelateerde adviesdiensten worden werkzaamheden van een accountant zoals het uitvoeren van een due diligence onderzoek niet als een zogenaamde assurance-opdracht gekwalificeerd. Niettemin kan een accountant aansprakelijkheidsproblemen onder ogen moeten zien, nu bij overnames niet zelden (ook) gebruik wordt gemaakt van een jaarrekening welke door een accountant zal zijn beoordeeld. Burggraaf ${ }^{754}$ wijst erop dat balansgaranties een belangrijke rol vervullen in overnametransacties. Het begrip "balansgarantie" wordt gebaseerd op de gecontroleerde jaarrekening van de doelwitvennootschap. Behoudens in het

\footnotetext{
${ }^{753}$ HR 2 december 1994, RvdW 1994, 265 (r.o. 5.1.)

* Zie ook HR 30 mei 2008, LJN BD2820 (TMF), in welk geval het ging om beleggingen in een niet levensvatbaar blijkend project. Gevorderd was de schade daarin bestaande dat er geen tegenwaarde voor de belegging was ontvangen. Er werd bezwaar tegen gemaakt dat de schade uitsluitend zou bestaan in het (mogelijke) verschil tussen de betalingen die de investeerders hadden gedaan en de werkelijke waarde van de aandelen op de dag dat zij toetraden tot het investeringsvehikel, de verwachtingswaarde op de dag dat zij toetraden daaronder begrepen. De Hoge Raad oordeelde in deze zaak: "Er is [...] plaats voor toewijzing van hun vordering die strekt tot vergoeding van hun gehele inleg, indien komt vast te staan dat het Project niet levensvatbaar was (waarbij de vergoedingsplicht van TMF uiteraard wel verminderd kan worden voor die schade (die, MB) mede een gevolg is van, kort gezegd, 'eigen schuld'). "

754 J.L. Burggraaf, Garanties bij overnames, Dossier 1996, nummer 24, p. 83.
} 
geval dat een overname plaatsvindt per een balansdatum als genoemd in de gecontroleerde jaarrekening, of het geval waarin er per de overnamedatum een echte overnamebalans wordt opgemaakt, wordt gebruik gemaakt van de gecontroleerde jaarrekening. Dit betreft dan een inmiddels gedateerd stuk. De waardebepaling van de doelwitvennootschap zal plaatsvinden tegen de zogenaamde toekomstwaarde. Burggraaf noemt een drietal categorieën van jaarrekeninggaranties, die dicht aanleunen tegen de goedkeurende accountantsverklaring:

- $\quad$ De 'getrouw beeld-garantie'. Wil een zodanige garantie enige waarde toekomen als garantie, dan dient deze een bepaling te bevatten over de grootte en samenstelling van het vermogen en de winst van de doelwitvennootschap. Die elementen dienen getrouw en stelselmatig te zijn weergegeven;

- De balansgarantie waarbij per de overnamedatum een minimum eigen vermogen van de doelwitvennootschap wordt gegarandeerd. In de praktijk worden verschillende definities gehanteerd van eigen vermogen. Een dergelijke garantie bakent voor de koper en de verkoper evenwel een duidelijke grens af. Het bedrag dat resulteert uit de definitie levert een harde norm op;

- De zogenaamde 'post-voor-post-garantie'. Dit betreft een jaarrekeninggarantie die wordt aangevuld met garanties per balanspost en/of per post in de verlies- en winstrekening.

In al de hiervoor genoemde gevallen is de gecontroleerde jaarrekening het referentiekader. Wanneer de accountant die de desbetreffende jaarrekening heeft goedgekeurd, zijn taak niet naar behoren heeft verricht, overschrijdt die daarmee een zorgvuldigheidsnorm ten opzichte van derden die zich voor het verkrijgen van zekerheid op de inhoud van de jaarrekening willen verlaten. Ik citeer een uitspraak van de rechtbank te Rotterdam van 19 november 1998: ${ }^{755}$

"In het kader van een aan hem verstrekte opdracht om een jaarrekening vast te stellen, dient een accountant volgens gangbare opvattingen zorgvuldig de aan hem voorgelegde gegevens te controleren. Op deze wijze wordt het voor de opdrachtgever en voor derden mogelijk om zekerheid te verkrijgen dat de jaarrekening een getrouw beeld geeft van het vermogen, het resultaat en - voor zover de aard van de jaarrekening dat toelaat - de solvabiliteit en liquiditeit van de onderneming en aan de daaraan te stellen eisen voldoet. (...) Rechtens staat vast dat de voor gedaagde als registeraccountant geldende wettelijke en tuchtrechtelijke bepalingen mede strekken ter bescherming van de belangen van degene van wie de accountant weet dat zij kunnen afgaan op de desbetreffende stukken."

In een arrest van de Hoge Raad van 13 oktober 2006 is een maatstaf geformuleerd voor de beoordeling van de vraag of de externe controlerende accountant heeft gehandeld in overeenstemming met de van hem in een concreet geval te vergen mate van zorg: ${ }^{.56}$

"De belangen die met een goede uitoefening van de taak van de externe controlerende accountant zijn gemoeid, zijn niet beperkt tot die van de rechtspersoon om wiens jaarrekening het gaat. In het maatschappelijk verkeer mogen derden verwachten dat informatie zoals deze door, veelal wettelijk verplichte, openbaarmaking van de jaarrekening en een goedkeurende verklaring naar buiten komt, naar het onafhankelijk en objectief inzicht van de accountant een getrouw beeld geeft van het vermogen, het resultaat en de solvabiliteit en liquiditeit van de onderneming en dat de jaarrekening voldoet aan de vereisten die de wet en (Europese) regelgeving stellen en in overeenstemming is met de normen en standaarden die te dier zake in deze beroepsgroep algemeen worden aanvaard. Ook derden moeten hun gedrag kunnen afstemmen op die informatie en bij het nemen of handhaven van hun (financiële) beslissingen kunnen vertrouwen dat het gepresenteerde beeld niet misleidend is. Aldus dient deze taakuitoefening van de accountant mede een wezenlijk publiek belang.

(...) bij de beantwoording van de vraag of de externe controlerende accountant heeft gehandeld in overeenstemming met de van hem in het concrete geval te vergen mate van zorg, komt het - met inachtneming van hetgeen hiervoor is vooropgesteld - aan op een

\footnotetext{
755 JOR 1999, 31

756 JOR 2006, 296 m.nt. H. Beckman.
} 
beoordeling van alle omstandigheden van het geval. Daarbij zal moeten worden onderzocht of en in hoeverre in nationale of Europese regelgeving neergelegde (dwingende) voorschriften omtrent de vervulling van die taak (...) zijn nageleefd. Voorts behoren tot de in de beoordeling te betrekken factoren de aard van de geschonden norm en de ernst van de geconstateerde schending daarvan, de door de accountant wel getroffen maatregelen of verschafte informatie, de mate waarin het gevaar van schade door aantasting van de in het geding zijnde vermogensbelangen voor de accountant redelijkerwijs voorzienbaar was en, mede in verband daarmee, of die (controle)maatregelen zijn genomen en die waarschuwingen zijn gegeven die in de gegeven omstandigheden redelijkerwijze van de accountant konden worden gevergd ter voorkoming van dit gevaar"

De laatst genoemde uitspraak van de Hoge Raad volgde de opvatting van A-G Timmerman, die eveneens van oordeel was dat de zorgplicht van een accountant zich verder moet uitstrekken dan alleen naar zijn opdrachtgever. ${ }^{757}$ De jaarrekening en de goedkeurende accountantsverklaring hebben naast een interne ook een externe informatiefunctie. Een jaarrekening en de daarbij behorende accountantsverklaring worden doorgaans krachtens wettelijke verplichting gepubliceerd.Dit brengt onder omstandigheden een zekere zorgplicht van de accountant mee ten opzichte van derden die bij het verrichten van een transactie op de door de accountant goedgekeurde jaarrekening afgaan. Van tevoren is door de publieke verspreiding van de jaarrekening niet te voorzien wie in een bepaald concreet geval vertrouwen hebben mogen ontlenen aan een goedkeurende verklaring bij een jaarrekening.

Uit de rechtspraak blijkt dat partijen bij overnametransacties in het geval van een verwijt aan een accountant daarbij nog wel eens betrekken, dat de accountant zich bewust had moeten zijn van het feit dat een door deze gecontroleerde jaarrekening gebruikt zou worden ten behoeve van een overname. $^{758}$ Op zichzelf voegt dat verwijt naar mijn oordeel weinig toe, nu de controle van een jaarrekening - die geen overnamebalans is - niet anders dient plaats te vinden dan volgens de bij een controle van de jaarrekening toepasselijke regels. Het feit dat accountants zich er soms van bewust zijn dat de jaarrekening ook zal worden gebruikt bij de gelegenheid van een overname (waardoor zij vaak onder druk hun werkzaamheden moeten voltooien) verandert aan het vorenstaande niet. In een geschil tussen Deloitte Accountants B.V. ("Deloitte") en de koper van het volledige geplaatste aandelenkapitaal in Grafisch Bureau Hepadru B.V. (“Hepadru”) kwam een en ander aan de orde. In opdracht van Hepadru had Deloitte de jaarrekening over 1999 opgesteld en gecontroleerd. Op 6 april 2000 sloot de houdstermaatschappij een intentieovereenkomst met betrekking tot de verkoop van aandelen in het kapitaal van Hepadru aan de koper (Ropoma Holding B.V., "Ropoma"). Deloitte had de jaarrekening van Hepadru over 1999 voorzien van een accountantsverklaring die werd gedateerd op een datum zes dagen na het tot stand komen van de intentieovereenkomst. Die verklaring hield in dat, gegeven de aard van de bedrijfsactiviteiten en de omvang van de onderneming de interne organisatie niet op economisch verantwoorde wijze zodanig kon worden ingericht, dat de accountantscontrole op rationele wijze de vereiste zekerheid kon verschaffen over de volledigheid van de in de jaarrekening opgenomen omzet en daarmee rechtstreeks samenhangende posten. In de verklaring stond verder "Uitsluitend om vorenstaande reden kunnen wij geen oordeel geven omtrent de getrouwheid van de jaarrekening als geheel. Ons onderzoek heeft echter geen tekortkomingen in deze jaarrekening aan het licht gebracht."

Op 20 april 2000 - 8 dagen na de datum van de accountantsverklaring - werd de koopovereenkomst verbindend. De koper had een due diligence onderzoek laten uitvoeren. Hoewel dit uit de uitspraak niet duidelijk wordt, waren daar kennelijk geen gebreken uit naar voren gekomen. Wel wordt uit de uitspraak duidelijk dat er na het tot stand komen van de transactie (alsnog) nader onderzoek is verricht naar de financiële situatie van Hepadru. Een en ander resulteerde in een settlement deed ${ }^{759}$ waarin de koopprijs werd verminderd. Na de overname droeg Hepadru "haar (gestelde) vordering op Deloitte wegens schadevergoeding" aan Ropama over. Het betrof een vordering die in de akte van cessie nader was aangeduid als "schadevergoeding voor het ontoereikend verzorgen van en adviseren over de fi-

\footnotetext{
${ }^{757}$ Onder 2.5 van diens conclusie. Timmerman stelde onder 2.2. van zijn conclusie dat er twee wegen waren waardoor in de jurisprudentie risico's voor aansprakelijkheid van een accountant konden worden beperkt: Door het aanleggen van een strenge norm voor aansprakelijkheid en/of door grenzen te stellen aan de kring van belanghebbenden die op een accountantsverklaring zouden mogen vertrouwen. De Hoge Raad koos uiteindelijk dus voor de eerste optie.

${ }^{758}$ Zie de hiervoor genoemde uitspraak van de rechtbank te Rotterdam van 19 november 1998 onder r.o. 5.1. en onder 3.2.1 sub (i) in het vonnis van de rechtbank te Rotterdam van 30 mei 2007, LJN BB6044.

759 Zie hoofdstuk 9.7.
} 
nanciële administratie en medeplichtigheid aan onregelmatigheid in het verleden". De verwijten kwamen erop neer dat Deloitte verzuimd had een groot aantal onregelmatigheden op te merken en overeenkomstig de toen van toepassing zijnde bepaling van artikel 13 lid 4 van de Verordening gedragsen beroepsregels registeraccountants 1994 niet een afkeurende verklaring maar een accountantsverklaring van oordeelonthouding had behoren af te geven. Volgens Ropama had Deloitte een verklaring van oordeelonthouding alleen mogen afgeven indien er geen materiële of wezenlijke fouten in de jaarrekening zouden zitten en had een bekwaam en redelijk handelende accountant deze verklaring in het onderhavige geval niet afgegeven. Het verwijt kwam er dus op neer dat Deloitte geen verklaring van oordeelonthouding had moeten afgeven, maar een afkeurende verklaring. Volgens Ropama hadden de onregelmatigheden waar het om ging aan het licht moeten komen bij een behoorlijke controle. Bij een normale cijferbeoordeling - vanwege jaarrekeningtechnische bedenkingen - had Deloitte al aanleiding moeten vinden voor een detailcontrole. Ropama voert aan dat derden in het maatschappelijk verkeer moeten mogen vertrouwen op accountantsrapportages. Deloitte zou extra zorgvuldig hebben moeten handelen - en dit zou ook het causale verband tussen het handelen van Deloitte en de gestelde schade moeten opleveren - omdat de speciale betrokkenheid van Deloitte bij de jaarrekening 1999 een essentieel onderdeel zou hebben gevormd van de onderhandelingen waarop de aankoopbeslissing was gebaseerd. In ieder geval zou Deloitte nooit - aldus Ropama - de accountantsverklaring hebben mogen voorzien van de vermelding "ons onderzoek heeft echter geen tekortkomingen in deze jaarrekening aan het licht gebracht". Deloitte voerde aan dat, voor zover de controlerend accountant al jegens derden aansprakelijk zou kunnen zijn, aansprakelijkheid niet aan de orde was indien de accountant die derde heeft aangegeven dat er in de gegeven omstandigheden niet zonder meer gesteund kon worden op zijn werkzaamheden. Deloitte stelde ook in het managementverslag dat bij de jaarrekening was gevoegd, uitdrukkelijk te hebben aangegeven dat de accountantscontrole niet was uitgevoerd in het kader van een eventuele overname en dat Ropama eigen onderzoek moest doen en niet kon steunen op de werkzaamheden van Deloitte bij haar beslissing om al dan niet een transactie aan te gaan. Ook had Deloitte geen toestemming gegeven om de jaarrekening als basis voor een balansgarantie te gebruiken bij de overname.

De rechtbank was van oordeel dat de accountant in het hier laatstbedoelde geval niet verplicht was een zorgplicht jegens een derde, niet zijnde diens opdrachtgever, te aanvaarden. Als reden noemde de rechtbank het feit dat het derden niet vrij staat altijd onder alle omstandigheden (zelfs als de accountant dat niet wil) gebruik te maken van de werkzaamheden van de accountant. Zo ver reikt volgens de rechtbank het aan de taakuitoefening van de accountant verbonden publieke belang niet. Daarmee was de zaak echter niet aangedaan. De door Deloitte in haar managementverslag en de accountantsverklaring gegeven waarschuwing dat door gebreken in de interne organisatie de accountantscontrole niet op rationele wijze de vereiste zekerheid had kunnen opleveren over de volledigheid van de in de jaarrekening opgenomen omzet en daarmee rechtstreeks samenhangende posten, nam op zichzelf het verwijt niet weg dat er geen of althans onvoldoende aanvullende detailcontrole was uitgevoerd, waarbij een aantal fouten aan het licht had moeten komen. De rechtbank verwijst naar het hiervoor genoemde arrest van 13 oktober 2006 en stelt dat met het oog op het feit dat Ropama maar ook derden hun gedrag moesten kunnen afstemmen op de jaarstukken 1999, in samenhang met de verklaring van oordeelonthouding, Deloitte er zorg voor had moeten dragen dat het gepresenteerde beeld niet misleidend was. Verder dienden alle omstandigheden van het geval bij de beoordeling te worden betrokken, waartoe de rechtbank rekende:

(a) de aard van de geschonden norm;

(b) de ernst van een geconstateerde schending daarvan;

(c) de door de accountant wel getroffen maatregel of verschafte informatie;

(d) de mate waarin het gevaar van schade door aantasting van de in het geding zijnde vermogensbelangen voor de accountant redelijkerwijze voorzienbaar was;

(e) of die (controle)maatregelen zijn genomen en die waarschuwingen zijn gegeven die in de gegeven omstandigheden redelijkerwijze van de accountant konden worden gevergd ter voorkoming van dit gevaar.

Nu het Ropama was die stelde dat Deloitte de op haar rustende zorgplicht had geschonden, legde de rechtbank de stelplicht - en bij voldoende betwisting de bewijslast - bij Ropama. De rechtbank droeg Ropama op ter nadere onderbouwing van haar stellingen nog de nodige informatie te verstrekken en kondigde aan voornemens te zijn één of meer onafhankelijke deskundigen te benoemen. De informatie 
welke Ropama nog diende te verschaffen, betrof onder meer stukken waaruit blijkt wat het due diligence onderzoek zou inhouden en welke stukken in het kader van het due diligence onderzoek werden opgemaakt, waaronder ook rapporten van de onderzoekers. Deze laatste stukken zal de rechtbank hebben willen zien om te weten te komen of het due diligence onderzoek niet voorwetenschap aan de zijde van Ropama had opgeleverd. Deloitte stelde dat bij de uitvoering van het due diligence onderzoek Ropama en haar adviseurs de beschikking hadden over de management letter en het volledige controledossier van Deloitte. Het due diligence onderzoek was uitgevoerd door Ernst \& Young, bijgestaan door bedrijfsadviseurs van Ropama. Ten behoeve van de due diligence was aan Deloitte aanvullende informatie verzocht en tijdens het besprekingsverslag naar aanleiding daarvan was er gesproken over geconstateerde problemen met de voorraad, het onderhanden werk, de voorziene dubieuze debiteuren en de voorziening back service pensioenen. Deloitte heeft daarbij aangegeven het niet mogelijk te achten de desbetreffende cijfers accuraat vastgesteld te krijgen. De uit de verklaring van oordeelonthouding blijkende onzekerheden in de controle impliceerde ook voor Ropama (toekomstige) onzekerheden. Ropama wist daarvan toen zij de overeenkomst tot koop van de aandelen aanging. De rechtbank vraagt van Ropama nadere informatie en gaat daarmee op zoek naar de vraag in hoeverre er op Ropama zelf verantwoordelijkheid rustte voor het aangaan van een overeenkomst, terwijl er de nodige onzekerheden bekend hadden moeten zijn. De rechtbank accepteert niet zonder meer de stelling van Ropama dat bij het due diligence onderzoek de gebreken duidelijker boven water zouden zijn gekomen, wanneer bij de accountantscontrole de door haar gestelde fouten al eerder aan het licht zouden zijn gekomen. Deze kwestie raakt aan de kwaliteit van het uitgevoerde due diligence onderzoek. De deskundige welke de rechtbank wil benoemen, moet zich verdiepen in de vraag of ten onrechte een verklaring van oordeelonthouding is afgegeven.

De rechtbank gaat niet mee met de trouvaille van de cessie van de vordering van Hepadru (de opdrachtgever van Deloitte) aan Ropama. Ropama zal haar eigen schade moeten concretiseren en onderbouwen.

Het is mij niet bekend hoe een en ander uiteindelijk is afgelopen. Toch biedt de hiervoor genoemde uitspraak een aardig inzicht in de wijze waarop een rechtbank met de problematiek van vermeende aansprakelijkheid van een accountant kan omgaan. Bij al het vorenstaande past de nuance die als rode draad door dit boek loopt, en dat is dat er moet worden gewaakt tegen algemene gevolgtrekkingen. De ene situatie is de andere niet. De ene transactie is de andere niet en de ene ondernemer is de andere niet. Raaijmakers heeft er naar mijn mening terecht op gewezen, dat het verschil maakt op welke wijze en in welke context een gelaedeerde is afgegaan op een jaarrekening en een verklaring van een accountant. ${ }^{760}$ In een beursgenoteerde vennootschap waar beleggers in beginsel niet persoonlijk met de vennootschap in contact treden maar afgaan op hetgeen publiek wordt gemaakt is de mate van reliance sterker dan wanneer de huisbank van een tweemans-bv om een nieuw krediet wordt gevraagd. De laatste kan zelf onderzoek doen en zal dit normaliter ook doen.

Voor een antwoord op de vraag of een accountant onrechtmatig heeft gehandeld en daarvoor aansprakelijk kan zijn, moet worden onderzocht wat van de accountant als redelijk handelende en redelijk bekwame externe controlerende registeraccountant moest worden gevergd in het kader van een zorgvuldige taakuitoefening met het oog op de belangen van diegene die bij het resultaat van zijn werkzaamheden belang hebben. Volgens de Hoge Raad geldt bij die taakuitoefening dat deze niet beperkt is tot de belangen van de desbetreffende rechtspersoon. In het maatschappelijk verkeer mogen derden verwachten dat informatie die door openbaarmaking van de jaarrekening en de goedkeurende verklaring naar buiten komt, naar het onafhankelijk en objectief inzicht van de accountant een getrouw beeld geeft en dat de jaarrekening voldoet aan de wettelijke vereisten en in overeenstemming is met de normen en standaarden die te dier zake in deze beroepsgroep algemeen worden aanvaard. Derden moeten er bij hun beslissing op kunnen vertrouwen dat het gepresenteerde beeld niet misleidend is. Aldus heeft de taakuitoefening mede een wezenlijk publiek belang. ${ }^{761}$

\footnotetext{
${ }^{760}$ M.J.G.C. Raaijmakers, Finad/Worst, AA 44 (1995) 12, p. 963-964. Zie ook de door hem genoemde rechtspraak en literatuur.

761 Zie HR 13 oktober 2006, JOR 2006, 296, r.o. 5.3. Beckman heeft op de hiervoor genoemde opvatting de nodige nuanceringen voorgesteld. Bijvoorbeeld de vraag of de jaarrekening en de goedkeurende verklaring wel op één lijn mogen worden gesteld. Dit roept de vraag op of een derde in het maatschappelijk verkeer afgaat op de openbaar gemaakte jaarrekening omdat daar een goedkeurende accountantsverklaring bij is afgelegd danwel of een jaarrekening en de accountantsverklaring vanuit de optiek van derden als gescheiden documenten moeten worden gezien. De verwijzing naar normen en standaarden in de beroepsgroep is volgens Beckman niet helder. Hij achtte duidelijk dat het gaat om de normen
} 


\section{Bewustzijnscriterium}

De gedachte dat een accountant zich er rekenschap van zou moeten geven dat een jaarrekening kan of zal worden gebruikt, kan zijn ingegeven door een overweging die A-G Timmerman noemde in diens conclusie onder een arrest van de Hoge Raad van 13 oktober $2006 .{ }^{762}$ Volgens de A-G zou als maatstaf voor het aannemen van aansprakelijkheid van een accountant moeten gelden de vraag of de accountant de jaarrekening in redelijkheid heeft kunnen goedkeuren:

"Deze maatstaf sluit aan bij de norm van 'redelijk handelende en redelijk bekwame accountant'. Deze norm is in de jurisprudentie van de Hoge Raad gangbaar voor vrije beroepsbeoefenaren. Het is een vage norm die met behulp van uiteenlopende gezichtspunten, zoals de ernst en de aard van het vergrijp, de ernst en de aard van de risico's, de aard van de relatie van de accountant met de derde, de voor de accountant geldende professionele standaarden, ingevuld dient te worden."

Ik blijf van oordeel dat het opstellen van een jaarrekening dient te geschieden volgens de darvoor geldende regels en normen. Het opstellen van een overnamebalans is iets anders., ook al kunnen de uitkomsten denkbaar tot hetzelfde resultaat leiden.

\section{Causaal verband}

Een apotheose in de rechtspraak met betrekking tot de eventuele aansprakelijkheid van een accountant, vormde het arrest van de Hoge Raad van 13 oktober 2006 in de kwestie van de teloorgang van levensverzekeraar Vie d'Or. ${ }^{763}$ Het arrest kwam hiervoor al een aantal keren ter sprake.

De accountants van Vie d'Or werd verweten dat zij ten onrechte goedkeurende verklaringen (met betrekking tot de jaren 1989, 1990, 1991 en 1992) hadden afgegeven. Daardoor zouden polishouders zijn misleid. Zij zouden aan de verklaringen de overtuiging hebben ontleend, dat de maatschappij solvabel was en dat er geen gevaar voor een faillissement bestond. Ten aanzien van het jaar 1992 gold nog als bijzonder verwijt, dat de controle van provisie en rekening courant verhoudingen met tussenpersonen en aan de bestuurder gelieerde vennootschappen onvoldoende was geweest. De tuchtrechter was eerder van oordeel dat de accountants in strijd hadden gehandeld met de normen en gedragsregels voor accountants. ${ }^{764}$ Het gerechtshof te 's-Gravenhage had op 27 mei 2004 geoordeeld, dat de accountants jegens de polishouders onrechtmatig hadden gehandeld. ${ }^{765}$

De inzet van de procedure waren vragen naar de kwaliteit van de controlerende taak van de accountants en over de informerende taak van accountants. In hoeverre kwalificeert het falen van accountants inderdaad als een onrechtmatige daad ten opzichte van (in dit geval) polishouders, die stellen door een en ander schade te hebben geleden? De rechtbank was eerder van oordeel dat de volgens de tuchtrechter geschonden normen in hoge mate overeenstemden met de zorgvuldigheidsnormen die de accountants in acht hadden moeten nemen jegens de polishouders. Daarom zou overtreding van de tuchtrechtelijke norm meebrengen dat er eveneens sprake was van onrechtmatigheid jegens de polishouders. Het gerechtshof had een soortgelijk standpunt betrokken.

De verhouding tussen de tuchtrechtelijke en civielrechtelijke verwijtbaarheid van het handelen van een beroepsbeoefenaar was eerder voorwerp van een geding in cassatie. ${ }^{766}$ De Hoge Raad overwoog toen:

"Vooropgesteld moet worden dat een ontkennend antwoord van de tuchtrechter op de vraag of er overeenkomstig een voor het desbetreffende beroep geldende norm is ge-

en standaarden ter zake van de controle, maar de overweging over het erop kunnen vertrouwen dat het gepresenteerde

beeld niet misleidend is, lijkt volgens hem meer op verslaggevingsnormen te wijzen.

762 JOR 2006, 296, m.n.t. H. Beckman, onder 2.6 van de conclusie.

763 JOR 2006, 296, m.nt. H. Beckman.

764 Uitspraak van de Raad van Tucht van 10 april 1997 en van het CBB van 3 december 1998, LJN ZG1037 (Vie d'Or/Deloitte).

765 JOR 2004, 206 m.nt. Van Ravels en Van Andel.

${ }^{766}$ Zie HR 15 november 1996, NJ 1997, 151 
handeld, de burgerlijke rechter niet dwingt tot het oordeel dat sprake is van wanprestatie of van onrechtmatige daad".

In een arrest van 10 januari $2003:^{.767}$

"Het wettelijk tuchtrecht voor beroepsbeoefenaren, zoals in het onderhavige geval notarissen, heeft in de eerste plaats tot doel, kort gezegd, in het algemeen belang een goede wijze van beroepsuitoefening te bevorderen. Het tuchtrecht komt tot gelding in een tuchtprocedure waarin, in het algemeen naar aanleiding van een klacht van een belanghebbende, wordt onderzocht of een beroepsbeoefenaar in overeenstemming met deze norm heeft gehandeld en, zo dit niet het geval is, een maatregel kan worden opgelegd. Hiermee strookt dat deze procedure niet in de eerste plaats ertoe dient de klager in geval van gegrondbevinding van zijn klacht genoegdoening te verschaffen, ook al kan dit wel het feitelijk resultaat zijn. Evenzo kan het oordeel van de tuchtrechter over het handelen van een beroepsbeoefenaar in een civiele procedure een rol spelen bij de beantwoording van de vraag of de beroepsbeoefenaar aansprakelijk is (vgl. HR 12 juli 2002, nr. C00/274, RvdW 2002, 122), en deze omstandigheid kan een belanghebbende (mede) aanleiding geven een klacht in te dienen, maar dit betekent niet dat een tuchtprocedure tot doel heeft de civielrechtelijke aansprakelijkheid van de beroepsbeoefenaar vast te stellen. In dit verband is van belang dat bij de beoordeling van de vraag of een tuchtklacht gegrond is, andere maatstaven worden gehanteerd dan bij de beoordeling van de civiele aansprakelijkheid, alsmede dat de mede ter bescherming van de gedaagde in een civiele procedure strekkende bewijsregels niet gelden in een tuchtprocedure".

A-G Timmerman ${ }^{768}$ benadrukt dat de civielrechtelijke zorgvuldigheidsnorm dus een andere is dan de tuchtrechtelijke zorgvuldigheidsnorm. Het tuchtrecht strekt primair tot bevordering van goede beroepsbeoefening, terwijl uit een negatief oordeel van de tuchtrechter niet zonder meer volgt dat er ook een zorgvuldigheidsnorm in civielrechtelijke zin is geschonden. In het algemeen zal daarvan sprake zijn indien een beroepsbeoefenaar zich niet heeft gedragen als redelijkerwijze van hem verlangd mocht worden. Het handelen in strijd met tuchtrechtelijk gesanctioneerde gedragsregels is één van de gezichtspunten die een rol spelen bij de vraag of een accountant al dan niet als een redelijk handelende en redelijk bekwame functionaris is opgetreden. Wel dient het oordeel van de civiele rechter over de aansprakelijkheid van de beroepsbeoefenaar in het licht van het tuchtrechtelijke oordeel begrijpelijk te zijn, aldus een door Timmerman geciteerde overweging uit HR 12 juli 2002, NJ 2003, 151: ${ }^{.79}$

"Bij de beoordeling van de motiveringsklacht van onderdeel 5.2 wordt vooropgesteld dat de rechter, indien hij bij de beoordeling van medisch handelen van een arts komt tot een oordeel dat afwijkt van het oordeel dat de tuchtrechter heeft gegeven naar aanleiding van een klacht met betrekking tot datzelfde medisch handelen, zijn oordeel zodanig dient te motiveren dat dit, ook in het licht van de beoordeling door de tuchtrechter, voldoende begrijpelijk is."

Het causaliteitsvereiste maakt dat voor het aannemen van aansprakelijkheid uit onrechtmatige daad volgens artikel 6:162 lid 1 wordt vereist dat de benadeelde "dientengevolge" schade heeft geleden. Aan dit vereiste wordt niet voldaan indien de schade ook zou zijn ingetreden indien de onrechtmatige gedraging niet zou zijn verricht (een conditio sine qua non verband tussen het handelen van - in dit geval de accountants - en het ontstaan van de schade). Deze laatst genoemde regel werd nog eens bevestigd door de Hoge Raad in het arrest in de kwestie van Vie d'Or. De vraag of causaal verband bestaat tussen de onrechtmatige gedraging en de schade, zal in beginsel voor iedere individuele ge-

767 NJ 2003, 537 (naar aanleiding van de vraag of de kosten verband houdende met een tuchtrechtelijke procedure, konden worden aangemerkt als kosten ter vaststelling van aansprakelijkheid als bedoeld in artikel 6:96 lid 2 onder b.).

768 Onder 2.8 in zijn conclusie onder HR 13 oktober 2006, JOR 2006, 296.

${ }^{769}$ Vergelijk hetgeen A-G Timmerman opmerkt in diens conclusie onder HR 8 april 2005 (Laurus) met betrekking tot de vraag of de constatering van wanbeleid door de Ondernemingskamer ook in andere procedures bindend is. Ik verwijs naar het gestelde onder 3.2 van die conclusie. In de praktijk zal de vaststelling van wanbeleid door de Ondernemingskamer als opmaat kunnen gelden voor een aansprakelijkheidstelling in een gewone dagvaardingsprocedure. Maeijer (in zijn noot onder HR 4 april 2003, NJ 2003, 538) wijst erop dat een dergelijke OK-beschikking de (bewijs)positie van de eiser in een aansprakelijkheidsprocedure in voordelige zin kan beïnvloeden. 
laedeerde moeten worden onderzocht. Dit maakt tevens dat niet zodanige algemene uitspraken kunnen worden gedaan dat een vordering ex artikel 3:305a op zijn plaats is. Wij zagen hiervoor (in hoofdstuk 8) dat op de laatstbedoelde overweging de vordering van vermeend gedupeerde aandeelhouders tegen Baan strandde. Indien een causaal verband al kan worden aangetoond, is de vaststelling van de schade nog een geheel ander thema. Dit onderwerp valt echter buiten het bestek van dit boek

\subsection{Toerekening van de kennis van de onderzoeker aan de opdrachtgever}

De opdrachtgever dient er rekening mee te houden dat deze onder omstandigheden zal worden geacht kennis te dragen van de kennis welke de onderzoekers tijdens een due diligence onderzoek hebben opgedaan. ${ }^{770}$ De onderzoeker valt immers aan te merken als hulppersoon van de opdrachtgever in de zin van artikel 6:74 e.v. (bij verbintenissen) en/of 6:171 (in het geval van een onrechtmatige daad). Aansprakelijkheid ten opzichte van derden voor onrechtmatig handelen door de onderzoekers (bijvoorbeeld middels het schenden van een wettelijke geheimhoudingsplicht) zal niet snel aan de opdrachtgever worden toegerekend. ${ }^{771}$ Omgekeerd zal echter wetenschap van een hulppersoon (of van een orgaan van een rechtspersoon) onder omstandigheden gelden als wetenschap van de opdrachtgever. Het gaat daarbij niet om het toerekenen van een fout aan de opdrachtgever, maar aan het de iure aanrekenen van bepaalde kennis in het kader van de beoordeling of er anders gehandeld had moeten worden danwel of anders handelen gewenst was geweest. ${ }^{772}$ Schijn van vertegenwoordigingsbevoegdheid kan hier vanzelfsprekend ook een rol spelen. Zo kan een wederpartij zich op het standpunt stellen dat deze op grond van een verklaring of gedraging van de opdrachtgever heeft aangenomen dat de hulppersoon gevolmachtigd was om namens de opdrachtgever te handelen. ${ }^{773}$

Op 11 november 2005 wees de Hoge Raad een arrest, waarin werd ingegaan op de vraag welke overwegingen een rol spelen bij een oordeel of de kennis van een adviseur aan diens opdrachtgever kan worden toegerekend. Die uitspraak maakt duidelijk dat de hoedanigheid van de opdrachtgever een rol speelt. In de desbetreffende zaak was de opdrachtgever niet terzake deskundig. Hem waren geen indicaties gegeven dat de handeling waarvan sprake was (vervreemding van een kasgeldvennootschap zonder waarborg voor latere aanwending van de vervangingsreserve) ongeoorloofd was. De opdrachtgever was volledig afgegaan op de adviezen van zijn adviseur en hem kon geen verwijt worden gemaakt met betrekking tot de keuze van die adviseur. Dit betrof een gerenommeerd kantoor. ${ }^{774}$

In cassatie werd aangevoerd dat bij de uitvoering van een transactie de wetenschap van de adviseur in het maatschappelijk verkeer had te gelden als de wetenschap van degene die de aandelen in het kapitaal van de desbetreffende vennootschap vervreemdde. De regel van artikel 3:66 lid 2 over toerekening van wetenschap bij volmacht zou van overeenkomstige toepassing moeten worden geacht en het feit dat er sprake was van benadeling door de Ontvanger der belastingen, maakte dat de betrokken algemene belangen van fiscale invordering de toerekening van wetenschap aan de opdrachtgever zou rechtvaardigen. Tenslotte werd gesteld dat in de gegeven omstandigheden het bestaan van de (veronderstelde, MB) wetenschap bij de opdrachtgever een omkering van de bewijslast rechtvaardigde, zulks naar analogie van de rechtspraak van de belastingrechter in het geval van een onjuiste of onvolledige aangifte tegenover de inspecteur.

De Hoge Raad overweegt als volgt:

"Bij de beoordeling van deze onderdelen wordt voorop gesteld dat toerekening van kennis, wetenschap of (reden tot) twijfel die iemand ten aanzien van de behoorlijke afwikkeling van een transactie heeft, aan een ander die deze kennis, wetenschap of

\footnotetext{
770 Zie in dit verband ook T.F.E. Tjong Tjin Tai, Toerekening van kennis en zorgvuldigheidsnorm, Bedrijfsjuridische Berichten, december 2005, nr. 26, p. 265 e.v.

771 Zie HR 21 december 2001, NJ 2002, 75. Ook artikel 6:76 BW moet restrictief worden uitgelegd. Zie HR 14 januari 2002, NJ 2002, 495 en HR 10 oktober 2003, NJ 2005, 89.

772 Zie HR 16 mei 1986, NJ 1986, 638, HR 9 januari 1998, NJ 1998, 586 en Gerechtshof Amsterdam 16 april 1998, NJ 1999, 161 (r.o. 5.3).

773 Zie in dit verband HR 26 september 2003, RvdW 2003, 152 (Regiopolitie).

774 Zie evenwel HR 4 april 2006, LJN AU 4658 en AU 4664, alsmede Rechtbank Amsterdam 26 mei 2006, LJN-nummer AX 6763 (McGregor), waar het ging om de vraag in hoeverre op adviezen van een adviseur mag worden vertrouwd.
} 
(reden tot) twijfel zelf niet had, weliswaar niet onder alle omstandigheden is uitgesloten, maar dat daarbij wel terughoudendheid moet worden betracht'.

De Hoge Raad voegde daaraan toe dat het vorenstaande des te meer klemde, nu het ging om een kwestie in het kader van een aansprakelijkheidsvraag. In het aansprakelijkheidsrecht geldt het uitgangspunt dat eenieder in beginsel alleen voor zijn eigen daden en nalatigheden aansprakelijk is te houden, behoudens wel omschreven, op de wet gebaseerde, uitzonderingen. ${ }^{775}$

In een weliswaar door de Hoge Raad wegens motiveringsgebreken vernietigde uitspraak van het gerechtshof te 's-Hertogenbosch van 31 mei $2005^{776}$ blijkt van een bereidheid van het gerechtshof om wetenschap van de lasthebber van een verkoper (in dit geval haar echtgenoot) aan de verkoper toe te rekenen, nu informatie door die lasthebber aan de koper zou zijn overhandigd maar waarvan de verkoopster zei (zelf) niet op de hoogte te zijn geweest. Doordat de verkoopster haar procespositie later wijzigde - nadat zij aanvankelijk had gesteld dat de desbetreffende informatie had gezeten in een ordner die haar echtgenoot aan de koopster zou hebben overhandigd - die erop neer kwam dat zij de stelling introk dat die informatie in de desbetreffende ordner had gezeten, kwam het arrest van het gerechtshof op losse schroeven te staan. Niet onbelangrijk acht ik toch dat het gerechtshof bereid was over te gaan tot een aantal assumpties, die ertoe leidden dat de kennis van de lasthebber / echtgenoot van de verkoopster aan de laatstgenoemde kon worden toegerekend. Het feit dat die echtgenoot de desbetreffende informatie niet aan de koper ter hand zou hebben gesteld, bracht het hof tot de constatering behoudens te leveren tegenbewijs (het ging om bodemverontreiniging) de verkoopster moest worden geacht de koper opzettelijk te hebben misleid.

Dat de wetenschap van een hulppersoon niet onder alle omstandigheden aan de opdrachtgever wordt toegerekend, werd ook bevestigd in HR 21 juni 2002. ${ }^{777}$ Naar aanleiding van de vraag of een sterke dieselgeur die bij het uitgraven van een olietank ruikbaar was geweest aan de gemeente kon worden toegerekend, die dat uitgraven had uitbesteed aan een derde, overwoog het hof - zonder dat de Hoge Raad daar bezwaar tegen maakte - dat het in een dergelijk geval te ver ging om de wetenschap van de hulppersoon aan de gemeente toe te rekenen.

\subsection{Reliance Letter}

Waar over het algemeen een due diligence onderzoek zal worden uitgevoerd door een partij die daartoe opdracht heeft gekregen, zal er een rechtsverhouding bestaan tussen de onderzoeker en de opdrachtgever. Er bestaat geen rechtsverhouding tussen anderen, die desondanks interesse kunnen hebben om - soms met de instemming van de opdrachtgever - kennis te nemen van de inhoud van het due diligence rapport. Daarbij kan het een derde betreffen, die zich bij het nemen van beslissingen terzake van de transactie waar het om gaat, tevens zal (willen) laten leiden door de inhoud van het due diligence rapport. Door het ontbreken van de rechtsverhouding tussen de onderzoeker en de derde zullen bijvoorbeeld de algemene voorwaarden van de onderzoeker niet op de rechtsverhouding tot de derde van toepassing zijn verklaard. Om aan dit gebrek tegemoet te komen en bovendien andere afspraken te maken welke de onderzoeker (of de opdrachtgever) van belang kunnen achten bij het kennis nemen door derden van de inhoud van het due diligence rapport, wordt wel gebruik gemaakt van een zogenaamde reliance letter. In die brief wordt dan benadrukt dat er geen overeenkomst van opdracht of van enige andere aard bestaat tussen de derde en de onderzoeker en dat - ofschoon de onderzoeker ermee instemt dat de derde van het rapport kennis neemt en zich daarop wellicht zelfs zal verlaten - de onderzoeker jegens de derde geen enkele aansprakelijkheid aanvaardt voor de inhoud van het rapport. De derde zal zich voorafgaand aan kennisneming van het rapport er bereid toe dienen te verklaren alle voorwaarden welke in het rapport zijn opgenomen - of in de op-

\footnotetext{
775 Zie HR 11 november 2005, LJN-nummer AT6018, JB 2006, 27. De maatstaf van vereenzelviging van een rechtspersoon met natuurlijke personen die haar aan het maatschappelijk en rechtsverkeer doen deelnemen, leent zich volgens de Hoge Raad niet voor de vraag of de (eventuele) kennis omtrent een transactie en eventuele (fiscale) gevolgen daarvan, welke kennis wel bij de adviseur maar niet bij de opdrachtgever aanwezig was, aan de opdrachtgever kan worden toegerekend. Het handelen van de opdrachtgever zelf kan dan niet als onrechtmatige gedraging van de opdrachtgever gelden. De Hoge Raad voegt daaraan toe dat vereenzelviging niet aan de orde is, omdat met betrekking tot de - dikwijls niet naar buiten blijkende verhouding tussen een adviseur en diens opdrachtgever, de opdrachtgever veelal ook zelfstandig kan en zal optreden.

${ }^{776}$ Kenbaar uit HR 23 november 2007, LJN BB3733.

${ }^{777}$ RvdW 2002, 106.
} 
drachtbevestiging voor het opstellen en uitbrengen van het rapport - te zullen respecteren, onverminderd het feit dat de derde ermee instemt geen juridische of andere actie jegens de onderzoeker te zullen entameren op grond van de inhoud van het rapport. Te denken valt aan bij een transactie betrokken banken, minderheidsaandeelhouders of nog weer anderen. Aan te raden is het ook om duidelijk te maken op welke versie van een rapport de reliance letter betrekking heeft en welk recht op de reliance letter van toepassing is. Het rapport zal aan een derde eerst ter inzage worden verschaft, nadat deze zich met de inhoud van de reliance letter schriftelijk akkoord zal hebben verklaard.

Reliance letters worden ook wel als restricted use letters aangeduid.

\subsection{Spontane adviesplicht adviseur?}

Heeft een onderzoeker naar aanleiding van hetgeen deze in een due diligence onderzoek aantreft, een waarschuwingsplicht of spontane adviesplicht, waar het onderwerpen betreft die tot zijn kennis kunnen worden gerekend en welke relevant zijn voor de opdrachtgever, maar waaromtrent door de opdrachtgever geen gerichte vragen zijn gesteld?

Deze vraag kwam aan de orde in een geschil tussen Kölnische Rückversicherungsgesellschaft AG en Cologne Reinsurance Finance Holdings B.V. enerzijds en Ernst \& Young anderzijds. Ernst \& Young werd verweten dat zij in een op 12 juni 1990 afgegeven tax comfort letter niet hadden gewezen op een voor de cliënt relevante verandering in de belastingwetgeving per 1 juli 1990. De discussie spitste zich toe op de vraag of de relatie tussen Ernst \& Young en haar cliënt zodanig was, dat er een spontane adviesplicht bestond, danwel of er geen sprake was van nalatigheid of toerekenbare tekortkoming, nu het ook van een redelijk bekwaam en redelijk handelend adviseur die deskundig is op het gebied van de vennootschapsbelasting ook waar het internationale (concern)verhoudingen betreft, niet zondermeer kon worden verlangd dat die zonder daartoe een gerichte vraag te hebben ontvangen, de cliënt zou waarschuwen voor komende wetswijzigingen. Het gerechtshof te Amsterdam besliste op 2 september 2004 dat een spontane adviesverplichting niet behoefde te worden aangenomen, maar dat de vraag of in de tax comfort letter - waar was gezegd dat er geen relevante zaken bestonden die bijzondere aandacht behoefden - de in zicht zijnde wetswijziging onvermeld had mogen blijven wat minder eenvoudig te beantwoorden was. Doordat in het verzoek om afgifte van een tax comfort letter de vraag voorkwam of er naar de mening van Ernst \& Young punten waren die bijzondere aandacht behoefden, zou wellicht een onderzoek naar de mogelijke toepasselijkheid van de komende wetswijziging wel op zijn plaats zijn geweest. De tax comfort letter had echter betrekking op het jaar 1989 en de wetswijziging zou eerst voor het boekjaar 1990 relevantie hebben. De Hoge Raad ${ }^{778}$ meende in april 2006 dat het hof de laatstbedoelde vraag onvoldoende had onderzocht of in ieder geval onvoldoende had gemotiveerd, waarom het had gemeend dat Ernst \& Young wel de cliënt had moeten waarschuwen voor de komende wetswijziging.

Deze uitspraak van 7 april 2006 was als gezegd van belang voor de vraag in hoeverre informatie zal dienen te worden verschaft door een adviseur die over informatie komt te beschikken ondanks het feit dat in de aan die adviseur verleende opdracht niet bijzonderlijk om het verschaffen van die informatie is gevraagd. Er was sprake van een bestendige relatie tussen de belastingadviseur en een cliënt, waarbij de cliënt aangifte vennootschapsbelasting laatstelijk zelf opstelde, maar die aangifte vooraf ter beoordeling voorlegde aan de belastingadviseur. Zo ging het ook met betrekking tot de aangifte over de jaren 1988 en 1989 ten behoeve van een dochtervennootschap van de cliënt in Bermuda. Op 1 juli 1990 trad artikel 28b van de Wet op de vennootschapsbelasting in werking, waardoor het aandelenbelang van de cliënt in de dochter op Bermuda - welk belang uitsluitend bestond uit beleggingen - in het vervolg diende te worden gewaardeerd op de waarde in het economisch verkeer. Voordien werd de historische kostprijs aangehouden. De wijziging in de belastingwet riep de kans in het leven dat de cliënt een aanzienlijke heffing terzake van vennootschapsbelasting tegemoet zou kunnen zien. De belastingadviseur gaf aan de cliënt ook zogenaamde "Tax Comfort Letters" ("TCL's") af, welke de beantwoording bevatten van (standaard) vragen van de accountant van de cliënt over (latente) belastingverplichtingen met het oog op het opstellen van de jaarrekening. Die vragen luidden, voor zover hier van belang:

\footnotetext{
${ }^{778}$ HR 7 april 2006, NJ 2006, 245
} 
"6. Particulars relating to items which fiscally require special treatment (...).

10. All other important points, which in your opinion, deserve attention".

Ernst \& young had vanaf de oprichting van CRFH tot 1980 een doorlopende opdracht tot verzorging van de aangiften in de vennootschapsbelasting en verrichtte voorkomende andere fiscale werkzaamheden voor CRFH. Met ingang van het jaar 1981 heeft CRFH de doorlopende opdracht tot het vaststellen van de aangiften in de vennootschapsbelasting ingetrokken. Ernst \& Young werd voortaan slechts in incidentele gevallen ingeschakeld, waarbij zij ad hoc, op basis van de alsdan beschikbaar gestelde informatie reageerde. CRFH heeft de aangiften in de vennootschapsbelasting betreffende de jaren 1981 tot en met 1991 zelf opgesteld. CRFH heeft die aangiften tot en met die over het jaar 1987 in concept ter beoordeling aan Ernst \& Young toegezonden en over de jaren 1988 en 1989 niet meer. Over 1988 en 1989 beoordeelde E\&Y de concept-aangiften dus inderdaad niet meer.

De belastingadviseur gaf op 12 juni 1990 wel een TCL af terzake het jaar 1989 en repte niet over de op handen zijnde verandering van de Wet op de vennootschapsbelasting. Het gerechtshof oordeelde dat er - en dat is hier van belang - niet de verplichting rustte spontaan de cliënt in te lichten omtrent de mogelijke toepasselijkheid van artikel 28 Wet vennootschapsbelasting. Bij dit oordeel nam het hof in aanmerking dat de relatie tussen partijen in het desbetreffende tijdvak met name daarin bestond dat de belastingadviseur (enkel) adviseerde wanneer haar daarom werd gevraagd.

De onderhavige zaak houdt niettemin een waarschuwing in, dat er acht geslagen moet worden op in ieder geval een tweetal normen, wanneer het gaat om de vraag of er een spontane adviesplicht aan de orde kan zijn:
de eigen kennis van de onderzoeker:
deze dient onder omstandigheden te handelen zoals mag worden verwacht van een redelijk bekwaam en redelijk handelend onderzoeker die deskundig is op het gebied waarop deze is ingeschakeld; en
de aard van de relatie tussen de onderzoeker en de cliënt, waarbij de omvang van de betrokkenheid van de onderzoeker (ook in andere hoedanigheden) bij de cliënt, de duur van de relatie en de kennis van de onderzoeker van de situatie van de cliënt, relevante factoren kunnen zijn bij beantwoording van de vraag of er op voor de cliënt relevante ontwikkelingen, waarvan de onderzoeker kennis draagt, behoort te worden gewezen.

Ernst \& Young kwam uiteindelijk met de schrik vrij, doordat het gerechtshof te 's-Gravenhage op 24 april $2008^{779}$ oordeelde dat er in het desbetreffende geval geen spontane adviesplicht aangenomen behoefde te worden. Volgens het hof hangt het antwoord op de vraag wat van een redelijk handelend en bekwaam belastingadviseur mocht worden verwacht samen met de mate van intensiteit van de adviesrelatie. De vraag of op Ernst \& Young een onderzoeksplicht rustte naar de toepasselijkheid van artikel $28 \mathrm{~b} \mathrm{Vpb}$ op de deelneming van de cliënt in een andere vennootschap (want daar ging het geschil om) bij de uitvoering van overige opdrachten, moest volgens het hof worden beantwoord in het licht van de relatie tussen partijen alsmede de aard en omvang van de opdracht.

Ik noem in dit kader nog het arrest van het gerechtshof te Arnhem van 2 november $2004,{ }^{780}$ waarin het ging om wetenschap van een vader, die zijn zoon had aangeraden een onroerend goed aan te schaffen, terwijl de vader verondersteld werd te hebben moeten weten dat er in dat onroerend goed van bodemverontreiniging sprake was of kon zijn. De vader had gewerkt als directeur bij het metaal- en constructiebedrijf dat later voor verontreiniging verantwoordelijk bleek te zijn. Het hof overwoog te dier zake:

"Indien, zoals eiser stelt, de vader van verweerder als adjunct-directeur van ... danwel van de in het pand gevestigde onderneming werkzaam is geweest en het initiatief heeft genomen tot de aankoop, dan rechtvaardigt dat nog niet de gevolgtrekking dat diens - betwiste - wetenschap omtrent de werkwijze van de machinefabriek aan verweerder c.s. bij de koop mocht of mag worden toegerekend".

\footnotetext{
${ }_{779}^{779}$ LJN BD0510.

${ }^{780}$ Kenbaar uit HR 2 juni 2006, LJN-nummer AW 6612.
} 
Het hof kende ook waarde toe aan het feit dat de vader niet was opgetreden als makelaar of als tussenpersoon. Er werd derhalve geen spontane adviesverplichting van de vader aangenomen.

Voor zover dit het optreden van een accountant in diens hoedanigheid betreft, vallen lessen te ontlenen aan de uitspraak van de Hoge Raad in de kwestie van Vie d'Or. ${ }^{781}$ In cassatie ging het onder meer over de informerende taak van een accountant. De accountants was verweten dat deze de raad van commissarissen onvoldoende hadden ingelicht. De betrokkenen hadden zich verweerd onder meer met de stelling - samengevat weergegeven - dat dergelijke inlichtingen ook mondeling konden worden verstrekt en dat zij de commissarissen van Vie d'Or informeel en mondeling op adequate wijze van informatie hadden voorzien. De Raad van Tucht had het verweer aanvaard dat het geven van inlichtingen niet aan een bepaalde vorm gebonden was en derhalve ook mondeling kon geschieden. Ook overwogen werd evenwel:

"Indien de accountant er echter voor kiest de raad van commissarissen primair mondeling op de hoogte te stellen van bepaalde belangrijke feiten en omstandigheden, dan dient hij toe te zien op ten minste een juiste vastlegging van hetgeen hij mondeling heeft meegedeeld, bijvoorbeeld in de notulen van de desbetreffende vergadering van de raad van commissarissen".

Niet in geschil was dat dit in het geval van Vie d'Or niet was geschied. De tegen de accountants ingebrachte klacht bij de Raad van Tucht werd derhalve gegrond verklaard. Het College van Beroep voor het Bedrijfsleven sanctioneerde de uitspraak van de Raad van Tucht, waarbij mede een rol speelde dat de raad van commissarissen had ontkend de mondelinge informatieverstrekking te hebben ontvangen. Overwogen werd dat het mondeling verschaffen van informatie alleen kan worden aanvaard voor zover schriftelijke vastlegging van die mondelinge informatieverstrekking plaatsvindt. Het was aan de accountants om aan te tonen dat informatieverstrekking werkelijk had plaatsgevonden. De Hoge Raad bleek eveneens van oordeel dat de accountants tekort waren geschoten in hun verplichting om commissarissen op adequate wijze te waarschuwen, zodat tijdig maatregelen hadden kunnen worden getroffen. Dat een en ander niet leidde tot rechtstreekse aansprakelijkheid jegens polishouders, hebben we hiervoor gezien.

In hoeverre op een notaris die in hoedanigheid handelt, een waarschuwingsplicht rust, kwam aan de orde in HR 14 december $2007 .^{782}$ Het ging in die zaak over zeer speculatieve transacties. De Hoge Raad overwoog:

"De onderdelen falen voor zover zij berusten op de opvatting dat op een notaris een verplichting rust nader te informeren naar de beweegredenen voor een transactie, wanneer hij op grond van eerdere contacten met een partij ervan mag uitgaan dat deze de te verrichten transactie, evenals voorgaande transacties, wenst aan te gaan uit speculatieve overwegingen, zoals in het onderhavige geval de verwachting dat de te verwerven bospercelen op termijn een lucratieve bestemming zullen krijgen. De omstandigheden dat de speculatieve transactie wordt verricht door een particulier en dat bij eerdere gelegenheden transacties werden aangegaan van een geringere omvang, brengen op zichzelf en in het algemeen niet mee dat een notaris uit hoofde van zijn zorgplicht zich ervan moet vergewissen dat de betrokken partij ook ten aanzien van de beoogde (omvangrijker) transactie bekend is met de risico's van speculatieve transacties. Niettemin kunnen deze omstandigheden in samenhang met hetgeen de notaris overigens bekend is omtrent de aard van de beoogde transactie en de ernst van de daarmee samenhangende risico's alsmede omtrent de hoedanigheid van de betrokken partij, meebrengen dat de notaris niet ermee volstaat bij de wederpartij te informeren naar de beweegredenen voor die transactie maar ook bij de betrokken partij zelf daarnaar informeert en zo nodig wijst op de aan de transactie verbonden risico's".

\footnotetext{
${ }^{781}$ HR 13 oktober 2006, JOR 2006, 296 m.nt. H. Beckman.

${ }^{782}$ HR 14 december 2007, RAV 2008, 23
} 


\title{
13.6
}

\section{Eigen aanspraken adviseur}

In de markt van fusies en overnames, wordt regelmatig opgetreden door bemiddelaars, die een beloning bedingen, wanneer er een succesvolle transactie tot stand komt. Afhankelijk van de inrichting van de opdracht, heeft een bemiddelaar wel of geen aanspraak op een beloning, wanneer een transactie afgebroken wordt, bijvoorbeeld na het uitvoeren van een due diligence onderzoek. In een uitspraak van de rechtbank Arnhem van 19 maart $2008^{783}$ ging het onder meer over de vordering van een bemiddelaar (Company Brokers), die stelde een provisiebetaling te hebben misgelopen, omdat de koper ten onrechte een beroep zou hebben gedaan op een ontbindende voorwaarde in de koopovereenkomst, nadat deze bekend was geworden met het resultaat van een uitgevoerd due diligence onderzoek (confirmatory due diligence). De verkoper en Company Brokers stelden dat het beroep op de ontbindende voorwaarde ten onrechte was en dat derhalve de koper jegens de verkoper en Company Brokers onrechtmatig had gehandeld. De koper in kwestie was VIBB. De verkoper Talent Invest. De onderhavige zaak kwam in dit boek al eerder aan de orde, maar onder het hier voor genoemde hoofd van deze paragraaf, is de navolgende overweging van de rechtbank nog het vermelden waard:

\begin{abstract}
"Als er geen sprake is van een tekortschieten of onrechtmatig handelen van VIBB tegenover Talent Invest is er reeds daarom evenmin sprake van onrechtmatig handelen van VIBB tegenover Company Brokers. Laatstgenoemde koppelt immers de jegens haar gepleegde onrechtmatige daad aan verwijtbaar handelen jegens Talent Invest. Is er wel sprake van verwijtbaar handelen van VIBB jegens Talent Invest, dan heeft zij daarmee volgens Company Brokers ook tegenover Company Brokers als makelaar van Talent Invest onrechtmatig gehandeld. Company Brokers stelt dat zij schade heeft geleden doordat in deze situatie Talent Invest haar voor de verrichte inspanningen geen courtage hoeft te betalen. Daarmee is echter nog niet gesteld dat dit uitblijven van een vergoeding schade vormt die veroorzaakt is door een onrechtmatig handelen van VIBB. Het beroep op de ontbindende voorwaarde maakt dat de overeenkomst tussen de klant van Company Brokers en VIBB ontbonden wordt. Of Company Brokers door die situatie betaling van courtage heeft bedongen, raakt VIBB in beginsel niet. Dat de schade die wordt gevormd door het uitblijven van courtage, is veroorzaakt door schending van een zorgvuldigheidsregel die VIBB tegenover Company Brokers in acht had te nemen, stelt Company Brokers niet. De stelling van Company Brokers dat een niet gerechtvaardigd beroep op de ontbindende voorwaarde tegenover Talent Invest onrechtmatig was jegens Company Brokers, is in zijn algemeenheid onjuist, reeds omdat hierin niet wordt aangegeven dat er een zorgvuldigheidsnorm bestond die VIBB tegenover de makelaar van haar onderhandelingspartner in acht had te nemen. Het voorgaande leidt tot de conclusie dat de vordering van Company Brokers moet worden afgewezen."
\end{abstract}

De benaderingswijze van de rechtbank lijkt juist. Eerst wanneer er sprake kan zijn van een rechtstreekse inbreuk op een eigen subjectief recht van een bemiddelaar, kan die stellen dat er sprake is van een onrechtmatige gedraging jegens deze zelf. Een bemiddelaar doet er goed aan zich te voorzien - zoals in de praktijk ook wel gebeurt - door in de overeenkomst van opdracht tevens afspraken te maken met betrekking tot de situatie dat door een aan de wederpartij van de opdrachtgever toe te rekenen omstandigheid, verrichtte werkzaamheden zonder resultaat zullen blijven. Niet ongebruikelijk is dat er een success-fee wordt betaald bij het slagen van een transactie en de bestede tijd op basis van een overeengekomen uurtarief wordt afgerekend indien de transactie geen doorgang vindt.

\footnotetext{
${ }^{783}$ LJN BC8052, r.o. 4.18 en 4.19
} 


\section{Slotopmerkingen}

Het is aan de lezer - eenmaal op deze bladzijde aangekomen - om te beoordelen of er iets terecht is gekomen van het voornemen om een overzichtsfoto te maken van het fenomeen due diligence. Het leek in ieder geval de moeite waard de poging te wagen een terreinverkenning te doen. Blijkens onderzoek uit 1999 werd toen al in 94\% van de gevallen waarin sprake was van fusies, overnames en joint ventures gebruik gemaakt van enige vorm van due diligence onderzoek. ${ }^{784}$ Het onderwerp due diligence verdiende het alleen daarom al dat daar eens een landkaart van getekend zou worden. Zo'n landkaart was tot dusverre in ons land niet voorhanden. Ik hoop te zijn geslaagd in de opzet om een eerste terreinverkenning te doen en de waarnemingen daarbij zo te hebben opgetekend dat die een goede weergave van het landschap geven.

Welke gevolgtrekkingen kunnen nu aan de voorafgaande inhoud van dit boek worden ontleend? Door de veelheid van onderwerpen, die met het voorwerp due diligence te maken hebben, zal op deze plaats niet opnieuw op al die onderwerpen kunnen worden ingegaan. $\mathrm{Na}$ een enkele algemene slotopmerking, wil ik daarom mijn beschouwingen afsluiten met enige afrondende opmerkingen over de vraag welke per saldo als de hoofdvraag ter zake van het onderwerp due diligence kan gelden. Dat is de vraag naar de plaats en betekenis van een due diligence onderzoek - in welke vorm dan ook - bij het aangaan van een transactie.

In de jaren 2006 en 2007 werd wereldwijd 8650 miljard dollar aan grote transacties gemeld. Het grootste deel daarvan is volgens onderzoekers tot mislukken gedoemd (volgens cijfers van Business Week en The Economist mislukt 70 procent van alle fusies en overnames, volgens de Utrechtse hoogleraar Schenk zelfs 85 procent). Toch wordt ter gelegenheid van die fusies en overnames in vrijwel alle gevallen vooraf onderzoek ingesteld en ligt er aan de besluitvorming een plan ten grondslag. ${ }^{785}$ De fase na het due diligence onderzoek is vervolgens bepalend voor het succes van een fusie of overname. Gelet op het veronderstelde aantal mislukte integratieprocessen - ondanks een uitgevoerd due diligence onderzoek - levert dit een aanwijzing op dat er in een due diligence onderzoek nog meer aandacht uit zou moeten gaan naar de zogenaamde 'zachte factoren' voorzover die meetbaar of inschatbaar zijn. ${ }^{786}$ Deze factoren zijn als indicatoren ook voor de kansen op succes voor het doormaken van een succesvol integratieproces belangrijk. Daarbij moet dan vooral worden gedacht aan cultuur. ${ }^{787} \mathrm{Er}$ is inmiddels een toenemend aantal mogelijkheden voorhanden om tijdens een due diligence onderzoek ook de bedoelde zachte factoren in kaart te brengen (zie hoofdstuk 2, onder 2.7). Vast te stellen is in ieder geval dat een due diligence onderzoek niet alleen maar een juridische of financiële aangelegenheid is of zou mogen zijn. Afhankelijk van het soort transactie zullen andere dan juridische en financiële aspecten de aandacht verdienen om uiteindelijk economische meerwaarde van een investering te secureren.

Onder de noemer van een due diligence onderzoek kan veel worden gevat, zoals wij in de eerste twee hoofdstukken hebben gezien. Een inzichtelijke inventarisatie van de verschillende betekenissen van de in transactieland gehanteerde begrippen ontbrak waar dit het onderwerp van de gepaste voorzichtigheid bij het aangaan van een transactie betrof.

Het ene due diligence onderzoek is het andere niet. Het is - wat de Engelsen zeggen - horses for courses, of zo zou het in elk geval moeten zijn. De ene transactie is de andere niet is en ook de ene partij daarbij is de ander niet. Onjuist is de gedachte dat bij transacties in de kapitaalmarkt, bij het tot stand brengen van financiële arrangementen of waar het de onderhandse koop van (ondernemingen door middel van de koop van) aandelen betreft, steeds (alleen) professionele partijen betrokken zijn. Ook een partij die als ondernemer in zijn bestaan voorziet is niet noodzakelijk wat Tjittes een repeat

\footnotetext{
${ }^{784}$ Zie F. Bos en J.P.F. Owen, Due diligence. De onmisbare schakel in het acquisitieproces, Tijdschrift voor Corporate Finance, 1999 , nr. 3, p. 75.

${ }^{785}$ D. Kalff, Groei als heilige grail. Grootbedrijf komt niet echt vooruit, Het Financieele Dagblad 12 januari 2008, p. 17.

${ }^{786}$ Volgens D. Mollan en Q. Solt in Wie neemt u mee naar het bedrijfsbal? (Het Financieele Dagblad 13 februari 2006, p. 5) is het grote aantal mislukte integratieprocessen na een transactie het gevolg van te weinig adequaat due diligence onderzoek, waarbij het accent te veel wordt gelegd op cijfers en het vermijden van juridsiche risico's.

${ }^{787} \mathrm{Zie}$ voor een nadere invulling van dat begrip onder meer F. Trompenaars en Ch. Hampden-Turner, Riding the waves of culture, Understanding Cultural Diversity in Business, ISBN 1-85788-176-1.
} 
player heeft genoemd. ${ }^{788} \mathrm{Er}$ zijn particulieren die veel ervaring hebben met aangaan van transacties en ondernemers die dat helemaal niet hebben. Er is voor iedereen een eerste keer. Bij het toedenken van een plaats aan het due diligence onderzoek in het landschap van financiële en andere transacties, lijkt daarom op het eerste oog van een "vaste plaatsbepaling" geen sprake te zijn, maar is het iedere keer "free seating". Waar het om een plaatsbepaling in het juridische landschap gaat, wil ik hierna als afronding van dit boek een poging wagen om - voor zover het fenomeen due diligence een eigen plaats in ons rechtsbestel is toe te wijzen - iets meer profiel aan dat leerstuk te geven in de algemene leerstukken waarin het gevat is. Dat kan hopelijk bijdragen aan duidelijkheid. Tot dusverre ontbrak naar mijn gevoel soms de onderkenning dat due diligence een eigen plaats toekomt in de algemene leerstukken die wij kennen als onderzoeks- en mededelingsplicht. Door het soort van zaken waarbij een due diligence onderzoek te pas komt en de met dat soort zaken verbonden eigen dynamiek, verdient het due diligence onderzoek te worden onderscheiden van de passende voorzichtigheid welke bij bijvoorbeeld consumentenovereenkomsten is aangewezen. Waar het een due diligence onderzoek betreft, gaat het niettemin eveneens om een 'onderzoeksplicht' waarvan de omvang mede kan worden bepaald door wat wij kennen als een 'mededelingsplicht'. Hoe gelukkig overigens de keuze voor het woord 'onderzoeksplicht' in het kader van ons onderwerp is, kwam eerder in dit boek al aan de orde en hierna wordt daar ook nog op teruggekomen. Ook kom ik nog terug op de samenhang tussen een onderzoeksplicht en een mededelingsplicht.

Als vertrekpunt bij de poging om tot een plaatsbepaling van een due diligence onderzoek te komen, ontkomen wij er niet aan om naar de algemene regels te kijken. Ik zal dat niet uitgebreid doen, nu anderen dat, zoals wij hoger op in dit boek zagen, al bekwaam gedaan hebben. Met het oog op een due diligence onderzoek verwijs ik dan naar het gestelde in artikel 7:17 lid 5 en in artikel 6:228 lid 1 sub b (de onrechtmatige daad actie van artikel 6:162 en/of 6:194 laat ik hierbij rusten, maar duidelijk zal zijn dat een onrechtmatige daad kan leiden tot een verplichting van het betalen van een schadevergoeding). ${ }^{789}$ Volgens artikel 7:17 lid 5 kan een koper zich niet op een gebrek in een zaak beroepen wanneer de zaak niet aan de overeenkomst beantwoordt, wanneer dit gebrek hem ten tijde van het sluiten van de overeenkomst bekend (was of) redelijkerwijs bekend kon zijn. lets dat bij een uitvoerbaar onderzoek vast te stellen was, had redelijkerwijs bekend kunnen zijn. Relevante begrippen bij het toepassingsbereik van artikel 7:17 zijn volgens lid 2 van die wetsbepaling de eigenschappen van het voorwerp van de transactie die voor het normale gebruik daarvan nodig zijn, aan de aanwezigheid waarvan niet getwijfeld behoefde te worden, alsmede de eigenschappen die nodig zijn voor een bijzonder gebruik dat in de overeenkomst tussen partijen is voorzien. De aard van de zaak en de mededelingen die de verkoper over de zaak heeft gedaan bepalen mede de inhoud van de overeenkomst. Het gaat dus in artikel 7:17 in ruimere zin om elementen waar zowel de verkoper (mededelingen, of, zo zou ik menen, het achterwege laten daarvan) voor verantwoordelijk kan worden gehouden, als om elementen waarvoor de koper verantwoordelijkheid toebedeeld kan krijgen (onvoldoende oriëntatie of onderzoek). Hoewel het daarbij in de eerste instantie om aansprakelijkheid gaat - er kan nakoming, ontbinding of schadevergoeding worden gevorderd - en nog niet om de vaststelling van een eventuele schadevergoeding, gaat het per saldo om risicoverdeling en het uiteindelijk opdraaien voor de gevolgen wanneer er na het voltooien van de transactie sprake is van non conformiteit. Het gaat er dus om aan wie per saldo de gevolgen van de problemen kunnen worden toegerekend. De gevolgen van een en ander in termen van schadevergoeding kunnen ook over partijen verdeeld worden wegens mede schuld wanneer in een combinatie toepassing kan worden gegeven aan artikel 7:17 jo. 6:74 en 6:101. ${ }^{790}$

Artikel 6:228 lid 1 sub 2 richt zich niet tot één partij in het bijzonder maar tot beide bij een transactie betrokken partijen. Zij beiden krijgen van de wetgever de instructie om de ander in te lichten waar het aangelegenheden betreft waarvan zij (wisten of) behoorden te weten dat dit bij de ander ter gelegenheid van het aangaan van de overeenkomst welke de transactie tot stand brengt een onjuiste veronderstelling in het leven zou roepen of zou laten bestaan, al naar gelang het geval. Wanneer er niet tij-

${ }^{788}$ R.P.J.L. Tjittes, Naar een bijzonder contractenrecht voor ondernemers in Onderneming en 5 jaar nieuw burgerlijk recht, Serie Onderneming en Recht, deel 7, p. 375 e.v.

${ }^{789}$ Zie bijvoorbeeld een uitspraak over een vordering tot vergoeding van schade wegens afgebroken onderhandelingen als het gevolg van een gesteld verzaken van een mededelingsplicht in de onderhandelingsfase, gerechtshof te 's-Hertogenbosch 29 november 2005, LJN AV2121.

790 Het achterwege laten van passende mededelingen in de precontractuele fase zal in een voorkomend geval (ook) als onrechtmatig kunnen worden gekwalificeerd in de zin van artikel 6:162. 
dig een voorstel tot wijziging van de gevolgen van de overeenkomst wordt voorgesteld, waardoor het nadeel op afdoende wijze wordt opgeheven, heeft een dwalende partij op grond van artikel 2:228 lid 1 het recht de overeenkomst te vernietigen. De partij die gedwaald heeft kan op grond van artikel 6:230 lid 2 de rechter ook vragen in plaats van de vernietiging uit te spreken de gevolgen van de overeenkomst ter opheffing van het ondervonden nadeel te wijzigen.

Artikel 6:228 is een andere rechtsgrond voor een actie dan artikel 7:17 en heeft andere rechtsgevolgen. ${ }^{791}$ Het gaat er echter ook in het geval van de toepassing van artikel 6:228 en 6:230 per saldo om voor wiens rekening de gevolgen van een gebrek in de wilsvorming dienen te blijven. Een due diligence onderzoek is er op gericht om vooraf de risico's te onderzoeken, die zich bij het tot stand komen van een overeenkomst zouden kunnen materialiseren. Wanneer risico's niet van tevoren zijn gesignaleerd en zich achteraf openbaren, zal het de vraag zijn of de koper resultaat zal kunnen verwachten van acties als hier voor bedoeld.

Het vorenstaande brengt op zich zelf nog niet mee, zo merkte ik in hoofdstuk 4 op (onder 4.1), dat er waar dit een due diligence onderzoek betreft in ons land (al) sprake is van de onderkenning van een rechtsfiguur sui generis. De hier voor genoemde wetsartikelen zien immers op allerlei soorten van transacties. Artikel 7:17 zou zonder de schakelbepaling van artikel 7:47 zelfs niet eens meespelen waar het transacties met betrekking tot aandelen betreft. Welke overweging rechtvaardigt dan dat het leerstuk betreffende due diligence wel als een leerstuk sui generis toch een wat meer identificeerbare plaats in ons rechtsbestel verdient? Wat voor een plaats zou dat dan moeten zijn?

In vervolg op het vorenstaande kan worden gezegd, dat een gemeenschappelijk kenmerk van al de eerder bedoelde soort van transacties (transacties in de kapitaalmarkt, het tot stand brengen van financiële arrangementen en de onderhandse koop van (ondernemingen door middel van de koop van) aandelen) is dat het steeds transacties betreft waarvan het voorwerp zich kenmerkt door een complex karakter. Ofwel het betreft financiële producten die zich zonder nadere toelichting - zeker voor de minder professionele wederpartij - of zonder een nader onderzoek niet eenvoudig laten overzien en doorzien, ${ }^{792}$ of het voorwerp van de transactie bestaat uit een samenstel van vermogensrechtelijke titels en obligatoire verantwoordelijkheden, waarvan zonder nadere toelichting en nader onderzoek evenmin een zodanig beeld gevormd kan worden dat zonder risico voor teleurstelling achteraf tot de transactie kan worden overgegaan. Bovendien betreft het transacties die zich vaak niet gemakkelijk weer ongedaan laten maken.

Ik realiseer mij dat het trekken van lijnen rond het speelveld van transacties met betrekking waartoe een onderzoek van de koper het karakter van een due diligence onderzoek toegekend kan worden niet eenvoudig is. Het zijn wellicht stippellijnen, maar ik zou dat speelveld willen bepalen door aanwijzing van in ieder geval die transacties die door ten minste één professionele partij worden aangegaan in de kapitaalmarkt en transacties van (ook) andere partijen met betrekking tot het financieren van, het deelnemen in of het verwerven van zeggenschap over (een onderdeel van) een onderneming. De hier bedoelde transacties duid ik hierna aan als "Investeringen". Degene die de investering doet, duid ik verder aan als de "Investeerder." Het onderzoek dat vooraf gaat of - zoals ik meen, behoort te gaan - aan Investeringen, geldt dan als een due diligence onderzoek.

Een eigen plaats van een due diligence onderzoek nu moet worden gepast binnen het kader van de hier voor aangesproken risicoverdeling tussen partijen bij het doen van Investeringen. In het algemeen geldt dat over het rechtskarakter van een onderzoeksplicht en de rechtsgevolgen van het niet voldoen aan een dergelijke wel of niet geldende verplichting verschillend wordt gedacht. Omstreden is of een onderzoeksverplichting in de precontractuele fase moet worden geduid als Obliegenheit, een rechtsplicht of een verbintenis. Van Baalen heeft er naar mijn mening terecht op gewezen, dat het toekennen van een plaats aan een onderzoeksplicht in het civiele recht aandacht verdient vanwege het toene-

791 Zie ook J.B.M. Vranken in diens noot onder HR 25 januari 2002, NJ 2003, 31 (Lampenier) en de door hem genoemde litera tuur. Gerbrandy stelde in 1990 al vast, dat de grens tussen dwalen bij sluiting van een overeenkomst (wilsgebrek) en nietontvangen wat men mocht verwachten, blijkend bij de uitvoering van de overeenkomst, uitermate vaag is. Zie S. Gerbrandy, De Omstandigheden, Op de grens tussen dwaling en wanprestatie in WPNR 5959, p. 288. Het is niettemin onduidelijk of het in het geding brengen van artikel 3:12 iets kan bijdragen. Strikt genomen kan dat meespelen bij het invullen van ook pre contractuele redelijkeheid en billijkheid, maar doordat bijvoorbeeld artikel 7:17 en 6:228 als een bijzondere regeling kunnen worden gezien, is er voor toepassing van algemene bepalingen wellicht geen ruimte.

792 Voor een nadere uitleg van het begrip "complex product" in de effectenhandel, zie S.B. van Baalen, Zorgplichten in de effectenhandel, Serie Recht en Praktijk, nummer 140, p. 154. 
mende belang van informatie- en onderzoeksplichten binnen het civiele recht als geheel en met het gegeven dat deze plichten een rol spelen in veel specifieke verbintenisrechtelijke leerstukken (zoals dwaling, onrechtmatige daad, misleidende mededelingen, de precontractuele redelijkheid en billijkheid en de conformiteitsvraag). ${ }^{793}$ Het rechtskarakter van een onderzoeksplicht is, zoals wij al meer zagen echter niet vastomlijnd. De toevlucht welke is gezocht in het gebruik van het begrip 'Obliegenheit' heeft daarbij uiteindelijk niet veel duidelijkheid opgeleverd. Van Baalen ${ }^{794}$ merkt hierover op:

“...[het] betreft in de kern een plicht die als zodanig in rechte niet kan worden afgedwongen. Het gaat slechts om de rechtsdrang (geen rechtsplicht) de verplichting na te komen. Schending van de 'Obliegenheit' heeft daarmee juridisch gezien slechts nadelige gevolgen binnen de leerstukken als dwaling en een vordering tot schadevergoeding. Anderen menen dat precontractuele zorgplichten rechtsplichten zijn die een sterkere gehoudenheid impliceren dan enkel rechtsdrang."

Al het vorenstaande bevestigt de in ons land heersende opvatting dat een koper geen op een wetsartikel terug te voeren verplichting heeft om voorafgaand aan het doen van een Investering een due diligence onderzoek uit te voeren. Het wel uitvoeren van een onderzoek (soms achteraf) kan wel meebrengen dat men zekere rechten kan doen gelden (denk aan de mogelijkheid afgifte van bekend geworden stukken te verlangen op grond van artikel 843a Rv of het feit dat de wederpartij geen beroep meer kan doen op artikel 7:17 lid 5) of althans rechten bewaard kan doen blijven (denk bijvoorbeeld aan de toepassing van artikel 7:23 lid 1 en artikel 6:89). Het achterwege laten van een (onder de omstandigheden passend) due diligence onderzoek kan wel tot verlies van rechten aanleiding geven (denk bijvoorbeeld aan de toepassing van artikel 3:35) en kan ook leiden tot de conclusie dat de gevolgen van een teleurstelling geheel of gedeeltelijk voor eigen rekening zullen blijven (denk aan artikel 2:228 lid 2 in het geval van dwaling en de toepassing van artikel 7:23 bijvoorbeeld, hoewel, tenzij er van een confirmatory due diligence sprake is, er gewoonlijk bij een inspectie van een ontvangen prestatie niet gesproken wordt van een due diligence onderzoek, maar ook aan artikel 6:101 in verband met artikel 6:74 en 7:17).

Zoals wij hoger op in dit boek hebben gezien, is een belangrijke reden voor een Investeerder om een due diligence onderzoek uit te voeren het vermijden van een noodzaak om op grondslag van een of meer van de hier voor genoemde wetsbepalingen achteraf te moeten proberen zijn schade te verhalen of nadeel opgeheven te krijgen welke het gevolg kan zijn van - want daar komt het in beide gevallen toch op neer - een onjuiste veronderstelling met betrekking tot het voorwerp van de Investering ten tijde van het aangaan daarvan. De wederpartij van de Investeerder zal de uitvoering van een due diligence onderzoek, zoals wij eveneens zagen, normaliter willen toestaan om een verwijt te vermijden dat deze niet aan diens mededelingsplicht heeft voldaan en om niet achteraf met een vordering van diens wederpartij op grond van een van de genoemde wetsbepalingen te worden geconfronteerd.

Volgens A-G Timmerman ${ }^{795}$ volgt uit de jurisprudentie dat in het geval van een professionele Investeerder deze geacht wordt betrekkelijk veel te weten of door onderzoek veel te weten te kunnen komen, hetgeen een reducerend effect kan hebben op de omvang van de mededelingsplicht van diens wederpartij. In geval van professionaliteit van de Investeerder komt de mededelingsplicht van de wederpartij echter niet zonder meer en onder alle omstandigheden te vervallen. Hetzelfde geldt, wanneer de Investeerder een due diligence onderzoek doet uitvoeren. Op zichzelf brengt het uitvoeren van een due diligence onderzoek niet mee dat de mededelingsplicht van de wederpartij komt te vervallen. Er zijn omstandigheden denkbaar waarin de Investeerder ondanks dat een due diligence onderzoek van de zijde van de Investeerder is uitgevoerd bepaalde mededelingen aan de laatst genoemde dient te doen. De feiten en omstandigheden spelen steeds een belangrijke rol.

Waar het de rol van die wederpartij betreft is er als gezegd onder omstandigheden sprake van wat te onzent een mededelingsplicht wordt genoemd. Volgens de rechtspraak mag de Investeerder, zoals eerder is vastgesteld (hoofdstuk 5 onder 5.2 en 5.3), in beginsel afgaan op door diens wederpartij gedane mededelingen. Het voldoen aan of verzaken van een mededelingsplicht kan daarom mede van invloed zijn op hetgeen er van de Investeerder verwacht mocht worden bij de gelegenheid van een due

\footnotetext{
793 S.B. van Baalen, Zorgplichten in de effectenhandel, Serie Recht en Praktijk, nummer 140, p. 249

794 A.w., p. 249-250.

795 Onder 4.1. in zijn conclusie bij LJN AO1214 (M\&M Beheer).
} 
diligence onderzoek. De vraag die gesteld kan worden is of niet ook de wederpartij van de Investeerder een eigen onderzoeksplicht heeft. Wat moet of mag er worden gelezen in de woorden "of behoorde te weten" in artikel 6:228 lid 1 sub b?

Mij dunkt, dat een Investeerder van diens wederpartij in ieder geval mag verwachten dat die mededeling zal doen van die informatie waarvan die weet of redelijkerwijs behoort te weten (vergelijk artikel 7:17 lid 5 in de andere richting), dat die informatie voor de Investeerder van belang kan zijn bij het nemen van diens beslissing over het wel of niet doen van de Investering. Dit is een regel die volgens artikel 2:228 lid 1 sub $b$ te onzent al geldt, wanneer wij althans het woord "redelijkerwijs" in die laatst bedoelde wetsbepaling begrepen kunnen achten. Wat behoort de wederpartij van de Investeerder te weten? Ik stelde hier voor al de vraag of er op die wederpartij een eigen onderzoeksplicht rust en zo ja, hoever gaat die dan? In elk geval doet de Investeerder er verstandig aan duidelijk te maken welke bedoelingen die bij een transactie heeft. Daar dat te doen, geeft deze immers inhoud aan hetgeen zijn wederpartij wist (en behoorde te weten). ${ }^{796}$ De behoefte om het hiervoor genoemde begrip "redelijkerwijs" dan in de regel van artikel 2:228 lid 1 sub b te lezen, kan dan minder groot zijn. Brengt een en ander een Obliegenheit van (ook) een mededelingsplicht aan de zijde van de Investeerder mee?

A-G Huydekoper noemt het in zijn conclusie bij een arrest van 23 januari $2004^{797}$ een betrekkelijk irrelevant en zelfs willekeurig keuzevraagstuk of de grondslag het etiket onrechtmatig handelen opgeplakt krijgt, dan wel schending van de mededelingsplicht of zelfs het toerekenbaar tekort schieten doordat het onderwerp van de overeenkomst door een aan de "mededelingsplichtige" partij toerekenbare oorzaak, niet aan de gerechtvaardige verwachtingen van de wederpartij beantwoord. Verschillende bronnen merken volgens hem als grondslag aan, dat het verzaken van de mededelingsplicht in de precontractuele fase onrechtmatig is, en dat aan deze onrechtmatige handelwijze, nadat een overeenkomst tot stand is gekomen, (ook) gevolgen mogen worden verbonden die inhoudelijk dezelfde zijn als de gevolgen van een tekortkoming in de uitvoering van een overeenkomst (waarbij dan onderscheid kan worden gemaakt tussen de sanctie van ongedaanmaking van de overeenkomst, die op een wilsgebrek kan worden gebaseerd, en overige sancties, die als (vorm van) schadevergoeding wegens het onrechtmatig handelen kunnen gelden). Een andere benadering - die de eerder besprokene overigens niet uitsluit - berust op deze gedachtegang: veronachtzaming van de mededelingsplicht in de fase vóór er een overeenkomst wordt gesloten leidt er gewoonlijk toe dat de gegevens ten aanzien waarvan een mededelingsplicht bestond, vervolgens eigenschappen van het onderwerp van de overeenkomst zijn geworden, ten aanzien waarvan de wederpartij de verwachtingen mocht koesteren die (mede) door de niet in acht genomen mededelingsplicht zijn gevormd. Doordat de mededelingsplicht niet is nagekomen, zijn bij de andere partij bij de inmiddels gesloten overeenkomst gerechtvaardigde maar onjuiste verwachtingen ten aanzien van het onderwerp van de overeenkomst gewekt, of blijven bestaan. Als het onderwerp van de overeenkomst niet voldoet aan de gerechtvaardigde verwachtingen van een van de partijen, en aannemelijk is dat een veronachtzaamde mededelingsplicht daaraan debet is, moet er, zolang er geen andere gegevens zijn die tot een andere uitkomst leiden, worden aangenomen dat er een (toerekenbare) tekortkoming is aan de kant van de partij die haar mededelingsplicht veronachtzaamde: verwachtingen die de andere partij op grond van de betreffende overeenkomst mocht koesteren worden dan beschaamd, door een aan de "mededelingsplichtige" partij toe te rekenen oorzaak, aldus nog steeds de A-G. Alle wegen leiden volgens hem naar dezelfde (materiële) uitkomsten; en als de mededelingsplicht in een uitdrukkelijke (garantie)clausule was opgenomen, doet dat feit aan die uitkomsten maar heel weinig toe of af. Wanneer dit laatste echter niet het geval is, lopen wij niettemin op tegen het feit dat vooralsnog te onzent de onderscheidene grondslagen onderscheidene rechtsgevolgen kennen. Dit zal zo zijn totdat ons hoogste rechtscollege of de wetgever op dit punt voor (meer) flexibiliteit zal hebben gezorgd. ${ }^{798}$

Wanneer wij bedenken dat het uitvoeren van een due diligence onderzoek als belangrijkste ratio het beperken van risico's kent en het zich doen verschaffen door degene die het onderzoek doet uitvoeren van een positie om tot afspraken te komen omtrent aansprakelijkheden, dan kan worden gesteld, dat het nalaten van een due diligence onderzoek in beginsel kan gelden als een vorm van risico aanvaar-

\footnotetext{
796 Denkbaar is dat de wederpartij van de Investeerder sowieso van iets op de hoogte had moeten zijn in verband met diens bij zondere positie of deskundigheid. Zie T\&C Boek 6, artikel 228, aant.3.

${ }^{797}$ LJN AL7051 (Pont Eecen/Stratex).

${ }^{798}$ Zo blijft het bijvoorbeeld ook een vraag of de verkeersopvattingen die nu alleen in artikel 6:228 met zoveel woorden worden genoemd, ook in andere situaties dan bij dwaling nadrukkelijker worden betrokken.
} 
ding. Plaatsen wij dit onderwerp voor een ogenblik in het leerstuk van de dwaling, dan draagt het gestelde in artikel 6:228 lid 2 bij aan duidelijkheid. A-G Langemeijer vroeg zich in zijn conclusie bij het arrest inzake Vletter-Stijnman af $^{799}$ of er op het vlak van de overname van aandelen ("of zelfs van een heel bedrij", zoals hij het stelde) anders dan bij consumentenovereenkomsten niet van verkeersopvattingen zou kunnen worden gesproken. Ik meen dat dit zeker het geval is. Mos, een verkeersopvatting, is het in het huidige tijdbestel, waarin niets meer eenvoudig is, om niet een Investering te doen zonder vooraf een onderzoek in te (doen) stellen, in welke vorm dan ook. Zó due is - om met Van Dunné te spreken ${ }^{800}$ - een due diligence onderzoek in het geval van een Investering. Per sector kunnen normen gelden waar het de invulling betreft van hetgeen te gelden heeft op het vlak van de mededelings- en onderzoeksplicht. Hetgeen naar verkeersopvattingen in een bepaalde branche te gelden heeft, kan bepalend zijn voor de omvang van een onderzoeks- en mededelingsplicht, maar volgens mij vooreerst ook of het (doen) instellen van een onderzoek vooraf er bij hoort. ${ }^{801}$

In hoofdstuk 4 (onder 4.1) wees ik er al op, dat er rechtspraak is gevormd waar het bijvoorbeeld de autobranche betreft, de paardenhandel, de onroerend goed branche of ter zake van kredietverlening en borgtocht. Waar het Investeringen betreft, geldt naar mijn mening dus dat het instellen van een onderzoek (naar vermogen, gelet op de omstandigheden van het geval) niet achterwege mag worden gelaten. Deze opvatting brengt ook consequenties mee voor de toepassing van artikel 2:9 en voor de beantwoording van de vraag in het enquêterecht, wanneer er gesproken kan worden over strijd met elementaire beginselen van verantwoord ondernemerschap, indien zou worden overgegaan tot het doen van een Investering zonder naar vermogen een due diligence onderzoek te hebben ingesteld.

$\mathrm{Nu}$ is, zoals gezegd de ene transactie de andere niet, maar als vuistregel moet naar mijn mening zonder twijfel gelden dat bij het doen van een Investering, degene die de Investering doet naar vermogen een due diligence onderzoek zal moeten doen wil er niet van risico aanvaarding sprake zijn. Het element in artikel 7:17 lid 5, dat een koper rechten doet verliezen, wanneer die 'redelijkerwijs' bekend kon zijn met het feit dat een zaak of vermogensrecht niet aan de overeenkomst beantwoord, benadrukt het belang van de toevoeging 'naar vermogen' aan het vorenstaande.

'Naar vermogen' zal ook buiten de werkingssfeer van artikel 7:17 moeten worden ingevuld naar de omstandigheden van het geval en afhankelijk van de hoedanigheid van een partij. Onder omstandigheden van het geval moet ook een antwoord op de vraag worden gerekend of er van garanties, vrijwaringen of andere verklaringen of gedragingen van de wederpartij sprake was, die maakten dat van een onderzoek kon worden afgezien of met een beperkt onderzoek mocht worden volstaan. Niettemin is het hier voor genoemde uitgangspunt - hoewel niet nieuw - belangrijk. Het betekent, zoals gezegd, dat nog duidelijker dan voorheen als uitgangspunt heeft te gelden dat het achterwege laten van een due diligence onderzoek - in de vorm en met de diepgang die onder de omstandigheden van elk geval en gelet op de hoedanigheid van degene die de Investering overweegt - als risico aanvaarding kan worden aangemerkt. Dat betekent dat de Investeerder zich in beginsel niet met de verwachting van succes zal kunnen beroepen op non-conformiteit (wanprestatie), dwaling of een onrechtmatige daad, wanneer niet met inachtneming van de hier voor genoemde nuanceringen, naar vermogen een due di-

${ }^{799}$ HR 16 juni 2000, NJ 2001, 559 m.nt. JH. Zie in hoofdstuk 4.2 onder Mededelingsplicht versus onderzoeksplicht?

800 Zie J.M. van Dunné, Onderzoeks- en spreekplichten bij bedrijfsovername, Hoe "due" is "due diligence"sinds Hoog Catharijne?, in Onderneming en 5 jaar nieuw burgerlijk recht, Serie Onderneming en Recht, deel 7, p. 399 e.v.

801 A-G Huydecoper zegt in zijn conclusie onder HR 8 december 2006 (LJN AY7456) dat er volgens hem geen wezenlijk verschil bestaat tussen de maatstaf waarnaar moet worden beoordeeld of dwaling "(on)verschoonbaar" is, danwel of dwaling naar verkeersopvatting voor rekening van de dwalende partij moet blijven, of er sprake is van een "onderzoeksplicht" die, als daaraan niet voldaan is, aan een beroep op dwaling in de weg mag staan: in ieder van deze varianten gaat het erom dat de omstandigheden van dien aard zijn dat de dwaling waarop een beroep wordt gedaan, voor rekening van de dwalende behoort te blijven. De verschillen in gekozen aanduidingen zien niet op een verschillende beoordelingsmaatstaf, maar geven slechts een indicatie van de categorie van omstandigheden die in het beoogde geval als doorslaggevend voor de toerekening aan de dwalende wordt aangemerkt (bij de aanduidingen "(on)verschoonbaar" danwel "onderzoeksplicht" denkt men dan eerder aan een al te lichtvaardige benadering door de dwalende partij zelf (of diens "hulppersoon"), terwijl "verkeersopvattingen" eerder zullen aanknopen bij de aard van de informatie waaromtrent gedwaald is: "gebrekkige kennis van sommige informatie wordt gerekend tot de risicosfeer van de partij die met miskenning daarvan tot een overeenkomst toetreedt en (gebrekkige) kennis omtrent andere informatie juist niet). Ik denk dat er niets aan in de weg staat om het begrip verkeersopvattingen ook te doen gelden als richtsnoer voor de beantwoording van de vraag of het uitvoeren van een due diligence onderzoek van een partij had mogen worden verwacht. Het achterwege laten daarvan kan meebrengen dat de dwaling voor rekening van de Investeerder behoort te blijven. 
ligence onderzoek zal zijn uitgevoerd. Soms zal dat onderzoek kunnen bestaan uit het zorgvuldig lezen van een financiële bijsluiter, in andere gevallen zal er een volledig team van specialisten op pad gestuurd moeten worden. De omvang en diepgang van een onderzoek zal als gezegd mede worden bepaald door hetgeen er gelet op de hoedanigheid van de betrokken partijen en in de omstandigheden van het geval van de Investeerder mag worden verwacht. In hoofdstuk 4 is al ingegaan op omstandigheden die kunnen maken dat er met een minder diepgaand onderzoek wordt volstaan of er zelfs van een due diligence onderzoek kan worden afgezien. Redenen voor een beperkt(er) due diligence onderzoek, of zelfs het achterwege laten daarvan, kunnen zijn dat er door de wederpartij mededelingen worden gedaan waar men in gemoede op af mag gaan of garanties worden gegeven, die vergezeld worden van verhaalsmogelijkheden in het geval die niet zouden worden nagekomen.

In de lagere rechtspraak is een veelheid van uitspraken bekend, waarin de onderzoeksplicht met de mededelingsplicht strijdt om de voorrang. De hoedanigheid van partijen en de feitelijke omstandigheden in elk geval zijn bepalend. Naar mijn mening moeten wij echter zien af te komen van de verwarrende vraagstelling of een onderzoeksplicht zwaarder weegt dan een mededelingsplicht of andersom. Het onderbrengen van de beide begrippen onderzoeksplicht en mededelingsplicht in het ene begrip toerekenbare (onjuiste) veronderstelling drukt beter uit dat beide partijen een rol (een zekere zorgplicht) hebben te vervullen bij het tot stand komen van een transactie om er voor te zorgen dat die zo tot stand komt, dat procederen achteraf niet nodig zal zijn.

Zoals in hoofdstuk 5 (onder 5.4) aangegeven vindt het begrip zorgplicht in ons land steeds meer ingang en niet alleen in het effectenverkeersrecht. Het begrip geeft naar mijn mening op passende wijze uitdrukking aan het gegeven dat een Investeerder, maar meer in het algemeen ook een koper, maar even zo goed diens wederpartij, zich beiden inspanning zouden moeten getroosten (de passende zorg moeten besteden) aan het op een zodanige wijze tot stand brengen van een door hen voorgenomen transactie, dat er met de gerechtvaardigde belangen van de ander rekening is gehouden. Er moet invulling worden gegeven aan wat door Van Baalen - zij het met het oog op de effectenhandel - als precontractuele zorgplichten is aangeduid. ${ }^{802}$ Wat mij betreft is er niet zo veel verschil tussen transacties in de effectenhandel (ook kapitaalmarkttransacties) en (andere) onderhandse transacties, zoals fusies, overnames en het nemen van participaties of het aangaan van joint ventures. Ook buiten het terrein van de effectenhandel kan daarom heel goed van het begrip zorgplicht gebruik worden gemaakt om aan te geven dat er een zorgvuldigheidsnorm aan de orde is waarvan beide bij een Investering betrokken partijen zich rekenschap dienen te geven.

Bij de beantwoording van de vraag wie welke duidelijkheid aan de ander had behoren te verschaffen moet zoals gezegd worden gelet op de hoedanigheid van de betrokken partijen en de omstandigheden van het geval. Door het gebruik van de definitie van Investering is de aard van de zaak een gegeven.

Het door mij eerder in dit boek genoemde begrip toerekenbare veronderstelling nu drukt naar mijn mening beter uit - of zo men wil, de toerekenbare onjuiste veronderstelling - dat er op beide partijen, aan beide zijden van een transactie een zekere zorgplicht rust of zou moeten rusten om rekening te houden met de (kenbare) belangen van de wederpartij. Afhankelijk van wat men weet, of behoort te weten wat de ander (niet) weet, past het binnen de opvattingen over de pre contractuele redelijkheid en billijkheid dat beide partijen over en weer zich er van vergewissen - en daarvoor zich inspannen door uitdrukking van of het stellen van vragen en het geven van inlichtingen omtrent de eigen positie - dat er bij hun wederpartij niet sprake is van een onjuiste veronderstelling. Spant men zich daarvoor onvoldoende in, dan is dat strijdig met een zorgplicht die ontleend kan worden aan de richtsnoer welke de Hoge Raad al in het arrest Baris/Riezenkamp ${ }^{803}$ gaf en welke nog te vinden is in de uitspraak van de Hoge Raad over het afbreken van onderhandelingen van 12 augustus $2005,{ }^{804}$ namelijk dat partijen hun gedrag door elkaars gerechtvaardigde belangen moeten laten bepalen. Voor ons onderwerp kan dit een bijstelling van het paradigma opleveren waar het gaat over de vraag hoe uitgebreid een due diligence onderzoek had moeten zijn. Dit geeft weer sturing bij de beantwoording van de vraag of een

\footnotetext{
802 S.B. van Baalen, Zorgplichten in de effectenhandel, Serie Recht en Praktijk, nummer 140, p. 137 e.v.

${ }^{803}$ HR 15 november 1958, NJ 1958, 67, waarin werd gezegd: "dat immers partijen, door in onderhandeling te treden over het sluiten van een overeenkomst, tot elkaar komen te staan in een bijzondere, door de goede trouw beheerste, rechtsverhouding, medebrengende, dat zij hun gedrag mede moeten laten bepalen door de gerechtvaardigde belangen van de wederpartij; dat dit onder meer medebrengt, dat voor degene die overweegt een overeenkomst aan te gaan, tegenover de wederpartij een gehoudenheid bestaat om binnen redelijke grenzen maatregelen te nemen om te voorkomen dat hij onder den invloed van onjuiste veronderstellingen zijn toestemming geeft, de omvang van welke gehoudenheid mede hierdoor wordt bepaald, dat men in den regel mag afgaan op de juistheid van door de wederpartij gedane mededeling".

804 NJ 2005, 467
} 
teleurstelling achteraf door diens wederpartij zou mogen worden beantwoord met een verwijt dat er door de Investeerder onvoldoende (diepgaand) onderzoek is gedaan. Het antwoord op die vraag wordt namelijk mede bepaald door het gedrag van die van die wederpartij zelf.

Er is als gezegd ook een gemeenschappelijk belang. De Investeerder/koper heeft belang bij eerlijke voorlichting en de wederpartij van de koper heeft er belang bij om na het voltooien van een transactie niet geconfronteerd te worden met reclames en vorderingen wegens teleurgestelde verwachtingen, niet-nakoming of dwaling. De Investeerder/koper moet zich inspannen om vooraf duidelijk te maken wat voor hem relevant is. Het gaat te ver om van een wederpartij te verlangen dat die zelfstandig een onderzoek doet naar de motieven van de Investeerder (onder omstandigheden kan een verschil in hoedanigheid tussen partijen (kennis en ervaring) wel een spontane onderzoeksplicht meebrengen, vergelijk de effectenhandel en het beleggingsprofiel). Het is in de eerste plaats echter - zo meen ik de verantwoordelijkheid van de Investeerder om diens motieven op de voorhand duidelijk te maken. ${ }^{805}$ Men kan zich zelfs afvragen of het niet op de voorhand duidelijk maken van de bedoelingen door een Investeerder - de considerans van een LOI is daar bijvoorbeeld een bij uitstek geschikte plaats voor niet tevens als een vorm van risico aanvaarding kan worden gezien. Niettemin hebben beide partijen de hier voor bedoelde precontractuele zorgplicht om tegen een onjuiste veronderstelling aan de zijde van de ander te waken. De eigen verantwoordelijkheid blijft daarnaast voor beiden gelden. Bij de verdeling van de gevolgen van een teleurstelling zal de wederpartij van de Investeerder afhankelijk van zijn eigen bijdrage aan de tot standkoming of het in stand houden van een onjuiste veronderstelling, wel of niet kunnen stellen dat een due diligence onderzoek onvoldoende grondig is geweest en zich wel of niet kunnen onttrekken aan de gevolgen van de teleurstelling aan de zijde van de Investeerder. Het zou daarbij de voorkeur verdienen wanneer het er daarbij niet toe zou behoeven te doen of er sprake is van een actie op grond van dwaling, non conformiteit of een onrechtmatige daad. Zolang er geen wettelijke algemene regel gegeven is voor pre contractuele verhoudingen, moeten wij het doen met de door de wetgever gegeven grondslagen en de normen welke uit de jurisprudentie kunnen worden afgeleid.

Zolang de dingen zijn zoals ze zijn, geldt voor een Investeerder die wil voorkomen dat die achteraf op grond van een (of meer) te kiezen grondslag(en) een actie zal moeten instellen om de gevolgen van een teleurstelling na verrichten van een Investering hersteld te zien, er beter aan doet vooraf een zo grondig mogelijk due diligence onderzoek in te stellen.

Soms wordt men niet in de gelegenheid gesteld om een due diligence onderzoek in te stellen. Toevlucht zal dan moeten worden genomen tot het bedingen van garanties, escrows, verrekeningsmechanismen en dergelijke of moeten afzien van de transactie. Wanneer er geen kijk in de keuken genomen kan worden, is het alternatief dat er gedetailleerde vragen worden gesteld. Aan de omvang en kwaliteit van de alsdan te verkrijgen informatie moeten hoge eisen worden gesteld. Degene die heeft geweigerd om een due diligence onderzoek toe te staan, neemt daarmee ook een verantwoordelijkheid op zich om er voor in te staan dat de welverschafte informatie deugdelijk is. Het kan voorkomen zelfs dat een verkoper kan worden geacht toch voldoende aan een informatieplicht te hebben voldaan, ondanks het feit dat geen due diligence onderzoek werd toegelaten. ${ }^{806}$ Nodeloos te zeggen dat in een geval waarin onvoldoende eigen waarneming mogelijk is geweest, niet alleen garanties, maar ook zekerheden voor de nakoming van die garanties proportioneel in belang toenemen.

$\mathrm{Nu}$ er onder omstandigheden voor beide partijen sprake kan zijn van een onderzoeksplicht en/of een mededelingsplicht ("plicht" als Obliegenheit of niet), vind ik de (te) zelfstandige betekenis, die deze begrippen hebben verkregen, eerder verwarrend dan verhelderend. Te veel roept "onderzoeksplicht" een associatie op met een verplichting (al dan niet alleen als "rechtsdrang") aan de zijde van de Investeerder of koper en "mededelingsplicht" als iets dat tot de verantwoordelijkheid van de wederpartij of verkoper zou moeten worden gerekend. De dynamiek die in de schuivende panelen van de wederzijdse

\footnotetext{
${ }^{805}$ Gerbrandy, a.w., wijst op HR 21 januari 1966, NJ 1966, 183 m.nt. G.J.S. (Booy/Wisman). "Wisman, koper, had duidelijk gezegd, dat hij een kraan nodig had die niet slechts, rijdenderwijs enige meters verplaatst kon worden, maar dat hij moest werken in verschillende plaatsen in Nederland, waarbij vervoer over de weg (en dus een kentekenbewijs) nodig was." Dat Wisman op zijn vraag of de kraan aan zijn eis voldeed een bevestigend antwoord had gekregen, kan als een mededeling van de verkoper waarop men mag afgaan worden uitgelged of zelfs als een garantie, maar feit blijft, dat de mededeling van Booy in dit geval het gevolg was van de door Wisman over diens positie vooraf verschafte duidelijkheid.

${ }^{806}$ Zie gerechtshof Amsterdam 16 april 1998, NJ 1999, 161.
} 
verantwoordelijkheden van de precontractuele redelijkheid en billijkheid besloten zit of althans zou behoren te zitten, komt daardoor voor mijn gevoel niet voldoende tot uitdrukking. Daarom beveel ik het hanteren van het begrip "toerekenbare (onjuiste) veronderstelling" aan, niet omdat daarbinnen niet een onderzoeksplicht en mededelingsplicht in de traditionele zin een rol spelen, maar omdat dat begrip tot uitdrukking brengt dat er een precontractuele zorgplicht geldt. Of op enig ogenblik van (het ontbreken van) gedragingen van een (van de) partijen nu het rechtsgevolg van het ontbreken van wilsovereenstemming kan worden verbonden, of een vordering tot nakoming, ontbinding of vergoeding van schade, doet er niet zo veel toe zoals wij zagen. In de rechtsverhouding tussen partijen, kan een tipping point ontstaan en worden aangewezen, mogelijk of zelfs heel denkbaar met gebruikmaking van noties als onderzoeks- en mededelingsplicht of onderzoeks- en mededelingsverantwoordelijkheid, welk maakt dat de rechtsgevolgen van een (onjuiste) veronderstelling aan de één of aan de ander moeten worden toegerekend. Het door de Investeerder nagestreefde rechtsgevolg zal dan - afhankelijk van de situatie en de ingeroepen grondslag - wel of niet kunnen intreden doordat een daartoe strekkende vordering zal worden toegewezen. Gebruikmaking van de door mij aanbevolen terminologie sluit wellicht beter aan bij de gedachte dat aan de voorkant van het bedoelde tipping point voor beide partijen bij een transactie geldt dat rekening moet worden gehouden met de redelijke belangen van de ander. Het voordeel van het begrip "toerekenbare (onjuiste) veronderstelling" is dat dit niet gehinderd wordt door het keurslijf van de formuleringen van artikel 6:17 of 6:228, maar beter aansluit bij de algemene norm van de precontractuele redelijkheid en billijkheid.

Een Investeerder tenslotte moet steeds blijven bedenken dat een transactie niet door behoeft te gaan. Sterker nog - in onderhandelingen geldt een gouden regel - en die is, "dat men een zaak nooit goed doet, wanneer men niet de bereidheid heeft die niet door te laten gaan." 


\section{Samenvatting}

Dit boek bevat de neerslag van de poging om een landkaart te tekenen van het fenomeen due diligence zoals dat in het Nederlands recht een plaats heeft verworven. Er werd tot dusverre met enige regelmaat in de literatuur aandacht aan het verschijnsel due diligence gegeven, maar een overzicht ontbrak.

Teneinde het onderwerp in kaart gebracht te krijgen is eerst een begripsomschrijving gegeven en is ingegaan op de eigen plaats van een due diligence onderzoek te midden van andere vormen van onderzoek (hoofdstuk 1). Na een blik op de herkomst van het fenomeen due diligence (als activiteit ter vermijding van risico en aansprakelijkheid in de Angelsaksische transactiepraktijk) en over de grens (Duitsland, Engeland en Frankrijk), wordt besproken op welke informatie een due diligence onderzoek zich gemeenlijk richt. Een eerste plaatsbepaling van het onderzoek stelt een due diligence onderzoek apart van andere soorten van onderzoek, zoals bijvoorbeeld een periodiek accountantsonderzoek, een waardeonderzoek of een onderzoek ten behoeve van een risk management project.

Een due diligence onderzoek is een instrument dat wordt gebruikt bij het tot stand brengen van transacties in de zakelijke sfeer.

Een equivalent voor het begrip due diligence in het Nederlands zou "gepaste voorzichtigheid" zijn of "verschuldigde oplettendheid". Een due diligence onderzoek komt aan de orde wanneer er sprake is van een wijziging in de zeggenschap over een rechtspersoon of in de eigendom van een onderneming of er een (andere) financiële transactie van betekenis aan de orde is. Te denken valt aan beursintroducties, fusies, overnames, het aangaan van joint ventures, het nemen van een financiële of juridische deelneming of het tot stand brengen van leningsarrangementen of andere financiële transacties. Een bijzondere vorm van onderzoek is de zogenaamde customer due diligence, het onderzoek dat van dienstverleners in de financiële markt verlangd wordt naar de identiteit en het risicoprofiel van hun cliënten.

Waar het bij de meeste van de hier voor bedoelde transacties van "buitenaf" niet te zien is of er in de doelwitvennootschap of bij de wederpartij aansprakelijkheden aan de orde (kunnen) zijn ("lijken in de kast") wordt een onderzoek uitgevoerd om teleurstellingen achteraf zoveel mogelijk te vermijden. Of er gesproken kan worden van "gepaste" voorzichtigheid of van "verschuldigde" oplettendheid, komt in het boek aan de orde. Afgezien van situaties waarin de Wet financieel toezicht het instellen van een onderzoek verlangt, is er in Nederland geen wettelijke regel met een verplichting om voorafgaand aan het aangaan van een transactie een onderzoek in te stellen. Van verschuldigdheid in de zin van een verplichting kan in het algemeen dus niet worden gesproken. Niettemin kan het nalaten van een zorgvuldige oriëntatie omtrent de betrouwbaarheid van een wederpartij en het voorwerp van een transactie tot grote nadelen leiden. Daarom luidt één van de stellingen in dit proefschrift, dat het uitvoeren van een due diligence onderzoek gerekend moet worden tot de elementaire beginselen van verantwoord ondernemerschap. Het nalaten van een onderzoek, kan leiden tot de kwalificatie dat er sprake is van wanbeleid (artikel 2:355 BW) en onder omstandigheden van onbehoorlijk bestuur (artikel 2:9 BW). De Nederlandse Corporate Governance Code zou nadrukkelijker tot uitdrukking moeten brengen dat het verrichten van een acquisitie zonder naar vermogen een due diligence onderzoek uit te (doen) voeren niet aanvaardbaar is. Voorgeschreven zou ook moeten worden dat in het geval dat een openbaar bod wordt aangekondigd de doelwitvennootschap een kerncommissie zou moeten instellen uit de raad van commissarissen (of bestaande uit algemene bestuurders in een one tier systeem). Die commissie zou het stuur gedurende de periode van besluitvorming over het bod in handen moeten nemen. Die kan ook toezien op een gelijke behandeling van partijen die inzage in informatie van de doelwitvennootschap willen nemen en er voor zorgen dat al het mogelijke wordt gedaan om misbruik van voorwetenschap te voorkomen. 
Een due diligence onderzoek komt voor in veel verschijningsvormen. Het wordt voor diverse doeleinden verricht. In hoofdstuk 2 worden die verschillende verschijningsvormen en toepassingen besproken. In het volgende hoofdstuk (3) met de titel "causa efficiens, aanleiding voor het instellen van een due diligence onderzoek" (rechtstreekse, onmiddellijke oorzaak) wordt meer in het bijzonder ingegaan op de redenen waarom een opdrachtgever aanleiding zal zien om een due diligence onderzoek te laten uitvoeren. Aandacht wordt gegeven aan de betekenis welke het inzetten van een dergelijk onderzoek en de uitkomst daarvan kan hebben in de strategie van onderhandelingen over een transactie. leder van de bij een transactie betrokken partijen heeft een eigen agenda. De belangen divergeren. Het tijdstip waarop een onderzoek wordt uitgevoerd en de manier waarop zijn niet zelden een integraal onderdeel van de strategie van beide partijen om de eigen agenda zoveel mogelijk gerealiseerd te krijgen. In relatie daarmee zijn aspecten als geheimhouding en een denkbare exhibitieplicht (artikel $843 \mathrm{Rv}$.) van betekenis. Hoeveel informatie wil men op welk tijdstip verkrijgen - of, al naar gelang het geval, prijsgeven - en welke resultaten van een onderzoek zal men willen of moeten delen met de andere partij? Op vragen welke daarmee samenhangen wordt ingegaan in hoofdstuk 10 en 11.

In hoofdstuk 4 wordt bezien hoe het fenomeen due diligence past in het in ons land geldende rechtstelsel. Nu het fenomeen due diligence in het Nederlands recht geen eigen plaats kende, moest die plaats worden gevonden door middel van kwalificatie van de verschillende elementen welke daarin te onderscheiden zijn. Dit leidde tot de toepassing van de leerstukken van de onderzoeksplicht en de mededelingsplicht, zoals die zich in ons recht hebben ontwikkeld. De leerstukken die ten grondslag liggen aan de leerstukken van een onderzoeksplicht en een mededelingsplicht worden in hoofdstuk 5 besproken met de beperking welke past bij een boek dat over due diligence gaat en niet over de leerstukken van dwaling, conformiteit, bedrog, onrechtmatige daad of wanprestatie zelf. De leerstukken van de onderzoeksplicht en mededelingsplicht hebben vooral een profiel verworven in de rechtspraak en de literatuur. De transacties waarbij een due diligence onderzoek te pas komt onderscheiden zich van gewone consumententransacties door hun omvang en complexiteit en het daarmee gemoeide financiële belang. Ook doordat het transacties betreft die zich over het algemeen niet gemakkelijk weer ongedaan laten maken. Sommigen menen dat een ander kenmerk is dat het om transacties gaat welke door professionele partijen - ondernemers - worden verricht. Ondernemers zullen weliswaar meer ervaring hebben met het aangaan van transacties in het algemeen dan gewone consumenten, maar de categorie van besluiten waarbij een due diligence onderzoek aan te raden is, kan ook voor ondernemers een incidentele ervaring betreffen. Niet elke ondernemer koopt of verkoopt regelmatig ondernemingen of sluit bij voortduring omvangrijke financiële transacties af.

De voor de ontwikkeling van de leerstukken van een onderzoeksplicht en een mededelingsplicht meest relevante uitspraken van ons hoogste rechtscollege in de periode 1958 tot en met 2000 worden geïnventariseerd. Dit is de periode waarin in ons land het leerstuk van due diligence meer handen en voeten heeft gekregen. Stilgestaan wordt bij de belangrijkste literatuur uit die periode. De rechtspraak leverde voor de due diligence praktijk in een aantal opzichten duidelijkheid op. Er werd jurisprudentie gevormd die rechtstreeks betrekking had op de koop en verkoop van aandelen en ondernemingen, hetgeen iets anders is dan de koop en verkoop van tweede hands auto's, huizen, geiten of andere enkelvoudige goederen. Eén van de belangrijkste conclusies was wel dat het nalaten van een onderzoek of het verrichten van een gebrekkig onderzoek, maakt dat er aan de zijde de koper of investeerder in de rechtsverhouding een component van risicoaanvaarding binnen treedt. Als er iets onduidelijk is, moet er navraag worden gedaan. Verder worden in de literatuur ontwikkelde vuistregels genoemd die onder meer inhouden dat de omvang van een onderzoeksplicht mede kan worden bepaald door omstandigheden als de onderlinge relatie tussen partijen (vertrouwen), de hoedanigheid van partijen (professionaliteit), de vraag of er sprake is van bijzondere eigenschappen van de zaak en of gegevens naar verkeersopvattingen als algemeen bekend mogen worden verondersteld.

Een door de Hoge Raad in 1958 ontwikkelde norm doet nog steeds opgeld en wordt zelfs nog meer actueel. Het betreft een uit de redelijkheid en billijkheid voortvloeiende wederzijdse zorgplicht van partijen om te voorkomen dat een transactie onder invloed van een onjuiste veronderstelling wordt aan- 
gegaan. Een andere in het boek verdedigde stelling is daarom dat er op beide partijen een verantwoordelijkheid rust om over en weer mededelingen te doen en onderzoek te verrichten omtrent het voorwerp van een transactie.

Ingegaan wordt op de vraag hoe een onderzoeksplicht en mededelingsplicht zich ten opzichte van elkaar verhouden. Het gebruik van het begrip "plicht" moet worden verstaan in het kader van de verantwoordelijkheid welke ingevolge de redelijkheid en billijkheid op beide partijen rust om te voorkomen dat de wederpartij onder invloed van een onjuiste veronderstelling tot een transactie toetreedt. Ook wordt stilgestaan bij de relatie van een onderzoeksplicht tot het verstrekken van garanties en vrijwaringen door één van de partijen (opgewekt vertrouwen). Als vuistregel kan gelden dat het ontvangen van specifieke mededelingen en/of garanties en vrijwaringen aanleiding kan zijn geen of minder (vergaand) onderzoek te doen. Risicoverdeling kent echter meer aspecten dan alleen een geruststelling in de vorm van een bijzondere mededeling of een garantie. Zo is daar de vraag of er in een voorkomend geval (voldoende) verhaal voorhanden is voor dekking van de (volledige) schade. Daarbij komt dat een onderzoek niet meer kan opleveren dan er aan informatie voorafgaand aan het tot stand komen van een transactie ter beschikking is gesteld en/of (anderszins) kon worden waargenomen.

Benadrukt wordt dat er ook sprake is van een onderzoeksplicht nà het tot stand komen van een transactie. Er zal voortvarend moeten worden onderzocht of een prestatie voldoet aan hetgeen werd overeengekomen en/of een afgeleverde zaak voldoet aan hetgeen gelet op de aard van de zaak en de ontvangen mededelingen de eigenschappen bezit die op grond van de overeenkomst mochten worden verwacht. Artikel 7:17 BW inzake conformiteit, zo wordt op een enkele uitzondering na algemeen aangenomen, is ook van toepassing op de koop van aandelen. Zowel op grond van artikel 7:23 BW als ook op grond van artikel 6:89 BW kan er verlies van reclamerecht optreden, wanneer er na aflevering van een zaak of een prestatie niet wordt geprotesteerd binnen bekwame tijd nadat het gebrek werd ontdekt of had moeten worden ontdekt.

In hoofdstuk 6 wordt de rechtspraak op het vlak van due diligence besproken zoals die na het jaar 2000 is ontwikkeld. Daarbij komen onderwerpen aan de orde als de vraag of het verwijtbaar is dat onderzoekers problemen over het hoofd gezien hebben, die zo bijzonder zijn, dat men op het bestaan daarvan niet bedacht behoefde te zijn. Verdedigd wordt dat niet te snel mag worden aangenomen dat onachtzaamheid verschoonbaar is. Ingegaan wordt op de vraag wanneer het bestaan van verkeersopvattingen mag worden aangenomen. Voor zover op het terrein van fusies en overnames sprake zou zijn van een verkeersopvatting dat een onderzoeksplicht zou moeten prevaleren boven een mededelingsplicht of andersom, wordt opgemerkt, dat ter zake geen algemene regel te formuleren valt. Een ander paradigma wordt aanbevolen. Door de vraag te stellen welke van de partijen het kan worden toegerekend dat de ander in een onjuiste veronderstelling verkeerde ten tijde van het aangaan van een transactie, kan de vraag worden beantwoord aan wie het risico van problemen achteraf behoort te worden toegerekend. Het is daarbij niet beslissend of het veroorzaken of in stand laten van een onjuiste veronderstelling met (kwade) opzet gebeurde. Het gebruik van het begrip 'toerekenbare veronderstelling' of 'toerekenbare (onjuiste) veronderstelling' maakt duidelijk dat beide bij een transactie betrokken partijen verantwoordelijkheid (hebben te) dragen om te vermijden dat er achteraf problemen ontstaan. In het normale geval hebben zij daar ook allebei belang bij. De connotatie dat een onderzoeksplicht duidt op verantwoordelijkheden van (alleen) de koper en een mededelingsplicht duidt op een verantwoordelijkheid van (alleen) de verkoper krijgt daar door minder kans om post te vatten.

Verder wordt in hoofdstuk 6 stilgestaan bij de betekenis van een onevenwichtige verdeling van deskundigheid bij contracterende partijen; de noodzaak om als vermeende gelaedeerde een vordering te kunnen onderbouwen; verdiscontering van risico wanneer beide partijen bij een transactie verantwoordelijk kunnen worden geacht voor de problemen welke zich eerst achteraf voordoen (daarbij ook de verantwoordelijkheid betrokken voor het inzetten van hulppersonen of gevolmachtigden) en bij bijkomende omstandigheden, zoals de voorwaarden welke (overigens) vervuld moeten zijn om met succes een beroep te doen op een gebrek in de prestatie of bijvoorbeeld non conformiteit van een afgeleverde zaak. Het hoofdstuk wordt afgesloten met een aantal nadere gevolgtrekkingen. Die komen er 
ruwweg gezegd op neer, dat tussen ondernemers voorop staat dat ieder in beginsel het eigen belang nastreeft. Het gaat om de toerekenbare veronderstelling. Ook tussen ervaren ondernemers geldt dat over en weer rekening moet worden gehouden met hetgeen men weet of kan vermoeden dat bij de ander de veronderstelling is omtrent de kennis van het voorwerp van de transactie. Een grotere (kenbare) deskundigheid bij een wederpartij zal eerder de veronderstelling opleveren dat die meer weet. Afgezien van aanprijzingen in algemene bewoordingen (artikel 3:44 lid 3 laatste zin BW) mag in de regel worden vertrouwd op de juistheid van gedane mededelingen. Bij twijfel dient nader onderzoek plaats te vinden.

In hoofdstuk 7 wordt ingegaan op een aantal juridische aspecten welke samenhangen met het fenomeen van een due diligence onderzoek. Bijvoorbeeld de vraag of het uitvoeren van een onderzoek moet meebrengen dat er nog maar beperkt garanties in overnamecontracten behoeven te worden opgenomen. Stilgestaan wordt bij functie van een zogenaamde disclosure letter en bij de vraag welke betekenis toekomt aan de opmerking dat informatie is verschaft 'naar beste wetenschap'. Kan er een rechtsplicht worden aangenomen om tijdens het onderzoek vastgestelde gebreken te melden aan vertegenwoordigers van het voorwerp van onderzoek?

Een due diligence onderzoek is bedoeld als waarborg tegen teleurstellingen. Dit betekent dat er veelal in de afspraken opgenomen wordt dat de uitslag van het onderzoek bepalend zal zijn voor de vraag of de onderzoekende partij uiteindelijk gebonden wil zijn aan een transactie. Besproken wordt welke rol opschortende of ontbindende voorwaarden in dit opzicht vervullen (zoals ook subject to board approval clausules). Er wordt stilgestaan bij material adverse change clausules, die het recht geven om van een transactie af te zien wanneer er zich bijvoorbeeld na afsluiting van het onderzoek nog een wijziging in de omstandigheden voordoet waardoor een (volstrekt) ander licht op de voorgenomen transactie wordt geworpen. Het hoofdstuk wordt afgesloten met de bespreking van enkele algemene onderwerpen zoals de vraag of het ten onrechte achterwege laten van mededelingen waarvan moet worden aangenomen dat die relevant zijn voor de wederpartij aanleiding kan zijn voor persoonlijke aansprakelijkheid.

Het maakt verschil of er sprake is van kapitaalmarkt transacties dan wel onderhandse transacties. Op die verschillen werd in hoofdstuk 1 al ingegaan. Due diligence wordt bij kapitaalmarkttransacties in een andere context gebruikt dan bij onderhandse transacties. In het eerste geval gaat het vooral om de mate van zorgvuldigheid die een bank als lead manager in acht moet nemen jegens het beleggend publiek, terwijl bij een onderhandse transactie men een onderzoek vooreerst voor zichzelf doet. Overigens doet een bank een onderzoek niet alleen maar ten behoeve van het beleggend publiek. De wens staat voor aansprakelijkheid te vermijden vanwege misleidende of onvolledige informatie in documentatie welke op een transactie betrekking heeft. Prospectusaansprakelijkheid is één van de onderwerpen welke in hoofdstuk 8 nader aan de orde komen. Ingegaan wordt op de vereisten waarmee een beursvennootschap heeft te rekenen wanneer het onderwerp due diligence aan de orde komt, zoals het vermijden van problemen rond voorwetenschap. Aandacht wordt besteed aan vragen van aansprakelijkheid van verschillende betrokken partijen op de primaire markt maar ook op de secundaire markt (de markt waar inmiddels aangeboden effecten worden verhandeld).

Vragen rond de uitvoering van een due diligence onderzoek (opdrachtformulering, wijze van rapporteren en dergelijke) komen aan de orde in hoofdstuk 9, evenals vragen rond kwaliteitswaarborgen bij de uitvoering van een onderzoek. Op welke normen dient een onderzoeker acht te slaan, moet deze bijvoorbeeld hoor en wederhoor toepassen alvorens rapport uit te brengen? Aspecten van geheimhouding hangen met een en ander rechtstreeks samen. Die komen in het volgende hoofdstuk (10) aan de orde. Vragen van deontologie (beroepsgedragsregels) alsmede bijzondere onderwerpen als afspraken rond de toelating tot informatie (data room protocol) en de Wet bescherming persoonsgegevens passeren de revue. In hoofdstuk 11 wordt daarna de betekenis besproken welke de nu sedert een aantal jaren in ons land geldende bepalingen van artikel 843a Rv. hebben voor de mogelijkheid om de inhoud van een due diligence rapport te kunnen beschouwen als behorend tot het exclusieve domein van degene die tot het verrichten van het onderzoek opdracht heeft gegeven. De bijzondere exhibitieplicht 
van artikel 843a Rv. geeft onder voorwaarden recht op inzage, afschrift of uittreksel van bepaalde bescheiden, zelfs wanneer die zich bij een derde bevinden. Wie kan er een beroep op doen dat deze uit hoofde van diens ambt, beroep of betrekking, niet aan een veroordeling tot overlegging van stukken behoeft te voldoen? Is artikel 843a Rv. van dwingendrechtelijke aard? Hoe moet met vragen als hier voor bedoeld worden omgegaan wanneer de fiscale autoriteiten inzage in de resultaten van een due diligence onderzoek willen nemen?

In hoofdstuk 12 wordt met een enkel woord ingegaan op de vraag of en hoe due diligence in artikel 25 van de Wet op de ondernemingsraden een rol kan spelen, waarna in hoofdstuk 13 vragen aan de orde worden gesteld rond beroepsaansprakelijkheid van onderzoekers en mogelijkheden van die onderzoekers om aansprakelijkheid te beperken of uit te sluiten (exoneratiemogelijkheden). Bij beantwoording van de vraag hoe ver de verantwoordelijkheid (en in het verlengde daarvan aansprakelijkheid) van onderzoekers strekt, zal met meerdere omstandigheden rekening moeten worden gehouden. In het algemeen geldt dat het aanbeveling verdient een due diligence onderzoek te laten uitvoeren door deskundigen die ter zake ervaring hebben. Kennis en het ontbreken daarvan aan de zijde van ingeschakelde hulppersonen worden als regel aan de opdrachtgever toegerekend.

Hoofdstuk 14 bevat een aantal slotopmerkingen. Er wordt onder meer op gewezen dat in de jaren 2006 en 2007 wereldwijd er voor 8.650 miljard aan grote transacties werd gemeld. Volgens onderzoekers was het grootste gedeelte daarvan tot mislukken gedoemd (volgens cijfers van Business Week en The Economist mislukt $70 \%$ van alle fusies en overnames, volgens de Utrechtse hoogleraar Schenk zelfs $85 \%$ ). Toch wordt ter gelegenheid van die fusies en overnames in vrijwel alle gevallen vooraf onderzoek ingesteld en ligt er aan de besluitvorming een plan ten grondslag. De fase na het due diligence onderzoek is vervolgens bepalend voor het succes van een fusie of overname. Gelet op het veronderstelde aantal mislukte integratieprocessen - ondanks een uitgevoerd due diligence onderzoek - levert dit een aanwijzing op dat er in een due diligence onderzoek nog meer aandacht uit zou moeten gaan naar de zogenaamde 'zachte factoren' voor zover die meetbaar of inschatbaar zijn. Deze factoren zijn als indicatoren ook voor de kansen op succes voor het doormaken van een succesvol integratieproces belangrijk. Daarbij moet dan vooral worden gedacht aan cultuur. Er is inmiddels een toenemend aantal mogelijkheden voorhanden om tijdens een due diligence onderzoek ook de bedoelde zachte factoren in kaart te brengen (hetgeen in hoofdstuk 2 wordt besproken). Vast te stellen is in ieder geval dat een due diligence onderzoek niet alleen maar een juridische of financiële aangelegenheid is of zou mogen zijn. Afhankelijk van het soort transactie zullen andere dan juridische en financiële aspecten de aandacht verdienen om uiteindelijk economische meerwaarde van een investering te secureren.

Het fenomeen due diligence kan in ons land nog niet als een rechtsfiguur sui generis worden gezien. Om tot een plaatsbepaling van een due diligence onderzoek in het Nederlands recht te komen, kan aan de toepassing van algemene leerstukken als conformiteit, wanprestatie en dwaling niet worden ontkomen. Voor zover aan het onderwerp due diligence in het juridisch landschap al een eigen plaats toe te kennen zou zijn, kan die plaats door niet meer dan een stippellijn worden gemarkeerd. Wel is het duidelijk dat due diligence een eigen plaats verdient in de algemene leerstukken die wij kennen als onderzoeks- en mededelingsplicht. Due diligence komt te pas bij in ieder geval die transacties die door tenminste één professionele partij worden aangegaan in de kapitaalmarkt en transacties van (ook) andere partijen met betrekking tot het financieren van, het deelnemen in of het verwerven van zeggenschap over (een onderdeel van) een onderneming. Het onderzoek dat aan het verrichten van een dergelijke transactie (verder "Investering"genoemd) vooraf zou behoren te gaan, is een due diligence onderzoek. Degene die de Investering doet wordt hierna "de Investeerder" genoemd. Het rechtskarakter van de onderzoeksplicht is niet vastomlijnd.

Voor het bestaan van een mededelingsplicht wordt een aanknopingspunt gevonden in artikel 6:228 lid 1 sub b BW. Het voldoen aan of verzaken van een mededelingsplicht kan mede van invloed zijn op hetgeen er van de Investeerder verwacht mocht worden bij wijze van een due diligence onderzoek. De vraag die gesteld kan worden is of niet ook de wederpartij van de Investeerder een eigen onderzoeks- 
plicht heeft. Wat moet of mag er worden gelezen in de woorden "of behoorde te weten" in artikel 6:228 lid 1 sub b BW?

Mij dunkt, dat een Investeerder van diens wederpartij in ieder geval mag verwachten dat die mededeling zal doen van die informatie waarvan die weet of redelijkerwijs behoort te weten (vergelijk artikel 7:17 lid 5 in de andere richting) dat die informatie voor de Investeerder van belang kan zijn bij het nemen van diens beslissing over het wel of niet doen van de Investering. Dit is een regel die volgens artikel 2:228 lid 1 sub $b$ te onzent al geldt, wanneer wij althans het woord "redelijkerwijs" in die laatst bedoelde wetsbepaling begrepen kunnen achten. Wat behoort de wederpartij van de Investeerder te weten? In elk geval doet de Investeerder er verstandig aan duidelijk te maken welke bedoelingen die bij een transactie heeft. Door dat te doen, geeft deze immers inhoud aan hetgeen zijn wederpartij wist (en behoorde te weten). De behoefte om het hiervoor genoemde begrip "redelijkerwijs" dan in de regel van artikel 2:228 lid 1 sub $b$ te lezen, kan dan minder groot zijn. Brengt een en ander (ook) een 'mededelingsplicht' aan de zijde van de Investeerder mee?

In de rechtspraak is een veelheid van uitspraken bekend, waarin de onderzoeksplicht met de mededelingsplicht strijdt om de voorrang. De hoedanigheid van partijen en de feitelijke omstandigheden in elk geval zijn bepalend. Aanbevolen wordt om afstand te nemen van de verwarrende vraagstelling of een onderzoeksplicht zwaarder weegt dan een mededelingsplicht of andersom. Het onderbrengen van de beide begrippen onderzoeksplicht en mededelingsplicht in het ene begrip toerekenbare (onjuiste) veronderstelling drukt beter uit dat beide partijen een rol (een zekere zorgplicht) hebben te vervullen bij het tot stand komen van een transactie om er voor te zorgen dat die zo tot stand komt, dat procederen achteraf niet nodig zal zijn.

Zoals (in hoofdstuk 5 onder 5.4) is aangegeven vindt het begrip zorgplicht in ons land steeds meer ingang en niet alleen in het effectenverkeersrecht. Het begrip geeft op passende wijze uitdrukking aan het gegeven dat een Investeerder maar even zo goed diens wederpartij, zich beiden inspanning zouden moeten getroosten (de passende zorg moeten besteden) aan het op een zodanige wijze tot stand brengen van een door hen voorgenomen transactie, dat er met de gerechtvaardigde belangen van de ander rekening is gehouden. Er moet invulling worden gegeven aan wat wel als precontractuele zorgplichten is aangeduid. Wat dit betreft is er niet zo veel verschil tussen transacties in de effectenhandel (ook kapitaalmarkttransacties) en (andere) onderhandse transacties, zoals fusies, overnames en het nemen van participaties of het aangaan van joint ventures. Ook buiten het terrein van de effectenhandel kan daarom heel goed van het begrip zorgplicht gebruik worden gemaakt om aan te geven dat er een zorgvuldigheidsnorm aan de orde is waarvan beide bij een Investering betrokken partijen zich rekenschap dienen te geven.

Bij de beantwoording van de vraag wie welke duidelijkheid aan de ander had behoren te verschaffen moet zoals gezegd worden gelet op de hoedanigheid van de betrokken partijen en de omstandigheden van het geval. Door het hier voor genoemde gebruik van de definitie van Investering is de aard van de zaak een gegeven.

Het eerder in dit boek genoemde begrip toerekenbare (onjuiste) veronderstelling nu drukt beter uit dat er op beide partijen, aan beide zijden van een transactie een zekere zorgplicht rust of zou moeten rusten om rekening te houden met de (kenbare) belangen van de wederpartij. Afhankelijk van wat men weet - of behoort te weten wat de ander (niet) weet - past het binnen de opvattingen over de precontractuele redelijkheid en billijkheid dat beide partijen over en weer zich er van vergewissen (en zich inspannen door uitdrukking van de eigen positie of door het stellen van vragen en het geven van inlichtingen) dat er bij hun wederpartij niet sprake is van een onjuiste veronderstelling. Spant men zich daarvoor onvoldoende in, dan is dat strijdig met een zorgplicht die ontleend kan worden aan de richtsnoer welke de Hoge Raad al in het arrest Baris/Riezenkamp ${ }^{807}$ gaf en welke onlangs nog te vinden

\footnotetext{
${ }^{807}$ HR 15 november 1958, NJ 1958, 67, waarin werd gezegd: "dat immers partijen, door in onderhandeling te treden over het sluiten van een overeenkomst, tot elkaar komen te staan in een bijzondere, door de goede trouw beheerste, rechtsverhouding, medebrengende, dat zij hun gedrag mede moeten laten bepalen door de gerechtvaardigde belangen van
} 
was in de uitspraak van de Hoge Raad over het afbreken van onderhandelingen van 12 augustus $2005,{ }^{808}$ namelijk dat partijen hun gedrag door elkaars gerechtvaardigde belangen moeten laten bepalen. Voor het onderwerp van dit boek kan dit een bijstelling van het paradigma opleveren waar het gaat over de vraag hoe uitgebreid een due diligence onderzoek moet zijn. Dit geeft weer sturing bij de beantwoording van de vraag of een teleurstelling achteraf door diens wederpartij zou mogen worden beantwoord met een verwijt dat er door de Investeerder onvoldoende (diepgaand) onderzoek is gedaan. Het antwoord op die vraag wordt namelijk mede bepaald door het gedrag van die wederpartij zelf.

de wederpartij; dat dit onder meer medebrengt, dat voor degene die overweegt een overeenkomst aan te gaan, tegenover de wederpartij een gehoudenheid bestaat om binnen redelijke grenzen maatregelen te nemen om te voorkomen dat hij onder den invloed van onjuiste veronderstellingen zijn toestemming geeft, de omvang van welke gehoudenheid mede hierdoor wordt bepaald, dat men in den regel mag afgaan op de juistheid van door de wederpartij gedane mededeling".

808 NJ 2005, 467 


\section{Summary}

This book contains the result of an attempt to draw a map of the phenomenon due diligence as it found its own position in Dutch law. So far, in literature more or less regularly attention was paid to the phenomenon of due diligence, but an overview did not exist.

In order to draw the map first of all definitions have been mentioned and attention has been paid to the identifiable meaning of a due diligence investigation amidst other sorts of investigation (chapter 1). After visiting the origins of the phenomenon due diligence (as an activity aimed at avoiding risk and liability in the Anglosaxan transaction practice) and a brief look across the border (Germany, United Kingdom and France) it is being discussed to what kind of information a due diligence investigation generally pertains. A first allocation of the nature of the investigation sets a due diligence investigation apart from other sorts of investigation, such as e.g. a periodical auditor's investigation, a value assessment or an investigation on behalf of a risk management project.

A due diligence investigation is an instrument which is used in order to realise transactions in a business environment.

An equivalent for the notion due diligence in the Dutch language would be "gepaste voorzichtigheid" ("required care") or "verschuldigde oplettendheid" ("due attentiveness"). A due diligence investigation becomes relevant in the event of a change in control over a legal entity or in the ownership of an undertaking or in the event another financial transaction of significance is at hand. Examples are initial public offerings, mergers, takeovers, the entering into joint venture agreements and the acquisition of a financial or legal participation or the realisation of credit arrangements or other financial transactions. A special form of investigation is the so-called customer due diligence, the investigation that financial service providers in the financial market need to carry out in order to verify the identity of their clients and to assess their risk profile.

Now that in most of the transactions as intended hereinabove it cannot be ascertained from the outside whether or not in the target company or on the part of the counterpart liabilities are existing or may be incurred ("corpses in the cupboard") an investigation is carried out in order to avoid disappointment afterwards. Whether the notion "required" care or "due" diligence is most apt, is being discussed in the book. Apart from situations where the Act on the financial supervision ("Wet financieel toezicht") require an investigation, in the Netherlands there is no statutory rule prescribing to carry out an investigation before entering into a transaction. In that sense one cannot say that there is a duty to investigate. Nevertheless failure to carry out a careful orientation where it concerns the reliability of a counterpart and the object of a transaction may result in substantial damages. This is why one of the theses in this book reads that the carrying out of a due diligence investigation must be considered part of the elementary principles of responsible entrepreneurship. The failure to carry out an investigation may lead to the qualification that mismanagement ("wanbeleid") has taken place (article 2:355 DCC) and under circumstances also to the qualification improper management in the sense of article 2:9 DCC ("onbehoorlijk bestuur"). The Dutch Corporate Governance Code would more explicitly have to express that entering into a transaction without having given the best effort to carry out a due diligence investigation ought not to be acceptable. It also ought to be prescribed that in the event a public offer has been announced, the target company would have to appoint a committee consisting of members of the supervisory board (or existing of general managing directors in case of a one tier system). This committee would have to take the steering wheel in hands where it concerns decision making. It can also supervise the equal treatment of parties wanting to investigate information pertaining to the target company and ascertaining that everything possible will be done to avoid issues of insider trading.

A due diligence investigation occurs in many forms. It is conducted for various purposes. In the second chapter these various forms and applications are being discussed. In the next chapter (3) (direct, 
immediate cause) the reasons for a principal to feel a need to have a due diligence investigation be carried out, are discussed into greater detail. Attention is given to the significance of a request to carry out a due diligence investigation and what the outcome thereof may mean within the context of negotiations about a transaction. Each of the parties involved in the transaction has their own agenda. The interests are different. The timing of an investigation and the manner in which it is carried out, are not seldom an integrated part of the strategy of both parties in order to realise their own agenda as much as possible. In connection therewith aspects of confidentiality and a possible duty to disclose information (article $843 \mathrm{Rv}$.) are relevant. What extent of information one wants to obtain at what point in time - or, as the case may be, have disclosed - and which results of the outcome of an investigation will be shared or will have to be shared with the other party? Questions related to these issues are being discussed in chapter 10 and 11.

In chapter 4 it is considered how the phenomenon due diligence fits into the Dutch legal system. Now that the phenomenon due diligence did not have its own statutory place in Dutch law, this place had to be allocated by means of qualification of the various elements which can be distinguished in that phenomenon. This leads to the application of the doctrines of a duty to investigate and a duty to inform as these has been developed in the Dutch legal system. The tenets forming the basis for the doctrines of a duty to investigate and a duty to inform, are discussed in chapter 5 with the limitation which is becoming for a book that concentrates on due diligence and was not written about the doctrines of error, conformity, deceit, tort or default as such. The doctrines of a duty to investigate and a duty to inform obtained an identifiable form mostly in jurisprudence and literature. The transactions whereby a due diligence investigation is indicated, distinguished themselves from normal consumer transactions by reason of their size and complexity and the financial interest involved. Also because it concerns transactions which in general cannot easily be reversed. Others maintain that another characteristic is that it concerns transactions which are undertaken by professional parties (entrepreneurs). Entrepreneurs, so much is granted, will in general avail over more experience when it comes to entering into transactions than ordinary consumers, but the category of decisions whereby a due diligence investigation is recommendable, may involve an incidental experience for entrepreneurs also. Not every entrepreneur sells or buys undertakings continuously or is in the habit of concluding substantial financial transactions regularly.

For the development of the doctrines of the duty to investigate and the duty to inform the most relevant judgements of the highest Court in the Netherlands in the period 1958 until the year 2000 inclusive are collected and discussed. It concerns the period during which in the Netherlands the tenet of due diligence materialised to a certain extent. Attention is paid to the most important literature from that period. In certain respects jurisprudence rendered direction for the due diligence practice. Jurisprudence became available which pertained directly to the acquisition and sale of shares and undertakings which is something different than the purchase and sale of second hand cars, houses, goats or other singular goods. One of the most important conclusions derived at was that failure to undertake an investigation or to carry out a superficial or insufficient investigation may result in it that the purchaser or investor will be deemed to have accepted a certain risk. In the event something is not entirely clear, further questioning is required. Also rules of thumb, developed in literature, are mentioned which amongst others say that the extent of a duty to investigate is in part also determined by circumstances such as the mutual relationship between the parties (trust), the capacity or nature of the parties (professionalism), the question whether the object of the transaction can be distinguished by means of special features and also whether certain information resulting from custom may be considered to be generally known or publicly available.

The norm as developed by the Supreme Court in 1958 is still applicable and is becoming even more actual. It concerns a mutual duty of care of both parties to avoid that a transaction is being concluded under the influence of misperception on either part, which duty of care stems from equitable principles. Another thesis in the book therefore is that both parties will have to accept a certain responsibility to investigate and inform each other concerning the object of a transaction. 
The question is addressed how a duty to investigate and a duty to inform relate to one another. The use of the notion "duty" will have to be understood within the framework of the responsibility which results from equitable principles which rest on both parties in order to prevent that the other party enters into a transaction under influence of misperception. Attention is also given to the relationship between a duty to investigate on the one hand and the rendering of representations and warranties by one of the parties on the other hand (justified trust). In general, obtaining specified information and/or representations and warranties may justify the absence of an investigation or an in depth investigation. Dividing risks however, entails more than obtaining comfort only in the form of receiving specific information or a guarantee. It is e.g. relevant, when appropriate, whether or not sufficient recourse will be available in order to cover damages in full. Moreover it need to be remembered that an investigation cannot render more information than what has been made available previous to the finalisation of a transaction and/or which otherwise could within reason be discovered.

It is emphasised that a duty to investigate is also at hand after a transaction has been concluded. Without delay it will have to be investigated whether or not a performance complies with what was agreed upon and/or whether a delivered object was in conformity with the information received and the nature of the object, meeting the requirements which could be expected in accordance with the agreement. It is generally accepted - apart from an incidental exception - that article 7:17 DCC on conformity is also applicable to the purchase of shares. Both on the basis of article 7:23 DCC and article 6:89 DCC a loss of a right to claim may occur in the event a protest has not been communicated with proper speed after a failure in the delivery of a good or the performance of an obligation was discovered or needed to have been discovered.

In chapter 6 jurisprudence in the field of due diligence is discussed as it has been developing after the year 2000. Topics are addressed like the question whether or not it will qualify as a reproach that investigators did not notice certain issues, which were so special that one needed not to be attentive on the existence thereof. The position is taken that one may not easily assume that inattention can be pardoned. The question is discussed when the occurrence of generally known information may be assumed. It is noted that in the field of mergers and acquisitions it is not possible to assume a general norm that the duty to investigate ought to prevail over a duty to inform or the other way around. A different paradigm is recommended. By posing the question which of the parties can be held responsible for the fact that the other party did not have a proper understanding at the time of entering into a transaction, the question can be addressed to whom the risk of problems afterwards ought to be attributed. Thereby it is not decisive whether or not the causing or letting exist a misconception occurred as a result of intent or ill intent. The use of the notion "attributable perception" or "attributable (mis)perception" makes it clear that both parties involved in a transaction are to be responsible for avoiding problems afterwards. In a normal event they both have an interest to ascertain no problems will occur afterwards. Less room will be left for the connotation that a duty to investigate expresses responsibilities of the purchaser only and the duty to inform of only the vendor.

Furthermore, in chapter 6 attention has been given to the significance of a disproportionate balance in professionalism on the part of the parties involved with a transaction; the necessity for a party who states to have suffered damages to evidence a claim; setting off risks in the event both parties to a transaction may be considered responsible for problems which occur first after a transaction has been concluded (inclusive the responsibility for the instruction of third parties or attorneys) and additional circumstances, such as the conditions which need to be fulfilled in order to successfully invoke a failure in a performance or e.g. a default in the conformity of a good that was delivered. The chapter ends with a number of further conclusions. Very briefly stated these entail that between entrepreneurs the principle applies that each will be trying to serve one's own interest. The attributable perception is relevant. Also between seasoned entrepreneurs the rule applies that mutually one needs to take account of the information available and what one can assume the perception to be on the part of one's counterpart where it concerns knowledge of the object of the transaction. An obviously vaster expertise on the part of a counterparty will sooner justify the assumption that this party already avails 
over the necessary information. Apart of recommendations in general terms (article 3:44 paragraph 3 final sentence DCC) one may as a rule rely on the correctness of information provided. In the event of doubt further investigation is required.

In chapter 7 a number of legal aspects is discussed which are related tot the phenomenon of a due diligence investigation. E.g. the question whether the conducting of an investigation will bring that only a limited number of guarantees will have to be provided in takeover contracts. The function of a socalled disclosure letter is being considered and also the question what meaning is to be attributed to the notion that information has been provided 'to the best of one's knowledge'. Can a legal duty be assumed to notify representatives of the object of investigation of issues of concern, while the investigation is taking place?

A due diligence investigation is intended as a safeguard against disappointments. This means that normally covenants are being included in the documentation of a transaction, saying that the result of the investigation will be decisive for the question whether or not the investigating party will ultimately want to be committed to finalise a transaction. It is being discussed what meaning in this respect suspending or rescinding conditions precedent can have (such as also subject to board approvalclauses). Attention is paid to material adverse change clauses, which allow that a transaction will not be completed in the event that e.g. after finalising the investigation changes in the circumstances occur which shed a different light on the envisaged transaction. The chapter ends with addressing certain general topics such as the question whether a failure to disclose certain information of which it had to be assumed that it was relevant for the counterparty, may result in personal liability.

It makes a difference whether a transaction is carried out on the regulated financial market or as a private transaction. These differences were already addressed in chapter 1. Due diligence in capital market transactions is used in a different manner than in the event of private transactions. In the first case focus is especially on the degree of care which a bank as lead manager will have to observe visà-vis the public, whereas in the event of a private transaction an investigation is carried out foremost for one's own interest. Nevertheless also a bank does not undertake an investigation only on behalf of investors amongst the general public. It is also intended to avoid liability as a result of misrepresentation or insufficient information in documentation pertaining to a transaction. Liability for the content of a prospectus is one of the topics addressed into greater detail in chapter 8 . Attention is given to the requirements to be observed by a stock exchange listed company in the event the subject of due diligence has to be put on the agenda, such as the avoidance of issues in respect of insider trading. Attention is also given to questions of liability of various parties involved in both the primary markets and secondary markets (the latter market being the market where securities already issued are being traded).

Questions concerning a due diligence investigation (formulating instruction of investigators, the manner of reporting and such) are being discussed in chapter 9 and also questions pertaining to quality safeguards in respect of the execution of an investigation. Which norms are to be observed by an investigator? Is there e.g. a need to submit a draft report to representatives of the object or company under investigation before reporting to one's own principal? Directly connected to this are aspects of confidentiality. These are addressed in chapter 10. Questions concerning deontology (professional rules of conduct) as well as special subjects like agreements concluded before access to information is granted (data room protocol) and the Act on protecting the privacy of persons ("Wet bescherming persoonsgegevens") are being looked into. In chapter 11 the meaning is discussed of the statutory provisions of article 843a Rv., which apply in the Netherlands since several years and which are relevant for answering the question whether the content of a due diligence report can be considered as the exclusive property of the person who instructed the investigation to take place. The special exhibition duty of article 843a Rv. under circumstances causes disclosure of information, even by means of a duty to submit copies or extracts of certain documents, even when these find themselves in the possession of a third party. Which parties may on ground of their profession, occupation or 
involvement refuse to adhere to a Court order to supply documents? Is article 843a Rv. of a compulsory nature? How to deal with questions as mentioned hereinabove in the event the tax authorities request disclosure of results of a due diligence investigation?

In chapter 12 attention is given in brief how due diligence may be relevant in terms of article 25 of the Dutch Act on the Works Councils ("Wet op de ondernemingsraden"), whereupon in chapter 13 questions are addressed involving professional liability of investigators and possibilities of those investigators to limit their liability or to exclude liability (possibilities to exonerate themselves). In answering the question what the extent is of responsibility (and in connection therewith, liability) of investigators, various circumstances will have to be taken into account. As a general rule it is recommended to have a due diligence investigation be carried out by parties who have expertise and experience in a certain matter. Both knowledge and the lack thereof on the part of representatives of the principal will as a rule be attributed to the principal.

Chapter 14 contains a number of closing remarks. Reference is made amongst others to the fact that in the years 2006 and 2007 on a global scale 8650 billion of large transactions were reported. According to scholars the major part thereof was deemed to fail (according to surveys of Business Week and the Economist $70 \%$ of all mergers and acquisitions are a failure and according to professor Schenk at the University of Utrecht even 85\%). Yet in almost all cases for the occasion of those mergers and acquisitions a previous investigation has been carried out and decision making has been done on the basis of a distinctive plan. The phase after the due diligence investigation is consequently determining for the success of a merger or acquisition. Considered the reported number of failed integration processes - in spite of a due diligence investigation having been carried out - this renders an indication that in a due diligence investigation even more attention will have to be given to the socalled soft factors in as far as these can be measured or estimated. These factors are also important as indicators for the chances of success to successfully complete an integration process. More in particularly culture. By now there is an increasing number of possibilities available during a due diligence investigation to also obtain an inventory of the intended soft factors (which have been discussed in chapter 2). In any event it can be concluded that a due diligence investigation ought not only to be a legal or financial undertaking. Depending on the kind of transaction other than legal and financial aspects will deserve attention in order to ultimately secure the economical upside of an investment.

The phenomenon due diligence in the Netherlands cannot yet be considered a tenet sui generis. In order to determine the place of a due diligence investigation in Dutch law it cannot be avoided to apply the general doctrines of conformity, default and error. In as far as the topic due diligence in the Dutch legal landscape has already procured its own place, this place cannot be marked by more than dotted lines. It is clear however that due diligence does deserve its own place in the general doctrine that we know as duty to investigate and duty to inform. Due diligence is relevant in any event in case of those transactions, which are being entered into by at least one professional party in the capital market, and the transactions of (also) other parties concerning the financing of, the participation in or the acquisition of control over (a part of) an undertaking. The investigation which ought to precede such a transaction (hereinafter referred to as "Investment") can be considered a due diligence investigation. The party undertaking the investment is hereinafter referred to as "the Investor". The legal nature of a duty to investigate is not clearly determined.

For the existence of a duty to inform a point of reference can be found in article 6:228 paragraph 1 sub b DCC. The compliance with or the failure to perform a duty to inform may also be of influence on what may be expected from the Investor in terms of a due diligence investigation. The question that can be raised is whether not also the counterparty of the Investor will have to carry out its own investigation. What is to be or can be read into the words "or ought to have known" in article 6:228 paragraph 1 sub b DCC? The view is taken that an Investor may in any event expect from its counterparty that information will be supplied of which the counterparty knows or within reason ought to know (compare article 7:17 
paragraph 5 in the reversed direction) that this information may be relevant for the Investor in order to derive at a decision whether or not to make the Investment. This rule already applies in the Netherlands according to article 2:228 paragraph 1 sub b. when at least the words "within reason" ("redelijkerwijs") may be deemed to form part of the latter statutory provision. What is it that the counterparty of the Investor ought to know? The Investor in any event will do the right thing to express clearly what the intentions are in respect of a transaction. By doing so content is given to what its counterparty knew and ought to have known. The need to read the abovementioned notion "within reason"("redelijkerwijs") into the provision of article 228 paragraph 1 sub b can then be less pressing. Does all this also incur 'a duty to inform' on the part of the Investor?

In jurisprudence a number of judgements is at hand in which the duty to investigate and the duty to inform are battling for priority. The capacity of the parties involved and the actual circumstances in each case will be determining. It is recommended abandon the confusing question whether a duty to investigate carries more weight than a duty to inform or the other way around. Absorption of both the notion duty to investigate and the duty to inform in the one notion attributable (mis)perception expresses much better that both parties have to observe a certain duty of care at the occasion of the coming into existence of an Investment in order to secure that in the event the Investment is completed, litigation afterwards will not be needed.

As has been mentioned (in chapter 5 under 5.4) the notion "duty of care" is becoming established more and more within the Netherlands and not only in the security exchange laws. The notion expresses in a suitable manner the understanding that an Investor, but also its counterparty, both will have to render effort (to apply due care) to realise an Investment as envisaged by them in such a manner that the justified interest of both parties will be taken into account. A duty of pre-contractual care will need to be observed. In as far as this is concerned, there is not much difference between the securities trade (also capital market transactions) and (other) private transactions, such as (other) mergers, acquisitions and participations or joint ventures. Also outside of the terrain of the securities trade the notion "duty of care" can be used very well to express that a duty of care is at hand in respect of what both parties involved in an Investment have to observe.

In order to answer the question who needs to provide clarity to whom, as said, attention will have to be paid to the nature of both parties and the circumstances of each case. As a result of the definition used for "investment" the nature of the case itself is a given.

The notion "attributable (mis)conception" as used earlier in this book expresses better that on both parties at both ends of a transaction as a result of equitable principles a certain duty of care is posed or ought to apply - to take into account the (recognisable) interest(s) of the other party. Depending on what one knows - or ought to know that the other party does or does not know - it is becoming within the framework of the perception of pre contractual reasonableness and fairness that both parties mutually make certain (and give effort by expressing their own position or by asking questions and rendering information) that there is no misperception on the part of their counterparty. In the event one does not render sufficient effort in this respect, this may be deemed in breach of the duty of care which can be derived from the norm which the Supreme Court has already laid down in the judgement Baris/Riezenkamp ${ }^{809}$, and which recently was again formulated in the judgement by the Supreme Court about the breaking off of negotiations of August $12,2005^{810}$ namely that the parties will have to let their behaviour be determined by their mutual interests. For the subject of this book this may lead to

\footnotetext{
809 Supreme Court November 15, 1958, NJ 1958, 67, in which was stated: "that were parties by entering into negotiations about the concluding of an agreement will enter into a special relationship, within the ambit of equitable principles, causing that they will have to let their behaviour be determined also by the justified interests of their counterparty; that this means amongst others that on the party considering to enter into an agreement vis-à-vis the counterparty an obligation exists to within reasonable boundaries take measures in order to avoid that consent will be given under influence of wrong perceptions or the content of which obligation is also determined by the fact that as a rule one may rely on the correctness of information provided by the counterparty".

810 NJ 2005, 467
} 
revisiting the manner in which one regards the question how extensive a due diligence investigation has to be. This again may help to answer questions whether a disappointment afterwards may be responded to by a counterparty with a reproach that the Investor has conducted too superficially an investigation. The answer to this question is then also determined by the behaviour of the counterparty itself. 


\section{Lijst van geraadpleegde literatuur en jurisprudentie}

Adam-van Straaten

Akker, van den

Akkermans \& Smeehuijzen

Assink

Baalen, Van

Baalen, Van

Baker \& Jillson

Bakker

Bannier c.s.

Best, De

Barendrecht \& Van den Akker

Barendrecht \& Van den Reek

Bax

Beckman

Bierenbroodspot

Blanco Fernandez c.s.
Th. Adam-van Straaten, Due diligence - een practische handleiding, BMM-Bulletin 2002, nr. 97, p. 142 e.v.

E.J.A.M. van den Akker, Beroepsaansprakelijkheid ten opzichte van derden, uitgave vanwege het Schoordijk Instituut, Den Haag: Boom Juridische uitgevers 2001, p. 79.

Zie A.J. Akkermans en J.L. Smeehuijzen, Disclosure statement, versie augustus 2005, www.rechten.vu.nl/iwmd-Projecten-

Vraagstellingen-disclosurestatement.

B.F. Assink, Rechterlijke toetsing van bestuurlijk gedrag, Groningse Serie, deel 59

S.B. van Baalen, Zorgplichten in de effectenhandel, Serie Recht en Praktijk, deel 140 S.B. van Baalen, De bijzondere zorgplicht bij financiële contracten, in: Contracteren 2006/4, p. 74 e.v.

David Baker \& Robert Jillson, Due Diligence, Disclosures and Warranties in the Corporat Acquisitions Practice (second edition), Graham \& Trotman and the International Bar Association P.S. Bakker, de grenzen van de exhibitieplicht, Practisch Procederen 2007/5, p. 143 e.v.

F.A.W. Bannier et al, Beroepsgeheim en verschoningsrecht, SDU 2008.

E.A. de Best, Bepalingen omtrent de invloed van due diligence onderzoek op de afdwingbaarheid van garanties, V\&O september 2004, nr. 9, p. 152 e.v.

J.M. Barendrecht en E.J.A.M. van den Akker, Informatieplichten van dienstverleners, Den Haag 1999, p. 171 e.v.

J.M. Barendrecht en W.A.J.P. van den Reek, Exhibitieplicht en bewijsbeslag, WPNR 94/6155, p. 739 e.v.

M. Bax, De rol van garanties in de overnamepraktijk, V\&O juni 2003, nummer 6, p. 94 e.v.

$\mathrm{H}$. Beckman, Due diligence en overname in Ondernemingsrecht 1999-16, p. 435.

R. Bierenbroodspot, Uitleg van overeenkomsten: maatwerk op basis van Haviltex, O\&F 2008, nr. 1, p. 62 e.v.

J.M. Blanco Fernandez, M. Holtzer en G. van Solinge, Nijmeegse Serie, deel 78. 
Blom

Bongard \& Van Wechem

Bollen

Bolt \& Spier

Booij

Bos \& Owen

Borne, Van den-Verheijen

Bos \& Owen

Booij

Borrius

Braak, Van

Brat

Breedveld

Brink

Brink

Brink \& Raaijmakers

Broek, Van den
M.A. Blom, Prospectusaansprakelijkheid van de lead manager, Nijmeegse Serie, deel 53

M.P. Bongard en T.H.M. van Wechem, Mededelingen van de verkoper en het leerstuk van de conformiteit, NTBR 1995/5, p. 115.

C. Bollen, Onjuiste mededelingen en de samenloop tussen dwaling en wanprestatie: de ene mededeling is de andere niet!,

NBTR 2004/9, p. 414 e.v.

A.T. Bolt en J. Spier, De uitdijende reikwijdte van de aansprakelijkheid uit onrechtmatige daad, in: Preadvies Nederlandse Juristen Vereniging, Zwolle: Tjeenk Willink 1996, p. 157.

J.A. Booij, Fiscale due diligence-rapporten niet meer veilig voor fiscus?, Ondernemingsrecht 2000/3, p. 71 e.v.

F. Bos en J.P.F. Owen, Due diligence: de onmisbare schakel in het acquisitieproces, Tijdschrift voor Corporate Finance jaargang 4, 1999 , nr. 3, p. 75 e.v.

C.H.D.W. van den Borne-Verheijen, De zorgplicht, de Wft en MiFID, Bb 2007, 47, p. 183 e.v.

F. Bos en J. Owen in Fusies en Overnames 2007, Elsevier.

J.A. Booij, Fiscale due diligence-rapporten niet meer veilig voor fiscus?, Ondernemingsrecht 2000-3, p. 71 e.v.

Y. Borrius, Mededelings- en onderzoeksplicht bij (ver)koop van verontreinigde grond, Contracteren 2001/4, p. 86 e.v.

L. van Braak, Van Kannenbier tot Coop: een overzicht van prospectusaansprakelijkheid in $L T$ Verzamelde 'Groninger' opstellen aangeboden aan Vino Timmerman, Groningse serie, deel 44, p. 15 e.v.

E.A. Brat en S.W. Claassen, Toepasselijkheid Titel 1 Boek 7 BW (koop) of verkoop van aandelen; consequenties voor de overnamepraktijk, Bb 24 juli 2003, nr. 14, p. 108 e.v.

C.G. Breedveld-de Voogd, De Wet kenbaarheid publiekrechtelijke beperkingen en de aansprakelijkheid van de verkoper, V\&O 2008, nr. 3, p. 54 e.v.

M. Brink, Voortgezette financiering bij joint venture, O\&F, 2002, nr. 54, p. 9.

M. Brink, Wanneer is een overnamebod 'vriendelijk'?, Bank- en Effectenbedrijf 1998/11, p. 26 e.v.

M. Brink en G.T.M.J. Raaijmakers, Beroepsaansprakelijkheid en legal opinions, in: Beroepsaansprakelijkheid, Ars Aequi Libri 1996, p. 53 e.v.

M.M. van den Broek, Op weg naar grotere transparantieverplichtingen voor aandeelhouders in beursgenoteerde ondernemingen, TOP 2008, nummer 2, p. 55 e.v 
Broek, Van den

Burggraaf

Capron \& Schnatterley

Castermans

Cohen Henriquez

Dam, Van \& Bloembergen

Dammingh

Davis

Deckers

Dijk, Van

Dunné, Van

Dunné, Van

Dunné, Van

Drion

Eijsden, Van

Ekelmans

Ekelmans

Ekelmans

Ekelmans

Eradus \& Contzé
M.M. van den Broek, Gedwongen overlegging due diligence rapport, V\&O 2004, nr. 7/8, p. 122 e.v.

J.L. Burggraaf, Garanties bij overnames, Dossier 1996, nummer 24, p. 80 e.v.

L. Capron en K. Schnatterly, How M\&A's can lead to governance failure, FT Master in Corporate Governance, p. 6.

A.G. Castermans, De mededelingsplicht in de onderhandelingsfase, Kluwer, 1992

E. Cohen Henriquez, Spreken is zilver, zwijgen is fout, NJB 8 mei 1976, p. 625 e.v.

Van Dam en Bloembergen c.s., Rechtshandeling en Overeenkomst (2001), nr. 169

J.J. Dammingh in Juridisch Up to Date, 14 februari 2008 , nr. 3, p.6 e.v. over HR 23 november 2007, RvdW 2007, 996

Chr. Davis, New Dimensions in Due Diligence, ICCLR 1997, nr. 7, p. 243 e.v.

F.B.M. Deckers RA, GBR en Richtlijnen bij due diligence, Accountancy News, 1 december 2000, p. 9.

Chr.H. van Dijk, Hoe te beoordelen of de deskundige deskundig is?, NTBR 2007/10, p. 434 e.v.

J.M. van Dunné, De heroriëntatie bij dwaling (WPNR 1968, nrs. 4978, 4979, 4980, 4981).

J.M. van Dunné, Onderzoeks- en spreekplichten bij bedrijfsovername, Onderneming en 5 jaar Nieuw Burgerlijk Recht, Serie Onderneming \& Recht, deel 7, p. 399 e.v.

J.M. van Dunné, Onderzoeks- en spreekplichten bij bedrijfsovername, Hoe "due" is "due diligence" sinds Hoog Catharijne? (p. 399 e.v.), in Onderneming en 5 jaar nieuw burgerlijk recht,

Serie Onderneming en Recht, deel 7.

C.E. Drion, Wie niet klaagt, die niet wint; op weg naar een klaagcultuur?, NJB 2008/7, p. 375.

J.A.R. van Eijsden, Due diligence rapporten toch veilig voor de fiscus?, WFR 2003/6530, p. 844 e.v.

J.Ekelmans, De exhibitieplicht in kort bestek. Een practische leidraad bij het opstellen en beoordelen van vorderingen tot verstrekking van bescheiden op grond van art. 843a Rv, Zutphen 2007.

J. Ekelmans, De exhibitieplicht in de praktijk: de ruime mogelijkheden tot opvragen van bescheiden, TCR 2005, nr. 3.

J. Ekelmans, Een onbalans in de eindbalans: de exhibitieplicht revisited, TCR 2006, nr. 4, p. 101 e.v.

J. Ekelmans, Art. 843a Wetboek van Burgerlijke Rechtsvordering ont(k)leed, TCR 2008, 2, p. 6566.

R.W.A. Eradus en D.B.C. Contzé, Due diligence in het MKV, een vak apart?, www.bdo.nl. 
Fox

Franke

Gelderman \& Modderman

Gelderman \& Modderman

Gerbrandy

Gielen

Graaf \& Stegeman

Graham \& Barrett

Grundmann-van de Krol

Grundmann-van de Krol

Grundmann-van de Krol

Hammerstein

Harmsen

Hartlief \& Tjittes

Heest, Van

Hijma

Hoff

Honée
Ronald D. Fox, Due diligence, disclosures and warranties in the corporate acquisitions practice, London (Graham \& Trotman) 1988, p. 137.

Door M. van Oosten genoemd (a.w.)

M.E. Franke, Aansprakelijkheid voor misleidende informatie in een emissieprospectus,

Bedrijfsjuridische berichten, 1989, p. 273-274.

P. Gelderman en F. Modderman, Dataroom als middel nog vaak onderschat (electronische dataroom maakt snel furore), Fusie \& Overname, juni 2004, p. 7 e.v.

P. Gelderman en F. Modderman, Dataroom als middel nog vaak onderschat (electronische dataroom maakt snel furore) in Fusie \& Overname juni 2004, p. 7 e.v.

S. Gerbrandy, De omstandigheden. Op de grens tussen dwaling en wanprestatie, WPNR 1990/5959, p. 285 e.v.

Ch. Gielen, IE-rechten, acquisities en joint ventures, De NV 74, 9 september 1996, p. 227 e.v.

F.G.B. Graaf en R.A. Stegeman, Wet op het financieel toezicht, Deventer: Kluwer 2007, p. 730.

R. Graham en Chr. Barrett, IT Due diligence corporate transactions, European Counsel, mei 1998, p. 21 e.v.

Zie C.M. Grundmann-van de Krol, Koersen door het effectenrecht, Den Haag: Boom Juridische uitgevers, p. 461, p. 472-477; p. 481-483; p. 528-531.

C.M. Grundmann-van de Krol, Koersen door de Wet op het financieel toezicht, Den Haag: Boom Juridische uitgevers, p. 121-122; p. 538-541; p. 542-546; p. 481-484.

C.M. Grundmann-van de Krol, Verboden effectendienstverlening: van zwart-wit naar zacht grijs?, JORplus 2003, p. 89.

A. Hammerstein, Garanties zijn geen garanties, in Onderneming en 5 jaar nieuw burgerlijk recht, Serie Onderneming en Recht, deel 7, p. 389 e.v. C.M. Harmsen, Materieel belang: de waarde van de accountantsverklaring en de werking van de verordening op de fraudemelding, TVVS 1996, 11, p.304-307.

T. Hartlief en R.J. Tjittes, Kroniek van het vermogensrecht, NJB 2005/31.

W. van Heest, Pensioenaanspraken bij fusies en overnames, TOP 2008, 3, p. 99 e.v.

Jac. Hijma, Nietigheid en vernietigbaarheid van rechtshandelingen (Kluwer 1988)

G.T.J. Hoff, De lessen van het Co op-arrest, in Onderneming en 5 jaar nieuw burgerlijk recht, Serie Recht en Onderneming, deel 7, p. 347 e.v. Ch.E. Honeé, Mededelings-, informatie- en onderzoeksplicht bij een aandelenfusie - De positie van de over te nemen vennootschap, in Onderneming en 5 jaar nieuw burgerlijk recht, Serie Onderneming en Recht, deel 7, p. 39 en $46-52$. 
Hoeven, van de \& Visser

Hoven, Van den

Hoyng

Huijgen

Ingh, van den

Jansen

Jansen c.s.

Jurgens

Kalff

Keizer

Kelly \& Li

Kersten

Kersten

Klik

Kluiver, De

Kluiver, De

Kluiver, De

Knigge

Koeman

Koenig
R. van de Hoeven en M.J.C. Visser, Identificatie en meldplicht van de advocaat, een frontale aanval op de geheimhoudingsplicht en het verschoningsrecht, NJB 2003, p. 1124 e.v.

J. van den Hoven, Informatietechnologie en rekenschap: due moral diligence, de Accountant nr. 4/ december 1999, p. 239 e.v.

K. Hoyng, Due diligence 24/7, F\&O 4, mei 2006, p. 28-29.

W.G. Huijgen, Koop en verkoop van onroerende zaken, 2003, par. 22d.

F.J.P. van den Ingh, Men gaat deur hovaardy ver boven't kappetael, Enige bespiegelingen omtrent de financiële draagkracht van kapitaalvennootschappen, in: Drie Nijmeegse redes, Nijmeegse Serie, deel 59

M. Jansen, Pont Eecen N.V./ Stratex B.V., BB 10 juni 2004-12, p. 17 e.v.

C.J.H. Jansen, E.R. Schreuder en H.L.E. Verhagen, Prospectusaansprakelijkheid, Amsterdam: NIBE-SVV, p. 70 e.v.

M. Jurgens, Financiële toezichtwetgeving op de agenda, Bank- en Effectenbedrijf ,september 2003, p. 4-5.

D. Kalff, Groei als heilige grail. Grootbedrijf komt niet echt vooruit, FD 12 januari 2008, p. 17.

A. Keizer, Exhibitieplicht bij overnamegeschillen, V\&O 2008, nr. 3, p. 53 e.v.

J. Kelly en P. Li, Document Management, confronting your skeletons, in PLC June 1997, p. 39 e.v.

H.H. Kersten, Het due diligence onderzoek, vrijwilige en onvrijwillige beperkingen, Dossier 47, juli 2001, p. 27 e.v.

H.H. Kersten, Het due diligence onderzoek, O\&F 2003, 58, p. 32.

P. Klik, De verhouding tussen spreek- en onderzoeksplicht, NTBR 1998/8, p. 297.

H.J. de Kluiver, Overnamecontracten, Letters of Intent en garanties, Dossier 47, juli 2001, p. 34 e.v.

H.J. de Kluiver, Overnamecontracten, Letters of Intent en Garanties, O\&F november 2003, 58, p. 36.e.v.

H.J. de Kluiver, Onderhandelen en privaatrecht, Kluert 1992, Serie Recht en Praktijk, nr. 65, p. 24.

A. Knigge, Aansprakelijkheid van franchisegevers, Bb 10 juli 2002, nr. 13, p.119 e.v.

N.S.J. Koeman, Aspecten van milieurecht in het kader van bedrijfsovername, De NV 1995/73, p. 192 e.v.

Koenig, "Determining the addressee of a decision ordering the recovery of state aid after the sale of substantial assets of the undertaking in receipt of aid", [2001] ECLR issue 6, Sweet \& Maxwell, p.238. 
Koppen, Van

Korst, Van der

Korst, Van der

Krol

Labohm

Lamp

Lange, De

Lawrence

Leeuwen, Van

Leijten

Leijten

Lodder \& Seitz

Loefs

Margetson

Maris \& Boele

Middelkoop

Mierlo, Van \& Bart

Möller

Mulder \& Stols
F.P. van Koppen, De vermogensrechtelijke status van het recht op de domeinnaam, Maandblad voor Vermogensrecht, juni 2006, nr. 6, p. 111 e.v.

P.J. van der Korst, Contractuele bescherming bedrijfsgeheimen, Ondernemingsrecht 2008-3, p. 127-128.

P.J. van der Korst, Bedrijfsgeheimen en transparantieplichten, Nijmeegse Serie, deel 92, p. 95.

A.N. Krol, Wetgeving inzake voorwetenschap, V\&O februari 2000 , p. 26 e.v.

A.N. Labohm, Het belang van de mediation overeenkomst, Tijdschrift voor Mediation 2002, nr. 2, p. 32 e.v.

R. Lamp, Eigen voorwetenschap en aanverwante kwesties, Ondernemingsrecht 2008, 4, p. 152 e.v.

S.C. de Lange, Exhibitieplicht in overnamegeschillen, Fusie \& Overname juli 2006, p. 13 e.v.

Gary M. Lawrence, Due Diligence in Business Transactions, Law Journal Press (SBN 9781588520661).

B.H.A. van Leeuwen, Beginselen van behoorlijk ondernemingsbestuur, IvO, deel 10, p.4.

A.F.J.A. Leijten, Reglement procedure beursnotering en due diligence, V\&O april 1997, afl. 4, p. 40 e.v.

A.F.J.A. Leijten, Vervolg Coop-procedure, V\&O 1996, p. 114 e.v.

A.N. Lodder en I. Seitz, Het due diligence onderzoek, de koper wil financieel, fiscaal, juridisch en milieutechnisch alles weten, F\&O april 1996, nr. 4, p. 13 e.v.

M. Loefs, De bank als belangrijke speler in een overnameproces, V\&O 2008, nr. 4, p. 70 e.v.

N.J. Margetson, De grenzen van de exhibitieplicht, PP 2007/5, p. 143 e.v.

A.G. Maris en S.A. Boele, Prospectusaansprakelijkheid, TVVS 1994, p. 143 e.v.

K.I.A. Middelkoop, Due diligencerapport: plicht tot overleggen? V\&O november 2005, nr. 11, p. 196 e.v.

A.I.M. van Mierlo, m.m.v. F.M. Bart, Parlementaire geschiedenis: herziening van het burgerlijk procesrecht voor burgerlijke zaken, Kluwer 2002, p. 157

J.M. Möller, De uitleg van het schadebegrip in overnamecontracten, V\&O 2008, 2, p. 31 e.v.

N. Mulder en D. Stols, Rechten tegen het licht houden, F\&O, mei 2005, p. 10 e.v. 
Muller

Nieuwenhuis

Nass

Nijs Bik, De

Nijs Bik, De

Oosten, Van

Oostwouder

Oppelaar

Du Perron \& Van Wechem

Perrick \& De Serière

Peters \& Snoeks

Planque, De

Raaijmakers, G.

Raaijmakers, G.

Raaijmakers, G.

Raaijmakers, G.

Raaijmakers, G.

Raaijmakers, G.

Raaijmakers, G.
L.H.E. Muller, Hoe ver reikt het zogenaamde "informele verschoningsrecht"?, WFR 2005/3.

J.H. Nieuwenhuis, Een gevaar op de weg, AA 1986, p. 315-321.

E.C.A. Nass, Tuchtrechtspraak voor accountants, Ondernemingsrecht 2007,125 , p. 427429.

W.W. de Nijs Bik, (Due) Diligence, TVVS 1996, p. 222 e.v.

W.W. de Nijs Bik, Het due diligenceonderzoek (Bedrijfsovername, Rechtop serie praktijkhandleidingen, $2^{e}$ druk, p. 51 e.v.)

M. van Oosten, De onderzoeksplicht bij de koop van aandelen, V\&O februari 2004, nr. 2, p. 22 e.v.

W.J. Oostwouder, Management Buy-out,

Groningse serie, deel 27, p. 46 e.v.

H.V. Oppelaar, Het wetsvoorstel openbare biedingen op effecten en de verhouding tot de dertiende EG-richtlijn en het wetsvoorstel beschermingsconstructies, Ondernemingsrecht 2000/10, p. 268.

C.E. du Perron en T.H.M. van Wechem. Het uitsluiten van het beroep op dwaling in overnameovereenkomsten: een acceptabele of onacceptabele kostenplaats VrA 2004, p. 4-18.

S. Perrick en V.P.G. de Serière, Effecten (algemeen deel), Serie Bank en effectenrecht, Deventer: Kluwer 1991, p. 103.

A. Peters en C. Snoeks, De transparantie van pensioenverplichtingen, Fusie \& Overname 2005, p. 22 e.v.

M.P.P. de Planque, Conformiteitsvereiste bij overnames, Vennootschap en Onderneming 2000, p. 186 e.v.

G.T.M.J. Raaijmakers, Garanties bij overnames (ISBN 905454248 9) p. 116-118.

G.T.M.J. Raaijmakers, Garanties bij overnames: het arrest ABP-FGH, WPNR 1996 / 6219, p. 267-268.

G.T.M.J. Raaijmakers, Due diligence bij onderhandse bedrijfsovername en openbare biedingen, Juridisch up to Date 9 september 1999, p. 12 e.v.

G.T.M.J. Raaijmakers, Garanties in het contractenrecht, Rechtsgeleerd Magazijn Themis 20053, p. 124 e.v.

G.T.M.J. Raaijmakers, Twee recente arresten over verkopersaansprakelijkheid, WPNR 2002/6507, p. 729-731.

G.T.M.J. Raaijmakers, Bedrijfsovernames: lijken in kasten en katten in zakken, Ars Aequi 2003, p. 892-893.

G.T.M.J. Raaijmakers, Bedrog bij bedrijfsovernames: een gewaarschuwd mens telt voor twee, NTBR 2004, 51, p. 277 e.v. 
Raaijmakers, G.

Raaijmakers, G.

Raaijmakers, M.

Raaijmakers, M.

Raaijmakers, M.

Raaijmakers, M.

Raaijmakers, M.

Reimers

Rinkes

Rossum, Van

Rooy, De

$\mathrm{Ru}, \mathrm{De}$

Ruyter, De

Rumora-Scheltema

Rutgers

Schaafsma \& Elsenga

Schepel

Schoordijk
G.T.M.J.. Raaijmakers, Twee arresten over verkopersaansprakelijkheid, WPNR 02/6507, p. 729 - 731.

Zie ook G.T.M.J. Raaijmakers, Due diligence bij onderhandse bedrijfsovername en openbare biedingen, Juridisch Up To Date 9 september 1999, p. 12 e.v.

M.J.G.C. Raaijmakers, Vennootschaps- en rechtspersonenrecht, Deventer: Gouda Quint 2000, p. 497.

M.J.G.C. Raaijmakers, Ondernemingsrecht, Deventer: Kluwer 2006, p. 357.

M.J.G.C. Raaijmakers, Finad/Worst, AA 44 (1995) 12, p. 959 e.v.

M.J.G.C. Raaijmakers in zijn noot onder OK 20 april 1989, NJ 1991, 205 (Best Golf \& Country Club), AA 1989, p. 850

M.J.G.C. Raaijmakers, Noot bij HR 2 december 1994, AA 1995, 44, p. 224 (ABN AMRO/Vereniging Coopag)

H.K.O. Reimers, AFM vs. Spyker, Bb 27 februari 2008, nr. 5, p. 43 e.v.

J.G.J. Rinkes, Juridische aspecten van de informatie- en zorgplichten van financiële ondernemingen onder het regime van de Wet op het financieel toezicht, Nederlands Tijdschrift voor Handelsrecht 2007-6, p. 223 e.v.

M.M. van Rossum, Overzicht Actualiteiten vermogensrecht, Juridisch Up to Date 2008, nr. 10, p. 4-5.

R.E. de Rooy, Emissies op de Nederlandse markt, Deventer: Kluwer 2003, p. 9.

C.F de Ru, Due diligenc- onderzoek en beroepsaansprakelijkheid, V\&O, december 1995, afl. 12, p. 126 e.v.

B.G.H. de Ruiter, Due-diligence rapporten buiten spel, Weekblad Fiscaal Recht 6665, 6 april 2006, p. 369 e.v. .

B.F.H. Rumora-Scheltema, Het polsen van grootaandeelhouders, V\&O november 2004, nr. 11, p. 189 e.v.

G.R. Rutgers, Bewijsaanbod in civiele contentieuze zaken, AA 54 (2005), nr. 4, p. 270 e.v.

A.C. Schaafsma en O.S. Elsenga, Afgebroken onderhandelingen; de betekenis van een voorbehoud toestemming (vennootschappelijk) orgaan, V\&O februari 2004, nr. 2, p. 29 e.v.

M.C. Schepel, Beliën/Provincie Brabant; potestatieve voorwaarde? V\&O november 1997, afl. 11, p. 123 e.v.

H.F.C. Schoordijk, Prospectusaansprakelijkheid, een garantieverplichting?, in Onderneming en 5 jaar nieuw burgerlijk recht, Serie Recht en Onderneming, deel 7, p. 329 e.v.; 
Slotboom \& Heringa

Schmidt

Schmidt auf Altenstadt, Von

Schoordijk

Schooten, Van

Schouten

Schut

Serière, De

Sijmonsma

Sijmonsma

Sijmonsma

Slagter

Slagter

Slagter

Slagter

Slagter

Solinge, Van

Solinge, Van \& Nieuwe Weme
M.M. Slotboom en L. Heringa, AKZO Nobel / Commissie: Teleurstellende uitspraak Europees Gerecht voor bedrijfsjuristen, Juridisch up to date, 25 oktober 2007, pp. 19-23.

D. Schmidt, Commentaire de la recommendation no. 2003-01 de la COB relative aux procédures dites de 'data room', JCP E 2004, no. 560.

P.J.M. von Schmidt auf Altenstadt, Opening van zaken, TCR 2002, nr. 1, p. 8 e.v.

H.F.C. Schoordijk, Prospectusaansprakelijkheid, een garantieverplichting?, in Onderneming en 5 jaar nieuw burgerlijk recht, Serie Recht en Onderneming, deel 7, p. 329 e.v.

M.R. van Schooten, Material Adverse Change / Material Adverse Events, Contracteren 2008, p. 8 M.C. Schouten, Inwerkingtreding nieuwe regels betreffende het openbaar bod op effecten, $\mathrm{Bb}$ 2008, 18, p. 69-72.

W.S.M. Schut, Letters of Intent, Studiepockets privaatrecht, 186 en B. Wessels, Overname-onderhandelingen in Bedrijfsovername (Tjeenk Willink), p. 6, en de door deze auteurs genoemde literatuur.

V.P.G. de Serière, Regelgeving van de Amsterdamse Effectenbeurs in zake beursintroducties, Jubileumbundel van de Vereniging voor Effectenrecht, p. 127 e.v.

J.R. Sijmonsma, Art. 843a Wetboek van Burgerlijke Rechtsvordering ont(k)leed, Nijmegen 2007. J.R. Sijmonsma, Exhibitieplicht in kort bestek, TCR 2008, 2, p. 60 e.v.

J.F. Sijmonsma, enkele aspecten van de inzageplicht van art. 843a $R v$, praktisch procederen 2005/5, p. 145 e.v.

W.J. Slagter, Due diligence en garanties, TVVS $1996 / 11$, p. 327.

W.J. Slagter, Het due diligence onderzoek, TVVS 1994, nr. 94/9, p. 225 e.v.

W.J. Slagter, Het due diligence onderzoek en de aansprakelijkheid van de accountant, Dossier nummer 24, 1996, p. 56.

Zie W.J. Slagter, Risicobeheersing door een due diligence onderzoek, Preadvies van de Nederlandse vereniging van Ondernemingsrechtadviseurs 1995, p. 15.

W.J. Slagter, Het due dliligence onderzoek en aansprakelijkheid van de accountant, Dossier 1996, nummer 24, p. 56 e.v.

G. van Solinge, Doorbraak van prospectusaansprakelijkheid, in: A-T-D, Opstellen aangeboden aan Prof. Mr. P. van Schilfgaarde, Deventer: Tjeenk Willink 2000, p. 417 e.v.

G. van Solinge en M.P. Nieuwe Weme, Gedragsregels in zake een openbaar bod op aandelen, Serie Onderneming \& Recht, deel 16, p. 95 e.v. 
Stevens c.s.

Stratenus

Strik

Strik

Teuben

Thelen c.s.

Tielemans

Tielens

Timmerman

Tjittes

Tjittes

Tjittes

Tjittes

Tjittes

Tjong Tjin Tai

Tjong Tjin Tai

Tjong Tjin Tai

Tjong Tjin Tai

Tollenaar
F. Stevens, R. Bering en K. Stevens, Eerst de cultuur veranderen, daarna komen de cijfers, als gepubliceerd in Leren excelleren, 12 jaar General Electric tegen de achtergrond van het INK-model, door (ISBN 901407 347X).

I.A. Stratenus, Voorwetenschap en het openbaar bod, V\&O mei 2000, p. 83 e.v.

D.A.M.H.W. Strik, De 'in control'- statement, TOP 2008, nr. 8, p. 330-334.

D.A.H.W. Strik, Aspecten van schadevergoeding bij inbreuk op garanties in overnamecontracten, in: Geschriften vanwege de Vereniging Corporate Litigation 2003-2004, p. 393 e.v.

K. Teuben, De verplichting tot het overleggen van stukken ex art. 843a Rv, Maandblad voor Vermogensrecht 2006, nr. 12, p. 218 e.v.

Thelen, Reid, Priest LLP, Intellectual property due diligence: a must when assets are transferred,

door: Technolgy, Intellectual Property and Trade Regulation Practice Group, 5 augustus 2002. Zie ook: http://www.constructionweblinks.com.

W.J. Tielemans, Het juridische ICT due diligence onderzoek voorafgaand aan een overname, V\&O 2006, nr. 11, p. 210 e.v.

J.E. Tielens, Zijn de banken aansprakelijk voor schade van World Online-beleggers?, NJB 2002, p. 745 .

L. Timmerman, Afbreken van onderhandelingen over de overname van een pakket aandelen, TVVS 1987, p. 129-130.

R.P.J.L. Tjittes, Naar een bijzonder contractenrecht voor ondernemers in Onderneming en 5 jaar nieuw burgerlijk recht, Serie Onderneming en Recht, deel 7, p. 384-385.

R.P.J.L. Tjittes, De hoedanigheid van contractspartijen, Kluwer 1994, p. 56 e.v..

R.P.J.L. Tjittes, Terug naar de tekst - een herwaardering van de tekstuele uitleg van contracten, WPNR 2007/6709, p. 417 e.v.

R.P.J.L. Tjittes, Uitleg van schriftelijke contracten, RM Themis 2005, p. 2 e.v.

R.P.J.L. Tjittes, De uitleg van garanties en vrijwaringen in overnamecontracten in Geschriften vanwege de Vereniging van Corporate Litigation 2007-2008, p. 113 e.v.

T.F.E. Tjong Tjin Tai, Zorgplichten en zorgethiek, (diss. UvA), Kluwer 2007.

T.F.E. Tjong Tjin Tai, Zorgplichten en zorgethiek, AA (56) 2007-9, p. 702 e.v.

T.F.E. Tjong Tjin Tai, Garantie, nakoming en schadevergoeding, WPNR 04/6577, p. 363 e.v.

T.F.E. Tjong Tjin Tai, Toerekening van kennis en zorgvuldigheidsnorm, Bedrijfsjuridische Berichten, december 2005, nr. 26, p. 265 e.v.

N.W.A. Tollenaar, Beschouwingen over artikel 6:89 en 7:23 BW in het bijzonder bij aandelen- 
Tonkelaar, Den

Tuytel

Uchelen, Van

Uittien

Valk

Valk

Veen, Van c.s.

Veersen, Van

Verhulst \& Van Niekerk

Velden, Van der

Vlaar \& Ezinga

Vles

Vranken

Vries, De

Wechem, Van

Wechem, Van

Weij, Van der

Wijers \& Haasjes

Werkhorst koop, NTBR 2005, 74.

J.D.A. den Tonkelaar, Opschortende en ontbindende voorwaarden, 1994, p. 94 e.v.

M.M. Tuytel, (Balans)garanties, V\&O 2001, p. 174-179.

P.J. van Uchelen, Bestuurdersaansprakelijkheid in geval van schending van de mededelingsplicht bij bedrijfsovername, Ondernemingsrecht 20046, p. 229 e.v.

Zie $\mathrm{H}$. Uittien, Gedwongen verstrekking van due diligence-rapportages, in: TOP januari 2007, p. 19 e.v.

W.L. Valk, in T\&C, aant. 3 onder artikel 6:228 lid 1

W.L.Valk, Klachtplicht en bewijslast, NTBR 2008, 2, p. 94 e.v. over HR 23 november 2007, RvdW 2007, 996

L. van Veen, F. Modderman, C. Suchtelen en J. de Bruijn, Vendor due diligence, vroegtijdig de meest ideale dealstructuur, Fusie \& Overname januari 2005, p. 30 e.v.

J.A.C. van Veersen, Exhibitieplicht ex artikel 3:15j BW; een ondergeschoven kindje,

V\&O januari 2006, nr. 1, p. 6 e.v

Verhulst en J.P. van Niekerk, Fiscus etaleert informatiehonger, Fusie \& Overname, maart 2005, p. 30 e.v.

J.W.P.M. van der Velden, Gronden van prospectusaansprakelijkheid, Aansprakelijkheid in beroep, bedrijf of ambt 2003, p. 673 e.v.

N.W. Vlaar en A. Ezinga, Het due diligence-onderzoek en de rol van de accountant, MAB december 1997, p. 636 e.v.

$\mathrm{N}$, Vles, Toevoeging to the seller's knowledge in commerciële overnamecontracten: een slag om de arm, V\&O november 2007, nr. 11, p. 203 e.v.

J.B.M. Vranken, Mededelings-, informatie- en onderzoeksplichten in het verbintenissenrecht (Tjeenk Willink, 1989)

G.J.P. de Vries, Mededelings- en onderzoeksplicht bij een vergoedingsaanspraak op grond van dwaling, NTBR 2002/7, p. 341 e.v.

Th.M. van Wechem, Annotaties bij uitspraak van de Rechtbank Utrecht 14 juni 2006, JOR 2006, 228 in: Actualia Contractspraktijk, Contracteren 2006/4 p. 83 e.v.

Th.M. van Wechem, De verhouding tussen mededelings- en informatieplichten, de betekenis van contractuele afspraken en de rol van artikel 7:17 BW hierbij en kan een beroep op dwaling contractueel worden uitgesloten, Contracteren 2008, p. 19 e.v.

C.T. van der Weij, Dwaling en bedrog bij het sluiten van overnameovereenkomsten, $\mathrm{V} \& \mathrm{O}, \mathrm{p}$. 52

W.P. Wijers en A.J. Haasjes, Exhibitie in het (Onderneming)recht, O\&F 2006, nr. 71, p. 49 e.v.

$\mathrm{K}$. Werkhorst, Wet MOT en witwassen; jurisprudentie biedt volop kansen voor beleid, in Tijd- 
(c) mr. M. Brink - 2008

schrift voor Financieel Recht, nr. 11/12, november/december 2007, p. 350 e.v. 
Werner

Wessels

Wessels

Wezeman

Wiel, van der

Wijngaarden, Van

Winter

Winters \& Vossenberg

Winters \& Vossenberg

Wolf, De \& Spliet

Wolters

IJsselmuiden

Zijst, Van
R. Werner, Haftungsrisiken bei Unternehmensakquisitionen: die Plicht des Vorstands zur Due Diligence, Zeitschrift für Wirtschaftsrecht,

9 juni 2000/S. 989, p. 996.

B. Wessels, Risicobeheer bij advisering, Pre-advies van de Nederlandse vereniging van Ondernemingsrechtadviseurs 1995, p. 46 e.v; hoofdstuk 2.7, Begrenzing door contractuele voorwaarden, p. 60 e.v.; tijdens het debat over zijn preadvies, p. 90.

B. Wessels, Koop: algemeen, Monografieën Nieuw BW B65a, nummer 83

J.B. Wezeman, Aansprakelijkheid van bestuurders, Groningse Serie, deel 29.

B.T.M. van der Wiel, De exhibitieplicht (te) terughoudend opgevat, NbBW 2004, nr. 4, p. 58 e.v.

T. van Wijngaarden, Ondernemingsrecht, Tuchtrechtspraak accountants 07-139, Juridisch Up to Date, 20 december 2007, p. 16 e.v.

J.W. Winter, Ontwikkelingen in het effectenverkeersrecht, NV 1996, p. 30 e.v.

B. Winters en J. Vossenberg, Aansprakelijkheid van bestuurders en commissarissen ter zake van een mislukte acquisitie; rechtsgevolgen van een verleende décharge, V\&O 1999, nr. 6, p. 66 e.v.

B. Winters en J. Vossenberg, Vissen in het enquêterecht, V\&O april 2005, nr. 4, p. 62 e.v.

$\mathrm{P}$. de Wolf en M. Spliet, Mediation en vertrouwelijkheid in het Burgerlijk recht - enkele practische tips, Trema mei 2005, 5, p. 215 e.v.

M. Wolters, De due-diligenceparadox,

Contracteren, 1999/1, p. 3 e.v.

Th.S. IJsselmuiden Op de koop van DRSC door Verto is op onderdelen gerechtvaardigde kritiek mogelijk. Toch geen wanbeleid, TVVS 1996, nr. 5 , p. 146-147.

M. van Zijst, De vaststellingsovereenkomst in strijd met dwingend recht, Dissertatie Universiteit van Amsterdam, Kluwer 2001, p. 54-55. 


\section{Vaste literatuur}

- Asser-Hartkamp 4-II

- Asser/Hartkamp \& Sieburgh 6-I*-2008

- Asser-Hijma (2001) nr. 337

- Asser-Hijma 5-I

- J. Hijma in verbintenissenrecht aant. 25 bij artikel 6:228

- Asser-Maeijer 2-III

\section{Artikelen}

- D. Mollan en Q. Solt, Wie neemt u mee naar het bedrijfsbal?, FD 13 februari 2006, p. 5

- $\quad$ FD 10 september 2007, p. 11

- $\quad$ FD 20 oktober 2007, Onderhandelen met dubbele petten

- VEB vreest voor privacy aandeelhouders, OpMaat Ondernemingsrecht 2008/118

\section{Officiële publicaties (wetgeving)}

- $\quad$ Handelingen der Staten-Generaal 1951-1952 II p. 1940

- $\quad$ TK 1991-1992K, $22340 \mathrm{nr} .8$

- $\quad$ TK 1997-1998, 25 892, nr 3, p.11-1 (Wbp)

- $\quad$ TK 1997-1998, 25095

- $\quad$ TK 2003-2004, 29279, nr. 14 (Rapport "Ruimte voor zorgplichten")

- $\quad$ Kamerstukken II, 27809

- $\quad$ TK 2004-2005, 29827

- $\quad$ TK 2005-2006, 29708

- $\quad$ TK 2007-2008, 29752 (modernisering van het ondernemingsrecht), nr. 5

- $\quad$ TK 2007-2008, 31237

- $\quad$ TK 2007-2008, 31238

- TK 2008-2009, 31 270, nr. 16, wijziging van de Wta teneinde te komen tot implementatie van richtlijnnummer 206/43/EG van het Europees Parlement en de raad van de Europese Unie van 17 mei 2006

- $\quad$ EK 2007-2008, 30397 B

$-\quad W f t$

- Vr. Wft

- Koninklijk Besluit van 17 december 1998, houdende bepalingen ter uitvoering van artikel 46, vierde lid van de Wet toezicht effectenverkeer 1995

- $\quad$ Artikel 46a Wte 1995

- Kamerstukken 30928

- Nederlandse Wetboeken december 2007, afl. 12, p. 7-9

- $\quad$ Artikel $29 \mathrm{Rv}$

- $\quad$ Artikel $272 \mathrm{Sr}$.

- $\quad$ Artikel 3:15j

- $\quad$ Artikel 6:172

\section{Publicaties Staatscourant}

- $\quad$ Strct. 1997, 75

- $\quad$ Stcrt. 2003,71, p. 17

- $\quad$ Stcrt. 3 februari 2003 , nr. 23, p. 16

- $\quad$ Stcrt. 23 december 2003, nr. 248, p. 59 


\section{Publicaties Staatsblad}

- $\quad$ Staatsblad 1988, 717

- Staatsblad 2001, 606 (Wet van 6 december 2001)

- Staatsblad 2003, 224

- Staatsblad 2003, 396

- Staatsblad 2003, 55 (Wet Actualisering en Harmonisatie Financiële Toezichtwetten)

- Staatsblad 2005, 346

- Staatsblad 2005, 467

- Staatsblad 2006, 510

\section{Publicaties algemeen}

\section{Nederlandse Corporate Governance Code}

- $\quad$ Bijzondere overeenkomsten I (Van Rossum), artikel 17, aantekening 11

- $\quad$ NAI 9 juli 2003, TvA 2004, 3

- $\quad$ Beleidsregel 03-01 van de AFM in zake de toepassing van artikelen 46 en 46a Wte bij het polsen van (potentiële) aandeelhouders in het kader van het verrichten van transacties

- Aanbeveling Ombudsman Financiële Dienstverlening ((KiFiD, 4 maart 2008) en de daarop gevolgde brief van de Minister van Financiën aan de Tweede kamer van 11 maart 2008 (n.a.v. TK 2006-2007, 29507, nr. 39)

- $\quad$ Besluit 10DGM4, V-N 1994, p. 456 e.v.

- $\quad$ BNB 2006, 21 en V-N 2005, 46.5

- $\quad$ Besluit nr. 10DGM4, V-N 1994, p. 456

- Besluit Directeur-Generaal Belastingdienst namens de Staatssecretaris van Financiën, 27 september 1994, nr. AFZ94/4517M, VN1995/27

- Besluit van 25 januari 2007, nr. CPP2006/2715M, Stcrt. 24

- De geheimhoudingsplicht van de belastingadviseur, Nederlandse Orde van Belastingadviseurs, Red. H. Koller e.a., 6 mei 2006 (zie www.nob.nl)

- Reglement voor de Beroepsuitoefening, Nederlandse Federatie van Belastingadviseurs (zie www.fb.nl)

- $\quad$ Rechtbank Amsterdam, Sector Bestuursrecht Algemeen d.d. 2 mei 2005, nr. AWB 04/819 WOB

- $\quad$ Niet gepubliceerde uitspraak van 12 oktober 2005, rolnummer 57600 HA ZA 04-2899

- Geschillencommissie Fusiegedragsregels SER 7 januari 2008, JOR 2008, 32

- Klachtencommissie DSI 23 april 2002, JOR 2002, 119

\section{Richtlijnen advocaten, accountants en belastingadviseurs}

- Verordening op de praktijkuitoefening in dienstbetrekking van de Nederlandse Orde van Advocaten

- Verordening op de beroepsaansprakelijkheid 1991 als laatstelijk gewijzigd op 28 november 2003 van de Nederlandse Orde van Advocaten

- Nadere Voorschriften in zake de continuïteit van de beroepsuitoefening door de openbaar accountant van 1 juli 2004, ook voor NOvAA (artikel 2 e.v.)

- $\quad$ Nadere voorschriften onafhankelijkheid interne accountant

- Nadere voorschriften onafhankelijkheid overheidsaccountants

- Nadere voorschriften accountantsafdelingen

- Verordening Gedrags Code (VGC)

- Gedragsrichtlijn in zake persoonsgerichte accountantsonderzoeken

- NV COS 315

- NV Cos 320

- $\quad$ NV COS 300-499 
NV Cos 330

NV COS 550

NV COS 4400

NV COS 3000-3699

NV COS $5500 \mathrm{~N}$

Reglement Beroepsuitoefening Nederlandse Orde van Belastingadviseurs van 11 juni 2002 en nadere toelichting van december 2006.

\section{Arresten van de Hoge Raad}

Hoge Raad 14 november 1924, NJ 1925, 97 (Koperdraad)

Hoge Raad 25 november 1927, NJ 1928, p. 364 (Kretzschmar/Mendes de Leon)

Hoge Raad 29 maart 1935, NJ 1935, 1470 (Nieuwendijkcafé)

Hoge Raad 15 november 1957, NJ 1958, 67

Hoge Raad 5 november 1957, NJ 1958, 68, m.nt. LEHoge Raad (Baris / Riezenkamp)

Hoge Raad 31 januari 1958, NJ 1958, 251 (Van Dullemen/Sala)

Hoge Raad 12 december 1958, NJ 1961, 270 m.nt. DJV

Hoge Raad 19 juni 1959, NJ 1960, 59 (Kantharos van Stevensweert)

Hoge Raad 21 januari 1966, NJ 1966, 183 m.nt. GJS (Booy/Wisman)

Hoge Raad 5 april 1968, NJ 1968, 251 (Pekingeenden)

Hoge Raad 2 mei 1969, NJ 1969, 344 (Beukinga-Van der Linden)

Hoge Raad 30 november 1973, NJ 1974, 97 m.nt. GJS (Van der Beek/Van Dartel)

Hoge Raad 4 juni 1976, NJ 1977, 336

Hoge Raad 13 maart 1981, NJ 1981, 442 m.nt. CJHB (Hilders/De Galan)

Hoge Raad 31 maart 1981, NJ 1981, 635 m.nt. CJHB (Haviltex)

Hoge Raad 15 mei 1981, NJ 1981, 641 m.nt. CJHB (Joba/Gerber)

Hoge Raad 18 juni 1982, NJ 1983, 723 (Plas/Valburg)

Hoge Raad 27 januari 1984, NJ 1984, 545

Hoge Raad 22 juni 1984, NJ 1985, 188 m.nt. WHH

Hoge Raad 1 maart 1985, NJ 1986, 173

Hoge Raad 7 juni 1985, NJ 1986,174

Hoge Raad 14 juni 1985, NJ 1986, 175

Hoge Raad 15 november 1985, NJ 1986, 213

Hoge Raad 4 april 1986, NJ 1986, 810

Hoge Raad 11 april 1986, NJ 1986, 570 (Kelly/Rietvelt)

Hoge Raad 18 april 1986, NJ 1986, 747

Hoge Raad 16 mei 1986, NJ 1986, 638

Hoge Raad 21 november 1986, NJ 1987, 318

Hoge Raad 6 maart 1987, NJ 1987, 1016

Hoge Raad 6 januari 1989, NJ 1989, 281 (De Vor/Amro)

Hoge Raad 10 januari 1990, NJ 1990, 466 m.nt. Ma

Hoge Raad 1 juni 1990, NJ 1991, 759 m.nt. CJHB (Van Lanschot/ Binck)

Hoge Raad 21 november 1990, NJ 1991, 251 (Van Geest/Nederlof)

Hoge Raad 21 december 1990, NJ 1991, 251

Hoge Raad 4 januari 1991, NJ 1991, 254 (Avery / VRG)

Hoge Raad 25 januari 1991, NJ 1992, 97

Hoge Raad 26 april 1991, NJ 1991, 455

Hoge Raad 28 juni 1991, NJ 1992, 420 m.nt. JBMV

Hoge Raad 22 november 1991, NJ 1992, 315

Hoge Raad 3 april 1992, NJ 1992, 396

Hoge Raad 25 september 1992, NJ 1993, 467 m.nt. HJS

Hoge Raad 27 november 1992, NJ 1993, 287

Hoge Raad 2 april 1993, NJ 1995, 94 m.nt. CJHB 
- $\quad$ Hoge Raad 14 mei 1993, NJ 1993, 446

- $\quad$ Hoge Raad 25 juni 1993, NJ 1994, 291

- $\quad$ Hoge Raad 31 december 1993, NJ 1995, 389

- $\quad$ Hoge Raad 11 maart 1994, NJ 1995, 3 (Kilbarr Corporation-Holan /Teeuwen)

- $\quad$ Hoge Raad 29 maart 1994, NJ 1994, 552

- $\quad$ Hoge Raad 15 april 1994, NJ 1995, 614

- $\quad$ Hoge Raad 3 juni 1994, NJ 1997, 287

- $\quad$ Hoge Raad 2 december 1994, NJ 1996, 246, m.nt. D.W.F. Verkade (ABN AMRO/Vereniging Coopag)

Hoge Raad 2 december 1994, RvdW 1994, 265

Hoge Raad 1 maart 1985, NJ 1986, 173

Hoge Raad 1 maart 1985, NJ 1986, 173, RvdW 1985, 52 (Ogem /Notaris Maas)

Hoge Raad 24 maart 1995, NJ 1997, 569 m.nt. CJHB

Hoge Raad 19 mei 1995, NJ 1997, 648

Hoge Raad 9 juni 1995, RvdW 1995, 129 (Finad/Worst)

Hoge Raad 9 juni 1995, NJ 1995, 692 m.nt. PvS

Hoge Raad 24 november 1995, 1996, 162 (Daily Mirror) met conclusie van A-G Hartkamp

Hoge Raad 22 december 1995, NJ 1996, 300 (Hoog Catharijne)

Hoge Raad 12 januari 1996, NJ 1996, 683

Hoge Raad 21 juni 1996, NJ 1996, 698

Hoge Raad 15 november 1996, NJ 1997, 151

Hoge Raad 22 november 1996, NJ 1997, 527 (Bloemendaalse olietank)

Hoge Raad 10 januari 1997, NJ 1997, 360 (Staleman/Van de Ven)

Hoge Raad 12 maart 1997, BNB 1997/146

Hoge Raad 23 mei 1997, NJ 1998, 192 (Rabobank/Everaars)

Hoge Raad 4 juni 1997, NJ 1997, 671

Hoge Raad 14 november 1997, RvdW 1997, 228c

Hoge Raad 14 november 1997, NJ 1998, 657

Hoge Raad 12 december 1997, NJ 1998, 208

Hoge Raad 9 januari 1998, NJ 1998, 272

Hoge Raad 9 januari 1998, NJ 1998, 586

Hoge Raad 20 februari 1998, NJ 1998, 493 (Briljant Schröders / ABP)

Hoge Raad 10 april 1998, NJ 1998, 666 m.nt. WMK (Offringa/Vinck)

Hoge Raad 10 april 1998, RvdW 1998, 84 (Antilliaans zwembad)

Hoge Raad 26 juni 1998, NJ 1998, 660 (Rabobank/Klundert)

Hoge Raad 18 september 1998, NJ 1988, 818 (KPI-Leba)

Hoge Raad 25 juni 1999, NJ 2000, 33

Hoge Raad 8 oktober 1999, NJ 1999, 781

Hoge Raad 28 januari 2000, NJ 2000, 575

Hoge Raad 4 februari 2000, NJ 2000, 562 m.nt. JBMV

Hoge Raad 18 februari 2000, NJ 2001, 259

Hoge Raad 16 juni 2000, NJ 2001, 559

Hoge Raad 27 september 2000, JOR 2000, 217, m.nt. M. Brink (Gucci)

Hoge Raad 20 april 2001, NJ 2001, 600

Hoge Raad 9 november 2001, LJN AD5302

Hoge Raad 7 december 2001, NJ 2002, 494 m.nt. DA

Hoge Raad 21 december 2001, NJ 2002, 75

Hoge Raad 14 januari 2002, NJ 2002, 495

Hoge Raad 18 januari 2002, LJN AD4924, NTBR 2002, 7

Hoge Raad 25 januari 2002, NJ 2003, 31 (J.M. Paalman / Lampenier)

Hoge Raad 25 januari 2002, RvdW 2002, 22

Hoge Raad 12 februari 2002, NJ 2002, 439

Hoge Raad 12 februari 2002, NJ 2002, 440 
- $\quad$ Hoge Raad 31 mei 2002, NJ 2003, 589

- $\quad$ Hoge Raad 14 juni 2002, RvdW 2002, 104 (Gemeente Boarnsterhim/ Heideveld c.s.)

- $\quad$ Hoge Raad 21 juni 2002, RvdW 2002, 106 (Van den Akker/ Gemeente Helmond)

- Hoge Raad 29 november 2002, JOR 2003, 2 m.nt. Bartman (Schwandt/Berhuizer Papierfabriek)

- $\quad$ Hoge Raad 10 januari 2003, NJ 2003, 537

- $\quad$ Hoge Raad 24 januari 2003, NJ 2003, 491

- $\quad$ Hoge Raad 21 februari 2003, JOR 2003, 57 m.nt. M.P. Nieuwe Weme (HBG)

- Hoge Raad 4 april 2003, NJ 2003, 538

- $\quad$ Hoge Raad 18 april 2003, JOR 2003, 110 m.nt. Blanco Fernández (Rodamco North America)

- $\quad$ Hoge Raad 23 mei 2003, LJN AF6689

- $\quad$ Hoge Raad 11 juli 2003, NJ 2005, 103

- $\quad$ Hoge Raad 11 juli 2003, JOR 2003, 199 (Kouwenberg/Rabobank)

- Hoge Raad 5 september 2003, NJ 2003, 677 (Kalkman-Baarsma)

- $\quad$ Hoge Raad 19 september 2003, NJ 2005, 234 m.nt. JH

- $\quad$ Hoge Raad 26 september 2003, RvdW 2003, 152 (Regiopolitie)

- $\quad$ Hoge Raad 10 oktober 2003, LJN AI0306 (Dutch Paint)

- $\quad$ Hoge Raad 10 oktober 2003, NJ 2005, 89

- $\quad$ Hoge Raad 5 december 2003, NJ 2004, 506

- $\quad$ Hoge Raad 23 januari 2004, RvdW 2004, 20

- $\quad$ Hoge Raad 23 januari 2004, LJN AL7051, met conclusie van A-G Huydecoper (Stratex)

- $\quad$ Hoge Raad 13 februari 2004, LJN AM2365

- $\quad$ Hoge Raad 20 februari 2004, RvdW 2004, 34 (DSM/Fox)

- $\quad$ Hoge Raad 14 mei 2004, LJN AO1214, JOL 2004, 248 (M\&M Beheer)

- $\quad$ Hoge Raad 11 juni 2004, NJ 2004, 604

- $\quad$ Hoge Raad 11 juni 2004, LJN AP1639

- $\quad$ Hoge Raad 29 juni 2004, NJ 2005, 273

- $\quad$ Hoge Raad 9 juli 2004, RvdW 2004, 94

- $\quad$ Hoge Raad 9 juli 2004, NJ 2005, m.nt. DA

- $\quad$ Hoge Raad 3 december 2004, NJ 2005, 160 m.nt. MMM

- $\quad$ Hoge Raad 11 maart 2005, JOR 2005, 169

- $\quad$ Hoge Raad 8 april 2005, JOR 2005, 119 m.nt. M. Brink

- $\quad$ Hoge Raad 12 augustus 2005, NJ 2005, 467 m.nt. CBB/JPO

- Hoge Raad 12 augustus 2005, RvdW 2005, 93

- $\quad$ Hoge Raad 9 september 2005, LJN AT5156

- $\quad$ Hoge Raad 23 september 2005, JOR 2005, 264, m.nt. P.J. van der Korst.

- $\quad$ Hoge Raad 23 september 2005, LJN AR6468

Hoge Raad 7 oktober 2005, RvdW 2005, 112

Hoge Raad 11 november 2005, LJN AT6018, JB 2006, 27

Hoge Raad 23 december 2005, JOR 2006, 20

Hoge Raad 23 december 2005, RvdW 2006, 17

Hoge Raad 13 januari 2006, NJ 2006, 480 m.nt. G.R. Rutgers

Hoge Raad 20 januari 2006, NJ 2006, 80

Hoge Raad 20 januari 2006, LJN AU 4529

Hoge Raad 24 januari 2006, LJN AU4666, met conclusie van A-G Vellinga

Hoge Raad 24 januari 2006, NJ 2006,109

Hoge Raad 4 april 2006, LJN AU 4658

Hoge Raad 4 april 2006, LJN AU 4664

Hoge Raad 7 april 2006, NJ 2006, 245

Hoge Raad 21 april 2006, LJN AW 2582, Maandblad voor Vermogensrecht, mei 2006, nr. 5, p. 96/97

Hoge Raad 21 april 2006, NJ 2006, 272

Hoge Raad 2 juni 2006, LJN AW6612

Hoge Raad 23 juni 2006 (zaaknummer R05/092Hoge Raad (OK 120, Call Active, artikel 81 RO) 
- $\quad$ Hoge Raad 1 september 2006 (zaaknummer R05/081Hoge Raad - Emba, artikel 81 RO)

- $\quad$ Hoge Raad 8 september 2006, NJ 2006, 494

- $\quad$ Hoge Raad 6 oktober 2006, LJN AX7774

- $\quad$ Hoge Raad 13 oktober 2006, RvdW 2006, 941-943 (Vie d'Or)

- Hoge Raad 13 oktober 2006, JOR 2006, 296 m.nt. H. Beckman

- Hoge Raad 8 december 2006, LJN AY7456, met conclusie van A-G Huydecoper

- Hoge Raad 15 december 2006, zaaknummer R06/040Hoge Raad, LJN AZ3172, met conclusie van A-G Timmerman

Hoge Raad 19 januari 2007, NJ 2007, 63

Hoge Raad 19 januari 2007, LJN AZ6541 (Kranendonck / Houthoff Buruma)

Hoge Raad 19 januari 2007, NJ 2007, 575 (Meyer/Pontmeyer)

Hoge Raad 29 januari 2007, JOR 2007, 166 (Meyer Europe) m.nt. R.P.J.L. Tjittes

Hoge Raad 6 februari 2007, RF 2007, 19 en JOR 2007,73

Hoge Raad 23 maart 2007, NJ 2007,176

Hoge Raad 23 maart 2007, LJN AZ3531

Hoge Raad 25 mei 2007, LJN BA2012

Hoge Raad 22 juni 2007, NJ 2007, 343

Hoge Raad 29 juni 2007, LJN AZ4850

Hoge Raad 29 juni 2007, LJN AZ7617

Hoge Raad 29 juni 2007, RvdW 2007, 634

Hoge Raad 29 juni 2007, JOR 2007, 198

Hoge Raad 29 juni 2007, JOR 2007, 259 m.nt. J.J. Dammingh

Hoge Raad 29 juni 2007, JOR 2007, 260 m.nt. J.J. Dammingh

Hoge Raad 29 juni 2007, NJ 2007, 576 m.nt. M.H. Wissink (Derksen/Homburg)

Hoge Raad 29 juni 2007, RvdW 2007, 636

Hoge Raad 29 juni 2007, JOL 2008, 480 (Uni-Invest)

Hoge Raad 29 juni 2007, JOR 2007, 198 m.nt. R.PJ.L. Tjittes

Hoge Raad 13 juli 2007, NJ 2007, 408

Hoge Raad 13 juli 2007, LJN BA3520

Hoge Raad 10 augustus 2007, AB 2007, 388

Hoge Raad 7 september 2007, LJN BA2014

Hoge Raad 7 september 2007, JOR 2007, 291 m.nt. R.P.J.L. Tjittes

Hoge Raad 21 september 2007, LJN BA6238

Hoge Raad 12 oktober 2007, LJN BA7630, met conclusie van A-G Huydecoper

Hoge Raad 19 oktober 2007, NJ 2007, 565 (Vodafone)

Hoge Raad 19 oktober 2007, JOR 2008, 23

Hoge Raad 26 oktober 2007, JAR 2007, 285

Hoge Raad 26 oktober 2007, RCR 2008, 2 (Roompot / De Efteling)

Hoge Raad 26 oktober 2007, LJN BA4494

Hoge Raad 26 oktober 2007, RvdW 2007, 923

Hoge Raad 23 november 2007, LJN BB3733

Hoge Raad 23 november 2007, RCR 2008, 8

Hoge Raad 23 november 2007, RCR 2008, 14

Hoge Raad 7 december 2007, LJN BB9421

Hoge Raad 14 december 2007, NJ 2008, 8

Hoge Raad 14 december 2007, RAV 2008, 23

Hoge Raad 11 januari 2008, RvdW 2008, 97

Hoge Raad 11 januari 2008, RCR 2008, 23

Hoge Raad 8 februari 2008, LJN BC3880

Hoge Raad 29 februari 2008, LJN BC1855 (Shell Nederland Verkoopmaatschappij)

Hoge Raad 9 mei 2008, LJN AZ7382 (Samas)

\section{Uitspraken van het gerechtshof}




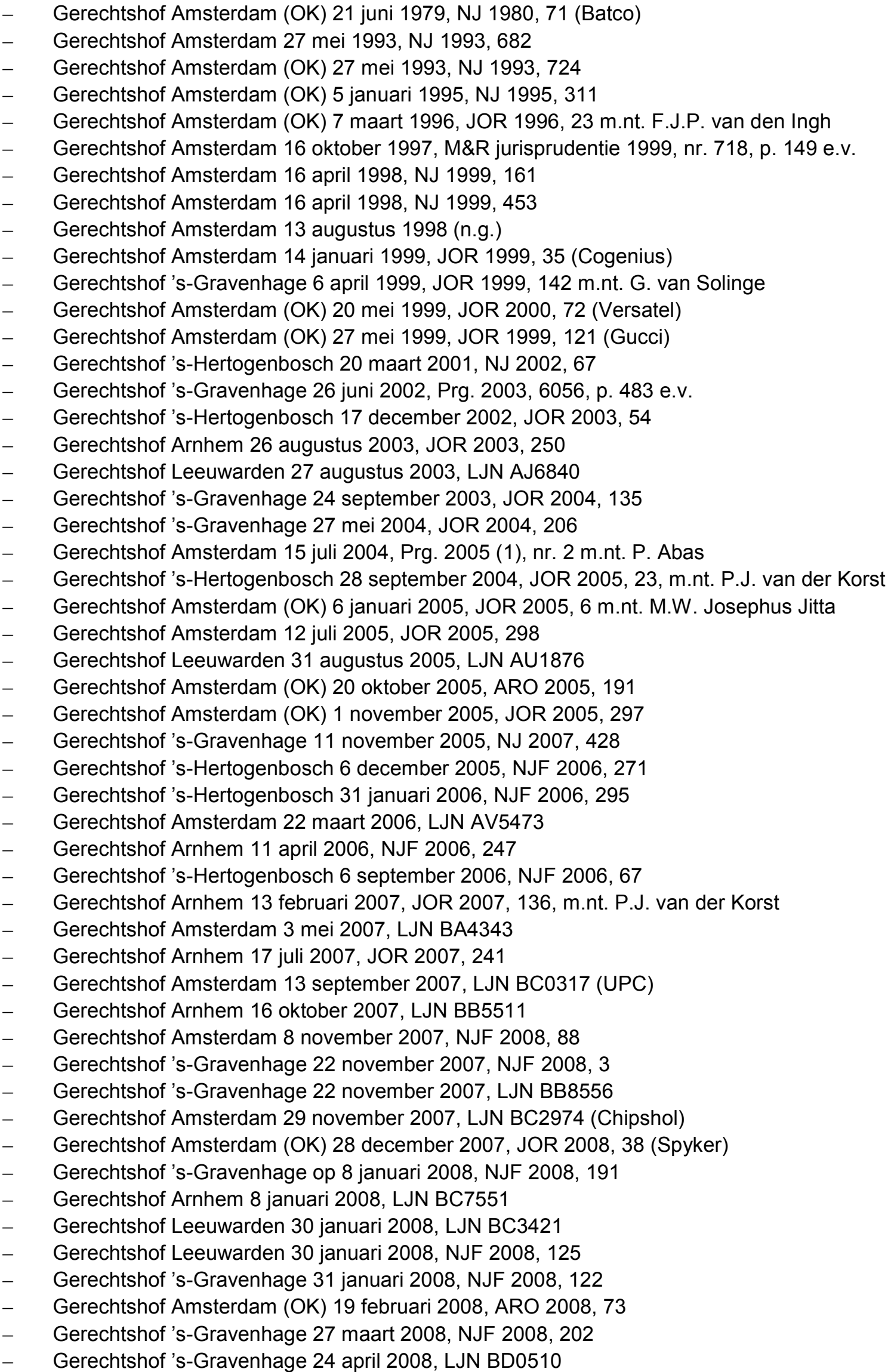




\section{Uitspraken van de rechtbank}

- $\quad$ Rechtbank Haarlem 1 december 1987, KG 1988, 49

- $\quad$ President Rechtbank Breda 24 december 1987, KG 1988, 56

- $\quad$ President Rechtbank Haarlem 10 oktober 1989, KG 1989, 390

- $\quad$ Rechtbank Amsterdam 7 december 1994, NJ 1995, 265

- $\quad$ Rechtbank Amsterdam 28 augustus 1996, JOR 1996,108

- $\quad$ Rechtbank Rotterdam 12 december 1996, JOR 1997, 50 m.nt. Van Solinge

- $\quad$ Rechtbank Assen 25 februari 1997, JOR 1997, 55

- $\quad$ Rechtbank Utrecht 23 april 1997, JOR 1997, 92

- $\quad$ Rechtbank Rotterdam 17 september 1998, JOR 1999, 4

- $\quad$ Rechtbank Haarlem 27 oktober 1998, JOR 1999, 12

- $\quad$ Rechtbank Rotterdam 19 november 1998, JOR 1999, 31

- $\quad$ Rechtbank Alkmaar 24 juni 1999, KG 1999, 183

- President Rechtbank Utrecht 7 september 1999, KG 1999, 284

- $\quad$ President Rechtbank Utrecht, 7 september 1999, JOR 2000, 42

- $\quad$ Rechtbank Dordrecht 23 maart 2000, LJN AA5229

- President Rechtbank Dordrecht, 23 maart 2000, JOR 2000, 80 (HBG/Boskalis)

- Rechtbank Roermond 17 mei 2001, JOR 2001, 134 (Gerrits/Rila)

- $\quad$ Rechtbank Breda 22 januari 2003, LJN AF3737

- $\quad$ Rechtbank Zutphen 7 mei 2003, NJ 2003, 480

- Rechtbank Amsterdam 3 juli 2003, JOR 2003, 205

- Voorzieningenrechter Rechtbank 's-Gravenhage 4 juli 2003, KG 2003, 183

- Rechtbank Maastricht 13 augustus 2003, LJN AN1928

- Voorzieningenrechter 's-Gravenhage 23 oktober 2003, JOR 2004, 136

- Rechtbank Alkmaar 6 november 2003, KG 2003

- $\quad$ Rechtbank Middelburg 17 december 2003, LJN AO0897

- $\quad$ Rechtbank Breda 14 januari 2004, JOR 2004, 70

- $\quad$ Rechtbank Haarlem 24 maart 2004, LJN A08130

- Rechtbank Middelburg 14 april 2004, LJN A09310

- Rechtbank Rotterdam 19 mei 2004, NJF 2004, 526

- Voorzieningenrechter Rechtbank Arnhem 24 mei 2004, LJN AP4372

- $\quad$ Rechtbank Amsterdam 3 november 2004, JOR 2004, 326

- $\quad$ Rechtbank Arnhem 24 november 2004, LJN AR8778

- Voorzieningenrechter Rechtbank Rotterdam 25 november 2004, NJF 2005, 2

- $\quad$ Rechtbank Amsterdam 26 januari 2005, JOR 2005, 96

- $\quad$ Rechtbank Arnhem 26 januari 2005, LJN AS8583

- $\quad$ Rechtbank Arnhem 23 maart 2005, JOR 2005, 140 (X e.a./Baan Company NV c.s.)

- $\quad$ Rechtbank Amsterdam 13 april 2005, JOR 2005, 142

- $\quad$ Rechtbank Arnhem 22 juni 2005, LJN AU1567

- Voorzieningenrechter Rechtbank Alkmaar 23 juni 2005, LJN AT8139

- Voorzieningenrechter Rechtbank Leeuwarden, 6 juli 2005, LJN AT 9151

- Rechtbank 's-Hertogenbosch 27 december 2005, Domjur 2006, 250

- $\quad$ Rechtbank Haarlem 22 februari 2006, LJN AV 5199

- $\quad$ Rechtbank Amsterdam 26 mei 2006, LJN AX 6763 (McGregor)

- $\quad$ Rechtbank Utrecht 14 juni 2006, JOR 2006, 228

- $\quad$ Rechtbank Utrecht 26 juli 2006, JOR 2006, 256

- $\quad$ Rechtbank Amsterdam 24 januari 2007, JOR 2007, 94

- $\quad$ Rechtbank Arnhem 24 januari 2007, LJN AZ9570

- $\quad$ Rechtbank Amsterdam 24 januari 2007, LJN AZ7826

- Rechtbank Groningen 14 februari 2007, NJF 2007, 343

- $\quad$ Rechtbank Rotterdam 30 mei 2007, LJN BB6044

- $\quad$ Rechtbank Amsterdam 4 juli 2007, RCR 2008, 21 
- $\quad$ Rechtbank Dordrecht 25 juli 2007, LJN BB0682

- $\quad$ Rechtbank Zutphen van 1 augustus 2007, NJF 2007, 567

- $\quad$ Rechtbank Rotterdam 15 augustus 2007, Pg. 2007, afl. 25/26, nr. 179

- Rechtbank Amsterdam 5 september 2007, Prg. 2008-1, 2

- Rechtbank Utrecht 12 september 2007, JOR 2007, 265, m.nt. P.J. van der Korst

- $\quad$ Rechtbank Arnhem, 19 september 2007, NJF 2007, 562

- Rechtbank Rotterdam 24 oktober 2007, LJN BB7874

- $\quad$ Rechtbank Utrecht 24 oktober 2007, LJN BB6509

- $\quad$ Rechtbank Arnhem 31 oktober 2007, LJN BB7535

- $\quad$ Rechtbank Haarlem 5 december 2007, NJF 2008, 198

- Rechtbank Rotterdam 21 november 2007, LJN BC0215

- $\quad$ Rechtbank Rotterdam 28 november 2007, LJN BB9319

- $\quad$ Rechtbank Rotterdam 12 december 2007, RCR 2008, 30

- Rechtbank Maastricht 12 december 2007, Prg. 2008, 80

- $\quad$ Rechtbank Utrecht 12 december 2007, JOR 2008, 10

- $\quad$ Rechtbank Arnhem 19 december 2007, NJF 2008, 52

- $\quad$ Rechtbank Haarlem van 9 januari 2008, LJN BC3247 (Laurus / Vomar)

- $\quad$ Rechtbank Arnhem 9 januari 2008, LJN BC2568

- Voorzieningenrechter Rechtbank Amsterdam 10 januari 2008, LJN BC3099

- $\quad$ Rechtbank Alkmaar 30 januari 2008, LJN BC5954

- $\quad$ Rechtbank Middelburg 6 februari 2008, LJN BC8397

- $\quad$ Rechtbank Amsterdam 6 februari 2008, LJN BC7179

- Rechtbank Rotterdam 13 februari 2008, LJN BC6343

- $\quad$ Rechtbank Arnhem 20 februari 2008, LJN BC5068

- $\quad$ Rechtbank Rotterdam 18 maart 2008, LJN BC7312

- $\quad$ Rechtbank Arnhem 19 maart 2008, LJN BC8052

- $\quad$ Rechtbank Leeuwarden 19 maart 2008, NJF 2008, 218

- Rechtbank 's-Hertogenbosch 14 april 2008, LJN BD0037

- $\quad$ Rechtbank Utrecht 23 april 2008, LJN BD0116

\section{Uitspraken van de rechtbank, sector kanton}

- $\quad$ Rechtbank Alkmaar, Sector Kanton 29 maart 2006, LJN AX4054

- Rechtbank Haarlem, Sector Kanton, locatie Zaandam 13 december 2007, Prg. 2008, 68

\section{Uitspraken van het College van Beroep voor het Bedrijfsleven}

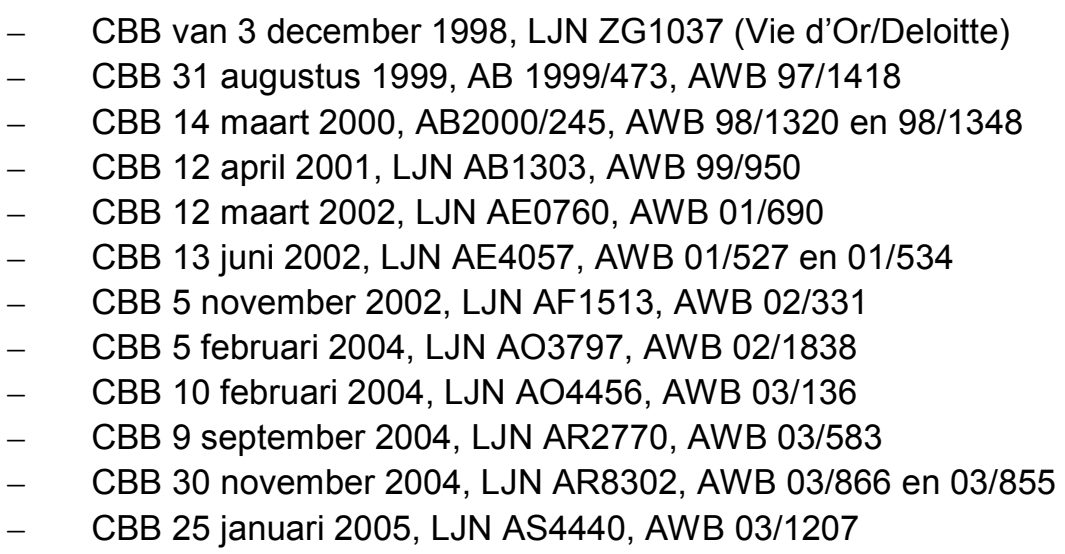

\section{Europese publicaties, Richtlijnen en Verordeningen}


- $\quad$ Prospectusrichtlijn (2003/71/EG), als op 31 december 2003 gepubliceerd in PbEG L 345/64, 31.12.2003, en per die datum in werking getreden.

- De Prospectusrichtlijn is op 1 juli 2005 in ons land geïmplementeerd. Bij de Prospectusrichtlijn hoort de Verordening Nr. 809/2004 die rechtstreeks doorwerkt in onze nationale wetgeving.

- $\quad$ Artikel 88 EG Verdrag en artikel 2 lid 1 van verordening 659/1999 van de Raad van 22 maart 1999 tot vaststelling van andere bepalingen voor de toepassing van artikel 93 [nu 88] van het EG Verdrag, PbEG 1999, L 83/1

- $\quad$ Richtlijn Marktmisbruik, Richtlijn 2004/72/EG van de Europese Commissie van 29 april 2004 tot uitvoering van Richtlijn 2003/6/EG van het Europese Parlement en de Raad, wat gebruikelijke marktpraktijken, de definitie van voorwetenschap met betrekking tot van grondstoffen afgeleide instrumenten, het opstellen van lijsten van personen met voorwetenschap, de melding van transacties van leidinggevende personen en de melding van verdachte transacties betreft, PbEG L 72

- $\quad$ Richtlijn 2003/71/EG van 4 november 2003, PbEG L 345

- $\quad$ Verordening nr. 809/2004 van 29 april 2004 ter uitvoering van de Prospectusrichtlijn 2003/71/EG, PbEG L. 149

- $\quad$ Verordening nr. 1787/2006 van 4 december 2006 tot wijziging van Verordening nr. 809/2004, PbEG L. 337

- $\quad$ Richtlijn 2005/60/EG van het Europees Parlement en de raad van de EU van 26 oktober 2005 tot voorkoming van het gebruik van het financiële stelsel voor het witwassen van geld en de financiering van terrorisme (PbEG L. 309)

- $\quad$ Richtlijn 2006/70 van de Commissie van de Europese Gemeenschappen van 1 augustus 2006 tot vaststelling van uitvoeringsmaatregelen van richtlijn 2005/60/EG van het Europees Parlement en de raad wat betreft de definitie van politiek prominente personen en wat betreft de technische criteria voor vereenvoudigde klantenonderzoeksprocedures en voor vrijstellingen op grond van operationele of zeer beperkte financiële activiteiten (PbEG L. 2014)

- $\quad$ Europees Gerecht van Eerste Aanleg, 17 september 2007, Akzo Nobel Chemicals Ltd. et al. v. Europese Commissie, T-125/03 en T-253/03

Richtlijn 2003/71/EG van 4 november 2003 (PbEU L 345)

- $\quad$ Verordening nr. 809/2004 van 29 april 2004 ter uitvoering van de Prospectusrichtlijn 2003/71/EG (PbEU L. 149) en Verordening nr. 1787/2006 van 4 december 2006 tot wijziging van Verordening nr. 809/2004 (PbEU L. 337)

- $\quad$ Markets in Financial Instruments Directive, 2004/39/EG van 21 april 2004 (PbEU L 145)

\section{Uitspraken van de Europese Commissie}

- 1999/720/EC, Besluit van de Commissie van 8 juli 1999, “GSW” besluit, [1999] PB L292/27

- 2000/567/EC, Besluit van de Commissie van 11 april 2000, "SMI” besluit [2000] PB L238/50

- 2000/796/EC, Besluit van de Commissie van 21 juni 2000, “CDA” besluit, [2000] PB L318/62

\section{Uitspraken van het Hof van Justitie EG}

- $\quad$ HvJ EG 18 mei 1982, AM \& S Europes Ltd / Europese Commissie, (zaak C-155/79)

- $\quad$ HvJ EG 21 november 1991, zaak C-354/90, Saumon, Jur. 1991, p. I-5505, r.o. 12

- HVJ EG 22 november 2005, JOR 2006, 49

- $\quad$ HvJ EG 26 juni 2007 (zaak C-305/05)

- $\quad$ HvJ EG 17 januari 2008 (zaak C-105/07)

\section{Buitenlandse jurisprudentie}

- $\quad$ Belgisch Grondwettelijk Hof 23 januari 2008 (Arrest 10/2008 onder rolnummer 3064 en 3065)

- $\quad$ Traité Joly, Sociétés Commerciales, Tome 2, p. 25 e.v.

- $\quad$ Securities Act 1933 (article 17 (a) en Section 10 (b)

- Rule 10b-5 van de Securities Exchange Act 1934 
- $\quad$ Escott v. BarChris Construction Corp. (283 F. Supp. 643 S.D.N.Y. 1968

- Zie Caparo Industries v. Dickman [1990] 2 WLR 358 en ADT Ltd. v. BDO Binder Hamlin [1996] BCC 808

- $\quad$ www.practicallaw.com/6-107-3752:: Due diligence and post-completion integration: acquisitions

- Due diligence, disclosures and warranties in the Corporate Acquisitions Practice, onder redactie van David Baker en Robert Jillson (second edition, 1992) Graham\&Trotman and IBA, p. xiii

- Zie American Arbitration Association, Dispute-wise Business Management-Improving Economic and Non-Economic Outcomes in Managing Business Conflicts, New York 2006

- Report Basel Committee on Banking Supervision. 